\title{
XI. SYNOPSIS OF PHARMACO-CHEMICAL AND PHARMACO-PHARMACOLOGIC INTERRELATIONS
}

In analyzing the mechanisms through which hormones can influence resistance, we must consider first the various forms of drug interactions in general and second the structural prerequisites for the protective actions of hormones. It is obvious that drugs and hormones may interact by influencing each other's absorption, excretion, distribution within the organism, metabolism, as well as by direct chemical or pharmacologic interactions that occur between drugs in vivo. However, these mechanisms are the subject of general pharmacology and hence they will only receive cursory attention here.

The principal objective of this section is to correlate the many experiments which we performed to obtain material for a glimpse into the structural (chemical) or pharmacologic prerequisites for the ability of steroids to protect the body against toxicants.

\section{VARIOUS FORMS OF DRUG INTE RACTIONS}

In discussing the various forms of interactions between drugs (including hormones), several mechanisms must be considered, for example:

1. The gastrointestinal absorption of one drug can be affected by another which alters the $\mathrm{pH}$ of the alimentary tract, the permeability of its epithelium or peristalsis.

2. Drugs may affect the renal, biliary, or intestinal excretion of other drugs.

3. One drug may alter the distribution of another drug within the organism, e.g.:

a) by altering the permeability of the hemato-encephalic barrier;

b) by competing for shared protein-binding sites in the plasma, thus augmenting the biologic activity of the displaced drug;

c) by competing for receptor sites in tissues, thus diminishing the activity of the displaced drug.

4. Drugs may affect the synthesis, degradation or activity of microsomal and extramicrosomal drug-metabolizing enzymes.

5. Direct chemical interactions between drugs (e.g., chelation) may lead to their inactivation in vivo. Addition of a pharmacologically inert radical to a potent drug may also alter the susceptibility of the latter to microsomal enzyme activity (e.g., morphine and barbital are resistant, whereas ethylmorphine and phenobarbital are highly susceptible to degradation by microsomal enzymes). Such an "opsonization" by addition of a radical may increase the liposolubility of a drug and hence, its capacity to penetrate through membranes. This type of synthesis has not been definitely proven to occur in vivo, but it may play a role in drug interactions.

6. Direct pharmacologic interactions between drugs (e.g., between a vasoconstrictor and a vasodilator, or between two vasodilators) may lead to an increase or a decrease in their activity. 


\section{Drug Interactions in General}

Fouts G77,566/64: Review (5 pp., 18 refs.) on the effect of drugs upon drug metabolism.

McIver G78,391/65: Review (4 pp., 43 refs.) on drug incompatibilities.

Remmer G78,385/65: Review (24 pp., 156 refs.) on the mechanism of drug interactions.

Gillette G78,390/67: Review (19 pp., 96 refs.) on theoretical aspects of drug interaction.

McIver G77,708/67: Review (6 pp., 41 refs.) on drug incompatibilities.

Block \& Lamy G81,054/68: Review (6 pp., 82 refs.) on therapeutic incompatibilities of importance to pharmacists.

Hartshorn G78,178/68: Greatly simplified but excellent revue (8 pp., about 35 refs.) enumerating various ways in which drugs can interact and illustrating each type with a few examples.

Hartshorn G81,056/68: Review (4 pp., 17 refs.) with practical hints on drug interactions useful to the pharmacist.

Hartshorn G81,057/68: Review (7 pp., 3 refs.) consisting mainly of tables concerning drug interactions.

Hussar G 81,059/68: Review (11 pp., 82 refs.) on drug incompatibilities.

Pelissier \& Burgee, Jr. G79,655/68: A brief guide to drug incompatibilities irrespective of the underlying mechanism.

Block \& Lamy G81,052/69: Review (5 pp., 27 refs.) on drug interactions with tabular summaries on changes in metabolism, binding to plasma and urinary $\mathrm{pH}$ changes produced by one substance which may alter the activity of another compound.

Dunphy G77,712/69: Review (11 pp., about 30 refs.) on drug interactions with an outline of an extremely simplified index listing a few examples of these.

Hartshorn G81,055/69: Review (7 pp., 33 refs.) on interactions among anti-infective agents.

Hussar G81,053/69: Practical hints concerning drug interactions of interest to the pharmacist.

Visconti G77,709/69: Review (10 pp., no refs.) on how drug interaction information may be used preventively.

Ariëns G79,943/70: Review (48 pp., about 160 refs.) on drug interactions with special reference to antagonisms, metabolic inactivation and metabolic activation. [Excellent summary, but the poor English is difficult to follow (H.S.).]
Neumann G80,018/70; G80,550/70: Review (5 pp., no refs.) on drug interactions in the style of a postgraduate lecture.

Mannering G74,881/71: Review of the literature on drug interactions in general leads to the conclusion that "a drug may alter the action of another drug in several ways: a) by producing one or more effects similar or opposite to those of the drug in question, b) by direct chemical or physical interaction of drugs, c) by displacement of drugs bound to plasma or other proteins, d) by altered renal clearance of drugs, e) through conditioning by previous drug effects, f) by interaction of drugs with receptor sites, and g) by inhibition or stimulation of the metabolic site. Examples of all of these interactions are given ..."

\section{Lipid Solubility}

Brodie G55,013/62: "Metabolism of the microsomal enzymes seems to be governed by lipid solubility, for only substances that are highly lipid soluble are metabolized by microsomes."

Mannering G71,818/68 (p. 74): A survey of the literature shows that compounds with low lipid solubility are poor inducers of drugmetabolizing microsomal enzymes, whereas potent inducers are, in general, highly soluble in organic solvents. [Yet all steroids are lipid soluble but are not good inducers (H.S.).]

\section{Carriers}

Baird \& Reid G51,827/67: Pancuronium bromide produces neuromuscular blockade in man.

Lewis et al. F95,691/67: In various test procedures, steroidal monoquaternary ammonium salts exhibited non-depolarizing neuromuscular blocking activity.

Bonta \& Goorissen G75,052/68; Buckett G75, 531/68: Pharmacologic studies on the neuromuscular-blocking effect of pancuronium.

Buckett et al. G56,175/68: "Pancuronium possesses up to ten times the potency of tubocurarine according to the species used for testing, while possessing similar duration of action."

Reyes et al. G71,233/69: In rats phenobarbital "enhanced hepatic uptake of an organic anion, bromsulphalein, in vivo and simultaneously increased the amount of $\mathrm{Y}$, a hepatic cytoplasmic organic anion-binding protein. This study supports the postulate that $\mathrm{Y}$ is a major determinant in the selective hepatic uptake of certain organic anions from 
plasma." Induction of $\mathrm{Y}$ may enhance hepatic uptake and metabolism of various substrates following treatment with phenobarbital and other inducers.

Wall et al. G69,969/69: A series of steroid esters of $\mathrm{p}$-[N,N-bis (2-chloroethyl) amino] phenylacetic acid (BCAPAA), steroidal sulfides of p-(N,N-bis-2-chloroethylamino)thiophenol, and a variety of steroidal ethylenimine derivatives were synthesized and tested for antitumor activity. "Activity was found only in those instances in which the steroid and potential oncolytic agent were connected by ester or heterocyclic ether linkages. The steroidal BCAPAA esters were of particular interest showing excellent inhibition of a DMBAinduced and transplantable mammary adenocarcinoma, and marked increase in survival when tested on a variety of rat leukemias. ... The steroidal BCAPAA esters were judged to be less toxic than some of the well-known nitrogen mustards in general use."
Chaouki et al. G77,223/70: In 50 patients, pancuronium bromide was found to be an active non-depolarizing neuromuscular blocking agent, about 5 times as active as curare and 25 times more potent than gallamine triethiodide. Its advantages are rapid onset of action, no release of histamine and little disturbance in blood pressure, because of a weak ganglioplegic action.

Dick et al. G77,777/70: Favorable clinical experiences with pancuronium as a muscle relaxant in anesthetized patients.

Feldman \& Tyrrell G76,666/70: Dacuronium bromide $(2 \beta, 16 \beta$-dipiperidino-5x-androstane$17 \beta$-diol-3x-acetate dimethobromide) is closely related to pancuronium bromide but the acetoxy group at $\mathrm{C}_{17}$ is replaced by a hydroxyl group. It has proven its usefulness as a nondepolarizing muscle relaxant in man. Its effect is fully reversible by edrophonium or neostigmine.

\section{PREREQUISITES FOR THE PROTECTIVE ACTIONS OF HORMONES}

Looking back upon research on hormones and resistance, as outlined in this monograph, it may be instructive to reexamine the justification of the path followed and to summarize the main points.

It is not without hesitation that we embarked upon this project some 35 years ago; we realized, to start with, that this would be a life-long undertaking with virtually no background data for logical planning. On the basis of what we had learned in 1936 about the role of the adrenal cortex in defense against stress, no other course seemed to be open to us but that of a purely empirical, large-scale screening of many steroids (more or less closely related to the corticoids) for possible protective effects against many toxicants.

However, the possibility of finding highly potent and comparatively nontoxic protective steroids appeared to hold considerable promise of practical applicability and the screening did not have to rely on chance alone. To some extent, we could be guided by the pharmacologic and chemical characteristics of compounds previously shown to have protective potency against certain substrates. We used the same guide lines for the identification of toxicants amenable to prophylaxis by steroids. It is on the basis of this kind of empirical research that we are now beginning to see outlines of a classification which permits us to predict, with some degree of probability, what compounds are likely to possess protective effects against what types of toxicants.

Because of the large number of experiments required to explore the many possible combinations of such interactions, we had to rely on simple in vivo observations in which directly visible (functional or structural) changes and mortality rates were our principal indices of activity. Yet, in the early days we were encouraged by the knowledge that similar screening efforts did prove to be eminently successful in many other fields. The classification of bacteria on the basis of their ability to grow on 
certain media or to take up the Gram stain, the screening of antibiotics on plates inoculated with various bacteria, the blind testing of 606 chemotherapeutic agents that finally led Ehrlich to the discovery of "Salvarsan," are but a few examples to illustrate this point.

In our own work we could demonstrate the nonspecificity of the pituitary-adrenal response only by countless in vivo tests with many stressors; only the screening of numerous calciphylactic sensitizers and challengers permitted us eventually to induce localized tissue calcification in a predictable and highly specific manner.

Naturally, as soon as any new protective phenomenon was discovered, in vitro studies in depth became necessary to clarify the underlying mechanisms; for example, after we noted the prevention by spironolactone of digitoxin and mercurial intoxication, or the extraordinary degree and spectrum of protective effects that can be induced in steroids by the introduction of a nitrile group. Much of this work is still to be done, but before we could even think about elucidating the manner in which a protective phenomenon works, we had to know first that the phenomenon exists.

So much for self-justification.

To begin with, we had to develop an economic procedure which permitted large scale experimentation with a minimum waste of steroids, many of which are difficult to synthesize. Then we had to design a technique for the correlative evaluation of the many individual observations made.

Our assay procedure consisted of the following three steps:

1. Establishment of possible protective potency against two standard toxicants: digitoxin and indomethacin.

2. Determination of the "protective spectrum" of the steroids found to be active in step 1.

3. Identification of damaging agents amenable to prophylaxis by steroids which have revealed interesting activities in step 2.

Before describing these steps in detail, we shall have to say a few words about the evaluation of the data obtained. The results of the first sereening have been tabulated in the conventional way (Table 135) by listing the mean severity of the actual changes as previously described for comparable studies on the effect of 304 steroids upon indomethacin and digitoxin poisoning (Selye G70,421/70).

In addition, we constructed Synoptic Tables (Tables 136, 137, 138) in which these and many additional results are summarized on the basis of the degree of the significance ratings (cf. "Statistical Evaluation," p. IX) according to a system developed by Mrs. I. Mécs of this Institute. The figures indicate the means of the statistical significance grades of the changes (functional or structural) used as indicators, plus that of the mortality rates divided by 2 . Thus, in an experiment in which the protection against intestinal ulcers had a significance rating of " 0 " (no protection), and the signifi- cance of the protection against mortality was 3 "***" (perfect protection), the figure given in the tables would be 1.5. Only in the case of compounds which normally cause no mortality (e.g., anesthetics, muscle relaxants) do the grades correspond to structural or functional lesions alone.

The Synoptic Tables $(136,137,138)$ also list the "Mean Overall Protective Index" computed according to a procedure closely related to the "Simplified Activity Grading" system previously described (Selye G70,421/70). This index represents the allgebraic sum of all the individual activity gradings for a certain protective substance divided by the number of toxicants against which it was tested.

In addition, we computed the "Total Overall Protective Index" which represents the arithmetic sum of all the individual activity gradings (disregarding negative grades).

Furthermore, we computed the "Protective Spectrum Index" which is the percentage of 
those toxicants tested against which significant protection is obtained (irrespective of the degree of significance). Thus, if a steroid offers significant protection against 6 out of 10 toxicants examined, its "Protective Spectrum Index" is $60 \%$.

In the Synoptic Tables, these Indexes have also been computed for the amenability to protection of the various toxicants (three bottom horizontal lines). In other words, here the figures indicate the mean degree or the percentile frequency of protection offered by the entire series of conditioners against any one toxicant.

Finally, to further facilitate the overview of this complex field we constructed a "Diagram Table" (Table 139) which graphically summarizes the highlights of Table 138, except that the results are registered only for one dose level of the toxicants and are expressed in a scale in which intermediates between the four grades are not recognized (for details $c f$. footnote on Table 139). Furthermore, in Table 138, the toxicants are listed in alphabetical order for easy identification, whereas in Table 139, they are enumerated according to decreasing "Total Overall-Protective Index" values.

Since the large number of experiments to be reported here was performed over a considerable period of time, in each case, a group of unpretreated controls received the same toxicant, simultaneously with the rats that had been pretreated with potentially protective substances. The statistical significance of the resulting changes in the pretreated animals was always calculated in comparison with the corresponding group of unpretreated controls handled under identical circumstances, at the same time and by the same technician.

Using these procedures for the evaluation of our data, we examined the steroids available for this work according to the above mentioned three-step procedure.

\section{First Step: Protection Against Digitoxin and Indomethacin}

The first systematic investigations designed to identify protective steroids consisted of a series of bioassays in which 304 natural and synthetic steroidal compounds were tested for their ability to protect the rat against digitoxin and indomethacin, under the experimental conditions outlined in the preceding section. Since these results have been the subject of an extensive review (Selye G70,421/70), we shall limit ourselves here to a brief description of the principal conclusions derived from them.

Protective activity was widespread among the steroids of this first series; it was demonstrable among gonanes, estranes, androstanes, androstenes, $5 \beta$ - and $5 \alpha$-pregnanes as well as among pregnenes, with one or more double bonds, and with or without halogen substitution in the ring system. On the other hand, cholanes, cholestanes and genins were uniformly inactive, with the sole exception of methylnordeoxycholanate ( $3 \alpha, 12 \alpha$-dihydroxy-24-nor-5 $\beta$-cholan-23-oic acid methyl ester).

Because of this widespread distribution of anti-indomethacin and antidigitoxin activity throughout various classes of steroids, it was difficult to formulate any clear-cut rules about pharmaco-chemical correlations in this field. It does appear, however, that although catatoxic activity is not strictly dependent upon any single structural prerequisite, in general the $17 \alpha$-propionic acid- $\gamma$-lactone side-chain is advantageous for both antidigitoxin and anti-indomethacin activity. It is perhaps also not purely coincidental that a very large number of active catatoxic steroids is found among the 1,4-androstadienes as well as among halogenated androstene and pregnene derivatives. It is likewise noteworthy that several of the most active catatoxic steroids are 19-nor compounds, hence the angular methyl group at $\mathrm{C}_{10}$ is not only dispensable but often advantageous. The most striking observation in this series of tests was that among all 304 steroids tested the most active against both substrates proved to be a cyano-compound, namely PCN. 
This first systematic screening series also revealed that the catatoxic activity is not strictly dependent upon any other known pharmacologic property, although most of the highly potent antidigitoxin and anti-indomethacin steroids also exhibit antimineralocorticoid or anabolic properties.

Because of the comparatively small number of animals that could be used for the bioassay of the many, not readily available, steroids, only the lowest and the highest activity grades were given serious consideration. However, even on this rigid basis of appraisal, we found that at a $10 \mathrm{mg}$ dose level, among 304 steroids tested, there were:

Active only against indomethacin: 42

Active only against digitoxin: 32

Active against both substrates: 24

the remainder being inactive or of doubtful

activity.

At the $0.5 \mathrm{mg}$ dose level, we found:

Active only against indomethacin: 1

(Cpd. 277 and betamethasone acetate)

Active only against digitoxin: 1

(CS-1)

Active against both substrates: 1

(PCN)

These compounds correspond to the following structures:

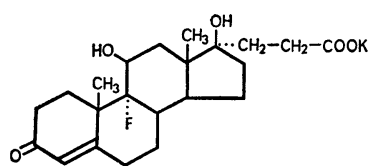

$C S-1$

$9 \alpha$-Fluoro-11 $\beta$-,17-dihydroxy-

3-oxo-4-androstene-17 $\alpha$-propionic acid potassium salt (SC-11927)

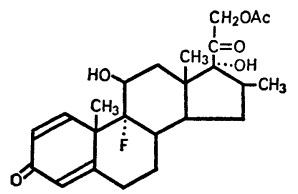

Betamethasone acetate

$9 \alpha$-Fluoro-16 $\beta$-methyl-11 $\beta, 17,21$ trihydroxy-1,4-pregnadiene-3,20dione 21-acetate

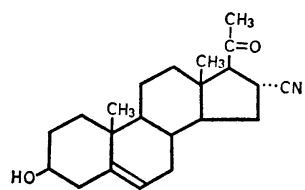

$P C N$

$3 \beta$-Hydroxy-2-oxo-5-pregnene$16 \alpha$-carbonitrile (SC-4674)

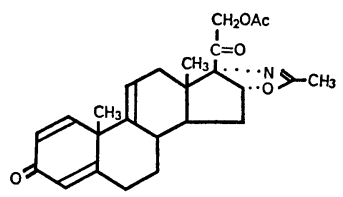

"Cpd. 27\%"

21-Hydroxy-3-oxo-1,4,9(11)pregnatrieno-[17 $\alpha, 16 \alpha-\mathrm{d}]-$ 2'-methyl-oxazoline acetate

It is especially noteworthy that several of the active catatoxic steroids are naturally occurring hormones, hormone precursors or hormone metabolites such as: progesterone, $17 \alpha$-hydroxyprogesterone, 5-pregnenolone, dehydroisoandrosterone. 
Encouraged by these first observations, we then proceeded to repeat some of the key observations at lower dose levels. We also performed similar tests on many additional steroids, especially carbonitriles and other compounds related to the most active members in the preliminary series. This work (Selye G 70,480/71) was done under experimental conditions exactly corresponding to those of the first screening tests, and the results are summarized in Table 135.

However, before describing these most recent experiments, we must say a few words about the SSS steroid terminology. Up to now, in discussing the literature, we used essentially the same terms as did the authors quoted. This was far from satisfactory, but unfortunately unavoidable, because we could not have taken the responsibility of translating into any accepted steroid nomenclature the often ambiguous mixtures of trivial and systematic designations that are sometimes employed even by the most reputable pharmacologists and clinicians. However, in the following description of our own experiments with fully characterized compounds, these will be identified not only by their structure formulas and the official designations accepted by the International Union for Pure and Applied Chemistry (IUPAC Commission G82,068/69), but also by the much more easily understandable and simpler SSS terms. The SSS (Symbolic Shorthand System of steroid terminology) (Selye et al. G79,034/71) can be briefly summarized as follows:

\section{Basic Principles}

The main advantages of the SSS nomenclature are: shortness of code terms, logical consisteney, and simplicity. The principles which guided its design are:

Rigid observance of left-to-right precedence order in the coining of symbols. The parent hydrocarbon comes first, then its substituents in a strictly determined sequence. Each substituent is named by a symbol followed by a positional number according to the principle of: "first what, then where" (e.g., 17 $\beta$-Hydroxyandrostan-3-one $=\mathbf{A o l}_{17 \beta} \mathrm{On}_{3}$ ).

We deviate from this rule only in the case of "secondary parent hydrocarbons" in which the main parent hydrocarbons (e.g., estrane, androstane) are provided with side-chains attached by $\mathrm{C}-\mathrm{C}$ linkages (e.g., methylandrostane or cyanopregnane). In such cases, substituents of the side-chains are mentioned immediately after the latter. E.g., an androstane with a hydroxylated (ol) methyl group (I) attached at $16 \beta$ is written $\mathbf{A I o l}_{16 \beta}$ and the whole expression is underlined (or boldface) to distinguish it from substituents on the main parent hydrocarbon itself which follow according to the order of precedence described below. For example, if the methylandrostane just mentioned also contains a ketone group at 3 and a fluorine in the $9 \alpha$-position, we write $\mathrm{AIol}_{16 \beta} \mathrm{On}_{3} \mathrm{~F}_{9 \alpha}$.

No signs to indicate two or more identical characteristics (e.g., diene, triol, dione). The sign $\Delta$ and the suffix "-ene" are also omitted since appropriate position numbers make them superfluous. After the symbol of the parent hydrocarbon (e.g., $\mathbf{A}=$ Androstane) superscript numerals suffice to designate the degree of unsaturation, while subscripts qualify the position and number of functional groups (e.g.: $\mathrm{A}^{4,6} \mathrm{ol}_{11 \beta, 17 \alpha} \mathrm{On}_{3}=11 \beta, 17_{\alpha}$-Dihydroxy-4,6androstadien-3-one).

No silent "e" (e.g., in "one"). This is always omitted, not only when the next syllable begins with a vowel. The final " $e$ " does not change either the meaning or the pronunciation of the syllable and, in many languages, it is not used in any case. Besides, SSS (like IUPAC) is not meant for oral communication.

Since esters are always formed with alcohols, the esterified $0 \mathrm{H}$ groups are not separately indicated. E.g., instead of $5 \alpha$ Androstane-3 $\beta, 17 \alpha$-diol 3-acetate 17-propionic acid ester, we merely write $\mathrm{A5}^{2}{ }^{*} \mathrm{II}^{\prime \prime}{ }_{3 \beta}{ }^{*} \mathrm{III}^{\prime \prime}{ }_{17 \alpha}$ ( ${ }^{*}=$ ester; ${ }^{\prime \prime}=$ acid $)$, since the $3 \beta$-acetate or $17 \alpha$-propionate can only be formed with the corresponding alcohols ( $c f$. also p. 775 and 776). Furthermore, we employ short symbols instead of writing out the full names of the esterified acids and, instead of the usual ".", we separate ester functions from the parent hydrocarbon by an asterisk which uses no more space than the dash and yet further characterizes the following symbols as an ester. 
No prefixes. It is superfluous to burden a codifier with a complex dictionary of rules according to which he must write a given symbol as a prefix or suffix. In SSS, the parent hydrocarbon is the first part of any designation; all other symbols are added as suffixes.

No synonyms. Every structural feature receives one name or symbol. This procedure is greatly facilitated by the omission of prefixes which complicate other systems. For example in IUPAC:

Carboxylic acids are named "Carboxy." as prefix, and "-oic", "-ic" or "carboxylic acid" as suffix.

Alcohols are "Hydroxy-" as prefix and "-ol" as suffix.

Aldehydes are "Oxo-" as prefix and "-al" as suffix.

Most confusingly, ketones are also "Oxo-" as prefix, but "-one" as suffix.

Typesetting and punetuation are used to specify chemical characteristies without lengthening names. Instead of separating all parts of a term by dashes (-), SSS uses no separating sign or (where there may be ambiguity) the shorter comma (,). The latter is replaced by an asterisk $\left(^{*}\right)$ to indicate ester function. Commas also separate the position numerals of identical functions (e.g., ol ${ }_{3 \beta, 9 \beta, 17 \alpha}$ ). No punctuation is used to separate the constituents of a single functional group. E.g., $* \mathrm{III}^{\prime \prime}{ }_{\beta}$, fully characterizes the location on $\mathrm{C}_{3}$ and the steric position of an alcohol group esterified with propionic acid; the three ingredients $\left(3, \beta, \mathrm{III}^{\prime \prime}\right)$ need not be separated by dashes or any other sign which would only tend to break up what is actually one unit of expression.

The simplest symbolic code terms are used for the most common expressions. Thus, the main parent hydrocarbons have symbols consisting only of the first letter of their full name (e.g., $\mathbf{G}=$ Gonane, $\mathbf{E}=$ Estrane, $\mathbf{A}=$ Androstane) although, in some instances, one or two additional letters are added to avoid ambiguity (e.g., $\mathbf{C H}=$ Cholane, $\mathbf{C H T}=$ Cholestane, etc.). For emphasis, the symbols of the main and secondary parent hydrocarbons including signs of intrinsic modifications such as: isomerism, unsaturation, nor, homo, abeo are underlined and always capitalized (in printing, italicized or set in boldface).

Whenever possible, simple, selfexplanatory mnemonic abbreviations are used for all substituent radicals, e.g., for normal alkyls roman numerals, indicating the number of carbon atoms contained:

$$
\begin{aligned}
& \text { I= Methyl } \text { II = Ethyl III = Propyl } \\
& \text { IV = Butyl } \\
& \text { V }=\text { Pentyl. }
\end{aligned}
$$

Longer and more complex radicals are represented by letter symbols, usually contractions of the IUPAC names ( $c f$. below).

When alkyls appear as side chains (secondary parent hydrocarbons), they follow the name of the parent hydrocarbon (on the same line) and, like the latter, are boldface (e.g., $\mathbf{A I}=$ methylandrostane).

Whenever the chemical formula characterizing a substituent is shorter than a meaningful corresponding word or abbreviation could be, we use the former (e.g., $=\mathrm{CH}_{2}$, $=\mathrm{NH},-\mathrm{CN}, \mathrm{K}, \mathrm{F}$ respectively for methylene, imino, carbonitrile, potassium or fluorine). In order to avoid three-line symbols, the positional numbers of such formulas as $=\mathrm{CH}_{2}$ are appended to a bracketed symbol e.g. $\left(\mathrm{CH}_{2}\right)_{16 \beta}$.

\section{The Main Parent Hydrocarbons

\begin{tabular}{|c|c|c|}
\hline ne & $=\mathbf{G}$ & stane $=\mathbf{E R}$ \\
\hline Estrane & $=\mathbf{E}$ & Stigmastan $=\mathbf{S T}$ \\
\hline stane & & lide $=\mathbf{C A R}$ \\
\hline & $=\mathbf{P}$ & $\mathrm{de}=\mathbf{B U F}$ \\
\hline 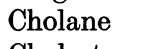 & $=\mathbf{C H}$ & Spirostane $=\mathbf{S P}$ \\
\hline stane & $=\mathbf{C H}$ & Other nuclei \\
\hline
\end{tabular} (in order of precedence)}

All ring modifications, other than those recognized above as parent hydrocarbons, are listed as derivatives at the end of each main category in this order:

Heterocyclic steroids, cf. p. 777

Nor-ring steroids $=\mathbf{n}$ (e.g., $\mathbf{A n A}=\mathbf{A}$-norandrostane, $\mathbf{P n B}=$ B-nor-pregnane).

Homo $=$ ho (e.g., PhoD=D-homo-pregnane)

Abeo $=\mathbf{a b}$

Cyclo $=$ eye

Retro $=$ ret

Seco $=$ sec

\section{Derivatives (in order of precedence)}

With each parent hydrocarbon, its immediate derivatives are classified in the following order:

Isomerism: Isomerism at $\mathrm{C}_{5}$ is indicated by $\boldsymbol{5} \boldsymbol{\alpha}$ or $\boldsymbol{5} \boldsymbol{\beta}$ following the symbol of the parent hydrocarbon (e.g., $\mathbf{A} 5 \boldsymbol{\alpha}=5 \alpha$-androstane). Isomers are listed next to each other, $\alpha$ before $\beta$. For ring-isomers, $c f$. below.

Unsaturation: $-\mathrm{C}-\mathrm{C}-$ (an), e.g., $\mathbf{A}$ (for Androstane), 
$-\mathrm{C}=\mathrm{C}-$ (en), e.g., $\mathrm{A}^{4}$ (for Androst-4-ene), $\mathrm{A}^{4,6}$ (for Androsta-4,6-diene).

The number of unsaturations is not indicated as it is evident from the positional number(s) in the superscript. Thus, $\mathbf{A}^{4,6}$ suffices to indicate that we are dealing with a diene. [Not $\Delta^{1,2, e t c .}$. Cyclosteroids are also identified by superscripts, e.g., $\mathbf{A}^{3(5)}$. The superscript numbers of triple bonds (-yn) are repeated (e.g., $\mathbf{P}^{20-20}$ ).

Alcohols: $-\mathrm{OH}$ (ol), e.g., $\mathrm{Aol}_{17 \alpha}$ (for Androstan-17 $\alpha$-ol),

Aol $_{3 \beta, 17 \alpha}$ (for Androstane-3 $\beta, 17 \alpha$-diol). [Not hydroxy, dihydroxy, etc.]

Esters: $-\mathrm{CO} \overline{\mathrm{OHH}} \mathrm{OC}-\left({ }^{*}\right)$, e.g., $\mathrm{P} * \mathrm{Bz}^{\prime \prime}{ }_{3 \alpha}$ ${ }^{*} \mathrm{II}^{\prime \prime}{ }_{17 \beta} \quad$ (for $3 \alpha, 17 \beta$-Dihydroxypregnane 3 benzoate 17 -acetate).

Esters are identified by an asterisk preceding the symbol of the acid, with which the steroid hydroxy group is esterified; they are listed immediately following the corresponding free alcohols. Since ester formation is possible only with alcohol groups, it is redundant to identify the position of each (the alcohol and acid) separately (cf. also below). [Not oxy (e.g., acetoxy) or "acid ester" (e.g., acetic acid ester)]. Esters of steroid acids are distinguished by placing the symbol for acid (") immediately after that of the steroid, before the asterisk (e.g., $\mathrm{P}^{\prime \prime *} \mathrm{IIol}_{21}$ for 21-pregnanoic acid esterified with ethanol).

Ketones: $\mathrm{C}=\mathrm{O}$ (-on), e.g., $\mathrm{E}^{1,3,5(10)} \mathrm{ol}_{3} \mathrm{On}_{17 \mathrm{\beta}}$ (for 3-Hydroxy-1,3,5(10)-estratrien-17-one or estrone). [Not oxo, keto, one (with terminal "e") and the redundant indication of the number of ketone groups by dione, trione, etc.]

Carboxylic acids: - $\mathrm{COOH}\left({ }^{\prime \prime}\right)$, e.g., $\mathbf{P}_{21}$ (for Pregnan-21-oic acid). Here the carboxyl group itself is considered to be part of the steroid skeleton, not an oxidized methyl sidechain on 21-norpregnane. However, a carboxyl which is not part of a recognized main parent hydrocarbon, but is attached to it by a C-C linkage, is written as an oxidized methyl sidechain (e.g., $\mathbf{A I}^{\prime \prime}{ }_{16 \alpha}$ for androstane $16 \alpha$-carboxylic acid). Carboxylic acids not attached to the steroid skeleton by C-C linkages, e.g., those of esters, are similarly identified (by "), e.g., $\mathrm{I}^{\prime \prime}=$ formic, $\mathrm{III}^{\prime \prime}=$ propionic, $\mathrm{V}^{\prime \prime}=$ pentanoic. $\mathrm{Bz}^{\prime \prime}=$ benzoic acid (cf. p. 778) for alkane symbols). [Not carboxylic acid or -oic acid.]

Steroid acid esterified (e.g., $\mathbf{P}^{\prime \prime *} \operatorname{IIIol}_{16 \alpha}$ ).

Steroid alcohol esterified (e.g., $\mathrm{P}^{*} \mathrm{III}^{\prime \prime}{ }_{16 \alpha}$ ).

Ethers: $-\mathrm{CO} \mathrm{HHO} \mathrm{C}-(\theta)$, e.g., $\theta \mathrm{I}, \theta \mathrm{II}$, $\theta$ PIII (for methyl, ethyl or propyl ethers). [Not methoxy or methyl ether.]

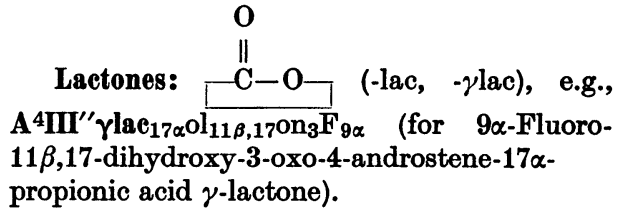

Aldehydes: - CHO (-al), e.g., $\mathbf{P}^{4} \mathrm{ol}_{11 \beta, 21}$ on $_{3,20} \mathrm{al}_{18}$ (for 11 $\beta, 21$-Dihydroxy-3,20-dioxo4-pregnen-18-al or aldosterone). As with the carboxylic acids, here the carbon bearing the aldehyde function is considered part of the parent hydrocarbon and is not derived from a methyl side chain. Otherwise, we would have the grotesque situation of deriving aldosterone from an 18nor, but 18 methylated pregnane.

Hemiacetals, acetals, hemiketals and ketals: The symbols used for hydroxy and other groups (e.g., ol, $\theta \mathrm{I}$ ) will be applied.

Hemiacetals: $\begin{gathered}\mathrm{H} \\ \mathrm{R}-\mathrm{C}-\mathrm{OH}(1 / 2 \text { acetal }) \text { reac- } \\ \mathrm{O}_{\mathrm{OR}} \mathbf{l}\end{gathered}$ tion product of an aldehyde with one alcohol group.

$\mathrm{H}$
Acetals: $\mathrm{R}-\mathrm{C}-\mathrm{OR}^{1}$ (acetal, not abbre-
$\mathrm{O}^{2}$ viated) reaction product of an aldehyde with two alcohol groups.

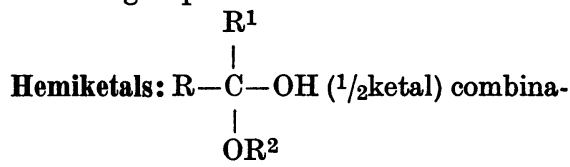

tion of a ketone with one alcohol group.

Ketals: $\begin{gathered}\mathrm{R}-\mathrm{C} \mathbf{C}-\mathrm{OR}^{2} \text { (ketal, not abbreviat- } \\ \text { I } \\ \mathrm{OR}^{3}\end{gathered}$

ed) combination of a ketone with two alcohol groups.

Epoxy: $\stackrel{\text { Ć }}{\text { - }}$ C̀ (regarded as ethers). An oxygen attached to two vicinal carbons, e.g., $\mathbf{A} \theta_{1 \alpha-2}$ (for 1,2 $\alpha$-epoxy-androstane).

Halo compounds: $\mathrm{Br}, \mathrm{Cl}, \mathrm{F}$, i (-bromo, -chloro, -fluoro, -iodo), e.g., $\mathrm{P}^{4} \mathrm{Cl}_{9 \alpha}$ (for $9 \alpha$ Chloro-4-pregnene). Instead of "I" for iodine write "i" (e.g., $\left.\mathbf{P}^{4} \mathbf{i}_{9 \alpha}\right)$ to avoid confusion with methyl, whose symbol is roman one.

Nitrogen containing steroids: $\mathrm{NH}_{2}$ (for amino), $\mathrm{NH}$ (for imino), $\mathrm{CN}$ (for carbonitrile or 
cyano). These symbols are used as such in SSS terms. However, symbols with subscript numbers $\left(\mathrm{NH}_{2}\right)$ are bracketed.

e.g., $\mathrm{ANH}_{17}$ (for 17-imino-androstane),

$\mathrm{P}^{5} \mathrm{CN}_{16 \alpha} \mathrm{Ol}_{3 \beta} \mathrm{On}_{20}$ (for 3 $\beta$-Hydroxy-20-oxo5-pregnene-16 $\alpha$-carbonitrile or PCN). All other N-containing steroids, including the alkaloids, belong to this group. The aza-steroids are listed last, in the heterocyclic category (cf. below).

Sulfosteroids: All thio compounds, e.g.,

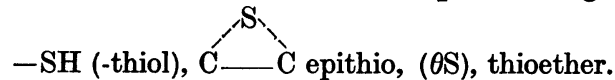

Heterocyclic steroids: These are listed separately for each element replacing carbon in the ring structure. They are indicated by the chemical symbol of the substituent in brackets, followed by a subscript number identifying the position of the replaced ring carbon after the symbol of the parent hydrocarbon (e.g., $\mathbf{A}\left(\mathbf{0}_{2}\right)$ for 2-Oxa-androstane, $\mathbf{P}\left(\mathrm{N}_{3}\right)$ for 3-Azapregnane).

Ring modifications: (cf. p. 775).

Other non alkyl-substituted compounds: Here, we list all those non alkyl-substituted compounds for which no category has been foreseen above.

\section{Secondary Parent Hydrocarbons}

All radicals attached to the parent hydrocarbon by a earbon-to-carbon linkage are considered to form "secondary parent hydrocarbons." They are written by attaching the symbol for the substituent following that of the parent hydrocarbon, both being underlined (e.g., $\mathbf{A} 5 \alpha \mathrm{I}_{17 \alpha}=17 \alpha$-methyl-5 $\alpha$-androstane).

All alkyl derivatives, except those listed themselves as main parent hydrocarbons (e.g., $17 \beta$-ethyl-androstane $=$ pregnane), are regarded as alkyl derivatives of the latter. This includes even $17 \alpha$-ethyl-androstane whose essential difference from pregnane is further emphasized by attaching the side chain to the structure formula of androstane, not only by an alpha (...) bond, but horizontally.

The alkyl side-chains are enumerated: 1. according to the increasing numbers of the carbon atoms to which they are attached on the skeleton of the main parent hydrocarbon and 2. according to increasing numbers of the carbon atoms they contain (methyl, ethyl, propyl, butyl, etc.). Saturated radicals are mentioned first, and those with double bonds in the order of increasing unsaturation. Triple bonds (superscript position numbers boldface e.g.: $\mathbf{P}^{20}$ ) are mentioned after all multiple double bonds. Branched and ringsubstituents are listed in the order of increasing complexity. (For corresponding symbols, cf. p. 778.)

Among the aliphatic 17-alkyl-androstanes, only pregnanes, cholanes, cholestanes, ergostane and stigmastan are regarded as special parent hydrocarbons because of their common occurrence.

\section{Order of Precedence in General}

The order of precedence for the above mentioned substituents is rigidly observed except in the first (underlined or boldface) portion of the SSS terms of secondary parent hydrocarbons. As previously stated, here all substituents attached to a side-chain are listed immediately after the positional number of the latter, to avoid subsequent repetition

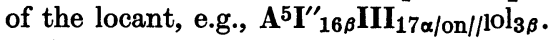

When two or more identical substituents appear in the same molecule, all these must be enumerated before considering compounds possessing additional substituents mentioned later in the above list (e.g., all -enes before -dienes, before -trienes, etc.; all -ols before -diols, before -triols, etc.). Only after this do we proceed to compounds having an additional type of substituent (e.g., only after all monoand polyols do we procede to -ones).

All unsaturations (double, triple and cyclizing bonds) and substitution products are listed according to the ascending order of the affected earbons (e.g., in pregnanes 1-21). Ring modifications, such as contractions (nor), expansions (homo), openings (sec), etc. are listed in the order of the ring lettering $(A-D)$.

\section{Computerization}

Subscript and superscript notations are unsuitable for computerization but SSS names can be written in a single line without loss of precision. E.g., normally we write dehydroepiandrosterone thus: $\mathrm{A}^{5} \mathrm{Ol}_{17} \beta^{\circ} \mathrm{n}_{3}$ and the corresponding $5 \alpha$ saturated compound thus: $A 5 \alpha \mathrm{ol}_{17 \beta} \mathrm{On}_{3}$. For computer use, these two steroids can be written respectively $\mathrm{A} 5$ ol $17 \beta$ on 3 and $A 5 \alpha$ ol $17 \beta$ on 3 .

The superscript position of a number following the symbol for the parent hydrocarbon (e.g., $\mathbf{A}^{5}$ ) merely facilitates its immediate recognition as a double bond. Similarly the subscript position of numbers helps to identify them as locants. But actually, this style is not indispensable if the constituent symbols are properly separated. The rule of "first what, 
then where" makes it obvious that the " 5 " belongs to the " $\mathbf{A}$ ", the " $17 \boldsymbol{\beta}$ " to the "ol", and the " 3 " to the "on". The number 5 could only indicate a double bond; it would have to be followed by $\alpha, \beta$, or $\xi$ if it were to denote the steric position of the 5-hydrogen. Even the omission of underlining (or boldface printing) of the parent hydrocarbon would not introduce any ambiguity. Greek letters such as $\alpha, \beta$, or $\xi$, can be written out as alpha, beta or xi, and the roman numerals can be composed by capitals on computers, just as on typewriters that do not have corresponding signs. The use of capital and small letters is likewise not necessary, but it helps rapid reading and is recommended for those who have the appropriate modern computer equipment.

\section{Chemical Symbols}

, = sign of separation. To be used at discretion of codifier, wherever two adjacent symbols might be read as one (e.g., on 4,6 ).
* = ester (precedes symbol of acid. E.g.: *III = propyl ester).

$\theta=$ ether (precedes symbol of alkyl. E.g.: $\theta \mathrm{I}=$ methoxy or methyl ether).

$\mathbf{A}=$ androstan (for symbols of other parent hydrocarbons, $c f$. p. 775). Only parent hydrocarbons and all alkyls attached to them by carbon-to-carbon linkages are bold face (E.g.: $\mathbf{A I I I}_{17 \beta} \mathbf{I}_{2 \alpha} \mathrm{Ol}_{4 \beta} \mathrm{On}_{11}=$ $17 \beta$-propyl-2 $\alpha$-methyl androstane with $4 \beta$-alcohol and 11-keto groups.)

$/, / /=$ successive levels (subdivisions) in a code, obviating the need for more than one subscript line (e.g., 2-methylbutane = $\left.\mathrm{IV}_{\mathrm{I} / 2}\right)$. The successive levels of more complex branchings coded according to the general formula: $R_{R}^{\prime} / 2 / / R^{\prime \prime} / / / 3$ (e.g., 2(3-methylbutyl)-heptane $=$ $\mathrm{VII}_{\left.\mathrm{IV} / 2 / / \mathrm{I} / / 3 \cdot \mathbf{3}^{\circ}\right)}$

( ) = brackets are used to enclose symbols with subscript numbers which might be confused with locants, e.g., $\left(\mathrm{NH}_{2}\right)$, $\left(\mathrm{CH}_{2}\right)$.

\begin{tabular}{|c|c|c|c|c|c|}
\hline \multirow{2}{*}{$\begin{array}{l}\text { Substituents } \\
\text { Alkanes, normal } \\
\text { Alkanes, branched }\end{array}$} & \multirow{2}{*}{$\begin{array}{l}\text { Methyl } \\
\text { Formic } \\
\text { I } \\
-\end{array}$} & \multirow{2}{*}{$\begin{array}{l}\text { Ethyl } \\
\text { Acetic }\end{array}$} & \multirow{2}{*}{$\begin{array}{l}\begin{array}{l}\text { Propyl } \\
\text { Propionic }\end{array} \\
\text { III } \\
\text { III I/2 } \\
\text { (2-methyl- } \\
\text { propane) }\end{array}$} & \multicolumn{2}{|l|}{ Butyl } \\
\hline & & & & \multicolumn{2}{|c|}{$\begin{array}{l}\text { IV } \\
\text { IV }_{\mathrm{I} / 2,3} \\
(2,3 \text {-dimethyl- } \\
\text { butane })\end{array}$} \\
\hline $\begin{array}{l}\text { Alcohols } \\
\text { Acids } \\
\text { Aldehydes }\end{array}$ & $\begin{array}{l}\text { I ol } \\
I^{\prime \prime} \\
\text { Ial }\end{array}$ & $\begin{array}{l}\text { II ol } \\
\text { II" } \\
\text { IIal }\end{array}$ & $\begin{array}{l}\text { III ol } \\
\text { III" } \\
\text { IIIal }\end{array}$ & $\begin{array}{l}\text { IV ol } \\
\text { IV' } \\
\text { IVal }\end{array}$ & $\begin{array}{l}\text { Symbols of side chains } \\
\text { bound to ring by carbon } \\
\text { to-carbon linkages, fol } \\
\text { low roman numerals. }\end{array}$ \\
\hline $\begin{array}{l}\text { Esters } \\
\text { Ethers }\end{array}$ & $\begin{array}{l}* \mathrm{I} \\
\theta \mathrm{I}\end{array}$ & $\begin{array}{l}* \mathrm{II} \\
\theta \mathrm{II}\end{array}$ & $\begin{array}{l}* \text { IIII } \\
\theta \text { III }\end{array}$ & $\begin{array}{l}* \text { IV } \\
\theta \mathrm{IV}\end{array}$ & $\begin{array}{l}\text { Symbols of groups } \\
\text { bound to ring by } \\
\text { oxygen, precede } \\
\text { roman numerals. }\end{array}$ \\
\hline
\end{tabular}

The 92 carbonitriles of Table 135 have been arranged according to the increasing number of the skeletal carbon atoms to which the - $\mathrm{CN}$ groups or - CN-bearing side-chains are attached. A few additional steroids, other than nitriles (Cpds. 93-99) are listed in arbitrary order.

The most potent catatoxic steroids against both substrates of this test were those bearing a $2 \alpha$ - or $16 \alpha$-carbonitrile group. Among these, several showed potency against one or both substrates at individual dose levels as low as $100 \mu \mathrm{g}$ or even $30 \mu \mathrm{g}$. In general, protection against indomethacin was more readily obtained than against digitoxin. 
Table 135. First step: Screening of steroids against digitoxin and indomethacin intoxication

\begin{tabular}{lcc}
\hline Group & Steroids & $\begin{array}{c}\text { Dose Digi- Indo- } \\
(\mathrm{mg})\end{array}$ \\
$\begin{array}{c}\text { toxin }{ }^{\mathrm{a}} \text { metha- } \\
\operatorname{cin}^{\mathrm{a}}\end{array}$ \\
\hline
\end{tabular}

$\mathrm{CN}_{1,2,3}$ Steroid Carbonitriles

1

IM $433^{\mathrm{b}}$<smiles>C[C@H]1CCC2C3CC[C@@H]4CC(=O)C[C@H](O)C4(C)C3CCC21</smiles>

2

IM 427<smiles>C[C@H]1CC(=O)C[C@H]2CCC3C4CC[C@H](O)C4(C)CCC3[C@]12C</smiles>

3

IM 364

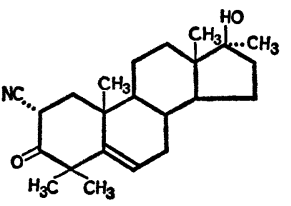

4

IM 568

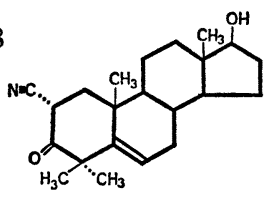

5

IM 368

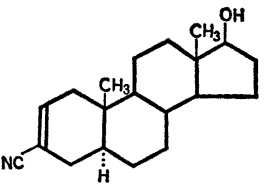

6

IM 365

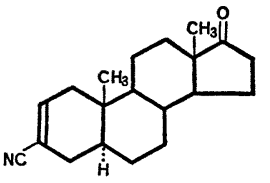

7

IM 367

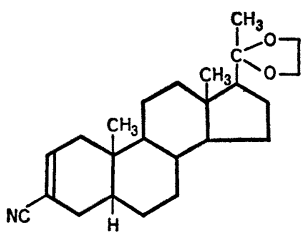

$17 \beta$-Hydroxy-3-oxo-5 $\alpha$-androstane- $\quad 0.5 \quad 0 \quad 0$ $1 \alpha$-carbonitrile acetate (SC-16027)

$\mathrm{A5} \alpha \mathrm{CN}_{1 \alpha} * \mathrm{II}^{\prime \prime}{ }_{17 \beta} \mathrm{On}_{3}$

17 $\beta$-Hydroxy-3-oxo-5 $\alpha$-androstane- $\quad 0.5 \quad 0 \quad 0$ $1 \alpha$-carbonitrile (SC-16026)

$\mathrm{A}_{5} \alpha \mathrm{CN}_{1 \alpha} \mathrm{Ol}_{17 \beta} \mathrm{On}_{3}$

17 $\beta$-Hydroxy-4,4,17-trimethyl-3- $\quad \begin{array}{llll}10 & 3 & 3\end{array}$ oxo-5-androstene-2 $\alpha$-carbonitrile. $\quad 0.5 \quad 2.5 \quad 3$

Trimethylandrostenolone carbonitrile, $\quad \begin{array}{llll}0.1 & 2 & 2\end{array}$

"TMACN" (Winthrop)

$\begin{array}{lll}0.03 & 0 & 0\end{array}$

$\mathbf{A}^{5} \mathbf{I}_{4,4,17 \alpha} \mathbf{C N}_{2 \alpha} \mathrm{Ol}_{17} \mathrm{On}_{3}$

$\begin{array}{lllll}17 \beta \text {-Hydroxy-4,4-dimethyl-3-oxo- } & 0.5 & 2 & 0.5\end{array}$ 5-pregnene-2 $\alpha$-carbonitrile (U-26854) $\quad 0.03 \quad 0 \quad-$

$\mathrm{A}^{5} \mathrm{I}_{4,4} \mathrm{CN}_{2 \alpha} \mathrm{Ol}_{17 \beta} \mathrm{On}_{3}$

$17 \beta$-Hydroxy-5 $\alpha$-androst-2-ene- $\quad 10 \quad 0.5 \quad 2$ $\begin{array}{llll}3 \text {-carbonitrile (Lepetit) } & 0.5 & 0 & 0\end{array}$

$\mathrm{A5} \ddot{\alpha}^{2} \mathrm{CN}_{3} \mathrm{Ol}_{17 \beta}$

17-0xo-5 $\alpha$-androst-2-ene- $\quad \begin{array}{llll}10 & 2 & 2\end{array}$

$\begin{array}{llll}3 \text {-carbonitrile (Lepetit) } & 0.5 & 0 & 0\end{array}$

$\mathrm{A}_{5} \alpha^{2} \mathrm{CN}_{3} \mathrm{On}_{17}$

20,20-(Ethylenedioxy)-5 $\beta$-pregn-2- $\quad 10 \quad 0 \quad 0$ ene-3-carbonitrile (Lepetit)

$\mathrm{P}_{5} \boldsymbol{\beta}^{2} \mathrm{CN}_{3} \theta \theta \mathrm{II}_{20}$

a For details, see Digitoxin and Indomethacin in the list of techniques used to produce and appraise various types of damage.

b Underneath the serial number of the compounds, the "IM" numbers (for Institut de Médecine et de Chirurgie expérimentales) are mentioned. These identify steroids in our collection and remain the same in all Tables as well as in other publications from this Institute. 
Table 135 (continued)

\begin{tabular}{|c|c|c|c|c|}
\hline Group & Steroids & $\begin{array}{l}\text { Dose } \\
\text { (mg) }\end{array}$ & $\begin{array}{l}\text { Digi- } \\
\text { toxin }\end{array}$ & $\begin{array}{l}\text { Indo- } \\
\text { metha- } \\
\text { cin }^{2}\end{array}$ \\
\hline \multirow[t]{2}{*}{$\begin{array}{l}8 \\
\text { IM } 366\end{array}$} & $\begin{array}{l}\text { 20,20-(Ethylenedioxy)-5 } \alpha \text {-pregn- } \\
\text { 2-ene-3-carbonitrile (Lepetit) }\end{array}$ & \multirow{2}{*}{$\begin{array}{c}10 \\
0.5 \\
-0.03\end{array}$} & \multirow{2}{*}{$\begin{array}{l}0.5 \\
0 \\
-\end{array}$} & \multirow{2}{*}{$\begin{array}{l}2 \\
2 \\
0\end{array}$} \\
\hline & $\mathrm{P} \alpha^{2} \mathrm{CN}_{3} \theta, \theta \mathrm{II}_{20}$ & & & \\
\hline \multirow[t]{2}{*}{$\begin{array}{l}9 \\
\text { IM } 424\end{array}$} & $\begin{array}{l}17 \beta \text {-Hydroxy-3} \xi \text {-amino- } 5 \alpha \text {-andro- } \\
\text { stane-3-carbonitrile (SC-13265) }\end{array}$ & \multirow[t]{2}{*}{0.5} & \multirow[t]{2}{*}{0} & \multirow[t]{2}{*}{0} \\
\hline & $\mathrm{A5} \alpha \mathrm{CN}_{3 \xi} \mathrm{Ol}_{17 \beta}\left(\mathrm{NH}_{2}\right)_{3}$ & & & \\
\hline
\end{tabular}

$\mathrm{CN}_{5}$

10

IM 420<smiles>CC12CCC(=O)CC1(C)C1CCC3C(CC[C@]3(C)O)C1CC2</smiles>

11

IM 434<smiles>CC12CCCC34CC5(CCC3C1CCC2O)CC(=O)CCC54C</smiles>

12

IM 432

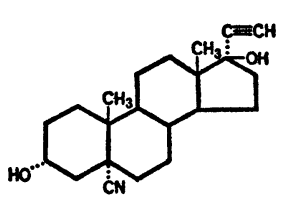

13

IM 431

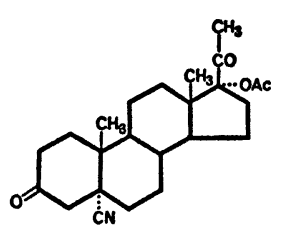

14

IM 430

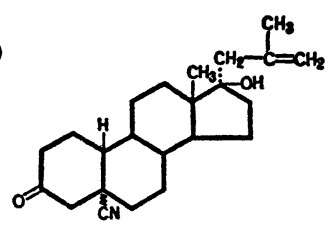

$17 \beta$-Hydroxy-3-oxo-5 $\beta$-androstane- $10 \quad 0 \quad 0$ $\begin{array}{llll}5 \text {-carbonitrile (SC-13389) } & 0.03 & 0 & 0\end{array}$

$\begin{array}{llll}{\mathrm{A} 5 \beta \mathrm{CN}_{5} \mathrm{Ol}_{17 \beta} \mathrm{On}_{3}} & 0.015 & 0 & 0 \\ & 0.005 & 0 & 0 \\ & 0.001 & 0 & 0\end{array}$

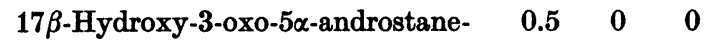
5-carbonitrile (SC-13269)

$\mathrm{AL}_{\alpha} \mathrm{CN}_{5} \mathrm{Ol}_{17 \beta} \mathrm{On}_{3}$

$3 \alpha, 17-D i h y d r o x y-5 \alpha, 17 \alpha-$ pregn-

$\begin{array}{lll}0.5 & 0 & 0\end{array}$ 20-yne-5-carbonitrile (SC-13675)

${\mathrm{A5} \alpha \mathrm{CN}_{5} \mathrm{II}^{1-1}{ }_{17 \alpha} \mathrm{Ol}_{3 \alpha, 17}}$

17-Hydroxy-3,20-dioxo-5 $\alpha$-pregnane- $0.5 \quad 0 \quad 0$ 5-carbonitrile acetate (SC-13795)

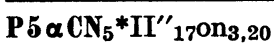

5 $\xi$-Cyano-17-hydroxy-17 $\alpha$-(2-methyl- $0.5 \quad 0 \quad 0$ allyl)-estran-3-one (SC-13969)

E5 CN $_{5} \mathrm{III}^{2}{ }_{17 \alpha / \mathrm{I} / / 2} \mathrm{Ol}_{17} \mathrm{On}_{3}$ 
Table 135 (continued)

\begin{tabular}{|c|c|c|c|c|}
\hline Group & Steroids & $\begin{array}{l}\text { Dose } \\
\text { (mg) }\end{array}$ & $\begin{array}{l}\text { Digi- } \\
\text { toxina }\end{array}$ & $\begin{array}{l}\text { Indo- } \\
\text { metha- } \\
\text { cin }^{\mathrm{a}}\end{array}$ \\
\hline \multirow[t]{2}{*}{$\begin{array}{l}15 \\
\text { IM } 428\end{array}$} & $\begin{array}{l}5 \beta \text {-Cyano-17-hydroxy-17 } \alpha \text {-(2-methyl- } \\
\text { allyl)-estran-3-one (SC-14373) } \\
\end{array}$ & 0.5 & $\mathbf{0}$ & 0 \\
\hline & $\mathrm{E} 5 \beta \mathrm{CN}_{5} \mathrm{III}_{17 \alpha / \mathrm{I} / / 2} \mathrm{Ol}_{17} \mathrm{On}_{3}$ & & & \\
\hline \multirow[t]{2}{*}{$\begin{array}{l}16 \\
\text { IM } 435\end{array}$} & $\begin{array}{l}\text { 17-Hydroxy-3-oxo-19-nor-5 } \beta, 17 \alpha- \\
\text { pregn-20-yne-5-carbonitrile (SC-13823) }\end{array}$ & 0.5 & 0 & 0 \\
\hline & $\mathrm{E} 5 \beta \mathrm{CN}_{5} \mathrm{II}^{1-1}{ }_{17 \alpha} \mathrm{Ol}_{17} \mathrm{On}_{3}$ & & & \\
\hline \multirow[t]{2}{*}{$\begin{array}{l}17 \\
\operatorname{IM} 426\end{array}$} & $\begin{array}{l}17 \beta \text {-Hydroxy-17-methyl-3-oxo-5 } \beta \text { - } \\
\text { androstane-5-carbonitrile (SC-13754) }\end{array}$ & 0.5 & 0 & 0 \\
\hline & $\mathrm{A5} \beta \mathrm{I}_{17 \alpha} \mathrm{CN}_{5} \mathrm{Ol}_{17} \mathrm{On}_{3}$ & & & \\
\hline \multirow[t]{2}{*}{$\begin{array}{l}18 \\
\text { IM } 425\end{array}$} & $\begin{array}{l}17 \beta \text {-Hydroxy-17-methyl-3-oxo-5 } \alpha \text { - } \\
\text { androstane-5-carbonitrile (SC-13503) }\end{array}$ & 0.5 & $\mathbf{0}$ & 0 \\
\hline & $\mathbf{A} 5 \alpha \mathbf{I}_{17 \alpha} \mathrm{CN}_{5} \mathrm{Ol}_{17} \mathrm{On}_{3}$ & & & \\
\hline \multirow[t]{2}{*}{$\begin{array}{l}19 \\
\text { IM } 422\end{array}$} & $\begin{array}{l}17 \beta \text {-Hydroxy-3-oxo-5 } \beta \text {-androstane- } \\
5 \text {-carbonitrile propionate (SC-14175) }\end{array}$ & 0.5 & 0 & 0 \\
\hline & $\mathrm{A} 5 \beta \mathrm{CN}_{5} * \mathrm{III}^{\prime \prime}{ }_{17 \beta} \mathrm{On}_{3}$ & & & \\
\hline \multirow[t]{2}{*}{$\begin{array}{l}20 \\
\text { IM } 421\end{array}$} & $\begin{array}{l}17 \beta \text {-Hydroxy-3-oxo-5 } \alpha \text {-androstane- } \\
5 \text {-carbonitrile propionate (SC-14174) }\end{array}$ & 0.5 & $\mathbf{0}$ & 0 \\
\hline & $\mathrm{A5} \alpha \mathrm{CN}_{5} * \mathrm{IIII}_{17 \beta} \mathrm{On}_{3}$ & & & \\
\hline \multicolumn{5}{|l|}{$\mathbf{C N}_{6}$} \\
\hline \multirow[t]{2}{*}{21} & $\begin{array}{l}\text { 3 } \beta, 5 \alpha \text {-Dihydroxy-20-oxopregnane- } \\
6 \beta \text {-carbonitrile (Syntex) }\end{array}$ & 0.5 & $\mathbf{0}$ & 0 \\
\hline & $\mathrm{P} 5 \alpha \mathrm{CN}_{6 \beta 0 \mathrm{O}_{3 \beta, 5} \mathrm{On}_{20}}$ & & & \\
\hline
\end{tabular}


Table 135 (continued)

\begin{tabular}{|c|c|c|c|c|}
\hline Group & Steroids & $\begin{array}{l}\text { Dose } \\
\text { (mg) }\end{array}$ & $\begin{array}{l}\text { Digi- } \\
\text { toxin }^{2}\end{array}$ & $\begin{array}{l}\text { Indo- } \\
\text { metha- } \\
\text { cin }^{\mathrm{a}}\end{array}$ \\
\hline \multirow[t]{2}{*}{$\begin{array}{l}22 \\
\text { IM } 455\end{array}$} & $\begin{array}{l}\text { 3-(2'-Chloroethoxy)-6-cyano- } 9 \alpha \text {-fluoro } \\
\text { 3,5-pregnadiene-16 } \alpha, 17 \alpha, 21 \text {-triol-11, } \\
\text { 20-dion-21-acetate-16,17-acetonide } \\
\text { (Farmitalia) }\end{array}$ & $0-0.5$ & 0 & 1 \\
\hline & $\begin{array}{l}\mathbf{P}^{3,5} \mathbf{C N}_{6} * \mathrm{II}^{\prime \prime}{ }_{21} \mathrm{on}_{11,20} \theta \mathrm{II}_{3 \beta / \mathrm{C} 1 / / 2} \\
\theta \theta \mathrm{I}_{16 \alpha-17 / \mathrm{I}, \mathrm{I}} \mathrm{F}_{9 \alpha}\end{array}$ & & & \\
\hline
\end{tabular}

23

IM 456

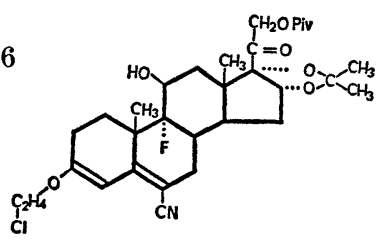

24

IM 457

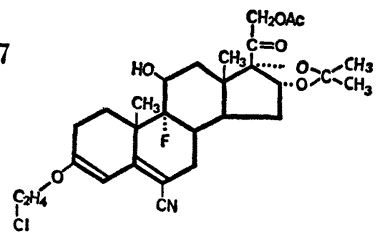

25

IM 458

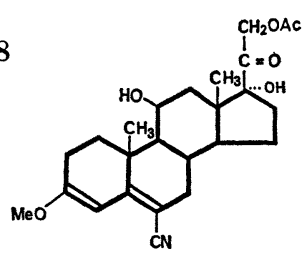

26

IM 459<smiles>CC(C)=O</smiles>

$\mathrm{CN}_{16}$

27

IM 346

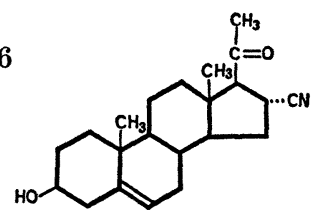

3-(2'-Chloroethoxy)-6-cyano-9 $\alpha$ -

$0.5 \quad 0$

fluoro-3,5-pregnadiene-11 $\beta, 16 \alpha, 17 \alpha$,

21-tetrol-20-one-21-pivalat-16,17-

acetonide (Farmitalia)

$\mathbf{P}^{3,5} \mathbf{C N}_{6} \mathrm{Ol}_{11 \beta}{ }^{*} \mathrm{IIII}_{21 / \mathrm{I} / 2,2} \mathrm{On}_{20}$

$\theta \mathrm{II}_{3 / \mathrm{C} 1 / 2} \theta \theta_{16 \alpha-17 / \mathrm{I}, \mathrm{I}} \mathrm{F}_{9 \alpha}$

3-( $2^{\prime}$-Chloroethoxy)-6-cyano-9 $\alpha$ -

fluoro-3,5-pregnadiene-11 $\beta, 16 \alpha, 17 \alpha$,

21-tetrol-20-one-21-acetate-16,17-

acetonide (Farmitalia)

$\mathrm{P}^{3,5} \mathrm{CN}_{6} \mathrm{ol}_{11 \beta} * \mathrm{III}_{21}{ }_{21} \mathrm{On}_{20}$

$\theta \mathrm{II}_{3 / \mathrm{C} 1 / / 2} \theta \theta \mathrm{I}_{16 \alpha-17 / \mathrm{I}, \mathrm{I}} \mathrm{F}_{9 \alpha}$

$3 \beta, 11 \beta, 17 \alpha, 21$-Tetrahydroxy-20-oxo-

3,5-pregnadiene-6-carbonitrile 3-me-

thyl ether, 21-acetate (BDH)

$\mathbf{P}^{3,5} \mathbf{C N}_{6} \mathrm{ol}_{11 \beta, 17 \alpha} * \mathrm{II}^{\prime \prime}{ }_{21} \mathrm{On}_{20} \theta \mathrm{I}_{3}$

3,16 $\alpha$-Dihydroxy-20-oxo-3,5-pregn-

adiene-6-carbonitrile 3-methyl ether,

16-acetate (Glaxo Canada Ltd.)

$\mathrm{P}^{3,5} \mathrm{CN}_{6} * \mathrm{II}^{\prime \prime}{ }_{16 \alpha} \mathrm{On}_{20} \theta \mathrm{I}_{3}$ $\begin{array}{lll}0.5 & 0 & 0\end{array}$

$\begin{array}{lll}0.5 & 0 & 0\end{array}$

$\begin{array}{lll}0.5 & 0 & 0\end{array}$

$3 \beta$-Hydroxy-20-oxo-5-pregnene-16 $\alpha$ - $10 \quad 3 \quad 3$

carbonitrile (SC-4674), (U-14975) 11303

Pregnenolone carbonitrile " $P C N$ " $\quad 0.5 \quad 3 \quad 3$

$\mathrm{P}^{5} \mathrm{CN}_{16 \alpha} \mathrm{Ol}_{3 \beta} \mathrm{On}_{20}$

$\begin{array}{lll}0.2 & 3 & 3\end{array}$

$\begin{array}{lll}0.1 & 3 & 3\end{array}$

$\begin{array}{lll}0.03 & 2 & 3\end{array}$

$\begin{array}{lll}0.015 & 0 & 0\end{array}$ 
Table 135 (continued)

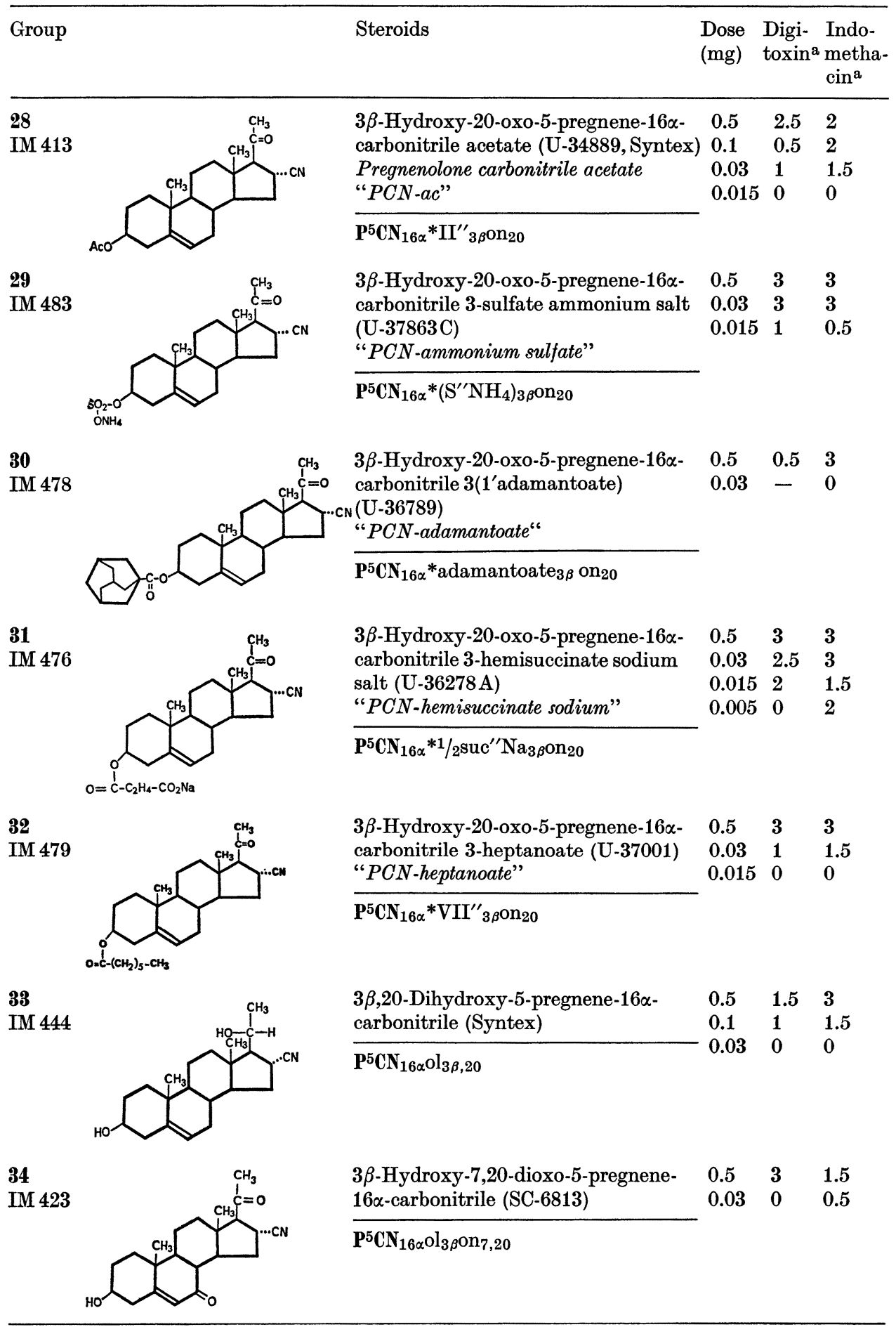


Table 135 (continued)

\begin{tabular}{|c|c|c|c|c|}
\hline Group & Steroids & $\begin{array}{l}\text { Dose } \\
\text { (mg) }\end{array}$ & $\begin{array}{l}\text { Digi- } \\
\text { toxin }^{2}\end{array}$ & $\begin{array}{l}\text { Indo- } \\
\text { a metha- } \\
\text { cin }^{2}\end{array}$ \\
\hline \multirow[t]{2}{*}{$\begin{array}{l}35 \\
\text { IM } 429\end{array}$} & $\begin{array}{l}3 \beta \text {-Hydroxy-7,20-dioxo-5-pregnene- } \\
16 \alpha \text {-carbonitrile acetate (SC-6703) }\end{array}$ & $\begin{array}{l}0.5 \\
0.03\end{array}$ & $\begin{array}{l}3 \\
\mathbf{0}\end{array}$ & $\begin{array}{l}2 \\
1.5\end{array}$ \\
\hline & $\mathrm{P}^{5} \mathrm{CN}_{16 \alpha} * \mathrm{II}^{\prime \prime}{ }_{3 \beta} \mathrm{On}_{7,20}$ & & & \\
\hline \multirow[t]{2}{*}{$\begin{array}{l}36 \\
\text { IM } 474\end{array}$} & $\begin{array}{l}\text { 4,4-Dimethyl-3,20-dioxo-5-pregnene- } \\
16 \alpha \text {-carbonitrile (U-35641) }\end{array}$ & $\begin{array}{l}0.5 \\
0.03\end{array}$ & 0.5 & $\begin{array}{l}\mathbf{3} \\
\mathbf{0}\end{array}$ \\
\hline & $\mathrm{P}^{5} \mathrm{I}_{4,4} \mathrm{CN}_{16 \alpha} \mathrm{On}_{3,20}$ & & & \\
\hline
\end{tabular}

37

IM 411

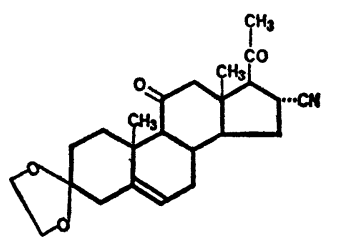

38

IM 418

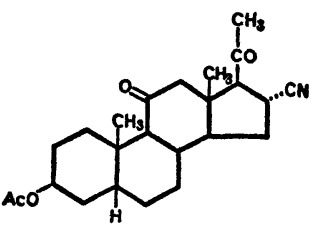

39

IM 464

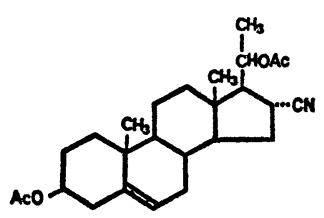

40

IM 462<smiles>CC1CC2C3CC=C4CC(O)CCC4(C)C3CCC2(C)C1C(=O)O</smiles>

41

IM 482

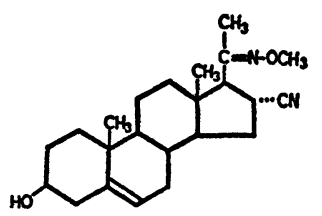

3,3-(Ethylenedioxy)-11,20-dioxo-5- $\quad 0.5 \quad 2.5 \quad 2$ pregnene-16 $\alpha$-carbonitrile (U-35006) $\quad 0.1 \quad 2.5 \quad 2$

$\begin{array}{llll}\mathrm{P}^{5} \mathrm{CN}_{16 \alpha} \mathrm{On}_{11,20} \theta \theta \mathrm{II}_{3,3} & 0.03 & 0 & 1.5 \\ & 0.015 & 0 & 1.5\end{array}$

3 $\beta$-Hydroxy-11,20-dioxo-5 $\beta$ pregnane-16 $\alpha$-carbonitrile acetate (U-34575)

$\begin{array}{lll}0.5 & 2.5 & 2\end{array}$

$\begin{array}{lll}0.1 & 2.5 & 2\end{array}$ $\begin{array}{lll}0.03 & 0 & 1.5\end{array}$

${\mathrm{P} 5 \beta \mathrm{CN}_{16 \alpha} * \mathrm{II}^{\prime \prime}{ }_{3 \beta} \mathrm{On}_{11,20}}$

$16 \alpha$-Cyano-5-pregnene-3 $\beta, 20 \beta$-diol diacetate (SC-5482)

$\begin{array}{lll}0.1 & 0 & 2\end{array}$ $0.03-0$
3 $\beta$-Hydroxy-20-oxo-5-pregnene-16 $\alpha$ - $0.5 \quad 3 \quad 3$ carbonitrile,20-oxime (U-37722)

$\begin{array}{llll}\mathrm{P}^{5} \mathrm{CN}_{16 \alpha} \mathrm{Ol}_{3 \beta} \mathrm{NOH}_{20} & 0.015 & 0.5 & 1 \\ 0.010 & - & 0\end{array}$

3 $\beta$-Hydroxy-20-oxo-5-pregnene-16 $\alpha-0.5 \quad 1 \quad 1.5$ carbonitrile,20-methyloxime (U-37694)

$\mathrm{P}^{5} \mathrm{CN}_{16 \alpha} \mathrm{Ol}_{3 \beta}\left(\mathrm{NOCH}_{3}\right)_{20}$ 
Table 135 (continued)

\begin{tabular}{|c|c|c|c|c|}
\hline Group & Steroids & $\begin{array}{l}\text { Dose } \\
\text { (mg) }\end{array}$ & $\begin{array}{l}\text { Digi- } \\
\text { toxin }\end{array}$ & $\begin{array}{l}\text { Indo- } \\
\text { metha- } \\
\text { cina }^{\mathrm{a}}\end{array}$ \\
\hline \multirow[t]{2}{*}{$\begin{array}{l}42 \\
\text { IM } 414\end{array}$} & $\begin{array}{l}\text { 20,20-(Ethylenedioxy)-3 } \beta \text {-hydroxy- } \\
\text { 5-pregnene-16 } \alpha \text {-carbonitrile } \\
\text { (U-19553) } \\
\end{array}$ & \multirow[t]{2}{*}{$\begin{array}{l}0.5 \\
0.1 \\
0.03 \\
0.015\end{array}$} & \multirow[t]{2}{*}{$\begin{array}{l}2.5 \\
2 \\
0.5 \\
0\end{array}$} & \multirow[t]{2}{*}{$\begin{array}{l}2 \\
2 \\
1.5 \\
0\end{array}$} \\
\hline & $\mathrm{P}^{5} \mathrm{CN}_{16 \alpha} \mathrm{Ol}_{3 \beta} \theta \theta \mathrm{II}_{20}$ & & & \\
\hline \multirow[t]{2}{*}{$\begin{array}{l}43 \\
\text { IM } 445\end{array}$} & $\begin{array}{l}3 \beta \text {-Hydroxy-20,20-ethylene-dioxy- } \\
\text { 5-pregnene-16 } \alpha \text {-carbonitrile acetate } \\
\text { (Syntex) }\end{array}$ & \multirow[t]{2}{*}{$\begin{array}{l}0.5 \\
0.1 \\
0.03\end{array}$} & \multirow[t]{2}{*}{$\begin{array}{l}1.5 \\
0 \\
0\end{array}$} & \multirow[t]{2}{*}{$\begin{array}{l}3 \\
1.5 \\
0\end{array}$} \\
\hline & $\mathrm{P}^{5} \mathrm{CN}_{16 \alpha} * \mathrm{II}^{\prime \prime}{ }_{3 \beta} \theta \theta \mathrm{II}_{20}$ & & & \\
\hline \multirow[t]{2}{*}{$\begin{array}{l}44 \\
\text { IM } 412\end{array}$} & $\begin{array}{l}\text { 3,3,20,20-Bis-ethylenedioxy-11-oxo- } \\
\text { 5-pregnene-16 } \alpha \text {-carbonitrile } \\
\text { (U-35910) }\end{array}$ & \multirow{2}{*}{$\begin{array}{l}0.5 \\
0.1 \\
0.03 \\
0.015\end{array}$} & \multirow{2}{*}{$\begin{array}{l}2.5 \\
0 \\
0 \\
0\end{array}$} & \multirow{2}{*}{$\begin{array}{l}2 \\
2 \\
1.5 \\
0\end{array}$} \\
\hline & $\mathrm{P}^{5} \mathrm{CN}_{16 \alpha} \mathrm{On}_{11} \theta \theta \mathrm{II}_{3,20}$ & & & \\
\hline \multirow[t]{2}{*}{$\begin{array}{l}45 \\
\text { IM } 475\end{array}$} & $\begin{array}{l}\text { 3,20-Dioxo-4-pregnene-16 } \alpha \text {-carbo- } \\
\text { nitrile,20-cyclic }\left(2^{\prime}, 2^{\prime} \text {-dimethyltrime- }\right. \\
\text { thylene acetal) (U-35655) }\end{array}$ & \multirow[t]{2}{*}{$\begin{array}{l}0.5 \\
0.03\end{array}$} & \multirow[t]{2}{*}{$\begin{array}{l}1.5 \\
0.5\end{array}$} & \multirow[t]{2}{*}{$\begin{array}{l}3 \\
0\end{array}$} \\
\hline & $\mathrm{P}^{4} \mathrm{CN}_{16 \alpha} \mathrm{On}_{3} \theta \theta \mathrm{III}_{20 / \mathrm{I} / / 2,2}$ & & & \\
\hline \multirow[t]{2}{*}{$\begin{array}{l}46 \\
\text { IM!461 }\end{array}$} & $\begin{array}{l}3 \beta \text {-Hydroxy-20-oxo-5-pregnene-16 } \alpha \text { - } \\
\text { carbonitrile, cyclic(2,2-dimethyl- } \\
\text { trimethylene acetal) (U-36961) }\end{array}$ & \multirow[t]{2}{*}{$\begin{array}{l}0.5 \\
0.03 \\
0.015\end{array}$} & \multirow[t]{2}{*}{$\begin{array}{l}2 \\
2 \\
0\end{array}$} & \multirow[t]{2}{*}{$\begin{array}{l}3 \\
\mathbf{0} \\
-\end{array}$} \\
\hline & $\mathrm{P}^{5} \mathrm{CN}_{16 \alpha} \mathrm{Ol}_{3 \beta} \theta \theta \mathrm{III}_{20 / \mathrm{I} / / 2,2}$ & & & \\
\hline \multirow[t]{2}{*}{$\begin{array}{l}47 \\
\text { IM } 481\end{array}$} & $\begin{array}{l}\text { 4,4-Dimethyl-3,20-dioxo-5-pregnene- } \\
16 \alpha \text {-carbonitrile,20-cyclic }\left(2^{\prime} 2^{\prime} \text {-di- }\right. \\
\text { methyltrimethylene acetal) (U-37542) }\end{array}$ & \multirow[t]{2}{*}{0.5} & \multirow[t]{2}{*}{$\mathbf{0}$} & \multirow[t]{2}{*}{0} \\
\hline & $\mathrm{P}^{5} \mathbf{I}_{4,4} \mathrm{CN}_{16 \alpha} \mathrm{On}_{3} \theta \theta \mathrm{III}_{20 / \mathrm{I} / 2,2}$ & & & \\
\hline \multirow[t]{2}{*}{$\begin{array}{l}\mathbf{4 8} \\
\text { IM } 480\end{array}$} & 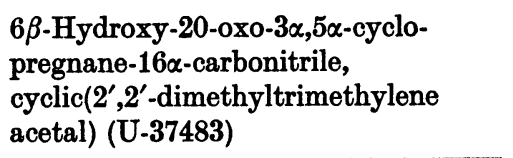 & \multirow[t]{2}{*}{$\begin{array}{l}0.5 \\
0.03\end{array}$} & \multirow[t]{2}{*}{$\begin{array}{l}1 \\
0\end{array}$} & \multirow[t]{2}{*}{$\begin{array}{l}\mathbf{3} \\
\mathbf{0}\end{array}$} \\
\hline & $\mathrm{P}^{3 \alpha(5)} 5 \alpha \mathrm{CN}_{16 \alpha} \mathrm{Ol}_{6 \beta} \theta \theta \mathrm{III}_{20 / \mathrm{T} / 2,2}$ & & & \\
\hline
\end{tabular}


Table 135 (continued)

\begin{tabular}{|c|c|c|c|c|}
\hline Group & Steroids & $\begin{array}{l}\text { Dose } \\
(\mathrm{mg})\end{array}$ & $\begin{array}{l}\text { Digi- } \\
\text { toxin }^{\mathrm{a}}\end{array}$ & $\begin{array}{l}\text { Indo- } \\
\text { a metha- } \\
\operatorname{cin}^{\mathrm{a}}\end{array}$ \\
\hline \multirow[t]{2}{*}{$\begin{array}{l}49 \\
\text { IM } 477\end{array}$} & $\begin{array}{l}6 \beta \text {-Hydroxy-20-oxo-3 } \alpha, 5 \alpha \text {-cyclo- } \\
\text { pregnane-16 } \alpha \text {-carbonitrile (U-36710) }\end{array}$ & \multirow[t]{2}{*}{$\begin{array}{l}0.5 \\
0.03\end{array}$} & \multirow[t]{2}{*}{$\begin{array}{l}2 \\
0\end{array}$} & \multirow[t]{2}{*}{$\begin{array}{l}3 \\
0\end{array}$} \\
\hline & $\mathrm{P}^{3 \alpha(5)} 5 \alpha \mathrm{CN}_{16 \alpha} \mathrm{ol}_{6 \beta} \mathrm{On}_{20}$ & & & \\
\hline \multirow[t]{2}{*}{$\begin{array}{l}50 \\
\text { IM } 466\end{array}$} & $\begin{array}{l}\text { 16 } \alpha \text {-Cyano-4-pregnene-3,20-dione } \\
\text { (SC-4688) }\end{array}$ & \multirow[t]{2}{*}{$\begin{array}{l}0.1 \\
0.015\end{array}$} & \multirow[t]{2}{*}{$\begin{array}{l}3 \\
0\end{array}$} & \multirow[t]{2}{*}{$\begin{array}{l}0 \\
0\end{array}$} \\
\hline & $\mathrm{P}^{4} \mathrm{CN}_{16 \alpha} \mathrm{On}_{3,20}$ & & & \\
\hline \multirow[t]{2}{*}{$\begin{array}{l}51 \\
\text { IM } 471\end{array}$} & $\begin{array}{l}\text { 16 } \alpha \text {-Cyano-3-hydroxy-3,5- } \\
\text { pregnadiene-7,20-dione (SC-6963) }\end{array}$ & \multirow[t]{2}{*}{0.1} & \multirow[t]{2}{*}{0} & \multirow[t]{2}{*}{-} \\
\hline & $\mathrm{P}^{3,5} \mathrm{CN}_{16 \alpha} \mathrm{Ol}_{3} \mathrm{On}_{7,20}$ & & & \\
\hline \multirow[t]{2}{*}{$\begin{array}{l}52 \\
\text { IM } 470\end{array}$} & $\begin{array}{l}\text { 16 } \alpha \text {-Cyano-3,5-pregnadiene-7, } \\
\text { 20-dione (SC-6786) }\end{array}$ & \multirow[t]{2}{*}{0.1} & \multirow[t]{2}{*}{0} & \multirow[t]{2}{*}{0} \\
\hline & $\mathbf{P}^{3,5} \mathbf{C N}_{16 \alpha} \mathrm{On}_{7,20}$ & & & \\
\hline \multirow[t]{2}{*}{$\begin{array}{l}53 \\
\text { IM } 395\end{array}$} & $\begin{array}{l}\text { 3-Methoxy-16-methyl-17-oxo-estra- } \\
\text { 1,3,5(10)-triene-16 } \xi \text {-carbonitrile } \\
\text { (Roussel) }\end{array}$ & \multirow[t]{2}{*}{0.5} & \multirow[t]{2}{*}{0} & \multirow[t]{2}{*}{0} \\
\hline & $\mathbf{E}^{1,3,5(10) \mathbf{I}_{16 \xi}} \mathbf{C N}_{16} \mathrm{On}_{17} \theta \mathrm{I}_{3}$ & & & \\
\hline \multirow[t]{2}{*}{$\begin{array}{l}\mathbf{5 4} \\
\text { IM } 392\end{array}$} & $\begin{array}{l}17 \beta \text {-Hydroxy-3-methoxy-16- } \\
\text { methylestra-1,3,5(10)-triene-16 } \beta \text { - } \\
\text { carbonitrile acetate (Roussel) }\end{array}$ & \multirow[t]{3}{*}{0.5} & \multirow[t]{3}{*}{0} & \multirow[t]{3}{*}{0} \\
\hline & $\mathbf{E}^{1,3,5(10) \mathbf{I}_{16 \alpha}} \mathbf{C N}_{16} * \mathrm{II}^{\prime \prime}{ }_{17 \beta} \theta \mathrm{I}_{3}$ & & & \\
\hline \multicolumn{2}{|l|}{$\mathbf{C N}_{17}$} & & & \\
\hline \multirow[t]{2}{*}{$\begin{array}{l}55 \\
\text { IM } 386\end{array}$} & $\begin{array}{l}3 \alpha \text {-Hydroxy- } 5 \beta \text {-androstane-17 } \beta \text { - } \\
\text { carbonitrile acetate (Roussel) }\end{array}$ & \multirow[t]{2}{*}{0.5} & \multirow[t]{2}{*}{0} & \multirow[t]{2}{*}{0} \\
\hline & $\mathrm{A5} \beta \mathrm{CN}_{17 \beta} * \mathrm{II}^{\prime \prime}{ }_{3 \alpha}$ & & & \\
\hline \multirow[t]{2}{*}{$\begin{array}{l}56 \\
\text { IM } 377\end{array}$} & $\begin{array}{l}3 \alpha, 17-D i h y d r o x y-5 \beta \text {-androstane-17 } \xi \text { - } \\
\text { carbonitrile } 3 \text {-acetate (Roussel) }\end{array}$ & \multirow[t]{2}{*}{0.5} & \multirow[t]{2}{*}{0} & \multirow[t]{2}{*}{0} \\
\hline & $\mathrm{A} 5 \beta \mathrm{CN}_{17} \mathrm{Ol}_{17 \xi} * \mathrm{II}^{\prime \prime}{ }_{3 \alpha}$ & & & \\
\hline
\end{tabular}


Table 135 (continued)

Group

58

IM 382

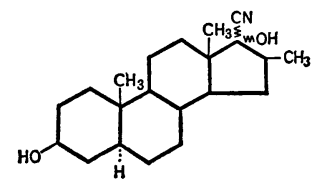

59

IM 374

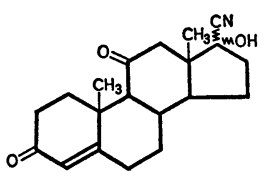

60

IM 378

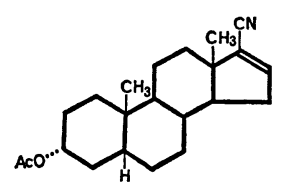

61

IM 389<smiles>CC12CCC3C4CCC5=CC(=O)CCC5(C)C4CCC3(C)C1C2</smiles>

62

IM 396<smiles>COC1CCC2(C)C(=CCC3C4CC=C(O)C4(C)CCC32)C1</smiles>

63

IM 390

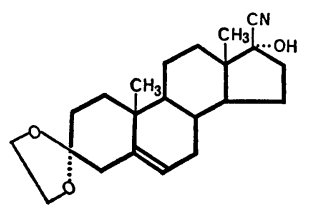

64

IM 380

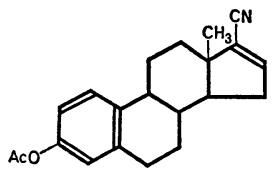

Steroids

17-Cyano-3 $\alpha$-hydroxy-11-oxo-5 $\beta$ -

androstane-17 $\beta$-malononitrile

(Roussel)

A5 $\beta_{17 / \mathrm{CN} / / 1,1} \mathrm{CN}_{17} \mathrm{Ol}_{3 \alpha} \mathrm{on}_{11}$

$3 \beta, 17-D i h y d r o x y-16 \beta$-methyl-5 $\alpha$ -

$\begin{array}{lll}0.5 & 0 & 0\end{array}$ androstane-17 $\xi$-carbonitrile

(Roussel)

$\mathrm{A5} \alpha \mathrm{I}_{16 \beta} \mathrm{CN}_{17} \mathrm{Ol}_{3 \beta, 17 \xi}$

17-Hydroxy-3,11-dioxo-4-androstene- $\begin{array}{cccc}0.5 & 0 & 0\end{array}$ $17 \xi$-carbonitrile (Roussel)

$\mathrm{A}^{4} \mathrm{CN}_{17 \mathrm{Ol}_{17} \mathrm{On}_{3,11}}$

$3 \alpha$-Hydroxy- $5 \beta$-androst-16-ene-

17-carbonitrile acetate (Roussel)

$\begin{array}{lll}0.5 & 0 & 0\end{array}$

A5 $\beta^{16} \mathrm{CN}_{17} * \mathrm{II}^{\prime \prime}{ }_{3 \alpha}$

3-0xo-4,16-androstadiene-17-

$\begin{array}{lll}0.5 & 0 & 0\end{array}$ carbonitrile (Roussel)

$\mathrm{A}^{4,16} \mathrm{CN}_{17 \mathrm{On}_{3}}$

$3 \beta$-Hydroxy-5,16-androstadiene-

17 -carbonitrile acetate (Roussel)

$\begin{array}{lll}0.5 & 0 & 0\end{array}$

$\mathrm{A}^{5,16} \mathrm{CN}_{17} * \mathrm{II}^{\prime \prime}{ }_{3 \beta}$

3,3-(Ethylenedioxy)-17-hydroxy- $\quad 0.5 \quad 0 \quad 0$ 5-pregnene-17 $\beta$-carbonitrile (Roussel)

$\mathbf{A}^{5} \mathbf{C N}_{17 \alpha} \mathrm{Ol}_{17} \vartheta \vartheta \mathrm{II}_{3}$

3-Hydroxy-1,3,5(10),16-estratetraene- $0.5 \quad 0 \quad 0$ 17-carbonitrile acetate (Roussel)

$\mathbf{E}^{1,3,5(10) 16} \mathrm{CN}_{17} * \mathrm{II}^{\prime \prime}{ }_{3}$ 
Table 135 (continued)

\begin{tabular}{|c|c|c|c|c|}
\hline Group & Steroids & $\begin{array}{l}\text { Dose } \\
(\mathrm{mg})\end{array}$ & $\begin{array}{l}\text { Digi- } \\
\text { toxin }^{a}\end{array}$ & $\begin{array}{l}\text { Indo- } \\
\text { a metha- } \\
\text { cin }^{\mathrm{a}}\end{array}$ \\
\hline \multirow[t]{2}{*}{$\begin{array}{l}65 \\
\text { IM } 400\end{array}$} & $\begin{array}{l}\text { 3-Methoxy-1,3,5(10),16-estratetraene- } \\
\text { 17-carbonitrile (Roussel) }\end{array}$ & 0.5 & 0 & 0 \\
\hline & $\mathbf{E}^{1,3,5(10) 16} \mathrm{CN}_{17} \theta \mathrm{I}_{3}$ & & & \\
\hline \multirow[t]{2}{*}{$\begin{array}{l}66 \\
\text { IM } 417\end{array}$} & $\begin{array}{l}\text { 17-Cyano-3 } \beta \text {-hydroxy-5-androstene- } \\
17 \beta \text {-malononitrile (U-28406) }\end{array}$ & 0.5 & 0 & 0 \\
\hline & $\mathbf{A}^{5} \mathbf{I}_{17 \beta / \mathrm{CN} / / 1,1} \mathbf{C N}_{17} \mathrm{Ol}_{3 \beta}$ & & & \\
\hline \multirow[t]{2}{*}{$\begin{array}{l}67 \\
\text { IM } 391\end{array}$} & 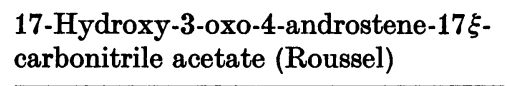 & 0.5 & 0 & 0 \\
\hline & $\mathrm{A}^{4} \mathrm{CN}_{17} * \mathrm{II}^{\prime \prime}{ }_{17 \xi} \mathrm{On}_{3}$ & & & \\
\hline \multirow[t]{2}{*}{$\begin{array}{l}68 \\
\text { IM } 375\end{array}$} & $\begin{array}{l}\text { 17-Hydroxy-3,11-dioxo-4-androstene } \\
17 \xi \text {-carbonitrile acetate (Roussel) }\end{array}$ & 0.5 & 0 & 0 \\
\hline & $\mathrm{A}^{4} \mathrm{CN}_{17} * \mathrm{II}^{\prime \prime}{ }_{17 \xi} \mathrm{On}_{3,11}$ & & & \\
\hline \multicolumn{5}{|c|}{ 16-Side chain CN } \\
\hline \multirow[t]{2}{*}{$\begin{array}{l}69 \\
\text { IM } 469\end{array}$} & $\begin{array}{l}\text { 16 } \alpha \text {-Cyanomethyl-3 } \beta \text {-hydroxy- } \\
\text { 5-pregnen-20-one (SC-6939) }\end{array}$ & 0.5 & 0 & 0 \\
\hline & $\mathrm{P}^{5} \mathrm{ICN}_{16 \alpha} \mathrm{Ol}_{3 \beta} \mathrm{On}_{20}$ & & & \\
\hline \multirow[t]{2}{*}{$\begin{array}{l}70 \\
\text { IM } 472\end{array}$} & $\begin{array}{l}\text { 16 } \alpha \text {-Cyanomethyl-4-pregnene- } \\
\text { 3,20-dione (SC-7097) }\end{array}$ & 0.5 & 0 & 0 \\
\hline & $\mathrm{P}^{4} \mathrm{ICN}_{16 \alpha} \mathrm{On}_{3,20}$ & & & \\
\hline \multirow[t]{2}{*}{$\begin{array}{l}71 \\
\text { IM } 409\end{array}$} & $\begin{array}{l}\alpha \text {-Cyano-3 } \beta \text {-hydroxy-20-oxo- } \\
5 \text {-pregnen-16 } \alpha \text {-acetic acid ethyl ester } \\
\text { (SK \& F) }\end{array}$ & 10 & 0 & 0 \\
\hline & $\mathrm{P}^{5} \mathrm{II}^{\prime \prime}{ }_{16 \alpha / \mathrm{CN} / / 2} * \mathrm{IIol}_{/ / / 1} \mathrm{Ol}_{3 \beta} \mathrm{On}_{20}$ & & & \\
\hline \multicolumn{5}{|c|}{ 17-Side chain CN } \\
\hline \multirow[t]{2}{*}{$\begin{array}{l}72 \\
\text { IM } 381\end{array}$} & $\begin{array}{l}3 \alpha-H y d r o x y-5 \beta \text {-androstan- } \\
17 \beta \text {-acetonitrile (Roussel) }\end{array}$ & 0.5 & 0 & 0 \\
\hline & 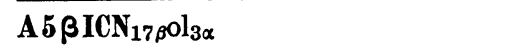 & & & \\
\hline
\end{tabular}


Table 135 (continued)

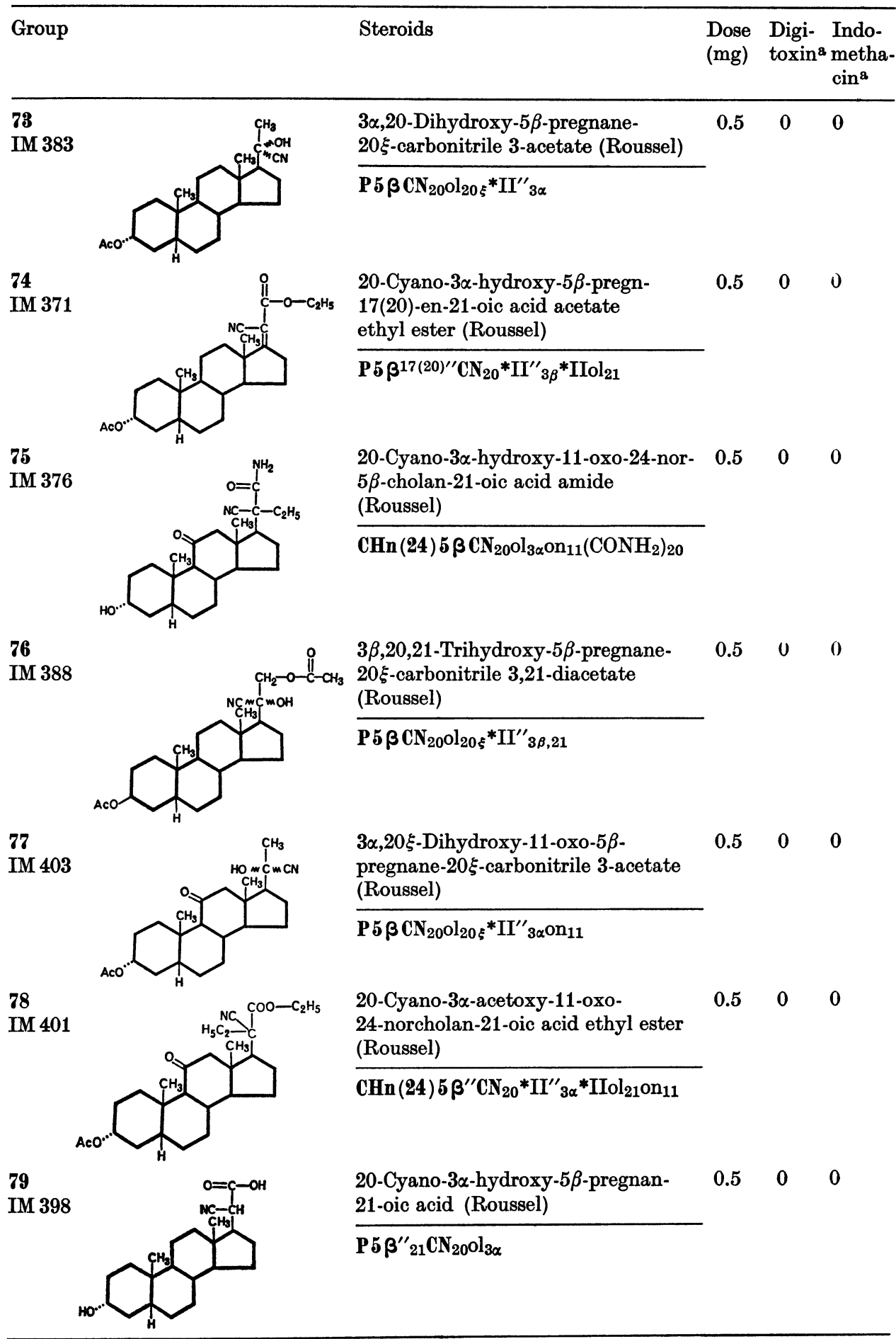


Table 135 (continued)

\begin{tabular}{|c|c|c|c|c|}
\hline Group & Steroids & $\begin{array}{l}\text { Dose } \\
(\mathrm{mg})\end{array}$ & $\begin{array}{l}\text { Digi- } \\
\text { toxin }^{\text {a }}\end{array}$ & $\begin{array}{l}\text { Indo- } \\
\text { metha- } \\
\text { cin }^{\mathrm{a}}\end{array}$ \\
\hline \multirow[t]{2}{*}{$\begin{array}{l}80 \\
\text { IM } 385\end{array}$} & $\begin{array}{l}3 \alpha \text {-Hydroxy-11-oxo- } 5 \beta \text {-androstan- } \\
17 \beta \text {-acetonitrile acetate (Roussel) }\end{array}$ & 0.5 & 0 & 0 \\
\hline & $\mathbf{A 5} \mathrm{ICN}_{17 \beta} * \mathrm{II}_{3 \alpha}^{\prime \prime} \mathrm{On}_{11}$ & & & \\
\hline
\end{tabular}

81

IM 384

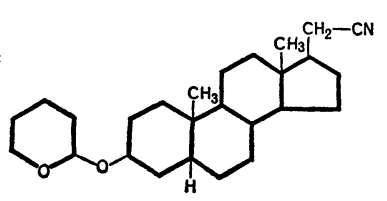

82

IM 406

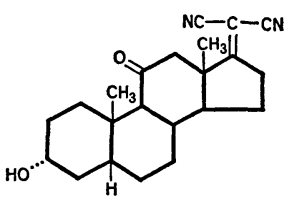

83

IM 393

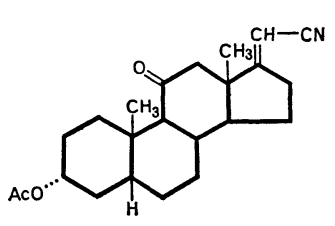

84

IM 408

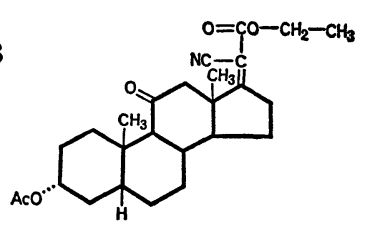

85

IM 405

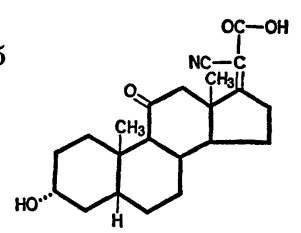

86

IM 394

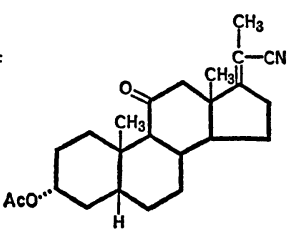

$3 \beta$-(Tetrahydropyran-2-yloxy)-

$0.5 \quad 0 \quad 0$

$5 \beta$-androstan- $17 \beta$-acetonitrile

(Roussel)

$\mathbf{A 5}$ ICN $_{17 \beta} \theta$ tetrahydropyranyl $_{3 \beta / 01} / / 2$

$3 \alpha$-Hydroxy-11-oxo-5 $\beta$-androstane$\Delta^{17}$-malononitrile (Roussel)

A5 $\beta^{17(20)} \mathbf{I}_{17 / \mathrm{CN} / / 1,1} \mathrm{ol}_{3 \alpha} \mathrm{On}_{11}$

$3 \alpha$-Hydroxy-11-oxo- $5 \beta$-androstan-

$0.5 \quad 0$

1.5 $\Delta^{17}$-acetonitrile acetate (Roussel)

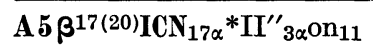

20-Cyano-3 $\alpha$-hydroxy-11-oxo-5 $\beta$ pregn-17(20)-en-21-oic acid acetate ethyl ester (Roussel)

P5 $\beta^{17(20) "} \mathrm{CN}_{20} * \mathrm{II}_{3 \alpha} * \mathrm{IIol}_{21} \mathrm{on}_{11}$

20-Cyano-3 $\alpha$-hydroxy-11-oxo- $5 \beta$ pregn-17(20)-en-21-oic acid (Roussel)

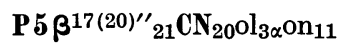

$3 \alpha$-Hydroxy-11-oxo-5 $\beta$-pregn-

$\begin{array}{lll}0.5 & 0.5 & 1.5\end{array}$ 17(20)-ene-20-carbonitrile acetate (Roussel)

P5 $\beta^{17(20)} \mathbf{C N}_{20} * \mathrm{II}^{\prime \prime}{ }_{3 \alpha} \mathrm{On}_{11}$ 
Table 135 (continued)

\begin{tabular}{|c|c|c|c|c|c|}
\hline Group & & Steroids & $\begin{array}{l}\text { Dose } \\
(\mathrm{mg})\end{array}$ & $\begin{array}{l}\text { Digi- } \\
\text { toxin }\end{array}$ & $\begin{array}{l}\text { Indo- } \\
\text { metha- } \\
\operatorname{cin}^{2}\end{array}$ \\
\hline \multirow[t]{2}{*}{$\begin{array}{l}87 \\
\text { IM } 404\end{array}$} & \multirow[t]{2}{*}{$\begin{array}{c}\mathrm{O}=\mathrm{C}_{\mathrm{HC}}^{\mathrm{CO}}-\mathrm{CH}_{2}-\mathrm{CH}_{3} \\
\mathrm{H}\end{array}$} & $\begin{array}{l}\text { 20-Cyano-3 } \beta \text {-hydroxy-5-pregnen-21- } \\
\text { oic acid acetate ethyl ester (Roussel) }\end{array}$ & \multirow[t]{2}{*}{0.5} & \multirow[t]{2}{*}{0} & \multirow[t]{2}{*}{$\mathbf{0}$} \\
\hline & & $\mathrm{P}^{5 / \prime} \mathrm{CN}_{20} * \mathrm{IIol}_{21} * \mathrm{II}^{\prime \prime}{ }_{3 \beta}$ & & & \\
\hline
\end{tabular}

88

IM 373<smiles>COC(=O)C(C)C1CCC2C3CC=C4CC(OC)CCC4(C)C3CCC12C</smiles>

89

IM 407<smiles>CC(C)(N)[C@H]1CCC2C3CCC4=CC(=O)CCC4=C3C=CC21C</smiles>

90

IM 399<smiles>CC(C)C1CCC2C3CC[C@H]4C[C@H](O)CCC4(C)C3CCC12CC#N</smiles>

91

IM 402<smiles>CCOC(=O)C(C#N)=CC1CCC2C3CC[C@@H]4CC(O)CCC4(C)C3CCC12C</smiles>

92

IM 370

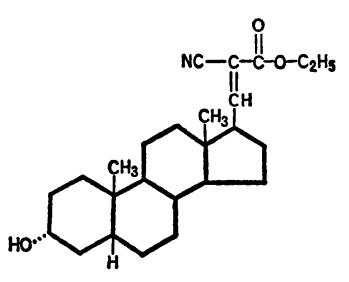

20-Cyano-3 $\beta$-hydroxy-5,17(20)pregnadien-21-oic acid 3-acetate ethyl ester (Roussel)

$\mathrm{P}^{5,17(20)}{ }^{\prime \prime} \mathrm{CN}_{20} * \mathrm{IIol}_{21} * \mathrm{II}^{\prime \prime}{ }_{3 \beta}$

20-Hydroxy-3-oxo-19-norpregna-

$\begin{array}{lll}0.5 & 0 & 0\end{array}$ 4,9,11-triene-20 $\xi$-carbonitrile (Roussel)

Pn 194, 9,11 $\mathrm{CN}_{20 \xi} \mathrm{Ol}_{20} \mathrm{On}_{3}$

$3 \alpha$-Hydroxy- $5 \beta$-androstan- $17 \beta$ glutaronitrile acetate (Roussel)

$\begin{array}{lll}0.5 & 0 & 0\end{array}$

$\mathrm{P}_{5} \mathrm{CCN}_{21} \mathrm{ICN}_{20} * \mathrm{II}^{\prime \prime} 3 \alpha$

21-Cyano-3 $\beta$-hydroxy-5 $\alpha$-pregn-20-

0.500 ene-21-carboxylic acid ethyl ester (Roussel)

$\mathrm{P}_{5} \alpha^{20 I^{\prime \prime}} 21{ }^{*}{ }_{\text {IIol }} \mathrm{CN}_{21} \mathrm{Ol}_{3 \beta}$

21-Cyano-3 $\alpha$-hydroxy-5 $\beta$-pregn-20ene-21-carboxylic acid ethyl ester (Roussel)

P5 $\beta^{20} I^{\prime \prime}{ }_{21} *_{\text {IIol }} \mathrm{CN}_{21} \mathrm{ol}_{3 \alpha}$ 
Table 135 (continued)

Group

Steroids

Dose Digi- Indo-

(mg) toxin ${ }^{a}$ metha$\operatorname{cin}^{2}$

\section{0ther Active Steroids}

93

IM 448

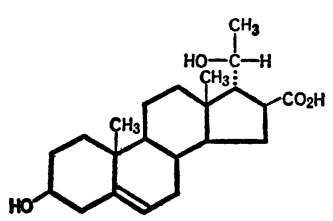

94

IM 446<smiles>CO[C@H]1[C@@H](N)CC2C3CC=C4CC(O)CCC43CCC21CCO</smiles>

95

IM 304<smiles>C#CC1(O)CCC2C3CCc4cc(OC)ccc4C3CCC21C</smiles>

96

IM 410

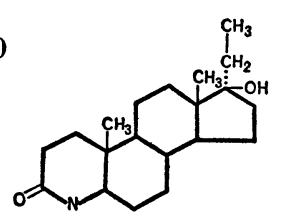

97

IM 454

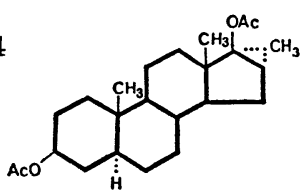

98

IM 489

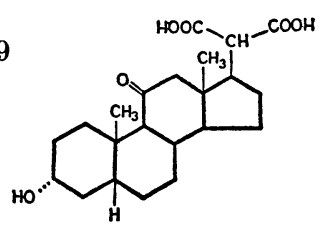

99

IM 527

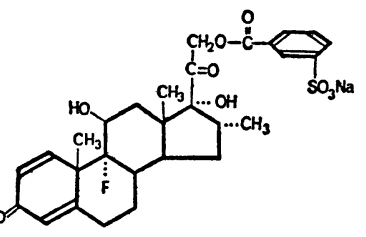

3 $\beta, 20$-Dihydroxy-17 $\alpha$-pregn-5-ene$16 \beta$-carboxylic acid (Syntex)

$\begin{array}{lll}0.5 & 1.5 & 3\end{array}$

$\begin{array}{lll}0.1 & 0.5 & 0\end{array}$

$\mathbf{A}^{5 \mathbf{I}^{\prime \prime}}{ }_{16 \beta} \mathrm{II}_{17 \alpha / 01 / / 1 \mathrm{Ol}_{3 \beta}}$ $0.03 \quad 0 \quad 0$

3 $\beta$-Hydroxy-20-oxo-17 $\alpha$-pregn-5-ene- $0.5 \quad 0 \quad 1.5$ $16 \beta$-carboxamide (Syntex) $\begin{array}{lll}0.1 & 0 & 0\end{array}$

$\mathrm{A}^{5} \mathrm{II}_{17 \alpha / \mathrm{on} / / 1}\left(\mathrm{CONH}_{2}\right)_{16 \alpha} \mathrm{Ol}_{3 \beta}$

3-Methoxy-19-nor-17 $\alpha$-pregna

1,3,5(10)-trien-20-yn-17-ol (Lilly) $\quad 0.5 \quad 0 \quad 3$ Mestranol

$\mathbf{E}^{1,3,5(10)} \mathrm{II}^{1-1}{ }_{17 \alpha} \mathrm{Ol}_{17} \theta \mathrm{I}_{3}$

17-Hydroxy-4-aza-17 $\alpha$-pregnan-3-one $10 \quad 1.5 \quad 3$ (Organon) $\begin{array}{lll}0.5 & 0 & 0\end{array}$

$\mathbf{A}\left(\mathbf{N}_{4}\right) \mathrm{II}_{17 \alpha \mathrm{Ol}_{17} \mathrm{On}_{3}}$

$16 \alpha, 17$-Dihydro-3 ${ }^{\prime} \mathrm{H}$-cyclopropa $(16,17)$-5 $\alpha$-androstane-3 $\beta, 17 \beta$-diol $103-$ diacetate (SC-21940)

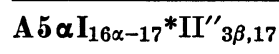

$3 \alpha$-Hydroxy-11-oxo- $5 \beta$-androstane$17 \beta$-malonic acid (Roussel)

$\begin{array}{lll}0.5 & 0 & 1.5\end{array}$

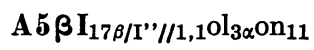

$9 \alpha$-Fluoro-16 $\alpha$-methyl-11 $\beta, 17,21$ -

trihydroxy-1,4-pregnadiene-3,20-

$\begin{array}{lll}0.5 & 0 & 1.5\end{array}$

dione 21-sodium m-sulfobenzoate

$0.03-0$

Dexamethasone sodium m-sulfobenzoate

(B.R.L.)

${ }^{1}{ }^{1,4} \mathbf{I}_{16 \alpha} \mathrm{Ol}_{11 \beta, 17} \mathrm{~m}$-sulfobenzoate $\mathrm{Na}_{21} \mathrm{on}_{3,20} \mathrm{~F}_{9 \alpha}$ 
Cpd. 54, the only $16 \beta$-carbonitrile of our series, as well as Cpd. 53 in which the steric position of the 16-carbonitrile is unknown, were inactive in protecting against either substrate, even at the dose level of $500 \mu \mathrm{g}$. Cpds. $69-71$ in which the $-\mathrm{CN}$ group is attached to a $16 \alpha$-side-chain (rather than to the $\mathrm{C}_{16}$ carbon of the steroid skeleton itself) showed no protective activity, even at the dose of $10 \mathrm{mg}$. On the other hand, it is hardly coincidental that among $2816 \alpha$-carbonitriles tested (Cpds. 27-54) all but three (Cpds. 47, 51, 52) were active, and most of them even at very low dose levels. This suggests that the attachment of a $-\mathrm{CN}$ group in the $16 \alpha-$ position directly to the steroid skeleton is very favorable for this type of protective effect; the configuration of the rest of the steroid molecule, though capable of influencing the degree of activity, is of much lesser importance.

It is known from our previous work that a carbonitrile group in position $2 \alpha$ (e.g., Cpd. 3, TMACN) is also compatible with high catatoxic activity against a variety of substrates; additional evidence justifying this conclusion is given in Tables 135, 136.

Carbonitrile groups in position 3, may or may not convey some potency (Cpds. 5-9), but steroids with carbonitriles attached to $\mathrm{C}_{1}$ (Cpds. 1, 2), $\mathrm{C}_{5}$ (Cpds. 10-20) or $\mathrm{C}_{6}$ (Cpds. 21-26) were uniformly inactive at all dose levels tested.

Carbonitrile substitution at $\mathrm{C}_{17}, \mathrm{C}_{20}, \mathrm{C}_{21}$ or in side-chains resulted in no remarkable catatoxic potency at the dose levels tested, with the exception of Cpds. 83 and 86 which were moderately effective in this respect at the dose level of $500 \mu \mathrm{g}$.

Among the steroids of Table 135 other than carbonitriles (Cpds. 93-99), special interest is attached to Cpd. 96 (an aza-steroid), Cpd. 95 (mestranol), a strong folliculoid used in anticonceptional pills, and Cpd.93 (a $16 \beta$-carboxylic acid) all of which showed some catatoxic activity at comparatively high dose levels. This degree of activity is of little practical significance, but it is interesting that a heterocyclic aza-compound, a $16 \beta$-carboxylic acid and a folliculoid can possess some catatoxic potency.

Finally, it is noteworthy that (except for the moderate potency of Cpd. 93) all 16-carboxylic acids (Cpds. 66, 67 and 69 in Table 135A) are devoid of catatoxic potency against both substrates. A priori, the possibility could not have been excluded that nitriles are metabolized in vivo into the corresponding carboxylic acids and that the latter would be responsible for catatoxic activity, but this does not appear to be the case.

Additional inactive steroids are listed in Table 135 A cf., p. 794.

\section{First Step: Synopsis of all 500 Steroids Tested for Their Ability to Prevent Digitoxin and Indomethacin Intoxication}

The preceding tables summarize our hitherto unpublished data on the protection by steroids, and particularly by carbonitriles, against digitoxin and indomethacin intoxication. However, in order to obtain a proper overview of this field, the following list summarizes the results obtained with all 500 steroids tested up to now, cf. Table $135 \mathrm{~B}$, p. 807. It will be kept in mind that all these experiments were performed under essentially identical conditions as outlined on p. VIII and in earlier publications (Selye G 70,421/70, G 70,480/71). Since no other laboratory has published comparable data on the detoxication of digitoxin and indomethacin by steroids, the list is assumed to be a reasonably complete inventory of all steroids tested for this effect and 
Table $135 \mathrm{~A}$. First step (Ctd.): Other inactive steroids. (Tested at $0.5 \mathrm{mg}$ dose level unless otherwise stated)

1

IM $522^{\mathrm{a}}$<smiles>CC(C)(C)OC1(C)CCC2C3CCC4=CC(=O)CCC4C3CCC21C(C)(C)C</smiles>

2

IM 505<smiles>CC(C)OC1(C)CCC2C3CCc4cc(O)ccc4C3CCC21OC(C)(C)C</smiles>

3

IM 504<smiles>CC(C)(C)OC1CCC2C3CCc4cc(O)ccc4C3CCC12C(C)(C)C</smiles>

4

IM 506<smiles>CC(=O)OC12CCC3C4CCc5cc(O)ccc5C4CCC3C1CC2</smiles>

5

IM 513<smiles>COC(=O)OC1CCC2C3CCc4cc(O)ccc4C3CCC12C(C)=O</smiles>

6

IM 507<smiles>CC(C)(C)OC(=O)O</smiles>

7 IM 509<smiles>CCOC(=O)C1CCC2C3CCc4cc(O)ccc4C3CCC12COC</smiles>

8

IM 510

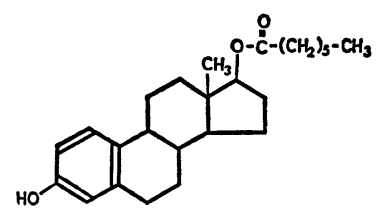

17 $\beta$-Hydroxy-4-estren-3-one 17-trichloroacetate 19-Nortestosterone trichloroacetate (Bio. Research Lab.) (B.R.L.)

$\mathbf{E}^{4} * \mathrm{II}^{\prime \prime}{ }_{17 \beta / \mathrm{Cl} / / 2,2,2}$ on $_{3}$

3,17 $\beta$-Dihydroxy-1,3,5(10)-estratriene 17-tribromoacetate (B.R.L.)

$\mathbf{E}^{1,3,5(10)} \mathrm{ol}_{3} * \mathrm{II}^{\prime \prime}{ }_{17 \beta / \mathrm{Br} / / 2,2,2}$

3,17 $\beta$-Dihydroxy-1,3,5(10)-estratriene 17-trichloroacetate

(B.R.L.)

$\mathrm{E}^{1,3,5(10)} \mathrm{ol}_{3} * \mathrm{II}^{\prime \prime}{ }_{17 \beta / \mathrm{C} / / 2,2,2}$

3,17 $\beta$-Dihydroxy-1,3,5(10)-estratriene 17-trifluoroacetate

(B.R.L.)

$\mathbf{E}^{1,3,5(10)} \mathrm{ol}_{3} * \mathrm{II}^{\prime \prime}{ }_{17 \beta / \mathrm{F} / / 2,2,2}$

3,17 $\beta$-Dihydroxy-1,3,5(10)-estratriene

17-[2'-hydroxy] propionate

(B.R.L.)

$\mathbf{E}^{1,3,5(10)} \mathrm{ol}_{3} * \mathrm{IIII}^{\prime \prime}{ }_{17 \beta / \mathrm{ol} / / 2}$

3,17 $\beta$-Dihydroxy-1,3,5(10)-estratriene

17-[2'-hydroxy-2'-methyl]propionate

(B.R.L.)

$\mathbf{E}^{1,3,5(10)} \mathrm{ol}_{3} * \mathrm{IIII}^{\prime \prime} 17 \beta / \mathrm{Tol} / / 2$

3,17 $\beta$-Dihydroxy-1,3,5(10)-estratriene

17-pentanoate

(B.R.L.)

$\mathbf{E}^{1,3,5(10)} \mathrm{ol}_{3} * \mathrm{~V}^{\prime \prime}{ }_{17 \beta}$

3,17 $\beta$-Dihydroxy-1,3,5(10)-estratriene

17-heptanoate

(B.R.L.)

$E^{1,3,5(10)} \mathrm{ol}_{3} * \mathrm{VII}^{\prime \prime}{ }_{17 \beta}$

a Underneath the serial number of the compounds, the "IM" numbers (for Institut de Médecine et de Chirurgie expérimentales) are mentioned. These identify steroids in our collection and remain the same in all Tables as well as in other publications from this Institute. 
Table 135 A (continued)

9

IM 511

10

IM 512<smiles>CC(C)O[C@H]1CCC2C3CCc4cc(O)ccc4C3CCC21O</smiles>

11

IM 508<smiles>CC1(C(=O)OC2CCC3C2CCC2c4ccc(O)cc4CCC23)CC2CCC1C2</smiles>

12

IM 519<smiles>CC(=O)Oc1ccc2c(c1)CCC1C2CCC2(C)C(O)CCC12</smiles>

3,17 $\beta$-Dihydroxy-1,3,5(10)-estratriene

17-palmitate

(B.R.L.)

$\mathbf{E}^{1,3,5(10)} \mathrm{ol}_{3} * \mathrm{XVI}^{\prime \prime}{ }_{17 \beta}$

3,17 $\beta$-Dihydroxy-1,3,5(10)-estratriene

17-benzoate

(B.R.L.)

$\mathrm{E}^{1,3,5(10)} \mathrm{ol}_{3} * \mathrm{Bz}^{\prime \prime}{ }_{17 \beta}$

3,17 $\beta$-Dihydroxy-1,3,5(10)-estratriene

17-adamantoate

(B.R.L.)

$\mathbf{E}^{1,3,5(10)} \mathrm{ol}_{3} *$ adamantoate $_{17 \beta}$

3,17 $\beta$-Dihydroxy-1,3,5(10)-estratriene

3-[2'-bromo-2'-methyl] propionate

(B.R.L.)

$\mathbf{E}^{1,3,5(10)} \mathrm{ol}_{17 \beta} * \mathrm{III}_{3 / \mathrm{I}}{ }^{\mathrm{B}} \mathrm{Br} / 2$

13

IM 518<smiles>COc1ccc2c(c1)CCC1C2CCC2(C)C(O)CCC12</smiles>

14

IM 514

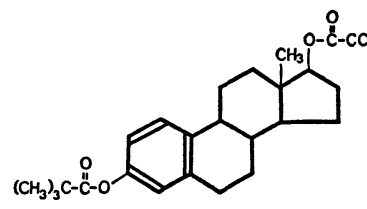

O-č-ccl

3,17 $\beta$-Dihydroxy-1,3,5(10)-estratriene

3-trimethylacetate

(B.R.L.)

$\mathbf{E}^{1,3,5(10)} \operatorname{ol}_{17 \beta} * \mathrm{II}^{\prime \prime}{ }_{3 / \mathrm{I} / / 2,2,2}$

3,17 $\beta$-Dihydroxy-1,3,5(10)-estratriene

17-trichloroacetate 3-trimethylacetate

(B.R.L.)

$\mathbf{E}^{1,3,5(10)} * \mathrm{II}^{\prime \prime}{ }_{3 / \mathrm{I} / / 2,2,2} * \mathrm{II}^{\prime \prime}{ }_{17 \beta / \mathrm{Cl} / / 2,2,2}$

15

IM 516

16

IM 515<smiles>CC(C)(C)Oc1ccc2c(c1)CCC1C2CCC2(O)C1CCC2C(C)(C)C</smiles>

(0.1mg)

3,17 $\beta$-Dihydroxy-1,3,5(10)-estratriene $-\mathrm{C}-(\mathrm{CHOH})_{2}-\mathrm{CO}_{2} \mathrm{CH} 30$-trimethylacetate 17 -methyltartrate (B.R.L.)

$\mathbf{E}^{1,3,5(10)} * \mathrm{II}_{3 / \mathrm{I} / / 2,2,2}^{\prime \prime}$ methyltartrate ${ }_{17 \beta}$

3,17 $\beta$-Dihydroxy-1,3,5(10)-estratriene

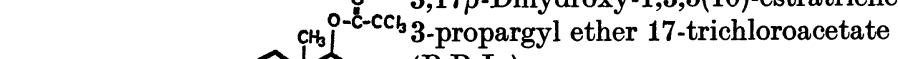

(B.R.L.) :

$\mathbf{E}^{1,3,5(10) * \mathrm{II}^{\prime \prime}{ }_{17 \beta / \mathrm{Cl} / / 2,2,2} \theta \mathrm{III}^{2} 3}$

17

IM 517

3,17 $\beta$-Dihydroxy-1,3,5(10)-estratriene

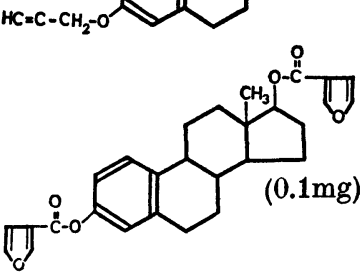

3,17-difuroate

(B.R.L.)

$\mathbf{E}^{1,3,5(10) * \text { furoate }_{3,17 \beta}}$ 
Table 135 A (continued)

18

IM 191

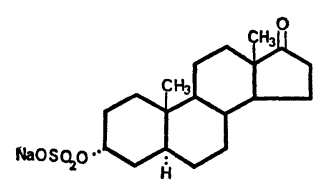

19

IM 313

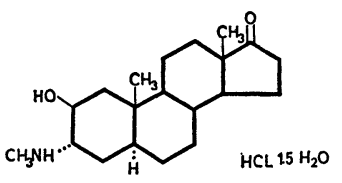

20

IM 140

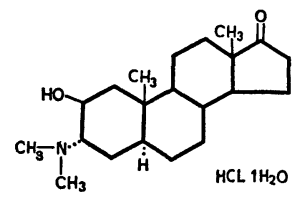

21

IM 284

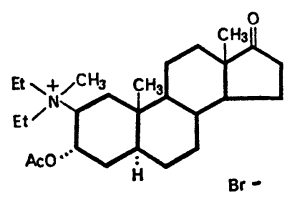

22

IM 260

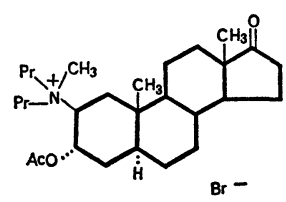

23

IM 453

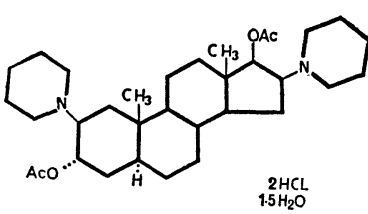

24

IM 185

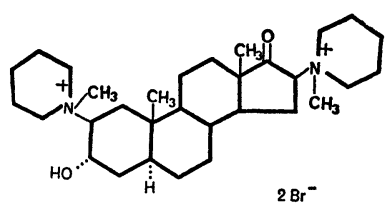

25

IM 419

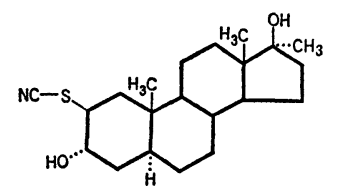

26

IM 442
$3 \alpha$-Hydroxy-5 $\alpha$-androstan-17-one 3-sodium sulphate

(Organon)

A5 $\alpha * \mathrm{~S}^{\prime \prime} \mathrm{Na}_{3 \alpha}$ on 17

$2 \beta$-Hydroxy-3 $\alpha$-methylamino-

$5 \alpha$-androstan-17-one hydrochloride hydrate

(Organon)

A5 $\alpha$ ol $_{2 \beta} \mathrm{On}_{17} \mathrm{NHI}_{3 \alpha} \cdot \mathrm{HCl} 15 \mathrm{H}_{2} \mathrm{O}$

$3 \alpha$-Dimethylamino- $2 \beta$-hydroxy-

$5 \alpha$-androstan-17-one hydrochloride monohydrate (Organon)

A5 $\alpha$ ol $_{2 \beta} \mathrm{On}_{17} \mathrm{~N}_{3 \alpha / \mathrm{I} / / 1,1} \cdot \mathrm{HCl} \mathrm{H} \mathrm{O}_{2} \mathrm{O}$

$2 \beta$-Diethylamino- $3 \alpha$-hydroxy- $5 \alpha$-androstan -17-one methobromide 3-acetate (Organon)

$\left[\mathrm{A5} \alpha * \mathrm{II}^{\prime \prime}{ }_{3 \alpha}\right.$ on $\left._{17} \mathrm{~N}_{2 \beta / \mathrm{I}, \mathrm{II}, \mathrm{II}]}\right] \mathrm{Br}^{-}$

$2 \beta$-Dipropylamino-3 $\alpha$-hydroxy- $5 \alpha$-androstan-

17-one methobromide 3 -acetate

(Organon)

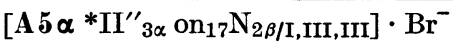

$2 \beta, 16 \beta$-Dipiperidino- $5 \alpha$-androstane- $3 \alpha$,

$17 \beta$-diol diacetate dihydrochloride

(Organon)

A5 $\alpha * \mathrm{II}^{\prime \prime}{ }_{3 \alpha, 17 \beta}$ piperidino $2 \beta, 16 \beta \cdot 2 \mathrm{HCl} 15 \mathrm{H}_{2} \mathrm{O}$

$2 \beta, 16 \beta$-Dipiperidino-3 $\alpha$-hydroxy-5 $\alpha$-androstan-

17-one dimethobromide

(Organon)

$\left[\mathrm{A} 5 \alpha \mathrm{ol}_{3 \alpha}\right.$ on $_{17}$ piperidino $\left.2 \beta, 16 \beta / \mathrm{I} / / 1,1\right] \cdot 2 \mathrm{Br}^{-}$

Thiocyanic acid $3 \alpha, 17 \beta$-dihydroxy-17-methyl-5 $\alpha$ -

androstan-2-yl-ester

(SC-12697)

$\mathrm{A} 5 \alpha \mathrm{I}_{17 \alpha} \mathrm{ol}_{3 \alpha, 17} \mathrm{SCN}_{2 \beta}$

$17 \alpha$-Methyl-3 $\beta, 17$-dihydroxy-5 $\alpha$-androstane- $2 \alpha$ -

hydroxymethyl

(Syntex)

$\mathbf{A 5} \alpha \mathrm{I}_{17 \alpha} \mathrm{Iol}_{2 \alpha} \mathrm{ol}_{3 \beta, 17}$ 
Table 135 A (continued)

27

IM 451<smiles>CC12CC(=CO)C(=O)C[C@H]1CCC1C2CCC2(C)C1CC[C@]2(C)O</smiles>

28

IM 443<smiles>CC1(O)CCC2C1CC13CC(=NN)C(=O)C[C@H]1CCC23</smiles>

29

IM 441

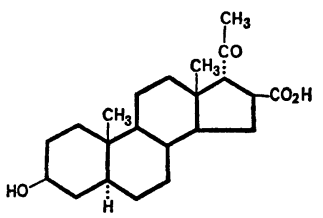

30

IM 495

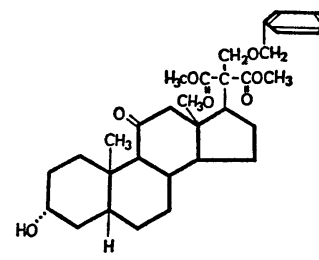

31

IM 150

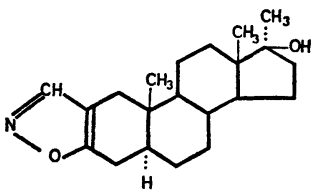

32

IM 563<smiles>O=C1C=C2CCC3C2[C@@H](O)CCC2(CC1)C(O)CCC32</smiles>

33

IM 199<smiles>CC12CCC(=O)C=C1CCC1C3CC[C@](C)(O)C3CCC12</smiles>

34

IM 502<smiles>CC12CCC(C(=O)O)CC1C1CCC3=CC(=O)CCC3C12C</smiles>

35

IM 450
$17 \beta$-Hydroxy-3-oxo-5 $\alpha$-androstane-2-hydroxymethylene

(Syntex)

$\mathrm{A5} \alpha \mathrm{CHOH}_{2} \mathrm{Ol}_{17 \beta} \mathrm{On}_{3}$

17 $\alpha$-Methyl-17-hydroxy-3-oxo-5 $\alpha$-androstan-2aminomethylene

(Syntex)

$A 5 \alpha I_{17 \alpha}\left(\mathrm{CH} \mathrm{NH}_{2}\right)_{2} \mathrm{Ol}_{17} \mathrm{On}_{3}$

$3 \beta$-Hydroxy-20-oxo-5 $\alpha, 17 \alpha$-pregnane-16 $\beta$ carboxylic acid

(Syntex)

$\mathrm{A} 5 \alpha \mathrm{I}^{\prime \prime}{ }_{16 \beta} \mathrm{II}_{17 \alpha / \mathrm{on} / / 1 \mathrm{ol}_{3}}$

$3 \alpha$-Hydroxy-11-oxo-5 $\beta$-androstane-

$17 \beta[\alpha$-benzyloxymethyl]-dimethyl-malonate

(Roussel)

A5 $\beta$ benzyloxy methyl-dimethyl

malonate ${ }_{17 \beta} \mathrm{Ol}_{3 \alpha} \mathrm{On}_{11}$

$17 \beta$-Hydroxy-17-methyl-5 $\alpha$-androstan-

[2,3-d]isoxazol (Sterling Winthrop)

$\mathrm{A5}^{2} \mathrm{I}_{17 \alpha}$ isoxazolyl $_{2-3 / 3,4} \mathrm{Ol}_{17}$

$11 \alpha$-Hydroxy-4-androstene-3,17-dione

(U-1680)

$\mathrm{A}^{4} \mathrm{ol}_{11 \alpha} \mathrm{On}_{3,17}$

$17 \beta$-Hydroxy-4-androsten-3-one

17 -sodium sulphate

(Organon)

$\mathbf{A}^{4} * \mathrm{~S}^{\prime \prime} \mathrm{Na}_{17 \beta} \mathrm{On}_{3}$

3-0xo-4-androstene-17 $\beta$-carboxylic acid (Roussel)

$\mathbf{A}^{4} \mathbf{I}^{\prime \prime}{ }_{17 \beta} \mathrm{On}_{3}$

$17 \beta$-Hydroxy-3-oxo-4-androstene-7 $\beta$-carboxamide (Syntex)

$\mathrm{A}^{4}\left(\mathrm{CONH}_{2}\right)_{7 \beta} \mathrm{Ol}_{17 \beta} \mathrm{On}_{3}$ 
Table 135 A (continued)

36

IM 362<smiles></smiles>

37

IM 501<smiles>CC12CCC(O)CC1=CCC1C2CCC2(C)C(C(=O)O)CCC12</smiles>

38

IM 440<smiles>CC(=O)[C@H]1C(C(=O)O)CC2C3CC=C4CC(O)CCC4(C)C3CCC21C</smiles>

39

IM 500<smiles>CC12CCC(O)CC1=CCC1C2CCC2(C)C1CC[C@]2(O)CC(=O)O</smiles>

40

IM 363<smiles>CC12CCC3C(CCC1C3C=CC1=CC(=O)[C@H]3O[C@@H]13)C2=O</smiles>

41

IM 498<smiles>CC(=O)OC1CCC2(C)C(=CCC3C2CCC2(C)C(C(=O)O)C=CC32)C1</smiles>

42

IM 452<smiles>CC1C(O)CCC2C1CC1C2CCC2=CC(=O)CCC21C</smiles>

43

IM 447<smiles>CC(=O)C1CCC2C3CC[C@@H]4CC(O)CCC4(C)C3CCC12C</smiles>

44

IM 135

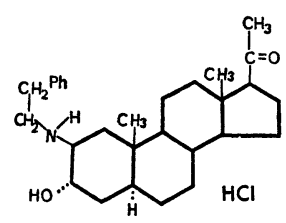

$3 \beta$-Hydroxy-5-androsten-17-one

3-sodium sulfate

(Organon)

$\mathbf{A}^{5} * \mathrm{~S}^{\prime \prime} \mathrm{Na}_{3 \beta} \mathrm{On}_{17}$

3 $\beta$-Hydroxy-5-androstene-17 $\beta$-carboxylic acid (Roussel)

$\mathbf{A}^{5} \mathbf{I}^{\prime \prime}{ }_{17 \beta} \mathrm{Ol}_{3 \beta}$

$3 \beta$-Hydroxy-20-oxo-17 $\alpha$-pregn-5-ene-16 $\beta$-carboxylic acid

(Syntex)

$\mathbf{A}^{5} \mathbf{I}_{16 \beta}^{\prime \prime} \mathbf{I I}_{17 \alpha / \mathrm{on}_{/ / 1} \mathrm{Ol}_{3 \beta}}$

3 $\beta, 17 \beta$-Dihydroxy-5-pregnen-20-yne-21-carboxylic acid (Roussel)

$\mathrm{A}^{5} \mathrm{III}^{2,2{ }^{\prime \prime}}{ }_{17 \alpha} \mathrm{Ol}_{3 \beta, 17}$

$1 \alpha, 2 \alpha$-Epoxy-4,6-androstadiene-3,17-dione

(Linet)

$\mathbf{A}^{4,6} \mathrm{on}_{3,17} \theta_{1 \alpha-2}$

$3 \beta$-Acetoxy-5,15-androstadiene-17-carboxylic acid (Roussel)

$\mathrm{A}^{5,15 \mathrm{I}^{\prime \prime}{ }_{17 \beta} * \mathrm{II}^{\prime \prime}{ }_{3 \beta}}$

$17 \beta$-Hydroxy-12 $\alpha$-13 $\beta$-etiojerv-4-en-3-one

(SC-19886)

An18,nC,hoD ${ }^{4} \mathbf{I}_{17 \alpha} \mathrm{ol}_{17 \beta} \mathrm{On}_{3}$

3 $\beta$-Hydroxy-5 $\alpha$-pregnan-20-one

(Steraloids)

$\mathbf{P 5} \alpha \mathrm{ol}_{3 \beta} \mathrm{On}_{20}$

$2 \beta$-(2'-Phenyl-ethylamino)-3 $\alpha$-hydroxy-5 $\alpha$-pregnan20-one hydrochloride

(Organon)

$\mathbf{P 5} \alpha \mathrm{ol}_{3 \alpha} \mathrm{On}_{20} \mathrm{NH}_{2 \beta / \mathrm{II} / / \mathrm{Ph} / / 2} \cdot \mathrm{HCl}$ 
Table 135 A (continued)

45

IM 82

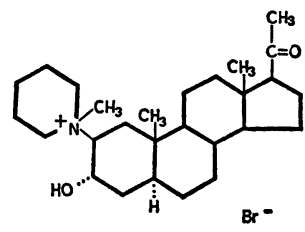

46

IM 460<smiles>CC(=O)C1CCC2C3CC[C@@H]4C[C@H](O)C(N5CCOCC5)C[C@]4(C)C3CC[C@]12C</smiles>

47

IM 496<smiles>CC12CCC3C(CC[C@@H]4CC(O)CCC34C)C1CCC2CC(C(=O)O)C(=O)O</smiles>

48

IM 497<smiles>CC12CC(=O)C3C(CCC4CC(O)CCC43C)C1CCC2CC(=O)O</smiles>

49

IM 545<smiles></smiles>

50

IM 544<smiles>CC(C=O)[C@H]1CCC2C3CC[C@H]4C[C@@H](O)CCC4(C)C3CCC21C</smiles>

51

IM 436<smiles>COC1C(C(N)=O)CC2C3CC[C@@H]4C[C@@H](O)CCC4(C)C3C(=O)CC21C</smiles>

52

IM 557

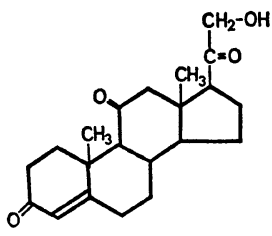

$2 \beta$-Piperidino-3 $\alpha$-hydroxy-5 $\alpha$-pregnan-20-one methobromide

(Organon)

$\left[\mathrm{P5} \alpha \mathrm{ol}_{3 \alpha} \mathrm{On}_{20}\right.$ piperidino $\left.2 \beta / \mathrm{I} / / 1\right] \cdot \mathrm{Br}^{-}$

$2 \beta$-Morpholino-3 $\alpha$-hydroxy-5 $\alpha$-pregnan-20-one hydrochloride

(Organon)

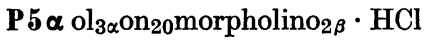

$3 \beta$-Hydroxy-5 $\alpha$-pregnane-21,21-dicarboxylic acid (Roussel)

$\mathbf{P 5} \alpha \mathbf{I}^{\prime \prime}{ }_{21,21} \mathrm{ol}_{3 \beta}$

$3 \beta$-Hydroxy-11-oxo-5 $\beta$-pregnan-21-oic acid (Roussel)

$\mathrm{P} 5 \boldsymbol{\beta}^{\prime \prime}{ }_{21} \mathrm{Ol}_{3 \alpha} \mathrm{On}_{11}$

3 $\alpha$-Acetoxy-23,24-bisnor-5 $\beta$-cholan-22-oic acid (B.R.L.)

$\mathrm{P5}_{\beta} \mathrm{I}_{20}^{\prime \prime} * \mathrm{II}^{\prime \prime}{ }_{3 \alpha}$

$3 \alpha$-Acetoxy-23,24-bisnor-5 $\beta$-cholan-22-al (B.R.L.)

P5 $\beta I \operatorname{al}_{20} * \mathrm{II}^{\prime \prime}{ }_{3 \alpha}$

$3 \alpha$-Hydroxy-11,20-dioxo-5 $\beta$-pregnane-16 $\alpha$-carboxamide (U-35827)

$P 5 \beta\left(\mathrm{CONH}_{2}\right)_{16 \alpha} \mathrm{ol}_{3 \alpha} \mathrm{On}_{11,20}$

21-Hydroxy-4-pregnene-3,11,20-trione (U-0569)

$\mathrm{P}^{4} \mathrm{Ol}_{21} \mathrm{On}_{3,11,20}$ 
Table 135 A (continued)

53

IM 556

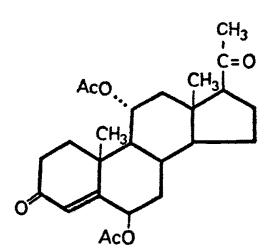

54

IM 561

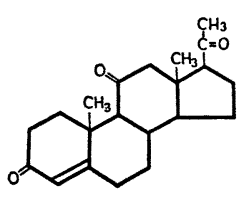

55

IM 555<smiles>CC(=O)C1CCC2C3CC(=O)C4=CC(O)CCC4(C)C3C(O)CC12C</smiles>

56

IM 546<smiles>CC(CO)[C@H]1CCC2C3CCC4=CC(=O)CCC4(C)C3CCC21C</smiles>

57

IM 548<smiles>C[C@H](O)[C@@H]1CCC2C3CCC4=CC(=O)CCC4(C)C3CCC21C</smiles>

58

IM 416<smiles>COC1CC2C3CCC4=CC(=O)CCC4(C)C3CCC2(C)C1OC(C)=O</smiles>

59

IM 547<smiles>C[C@H](O)[C@]1(C)CCC2C3CCC4=CC(=O)CCC4(C)C3CCC21</smiles>

60

IM 207

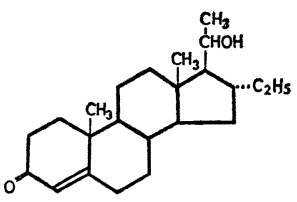

6 $\beta, 11 \alpha$-Dihydroxy-4-pregnene-3,20-dione diacetate (U-0471)

$\mathrm{P}^{4} * \mathrm{II}^{\prime \prime}{ }_{6 \beta, 11 \alpha \mathrm{OO}_{3,20}}$

4-Pregnene-3,11,20-trione

(B.R.L.)

$\mathbf{P}^{4} \mathrm{On}_{3,11,20}$

4-Pregnene-3,6,11,20-tetrone (U-0460)

$\mathrm{P}^{4} \mathrm{On}_{3,6,11,20}$

22-Hydroxy-23,24-bisnorchol-4-en-3-one (B.R.L.)

$\mathbf{P}^{4} \mathrm{Iol}_{20} \mathrm{On}_{3}$

3-Oxo-23,24-bisnor-4-cholen-22-oic acid (B.R.L.)

$\mathbf{P}^{4} \mathbf{I}^{\prime \prime}{ }_{20} \mathrm{On}_{3}$

3,20-Dioxo-4-pregnene-16 $\alpha$-carboxylic acid methyl ester

(U-35258)

$\mathbf{P}^{4} \mathbf{I}^{\prime \prime}{ }_{16 \alpha /}{ }^{*}{ }_{\mathrm{Iol} \mathrm{OO}}{ }_{3,20}$

3-Oxo-23,24-bisnor-4-cholen-22-al (B.R.L.)

$\mathbf{P}^{4} \mathrm{Ial}_{20} \mathrm{On}_{3}$

$16 \alpha$-Ethyl-20 $\beta$-hydroxy-4-pregnen-3-one (Organon)

$\mathrm{P}^{4} \mathrm{II}_{16 \alpha} \mathrm{Ol}_{20} \mathrm{On}_{3}$ 
Table 135 A (continued)

\begin{tabular}{|c|c|c|}
\hline \multirow[t]{2}{*}{$\begin{array}{l}61 \\
\text { IM } 524\end{array}$} & 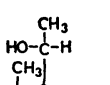 & $\begin{array}{l}\text { 5-Pregnen-3 } \beta \text {-20 } \beta \text {-diol 3-acetate } \\
\text { (B.R.L.) }\end{array}$ \\
\hline & & $\mathrm{P}^{5} \mathrm{ol}_{20 \beta} * \mathrm{II}_{3 \beta}^{\prime \prime}$ \\
\hline \multirow[t]{2}{*}{$\begin{array}{l}62 \\
\text { IM } 523\end{array}$} & & $\begin{array}{l}\text { 3 } \beta, 21-D i h y d r o x y-5 \text {-pregnen-20-one diacetate } \\
\text { (B.R.L.) }\end{array}$ \\
\hline & & $\mathrm{P} 5 * \mathrm{II}^{\prime \prime}{ }_{3 \beta, 21} \mathrm{on}_{20}$ \\
\hline \multirow[t]{2}{*}{$\begin{array}{l}63 \\
\text { IM } 467\end{array}$} & & $\begin{array}{l}\text { 16 } \beta \text {-Carboxy-5-pregnene-3 } \beta, 20 \beta \text {-diol } \gamma \text {-lactone } \\
3 \text {-acetate } \\
\text { (SC-5634) }\end{array}$ \\
\hline & & $\mathrm{P}^{5} \mathrm{I}^{\prime \prime} \gamma \operatorname{lac}_{16 \beta-20} * \mathrm{II}^{\prime \prime}{ }_{3 \beta}$ \\
\hline \multirow[t]{2}{*}{$\begin{array}{l}64 \\
\text { IM } 525\end{array}$} & & $\begin{array}{l}\text { 3,20-Dioxo-5-pregnene 3,3-20,20 bis-(ethylenedioxy) } \\
\text { (B.R.L.) }\end{array}$ \\
\hline & & $\mathbf{P}^{5} \vartheta \vartheta \mathrm{II}_{3,20}$ \\
\hline \multirow[t]{2}{*}{$\begin{array}{l}65 \\
\text { IM } 552\end{array}$} & & $\begin{array}{l}9 \xi, 11 \xi-\text { Epoxy-3 } \beta \text { - } \\
\text { hydroxy-5 } \alpha \text {-pregn-6-en-20-one- } \\
5,8 \alpha \text {-maleic anhydride adduct, acetate } \\
(\mathrm{U}-0156)\end{array}$ \\
\hline & & $\begin{array}{l}\mathrm{P5} \alpha^{6} * \mathrm{II}^{\prime \prime}{ }_{3 \beta} \mathrm{On}_{20} \theta_{9 \xi-11} \\
\text { maleic anhydride adduct } \\
5 \alpha-8\end{array}$ \\
\hline \multirow[t]{2}{*}{$\begin{array}{l}66 \\
\text { IM } 465\end{array}$} & & $\begin{array}{l}\text { 16 } \alpha \text {-Carboxy-5-pregnene-3 } \alpha, 20 \text {-diol diacetate } \\
\text { (SC-5934) }\end{array}$ \\
\hline & & $\mathbf{P}^{5} \mathbf{I}^{\prime \prime}{ }_{16 \alpha} * \mathrm{III}^{\prime \prime}{ }_{3 \alpha, 20}$ \\
\hline \multirow[t]{2}{*}{$\begin{array}{l}67 \\
\text { IM } 415\end{array}$} & & $\begin{array}{l}20,20 \text {-(Ethylenedioxy)-3 } \beta \text {-hydroxy-5-pregnene- } \\
16 \alpha \text {-carboxylic acid } \\
\text { (U-12872 E) }\end{array}$ \\
\hline & & $\mathbf{P}^{5} \mathbf{I}^{\prime \prime}{ }_{16 \alpha}{ }_{0} \mathrm{l}_{3 \beta} \theta \theta \mathrm{II}_{20}$ \\
\hline \multirow[t]{2}{*}{$\begin{array}{l}68 \\
\text { IM } 438\end{array}$} & & $\begin{array}{l}\text { 20,20-(Ethylenedioxy)-3 } \beta \text {-hydroxy-5-pregnene- } \\
16 \alpha \text {-carboxylic acid methyl ester } \\
\text { (U-36548) }\end{array}$ \\
\hline & & $\mathbf{P}^{5} \mathrm{I}^{\prime \prime}{ }_{16 \alpha /}{ }{ }_{\mathrm{I}_{013 \beta}} \theta \theta \mathrm{II}_{20}$ \\
\hline
\end{tabular}


Table 135 A (continued)

69

IM 437

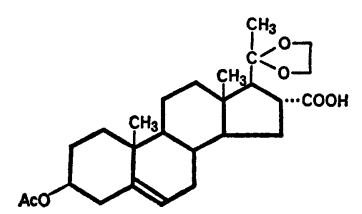

70

IM 71

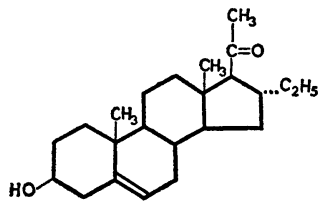

20,20-(Ethylenedioxy)-3 $\beta$-acetoxy-5-pregnene-16 $\alpha$ carboxylic acid (U-35939)

$\mathbf{P}^{5} \mathbf{I}^{\prime \prime}{ }_{16 \alpha} * \mathrm{II}^{\prime \prime}{ }_{3 \beta} \theta \theta \mathrm{II}_{20}$

\section{$3 \beta$-Hydroxy-16 $\alpha$-ethyl-5-pregnen-20-one} (Organon)

$\mathrm{P}^{5} \mathrm{II}_{16 \alpha} \mathrm{Ol}_{3 \beta} \mathrm{On}_{20}$

$3 \beta$-Hydroxy-16 $\alpha$-isobutyl-5-pregnen-20-one

71

IM 210

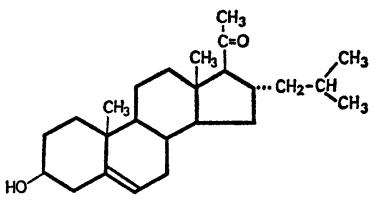

72

IM 499

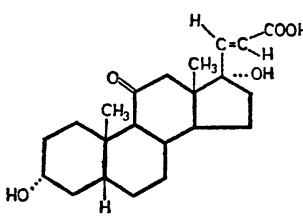

73

IM 526<smiles>CC12C=CC(=O)C=C1CCC1C2C(=O)CC2(C(C)(C)O)C1CCC2(C)C(=O)O</smiles>

74

IM 503

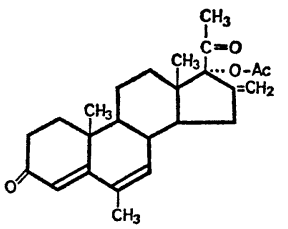

75

IM 553

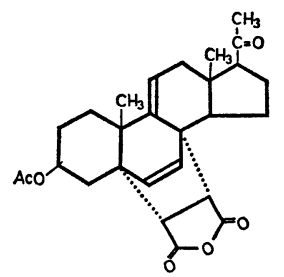

76

IM 99

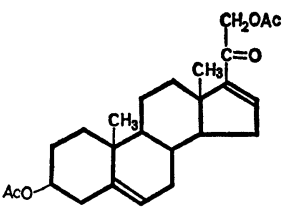

(Organon)

$\mathrm{P}^{5} \mathrm{III}_{16 \alpha / \mathrm{I} / / 2} \mathrm{Ol}_{3 \beta} \mathrm{On}_{20}$

$3 \alpha, 17 \alpha$-Dihydroxy-11-oxo-5 $\beta$-pregn-20-ene-21carboxylic acid

(Roussel)

$\mathbf{P} 5 \beta^{20} \mathbf{I}^{\prime \prime}{ }_{21} \mathrm{ol}_{3 \alpha, 17} \mathrm{On}_{11}$

17,21-Dihydroxy-1,4-pregnadiene-3,11,20-trione Prednisone

(B.R.L.)

$\mathbf{P}^{1,4} \mathrm{ol}_{17,21} \mathrm{On}_{3,11,20}$

17-Hydroxy-6-methyl-16-methylene-4,6-pregnadiene3,20-dione acetate (U-21240)

$\mathrm{P}^{4,6} \mathbf{I}_{6}\left(\mathrm{CH}_{2}\right)_{16}{ }^{*} \mathrm{II}^{\prime \prime}{ }_{17} \mathrm{On}_{3,20}$

$3 \beta$-Hydroxy-5 $\alpha$-pregna-6,9(11)-dien-20-one-5,8 $\alpha$-maleic anhydride adduct, acetate

(U-0157)

$\mathbf{P} 5 \alpha^{6,9(11)}$ maleic anhydride adduct $5 \alpha-8$

3 $\beta, 21$-Dihydroxy-5,16-pregnadien-20-one diacetate (Organon)

$\mathrm{P}^{5,16} * \mathrm{II}^{\prime \prime}{ }_{3 \beta, 21} \mathrm{on}_{20}$ 
Table 135 A (continued)

77

IM 296<smiles>CC1CCC2C(CCC3C2CC[C@@H]2CCCCC32C)C1[C@H](C)CCO</smiles>

78

IM 493

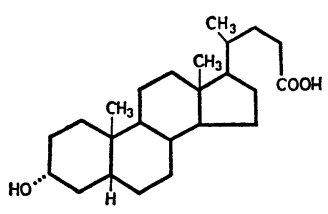

79

IM 485

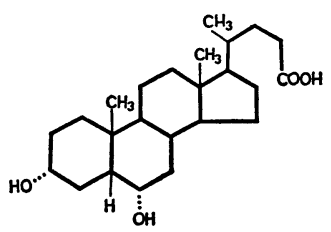

80

IM 492

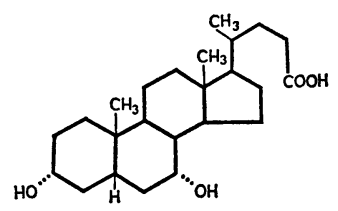

81

IM 490

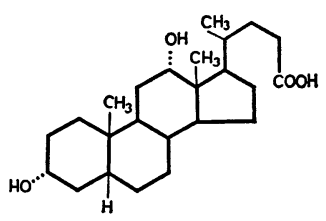

82

IM 488

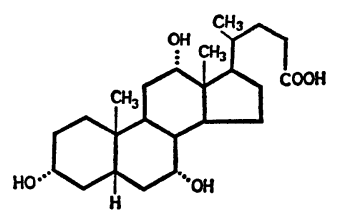

83

IM 487

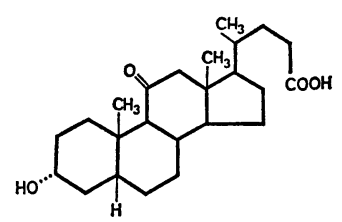

84

IM 550

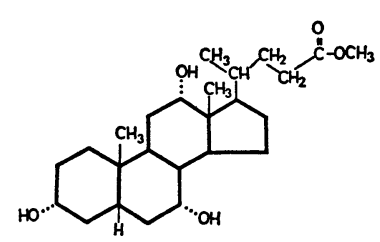

$5 \beta$-Cholan-24-oic acid

(Roussel)

CH5 $\beta^{\prime \prime}{ }_{24}$

$3 \alpha$-Hydroxy- $5 \beta$-cholan-24-oic acid

Lithocholic acid

(Roussel)

CH5 $\beta^{\prime \prime}{ }_{24} \mathrm{Ol}_{3 \alpha}$

$3 \alpha, 6 \alpha$-Dihydroxy-5 $\beta$-cholan-24-oic acid.

Hyodesoxylic acid

(Roussel)

CH5 $\beta^{\prime \prime}{ }_{24} \mathrm{Ol}_{3 \alpha, 6 \alpha}$

$3 \alpha, 7 \alpha$-Dihydroxy-5 $\beta$-cholan-24-oic acid.

Chenodesoxylic acid

(Roussel)

CH $5 \boldsymbol{\beta}^{\prime \prime}{ }_{24} \mathrm{Ol}_{3 \alpha, 7 \alpha}$

$3 \alpha, 12 \alpha$-Dihydroxy-5 $\beta$-cholan-24-oic acid.

Desoxycholic acid

(Roussel)

CH5 $\beta^{\prime \prime}{ }_{24} \mathrm{Ol}_{3 \alpha, 12 \alpha}$

$3 \alpha, 7 \alpha, 12 \alpha$-Trihydroxy-5 $\beta$-cholan-24-oic acid.

Cholic acid

(Roussel)

CH5 $\beta^{\prime \prime}{ }_{24} \mathrm{Ol}_{3 \alpha, 7 \alpha, 12 \alpha}$

$3 \alpha$-Hydroxy-11-oxo-5 $\beta$-cholan-24-oic acid (Roussel)

CH5 $\beta^{\prime \prime}{ }_{24} \mathrm{Ol}_{3 \alpha} \mathrm{On}_{11}$

$3 \alpha, 7 \alpha, 12 \alpha$-Trihydroxy-5 $\beta$-cholan-24-oic acid methyl ester

(U-0021)

CH5 $\beta^{\prime \prime}$ ol $_{3 \alpha, 7 \alpha, 12 \alpha} * \mathrm{I}_{24}$ 
Table 135 A (continued)

85

IM 541<smiles>CC(CC(=O)O)C1CCC2C3C(=O)C[C@@H]4CC(=O)CCC4(C)C3CC(=O)C12C</smiles>

86

IM 491<smiles>CC1CCC(=O)OCCC2C3CC=C4C[C@@H](O)CCC4(C)C3CCC12C</smiles>

87

IM 554

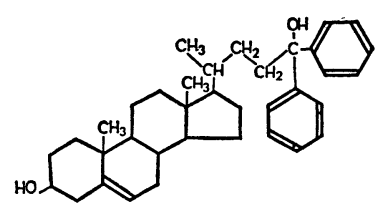

88

IM 198<smiles>CO[C@H]1CC[C@]2(C)C(=CCC3C4CCC(C(C)CCC(C)C)C4(C)CCC32)C1</smiles>

89

IM 532<smiles>CC(C)CCCC(C)C1CCC2C3CC=C4CC(CCC3C12C)OC1CCCC1OC1CCCC41C</smiles>

3,7,12-Trioxo-5 $\beta$-cholan-24-oic acid

(B.R.L.)

СH $5 \beta^{\prime \prime}{ }_{24} \mathrm{On}_{3,7,12}$

$3 \alpha$-Hydroxy-5-cholen-24-oic acid

(Roussel)

$\mathrm{CH}^{5 \prime \prime}{ }_{24} \mathrm{Ol}_{3 \alpha}$

24,24-Diphenyl-5-cholene-3 $\beta, 24$-diol

(U-0359)

$\mathrm{CH}^{5} \mathrm{Ph}_{24,24} \mathrm{Ol}_{3 \beta, 24}$
90

IM 530

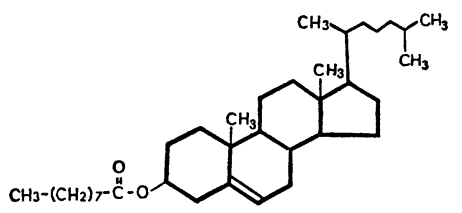

3 $\beta$-Hydroxy-5-cholestene 3-sodium sulphate (Organon)

CHT $^{5} * \mathrm{~S}^{\prime \prime} \mathrm{Na}_{3 \beta}$

5-Cholesten-3 $\beta$-ol chloroformate

(B.R.L.)

$\mathrm{CHT}^{5} * \mathrm{I}^{\prime \prime} \mathrm{Cl}_{3 \beta}$

91

IM 531

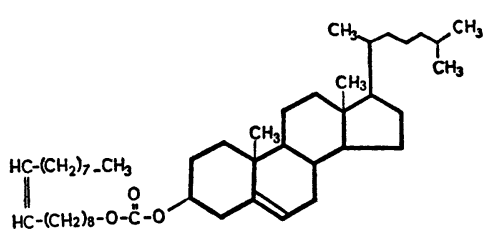

5-Cholesten-3 $\beta$-ol pelargonate (B.R.L.)

$\mathrm{CHT}^{5} * \mathrm{IX}^{\prime \prime}{ }_{3 \beta}$

92

IM 529

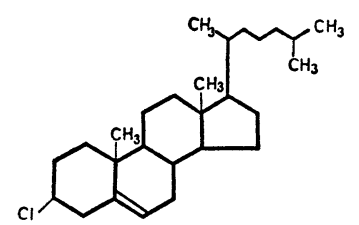

3 $\beta$-Chloro-5-cholestene

(B.R.L.)

$\mathrm{CHT}^{5} \mathrm{Cl}_{3 \beta}$
5-Cholesten-3 $\beta$-ol oleyl carbonate (B.R.L.)

$\mathrm{CHT}^{5} * \mathrm{XIX}^{10 /{ }_{3 \beta}}$ 
Table 135 A (continued)

93

IM 558<smiles>CC(Cl)CCCC(C)C1CCC2C3CC(Cl)=C4CC(O)CCC4(C)C3CCC12C</smiles>

94

IM 536<smiles>C/C(=C\C(C)C1CCC2C3=CCC4=CC(=O)CCC4(C)C3CCC21C)C(C)C</smiles>

95

IM 535<smiles>CC(C)=CC(C)C1CCC2C3=CC=C4CC(O)CCC4(C)C3CCC21C</smiles>

96

IM 551

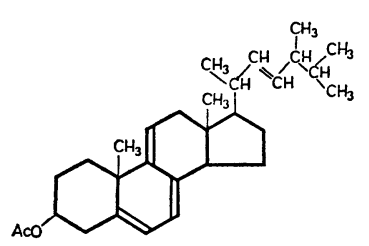

97

IM 537<smiles>CCC(C)=CC(C)C1CCC2C3CC[C@@H]4C[C@@H](O)CCC4(C)C3CCC12C</smiles>

98

IM 538<smiles>C/C(=C/C(C)C)C1CCC2C3CC[C@H]4C[C@@H](C(C)C)CCC4(C)C3CCC12C</smiles>

$3 \alpha$-Hydroxy-5 $\beta$-stigmast-22-ene acetate (B.R.L.)

$\operatorname{ST5} \beta^{22} * \mathrm{II}^{\prime \prime} 3 \alpha$

5,22-Stigmastadien-3 $\beta$-ol

Stigmasterol

(B.R.L.)

$\mathrm{ST}^{5,22} \mathrm{Ol}_{3 \beta}$ 
Table 135 A (continued)

100

IM 534<smiles>CC(C)=CC(C)C1CCC2C3CCC4=CC(=O)CCC4(C)C3CCC12C</smiles>

101

IM 494

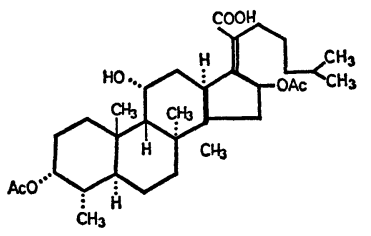

102

IM 542

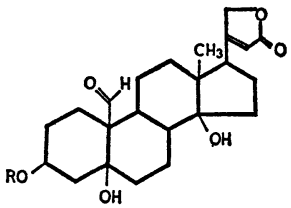

103

IM 521<smiles>CCC(c1ccc(O)cc1)C(CC)c1ccc(O)cc1</smiles>

104

IM 520<smiles>CCC(=C(CC)c1ccc(O)cc1)c1ccc(O)cc1</smiles>

105

IM 539

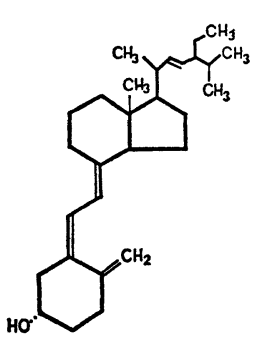

4,22-Stigmastadien-3-one

(B.R.L.)

$\mathrm{ST}^{4,22} \mathrm{On}_{3}$

$3 \alpha, 16 \beta$-Diacetoxy-11 $\alpha$-hydroxy-31-

nor- $5 \alpha, 8 \alpha, 9 \beta, 13 \alpha$,

14 $\beta$-dammaran-17(20)-en-21-oic acid

(Roussel)

Dammaran n3117 (20) $5 \alpha, 8 \alpha, 9 \beta, 13 \alpha, 14 \beta I^{\prime \prime}{ }_{21}$ ol $_{11 \alpha}$

$* \mathrm{II}_{3 \alpha, 16 \beta}$

$3 \beta, 5,14-$ Trihydroxy-19-oxo-5 $\beta$,

$14 \beta$-card-20(22)-enolide mixture of 3-glycosides

( $\beta$-glucose- $\beta$-glucose-cymarose-,

$\beta$-glucose-cymarose-, cymarose)

(B.R.L.)

CAR 5 $\beta^{20(22)} \operatorname{Ial}_{19 \beta} \mathrm{Ol}_{5,14 \beta} * \mathrm{R}_{3}$

3,4-Bis(p-hydroxy-phenyl)-n-hexane (Hexestrol)

(B.R.L.)

3,4-Bis(p-hydroxy-phenyl)-n-hex-3-ene (Diethylstilbestrol)

(B.R.L.)

Calciferol

(Vitamin $D_{2}$ )

(B.R.L.)

Calciferol

eminently suitable for pharmaco-chemical correlation studies. It must be kept in mind, however, that these assessments of activity are subjective and hence only very high or essentially negative ratings deserve serious consideration as indexes of strong and negligible activity respectively. This is all the more true since, in many instances, the total number of rats had to be limited to five per group because the majority of the steroids tested were available only in small amounts. On the other hand, all compounds which are highly potent in increasing resistance to one or both of these toxicants were retested at lower dose levels. 
Table 135B. First step (ctd.): Synopsis of all 500 steroids tested for their ability to prevent digitoxin and indomethacin intoxication

\begin{tabular}{|c|c|c|c|c|c|}
\hline Group & SSS Name & $\begin{array}{l}\text { Dose } \\
\text { (mg) }\end{array}$ & $\begin{array}{l}\text { Digi- } \\
\text { toxin }^{2}\end{array}$ & $\begin{array}{l}\text { Indo- } \\
\text { methacin }\end{array}$ & $\begin{array}{l}\text { Activity } \\
\text { index }{ }^{b}\end{array}$ \\
\hline $\begin{array}{l}1 \\
\text { IM } 360\end{array}$ & $\begin{array}{l}\mathbf{G}^{4} \mathbf{I I}_{13 \alpha, 17 \alpha} \mathrm{ol}_{17 \mathrm{OO}_{3}} \\
\text { (d-Norbolethone) }\end{array}$ & 10 & 3 & 3 & 0.3 \\
\hline $\begin{array}{l}2 \\
\text { IM } 343\end{array}$ & $\begin{array}{l}\mathbf{G}^{4} \mathrm{I}_{18,17 \alpha} \mathrm{ol}_{17 \mathrm{On}_{3}} \\
\text { (d,1-Norbolethone) }\end{array}$ & $\begin{array}{c}10 \\
0.5 \\
0.1\end{array}$ & $\begin{array}{l}3 \\
0 \\
0\end{array}$ & $\begin{array}{l}3 \\
0.5 \\
-\end{array}$ & $\begin{array}{l}0.3 \\
0.5 \\
0\end{array}$ \\
\hline $\begin{array}{l}3 \\
\text { IM } 142\end{array}$ & $\mathrm{E}^{4} \mathrm{Ol}_{17 \beta}$ & 10 & 0 & 3 & 0.15 \\
\hline $\begin{array}{l}4 \\
\text { IM } 147\end{array}$ & $\mathbf{E}^{4} \mathrm{on}_{17}$ & 10 & $\mathbf{0}$ & 2 & 0.1 \\
\hline $\begin{array}{l}5 \\
\text { IM } 188\end{array}$ & $\mathrm{E}^{4} \mathrm{On}_{3,17}$ & 10 & 1 & 2 & 0.15 \\
\hline $\begin{array}{l}6 \\
\text { IM } 146\end{array}$ & $\mathrm{E}^{4} \mathrm{Ol}_{17 \beta} \mathrm{On}_{3} \quad$ (Nortestosterone) & 10 & 2 & 0 & 0.1 \\
\hline $\begin{array}{l}7 \\
\text { IM } 522\end{array}$ & $\mathrm{E}^{4 *} \mathrm{II}^{\prime \prime}{ }_{17 \beta / \mathrm{C} 1 / 2,2,2} \mathrm{On}_{3}$ & 0.5 & 0 & 0 & 0 \\
\hline $\begin{array}{l}8 \\
\text { IM } 340\end{array}$ & $\begin{array}{l}\mathrm{E}^{4 *} \mathrm{IIII}^{\prime \prime} \mathrm{Ph}_{12 \beta} \mathrm{On}_{3} \\
\text { (Nandrolonephenyl pr.) }\end{array}$ & 10 & 0 & $\mathbf{0}$ & 0 \\
\hline $\begin{array}{l}\text { 9 } \\
\text { IM } 339\end{array}$ & $\mathrm{E}^{4 *} \mathrm{X}^{\prime \prime}{ }_{17 \beta} \mathrm{On}_{3}$ (Nondrolone dec.) & 10 & 0 & 0 & 0 \\
\hline $\begin{array}{l}10 \\
\text { IM } 186\end{array}$ & $\mathrm{E}^{1(10), 5 \mathrm{Ol}_{3 \beta} \mathrm{On}_{17}}$ & 10 & 0 & 3 & 0.15 \\
\hline $\begin{array}{ll}11 & \\
\text { IM } 33\end{array}$ & $\mathbf{E}^{1,3,5(10)_{0}}{ }_{3,17 \beta} \quad$ (Estradiol) & $\begin{array}{r}10 \\
1\end{array}$ & $\begin{array}{l}0 \\
0\end{array}$ & $\overline{0.5}$ & $\begin{array}{l}0 \\
0.25\end{array}$ \\
\hline $\begin{array}{l}12 \\
\text { IM } 505\end{array}$ & 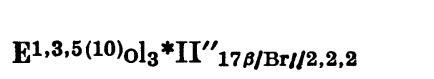 & 0.5 & 0 & 0 & 0 \\
\hline $\begin{array}{l}13 \\
\text { IM } 504\end{array}$ & 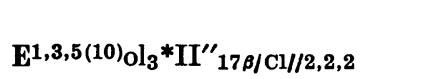 & 0.5 & 0 & 0 & 0 \\
\hline
\end{tabular}

a As in the previously reported data the figures indicate the means of the statistical difference grades of protection ranging from " 0 " (no protection) to " 3 " (perfect protection). For further data concerning the techniques $c f . p$. VIII.

b Based on the formula $\frac{D+I}{2} \times \frac{1}{m g}$, where $D=$ reading for digitoxin, $I=$ indomethacin, $\mathrm{mg} \sim$ the dose tested.

It is noteworthy that, among the 500 steroids listed in Table $135 \mathrm{~B}$, only 20 exhibited an activity index of 10 or more. It is hardly coincidental that all compounds of this select group are $16 \alpha$-carbonitriles, except for TMACN (Cpd. 149) which is a $2 \alpha$-carbonitrile, the $16 \alpha$-17-methyloxazolyl (Cpd. 329), CS-1 (Cpd. 191), and dexamethasone acetate (Cpd. 360). It may be significant that within this small group of exceptions we find: one steroid (Cpd. 149) which also carries a carbonitrile substituent on the ring, although in the $2 \alpha$-position, two $9 \alpha$-fluoro-compounds (CS-1 and dexamethasone), one steroid (Cpd. 329) substituted at $16 \alpha$, although not by a carbonitrile. It will be interesting to see whether other $16 \alpha$-substituted or halogenated steroids possess considerable catatoxic activity and whether the latter can be further increased by the introduction of several apparently advantageous substituents into the same molecule. 
Table 135 B (continued)

\begin{tabular}{|c|c|c|c|c|c|}
\hline Group & SSS Name & $\begin{array}{l}\text { Dose } \\
\text { (mg) }\end{array}$ & $\begin{array}{l}\text { Digi- } \\
\text { toxin }^{\text {a }}\end{array}$ & $\begin{array}{l}\text { Indo- } \\
\text { methacin }^{a}\end{array}$ & $\begin{array}{l}\text { Activity } \\
\text { index }\end{array}$ \\
\hline $\begin{array}{l}14 \\
\text { IM } 506\end{array}$ & $\mathrm{E}^{1,3,5(10)} \mathrm{ol}_{3}{ }^{*} \mathrm{II}^{\prime \prime}{ }_{17 / / \mathrm{F} / / 2,2,2}$ & 0.5 & 0 & 0 & 0 \\
\hline $\begin{array}{l}15 \\
\text { IM } 513\end{array}$ & 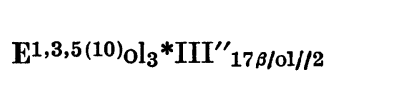 & 0.5 & 0 & 0 & 0 \\
\hline $\begin{array}{l}16 \\
\text { IM } 507\end{array}$ & $\mathrm{E}^{1,3,5(10)_{0}{ }_{3} * \mathrm{III}^{\prime \prime}{ }_{17 \beta / \mathrm{I}}, \mathrm{ol} / / 2}$ & 0.5 & 0 & 0 & 0 \\
\hline $\begin{array}{l}17 \\
\text { IM } 509\end{array}$ & $\mathrm{E}^{1,3,5(10)_{\mathrm{Ol}_{3}} * V^{\prime \prime} 17 \beta}$ & 0.5 & 0 & 0 & 0 \\
\hline $\begin{array}{l}18 \\
\text { IM } 510\end{array}$ & $\mathrm{E}^{\left.1,3,5(10)_{0}\right)_{3} * \mathrm{VII}^{\prime \prime} 17 \beta}$ & 0.5 & 0 & 0 & 0 \\
\hline $\begin{array}{l}19 \\
\text { IM } 511\end{array}$ & 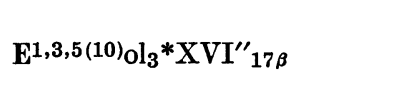 & 0.5 & 0 & 0 & 0 \\
\hline $\begin{array}{l}20 \\
\text { IM } 512\end{array}$ & 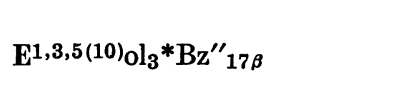 & 0.5 & 0 & 0 & 0 \\
\hline $\begin{array}{l}21 \\
\text { IM } 508\end{array}$ & $\mathbf{E}^{1,3,5(10) \mathrm{ol}_{3} * \text { adamantoate }}{ }_{17 \beta}$ & 0.5 & 0 & 0 & 0 \\
\hline $\begin{array}{l}22 \\
\text { IM } 518\end{array}$ & 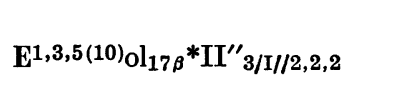 & 0.5 & 0 & 0 & 0 \\
\hline $\begin{array}{l}23 \\
\text { IM } 519\end{array}$ & $\mathrm{E}^{1,3,5(10) \mathrm{ol}_{17 \beta} * \mathrm{III}^{\prime \prime}{ }_{3 / \mathrm{I}}, \mathrm{Br} / / 2}$ & 0.1 & 0 & 0 & 0 \\
\hline $\begin{array}{l}24 \\
\text { IM } 514\end{array}$ & 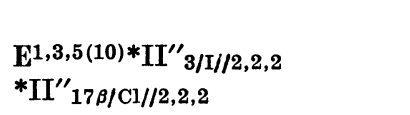 & 0.5 & 0 & 0 & 0 \\
\hline $\begin{array}{l}25 \\
\text { IM } 516\end{array}$ & $\begin{array}{l}\mathbf{E}^{1,3,5(10) * I^{\prime \prime}} 3 / \mathrm{I} / / 2,2,2 \\
\text { *methyltartrate }_{17 \beta}\end{array}$ & 0.1 & 0 & 0 & 0 \\
\hline $\begin{array}{l}26 \\
\text { IM } 517\end{array}$ & $E^{1,3,5(10) *} *_{\text {furoate }}, 17 \beta$ & 0.1 & 0 & 0 & 0 \\
\hline $\begin{array}{l}27 \\
\text { IM } 21\end{array}$ & $\mathbf{E}^{1,3,5(10) \text { ol }_{3} \mathrm{On}_{17} \quad \text { (Estrone) }}$ & 10 & 0 & 2.5 & 0.125 \\
\hline $\begin{array}{l}28 \\
\text { IM } 515\end{array}$ & $\mathrm{E}^{1,3,5(10) * \mathrm{II}^{\prime \prime}{ }_{17 \beta / \mathrm{C}} 1 / / 2,2,2} \theta \mathrm{IIII}^{2}{ }_{3}$ & 0.5 & 0 & 0 & 0 \\
\hline $\begin{array}{l}29 \\
\text { IM } 194\end{array}$ & $\mathbf{E}^{1,3,5(10)}$ on $_{17} \theta \mathrm{I}_{3}$ & 10 & 0 & 1.5 & 0.075 \\
\hline $\begin{array}{l}30 \\
\text { IM } 356\end{array}$ & $\mathrm{E}^{4,9,11_{\mathrm{On}_{3,17}}}$ & 10 & 0.5 & 0 & 0.025 \\
\hline $\begin{array}{l}31 \\
\text { IM } 355\end{array}$ & 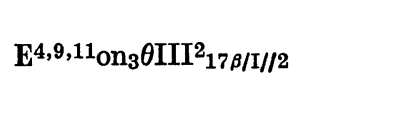 & $\begin{array}{c}10 \\
0.5\end{array}$ & $\begin{array}{l}1.5 \\
-\end{array}$ & $\begin{array}{l}3 \\
0\end{array}$ & $\begin{array}{l}0.225 \\
0\end{array}$ \\
\hline $\begin{array}{l}32 \\
\text { IM } 435\end{array}$ & $\mathrm{E} 5 \beta \mathrm{CN}_{5} \mathrm{II}^{1-1}{ }_{17 \alpha} \mathrm{Ol}_{17} \mathrm{On}_{3}$ & 0.5 & 0 & 0 & 0 \\
\hline $\begin{array}{l}33 \\
\text { IM } 428\end{array}$ & E $5 \beta \mathrm{CN}_{5} \mathrm{III}_{17 \alpha / \mathrm{I} / / 2} \mathrm{Ol}_{17} \mathrm{On}_{3}$ & 0.5 & 0 & 0 & 0 \\
\hline
\end{tabular}


Table 135 B (continued)

\begin{tabular}{|c|c|c|c|c|c|}
\hline Group & SSS Name & $\begin{array}{l}\text { Dose } \\
\text { (mg) }\end{array}$ & $\begin{array}{l}\text { Digi- } \\
\text { toxin }^{a}\end{array}$ & $\begin{array}{l}\text { Indo- } \\
\text { methacin a }\end{array}$ & $\begin{array}{l}\text { Activity } \\
\text { index }\end{array}$ \\
\hline $\begin{array}{l}\mathbf{3 4} \\
\text { IM } 430\end{array}$ & E5 $\xi \mathrm{CN}_{5} \mathrm{III}_{17 \alpha / \mathrm{I} / / 2} \mathrm{Ol}_{17} \mathrm{On}_{3}$ & 0.5 & 0 & 0 & 0 \\
\hline $\begin{array}{l}35 \\
\text { IM } 192\end{array}$ & $\mathbf{E}^{4} \mathbf{I}_{17 \alpha} \mathrm{Ol}_{17} \mathrm{On}_{3}$ & $\begin{array}{c}10 \\
0.5\end{array}$ & 3 & $\begin{array}{l}3 \\
0\end{array}$ & $\begin{array}{l}0.3 \\
0\end{array}$ \\
\hline $\begin{array}{l}36 \\
\text { IM } 79\end{array}$ & $\mathbf{E}^{4} \mathbf{I}_{17 \alpha} \mathrm{Ol}_{4,17} \mathrm{On}_{3}$ & $\begin{array}{c}10 \\
0.5\end{array}$ & $\underline{0}$ & $\begin{array}{l}3 \\
0\end{array}$ & $\begin{array}{l}0.15 \\
0\end{array}$ \\
\hline $\begin{array}{l}37 \\
\text { IM } 59\end{array}$ & $\mathbf{E}^{4} \mathrm{II}_{17 \alpha} \mathrm{Ol}_{17} \quad$ (Ethylestrenol) & $\begin{array}{c}10 \\
0.5\end{array}$ & $\begin{array}{l}3 \\
0\end{array}$ & $\begin{array}{l}3 \\
0\end{array}$ & $\begin{array}{l}0.3 \\
0\end{array}$ \\
\hline $\begin{array}{l}38 \\
\text { IM } 76\end{array}$ & $\mathbf{E}^{4} \mathrm{II}_{17 \alpha} \mathrm{Ol}_{17} * \mathrm{III}^{\prime \prime}{ }_{3 \beta}$ & 10 & 0 & 3 & 0.15 \\
\hline $\begin{array}{l}39 \\
\text { IM } 57\end{array}$ & $\mathbf{E}^{4} \mathrm{II}_{17 \alpha \mathrm{Ol}_{17} \mathrm{On}_{3} \quad \text { (Norethandrolone) }}$ & 10 & 3 & 0.5 & 0.175 \\
\hline $\begin{array}{l}40 \\
\text { IM } 193\end{array}$ & $\mathbf{E}^{4} \mathbf{I I}_{17 \alpha}{ }_{17} \mathrm{Ol}_{17} \mathrm{On}_{3}$ & 10 & 1 & 2 & 0.15 \\
\hline $\begin{array}{l}41 \\
\text { IM } 315\end{array}$ & E4III' $^{4} \mathbf{l a c}_{17 \alpha} \mathrm{On}_{3}$ & 10 & 3 & 2.5 & 0.275 \\
\hline $\begin{array}{l}42 \\
\text { IM } 101\end{array}$ & $\mathbf{E}^{4} \mathrm{IIII}_{17 \alpha}{ }_{17} \mathrm{Ol}_{17} \quad$ (Allylestrenol) & 10 & 0 & 3 & 0.15 \\
\hline $\begin{array}{l}43 \\
\text { IM } 338\end{array}$ & $\mathbf{E}^{5(10)} \Pi^{1-1} 1_{17 \alpha} \mathrm{Ol}_{17} \mathrm{On}_{3} \quad$ (Norethynodrel) & 10 & 0 & 0 & 0 \\
\hline $\begin{array}{l}44 \\
\text { IM } 392\end{array}$ & $\mathrm{E}^{1,3,5(10)} \mathbf{I}_{16 \alpha} \mathbf{C N}_{16} * \mathrm{II}^{\prime \prime}{ }_{17 \beta} \theta \mathrm{I}_{3}$ & 0.5 & 0 & 0 & 0 \\
\hline $\begin{array}{l}45 \\
\text { IM } 395\end{array}$ & $\mathrm{E}^{1,3,5(10) \mathbf{I}_{16 \xi}} \mathrm{CN}_{16} \mathrm{On}_{17} \theta \mathrm{I}_{3}$ & 0.5 & 0 & 0 & 0 \\
\hline $\begin{array}{l}46 \\
\text { IM } 35\end{array}$ & $\begin{array}{l}\mathbf{E}^{1,3,5(10)} \mathrm{II}^{1-1}{ }_{17 \alpha} \mathrm{ol}_{3,17} \\
\text { (Ethynylestradiol) }\end{array}$ & 10 & 0 & 0 & 0 \\
\hline $\begin{array}{l}\mathbf{4 7} \\
\text { IM } 304\end{array}$ & $\mathrm{E}^{1,3,5(10)} \mathrm{II}^{1-1}{ }_{17 \alpha} \mathrm{ol}_{17} \theta \mathrm{I}_{3 \beta}$ & $\begin{array}{c}10 \\
0.5\end{array}$ & 0 & $\begin{array}{l}3 \\
0\end{array}$ & $\begin{array}{l}0.15 \\
0\end{array}$ \\
\hline $\begin{array}{l}48 \\
\text { IM } 168\end{array}$ & $\mathrm{E}^{1,3,5(10), 7^{\text {furyl }}}{ }_{17 \alpha / 3} \mathrm{ol}_{17} * \mathrm{II}^{\prime \prime}{ }_{3 \beta}$ & 10 & 0 & 2.5 & 0.125 \\
\hline $\begin{array}{l}49 \\
\text { IM } 169\end{array}$ & $\mathrm{E}^{1,3,5(10),{ }^{7} \text { furyl }_{17 \alpha / 3} \mathrm{ol}_{17} \theta \mathrm{cycV} / 3 \beta}$ & 10 & 0 & 3 & 0.15 \\
\hline $\begin{array}{l}50 \\
\text { IM } 380\end{array}$ & $\mathrm{E}^{1,3,5(10), 16} \mathrm{CN}_{17} * \mathrm{II}^{\prime \prime}{ }_{3}$ & 0.5 & 0 & 0 & 0 \\
\hline $\begin{array}{l}51 \\
\text { IM } 400\end{array}$ & $\mathbf{E}^{1,3,5(10), 16} \mathrm{CN}_{17} \theta \mathrm{I}_{3}$ & 0.5 & 0 & 0 & 0 \\
\hline $\begin{array}{l}52 \\
\text { IM } 326\end{array}$ & $\mathrm{E}\left(\mathrm{O}_{2}\right)^{4,9(10) \mathrm{ol}_{17 \beta} \mathrm{On}_{3}}$ & $\begin{array}{l}10 \\
0.5\end{array}$ & $\begin{array}{l}3 \\
1\end{array}$ & 0 & $\begin{array}{l}0.15 \\
2\end{array}$ \\
\hline $\begin{array}{l}\text { 53 } \\
\text { IM } 328\end{array}$ & $\mathrm{E}\left(\mathrm{O}_{2}\right)^{4,9,11_{\mathrm{ol}_{17 \beta} \mathrm{On}_{3}}}$ & 10 & 1.5 & 0.5 & 0.1 \\
\hline
\end{tabular}


Table 135 B (continued)

\begin{tabular}{|c|c|c|c|c|c|}
\hline Group & SSS Name & $\begin{array}{l}\text { Dose } \\
\text { (mg) }\end{array}$ & $\begin{array}{l}\text { Digi- } \\
\text { toxin }^{\mathrm{a}}\end{array}$ & $\begin{array}{l}\text { Indo- } \\
\text { methacin }^{a}\end{array}$ & $\begin{array}{l}\text { Activity } \\
\text { index }\end{array}$ \\
\hline $\begin{array}{l}54 \\
\text { IM } 336\end{array}$ & $\mathbf{E a b}^{10(5 \rightarrow 4)} \mathbf{I}_{7 \alpha, 17 \alpha} \mathrm{Ol}_{17} \mathrm{On}_{3,5}$ & 10 & 2 & 1.5 & 0.175 \\
\hline $\begin{array}{l}55 \\
\text { IM } 196\end{array}$ & $\mathrm{~A} 5 \alpha \mathrm{ol}_{11 \beta, 17 \beta}$ & 10 & 3 & 0 & 0.15 \\
\hline $\begin{array}{l}56 \\
\text { IM } 183\end{array}$ & A5 $\alpha$ on $_{3,17}$ & 10 & 3 & 0.5 & 0.175 \\
\hline $\begin{array}{l}57 \\
\text { IM } 100\end{array}$ & 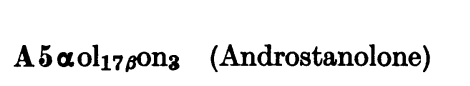 & 10 & 2 & 0 & 0.1 \\
\hline $\begin{array}{l}58 \\
\text { IM } 191\end{array}$ & $\mathrm{~A} 5 \alpha * \mathrm{~S}^{\prime \prime} \mathrm{Na}_{3 \alpha} \mathrm{On}_{17}$ & 0.5 & 0 & 0 & 0 \\
\hline $\begin{array}{l}59 \\
\text { IM } 327\end{array}$ & $\mathbf{A} 5 \alpha \operatorname{on}_{17} \theta_{2 \beta-19} \mathrm{Cl}_{3 \alpha}$ & 10 & 0 & 2 & 0.1 \\
\hline $\begin{array}{l}60 \\
\text { IM } 252\end{array}$ & $\mathrm{A5} \alpha * \mathrm{II}^{\prime \prime}{ }_{3 \beta} \mathrm{On}_{17} \mathrm{Cl}_{5,6 \beta}$ & 10 & $\mathbf{0}$ & $\mathbf{0}$ & 0 \\
\hline $\begin{array}{l}61 \\
\text { IM } 229\end{array}$ & $\mathbf{A 5} \alpha \mathrm{NOH}_{17}$ & 10 & 3 & 3 & 0.3 \\
\hline $\begin{array}{l}62 \\
\text { IM } 213\end{array}$ & $\mathrm{~A}^{5} \boldsymbol{\alpha \mathrm { ol } _ { 1 1 } \beta} \mathrm{NOH}_{17}$ & 10 & 3 & 3 & 0.3 \\
\hline $\begin{array}{l}63 \\
\text { IM } 224\end{array}$ & $A 5 \alpha \operatorname{ol}_{11 \beta}\left(\mathrm{NH}_{2}\right)_{17 \beta}$ & 10 & 1.5 & 0 & 0.075 \\
\hline $\begin{array}{l}64 \\
\text { IM } 246\end{array}$ & 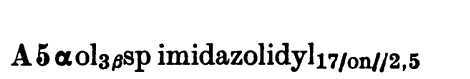 & 10 & 0 & 0 & 0 \\
\hline $\begin{array}{l}65 \\
\text { IM } 319\end{array}$ & $A 5 \alpha \mathrm{ol}_{3 \alpha} \mathrm{On}_{17}\left(\mathrm{~N}_{3}\right)_{2 \beta}$ & 10 & 0 & 0 & 0 \\
\hline $\begin{array}{l}66 \\
\text { IM } 313\end{array}$ & $\mathrm{~A} 5 \alpha \mathrm{ol}_{2 \beta} \mathrm{On}_{17} \mathrm{NH}_{3 \alpha / \mathrm{I}} \cdot \mathrm{HCl} 15 \mathrm{H}_{2} \mathrm{O}$ & 0.5 & 0 & 0 & 0 \\
\hline $\begin{array}{l}67 \\
\text { IM } 140\end{array}$ & $\mathrm{A5} \alpha \mathrm{ol}_{2 \beta} \mathrm{On}_{17} \mathrm{~N}_{3 \alpha / \mathrm{I} / / 1,1} \cdot \mathrm{HClH}_{2} \mathrm{O}$ & 0.5 & 0 & 0 & 0 \\
\hline $\begin{array}{l}68 \\
\text { IM } 284\end{array}$ & {$\left[\mathrm{~A} 5 \alpha^{*} \mathrm{II}^{\prime \prime}{ }_{3 \alpha} \mathrm{On}_{17} \mathrm{~N}_{2 \beta / \mathrm{I}, \mathrm{II}, \mathrm{II}] \mathrm{Br}^{-}}\right.$} & 0.5 & 0 & 0 & 0 \\
\hline $\begin{array}{l}69 \\
\text { IM } 260\end{array}$ & 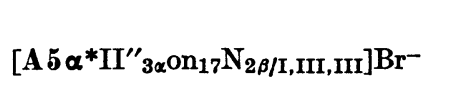 & 0.5 & 0 & 0 & 0 \\
\hline $\begin{array}{l}70 \\
\text { IM } 253\end{array}$ & $\mathrm{~A} 5 \alpha^{*} \mathrm{II}^{\prime \prime}{ }_{3 \beta} \mathrm{On}_{17} \mathrm{Cl}_{5}\left(\mathrm{~N}_{3}\right)_{6 \beta}$ & 10 & 0 & 0 & 0 \\
\hline $\begin{array}{l}71 \\
\text { IM } 453\end{array}$ & $\begin{array}{c}\mathrm{A} 5 \alpha * \mathrm{II}^{\prime \prime}{ }_{3 \alpha, 17 \beta \text { piperidino }}{ }_{2 \beta, 16 \beta} \\
\cdot 2 \mathrm{HCl} 15 \mathrm{H}_{2} \mathrm{O}\end{array}$ & 0.5 & 0 & 0 & 0 \\
\hline $\begin{array}{l}72 \\
\text { IM } 361\end{array}$ & $\begin{array}{l}{\left[\mathrm{A5} \alpha^{*} \mathrm{II}^{\prime \prime}{ }_{3 \alpha, 17 \beta} \text { piperidino } 2 \beta, 16 \beta\right]} \\
(\text { Pancuronium } \mathrm{Br}) \cdot 2 \mathrm{Br}-\mathrm{H}_{2} \mathrm{O}\end{array}$ & 10 & 0 & 1.5 & 0.075 \\
\hline $\begin{array}{l}73 \\
\text { IM } 185\end{array}$ & $\begin{array}{r}{\left[\mathrm{A} 5 \alpha \mathrm{ol}_{3 \alpha} \mathrm{On}_{17} \text { piperidino }_{2 \beta, 16 \beta / \mathrm{I} / 1,1]}\right]} \\
\cdot 2 \mathrm{Br}\end{array}$ & 0.5 & 0 & 0 & 0 \\
\hline
\end{tabular}


Table 135 B (continued)

\begin{tabular}{|c|c|c|c|c|c|}
\hline Group & SSS Name & $\begin{array}{l}\text { Dose } \\
\text { (mg) }\end{array}$ & $\begin{array}{l}\text { Digi- } \\
\text { toxin }^{a}\end{array}$ & $\begin{array}{l}\text { Indo- } \\
\text { methacin }^{a}\end{array}$ & $\begin{array}{l}\text { Activity } \\
\text { index }\end{array}$ \\
\hline $\begin{array}{l}74 \\
\text { IM } 325\end{array}$ & $\mathrm{~A} 5 \alpha^{*} \mathrm{III}^{\prime \prime}{ }_{17 \beta / \mathrm{cycV} / / 3} \mathrm{~S}_{2 \alpha-3}$ & 10 & 0 & 0 & 0 \\
\hline $\begin{array}{l}75 \\
\text { IM } 250\end{array}$ & $\mathrm{~A} 5 \beta * \mathrm{II}^{\prime \prime}{ }_{3 \beta} \mathrm{On}_{17} \theta_{5 \beta-6}$ & 10 & $\mathbf{0}$ & 0 & 0 \\
\hline $\begin{array}{l}76 \\
\text { IM } 141\end{array}$ & $\mathrm{~A}^{4} \mathrm{On}_{3,17} \quad$ (Androstenedione) & 10 & 1 & 0.5 & 0.075 \\
\hline $\begin{array}{l}77 \\
\text { IM } 8\end{array}$ & $\mathrm{~A}^{4} \mathrm{on}_{3,11,17}$ (Andrenosterone) & 10 & 0 & - & 0 \\
\hline $\begin{array}{l}78 \\
\text { IM } 53\end{array}$ & $\mathrm{~A}^{4} \mathrm{Ol}_{17 \beta} \mathrm{On}_{3} \quad$ (Testosterone) & $\begin{array}{c}10 \\
0.5\end{array}$ & $\begin{array}{l}3 \\
\mathbf{0}\end{array}$ & $\begin{array}{l}0.5 \\
0\end{array}$ & $\begin{array}{l}0.175 \\
0\end{array}$ \\
\hline $\begin{array}{l}79 \\
\text { IM } 131\end{array}$ & $\mathrm{~A}^{4 *} \mathrm{II}^{\prime \prime}{ }_{17 \beta O n_{3}}$ (Testosterone acetate) & 10 & $\mathbf{0}$ & $\mathbf{0}$ & 0 \\
\hline $\begin{array}{l}80 \\
\text { IM } 58\end{array}$ & $\mathrm{~A}^{4 *} \mathrm{IIII}_{17 \beta}^{\prime \prime} \mathrm{On}_{3} \quad$ (Testosterone pr.) & 10 & 0 & 0 & 0 \\
\hline $\begin{array}{l}81 \\
\text { IM } 199\end{array}$ & $A^{4 * S^{\prime \prime} \mathrm{Na}_{17 \beta} \mathrm{On}_{3}}$ & 0.5 & 0 & 0 & 0 \\
\hline $\begin{array}{l}82 \\
\text { IM } 226\end{array}$ & $\mathrm{~A}^{4 *} \mathrm{II}^{\prime \prime}{ }_{11 \alpha, 17 \beta} \mathrm{On}_{3}$ & 10 & $\mathbf{0}$ & 2 & 0.1 \\
\hline $\begin{array}{l}83 \\
\text { IM } 563\end{array}$ & $\mathrm{~A}^{4} \mathrm{ol}_{11 \alpha} \mathrm{On}_{3,17}$ & 0.5 & 0 & $\mathbf{0}$ & 0 \\
\hline $\begin{array}{l}84 \\
\text { IM } 187\end{array}$ & $\mathrm{~A}^{4} \mathrm{Ol}_{19} \mathrm{On}_{3,17}$ & 10 & $\mathbf{0}$ & $\mathbf{0}$ & 0 \\
\hline $\begin{array}{l}85 \\
\text { IM } 358\end{array}$ & $\mathrm{~A}^{4 *} \mathrm{cycVI}^{\prime \prime}{ }_{17 \beta} \mathrm{On}_{3} \mathrm{~F}_{2 \alpha}$ & 10 & 0 & 0 & $\mathbf{0}$ \\
\hline $\begin{array}{l}86 \\
\text { IM } 216\end{array}$ & $A^{4 *} I I I I^{\prime \prime}{ }_{17 \beta} \mathrm{On}_{3} \mathrm{~F}_{6 \alpha}$ & 10 & 0 & 0 & 0 \\
\hline $\begin{array}{l}87 \\
\text { IM } 41\end{array}$ & $\begin{array}{l}\mathrm{A}^{4} \mathrm{ol}_{11 \beta} \mathrm{On}_{3,17} \mathrm{~F}_{9 \alpha} \\
\text { (Fluorohydroxyandrostenedione) }\end{array}$ & 10 & 0.5 & 1.5 & 0.1 \\
\hline $\begin{array}{l}88 \\
\text { IM } 251\end{array}$ & $\mathrm{~A}^{4} \mathrm{Ol}_{3 \beta} \mathrm{On}_{17}\left(\mathrm{~N}_{3}\right)_{6 \beta}$ & 10 & $\mathbf{0}$ & 3 & 0.15 \\
\hline $\begin{array}{l}89 \\
\text { IM } 17\end{array}$ & $\mathbf{A}^{5} \mathrm{ol}_{3 \beta, 16 \alpha} \quad$ (Cetadiol) & 10 & 0 & 0 & 0 \\
\hline $\begin{array}{l}90 \\
\text { IM } 139\end{array}$ & $\mathrm{~A}^{5 *} \mathrm{II}^{\prime \prime}{ }_{3 \beta} * \mathrm{Bz}^{\prime \prime}{ }_{17 \beta}$ & 10 & 0 & 2.5 & 0.125 \\
\hline $\begin{array}{l}91 \\
\text { IM } 31\end{array}$ & $\mathbf{A}^{5} \mathrm{ol}_{3 \beta} \mathrm{On}_{17} \quad$ (Dehydroepiandrosterone) & $\begin{array}{l}10 \\
0.5\end{array}$ & $\begin{array}{l}2 \\
0\end{array}$ & $\begin{array}{l}3 \\
0.5\end{array}$ & $\begin{array}{l}0.25 \\
0\end{array}$ \\
\hline $\begin{array}{l}92 \\
\text { IM } 27\end{array}$ & $\begin{array}{l}\mathrm{A}^{5 *} \mathrm{II}^{\prime \prime}{ }_{3 \beta} \mathrm{On}_{17} \\
\text { (Dehydroepiandrosterone acetate) }\end{array}$ & $\begin{array}{c}10 \\
0.5\end{array}$ & $\underline{0}$ & $\begin{array}{l}3 \\
\mathbf{0}\end{array}$ & $\begin{array}{l}0.15 \\
0\end{array}$ \\
\hline $\begin{array}{l}93 \\
\text { IM } 362\end{array}$ & 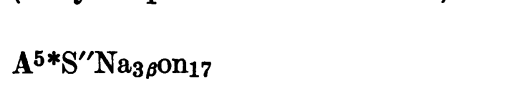 & 0.5 & 0 & 0 & 0 \\
\hline
\end{tabular}


Table 135B (continued)

\begin{tabular}{|c|c|c|c|c|c|}
\hline Group & SSS Name & $\begin{array}{l}\text { Dose } \\
(\mathrm{mg})\end{array}$ & $\begin{array}{l}\text { Digi- } \\
\text { toxin }^{a}\end{array}$ & $\begin{array}{l}\text { Indo- } \\
\text { methacin }^{a}\end{array}$ & $\begin{array}{l}\text { Activity } \\
\text { index }^{b}\end{array}$ \\
\hline $\begin{array}{l}94 \\
\text { IM } 184\end{array}$ & $\mathrm{~A}^{5} \mathrm{ol}_{3 \beta, 19} \mathrm{On}_{17}$ & 10 & 0 & 0 & 0 \\
\hline $\begin{array}{l}95 \\
\text { IM } 245\end{array}$ & $\mathbf{A}^{5_{0} l_{3 \beta} \text { sp imidazolidinyl }}{ }_{17 / o n / / 2,5}$ & 10 & 0 & 0 & 0 \\
\hline $\begin{array}{l}96 \\
\text { IM } 332\end{array}$ & $\begin{array}{c}\mathrm{A}^{5} \mathrm{ol}_{3 \beta}(2 \text {-Disopropylaminoethyl } \\
\text { formamido })_{17 \beta}\end{array}$ & 10 & 0 & 0 & 0 \\
\hline $\begin{array}{l}97 \\
\text { IM } 321 \\
98\end{array}$ & $\begin{array}{r}\mathbf{A}^{5} \mathrm{ol}_{3 \beta}(3-\text { Dimethylaminopropyl } \\
\text { methylamino })_{17 \beta} \cdot 2 \mathrm{HCl}\end{array}$ & 10 & 0 & 0 & 0 \\
\hline $\begin{array}{l}98 \\
\text { IM } 247\end{array}$ & $\mathrm{~A}^{5 * \mathrm{II}^{\prime \prime}}{ }_{3 \beta} \mathrm{Sp}$ oxazolyl $17 / \mathrm{I} / / 2$ & 10 & 0 & 0 & 0 \\
\hline $\begin{array}{l}99 \\
\text { IM } 363\end{array}$ & $\mathrm{~A}^{4,6} \mathrm{On}_{3,17} \theta_{1 \alpha-2}$ & 10 & 0 & 0 & 0 \\
\hline $\begin{array}{l}100 \\
\text { IM } 153\end{array}$ & $\mathrm{~A}^{4,9(11)_{\mathrm{Ol}_{17 \beta} \mathrm{On}_{3}}}$ & 10 & 0 & 1.5 & 0.075 \\
\hline $\begin{array}{l}101 \\
\text { IM } 280\end{array}$ & $\mathrm{~A}_{5} \alpha \mathrm{I}_{1 \alpha} \mathrm{Ol}_{17 \beta} \mathrm{On}_{3}$ & 10 & 0.5 & 0 & 0.025 \\
\hline $\begin{array}{l}102 \\
\text { IM } 189\end{array}$ & $\mathrm{A5}_{5} \alpha \mathrm{I}_{4 \alpha} \mathrm{Ol}_{17 \beta} \mathrm{On}_{3}$ & 10 & 3 & 0.5 & 0.175 \\
\hline $\begin{array}{l}103 \\
\text { IM } 51 / d \\
104\end{array}$ & $\begin{array}{l}\text { A5 } \alpha \mathrm{I}_{17 \alpha} \mathrm{Ol}_{3 \beta, 11 \beta, 17} \\
\text { androstanetriol) }\end{array}$ & 10 & 3 & 3 & 0.3 \\
\hline $\begin{array}{l}104 \\
\text { IM } 190\end{array}$ & $\mathbf{A 5} \alpha \mathbf{I}_{17 \alpha} \mathrm{ol}_{17} \mathrm{On}_{3}$ & 10 & 3 & 0 & 0.15 \\
\hline $\begin{array}{l}\text { 105 } \\
\text { IM } 163\end{array}$ & $\mathbf{A 5} \alpha \mathbf{I}_{17 \alpha} \mathrm{Ol}_{11 \beta, 17} \mathrm{on}_{3}$ & 10 & 3 & 3 & 0.3 \\
\hline $\begin{array}{l}106 \\
\text { IM } 320\end{array}$ & $\mathbf{A 5} \alpha \mathbf{I}_{17 \alpha} \mathrm{Ol}_{17} \theta \mathrm{I}_{3 \alpha}$ & $\begin{array}{l}10 \\
0.5\end{array}$ & $\begin{array}{l}3 \\
0\end{array}$ & $\begin{array}{l}1.5 \\
-\end{array}$ & $\begin{array}{l}0.225 \\
0\end{array}$ \\
\hline $\begin{array}{l}107 \\
\text { IM } 419\end{array}$ & $\mathbf{A 5} \alpha \mathrm{I}_{17 \alpha} \mathrm{Ol}_{3 \alpha, 17} \mathrm{SCN}_{2 \beta}$ & 0.5 & 0 & 0 & 0 \\
\hline $\begin{array}{l}108 \\
\text { IM } 248\end{array}$ & $\mathbf{A 5} \alpha \mathrm{I}_{17 \alpha} \mathrm{ol} \mathrm{l}_{3 \beta, 5,17}\left(\mathrm{~N}_{3}\right)_{6 \beta}$ & 10 & 0 & 0.5 & 0.025 \\
\hline $\begin{array}{l}109 \\
\text { IM } 454\end{array}$ & $\mathrm{~A} 5 \alpha \mathrm{I}_{16 \alpha, 17 \alpha} * \mathrm{II}_{3,17}$ & $\begin{array}{c}10 \\
0.5\end{array}$ & $\begin{array}{l}3 \\
0\end{array}$ & $\overline{0}$ & $\begin{array}{l}\mathbf{0 . 3} \\
0\end{array}$ \\
\hline $\begin{array}{l}110 \\
\operatorname{IM} 451\end{array}$ & $\mathrm{A5} \alpha \mathrm{CHOH}_{2} \mathrm{Ol}_{17 \beta} \mathrm{On}_{3}$ & 0.5 & 0 & 0 & 0 \\
\hline $\begin{array}{l}111 \\
\text { IM } 427\end{array}$ & $\mathrm{~A} 5 \alpha \mathrm{CN}_{1 \alpha} \mathrm{Ol}_{17 \beta} \mathrm{On}_{3}$ & 0.5 & 0 & 0 & 0 \\
\hline $\begin{array}{l}\text { I12 } \\
\text { IM } 433\end{array}$ & $\mathrm{A5} \alpha \mathrm{CN}_{1 \alpha} * \mathrm{II}^{\prime \prime}{ }_{17 \beta} \mathrm{On}_{3}$ & 0.5 & 0 & 0 & 0 \\
\hline $\begin{array}{l}113 \\
\text { IM } 424\end{array}$ & $\mathrm{A5} \alpha \mathrm{CN}_{3 \xi} \mathrm{Ol}_{17 \beta}\left(\mathrm{NH}_{2}\right)_{3}$ & 0.5 & 0 & 0 & 0 \\
\hline
\end{tabular}


Table 135B (continued)

\begin{tabular}{|c|c|c|c|c|c|}
\hline Group & SSS Name & $\begin{array}{l}\text { Dose } \\
(\mathrm{mg})\end{array}$ & $\begin{array}{l}\text { Digi- } \\
\text { toxin }\end{array}$ & $\begin{array}{l}\text { Indo- } \\
\text { methacin }^{a}\end{array}$ & $\begin{array}{l}\text { Activity } \\
\text { index }{ }^{b}\end{array}$ \\
\hline $\begin{array}{l}\text { 114 } \\
\text { IM } 434\end{array}$ & $\mathrm{~A} 5 \alpha \mathbf{C N}_{5} \mathrm{Ol}_{17 \beta} \mathrm{On}_{3}$ & 0.5 & 0 & 0 & 0 \\
\hline $\begin{array}{l}115 \\
\text { IM } 420\end{array}$ & $\mathrm{~A} 5 \beta \mathrm{CN}_{5} \mathrm{Ol}_{17} \mathrm{On}_{3}$ & $\begin{array}{l}10 \\
0.03 \\
0.015 \\
0.005 \\
0.001\end{array}$ & $\begin{array}{l}0 \\
0 \\
0 \\
0 \\
0\end{array}$ & $\begin{array}{l}0 \\
0 \\
0 \\
0 \\
0\end{array}$ & $\begin{array}{l}0 \\
0 \\
0 \\
0 \\
0\end{array}$ \\
\hline $\begin{array}{l}116 \\
\text { IM } 421\end{array}$ & $\mathrm{A5} \alpha \mathrm{CN}_{5} * \mathrm{IIII}_{17 \beta} \mathrm{On}_{3}$ & 0.5 & 0 & 0 & 0 \\
\hline $\begin{array}{l}117 \\
\text { IM } 422\end{array}$ & $\mathrm{A5} \beta \mathrm{CN}_{5} * \mathrm{III}^{\prime \prime}{ }_{17 \beta} \mathrm{On}_{3}$ & 0.5 & 0 & 0 & 0 \\
\hline $\begin{array}{l}118 \\
\text { IM } 442\end{array}$ & $\mathbf{A 5} \alpha \mathrm{I}_{17 \alpha} \mathrm{Iol}_{2 \alpha} \mathrm{Ol}_{3 \beta, 17}$ & 0.5 & 0 & 0 & 0 \\
\hline $\begin{array}{l}119 \\
\text { IM } 98 / a\end{array}$ & $\mathbf{A 5} \alpha \mathbf{I}_{17 \alpha} \mathrm{CHOH}_{2} \mathrm{Ol}_{17} \mathrm{On}_{3}$ (Oxymetholone) & 10 & 3 & 0 & 0.15 \\
\hline $\begin{array}{l}120 \\
\text { IM } 443\end{array}$ & $\mathrm{~A} 5 \alpha \mathbf{I}_{17 \alpha}\left(\mathrm{CHNH}_{2}\right)_{2} \mathrm{Ol}_{17} \mathrm{On}_{3}$ & 0.5 & 0 & 0 & 0 \\
\hline $\begin{array}{l}\text { I21 } \\
\text { IM } 425\end{array}$ & $\mathrm{~A} 5 \alpha \mathrm{I}_{17 \alpha} \mathrm{CN}_{5} \mathrm{ol}_{17} \mathrm{On}_{3}$ & 0.5 & 0 & 0 & 0 \\
\hline $\begin{array}{l}122 \\
\text { IM } 382\end{array}$ & $\mathrm{~A} 5 \alpha \mathrm{I}_{16 \beta} \mathrm{CN}_{17} \mathrm{O} \mathrm{l}_{3 \beta, 17 \xi}$ & 0.5 & 0 & 0 & 0 \\
\hline $\begin{array}{l}123 \\
\text { IM } 275\end{array}$ & $\mathrm{A5} \alpha \mathrm{II}_{17 \alpha / \mathrm{on} / / 1 \mathrm{ol}_{3 \beta} \theta_{16 \beta-17}}$ & 10 & 3 & 3 & $\mathbf{0 . 3}$ \\
\hline $\begin{array}{l}124 \\
\text { IM } 276\end{array}$ & $A 5 \alpha I_{17 \alpha / o n / / 10^{\circ, 11}} \theta_{16 \beta-17}$ & 10 & 2 & 3 & 0.25 \\
\hline $\begin{array}{l}125 \\
\text { IM } 441\end{array}$ & $A 5 \alpha I^{\prime \prime}{ }_{16 \beta} I_{17 \alpha / \mathrm{on} / / 1} \mathrm{ol}_{3 \beta}$ & 0.5 & 0 & 0 & 0 \\
\hline $\begin{array}{l}126 \\
\text { IM } 432\end{array}$ & $A 5 \alpha \mathrm{II}^{1-1}{ }_{17 \alpha} \mathrm{CN}_{5} \mathrm{ol}_{3 \alpha, 17}$ & 0.5 & 0 & 0 & 0 \\
\hline $\begin{array}{l}127 \\
\text { IM } 335\end{array}$ & $\mathrm{A5} \alpha \mathrm{III}_{17 \alpha / \mathrm{I} / / 2} \mathrm{Ol}_{3 \beta, 17}$ & $\begin{array}{c}10 \\
0.5\end{array}$ & 3 & $\begin{array}{l}3 \\
0\end{array}$ & $\begin{array}{l}0.3 \\
0\end{array}$ \\
\hline $\begin{array}{l}128 \\
\text { IM } 78\end{array}$ & $\begin{array}{l}\mathbf{A 5} \alpha^{1} I_{1} * I^{\prime \prime}{ }_{17 \beta} \mathrm{On}_{3} \\
\text { (Methenolone acetate) }\end{array}$ & 10 & 1.5 & 0 & 0.075 \\
\hline $\begin{array}{l}\text { 129 } \\
\text { IM } 77\end{array}$ & $\begin{array}{l}\text { A5 } \alpha^{1} \mathbf{I}_{1} * \mathrm{VII}^{\prime \prime}{ }_{17 \beta} \mathrm{On}_{3} \\
\text { (Methenolone oenonthate) }\end{array}$ & 10 & 2.5 & 0 & 0.125 \\
\hline $\begin{array}{l}130 \\
\text { IM } 318\end{array}$ & $\mathbf{A 5} \alpha^{2} \mathbf{I}_{17 \alpha} \mathrm{Ol}_{17}$ & 10 & 1.5 & 1 & 0.125 \\
\hline $\begin{array}{l}\text { 131 } \\
\text { IM } 365\end{array}$ & $\mathbf{A 5} \alpha^{2} \mathrm{CN}_{3} \mathrm{On}_{17}$ & $\begin{array}{c}10 \\
0.5\end{array}$ & $\begin{array}{l}2 \\
0\end{array}$ & $\begin{array}{l}2 \\
0\end{array}$ & $\begin{array}{l}0.2 \\
0\end{array}$ \\
\hline $\begin{array}{l}132 \\
\text { IM } 150\end{array}$ & $\left.\mathbf{A 5} \alpha^{2}\right|_{17 \alpha}$ isoxazolyl $_{2-3 / 3,4} \mathrm{ol}_{17}$ & $\begin{array}{c}10 \\
0.5\end{array}$ & $\begin{array}{l}1.5 \\
0\end{array}$ & $\begin{array}{l}0.5 \\
0\end{array}$ & $\begin{array}{l}0.1 \\
0\end{array}$ \\
\hline
\end{tabular}


814 Synopsis of Pharmaco-Chemical and Pharmaco-Pharmacologic Interrelations

Table 135B (continued)

\begin{tabular}{|c|c|c|c|c|c|}
\hline Group & SSS Name & $\begin{array}{l}\text { Dose } \\
(\mathrm{mg})\end{array}$ & $\begin{array}{l}\text { Digi- } \\
\text { toxin }^{2}\end{array}$ & $\begin{array}{l}\text { Indo- } \\
\text { methacin a }^{\text {a }}\end{array}$ & $\begin{array}{l}\text { Activity } \\
\text { index }\end{array}$ \\
\hline $\begin{array}{l}133 \\
\text { IM } 249\end{array}$ & $\mathrm{~A}_{5} \beta \mathrm{I}_{17 \alpha} \mathrm{ol}_{17} * \mathrm{II}^{\prime \prime}{ }_{3 \beta} \theta_{5 \beta-6}$ & 10 & $\mathbf{0}$ & 1.5 & 0.075 \\
\hline $\begin{array}{l}134 \\
\text { IM } 165\end{array}$ & $A 5 \beta I_{17 \alpha} \operatorname{ol}_{17} \mathrm{On}_{3,11} \mathrm{~F}_{9 \alpha}$ & 10 & 2 & 0.5 & 0.125 \\
\hline $\begin{array}{l}135 \\
\text { IM } 357\end{array}$ & A5 $\beta \operatorname{Ial}_{17 \beta} \mathrm{Ol}_{3 \alpha, 17} \mathrm{On}_{11}$ & 10 & 0 & 0 & 0 \\
\hline $\begin{array}{l}136 \\
\text { IM } 386\end{array}$ & $A 5 \beta \mathrm{CN}_{17 \beta}{ }^{*} \mathrm{II}^{\prime \prime} 3 \alpha$ & 0.5 & 0 & $\mathbf{0}$ & 0 \\
\hline $\begin{array}{l}137 \\
\text { IM } 377\end{array}$ & $\mathrm{~A} 5 \beta \mathrm{CN}_{17} \mathrm{Ol}_{17 \xi} * \mathrm{II}_{3 \alpha}{ }_{3 \alpha}$ & 0.5 & $\mathbf{0}$ & $\mathbf{0}$ & 0 \\
\hline $\begin{array}{l}138 \\
\text { IM } 426\end{array}$ & $\mathbf{A} 5 \beta \mathrm{I}_{17 \alpha} \mathrm{CN}_{5} \mathrm{Ol}_{17} \mathrm{On}_{3}$ & 0.5 & 0 & $\mathbf{0}$ & $\mathbf{0}$ \\
\hline $\begin{array}{l}139 \\
\text { IM } 489\end{array}$ & $\mathbf{A 5} \beta \mathrm{I}_{17 \beta / \mathrm{I}}, / / 1,1 \mathrm{ol}_{3 \alpha} \mathrm{On}_{11}$ & $\begin{array}{l}0.5 \\
0.03\end{array}$ & 0 & $\begin{array}{l}1.5 \\
0\end{array}$ & $\begin{array}{l}1.5 \\
0\end{array}$ \\
\hline $\begin{array}{l}140 \\
\text { IM } 381\end{array}$ & $\mathrm{~A}_{5} \mathrm{ICN}_{17 \beta} \mathrm{O} \mathrm{l}_{3 \alpha}$ & 0.5 & $\mathbf{0}$ & 0 & 0 \\
\hline $\begin{array}{l}141 \\
\text { IM } 385\end{array}$ & $A 5 \beta \operatorname{ICN}_{17 \beta} * I^{\prime \prime}{ }_{3 \alpha} \mathrm{On}_{11}$ & 0.5 & 0 & $\mathbf{0}$ & 0 \\
\hline $\begin{array}{l}142 \\
\text { IM } 384\end{array}$ & $\mathbf{A 5} \beta \mathbf{I}_{17 \beta / \mathrm{CN}}$ tetrahydropyranyl $\mathrm{l}_{3 \beta / \mathrm{ol} / / 2}$ & 0.5 & 0 & 0 & $\mathbf{0}$ \\
\hline $\begin{array}{l}143 \\
\text { IM } 369\end{array}$ & $\mathrm{~A} 5 \beta \mathrm{I}_{17 \beta / \mathrm{CN} / / 1,1} \mathrm{CN}_{17} \mathrm{Ol}_{3 \alpha} \mathrm{On}_{11}$ & 0.5 & 0 & 0 & 0 \\
\hline $\begin{array}{l}144 \\
\text { IM } 495\end{array}$ & $\begin{array}{l}\text { A5 } \beta \text { benzyloxy methyl-dimethyl ma- } \\
\text { lonate }_{17 \beta \mathrm{Ol}_{3 \alpha} \mathrm{On}_{11}}\end{array}$ & 0.5 & 0 & 0 & 0 \\
\hline $\begin{array}{l}145 \\
\text { IM } 368\end{array}$ & $\mathrm{~A} 5 \beta^{2} \mathrm{CN}_{3} \mathrm{Ol}_{17 \beta}$ & $\begin{array}{c}10 \\
0.5\end{array}$ & $\begin{array}{l}0.5 \\
0\end{array}$ & $\begin{array}{l}2 \\
0\end{array}$ & $\begin{array}{l}0.125 \\
0\end{array}$ \\
\hline $\begin{array}{l}146 \\
\text { IM } 254\end{array}$ & $\mathbf{A 5} \beta^{2} \Pi_{3 \beta / 0 n / / 1} \mathrm{ol}_{17 \beta}$ & 10 & 0 & 0 & 0 \\
\hline $\begin{array}{l}147 \\
\text { IM } 378\end{array}$ & $A 5 \beta^{16} \mathrm{CN}_{17}{ }^{*} I^{\prime \prime}{ }_{3 \alpha}$ & 0.5 & 0 & $\mathbf{0}$ & 0 \\
\hline $\begin{array}{l}148 \\
\text { IM } 393\end{array}$ & $A 5 \beta^{17(20)} \mathrm{ICN}_{17 \beta^{*}} \mathrm{II}^{\prime \prime}{ }_{3 \alpha} \mathrm{On}_{11}$ & 0.5 & 0 & 1.5 & 1.5 \\
\hline $\begin{array}{l}149 \\
\text { IM } 406\end{array}$ & $A 5 \beta^{17(20) I_{17 \beta / C N / / 1,1} \mathrm{ol}_{3 \alpha} \mathrm{On}_{11}}$ & 0.5 & 0 & 0 & 0 \\
\hline $\begin{array}{l}150 \\
\text { IM } 120\end{array}$ & $\mathbf{A}^{4} \mathbf{I}_{6 \alpha} \mathrm{Ol}_{17 \beta} \mathrm{On}_{3} \quad$ (Methyltestosterone) & 10 & 2.5 & 3 & 0.275 \\
\hline $\begin{array}{l}151 \\
\text { IM } 208\end{array}$ & $\mathbf{A}^{4} \mathbf{I}_{6 \alpha} \mathrm{Ol}_{11 \beta, 17 \beta} \mathrm{On}_{3}$ & $\begin{array}{l}10 \\
0.5\end{array}$ & $\begin{array}{l}3 \\
-\end{array}$ & $\begin{array}{l}3 \\
0\end{array}$ & $\begin{array}{l}0.3 \\
0\end{array}$ \\
\hline $\begin{array}{l}152 \\
\text { IM } 55\end{array}$ & $\mathbf{A}^{4} \mathbf{I}_{17 \alpha} \mathrm{ol}_{17} \mathrm{On}_{3} \quad$ (Methyltestosterone) & 10 & 3 & 1.5 & 0.225 \\
\hline
\end{tabular}


Table 135 B (continued)

\begin{tabular}{|c|c|c|c|c|c|}
\hline Group & SSS Name & $\begin{array}{l}\text { Dose } \\
\text { (mg) }\end{array}$ & $\begin{array}{l}\text { Digi- } \\
\text { toxin }^{2}\end{array}$ & $\begin{array}{l}\text { Indo- } \\
\text { methacin }\end{array}$ & $\begin{array}{l}\text { Activity } \\
\text { index }^{b}\end{array}$ \\
\hline $\begin{array}{l}153 \\
\text { IM } 90\end{array}$ & $\mathbf{A}^{4} \mathbf{I}_{17 \alpha} \mathrm{Ol}_{4,17} \mathrm{On}_{3} \quad$ (Oxymesterone) & 10 & 0.5 & 3 & 0.175 \\
\hline $\begin{array}{l}154 \\
\text { IM } 223\end{array}$ & $\mathbf{A}^{4} \mathbf{I}_{17 \alpha} \mathrm{Ol}_{6 \beta, 170 n_{8}}$ & 10 & 0 & 1 & 0.05 \\
\hline $\begin{array}{l}155 \\
\text { IM } 160\end{array}$ & $\mathbf{A}^{4} \mathbf{I}_{17 \alpha} \mathrm{Ol}_{11 \alpha, 170 \mathrm{n}_{3}}$ & 10 & $\mathbf{3}$ & 3 & 0.3 \\
\hline $\begin{array}{l}156 \\
\text { IM } 241\end{array}$ & $\mathbf{A}^{4} \mathbf{I}_{17 \alpha} \mathrm{Ol}_{11 \beta, 170 n_{3}}$ & $\begin{array}{c}10 \\
0.5\end{array}$ & $\begin{array}{l}\mathbf{3} \\
\mathbf{2}\end{array}$ & $\begin{array}{l}3 \\
-\end{array}$ & $\begin{array}{l}0.3 \\
4.0\end{array}$ \\
\hline $\begin{array}{l}157 \\
\text { IM } 85\end{array}$ & $\mathrm{~A}^{4} \mathbf{I}_{17 \alpha} \mathrm{ol}_{17 \beta}{ } \mathrm{SII}^{\prime \prime}{ }_{1 \alpha, 7 \alpha \mathrm{On}_{3}} \quad$ (Emdabol) & $\begin{array}{c}10 \\
0.5 \\
0.1\end{array}$ & $\begin{array}{l}2 \\
0.5 \\
0\end{array}$ & $\begin{array}{l}1 \\
0 \\
-\end{array}$ & $\begin{array}{l}0.15 \\
0.5 \\
0\end{array}$ \\
\hline $\begin{array}{l}158 \\
\text { IM } 81\end{array}$ & 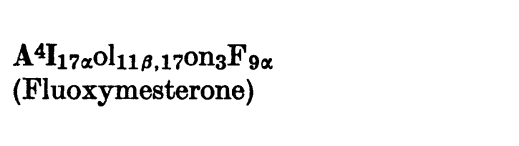 & $\begin{array}{c}10 \\
0.5 \\
0.1\end{array}$ & $\begin{array}{l}3 \\
3 \\
0\end{array}$ & $\begin{array}{l}2 \\
0 \\
-\end{array}$ & $\begin{array}{l}0.25 \\
\mathbf{3 . 0} \\
0\end{array}$ \\
\hline $\begin{array}{l}\text { 159 } \\
\text { IM } 162\end{array}$ & $\mathbf{A}^{4} \mathbf{I}_{17 \alpha} \mathrm{Ol}_{17} \mathrm{On}_{3,11} \mathbf{F}_{9 \alpha}$ & 10 & 3 & 2 & 0.25 \\
\hline $\begin{array}{l}160 \\
\text { IM } 502\end{array}$ & $\mathbf{A}^{4} \mathbf{I}^{\prime \prime}{ }_{17 \beta} \mathrm{On}_{3}$ & 0.5 & $\mathbf{0}$ & 0 & 0 \\
\hline $\begin{array}{l}161 \\
\text { IM } 450\end{array}$ & $\mathrm{~A}^{4}\left(\mathrm{CONH}_{2}\right)_{7 \beta} \mathrm{Ol}_{17 \beta} \mathrm{On}_{3}$ & 0.5 & 0 & 0 & 0 \\
\hline $\begin{array}{l}162 \\
\text { IM } 391\end{array}$ & $\mathrm{~A}^{4} \mathrm{CN}_{17} * \mathrm{II}^{\prime \prime}{ }_{17 \xi} \mathrm{On}_{3}$ & 0.5 & 0 & 0 & 0 \\
\hline $\begin{array}{l}163 \\
\text { IM } 374\end{array}$ & $\mathbf{A}^{4} \mathbf{C N}_{17} \mathrm{Ol}_{17 \xi} \mathrm{On}_{3,11}$ & 0.5 & 0 & 0 & 0 \\
\hline $\begin{array}{l}164 \\
\text { IM } 375\end{array}$ & $\mathrm{~A}^{4} \mathrm{CN}_{17} * \mathrm{II}^{\prime \prime}{ }_{17 \xi} \mathrm{On}_{3,11}$ & 0.5 & 0 & 0 & 0 \\
\hline $\begin{array}{l}165 \\
\text { IM } 36\end{array}$ & $\mathrm{~A}^{4} \mathrm{II}^{1-1}{ }_{17 \alpha} \mathrm{Ol}_{17} \mathrm{On}_{3} \quad$ (Ethyltestosterone) & 10 & 0 & 1 & 0.05 \\
\hline $\begin{array}{l}166 \\
\text { IM } 10\end{array}$ & $\mathbf{A}^{4} \mathrm{III}^{\prime \prime} \mathrm{K}_{17 \alpha} \mathrm{Ol}_{11 \beta, 17 \mathrm{On}_{3} \mathrm{~F}_{9 \alpha}} \quad(\mathrm{CS}-1)$ & $\begin{array}{l}10 \\
0.5 \\
0.1 \\
0.03\end{array}$ & $\begin{array}{l}\mathbf{3} \\
\mathbf{3} \\
\mathbf{1} \\
\mathbf{0}\end{array}$ & $\begin{array}{l}3 \\
3 \\
1.5 \\
0\end{array}$ & $\begin{array}{c}0.3 \\
6.0 \\
12.5 \\
0\end{array}$ \\
\hline $\begin{array}{l}167 \\
\text { IM } 314\end{array}$ & $\mathbf{A}^{4} \mathrm{III}^{\prime \prime} \gamma \mathbf{l a c}_{17 \alpha} \mathrm{On}_{3}$ & $\begin{array}{l}10 \\
0.5\end{array}$ & $\begin{array}{l}3 \\
-\end{array}$ & $\begin{array}{l}3 \\
0\end{array}$ & $\begin{array}{l}\mathbf{0 . 3} \\
0\end{array}$ \\
\hline $\begin{array}{l}168 \\
\text { IM } 9\end{array}$ & $\begin{array}{l}\mathbf{A}^{4} \mathrm{IIII}^{\prime \prime} \mathbf{\gamma l a c}_{17 \alpha} * \mathrm{SIII}^{\prime \prime}{ }_{7 \alpha \mathrm{O}_{3}} \\
\text { (Spironolactone) }\end{array}$ & $\begin{array}{c}10 \\
0.5 \\
0.1\end{array}$ & $\begin{array}{l}3 \\
0 \\
-\end{array}$ & $\begin{array}{l}3 \\
0 \\
0\end{array}$ & $\begin{array}{l}0.3 \\
1.5 \\
0\end{array}$ \\
\hline $\begin{array}{l}169 \\
\text { IM } 66\end{array}$ & $\mathrm{~A}^{4} \mathrm{IIII}^{\prime \prime} \gamma \mathrm{lac}_{17 \alpha} \mathrm{Ol}_{11 \beta} \mathrm{On}_{3} \mathrm{~F}_{9 \alpha}$ & $\begin{array}{c}10 \\
0.5\end{array}$ & $\begin{array}{l}3 \\
3\end{array}$ & 2 & $\begin{array}{l}0.25 \\
6.0\end{array}$ \\
\hline
\end{tabular}


Table 135 B (continued)

\begin{tabular}{|c|c|c|c|c|c|}
\hline Group & SSS Name & $\begin{array}{l}\text { Dose } \\
(\mathrm{mg})\end{array}$ & $\begin{array}{l}\text { Digi- } \\
\text { toxin }^{\text {a }}\end{array}$ & $\begin{array}{l}\text { Indo- } \\
\text { methacina }\end{array}$ & $\begin{array}{l}\text { Activity } \\
\text { index }\end{array}$ \\
\hline $\begin{array}{l}170 \\
\text { IM } 342\end{array}$ & $\begin{array}{l}\mathrm{A}^{4} \text { tetrahydrofuryl } \\
\text { (Spiroxasone) }\end{array}$ & $\begin{array}{c}10 \\
0.5 \\
0.1\end{array}$ & $\begin{array}{l}3 \\
0 \\
-\end{array}$ & $\begin{array}{l}3 \\
1.5 \\
0.5\end{array}$ & $\begin{array}{l}0.3 \\
1.5 \\
5.0\end{array}$ \\
\hline $\begin{array}{l}171 \\
\text { IM } 312\end{array}$ & $A^{4}$ imidazolyl $_{17 \beta / \mathrm{I} / 2 \mathrm{On}_{3}}$ & 10 & 0 & 1 & 0.05 \\
\hline $\begin{array}{l}172 \\
\text { IM } 54\end{array}$ & $\mathbf{A}^{5} \mathbf{I}_{17 \alpha} \mathrm{Ol}_{3 \beta, 17} \quad$ (Methylandrostenediol) & 10 & 0 & 0 & 0 \\
\hline $\begin{array}{l}173 \\
\text { IM } 159\end{array}$ & $\mathbf{A}^{5} \mathbf{I}_{4,4} \mathrm{Ol}_{17 \beta} \mathrm{On}_{3}$ & 10 & 0 & 1.5 & 0.075 \\
\hline $\begin{array}{l}174 \\
\text { IM } 501\end{array}$ & $\mathbf{A}^{5} \mathbf{I}^{\prime \prime}{ }_{17 \beta} \mathrm{Ol}_{3 \beta}$ & 0.5 & 0 & 0 & 0 \\
\hline $\begin{array}{l}175 \\
\text { IM } 306\end{array}$ & 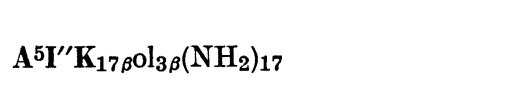 & 10 & 0 & 0 & 0 \\
\hline $\begin{array}{l}176 \\
\text { IM } 255\end{array}$ & $\mathbf{A}^{5} \mathbf{I}^{\prime \prime}{ }_{17 \alpha /{ }^{*} I} * \mathrm{II}^{\prime \prime}{ }_{3 \alpha} \mathrm{NHII}_{17}{ }_{17}$ & 10 & 3 & 1 & 0.2 \\
\hline $\begin{array}{l}\text { 177 } \\
\text { IM } 390\end{array}$ & $\mathbf{A}^{5} \mathbf{C N}_{17} \mathrm{ol}_{17 \alpha} \theta \theta \mathrm{II}_{3}$ & 0.5 & 0 & $\mathbf{0}$ & 0 \\
\hline $\begin{array}{l}178 \\
\text { IM } 182\end{array}$ & $\mathbf{A}^{5} \mathbf{I}_{17 \alpha} \mathbf{I}_{17 / * \mathrm{I}^{\prime} \mathbf{l}_{3 \beta}}$ & 10 & 0 & 1.5 & 0.075 \\
\hline $\begin{array}{l}179 \\
\text { IM } 568\end{array}$ & $\mathbf{A}^{5} \mathbf{I}_{4,4} \mathbf{C N}_{2 \alpha} \mathrm{Ol}_{17} \mathrm{On}_{3}$ & $\begin{array}{l}0.5 \\
0.03\end{array}$ & 2 & $\begin{array}{l}0.5 \\
-\end{array}$ & $\begin{array}{l}2.5 \\
0\end{array}$ \\
\hline $\begin{array}{l}180 \\
\text { IM } 364\end{array}$ & $\mathbf{A}^{5} \mathbf{I}_{4,4,17 \alpha} \mathbf{C N}_{2 \alpha} \mathrm{Ol}_{17} \mathrm{on}_{3} \quad(\mathrm{TMACN})$ & $\begin{array}{l}10 \\
0.5 \\
0.1 \\
0.03\end{array}$ & $\begin{array}{l}3 \\
2.5 \\
2 \\
0\end{array}$ & $\begin{array}{l}3 \\
3 \\
2 \\
0\end{array}$ & $\begin{array}{r}0.3 \\
5.5 \\
20.0 \\
0\end{array}$ \\
\hline $\begin{array}{l}181 \\
\text { IM } 308\end{array}$ & $\mathrm{~A}^{5} \mathrm{II}_{17 \alpha / \mathrm{on} / / 1 / / / \mathrm{ol} / / / / 2} * \mathrm{II}^{\prime \prime}{ }_{3 \beta} \theta_{16 \beta-17}$ & 10 & 0 & 0 & 0 \\
\hline $\begin{array}{l}182 \\
\text { IM } 448\end{array}$ & $\mathbf{A}^{5} \mathbf{I}^{\prime \prime}{ }_{16 \beta} \mathrm{II}_{17 \alpha / \mathrm{ol} / / 1 \mathrm{Ol}_{3 \beta}}$ & $\begin{array}{l}0.5 \\
0.1 \\
0.03\end{array}$ & $\begin{array}{l}1.5 \\
0.5 \\
0\end{array}$ & $\begin{array}{l}3 \\
0 \\
0\end{array}$ & $\begin{array}{l}4.5 \\
2.5 \\
0\end{array}$ \\
\hline $\begin{array}{l}183 \\
\text { IM } 440\end{array}$ & $\mathbf{A}^{5} \mathbf{I}^{\prime \prime}{ }_{16 \beta} \mathrm{II}_{17 \alpha / \mathrm{on} / / 1^{\mathrm{ol}}} \mathrm{l}_{3 \beta}$ & 0.1 & 0 & 0 & 0 \\
\hline $\begin{array}{l}184 \\
\text { IM } 446\end{array}$ & $A^{5} I_{17 \alpha / o n / / 1}\left(\mathrm{CONH}_{2}\right)_{16 \beta} \mathrm{Ol}_{3 \beta}$ & $\begin{array}{l}0.5 \\
0.1\end{array}$ & $\begin{array}{l}0 \\
0\end{array}$ & $\begin{array}{l}1.5 \\
0\end{array}$ & $\begin{array}{l}1.5 \\
0\end{array}$ \\
\hline $\begin{array}{l}185 \\
\text { IM } 417\end{array}$ & $\mathbf{A}^{5} \mathbf{C N}_{17} \mathbf{I}_{17 \beta / \mathrm{CN} / 1,1} \mathrm{ol}_{3 \beta}$ & 0.5 & 0 & 0 & 0 \\
\hline $\begin{array}{l}186 \\
\text { IM } 118\end{array}$ & $\mathrm{~A}^{5} \mathrm{II}^{1-1}{ }_{17 \alpha} \mathrm{Ol}_{3 \beta, 17}$ & 10 & 0 & 0 & 0 \\
\hline $\begin{array}{l}187 \\
\text { IM } 350\end{array}$ & $\mathbf{A}^{5} \mathrm{IIII}^{\prime \prime} \gamma \mathbf{l a c}_{17 \alpha} \mathrm{Ol}_{3 \beta}$ & $\begin{array}{c}10 \\
0.5\end{array}$ & 0 & $\begin{array}{l}3 \\
0\end{array}$ & $\begin{array}{l}\mathbf{0 . 1 5} \\
0\end{array}$ \\
\hline
\end{tabular}


Table 135 B (continued)

\begin{tabular}{|c|c|c|c|c|c|}
\hline Group & SSS Name & $\begin{array}{l}\text { Dose } \\
(\mathrm{mg})\end{array}$ & $\begin{array}{l}\text { Digi- } \\
\text { toxin }^{a}\end{array}$ & $\begin{array}{l}\text { Indo- } \\
\text { methacin a }^{2}\end{array}$ & $\begin{array}{l}\text { Activity } \\
\text { index }^{\mathrm{b}}\end{array}$ \\
\hline $\begin{array}{l}188 \\
\text { IM } 351\end{array}$ & $\mathbf{A}^{5} \mathrm{III}^{1 /} \gamma \mathbf{l a c}_{17 \alpha} \mathrm{Ol}_{3 \beta}$ & $\begin{array}{c}10 \\
0.5\end{array}$ & $\begin{array}{l}3 \\
-\end{array}$ & $\begin{array}{l}3 \\
0.5\end{array}$ & $\begin{array}{l}0.3 \\
1\end{array}$ \\
\hline $\begin{array}{l}189 \\
\text { IM } 354\end{array}$ & $\mathrm{~A}^{5} \mathrm{IIII}^{1-1^{\prime \prime}}{ }_{17 \alpha} \mathrm{Ol}_{3 \beta, 17}$ & 10 & 0 & 0 & 0 \\
\hline $\begin{array}{l}190 \\
\text { IM } 500\end{array}$ & $\mathbf{A}^{5} \mathrm{III}^{2-2^{\prime \prime}}{ }_{17 \alpha} \mathrm{Ol}_{3 \beta, 17}$ & 0.5 & 0 & 0 & 0 \\
\hline $\begin{array}{l}191 \\
\text { IM } 217\end{array}$ & $\mathbf{A}^{1,4} \mathbf{I}_{6 \alpha} \mathrm{On}_{3,11,17}$ & $\begin{array}{c}10 \\
0.5\end{array}$ & 3 & $\begin{array}{l}3 \\
1\end{array}$ & $\begin{array}{l}0.3 \\
2\end{array}$ \\
\hline $\begin{array}{l}192 \\
\text { IM } 281\end{array}$ & $\mathbf{A}^{1,4} \mathbf{I}_{17 \alpha \mathrm{Ol}_{17} \mathrm{On}_{3}}$ & 10 & 0.5 & 1 & 0.075 \\
\hline $\begin{array}{l}193 \\
\text { IM } 164\end{array}$ & $\mathbf{A}^{1,4} \mathbf{I}_{17 \alpha} \mathrm{Ol}_{11 \beta, 17} \mathrm{On}_{3}$ & 10 & 2 & 1.5 & 0.175 \\
\hline $\begin{array}{l}194 \\
\text { IM } 323\end{array}$ & $\begin{array}{l}\mathbf{A}^{4,6} \mathbf{I I I}^{\prime} \mathbf{K}_{17 \alpha} \mathrm{ol}_{17} \mathrm{on}_{3} \\
\text { (Aldadiene Kalium) }\end{array}$ & $\begin{array}{c}10 \\
0.5\end{array}$ & $\begin{array}{l}3 \\
0\end{array}$ & $\begin{array}{l}3 \\
-\end{array}$ & $\begin{array}{l}0.3 \\
0\end{array}$ \\
\hline $\begin{array}{l}195 \\
\text { IM } 316\end{array}$ & $\begin{array}{l}\mathbf{A}^{4,6} \mathbf{I I I}^{\prime \prime} \mathbf{\gamma l a c}_{17 \alpha} \mathrm{Ol}_{17} \mathrm{On}_{3} \\
\text { (Aldadiene) }\end{array}$ & $\begin{array}{c}10 \\
0.5\end{array}$ & $\begin{array}{l}3 \\
0\end{array}$ & 3 & $\begin{array}{l}0.3 \\
0\end{array}$ \\
\hline $\begin{array}{l}196 \\
\text { IM } 157\end{array}$ & $\mathbf{A}^{4,9(11)} \mathbf{I}_{17 \alpha} \mathrm{ol}_{17} \mathrm{On}_{3}$ & 10 & 3 & 3 & 0.3 \\
\hline $\begin{array}{l}197 \\
\text { IM } 222\end{array}$ & $\mathrm{~A}^{4,9(11)} \mathbf{I}_{2 \alpha, 17 \alpha} \mathrm{Ol}_{17} \mathrm{On}_{3}$ & 10 & 3 & 1 & 0.2 \\
\hline $\begin{array}{l}198 \\
\text { IM } 389\end{array}$ & $\mathrm{~A}^{4,16} \mathrm{CN}_{17} \mathrm{On}_{3}$ & 0.5 & 0 & 0 & 0 \\
\hline $\begin{array}{l}\text { 199 } \\
\text { IM } 498\end{array}$ & $\mathbf{A}^{5,15 I^{\prime \prime}}{ }_{17 \beta} * \mathrm{II}^{\prime \prime}{ }_{3 \beta}$ & 0.5 & 0 & 0 & 0 \\
\hline $\begin{array}{l}200 \\
\text { IM } 396\end{array}$ & $\mathrm{~A}^{5,16} \mathrm{CN}_{17} * \mathrm{II}^{\prime \prime}{ }_{3 \beta}$ & 0.5 & 0 & 0 & 0 \\
\hline $\begin{array}{l}201 \\
\text { IM } 322\end{array}$ & $\mathbf{A}\left(\mathbf{0}_{2}\right) 5 \propto \mathbf{I}_{17 \alpha} \mathrm{Ol}_{17}$ & 10 & 3 & 1.5 & 0.225 \\
\hline $\begin{array}{l}202 \\
\text { IM } 80\end{array}$ & $\mathbf{A}\left(\mathbf{0}_{2}\right)^{4} \mathbf{I}_{17 \alpha} \mathrm{Ol}_{17} \mathrm{On}_{3} \quad$ (Oxandrolone) & $\begin{array}{c}10 \\
0.5\end{array}$ & $\begin{array}{l}3 \\
0\end{array}$ & $\begin{array}{l}3 \\
0\end{array}$ & $\begin{array}{l}\mathbf{0 . 3} \\
0\end{array}$ \\
\hline $\begin{array}{l}203 \\
\text { IM } 410\end{array}$ & $\mathbf{A}\left(\mathbf{N}_{4}\right) \mathbf{I I}_{17 \alpha} \mathrm{ol}_{17 \mathrm{On}_{3}}$ & $\begin{array}{c}10 \\
0.5\end{array}$ & $\begin{array}{l}1.5 \\
0\end{array}$ & $\begin{array}{l}3 \\
0\end{array}$ & $\begin{array}{l}0.225 \\
0\end{array}$ \\
\hline $\begin{array}{l}204 \\
\text { IM } 302\end{array}$ & $\operatorname{AnA} 5 \alpha \mathrm{on}_{2,16}$ & 10 & 3 & 3 & 0.3 \\
\hline $\begin{array}{l}205 \\
\text { IM } 126\end{array}$ & $\mathrm{AnB}^{4} \mathrm{ol}_{17 \beta} \mathrm{On}_{3} \quad$ (B-Nortestosterone) & 10 & 0.5 & 1 & 0.075 \\
\hline $\begin{array}{l}206 \\
\text { IM } 84\end{array}$ & $\operatorname{AhoD}\left(0_{17 \alpha}\right)^{1,4} \mathrm{on}_{3,17}$ & 10 & 2 & 3 & 0.25 \\
\hline $\begin{array}{l}207 \\
\text { IM } 452\end{array}$ & An 18,nC,hoD ${ }^{4} \mathrm{I}_{17 \alpha} \mathrm{Ol}_{17} \mathrm{On}_{3}$ & 0.5 & 0 & 0 & 0 \\
\hline
\end{tabular}


Table 135B (continued)

\begin{tabular}{|c|c|c|c|c|c|}
\hline Group & SSS Name & $\begin{array}{l}\text { Dose } \\
\text { (mg) }\end{array}$ & $\begin{array}{l}\text { Digi- } \\
\text { toxin }^{a}\end{array}$ & $\begin{array}{l}\text { Indo- } \\
\text { methacina }\end{array}$ & $\begin{array}{l}\text { Activity } \\
\text { index }^{b}\end{array}$ \\
\hline $\begin{array}{l}208 \\
\text { IM } 143\end{array}$ & $\mathrm{~A}^{49} \boldsymbol{9}, 10 \alpha \mathrm{ol}_{17 \beta} \circ \mathrm{n}_{8} \quad$ (Retrotestosterone) & 10 & 0 & 0.5 & 0.025 \\
\hline $\begin{array}{l}209 \\
\text { IM } 145 \\
210\end{array}$ & $\begin{array}{l}\text { A }^{49} \beta, 10 \alpha \text { on }_{3,17} \text { (Retroandrostene- } \\
\text { dione) }\end{array}$ & 10 & 3 & 0.5 & 0.175 \\
\hline $\begin{array}{l}210 \\
\text { IM } 243\end{array}$ & $\mathrm{P}_{5} \alpha \mathrm{on}_{3,20}$ & 10 & 0.5 & 0.5 & 0.05 \\
\hline $\begin{array}{l}211 \\
\text { IM } 72\end{array}$ & $\mathbf{P}^{5} \beta_{o_{3,20}}$ (Pregnanedione) & $\begin{array}{l}10 \\
0.5\end{array}$ & 0 & $\begin{array}{l}2 \\
0\end{array}$ & $\begin{array}{l}0.1 \\
0\end{array}$ \\
\hline $\begin{array}{l}212 \\
\text { IM } 106\end{array}$ & $\mathrm{P}^{2} \propto \mathrm{on}_{3,11,20}$ & 10 & $\mathbf{3}$ & 3 & 0.3 \\
\hline $\begin{array}{l}213 \\
\text { IM } 115\end{array}$ & P5 $\beta$ on $_{3,11,20}$ & $\begin{array}{c}10 \\
0.5\end{array}$ & $\begin{array}{l}2.5 \\
-\end{array}$ & $\begin{array}{l}3 \\
\mathbf{0}\end{array}$ & $\begin{array}{l}0.275 \\
0\end{array}$ \\
\hline $\begin{array}{l}214 \\
\text { IM } 447\end{array}$ & $\mathrm{PL}_{\mathrm{Nol}} \mathrm{OO}_{20}$ & 0.5 & $\mathbf{0}$ & 0 & 0 \\
\hline $\begin{array}{l}215 \\
\text { IM } 261\end{array}$ & P5 $\alpha$ ol $_{3 \beta, 16 \alpha} \mathrm{On}_{20}$ & 10 & $\mathbf{0}$ & 0.5 & 0.025 \\
\hline $\begin{array}{l}216 \\
\text { IM } 136\end{array}$ & P5 $\alpha \mathrm{ol}_{3 \beta} \mathrm{On}_{11,20}$ & 10 & 1.5 & 3 & 0.225 \\
\hline $\begin{array}{l}217 \\
\text { IM } 301\end{array}$ & $P 5 \beta$ ol $_{3 \beta} \mathrm{On}_{11,20}$ & $\begin{array}{l}10 \\
0.5\end{array}$ & $\begin{array}{l}3 \\
-\end{array}$ & $\begin{array}{l}3 \\
0\end{array}$ & $\begin{array}{l}0.3 \\
0\end{array}$ \\
\hline $\begin{array}{l}218 \\
\text { IM } 122\end{array}$ & P5 $\propto \mathrm{ol}_{3 \beta, 17} \mathrm{on}_{11,20}$ & 10 & 3 & 3 & 0.3 \\
\hline $\begin{array}{l}219 \\
\text { IM } 277\end{array}$ & $\mathrm{P}_{5} \alpha \mathrm{ol}_{3 \beta} \mathrm{On}_{11,20} \theta_{16 \alpha-17}$ & 10 & 3 & 3 & 0.3 \\
\hline $\begin{array}{l}220 \\
\text { IM } 272\end{array}$ & $\mathrm{P} 5 \alpha^{*} \mathrm{II}^{\prime \prime}{ }_{3 \beta} \mathrm{On}_{20} \mathrm{Cl}_{5,6 \beta}$ & 10 & 0 & 0.5 & 0.025 \\
\hline $\begin{array}{l}221 \\
\text { IM } 273\end{array}$ & $\mathrm{P} 5 \alpha \mathrm{ol}_{3 \beta, 17} \mathrm{On}_{20} \mathrm{Cl}_{5,6 \beta}$ & 10 & 0 & 0.5 & 0.025 \\
\hline $\begin{array}{l}222 \\
\text { IM } 215\end{array}$ & $P 5 \propto \mathrm{ol}_{5} \mathrm{On}_{3,20} \mathrm{~F}_{6 \beta}$ & 10 & 0 & 0 & 0 \\
\hline $\begin{array}{l}223 \\
\mathrm{IM} 290\end{array}$ & $\mathrm{P} 5 \alpha^{*} \mathrm{II}^{\prime \prime}{ }_{3 \beta, 20} \theta_{5 \alpha-6}$ methyloxazolyl $\mathrm{l}_{16 \alpha-17}$ & 10 & 2 & 3 & 0.25 \\
\hline $\begin{array}{l}224 \\
\text { IM } 285\end{array}$ & $\mathrm{P}_{5} \alpha^{*} \mathrm{II}^{\prime \prime}{ }_{3 \beta} \mathrm{On}_{11,20}$ methyloxazolyl $\mathrm{l}_{16 \alpha-17}$ & 10 & 0.5 & 1 & 0.075 \\
\hline $\begin{array}{l}225 \\
\text { IM } 286\end{array}$ & P5 $\alpha^{*} \mathrm{III}_{3 \beta}{ }_{3 \beta} \mathrm{On}_{11,20}$ ethyloxazolyl ${ }_{16 \alpha-17}$ & 10 & 1 & 0.5 & 0.075 \\
\hline $\begin{array}{l}226 \\
\text { IM } 331\end{array}$ & $\begin{array}{l}\text { P5 } \alpha \text { ol }_{3 \beta}[N \text {-(piperidinoethyl)- } \\
\text { formamido }]_{20 \beta}\end{array}$ & 10 & 0.5 & 2.5 & 0.15 \\
\hline $\begin{array}{l}227 \\
\text { IM } 82\end{array}$ & {$\left[\mathrm{P} 5 \alpha \mathrm{ol}_{3 \alpha} \mathrm{on}_{20}\right.$ piperidino $\left.2 \beta / \mathrm{I} / / 1\right] \mathrm{Br}^{-}$} & 0.5 & 0 & 0 & 0 \\
\hline
\end{tabular}


Table 135B (continued)

\begin{tabular}{|c|c|c|c|c|c|}
\hline Group & SSS Name & $\begin{array}{l}\text { Dose } \\
\text { (mg) }\end{array}$ & $\begin{array}{l}\text { Digi- } \\
\text { toxin }^{a}\end{array}$ & $\begin{array}{l}\text { Indo- } \\
\text { methacina }\end{array}$ & $\begin{array}{l}\text { Activity } \\
\text { index }^{\mathbf{b}}\end{array}$ \\
\hline $\begin{array}{l}228 \\
\text { IM } 135\end{array}$ & $\mathrm{P} 5 \alpha{ } \mathrm{ol}_{3 \alpha} \mathrm{On}_{20} \mathrm{NH}_{2 \beta / \mathrm{II} / / \mathrm{Ph} / / / 2} \cdot \mathrm{HCl}$ & 0.5 & $\mathbf{0}$ & 0 & $\mathbf{0}$ \\
\hline $\begin{array}{l}229 \\
\text { IM } 274\end{array}$ & $\mathrm{P} 5 \alpha \mathrm{ol}_{5} * \mathrm{III}_{3 \beta}^{\prime \prime} \mathrm{On}_{20}\left(\mathrm{~N}_{3}\right)_{6 \beta}$ & 10 & 0 & 1.5 & 0.075 \\
\hline $\begin{array}{l}\mathbf{2 3 0} \\
\text { IM } 283\end{array}$ & $P 5 \alpha \operatorname{ol}_{3 \beta, 17} \mathrm{On}_{11,20}\left(\mathrm{~N}_{3}\right)_{16 \beta}$ & 10 & 0 & 0 & $\mathbf{0}$ \\
\hline $\begin{array}{l}231 \\
\text { IM } 282\end{array}$ & $P 5 \alpha \operatorname{ol}_{3 \beta, 16 \alpha} \mathrm{On}_{11,20}\left(\mathrm{~N}_{3}\right)_{17}$ & 10 & 2 & 1 & 0.15 \\
\hline $\begin{array}{l}232 \\
\text { IM } 460\end{array}$ & 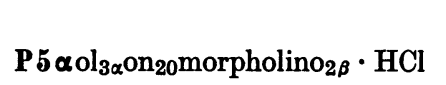 & 0.5 & 0 & 0 & 0 \\
\hline $\begin{array}{l}233 \\
\text { IM } 269 \\
234\end{array}$ & P5 $\alpha^{16}$ on $_{3,11,20}$ & $\begin{array}{l}10 \\
0.5\end{array}$ & 0 & $\begin{array}{l}3 \\
0\end{array}$ & $\begin{array}{l}0.15 \\
0\end{array}$ \\
\hline $\begin{array}{l}284 \\
\text { IM } 264\end{array}$ & $\mathrm{P} 5 \alpha^{16 *} \mathrm{II}^{\prime \prime}{ }_{3 \beta, 11 \alpha} \mathrm{On}_{20}$ & 10 & 0 & 3 & 0.075 \\
\hline $\begin{array}{l}235 \\
\text { IM } 263\end{array}$ & $\mathrm{P} 5 \alpha^{16 *} \mathrm{III}^{\prime \prime}{ }_{3 \beta} \mathrm{On}_{11,20}$ & 10 & 0 & 0 & 0 \\
\hline $\begin{array}{l}236 \\
\text { IM } 270\end{array}$ & $P 5 \alpha^{16} o_{11,20} \theta I_{3,3}$ & $\begin{array}{c}10 \\
0.5\end{array}$ & $\begin{array}{l}1.5 \\
-\end{array}$ & $\begin{array}{l}3 \\
0\end{array}$ & $\begin{array}{l}0.225 \\
0\end{array}$ \\
\hline $\begin{array}{l}237 \\
\text { IM } 265\end{array}$ & $\mathrm{P} 5 \alpha^{17(20) * \mathrm{II}^{\prime \prime}{ }_{3 \beta, 20}}$ & 10 & 0 & 3 & 0.15 \\
\hline $\begin{array}{l}238 \\
\text { IM } 128\end{array}$ & $\mathrm{P} 5 \beta_{\mathrm{ol}_{3 \alpha, 12 \alpha, 20}}$ & $\begin{array}{l}10 \\
0.5\end{array}$ & $\begin{array}{l}3 \\
0\end{array}$ & 3 & $\begin{array}{l}0.3 \\
0\end{array}$ \\
\hline $\begin{array}{l}239 \\
\text { IM } 129\end{array}$ & P5 $\beta$ ol $_{3 \alpha, 20} \mathrm{on}_{12}$ & 10 & 3 & 3 & 0.3 \\
\hline $\begin{array}{l}\mathbf{2 4 0} \\
\text { IM } 113\end{array}$ & P5 $\beta * I^{\prime \prime}{ }_{3 \alpha, 20} \mathrm{on}_{12}$ & $\begin{array}{l}10 \\
0.5\end{array}$ & $\begin{array}{l}\mathbf{3} \\
\mathbf{0}\end{array}$ & $\begin{array}{l}3 \\
0\end{array}$ & $\begin{array}{l}0.3 \\
0\end{array}$ \\
\hline $\begin{array}{l}241 \\
\text { IM } 112\end{array}$ & $\mathrm{P} 5 \boldsymbol{\beta o l}_{3 \alpha} \mathrm{On}_{20}$ & 10 & 0 & 3 & 0.15 \\
\hline $\begin{array}{l}242 \\
\text { IM } 110\end{array}$ & $P 5 \beta_{0}{ }_{3 \alpha} * I I^{\prime \prime}{ }_{12 \alpha} \mathrm{On}_{20}$ & 10 & 0 & 3 & 0.15 \\
\hline $\begin{array}{l}\mathbf{2 4 3} \\
\text { IM } 127\end{array}$ & $\mathrm{P} 5 \beta^{*} \mathrm{II}^{\prime \prime}{ }_{3 \alpha, 12 \alpha} \mathrm{On}_{20}$ & 10 & 0.5 & $\mathbf{3}$ & 0.175 \\
\hline $\begin{array}{l}\mathbf{2 4 4} \\
\text { IM } 11\end{array}$ & $\begin{array}{l}\text { P5 } \beta{ }^{*} \text { suc }^{\prime \prime} \mathrm{Na}_{21} \mathrm{on}_{3,20} \\
\text { (Hydroxydione Sodium) }\end{array}$ & $\begin{array}{l}10 \\
0.5\end{array}$ & $\begin{array}{l}2 \\
0\end{array}$ & 0 & $\begin{array}{l}0.15 \\
0\end{array}$ \\
\hline $\begin{array}{l}245 \\
\text { IM } 121\end{array}$ & $P_{5} \beta_{o_{3 \alpha}} \mathrm{On}_{11,20}$ & 10 & 3 & 1.5 & 0.225 \\
\hline $\begin{array}{l}246 \\
\text { IM } 293\end{array}$ & $\mathrm{P} 5 \beta^{*} \mathrm{II}^{\prime \prime}{ }_{3 \alpha} \mathrm{On}_{11,20}$ & $\begin{array}{l}10 \\
0.5\end{array}$ & 3 & $\begin{array}{l}3 \\
\mathbf{0}\end{array}$ & $\begin{array}{l}0.3 \\
0\end{array}$ \\
\hline $\begin{array}{l}247 \\
\text { IM } 294\end{array}$ & P5 $\beta \mathrm{ol}_{3 \alpha, 17 \mathrm{On}_{11,20}}$ & $\begin{array}{c}10 \\
0.5\end{array}$ & 2 & $\begin{array}{l}3 \\
0\end{array}$ & $\begin{array}{l}0.25 \\
0\end{array}$ \\
\hline
\end{tabular}


Table 135 B (continued)

\begin{tabular}{|c|c|c|c|c|c|}
\hline Group & SSS Name & $\begin{array}{l}\text { Dose } \\
(\mathrm{mg})\end{array}$ & $\begin{array}{l}\text { Digi- } \\
\text { toxin }^{a}\end{array}$ & $\begin{array}{l}\text { Indo- } \\
\text { methacin }^{a}\end{array}$ & $\begin{array}{l}\text { Activity } \\
\text { index }^{\mathrm{b}}\end{array}$ \\
\hline $\begin{array}{l}248 \\
\text { IM } 303\end{array}$ & $\mathrm{P} 5 \beta_{\mathrm{ool}}{ }_{3 \alpha, 17} * \mathrm{II}^{\prime \prime}{ }_{21} \mathrm{on}_{11,20}$ & 10 & 0 & 1.5 & 0.075 \\
\hline $\begin{array}{l}249 \\
\text { IM } 300\end{array}$ & $P 5 \beta_{o_{17}} * I I_{3 \alpha, 21}^{\prime \prime}$ on $_{11,20}$ & 10 & 0 & 0 & 0 \\
\hline $\begin{array}{l}250 \\
\text { IM } 305\end{array}$ & P5 $\beta$ ol $_{17} * \mathrm{II}_{21}{ }_{21} \mathrm{on}_{3,11,20}$ & 10 & 0 & 0.5 & 0.025 \\
\hline $\begin{array}{l}251 \\
\text { IM } 497\end{array}$ & $P 5 \beta^{\prime \prime}{ }_{21} \mathrm{ol}_{3 \alpha} \mathrm{On}_{11}$ & 0.5 & 0 & 0 & 0 \\
\hline $\begin{array}{l}252 \\
\text { IM } 116\end{array}$ & $\mathrm{P} 5 \beta \mathrm{ol}_{3 \alpha, 20} \theta_{11 \beta-12}$ & $\begin{array}{c}10 \\
0.5\end{array}$ & 3 & $\begin{array}{l}3 \\
0\end{array}$ & $\begin{array}{l}\mathbf{0 . 3} \\
0\end{array}$ \\
\hline $\begin{array}{l}253 \\
\text { IM } 74\end{array}$ & $\mathbf{P}^{4} \mathrm{On}_{3,20} \quad$ (Progesterone) & $\begin{array}{c}10 \\
0.5\end{array}$ & $\begin{array}{l}1.5 \\
0\end{array}$ & $\begin{array}{l}3 \\
0\end{array}$ & $\begin{array}{l}0.225 \\
0\end{array}$ \\
\hline $\begin{array}{l}254 \\
\text { IM } 561\end{array}$ & $\mathrm{P}^{4} \mathrm{On}_{3,11,20}$ & 0.5 & 0 & 0 & 0 \\
\hline $\begin{array}{l}255 \\
\text { IM } 555\end{array}$ & $\mathrm{P}^{4} \mathrm{On}_{3,6,11,20}$ & 0.5 & 0 & 0 & 0 \\
\hline $\begin{array}{l}256 \\
\text { IM } 133\end{array}$ & $\mathrm{P}^{4} \mathrm{Ol}_{3 \beta, 16 \alpha, 17} \mathrm{On}_{20}$ & 10 & 0 & 0 & 0 \\
\hline $\begin{array}{l}257 \\
\text { IM } 119\end{array}$ & $\mathbf{P}^{4} \mathrm{Ol}_{11 \alpha} \mathrm{on}_{3,20} \quad$ (Hydroxyprogesterone) & $\begin{array}{c}10 \\
0.5\end{array}$ & $\begin{array}{l}1.5 \\
0\end{array}$ & $\begin{array}{l}3 \\
0\end{array}$ & $\begin{array}{l}\mathbf{0 . 2 2 5} \\
0\end{array}$ \\
\hline $\begin{array}{l}258 \\
\text { IM } 47\end{array}$ & $\mathbf{P}^{4} \mathrm{Ol}_{17} \mathrm{On}_{3,20} \quad$ (Hydroxyprogesterone) & 10 & 3 & 3 & $\mathbf{0 . 3}$ \\
\hline $\begin{array}{l}259 \\
\text { IM } 73\end{array}$ & $\mathrm{P}^{4 *} \mathrm{II}^{\prime \prime}{ }_{17} \mathrm{On}_{3,20} \quad$ (Acetoxyprogesterone) & $\begin{array}{c}10 \\
0.5\end{array}$ & $\begin{array}{l}3 \\
0\end{array}$ & $\begin{array}{l}3 \\
0.5\end{array}$ & $\begin{array}{l}0.3 \\
0.5\end{array}$ \\
\hline $\begin{array}{l}260 \\
\text { IM } 244\end{array}$ & $\mathbf{P}^{4} \mathrm{Ol}_{21} \mathrm{On}_{3,20} \quad$ (Desoxycorticosterone) & 10 & 3 & 2 & 0.25 \\
\hline $\begin{array}{l}261 \\
\text { IM } 25\end{array}$ & $\begin{array}{l}\mathrm{P}^{4 *} \mathrm{III}^{\prime \prime}{ }_{21} \mathrm{On}_{3,20} \\
\text { (Desoxycorticosterone acetate) }\end{array}$ & $\begin{array}{c}10 \\
0.5\end{array}$ & 1 & $\begin{array}{l}0 \\
0.5\end{array}$ & $\begin{array}{l}0.05 \\
1.0\end{array}$ \\
\hline $\begin{array}{l}262 \\
\text { IM } 53\end{array}$ & $\mathrm{P}^{4 * \mathrm{II}^{\prime \prime}}{ }_{6 \beta, 11 \alpha} \mathrm{On}_{3,20}$ & 0.5 & 0 & 0 & 0 \\
\hline $\begin{array}{l}\mathbf{2 6 3} \\
\text { IM } 23\end{array}$ & $\begin{array}{l}\mathbf{P}^{4} \mathrm{ol}_{11 \beta, 21} \mathrm{On}_{3,20} \\
\text { (Corticosterone, Kendall "Cpd. B") }\end{array}$ & $\begin{array}{c}10 \\
0.5\end{array}$ & $\begin{array}{l}3 \\
\mathbf{0}\end{array}$ & $\begin{array}{l}3 \\
0\end{array}$ & $\begin{array}{l}0.3 \\
0\end{array}$ \\
\hline $\begin{array}{l}264 \\
\text { IM } 134\end{array}$ & $\begin{array}{l}\mathrm{P}^{4} \mathrm{Ol}_{11 \beta} * \mathrm{II}^{\prime \prime}{ }_{21} \mathrm{On}_{3,20} \\
\text { (Corticosterone acetate) }\end{array}$ & 10 & 2 & 1.5 & 0.175 \\
\hline $\begin{array}{l}265 \\
\text { IM } 70\end{array}$ & $\begin{array}{l}\mathbf{P}^{4} \mathrm{ol}_{17,21} \mathrm{on}_{3,20} \\
\text { (Hydroxydesoxy-corticosterone) }\end{array}$ & 10 & 3 & 3 & 0.3 \\
\hline $\begin{array}{l}266 \\
\text { IM } 235\end{array}$ & $\mathrm{P}^{4} \mathrm{Ol}_{11 \alpha, 17,21} \mathrm{On}_{3,20}$ & 10 & 3 & 3 & 0.3 \\
\hline
\end{tabular}


Table 135 B (continued)

\begin{tabular}{|c|c|c|c|c|c|}
\hline Group & SSS Name & $\begin{array}{l}\text { Dose } \\
(\mathrm{mg})\end{array}$ & $\begin{array}{l}\text { Digi- } \\
\text { toxin }^{a}\end{array}$ & $\begin{array}{l}\text { Indo- } \\
\text { methacin }^{a}\end{array}$ & $\begin{array}{l}\text { Activity } \\
\text { index }\end{array}$ \\
\hline \\
\hline $\operatorname{IM} 45 / \mathrm{a}$ & $\begin{array}{l}\mathbf{P}^{4} \mathrm{ol}_{11 \beta, 17,21} \text { on }_{3,20} \\
\text { (Hydrocortisone, Cortisol) }\end{array}$ & 10 & 3 & 1 & 0.2 \\
\hline \multicolumn{6}{|c|}{ (1925 } \\
\hline IM 45 & $\begin{array}{l}\mathrm{P}^{4} \mathrm{Ol}_{11 \beta, 17} * \mathrm{II}^{\prime \prime}{ }_{21} \mathrm{On}_{3,20} \\
\text { (Cortisol acetate) }\end{array}$ & $\begin{array}{c}10 \\
0.5\end{array}$ & $\begin{array}{l}3 \\
0\end{array}$ & $\begin{array}{l}0 \\
0\end{array}$ & $\begin{array}{l}0.15 \\
0\end{array}$ \\
\hline \multicolumn{6}{|l|}{269} \\
\hline IM 298 & $\begin{array}{l}\mathrm{P}^{4} \mathrm{ol}_{11 \beta, 17} * \mathrm{IV}^{\prime \prime}{ }_{21 / \mathrm{I} / / 3,3} \mathrm{On}_{3,20} \\
\text { (Cortisol tetrabutylacetate) }\end{array}$ & 10 & 0 & 0 & 0 \\
\hline \multicolumn{6}{|c|}{ 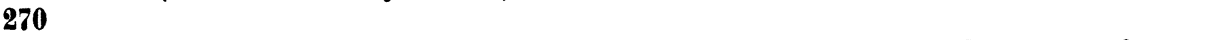 } \\
\hline IM 98 & $\begin{array}{l}\mathbf{P}^{4} \text { ol }_{11 \beta, 17}{ }^{*} \text { suc }^{\prime \prime}{ }_{21} \text { on }_{3,20} \\
\text { (Cortisol hemisuccinate) }\end{array}$ & 10 & 0 & 0 & 0 \\
\hline \\
\hline IM 337 & $\begin{array}{l}\mathbf{P}^{4} \mathrm{ol}_{11 \beta, 17} * \mathrm{suc}^{\prime \prime} \mathrm{Na}_{21} \mathrm{on}_{3,20} \\
\text { (Cortisol sodium succinate) }\end{array}$ & 10 & 2 & 0.5 & 0.125 \\
\hline $\begin{array}{l}272 \\
\text { IM } 256\end{array}$ & \multicolumn{4}{|l|}{ 1 } & 0.2 \\
\hline \multicolumn{6}{|l|}{273} \\
\hline $\begin{array}{l}274 \\
\text { IM } 557\end{array}$ & \multicolumn{4}{|c|}{274} & 0 \\
\hline \\
\hline IM 102 & & 0.5 & 0 & - & 0 \\
\hline \\
\hline IM 22 & $\begin{array}{l}\mathrm{P}^{4} \mathrm{ol}_{17} * \mathrm{II}^{\prime \prime}{ }_{21} \mathrm{on}_{3,11,20} \\
\text { (Cortisone acetate) }\end{array}$ & $\begin{array}{c}10 \\
0.5\end{array}$ & $\begin{array}{l}3 \\
0\end{array}$ & $\begin{array}{l}0 \\
0\end{array}$ & $\begin{array}{l}0.15 \\
0\end{array}$ \\
\hline \multicolumn{6}{|l|}{278} \\
\hline IM 43 & $\mathbf{P}^{4} \mathrm{ol}_{11 \beta, 21} \mathrm{On}_{3,20} \mathrm{al}_{18} \quad$ (Aldosterone) & 10 & 0 & 0 & 0 \\
\hline $\begin{array}{l}278 \\
\text { IM } 149\end{array}$ & $\begin{array}{l}\mathbf{P}^{4} \mathrm{ol}_{11 \beta, 21} \mathrm{on}_{3,20} \theta \theta_{16 \alpha-171}, \mathrm{I} \\
\text { (Cortisol acetonide) }\end{array}$ & 10 & 3 & 0 & 0.15 \\
\hline \multicolumn{6}{|c|}{ f } \\
\hline IM 130 & $\begin{array}{l}\mathrm{P}^{4} * \mathrm{II}^{\prime \prime}{ }_{21} \mathrm{on}_{3,20} \theta_{16 \alpha-17} \\
\text { (Epoxy-desoxycorticosterone) }\end{array}$ & 10 & 0 & 1.5 & 0.075 \\
\hline $\begin{array}{l}280 \\
\text { IM } 123\end{array}$ & $\mathbf{P}^{4} \mathrm{on}_{3,20} \theta_{16 \alpha-17} \quad$ (Epoxyprogesterone) & 10 & 0.5 & 3 & 0.175 \\
\hline \multicolumn{6}{|l|}{281} \\
\hline IM 16 & $\mathrm{P}^{4} \mathrm{On}_{3,11,20} \mathrm{Br}_{9 \alpha}$ & $\begin{array}{l}10 \\
0.5\end{array}$ & 1 & $\begin{array}{l}1 \\
3\end{array}$ & $\begin{array}{l}0.2 \\
0\end{array}$ \\
\hline $\begin{array}{l}282 \\
\text { IM } 179\end{array}$ & $\mathbf{P}^{4} \mathrm{On}_{3,20} \mathrm{Br}_{17} \quad$ (Bromoprogesterone) & 10 & 0.5 & 3 & 0.175 \\
\hline \multicolumn{6}{|c|}{ - } \\
\hline IM 18 & $\begin{array}{l}\mathrm{P}^{4} \mathrm{ol}_{17} * \mathrm{II}^{\prime \prime}{ }_{21} \mathrm{on}_{3,11,20} \mathrm{Cl}_{4} \\
\text { (Chlorocortisone acetate) }\end{array}$ & 10 & 0.5 & - & 0.05 \\
\hline \multicolumn{6}{|l|}{284} \\
\hline IM 19 & $\begin{array}{l}\mathrm{P}^{4} \mathrm{Ol}_{11 \beta, 17} * \mathrm{II}^{\prime \prime}{ }_{21} \mathrm{On}_{3,20} \mathrm{Cl}_{9 \alpha} \\
\text { (Chlorocortisol acetate) }\end{array}$ & 10 & 0 & - & 0 \\
\hline
\end{tabular}


Table 135B (continued)

\begin{tabular}{|c|c|c|c|c|c|}
\hline Group & SSS Name & $\begin{array}{l}\text { Dose } \\
\text { (mg) }\end{array}$ & $\begin{array}{l}\text { Digi- } \\
\text { toxin }\end{array}$ & $\begin{array}{l}\text { Indo- } \\
\text { methacins }\end{array}$ & $\begin{array}{l}\text { Activity } \\
\text { index }{ }^{\mathrm{b}}\end{array}$ \\
\hline $\begin{array}{l}285 \\
\text { IM } 230\end{array}$ & $\mathrm{P}^{4} \mathrm{Ol}_{11 \alpha} \mathrm{On}_{3,20} \mathrm{~F}_{6 \alpha}$ & 10 & 2 & 3 & 0.25 \\
\hline $\begin{array}{l}286 \\
\text { IM } 214\end{array}$ & $\begin{array}{l}\mathrm{P}^{4} \mathrm{ol}_{11 \beta, 17} * \mathrm{II}^{\prime \prime}{ }_{21} \mathrm{O}_{3,20} \mathrm{~F}_{6 \alpha} \\
\text { Fluorohydrocortisone acetate) }\end{array}$ & 10 & 0 & 1.5 & 0.075 \\
\hline $\begin{array}{l}287 \\
\text { IM } 170\end{array}$ & $\mathrm{P}^{4} \mathrm{ol}_{11 \beta}{ }^{*} \mathrm{II}_{3 \beta}{ }_{3 \beta} \mathrm{On}_{20} \theta \theta \mathrm{I}_{16 \alpha-17 / \mathrm{I}, \mathrm{I}} \mathrm{P}_{6 \alpha}$ & 10 & $\mathbf{0}$ & $\mathbf{0}$ & 0 \\
\hline $\begin{array}{l}288 \\
\text { IM } 173\end{array}$ & $\mathrm{P}^{4} \mathrm{ol}_{11 \beta} \mathrm{on}_{3,20} \theta \theta \mathrm{I}_{16 \alpha-17 / \mathrm{I}, \mathrm{I}_{6 \alpha}}$ & $\begin{array}{l}10 \\
0.5\end{array}$ & $\begin{array}{l}3 \\
0\end{array}$ & 1.5 & $\begin{array}{l}0.225 \\
0\end{array}$ \\
\hline $\begin{array}{l}289 \\
\text { IM } 15\end{array}$ & $\mathrm{P}^{4} \mathrm{Ol}_{11 \beta} \mathrm{On}_{3,20} \mathrm{~F}_{9 \alpha}$ & 10 & 3 & 3 & 0.3 \\
\hline $\begin{array}{l}290 \\
\text { IM } 39\end{array}$ & $\begin{array}{l}\mathrm{P}^{4} \text { ol }_{11 \beta, 17} * \mathrm{II}^{\prime \prime}{ }_{21} \mathrm{On}_{3,20} \mathrm{~F}_{9 \alpha} \\
\text { (Fluorocortisol acetate) }\end{array}$ & 10 & 1.5 & 2.5 & 0.2 \\
\hline $\begin{array}{l}291 \\
\text { IM } 174\end{array}$ & $\mathrm{P}^{4} \mathrm{ol}_{11 \beta} \mathrm{On}_{3,20} \theta \theta \mathrm{I}_{16 \alpha-17 / \mathrm{I}, \mathrm{I}} \mathrm{F}_{6 \alpha, 9 \alpha}$ & 10 & $\mathbf{0}$ & 0.5 & 0.025 \\
\hline $\begin{array}{l}292 \\
\text { IM } 524\end{array}$ & $\mathrm{P}^{5} \mathrm{ol}_{20 \beta} * \mathrm{II}^{\prime \prime}{ }_{3 \beta}$ & 0.5 & 0 & $\mathbf{0}$ & 0 \\
\hline $\begin{array}{l}293 \\
\text { IM } 69\end{array}$ & $\mathrm{P}^{5} \mathrm{Ol}_{3 \beta} \mathrm{On}_{20}$ (Pregnenolone) & 10 & 1 & 3 & 0.2 \\
\hline $\begin{array}{l}294 \\
\text { IM } 125\end{array}$ & $\mathrm{P}^{5} * \mathrm{II}^{\prime \prime}{ }_{3 \beta} \mathrm{On}_{20}$ & 10 & 0 & 1 & 0.05 \\
\hline $\begin{array}{l}295 \\
\text { IM } 195\end{array}$ & $\mathrm{P}^{5} \mathrm{ol}_{3 \beta, 17} \mathrm{On}_{20}$ & 10 & 0 & $\mathbf{0}$ & 0 \\
\hline $\begin{array}{l}296 \\
\text { IM } 132\end{array}$ & $\mathrm{P}^{5} \mathrm{ol}_{17}{ }^{*} \mathrm{II}_{3 \beta}^{\prime \prime} \mathrm{On}_{20}$ & 10 & 0 & 0 & 0 \\
\hline $\begin{array}{l}297 \\
\text { IM } 3\end{array}$ & $\begin{array}{l}\mathrm{P}^{5} \mathrm{ol}_{3 \beta^{*}}{ }^{\mathrm{III}^{\prime \prime}}{ }_{21} \mathrm{n}_{20} \\
\text { (Acetoxypregnenolone) }\end{array}$ & 10 & 0 & 1.5 & 0.075 \\
\hline $\begin{array}{l}298 \\
\text { IM } 523\end{array}$ & $\mathrm{P}^{5 * \mathrm{II}^{\prime \prime}{ }_{3 \beta, 21} \mathrm{On}_{20}}$ & 0.5 & 0 & $\mathbf{0}$ & 0 \\
\hline $\begin{array}{l}299 \\
\text { IM } 176\end{array}$ & {$\left[\mathrm{P}^{5} * \mathrm{II}^{\prime \prime}{ }_{17}{ }^{\left.* \mathrm{~S}^{\prime \prime}{ }_{3 \beta} \mathrm{On}_{20}\right] \text { pyridinium }}{ }^{+}\right.$} & 10 & 1.5 & 3 & 0.225 \\
\hline $\begin{array}{l}300 \\
\text { IM } 108\end{array}$ & $\mathrm{P}^{5} \mathrm{Ol}_{17} * \mathrm{II}_{3 \beta, 21}^{\prime \prime} \mathrm{on}_{20}$ & 10 & 0 & 1 & 0.05 \\
\hline $\begin{array}{l}301 \\
\text { IM } 297\end{array}$ & $\mathbf{P}^{5} \mathrm{on}_{20} \theta \mathrm{I}_{3 \beta}$ & $\begin{array}{c}10 \\
0.5\end{array}$ & 1 & $\begin{array}{l}3 \\
0\end{array}$ & $\begin{array}{l}0.2 \\
0\end{array}$ \\
\hline $\begin{array}{l}302 \\
\text { IM } 525\end{array}$ & $\mathbf{P}^{5} \mathrm{O}, \mathrm{OII}_{3,20}$ & 0.5 & 0 & 0 & 0 \\
\hline $\begin{array}{l}303 \\
\text { IM } 359\end{array}$ & $\mathrm{P}^{5} * \mathrm{I}^{\prime \prime}{ }_{11 \alpha} \mathrm{O}, \mathrm{OI}_{17-20,20-21} \mathrm{O}, 0 \mathrm{II}_{3}$ & $\begin{array}{l}10 \\
0.5\end{array}$ & 0.5 & $\begin{array}{l}3 \\
0\end{array}$ & $\begin{array}{l}0.175 \\
0\end{array}$ \\
\hline $\begin{array}{l}304 \\
\text { IM } 177\end{array}$ & $\mathrm{P}^{5} \mathrm{Ol}_{3 \beta} \mathrm{On}_{20} \theta_{16 \alpha-17}$ & 10 & 0 & 0.5 & 0.025 \\
\hline
\end{tabular}


Table 135 B (continued)

\begin{tabular}{|c|c|c|c|c|c|}
\hline Group & SSS Name & $\begin{array}{l}\text { Dose } \\
(\mathrm{mg})\end{array}$ & $\begin{array}{l}\text { Digi- } \\
\text { toxin }^{a}\end{array}$ & $\begin{array}{l}\text { Indo- } \\
\text { methacina }\end{array}$ & $\begin{array}{l}\text { Activity } \\
\text { index }\end{array}$ \\
\hline $\begin{array}{l}305 \\
\text { IM } 109\end{array}$ & $\mathrm{P}^{5} \mathrm{Ol}_{3 \beta} * \mathrm{II}_{21}^{\prime \prime} \mathrm{on}_{20} \theta_{16 \alpha-17}$ & 10 & 0 & 0.5 & 0.025 \\
\hline $\begin{array}{l}306 \\
\text { IM } 178\end{array}$ & $\mathbf{P}^{5} \mathrm{Ol}_{3 \beta} \mathrm{On}_{20} \mathrm{Br}_{17} \quad$ (Bromopregnenolone) & 10 & 0 & 0 & 0.15 \\
\hline $\begin{array}{l}307 \\
\text { IM } 317\end{array}$ & $\mathbf{P}^{1,4} \mathrm{On}_{3,15,20}$ & 10 & 3 & 3 & $\mathbf{0 . 3}$ \\
\hline $\begin{array}{l}308 \\
\text { IM } 7\end{array}$ & $\mathbf{P}^{1,4} \mathrm{ol}_{11 \beta, 17,21} \mathrm{on}_{3,20} \quad$ (Prednisolone) & 10 & 3 & 0.5 & 0.175 \\
\hline $\begin{array}{l}309 \\
\text { IM } 56 \\
310\end{array}$ & $\begin{array}{l}\mathbf{P}^{1,4} \mathrm{ol}_{11 \beta, 17} * \mathrm{II}^{\prime \prime}{ }_{21} \mathrm{On}_{3,20} \\
\text { (Prednisolone acetate) }\end{array}$ & $\begin{array}{l}10 \\
0.5\end{array}$ & $\begin{array}{l}2 \\
0\end{array}$ & $\begin{array}{l}3 \\
0\end{array}$ & $\begin{array}{l}0.25 \\
0\end{array}$ \\
\hline IM 96 & $\begin{array}{l}\mathbf{P}^{1,4} \mathrm{ol}_{11 \beta, 17}{ }^{*} \text { suc }{ }_{21} \mathrm{on}_{3,20} \\
\text { (Prednisolone hemisuccinate) }\end{array}$ & $\begin{array}{c}10 \\
0.5\end{array}$ & $\begin{array}{l}3 \\
0\end{array}$ & 3 & $\begin{array}{l}\mathbf{0 . 3} \\
0\end{array}$ \\
\hline $\begin{array}{l}311 \\
\text { IM } 97\end{array}$ & $\begin{array}{l}\mathbf{P}_{1,4} \mathrm{Ol}_{11 \beta, 17} * \mathrm{Bz}^{\prime \prime}{ }_{21 / \mathrm{S}^{\prime \prime} \mathrm{Na} / / \mathrm{BO}_{3,20}} \\
\text { (Prednisolone } \mathrm{m} \text {-sulfobenzoate sodium) }\end{array}$ & 10 & 3 & 1.5 & 0.225 \\
\hline $\begin{array}{l}312 \\
\text { IM } 526\end{array}$ & $\mathbf{P}^{1,4} \mathrm{ol}_{17,21} \mathrm{On}_{3,11,20}$ & 0.5 & 0 & 0 & 0 \\
\hline $\begin{array}{l}\mathbf{3 1 3} \\
\text { IM } 68 / a\end{array}$ & $\begin{array}{l}\mathrm{P}^{1,4} \mathrm{ol}_{17}{ }^{*} \mathrm{II}^{\prime \prime}{ }_{21} \mathrm{on}_{3,11,20} \\
\text { (Prednisone acetate) }\end{array}$ & $\begin{array}{c}10 \\
0.5\end{array}$ & $\begin{array}{l}3 \\
0\end{array}$ & $\begin{array}{l}3 \\
-\end{array}$ & $\begin{array}{l}\mathbf{0 . 3} \\
0\end{array}$ \\
\hline $\begin{array}{l}314 \\
\text { IM } 211 \\
\mathbf{3 1 5}\end{array}$ & $\begin{array}{l}\mathrm{P}^{1,4} \mathrm{ol}_{11 \beta, 17,21} \mathrm{on}_{3,20} \mathrm{~F}_{6 \alpha} \\
\text { (Fluoroprednisolone) }\end{array}$ & 10 & 3 & 0.5 & 0.175 \\
\hline IM 32 & $\begin{array}{l}\mathrm{P}^{1,4} \mathrm{ol}_{11 \beta, 16 \alpha, 17,21} \mathrm{on}_{3,20} \mathrm{~F}_{9 \alpha} \\
\text { (Triamcinolone) }\end{array}$ & $\begin{array}{r}10 \\
2\end{array}$ & $\begin{array}{l}0 \\
0\end{array}$ & $\begin{array}{l}0 \\
0\end{array}$ & $\begin{array}{l}0 \\
0\end{array}$ \\
\hline $\begin{array}{l}\text { 316 } \\
\text { IM } 148\end{array}$ & $\begin{array}{l}\mathbf{P}_{1,4} \text { ol }_{11 \beta, 21} \text { on }_{3,20} \theta \theta \mathrm{I}_{16 \alpha-17 / \mathrm{I}, \mathrm{I}} \mathrm{F}_{9 \alpha} \\
\text { (Triamcinolone acetonide) }\end{array}$ & 10 & 0 & 0 & 0 \\
\hline $\begin{array}{l}317 \\
\text { IM } 257\end{array}$ & $\mathrm{P}^{3,5} \mathrm{ol}_{17} * \mathrm{II}^{\prime \prime}{ }_{3,21} \mathrm{on}_{20}$ & $\begin{array}{l}10 \\
0.5\end{array}$ & 3 & $\begin{array}{l}3 \\
0\end{array}$ & $\begin{array}{l}0.3 \\
0\end{array}$ \\
\hline $\begin{array}{l}\mathbf{3 1 8} \\
\text { IM } 288\end{array}$ & $\mathrm{P}^{3,5 *} \mathrm{II}^{\prime \prime}{ }_{21} \mathrm{on}_{20} \theta \mathrm{I}_{3 \beta}$ methyloxalolyl ${ }_{16 \alpha-17}$ & $\begin{array}{c}10 \\
0.5\end{array}$ & $\begin{array}{l}1.5 \\
-\end{array}$ & $\begin{array}{l}3 \\
0\end{array}$ & $\begin{array}{l}0.225 \\
0\end{array}$ \\
\hline $\begin{array}{l}319 \\
\text { IM } 171\end{array}$ & 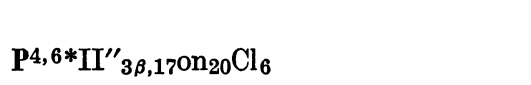 & 10 & 2 & 1 & 0.15 \\
\hline $\begin{array}{l}320 \\
\text { IM } 172\end{array}$ & $\mathrm{P}^{4,6} \mathrm{III}^{\prime \prime}{ }_{17} \mathrm{On}_{3,20} \mathrm{Cl}_{6}$ & $\begin{array}{l}10 \\
0.5\end{array}$ & $\begin{array}{l}3 \\
0\end{array}$ & $\begin{array}{l}3 \\
0\end{array}$ & $\begin{array}{l}0.3 \\
0\end{array}$ \\
\hline 321 & & & & & \\
\hline $\mathrm{IM} 206$ & $\mathbf{P}^{4,16} \mathrm{on}_{3,20}$ & $\begin{array}{l}10 \\
0.5\end{array}$ & $\frac{2}{-}$ & $\begin{array}{l}3 \\
0\end{array}$ & $\begin{array}{l}0.25 \\
0\end{array}$ \\
\hline $\begin{array}{l}322 \\
\text { IM } 154\end{array}$ & $\mathbf{P}^{4,17(20) \mathrm{ol}_{11 \beta, 21} \mathrm{On}_{3}}$ & $\begin{array}{c}10 \\
0.5\end{array}$ & $\begin{array}{l}3 \\
0\end{array}$ & $\begin{array}{l}3 \\
0\end{array}$ & $\begin{array}{l}\mathbf{0 . 3} \\
0\end{array}$ \\
\hline
\end{tabular}


Table 135 B (continued)

\begin{tabular}{|c|c|c|c|c|c|}
\hline Group & SSS Name & $\begin{array}{l}\text { Dose } \\
(\mathrm{mg})\end{array}$ & $\begin{array}{l}\text { Digi- } \\
\text { toxin }^{a}\end{array}$ & $\begin{array}{l}\text { Indo- } \\
\text { methacin }^{\mathrm{a}}\end{array}$ & $\begin{array}{l}\text { Activity } \\
\text { index }\end{array}$ \\
\hline $\begin{array}{l}323 \\
\text { IM } 240\end{array}$ & 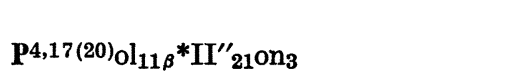 & 10 & 1 & 0 & 0.05 \\
\hline $\begin{array}{l}324 \\
\text { IM } 239\end{array}$ & $\mathrm{P}^{4,17(20)} " * \mathrm{I}_{21} \mathrm{on}_{3,11}$ & $\begin{array}{l}10 \\
0.5\end{array}$ & 3 & $\begin{array}{l}3 \\
0\end{array}$ & $\begin{array}{l}\mathbf{0 . 3} \\
0\end{array}$ \\
\hline $\begin{array}{l}325 \\
\text { IM } 156\end{array}$ & $\mathrm{P}^{4,17(20)_{\mathrm{ol}} \mathrm{l}_{11 \beta} \mathrm{On}_{3} \mathrm{al}} \mathrm{l}_{21}$ & 10 & 0 & 0 & 0 \\
\hline $\begin{array}{l}326 \\
\text { IM } 180\end{array}$ & $\mathrm{P}^{5,16} \mathrm{ol}_{3 \beta} \mathrm{On}_{20}$ (Dehydropregnenolone) & 10 & 0 & 3 & 0.15 \\
\hline $\begin{array}{l}327 \\
\text { IM } 111\end{array}$ & $\begin{array}{l}\mathrm{P5}, 16 * \mathrm{II}^{\prime \prime}{ }_{3 \beta} \mathrm{On}_{20} \\
\text { (Dehydropregnenolone acetate) }\end{array}$ & 10 & 0 & 1.5 & 0.075 \\
\hline $\begin{array}{l}020 \\
\text { IM } 99 \\
329\end{array}$ & $\mathrm{P}^{5,16 * \mathrm{II}^{\prime \prime}}{ }_{3 \beta, 21} \mathrm{On}_{20}$ & 0.5 & 0 & 0 & 0 \\
\hline IM 287 & $\begin{array}{r}\mathrm{P}^{1,4,9(11)} * \mathrm{II}^{\prime \prime}{ }_{21} \mathrm{on}_{3,20} \\
\text { methyloxazolyl }{ }_{16 \alpha-17}\end{array}$ & $\begin{array}{c}10 \\
0.5 \\
0.2\end{array}$ & $\begin{array}{l}3 \\
3 \\
-\end{array}$ & $\begin{array}{l}\mathbf{3} \\
\mathbf{3} \\
\mathbf{3}\end{array}$ & $\begin{array}{c}0.3 \\
6 \\
10.0\end{array}$ \\
\hline $\begin{array}{l}330 \\
\text { IM } 161\end{array}$ & $\mathrm{P}^{1,4,17(20)_{\mathrm{ol}}}{ }_{11 \beta, 21} \mathrm{on}_{3}$ & $\begin{array}{c}10 \\
0.5\end{array}$ & $\begin{array}{l}3 \\
0\end{array}$ & 3 & $\begin{array}{l}\mathbf{0 . 3} \\
0\end{array}$ \\
\hline $\begin{array}{l}331 \\
\text { IM } 228\end{array}$ & $\mathrm{P}^{1,4,17(20) \mathrm{ol}_{11 \beta} * \mathrm{II}^{\prime \prime}{ }_{21} \mathrm{On}_{3}}$ & 10 & 0 & 0.5 & 0.025 \\
\hline $\begin{array}{l}332 \\
\text { IM } 231\end{array}$ & $\mathrm{P}^{1,4,17(20) \mathrm{ol}_{11 \beta, 16 \alpha}}{ }^{*} \mathrm{II}_{21}^{\prime \prime} \mathrm{on}_{3}$ & 10 & 3 & 2 & 0.25 \\
\hline $\begin{array}{l}333 \\
\text { IM } 329\end{array}$ & $\mathbf{P}^{5,17(20), 20 * I I^{\prime \prime}}{ }_{3 \beta, 21}$ & 10 & 0 & 0 & 0 \\
\hline $\begin{array}{l}\mathbf{3 3 4} \\
\text { IM } 330\end{array}$ & 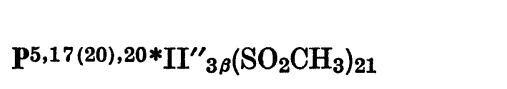 & 10 & 1 & 0 & 0.05 \\
\hline $\begin{array}{l}335 \\
\text { IM } 212\end{array}$ & $P 5 \alpha I_{6 \beta} \mathrm{Ol}_{5,11 \alpha} \mathrm{on}_{3,20}$ & $\begin{array}{l}10 \\
0.5\end{array}$ & $\begin{array}{l}3 \\
0\end{array}$ & $\begin{array}{l}3 \\
0\end{array}$ & $\begin{array}{l}\mathbf{0 . 3} \\
0\end{array}$ \\
\hline $\begin{array}{l}336 \\
\text { IM } 233\end{array}$ & $\mathrm{P} 5 \alpha \mathrm{I}_{6 \beta} \mathrm{ol}_{5,11 \beta, 17} * \mathrm{II}^{\prime \prime}{ }_{21} \mathrm{On}_{3,20}$ & 10 & 0 & 1.5 & 0.075 \\
\hline $\begin{array}{l}337 \\
\text { IM } 262\end{array}$ & $P 5 \alpha I_{16 \alpha} \mathrm{Ol}_{17} * \mathrm{II}_{21}^{\prime \prime} \mathrm{On}_{3,20}$ & 10 & 0 & 0 & 0 \\
\hline $\begin{array}{l}338 \\
\text { IM } 266\end{array}$ & $\mathrm{P} 5 \alpha \mathrm{I}_{16 \beta} \mathrm{Ol}_{3 \beta} \mathrm{On}_{20}$ & 10 & 0 & 0 & 0 \\
\hline $\begin{array}{l}339 \\
\text { IM } 259\end{array}$ & $P 5 \alpha I_{16 \beta} \mathrm{ol}_{11 \alpha, 17} * \mathrm{II}_{21}^{\prime \prime} \mathrm{on}_{3,20}$ & $\begin{array}{l}10 \\
0.5\end{array}$ & $\begin{array}{l}3 \\
-\end{array}$ & $\begin{array}{l}3 \\
0.5\end{array}$ & $\begin{array}{l}0.3 \\
1\end{array}$ \\
\hline $\begin{array}{l}340 \\
\text { IM } 258\end{array}$ & $\mathrm{P} 5 \alpha \mathrm{I}_{16 \beta} \mathrm{Ol}_{17} * \mathrm{II}^{\prime \prime}{ }_{21} \mathrm{On}_{3,11,20}$ & $\begin{array}{c}10 \\
0.5\end{array}$ & 2 & $\begin{array}{c}3 \\
0\end{array}$ & $\begin{array}{l}0.25 \\
0\end{array}$ \\
\hline $\begin{array}{l}341 \\
\text { IM } 267\end{array}$ & $\mathrm{P} 5 \alpha \mathrm{I}_{16 \beta} \mathrm{Ol}_{3 \beta, 11 \alpha} \mathrm{On}_{20} \theta_{16 \alpha-17}$ & $\begin{array}{c}10 \\
0.5\end{array}$ & $\begin{array}{l}3 \\
0\end{array}$ & $\begin{array}{l}3 \\
0.5\end{array}$ & $\begin{array}{l}0.3 \\
0.5\end{array}$ \\
\hline $\begin{array}{l}342 \\
\text { IM } 431\end{array}$ & $\mathrm{P} 5 \alpha \mathrm{CN}_{5} * \mathrm{II}^{\prime \prime}{ }_{17} \mathrm{On}_{3,20}$ & 0.5 & 0 & 0 & 0 \\
\hline
\end{tabular}


Table 135 B (continued)

\begin{tabular}{|c|c|c|c|c|c|}
\hline Group & SSS Name & $\begin{array}{l}\text { Dose } \\
\text { (mg) }\end{array}$ & $\begin{array}{l}\text { Digi- } \\
\text { toxin }^{a}\end{array}$ & $\begin{array}{l}\text { Indo- } \\
\text { methacin }\end{array}$ & $\begin{array}{l}\text { Activity } \\
\text { index } \mathbf{b}\end{array}$ \\
\hline $\begin{array}{l}343 \\
\text { IM } 449\end{array}$ & $\mathrm{P}_{5} \alpha \mathrm{CN}_{6 \beta} \mathrm{Ol}_{3 \beta, 5} \mathrm{On}_{20}$ & 0.5 & 0 & 0 & 0 \\
\hline $\begin{array}{l}\mathbf{3 4 4} \\
\text { IM } 307\end{array}$ & $\mathrm{P} 5 \alpha\left(\mathrm{CH}_{2}\right)_{16} \mathrm{Ol}_{17} * \mathrm{II}^{\prime \prime}{ }_{3 \beta} \mathrm{On}_{11,20}$ & 10 & 0.5 & 0 & 0.025 \\
\hline $\begin{array}{l}345 \\
\text { IM } 496\end{array}$ & $P 5 \alpha I^{\prime \prime}{ }_{21,21} \mathrm{ol}_{3 \beta}$ & 0.5 & 0 & 0 & 0 \\
\hline $\begin{array}{l}346 \\
\text { IM } 366\end{array}$ & $\mathrm{P}_{5} \alpha^{2} \mathrm{CN}_{3} \theta \theta \mathrm{II}_{20}$ & $\begin{array}{l}10 \\
0.5 \\
0.03\end{array}$ & $\begin{array}{l}0.5 \\
0 \\
-\end{array}$ & $\begin{array}{l}2 \\
2 \\
0\end{array}$ & $\begin{array}{l}0.125 \\
2.0 \\
0\end{array}$ \\
\hline $\begin{array}{l}\text { 347 } \\
\text { IM } 552 \\
348\end{array}$ & 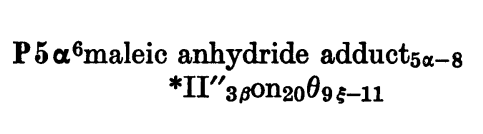 & 0.5 & 0 & 0 & 0 \\
\hline $\begin{array}{l}\text { IM } 402 \\
349\end{array}$ & $\mathrm{P} 5 \alpha^{20 \prime} \mathrm{CN}_{21} \mathrm{O} \mathrm{l}_{3 \beta} * \mathrm{II}_{21}$ & 0.5 & 0 & 0 & 0 \\
\hline $\begin{array}{l}\text { IM } 553 \\
\mathbf{3 5 0}\end{array}$ & $\begin{array}{l}\text { P5 } \alpha^{6,9(11)} \text { maleic anhydride } \\
\text { adduct }{ }_{5 \alpha-8}{ }^{*} \mathrm{II}^{\prime \prime}{ }_{3 \beta} \mathrm{On}_{20}\end{array}$ & 0.5 & 0 & 0 & 0 \\
\hline $\begin{array}{l}\text { IM } 28 \\
\mathbf{3 5 1}\end{array}$ & $\begin{array}{l}\text { P5 } \alpha^{6,9(11)} \text { maleic anhydrid } \\
\text { adduct }_{5 \alpha-8}{ }^{* I I^{\prime \prime}}{ }_{3 \beta, 21} \text { on }_{20}\end{array}$ & 10 & 0 & 0 & 0 \\
\hline IM 166 & $\mathrm{P}_{5} \boldsymbol{\beta} \mathrm{I}_{11 \alpha} \mathrm{On}_{3,20}$ & 10 & 0 & 1 & 0.05 \\
\hline $\begin{array}{l}\mathbf{3 5 2} \\
\text { IM } 227\end{array}$ & P5 $\beta \mathrm{I}_{11 \alpha} \mathrm{Ol}_{11} \mathrm{NOH}_{3,20} \cdot \mathrm{H}_{2} \mathrm{O}$ & $\begin{array}{l}10 \\
0.5\end{array}$ & $\begin{array}{l}3 \\
0\end{array}$ & 3 & $\begin{array}{l}\mathbf{0 . 3} \\
0\end{array}$ \\
\hline $\begin{array}{l}353 \\
\text { IM } 545\end{array}$ & $\mathrm{P5} \beta \mathrm{I}^{\prime \prime}{ }_{20} * \mathrm{II}^{\prime \prime}{ }_{3 \alpha}$ & 0.5 & 0 & 0 & 0 \\
\hline $\begin{array}{l}354 \\
\text { IM } 544\end{array}$ & P5 $\beta \mathrm{Ial}_{20} * \mathrm{II}_{3 \alpha}$ & 0.5 & 0 & 0 & 0 \\
\hline $\begin{array}{l}355 \\
\text { IM } 436\end{array}$ & $\mathrm{P} 5 \beta\left(\mathrm{CONH}_{2}\right)_{16 \alpha} \mathrm{Ol}_{3 \alpha} \mathrm{On}_{11,20}$ & 0.5 & 0 & 0 & 0 \\
\hline $\begin{array}{l}356 \\
\text { IM } 418\end{array}$ & $\mathrm{P} 5 \beta \mathrm{CN}_{16 \alpha} * \mathrm{II}^{\prime \prime}{ }_{3 \beta} \mathrm{O} \mathrm{n}_{11,20}$ & $\begin{array}{l}0.5 \\
0.1 \\
0.03 \\
0.015\end{array}$ & $\begin{array}{l}2.5 \\
2.5 \\
0 \\
0\end{array}$ & $\begin{array}{l}2 \\
2 \\
1.5 \\
1.5\end{array}$ & $\begin{array}{r}4.5 \\
22.5 \\
25.0 \\
50.0\end{array}$ \\
\hline $\begin{array}{l}\mathbf{3 5 7} \\
\text { IM } 383\end{array}$ & $\mathrm{P} 5 \beta \mathrm{CN}_{20} \mathrm{Ol}_{20 \xi} * \mathrm{II}^{\prime \prime}{ }_{3 \alpha}$ & 0.5 & 0 & 0 & 0 \\
\hline $\begin{array}{l}\text { 358 } \\
\text { IM } 388\end{array}$ & $\mathrm{P} 5 \beta \mathrm{CN}_{20} \mathrm{Ol}_{20 \xi} * \mathrm{II}^{\prime \prime}{ }_{3 \beta, 21}$ & 0.5 & 0 & 0 & 0 \\
\hline $\begin{array}{l}\text { 359 } \\
\text { IM } 403\end{array}$ & $\mathrm{P} 5 \beta \mathrm{CN}_{20 \mathrm{O}_{20 \xi}} * \mathrm{II}^{\prime \prime}{ }_{3 \alpha} \mathrm{On}_{11}$ & 0.5 & 0 & 0 & 0 \\
\hline $\begin{array}{l}360 \\
\text { IM } 398\end{array}$ & $\mathrm{P} 5 \boldsymbol{\beta}^{\prime \prime}{ }_{21} \mathrm{CN}_{20} \mathrm{ol}{ }_{3 \alpha}$ & 0.5 & 0 & 0 & 0 \\
\hline $\begin{array}{l}361 \\
\text { IM } 399\end{array}$ & $\mathrm{P} 5 \beta \mathrm{CN}_{21} \mathrm{ICN}_{20} * \mathrm{II}^{\prime \prime}{ }_{3 \alpha}$ & 0.5 & 0 & 0 & 0 \\
\hline
\end{tabular}


Table 135 B (continued)

\begin{tabular}{|c|c|c|c|c|c|}
\hline Group & SSS Name & $\begin{array}{l}\text { Dose } \\
\text { (mg) }\end{array}$ & $\begin{array}{l}\text { Digi- } \\
\text { toxin }^{a}\end{array}$ & $\begin{array}{l}\text { Indo- } \\
\text { methacin a }\end{array}$ & $\begin{array}{l}\text { Activity } \\
\text { index }^{\mathrm{b}}\end{array}$ \\
\hline $\begin{array}{l}362 \\
\text { IM } 367\end{array}$ & $\mathbf{P} 5 \boldsymbol{\beta}^{2} \mathbf{C N}_{3} \theta \theta \mathrm{II}_{20}$ & 10 & 0 & 0 & 0 \\
\hline $\begin{array}{l}363 \\
\text { IM } 394\end{array}$ & $P 5 \beta^{17(20)} \mathrm{CN}_{20} * \mathrm{II}^{\prime \prime}{ }_{3 \alpha} \mathrm{On}_{11}$ & 0.5 & 0.5 & 1.5 & $\mathbf{2 . 0}$ \\
\hline $\begin{array}{l}364 \\
\text { IM } 371\end{array}$ & $\mathrm{P} 5 \beta^{17(20)^{\prime \prime}} \mathrm{CN}_{20} * \mathrm{II}^{\prime \prime}{ }_{3 \alpha} * \mathrm{IIol}_{21}$ & 0.5 & 0 & 0 & 0 \\
\hline $\begin{array}{l}365 \\
\text { IM } 405\end{array}$ & $P 5 \beta^{17(20) "}{ }_{21} \mathrm{CN}_{20} \mathrm{ol}_{3 \alpha} \mathrm{On}_{11}$ & 0.5 & 0 & 0 & 0 \\
\hline $\begin{array}{l}366 \\
\text { IM } 408\end{array}$ & $\mathrm{P} 5 \beta^{17(20) \prime \prime} \mathrm{CN}_{20} * \mathrm{II}^{\prime \prime}{ }_{3 \alpha} * \mathrm{II}_{21} \mathrm{on}_{11}$ & 0.5 & 0 & 0 & 0 \\
\hline $\begin{array}{l}367 \\
\text { IM } 499\end{array}$ & $\mathrm{P}_{5} \beta^{20 \mathrm{I}^{\prime \prime}}{ }_{21} \mathrm{ol}_{3 \alpha, 17} \mathrm{Ol}_{3 \alpha, 17 \alpha} \mathrm{On}_{11}$ & 0.5 & 0 & 0 & 0 \\
\hline $\begin{array}{l}368 \\
\text { IM } 370\end{array}$ & $\mathrm{P} 5 \beta^{20 \prime \prime} \mathrm{CN}_{21} \mathrm{ol}_{3 \alpha} * \mathrm{II}_{21}$ & 0.5 & 0 & 0 & 0 \\
\hline $\begin{array}{l}369 \\
\text { IM } 158\end{array}$ & $\begin{array}{l}\mathbf{P}^{4} \mathbf{I}_{2 \alpha} \mathrm{ol}_{11 \beta, 17} * \mathrm{II}^{\prime \prime}{ }_{21} \mathrm{on}_{3,20} \\
\text { (Methylcortisol acetate) }\end{array}$ & 10 & 3 & 2.5 & 0.275 \\
\hline $\begin{array}{l}370 \\
\text { IM } 51 / \mathrm{h}\end{array}$ & $\mathbf{P}^{4} \mathbf{I}_{2 \alpha} \mathrm{Ol}_{17} * \mathrm{II}^{\prime \prime}{ }_{21} \mathrm{on}_{3,20} \theta_{9 \beta-11}$ & $\begin{array}{c}10 \\
0.5\end{array}$ & $\begin{array}{l}3 \\
0\end{array}$ & $\begin{array}{l}3 \\
1.5\end{array}$ & $\begin{array}{l}0.3 \\
1.5\end{array}$ \\
\hline $\begin{array}{l}371 \\
\operatorname{IM} 51 / \mathrm{j}\end{array}$ & $\mathbf{P}^{4} \mathbf{I}_{2 \alpha} \mathrm{Ol}_{11 \beta, 17} * \mathrm{II}^{\prime \prime}{ }_{21} \mathrm{On}_{3,20} \mathrm{Cl}_{9 \alpha}$ & 10 & 0 & 1.5 & 0.075 \\
\hline $\begin{array}{l}372 \\
\text { IM } 51 / f\end{array}$ & $\mathbf{P}^{4} \mathbf{I}_{6 \alpha} \mathrm{on}_{3,11,20}$ & $\begin{array}{c}10 \\
0.5\end{array}$ & $\begin{array}{l}3 \\
0\end{array}$ & $\begin{array}{l}3 \\
0\end{array}$ & $\begin{array}{l}0.3 \\
0\end{array}$ \\
\hline $\begin{array}{l}373 \\
\text { IM } 51 / c\end{array}$ & $\mathbf{P}^{4} \mathbf{I}_{6 \alpha} \mathrm{Ol}_{11 \beta} \mathrm{On}_{3,20}$ & $\begin{array}{c}10 \\
0.5\end{array}$ & $\begin{array}{l}3 \\
0\end{array}$ & 3 & $\begin{array}{l}\mathbf{0 . 3} \\
0\end{array}$ \\
\hline $\begin{array}{l}374 \\
\text { IM } 220\end{array}$ & $\mathbf{P}^{4} \mathbf{I}_{6 \alpha} \mathrm{Ol}_{17} \mathrm{on}_{3,20}$ & $\begin{array}{c}10 \\
0.5\end{array}$ & $\begin{array}{l}3 \\
0.5\end{array}$ & 3 & $\begin{array}{l}0.3 \\
1\end{array}$ \\
\hline $\begin{array}{l}375 \\
\text { IM } 219\end{array}$ & $\mathbf{P}^{4} \mathbf{I}_{6 \alpha} * \mathrm{II}^{\prime \prime}{ }_{17} \mathrm{On}_{3,20}$ & $\begin{array}{c}10 \\
0.5\end{array}$ & $\begin{array}{l}3 \\
0\end{array}$ & 3 & $\begin{array}{l}\mathbf{0 . 3} \\
0\end{array}$ \\
\hline $\begin{array}{l}376 \\
\text { IM } 51 / i\end{array}$ & $\mathbf{P}^{4} \mathbf{I}_{6 \alpha} \mathrm{ol}_{11 \beta, 17} \mathrm{On}_{3,20}$ & $\begin{array}{c}10 \\
0.5\end{array}$ & $\begin{array}{l}3 \\
0\end{array}$ & 3 & $\begin{array}{l}0.3 \\
0\end{array}$ \\
\hline $\begin{array}{l}377 \\
\text { IM } 242\end{array}$ & $\mathbf{P}^{4} \mathbf{I}_{6 \alpha} \mathrm{ol}_{11 \beta, 17,21} \mathrm{on}_{3,20}$ (Methylcortisol) & 10 & 3 & 0 & 0.15 \\
\hline $\begin{array}{l}378 \\
\text { IM } 209\end{array}$ & $\begin{array}{l}\mathbf{P}_{4}^{4} \mathbf{I}_{6 \alpha} \mathrm{Ol}_{11 \beta, 17} * \mathrm{III}_{21}^{\prime \mathrm{On}_{3,20}} \\
\text { (Methylcortisol acetate) }\end{array}$ & 10 & 2 & 0.5 & 0.125 \\
\hline $\begin{array}{l}379 \\
\text { IM } 546\end{array}$ & $\mathbf{P}^{4} \mathbf{I}_{0} \mathbf{l}_{20} \mathrm{On}_{3}$ & 0.5 & 0 & 0 & 0 \\
\hline $\begin{array}{l}380 \\
\text { IM } 416\end{array}$ & $\mathbf{P}^{4} \mathbf{I}^{\prime \prime}{ }_{16 \alpha /{ }^{*} \mathrm{IO}_{3,20}}$ & 0.5 & 0 & 0 & 0 \\
\hline $\begin{array}{l}381 \\
\text { IM } 155\end{array}$ & $\mathbf{P}^{4} \mathbf{I a l}_{20 \beta} \mathrm{On}_{3}$ & 10 & 0.5 & 0 & 0.025 \\
\hline
\end{tabular}


Table 135 B (continued)

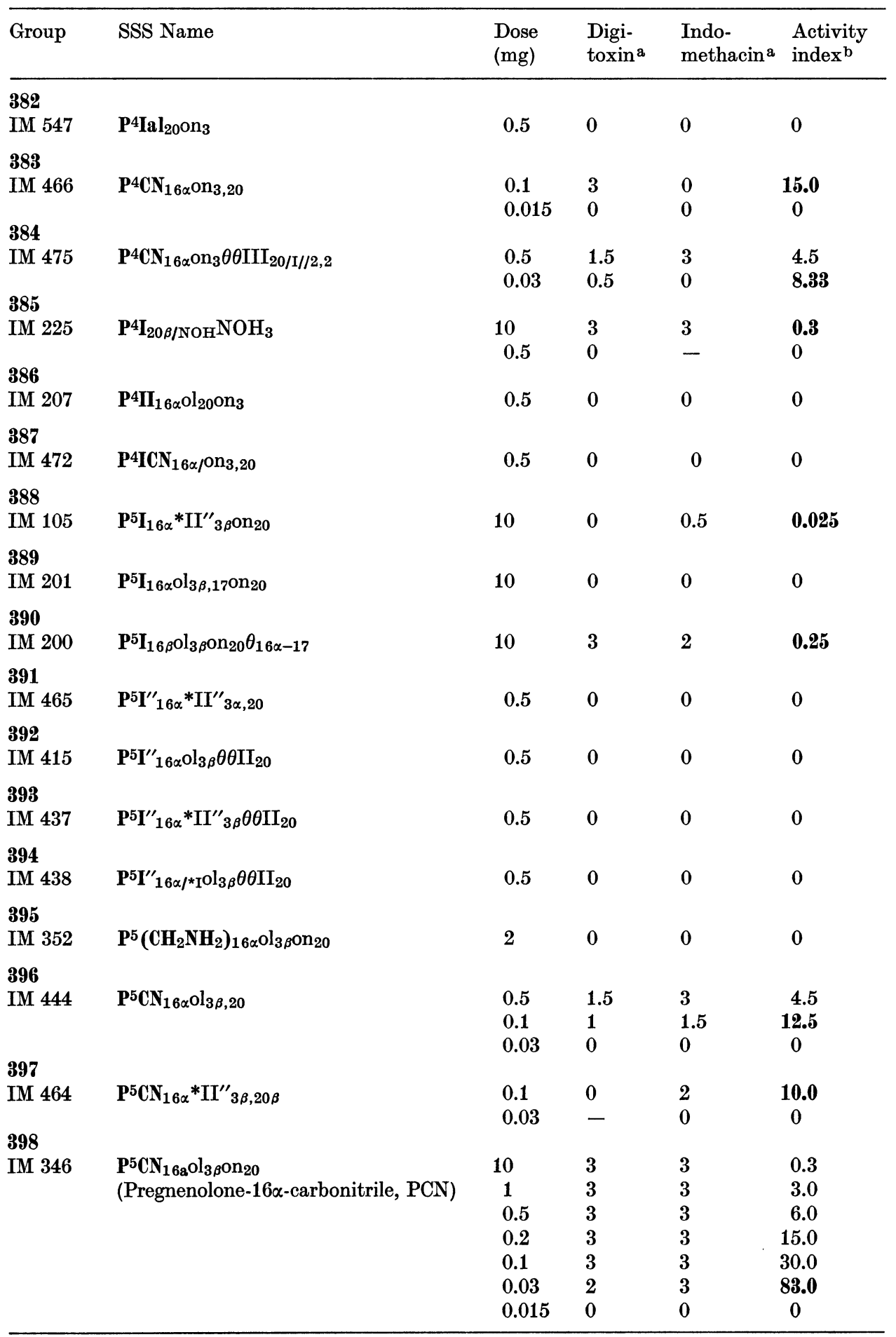


Table 135B (continued)

\begin{tabular}{|c|c|c|c|c|c|}
\hline Group & SSS Name & $\begin{array}{l}\text { Dose } \\
\text { (mg) }\end{array}$ & $\begin{array}{l}\text { Digi- } \\
\text { toxin }^{a}\end{array}$ & $\begin{array}{l}\text { Indo- } \\
\text { methacin }{ }^{a}\end{array}$ & $\begin{array}{l}\text { Activity } \\
\text { index }^{b}\end{array}$ \\
\hline \multicolumn{6}{|l|}{399} \\
\hline \multirow[t]{4}{*}{ IM 413} & $\mathrm{P}^{5} \mathrm{CN}_{16 \alpha}{ }^{*} \mathrm{II}^{\prime \prime}{ }_{3 \beta} \mathrm{On}_{20}$ & 0.5 & 2.5 & 2 & 4.5 \\
\hline & & 0.1 & 0.5 & 2 & 12.5 \\
\hline & & 0.03 & 1 & 1.5 & 41.67 \\
\hline & & 0.015 & 0 & $\mathbf{0}$ & 0 \\
\hline \multicolumn{6}{|l|}{400} \\
\hline \multirow[t]{3}{*}{ IM 479} & $\mathrm{P}^{5} \mathrm{CN}_{16 \alpha} * \mathrm{VII}^{\prime \prime}{ }_{3 \beta} \mathrm{On}_{20}$ & 0.5 & 3 & 3 & 6.0 \\
\hline & & 0.03 & 1 & 1.5 & 41.67 \\
\hline & & 0.015 & 0 & 0 & 0 \\
\hline \multicolumn{6}{|l|}{401} \\
\hline \multirow[t]{4}{*}{ IM 476} & $\mathrm{P}^{5} \mathrm{CN}_{16 \alpha}{ }^{*} \mathrm{suc}^{\prime \prime} \mathrm{Na}_{3 \beta} \mathrm{On}_{20}$ & 0.5 & 3 & 3 & 6.0 \\
\hline & (PCN sodium hemisuccinate) & 0.03 & 2.5 & 3 & 91.67 \\
\hline & & 0.015 & 2 & 1.5 & 116.67 \\
\hline & & 0.005 & 0 & 2 & 00.0 \\
\hline \multicolumn{6}{|l|}{402} \\
\hline \multirow[t]{2}{*}{ IM 478} & $\mathrm{P}^{5} \mathrm{CN}_{16 \alpha}{ }^{*}$ adamantoate ${ }_{3 \beta} \mathrm{On}_{20}$ & 0.5 & 0.5 & 3 & 3.5 \\
\hline & & 0.03 & - & 0 & 0 \\
\hline \multicolumn{6}{|l|}{403} \\
\hline \multirow[t]{3}{*}{ IM 483} & $\mathrm{P}^{5} \mathrm{CN}_{16 \alpha}{ }^{*} \mathrm{~S}^{\prime \prime}\left(\mathrm{NH}_{4}\right)_{3 \beta} \mathrm{On}_{20}$ & 0.5 & 3 & 3 & 6.0 \\
\hline & (PCN ammonium sulfate) & 0.03 & 3 & 3 & 100.0 \\
\hline & & 0.015 & 1 & 0.5 & 50.0 \\
\hline \multicolumn{6}{|l|}{404} \\
\hline \multirow[t]{2}{*}{ IM 423} & $\mathrm{P}^{5} \mathrm{CN}_{16 \alpha} \mathrm{Ol}_{3 \beta} \mathrm{On}_{7,20}$ & 0.5 & 3 & 1.5 & 4.5 \\
\hline & & 0.03 & 0 & 0.5 & 8.33 \\
\hline 405 & & 0.5 & $\mathbf{3}$ & 2 & 5.0 \\
\hline IM 429 & $\mathrm{P}^{5} \mathrm{CN}_{16 \alpha} * \mathrm{II}^{\prime \prime}{ }_{3 \beta} \mathrm{On}_{7,20}$ & 0.03 & 0 & 1.5 & $\mathbf{2 5 . 0}$ \\
\hline \multicolumn{6}{|l|}{406} \\
\hline \multirow[t]{4}{*}{ IM 411} & $\mathrm{P}^{5} \mathrm{CN}_{16 \alpha} \mathrm{On}_{11,20} \theta \theta \mathrm{II}_{3}$ & 0.5 & 2.5 & 2 & 4.5 \\
\hline & & 0.1 & 2.5 & 2 & 22.5 \\
\hline & & 0.03 & 0 & 1.5 & 25.0 \\
\hline & & 0.015 & 0 & 15 & $\mathbf{5 0 . 0}$ \\
\hline \multicolumn{6}{|l|}{407} \\
\hline \multirow[t]{4}{*}{ IM 414} & $\mathbf{P}^{5} \mathbf{C N}_{16 \alpha} \mathrm{Ol}_{3 \beta} \theta \theta \mathrm{II}_{20}$ & 0.5 & 2.5 & 2 & 4.5 \\
\hline & & 0.1 & 2 & 2 & 20.0 \\
\hline & & 0.03 & 0.5 & 1.5 & 33.3 \\
\hline & & 0.015 & 0 & 0 & 0 \\
\hline \multicolumn{6}{|l|}{408} \\
\hline \multirow[t]{4}{*}{ IM 412} & $\mathrm{P}^{5} \mathrm{CN}_{16 \alpha} \mathrm{On}_{11} \theta \theta \mathrm{II}_{3,20}$ & 0.5 & 2.5 & 2 & 4.5 \\
\hline & & 0.1 & 0 & $\overline{2}$ & 10.0 \\
\hline & & 0.03 & 0 & 1.5 & $\mathbf{2 5 . 0}$ \\
\hline & & 0.015 & 0 & 0 & 0 \\
\hline \multicolumn{6}{|l|}{409} \\
\hline \multirow[t]{3}{*}{ IM 461} & $\mathrm{P}^{5} \mathrm{CN}_{16 \alpha} \mathrm{Ol}_{3 \beta} \theta \theta \mathrm{III}_{20 / \mathrm{I} / / 2,2}$ & 0.5 & 2 & 3 & 5.0 \\
\hline & & 0.03 & 2 & 0 & 33.3 \\
\hline & & 0.015 & 0 & - & 0 \\
\hline \multicolumn{6}{|l|}{410} \\
\hline IM 445 & $\mathrm{P}^{5} \mathrm{CN}_{16 \alpha}{ }^{*} \mathrm{II}^{\prime \prime}{ }_{3 \beta} \theta \theta \mathrm{II}_{20}$ & 0.5 & 1.5 & 3 & 4.5 \\
\hline & & 0.1 & 0 & 1.5 & 7.5 \\
\hline & & 0.03 & 0 & 0 & 0 \\
\hline
\end{tabular}


Table 135 B (continued)

\begin{tabular}{|c|c|c|c|c|c|}
\hline Group & SSS Name & $\begin{array}{l}\text { Dose } \\
(\mathrm{mg})\end{array}$ & $\begin{array}{l}\text { Digi- } \\
\text { toxina }\end{array}$ & $\begin{array}{l}\text { Indo- } \\
\text { methacin }{ }^{a}\end{array}$ & $\begin{array}{l}\text { Activity } \\
\text { index }^{b}\end{array}$ \\
\hline $\begin{array}{l}411 \\
\text { IM } 482\end{array}$ & $\mathrm{P}^{5} \mathrm{CN}_{16 \alpha} \mathrm{Ol}_{3 \beta}\left(\mathrm{NOCH}_{3}\right)_{20}$ & $\begin{array}{l}0.5 \\
0.03 \\
0.015\end{array}$ & $\begin{array}{l}1 \\
1.5 \\
0\end{array}$ & $\begin{array}{l}1.5 \\
0 \\
-\end{array}$ & $\begin{array}{r}2.5 \\
25.0 \\
0\end{array}$ \\
\hline $\begin{array}{l}412 \\
\text { IM } 462\end{array}$ & $\mathrm{P}^{5} \mathrm{CN}_{16 \alpha} \mathrm{Ol}_{3 \beta} \mathrm{NOH}_{20}$ & $\begin{array}{l}0.5 \\
0.03 \\
0.015 \\
0.010\end{array}$ & $\begin{array}{l}3 \\
2.5 \\
0.5 \\
-\end{array}$ & $\begin{array}{l}3 \\
3 \\
1 \\
0\end{array}$ & $\begin{array}{c}6.0 \\
91.67 \\
50.0 \\
0\end{array}$ \\
\hline $\begin{array}{l}413 \\
\text { IM } 404\end{array}$ & $\mathrm{P}^{5}{ }^{\prime \prime} \mathrm{CN}_{20} * \mathrm{II}^{\prime \prime}{ }_{3 \beta} * \mathrm{II}_{21}$ & 0.5 & 0 & 0 & 0 \\
\hline $\begin{array}{l}414 \\
\text { IM } 474\end{array}$ & $\mathrm{P}^{5} \mathrm{I}_{4,4} \mathrm{CN}_{16 \alpha} \mathrm{on}_{3,20}$ & $\begin{array}{l}0.5 \\
0.03\end{array}$ & $\begin{array}{l}0.5 \\
-\end{array}$ & $\begin{array}{l}3 \\
0\end{array}$ & $\begin{array}{l}3.5 \\
0\end{array}$ \\
\hline $\begin{array}{l}\text { 415 } \\
\text { IM } 481\end{array}$ & $\mathrm{P}^{5} \mathrm{I}_{4,4} \mathrm{CN}_{16 \alpha} \mathrm{On}_{3} \theta \theta \mathrm{III} \mathrm{I}_{20 / \mathrm{I} / / 2,2}$ & 0.5 & 0 & 0 & 0 \\
\hline $\begin{array}{l}416 \\
\text { IM } 71\end{array}$ & $\mathrm{P}^{5} \mathrm{II}_{16 \alpha} \mathrm{Ol}_{3 \beta} \mathrm{On}_{20}$ & 0.5 & 0 & 0 & 0 \\
\hline $\begin{array}{l}417 \\
\text { IM } 469\end{array}$ & $\mathrm{P}^{5} \mathrm{ICN}_{16 \alpha} \mathrm{Ol}_{3 \beta} \mathrm{On}_{20}$ & 0.5 & 0 & 0 & 0 \\
\hline $\begin{array}{l}418 \\
\text { IM } 409\end{array}$ & 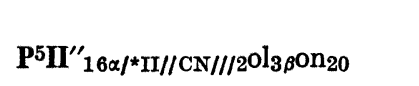 & 10 & 0 & 0 & 0 \\
\hline $\begin{array}{l}\mathbf{4 1 9} \\
\text { IM } 210\end{array}$ & $\mathrm{P}^{5} \mathrm{III}_{16 \alpha / \mathrm{I} / / 2} \mathrm{Ol}_{3 \beta} \mathrm{On}_{20}$ & 0.5 & 0 & 0 & 0 \\
\hline $\begin{array}{l}420 \\
\text { IM } 467\end{array}$ & $\mathrm{P}^{5} \mathrm{I}^{\prime \prime} \operatorname{lac}_{16 \beta-20} * \mathrm{II}_{3 \beta}^{\prime \prime}$ & 0.5 & 0 & 0 & 0 \\
\hline $\begin{array}{l}421 \\
\text { IM } 52 \\
422\end{array}$ & $\begin{array}{l}\mathbf{P 1}^{1,4} \mathbf{I}_{6 \alpha} \mathrm{ol}_{11 \beta, 17,21} \text { on }_{3,20} \\
\text { (Methylprednisolone) }\end{array}$ & $\begin{array}{c}10 \\
0.5\end{array}$ & $\begin{array}{l}\mathbf{3} \\
\mathbf{0}\end{array}$ & $\begin{array}{l}3 \\
\mathbf{0}\end{array}$ & $\begin{array}{l}0.3 \\
0\end{array}$ \\
\hline $\begin{array}{l}422 \\
\text { IM } 52 / a\end{array}$ & $\begin{array}{l}\mathbf{P 1}^{1,4} \mathbf{I}_{6 \alpha} \mathrm{ol}_{11 \beta, 17^{*}} \mathrm{II}^{\prime \prime}{ }_{21} \mathrm{On}_{3,20} \\
\text { (Methylprednisolone acetate) }\end{array}$ & $\begin{array}{l}10 \\
0.5\end{array}$ & $\begin{array}{l}\mathbf{3} \\
\mathbf{1}\end{array}$ & 2 & $\begin{array}{l}0.25 \\
2.0\end{array}$ \\
\hline IM 221 & $\mathbf{P 1 , 4} \mathbf{I}_{6 \alpha} \mathrm{ol}_{11 \beta, 17}{ } \mathrm{suc}^{\prime} \mathrm{Na}_{21} \mathrm{on}_{3,20}$ & $\begin{array}{l}10 \\
0.5\end{array}$ & $\begin{array}{l}3 \\
0\end{array}$ & 1.5 & $\begin{array}{l}0.225 \\
0\end{array}$ \\
\hline $\begin{array}{l}424 \\
\text { IM } 218\end{array}$ & $\mathbf{P}^{1,4} \mathbf{I}_{6 \alpha} \mathrm{Ol}_{11 \beta, 17} \mathrm{on}_{3,20} \mathrm{~F}_{9 \alpha}$ & 10 & 2 & 0 & 0.1 \\
\hline $\begin{array}{l}425 \\
\operatorname{IM} 51 / \mathrm{e} \\
426\end{array}$ & $\mathrm{P}^{1,4} \mathbf{I}_{6 \alpha} \mathrm{Ol}_{11 \beta, 17} \mathrm{On}_{3,20} \mathrm{~F}_{9 \alpha, 21}$ & 10 & 1.5 & - & 0.15 \\
\hline IM 345 & $\begin{array}{l}\mathrm{P}_{1,4} \mathrm{I}_{16 \alpha} \mathrm{Ol}_{11 \beta, 17} * \mathrm{II}^{\prime \prime}{ }_{21} \mathrm{on}_{3,20} \mathrm{~F}_{6 \alpha} \\
\text { (Methylprednisolone) }\end{array}$ & 10 & 0.5 & 1.5 & 0.1 \\
\hline $\begin{array}{l}427 \\
\text { IM } 152\end{array}$ & $\begin{array}{l}\mathrm{P}_{1,4} \mathrm{I}_{16 \alpha} \mathrm{ol}_{11 \beta, 17} * \mathrm{II}^{\prime \prime}{ }_{21} \mathrm{on}_{3,20} \mathrm{~F}_{9 \alpha} \\
\text { (Dexamethasone acetate) }\end{array}$ & $\begin{array}{l}10 \\
1 \\
0.5 \\
0.1 \\
0.03 \\
0.015\end{array}$ & $\begin{array}{l}3 \\
3 \\
2.5 \\
3 \\
3 \\
0\end{array}$ & $\begin{array}{l}0 \\
1.5 \\
0.5 \\
1 \\
0 \\
-\end{array}$ & $\begin{array}{c}0.15 \\
2.25 \\
3.0 \\
20.0 \\
50.0 \\
0\end{array}$ \\
\hline
\end{tabular}


Table 135 B (continued)

\begin{tabular}{|c|c|c|c|c|c|}
\hline Group & SSS Name & $\begin{array}{l}\text { Dose } \\
(\mathrm{mg})\end{array}$ & $\begin{array}{l}\text { Digi- } \\
\text { toxin }^{\text {a }}\end{array}$ & $\begin{array}{l}\text { Indo- } \\
\text { methacin a }\end{array}$ & $\begin{array}{l}\text { Activity } \\
\text { index }\end{array}$ \\
\hline $\begin{array}{l}428 \\
\text { IM } 527\end{array}$ & 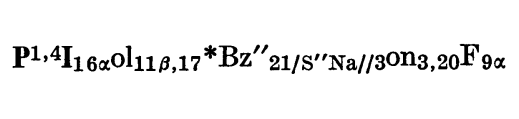 & $\begin{array}{l}0.5 \\
0.03\end{array}$ & $\underline{0}$ & $\begin{array}{l}1.5 \\
0\end{array}$ & $\begin{array}{l}1.5 \\
0\end{array}$ \\
\hline $\begin{array}{l}429 \\
\text { IM } 151\end{array}$ & $\begin{array}{l}\mathbf{P}^{1,4} \mathbf{I}_{16 \beta} \mathrm{ol}_{11 \beta, 17} * \mathrm{II}^{\prime \prime}{ }_{21} \mathrm{On}_{3,20} \mathrm{~F}_{9 \alpha} \\
\text { (Betamethasone acetate) }\end{array}$ & $\begin{array}{c}10 \\
2 \\
1 \\
0.5 \\
0.1\end{array}$ & $\begin{array}{l}2 \\
3 \\
2 \\
1.5 \\
0\end{array}$ & $\begin{array}{l}0 \\
3 \\
1.5 \\
1.5 \\
1\end{array}$ & $\begin{array}{l}0.1 \\
1.5 \\
1.75 \\
3.0 \\
5.0\end{array}$ \\
\hline $\begin{array}{l}430 \\
\text { IM } 95\end{array}$ & $\begin{array}{l}\mathbf{P 1 , 4} \mathbf{I}_{21} \mathrm{ol}_{11 \beta, 17} * \mathrm{II}^{\prime \prime}{ }_{21} \mathrm{on}_{3,20} \mathrm{~F}_{9 \alpha} \\
\text { (Fluperolone acetate) }\end{array}$ & $\begin{array}{c}10 \\
0.5\end{array}$ & $\begin{array}{l}3 \\
0\end{array}$ & 2 & $\begin{array}{l}0.25 \\
0\end{array}$ \\
\hline $\begin{array}{l}\text { 431 } \\
\text { IM } 289 \\
432\end{array}$ & $\begin{array}{l}\text { P3,5Ial }_{6} * \mathrm{III}_{21}^{\prime \prime} \text { on }_{20} \theta \mathrm{I}_{3 \beta} \text { methyl- } \\
\text { oxazolyl }{ }_{16 \alpha-17}\end{array}$ & $\begin{array}{c}10 \\
0.5\end{array}$ & 2 & $\begin{array}{l}3 \\
0\end{array}$ & $\begin{array}{l}0.25 \\
0\end{array}$ \\
\hline IM 459 & $\mathrm{P}^{3,5} \mathrm{CN}_{6} * \mathrm{II}^{\prime \prime}{ }_{16 \alpha} \mathrm{On}_{20} \theta \mathrm{I}_{3}$ & 0.5 & 0 & 0 & 0 \\
\hline $\begin{array}{l}433 \\
\text { IM } 458\end{array}$ & $\mathrm{P}^{3,5} \mathrm{CN}_{6} \mathrm{ol}_{11 \beta, 17 \alpha} * \mathrm{II}_{21}^{\prime \prime} \mathrm{On}_{20} \theta \mathrm{I}_{3}$ & 0.5 & 0 & 0 & 0 \\
\hline $\begin{array}{l}434 \\
\text { IM } 455\end{array}$ & $\begin{array}{l}\mathbf{P}^{3,5} \mathbf{C N}_{6} * \mathrm{II}^{\prime \prime}{ }_{21} \mathrm{on}_{11,20} \theta \mathrm{II}_{3 \beta / \mathrm{C} 1 / / 2} \\
\theta \theta \mathrm{I}_{16 \alpha-17 / \mathrm{I}, \mathrm{I}_{9 \alpha}}\end{array}$ & 0.5 & 0 & 1 & 1.0 \\
\hline $\begin{array}{l}435 \\
\text { IM } 456\end{array}$ & $\begin{array}{l}\mathbf{P}^{3,5} \mathbf{C N}_{6} \mathrm{ol}_{11 \beta} * \mathrm{III}^{\prime \prime}{ }_{21 / \mathrm{I} / 2,2} \mathrm{On}_{20} \theta \mathrm{II} \mathrm{I}_{3 / \mathrm{Cl} / / 2} \\
\theta \theta \mathrm{I}_{16 \alpha-17 / \mathrm{I}, \mathrm{I} \mathrm{F}_{9 \alpha}}\end{array}$ & 0.5 & 0 & 0 & 0 \\
\hline $\begin{array}{l}436 \\
\text { IM } 457\end{array}$ & $\begin{array}{l}\mathbf{P}^{3,5} \mathbf{C N}_{6} \mathrm{Ol}_{11 \beta}{ }^{*} \mathrm{II}^{\prime \prime}{ }_{21} \mathrm{on}_{20} \theta \mathrm{II}_{3 / \mathrm{Cl} / / 2} \\
\theta \theta \mathrm{I}_{16 \alpha-17 / \mathrm{I}, \mathrm{I} \mathrm{F}_{9 \alpha}}\end{array}$ & 0.5 & 0 & 0 & 0 \\
\hline $\begin{array}{l}\mathbf{4 3 7} \\
\text { IM } 470\end{array}$ & $\mathrm{P}^{3,5} \mathrm{CN}_{16 \alpha} \mathrm{On}_{7,20}$ & 0.1 & 0 & 0 & 0 \\
\hline $\begin{array}{l}438 \\
\text { IM } 471\end{array}$ & $\mathrm{P}^{3,5} \mathrm{CN}_{16 \alpha} \mathrm{Ol}_{3} \mathrm{On}_{7,20}$ & 0.1 & 0 & - & 0 \\
\hline $\begin{array}{l}439 \\
\text { IM } 167\end{array}$ & $\mathbf{P}^{4,6} \mathbf{I}_{17} * \mathrm{II}^{\prime \prime}{ }_{3 \beta} \mathrm{On}_{20} \mathrm{Cl}_{6}$ & $\begin{array}{c}10 \\
0.5\end{array}$ & 3 & $\begin{array}{l}3 \\
0\end{array}$ & $\begin{array}{l}0.3 \\
0\end{array}$ \\
\hline $\begin{array}{l}440 \\
\text { IM } 279\end{array}$ & $\begin{array}{l}\mathbf{P}^{4,6} \mathbf{I}_{1 \alpha-2} * \mathrm{II}^{\prime \prime}{ }_{17} \mathrm{On}_{3,20} \mathrm{Cl}_{6} \\
\text { (Cyproterone acetate) }\end{array}$ & $\begin{array}{c}10 \\
1 \\
0.5 \\
0.1\end{array}$ & $\begin{array}{l}3 \\
2.5 \\
2 \\
0\end{array}$ & $\begin{array}{l}3 \\
3 \\
3 \\
0.5\end{array}$ & $\begin{array}{l}0.3 \\
2.75 \\
5.0 \\
2.5\end{array}$ \\
\hline $\begin{array}{l}441 \\
\text { IM } 175\end{array}$ & $\mathbf{P}^{4,6} \mathbf{I}_{6,17} \mathrm{On}_{3,20}$ & $\begin{array}{c}10 \\
0.5\end{array}$ & $\begin{array}{l}3 \\
0\end{array}$ & $\begin{array}{l}3 \\
1.5\end{array}$ & $\begin{array}{l}0.3 \\
1.5\end{array}$ \\
\hline $\begin{array}{l}442 \\
\text { IM } 503\end{array}$ & $\mathbf{P}^{4,6} \mathbf{I}_{6}\left(\mathrm{CH}_{2}\right)_{16} * \mathrm{II}^{\prime \prime}{ }_{17} \mathrm{On}_{3,20}$ & 0.5 & 0 & 0 & 0 \\
\hline $\begin{array}{l}443 \\
\text { IM } 295\end{array}$ & $\mathbf{P}^{5,16} \mathbf{I}_{6} * \mathrm{II}^{\prime \prime}{ }_{3 \beta} \mathrm{On}_{20}$ & 10 & 0 & 3 & 0.15 \\
\hline $\begin{array}{l}444 \\
\text { IM } 268\end{array}$ & $\mathrm{P}^{5,16} \mathbf{I}_{16} * \mathrm{I}^{\prime \prime}{ }_{3 \beta} \mathrm{On}_{20}$ & 10 & 3 & 1 & 2 \\
\hline
\end{tabular}


Table 135 B (continued)

\begin{tabular}{|c|c|c|c|c|c|}
\hline Group & SSS Name & $\begin{array}{l}\text { Dose } \\
(\mathrm{mg})\end{array}$ & $\begin{array}{l}\text { Digi- } \\
\text { toxin }^{a}\end{array}$ & $\begin{array}{l}\text { Indo- } \\
\text { methacin }{ }^{2}\end{array}$ & $\begin{array}{l}\text { Activity } \\
\text { index }\end{array}$ \\
\hline $\begin{array}{l}445 \\
\text { IM } 373\end{array}$ & $\mathrm{P} 5,17(20)^{\prime \prime} \mathrm{CN}_{20} * \mathrm{II}^{\prime \prime}{ }_{3 \beta} * \mathrm{II}_{21}$ & 0.5 & 0 & 0 & 0 \\
\hline $\begin{array}{l}446 \\
\text { IM } 278\end{array}$ & Pn 194*VI' ${ }_{17} \mathrm{On}_{3,20}$ (Depostat) & $\begin{array}{l}10 \\
0.5\end{array}$ & 3 & $\begin{array}{l}3 \\
0\end{array}$ & $\begin{array}{l}\mathbf{0 . 3} \\
0\end{array}$ \\
\hline $\begin{array}{l}\mathbf{4 4 7} \\
\mathrm{IM} 407\end{array}$ & Pn $194,9,11 \mathrm{CN}_{20 \xi} \mathrm{Ol}_{20} \mathrm{On}_{3}$ & 0.5 & 0 & 0 & 0 \\
\hline $\begin{array}{l}\mathbf{4 4 8} \\
\text { IM } 477\end{array}$ & $\mathrm{P}^{3 \alpha(5)} 5 \alpha \mathrm{CN}_{16 \alpha} \mathrm{Ol}_{6 \beta} \mathrm{On}_{20}$ & $\begin{array}{l}0.5 \\
0.03\end{array}$ & $\begin{array}{l}2 \\
0\end{array}$ & $\begin{array}{l}3 \\
0\end{array}$ & $\begin{array}{l}\mathbf{5 . 0} \\
0\end{array}$ \\
\hline $\begin{array}{l}\mathbf{4 4 9} \\
\text { IM } 480\end{array}$ & $\mathrm{P}^{3 \alpha(5)} 5 \alpha \mathrm{CN}_{16 \alpha} \mathrm{Ol}_{6 \beta} \theta \theta \mathrm{III}_{20 / \mathrm{I} / / 2,2}$ & $\begin{array}{l}0.5 \\
0.03\end{array}$ & $\begin{array}{l}1 \\
0\end{array}$ & $\begin{array}{l}3 \\
0\end{array}$ & $\begin{array}{l}4.0 \\
0\end{array}$ \\
\hline $\begin{array}{l}450 \\
\text { IM } 144\end{array}$ & P9 $\beta, 10 \alpha^{4} \mathrm{on}_{3,20} \quad$ (Retroprogesterone) & 10 & 2 & 3 & 0.25 \\
\hline $\begin{array}{l}451 \\
\text { IM } 349\end{array}$ & CH5 $\beta_{\text {ol }_{3 \alpha, 12 \alpha, 24}}$ & 10 & 0 & 1 & 0.05 \\
\hline $\begin{array}{l}452 \\
\text { IM } 296\end{array}$ & CH5 $\beta^{\prime \prime}{ }_{24}$ (Cholanic acid) & 0.5 & 0 & 0 & 0 \\
\hline $\begin{array}{l}453 \\
\text { IM } 493\end{array}$ & CH5 $\beta^{\prime \prime}{ }_{24} \mathrm{Ol}_{3 \alpha}$ & 0.5 & 0 & 0 & 0 \\
\hline $\begin{array}{l}454 \\
\text { IM } 485\end{array}$ & $\mathrm{CH} 5 \beta^{\prime \prime}{ }_{24} \mathrm{Ol}_{3 \alpha, 6 \alpha}$ & 0.5 & 0 & 0 & 0 \\
\hline $\begin{array}{l}455 \\
\text { IM } 492\end{array}$ & CH5 $\beta^{\prime \prime}{ }_{24} \mathrm{Ol}_{3 \alpha, 7 \alpha}$ & 0.5 & 0 & 0 & 0 \\
\hline $\begin{array}{l}\mathbf{4 5 6} \\
\text { IM } 490\end{array}$ & CH5 $\beta^{\prime \prime}{ }_{24} \mathrm{O} \mathrm{l}_{3 \alpha, 12 \alpha}$ & 0.5 & 0 & 0 & 0 \\
\hline $\begin{array}{l}457 \\
\text { IM } 488\end{array}$ & CH5 $\beta^{\prime \prime}{ }_{24} \mathrm{Ol}{ }_{3 \alpha, 7 \alpha, 12 \alpha}$ & 0.5 & 0 & 0 & 0 \\
\hline $\begin{array}{l}458 \\
\text { IM } 311\end{array}$ & {$\left[\mathrm{CH} 5 \beta^{\prime \prime} \mathrm{ol}_{3 \alpha, 12 \alpha} * \mathrm{II}_{24 / \mathrm{N} / / \mathrm{I}, \mathrm{II}, \mathrm{II}] \mathrm{Br}^{-}}\right.$} & 10 & 0 & 0 & 0 \\
\hline $\begin{array}{l}459 \\
\text { IM } 550\end{array}$ & CH5 $\beta^{\prime \prime} \mathrm{ol}_{3 \alpha, 7 \alpha, 12 \alpha} * \mathrm{I}_{24}$ & 0.5 & 0 & 0 & 0 \\
\hline $\begin{array}{l}460 \\
\text { IM } 310\end{array}$ & 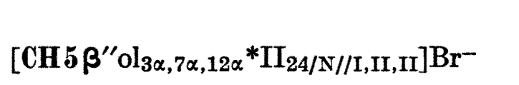 & 10 & 0 & 0 & 0 \\
\hline $\begin{array}{l}461 \\
\text { IM } 541\end{array}$ & СH5 $\beta^{\prime \prime}{ }_{24} \mathrm{On}_{3,7,12}$ & 0.5 & 0 & 0 & 0 \\
\hline $\begin{array}{l}462 \\
\text { IM } 487\end{array}$ & CH5 $\beta^{\prime \prime}{ }_{24} \mathrm{Ol}_{3 \alpha} \mathrm{On}_{11}$ & 0.5 & 0 & 0 & 0 \\
\hline $\begin{array}{l}463 \\
\text { IM } 117\end{array}$ & CH5 $\beta^{\prime \prime *} \mathrm{I}_{24} * \mathrm{II}^{\prime \prime}{ }_{3 \alpha, 7 \alpha \mathrm{on}_{12}}$ & 10 & 0 & 0 & 0 \\
\hline $\begin{array}{l}464 \\
\text { IM } 309\end{array}$ & $\mathrm{CH} 5 \beta^{\prime \prime} * \mathrm{II}_{24 / \mathrm{N} / / \mathrm{II}, \mathrm{II} \mathrm{O}_{3,12}} \cdot \mathrm{HCl}$ & 10 & 0 & 0 & 0 \\
\hline $\begin{array}{l}465 \\
\text { IM } 491\end{array}$ & $\mathrm{CH}^{5 \prime}{ }_{24} \mathrm{Ol}_{3 \alpha}$ & 0.5 & 0 & 0 & 0 \\
\hline
\end{tabular}


Table 135 B (continued)

\begin{tabular}{|c|c|c|c|c|c|}
\hline Group & SSS Name & $\begin{array}{l}\text { Dose } \\
(\mathrm{mg})\end{array}$ & $\begin{array}{l}\text { Digi- } \\
\text { toxin }^{2}\end{array}$ & $\begin{array}{l}\text { Indo- } \\
\text { methacin a }\end{array}$ & $\begin{array}{l}\text { Activity } \\
\text { index } \mathbf{b}^{\mathbf{b}}\end{array}$ \\
\hline $\begin{array}{l}466 \\
\text { IM } 282\end{array}$ & $\mathrm{CH}^{5 \prime} \mathrm{ol}_{3 \beta} * \mathrm{I}_{24}$ & 10 & 0 & 0 & 0 \\
\hline $\begin{array}{l}467 \\
\text { IM } 554\end{array}$ & $\mathrm{CH}^{5} \mathrm{Ph}_{24,24} \mathrm{Ol}_{3 \beta, 24}$ & 0.5 & 0 & 0 & 0 \\
\hline $\begin{array}{l}468 \\
\text { IM } 124\end{array}$ & $\begin{array}{l}\text { CHn 245 } \beta^{\prime \prime} \text { ol }_{3 \alpha, 12 \alpha} * \mathrm{I}_{23} \\
\text { (Methyl nordeoxycholanate) }\end{array}$ & $\begin{array}{l}10 \\
0.5\end{array}$ & $\begin{array}{l}3 \\
0\end{array}$ & $\begin{array}{l}3 \\
0\end{array}$ & $\begin{array}{l}\mathbf{0 . 3} \\
0\end{array}$ \\
\hline $\begin{array}{l}469 \\
\text { IM } 376\end{array}$ & $\mathrm{CHn}(24) 5 \beta \mathrm{CN}_{20} \mathrm{Ol}_{3 \alpha} \mathrm{On}_{11}\left(\mathrm{CONH}_{2}\right)_{20}$ & 0.5 & 0 & 0 & 0 \\
\hline $\begin{array}{l}\mathbf{4 7 0} \\
\text { IM } 401\end{array}$ & CHn(24) $5 \beta^{\prime \prime} \mathrm{CN}_{20} * \mathrm{II}^{\prime \prime}{ }_{3 \alpha}{ }^{*} \mathrm{II}_{21} \mathrm{On}_{11}$ & 0.5 & 0 & 0 & 0 \\
\hline $\begin{array}{l}\mathbf{4 7 1} \\
\text { IM } 107\end{array}$ & CHT5 $\alpha \mathrm{ol}_{3 \beta} \quad$ (Dihydrocholesterol) & 10 & 0 & 0 & 0 \\
\hline $\begin{array}{l}472 \\
\text { IM } 114\end{array}$ & CHT $^{4} \mathrm{On}_{3} \quad$ (Cholestenone) & 10 & 0 & 0 & 0 \\
\hline $\begin{array}{l}473 \\
\text { IM } 104\end{array}$ & 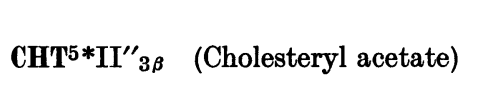 & 10 & 0 & 0 & 0 \\
\hline $\begin{array}{l}\mathbf{4 7 4} \\
\mathrm{IM} 530\end{array}$ & CHT $^{5 *} \operatorname{IX}_{3 \beta}^{\prime \prime}$ & 0.5 & 0 & 0 & 0 \\
\hline $\begin{array}{l}475 \\
\text { IM } 531\end{array}$ & CHT $^{5 *}$ carbonate $_{3 \alpha / *} \mathrm{XVIII}^{9}$ & 0.5 & 0 & 0 & 0 \\
\hline $\begin{array}{l}476 \\
\text { IM } 198\end{array}$ & $\mathrm{CHT}^{5} * \mathrm{~S}^{\prime \prime} \mathrm{Na}_{3 \beta}$ & 0.5 & 0 & 0 & 0 \\
\hline $\begin{array}{l}477 \\
\text { IM } 348\end{array}$ & $\mathrm{CHT}^{5} \mathrm{Ol}_{3 \beta} \mathrm{On}_{7}$ & 10 & 3 & 0 & 0.15 \\
\hline $\begin{array}{l}478 \\
\text { IM } 529\end{array}$ & $\mathbf{C H T}^{5} \mathrm{Cl}_{3 \beta}$ & 0.5 & 0 & 0 & 0 \\
\hline $\begin{array}{l}479 \\
\text { IM } 532\end{array}$ & $\mathbf{C H T}^{5 *} \mathrm{I}^{\prime \prime} \mathrm{Cl}_{3 \beta}$ & 0.5 & 0 & 0 & 0 \\
\hline $\begin{array}{l}480 \\
\text { IM } 558\end{array}$ & $\mathrm{CHT}^{5} \mathrm{Ol}_{3 \beta} \mathrm{HgCl}_{6}$ & 0.5 & 0 & 0 & 0 \\
\hline $\begin{array}{l}481 \\
\text { IM } 138\end{array}$ & 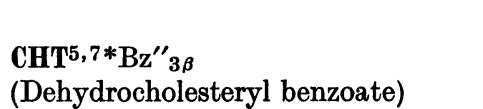 & 10 & 0 & 0 & 0 \\
\hline $\begin{array}{l}482 \\
\text { IM } 232\end{array}$ & $\operatorname{CHT}\left(\mathrm{NO}_{25}\right)^{5} \mathrm{ol}_{3 \beta}$ & 10 & 0 & 1.5 & 0.075 \\
\hline $\begin{array}{l}483 \\
\text { IM } 341\end{array}$ & $\operatorname{ER5} \alpha^{22} \mathrm{ol}_{3 \beta} \mathrm{On}_{11}$ & 10 & 0 & 0 & 0 \\
\hline $\begin{array}{l}484 \\
\text { IM } 299\end{array}$ & $\operatorname{ER} 5 \alpha^{8,22 *} \mathrm{II}^{\prime \prime}{ }_{3 \beta} \mathrm{On}_{11}$ & 10 & 0 & 0 & 0 \\
\hline $\begin{array}{l}485 \\
\text { IM } 536\end{array}$ & $\mathbf{E R}^{4,7,22} \mathrm{On}_{3}$ & 0.1 & 0 & 0 & 0 \\
\hline
\end{tabular}


Table 135 B (continued)

\begin{tabular}{|c|c|c|c|c|c|}
\hline Group & SSS Name & $\begin{array}{l}\text { Dose } \\
\text { (mg) }\end{array}$ & $\begin{array}{l}\text { Digi- } \\
\text { toxin }^{2}\end{array}$ & $\begin{array}{l}\text { Indo- } \\
\text { methacina }\end{array}$ & $\begin{array}{l}\text { Activity } \\
\text { index }\end{array}$ \\
\hline $\begin{array}{l}486 \\
\text { IM } 535\end{array}$ & $\mathbf{E R}^{5,7,22} \mathrm{ol}_{3 \beta}$ & 0.5 & 0 & 0 & 0 \\
\hline $\begin{array}{l}487 \\
\text { IM } 551\end{array}$ & $\mathrm{ER}^{5,7,9(11), 22 * \mathrm{II}^{\prime \prime}}{ }_{3 \beta}$ & 0.5 & 0 & $\mathbf{0}$ & 0 \\
\hline $\begin{array}{l}488 \\
\text { IM } 537\end{array}$ & ST $5 \beta^{22} \mathrm{ol}_{3 \alpha}$ & 0.5 & 0 & 0 & 0 \\
\hline $\begin{array}{l}489 \\
\text { IM } 538\end{array}$ & $\operatorname{ST} 5 \beta^{22 *} \mathrm{II}_{3 \alpha}^{\prime \prime}$ & 0.5 & 0 & 0 & 0 \\
\hline $\begin{array}{l}490 \\
\text { IM } 103\end{array}$ & $\mathbf{S T}^{5} \mathbf{o l}_{3 \beta} \quad(\beta$-Sitosterol $)$ & 10 & 0 & 0 & 0 \\
\hline $\begin{array}{l}491 \\
\text { IM } 534\end{array}$ & $\mathrm{ST}^{4,22} \mathrm{On}_{3}$ & 0.5 & $\mathbf{0}$ & $\mathbf{0}$ & 0 \\
\hline $\begin{array}{l}492 \\
\text { IM } 533\end{array}$ & $\mathrm{ST}^{5,22} \mathrm{ol}_{3 \beta}$ & 0.5 & 0 & 0 & 0 \\
\hline $\begin{array}{l}493 \\
\text { IM } 204\end{array}$ & $\operatorname{SP} 5 \alpha^{*} I^{\prime \prime}{ }_{3 \beta}$ & 10 & 0 & 0 & 0 \\
\hline $\begin{array}{l}494 \\
\text { IM } 203\end{array}$ & $\mathrm{SP} 5 \alpha^{*} \mathrm{II}_{3 \beta}^{\prime \prime} \mathrm{On}_{12}$ & 10 & 0 & 0 & 0 \\
\hline $\begin{array}{l}495 \\
\text { IM } 205\end{array}$ & SP $5 \beta_{o_{3}}$ & 10 & 0 & 0 & 0 \\
\hline $\begin{array}{l}496 \\
\text { IM } 137\end{array}$ & $\mathrm{SP}^{5} \mathrm{III}_{3 \beta}^{\prime \prime}$ & 10 & 0 & 0 & 0 \\
\hline $\begin{array}{l}497 \\
\text { IM } 202\end{array}$ & $\mathrm{SP}^{5} \mathrm{Ol}_{3 \beta} \mathrm{On}_{12}$ & 10 & 0 & 1.5 & 0.075 \\
\hline $\begin{array}{l}498 \\
\text { IM } 291\end{array}$ & $\operatorname{SP} 5 \alpha^{9(11) *} \mathrm{II}_{3 \beta}{ }_{3 \beta}$ & 10 & 0 & 0 & 0 \\
\hline $\begin{array}{l}499 \\
\text { IM } 542\end{array}$ & $\operatorname{CAR} 5 \beta^{20(22)} \mathrm{Ial}_{19 \beta} \mathrm{Ol} \mathrm{l}_{5,14 \beta} * \mathrm{R}_{3}$ & 0.5 & 0 & 0 & 0 \\
\hline $\begin{array}{l}500 \\
\text { IM } 494\end{array}$ & $\begin{array}{l}\text { Dammaran-n31 }{ }^{17(20)} 5 \alpha, 8 \alpha, 9 \beta, \\
13 \alpha, 14 \beta I^{\prime \prime}{ }_{21}{ }^{0 l_{11 \alpha}}{ }_{11} I_{3 \alpha, 16 \beta}\end{array}$ & 0.5 & 0 & 0 & 0 \\
\hline
\end{tabular}

The "Activity Index" is based on the formula $\frac{\mathrm{D}+\mathrm{I}}{2} \times \frac{1}{\mathrm{mg}}$ where $\mathrm{D}=$ reading for digitoxin, $\mathrm{I}=$ indomethacin, and $\mathrm{mg}=$ the dose tested. Thus, the index reflects overall activity against both substrates at any one dose level. The highest Activity Index reading for each steroid is emphasized by boldface numerals, but direct intercomparisons are possible only at corresponding dose levels. Naturally, a compound tested only at the high level of $10 \mathrm{mg}$ per dose could not reveal its full potency in this method of expression, but if it had little or no activity, lower doses were not tested. 
On the other hand, steroids available only in very small amounts could be assayed only at dose levels too low for comparison with many other compounds.

For simplicity's sake the compounds are designated and sequentially enumerated according to the rules of the "SSS Nomenclature of Steroids" (cf. p. 774).

\section{Second Step: Determination of "Protective Spectrum"}

Having selected the most promising protective substances by first screening them for activity against digitoxin and indomethacin, we proceeded to appraise the "Protective Spectrums" of the most potent ones among them. These compounds were now tested against a heterogenous set of 10 pathogens, widely differing in their chemical structure and in the organ changes that they elicit.

The statistical significance of the results was computed (as outlined on p. 771) for the inhibition or aggravation of the changes produced by each of the 10 model toxicants. After this, the "Overall Protective Indexes" ("OPI") and the "Protective Spectrum Index" ("PSI") were calculated, as rough indications of the mean degree and the specificity of protection, that is of the quantitative and qualitative prophylactic potencies respectively. These data are summarized in Tables 136, p. 836 and 137.

For the 10 toxicants enumerated in the caption of Table 136 the techniques of administration and the manner in which protection is expressed have been described in an earlier paper (Selye G 70,420/71), as well as in the sections devoted to the effect of various steroids upon each toxicant in this monograph. Suffice it to recall that the highest possible degree of protection corresponds to grade " 3 ", the "OPI" expresses the mean grade of protection, whereas the "PSI" gives the percentage of the toxicants tested against which significant protection is obtained (irrespective of the degree of significance). These two indexes - given in the last two vertical columns of Table 136 - do not run strictly parallel but the various compounds tested for protective potency are listed roughly in decreasing order of their OPIs. Whenever the material at our disposal permitted it, compounds active at a certain dose were retested at a lower dose level. Of course, the two indexes were not calculated for dose levels at which, because of toxicity or lack of material, not all protective compounds could be tested (marked with a dash); hence the OPI and PSI are listed only for the highest, but still well tolerated, dose of each protective compound. The last two horizontal lines in Table 136 list the indexes for the amenability of the toxicants to detoxication by the conditioning agents as explained on p. 772 .

Perusal of Table 136 indicates that almost all steroids were active in offering protection, at least against some of the damaging agents; but this is so merely because most of the steroids tested here were included in this study precisely because they had shown some potency in preliminary tests.

It is noteworthy that among all steroids tested PCN (Cpd. 1), again exhibited the highest catatoxic activity as judged by both indexes. It was even more active than any of the other $16 \alpha$-carbonitriles tested against all 10 substrates. CS-1, spironolactone, Cpds. 4, 5, cyproterone acetate, ethylestrenol, norbolethone, TMACN and Cpd. 10 were almost equally efficacious at the highest dose $(10 \mathrm{mg})$, but at the $500 \mu \mathrm{g}$ dose level, activity fell roughly in the order in which the compounds are mentioned here. Indomethacin and digitoxin are most readily detoxified by these steroids - in the case of PCN even at the dose level of $300 \mu \mathrm{g} / \mathrm{kg}$. However, the general indexes of 
activity are not very meaningful at the low dose levels at which efficacy against other toxicants has not been examined; hence they are listed only for the optimal protective dose. It will be noted that usually this is $10 \mathrm{mg}$ (the highest dose tested) but in the case of such compounds as the strong glucocorticoids or estradiol, inherent toxicity of heavy overdosage counteracts the protective effect against drugs by causing severe mortality. In these instances, lower dose levels were selected for the computation of the OPI and PSI (last two vertical columns at right).

On the other hand, Cpd. 34 and the steroids listed after it in Table 136 exhibit only negligible if any activity, with the exception of occasional strong inhibitory effects (grade 2 or 3) against individual toxicants (e.g., pregnanedione against parathion, hexobarbital and indomethacin; progesterone against indomethacin; $11 \alpha$-hydroxyprogesterone against indomethacin, hydroxydione against digitoxin, DOC against nicotine). This singular specificity of protection among compounds having a very low, if any, protective effect against other substrates may well depend upon specific so-called "physiologic antagonisms" (e.g., the anesthetic effect of hydroxydione or the mineralocorticoid action of DOC), but further experiments will be necessary to prove this.

A glance at the OPI and PSI of the toxicants (last two horizontal lines at the bottom of Table 136) shows that digitoxin, dioxathion, hexobarbital, progesterone, indomethacin and DHT were most readily detoxified by the largest number of conditioning agents, whereas parathion, nicotine, zoxazolamine and especially the infarctoid cardiopathy produced by fluorocortisol $+\mathrm{Na}_{2} \mathrm{HPO}_{4}+$ corn oil were most resistant.

Among the nonsteroidal agents of Table 137 rather specific antagonisms were quite common. For example, ACTH increased resistance to the neuromuscular blocking action of zoxazolamine, although it had little if any effect against other agents.

Vitamin E offered some protection against DHT; whereas acetylsalicylic acid protected against progesterone anesthesia, zoxazolamine paralysis and indomethacin ulcers, but these compounds offered no noteworthy protection against other toxicants.

Bile duct ligature offered complete protection against DHT-induced calcinosis, the F-COL $+\mathrm{Na}_{2} \mathrm{HPO}_{4}+$ oil cardiopathy and indomethacin ulcers, but the mortality was not completely prevented and hence, the grade of protection - which reflects the mean inhibition of lesions plus mortality - is comparatively moderate. It is very likely that occlusion of the choledochus acts by preventing bile secretion, thereby interfering with lipid absorption and the enterohepatic circulation of drugs.

Digitoxin, indomethacin, vitamin A and vitamin D - all of which are readily detoxified under the influence of catatoxic steroids - do not act as inducers of protective enzymes against any of the substrates tested. Obviously, there is no relationship between amenability to detoxication by steroid-induced enzymes and the power to induce such enzymes.

As with the steroidal protective agents, indomethacin intoxication appears to be particularly easy to prevent, but digitoxin poisoning (which is likewise combated by virtually all catatoxic steroids) is singularly resistant to protection by nonsteroidal agents, with the exception of nicotine and phentolamine.

Among the nonsteroidal agents, the highest general protective indexes are exhibited by phetharbital, diphenylhydantion, phenobarbital and phenylbutazone, but at high dose levels, tolbutamide and compound W-1372 are also quite efficacious. 


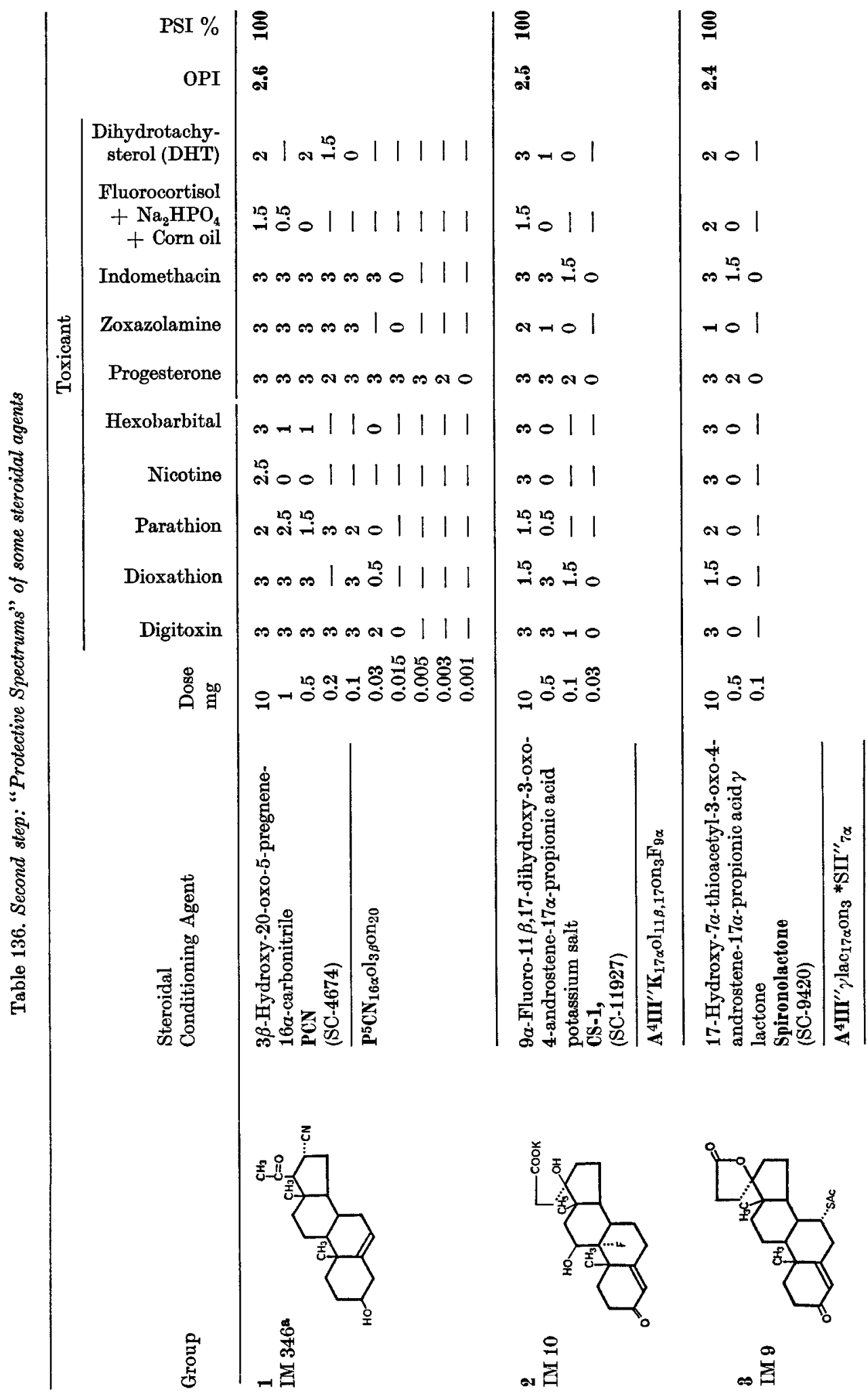




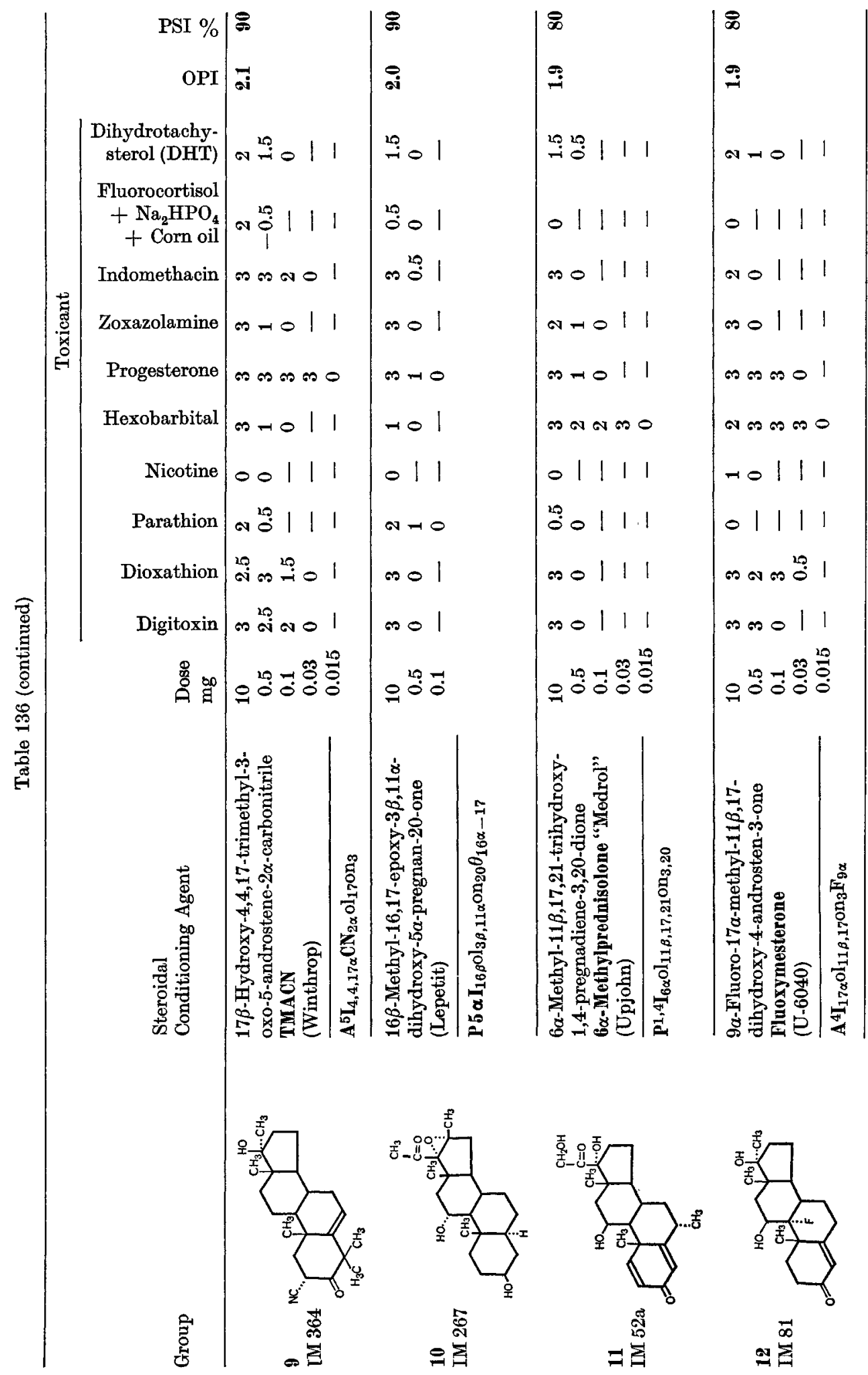




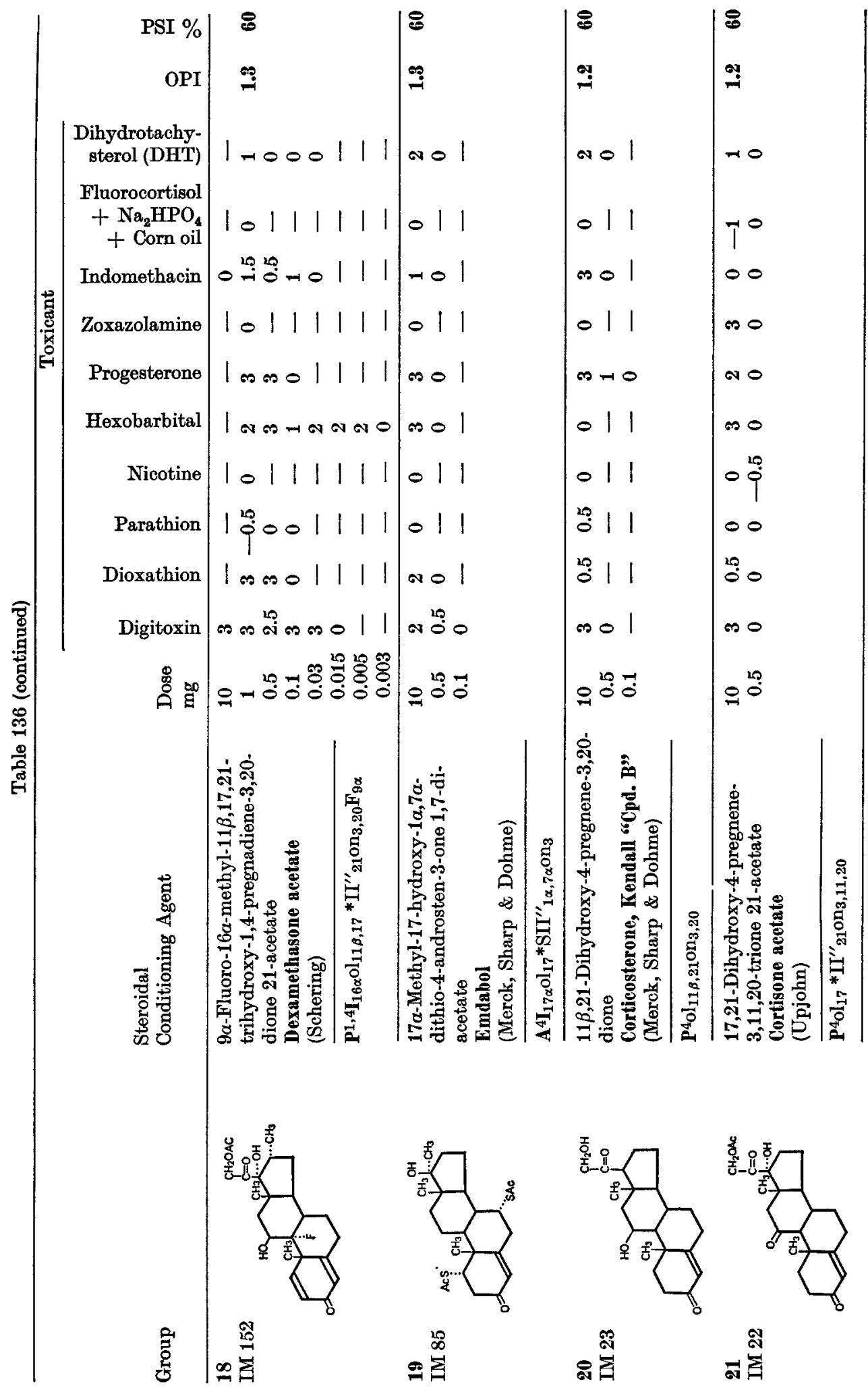




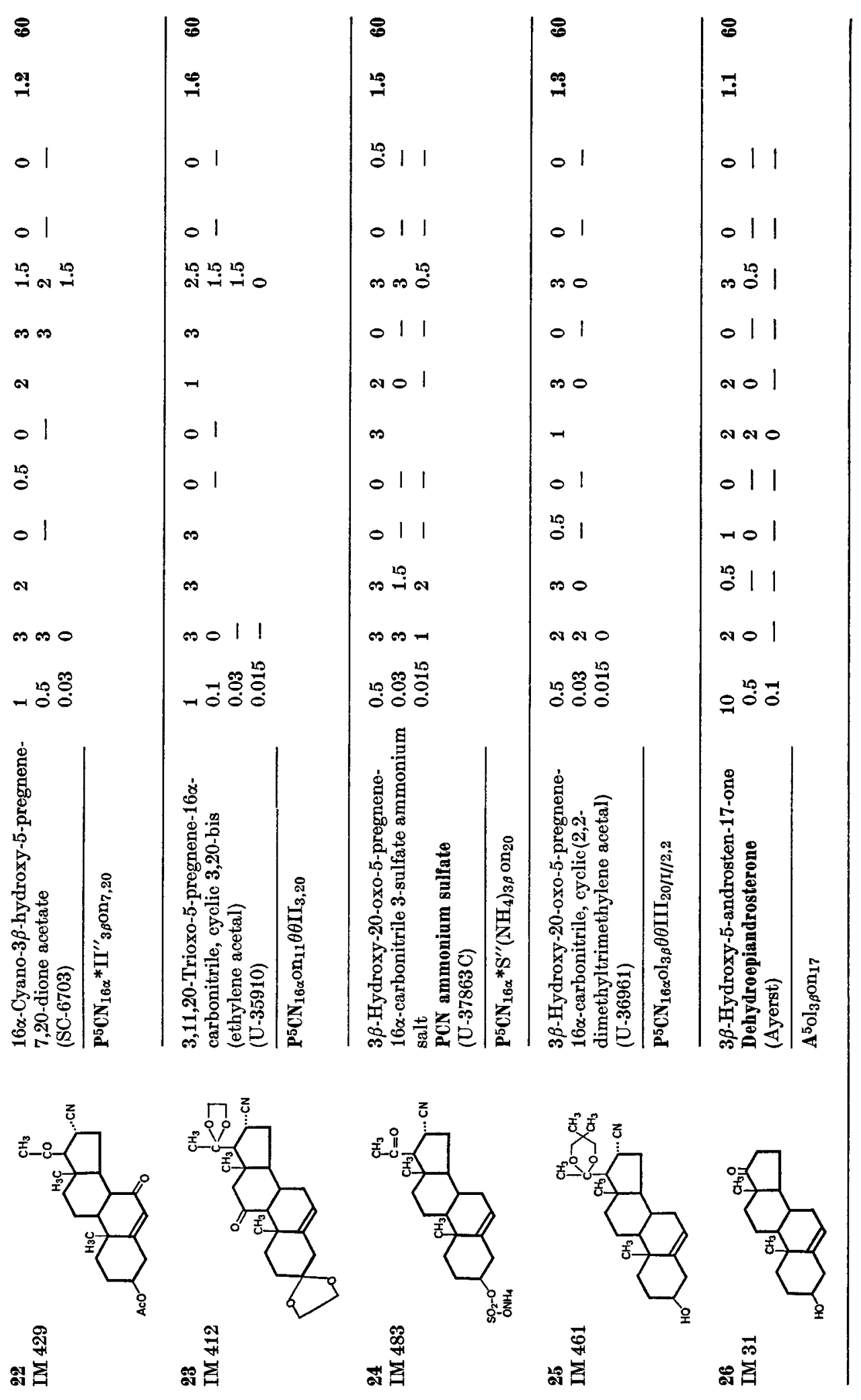




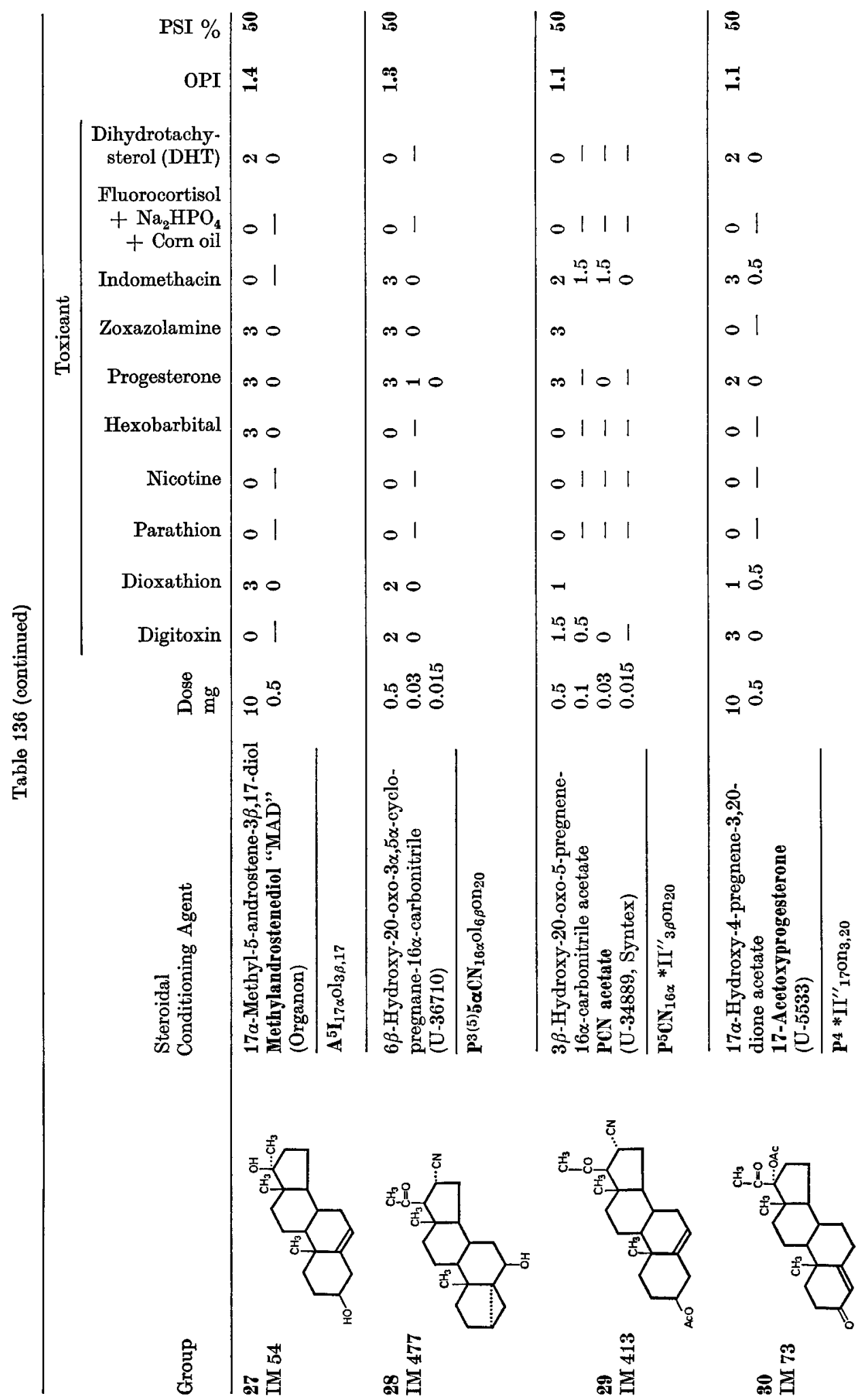




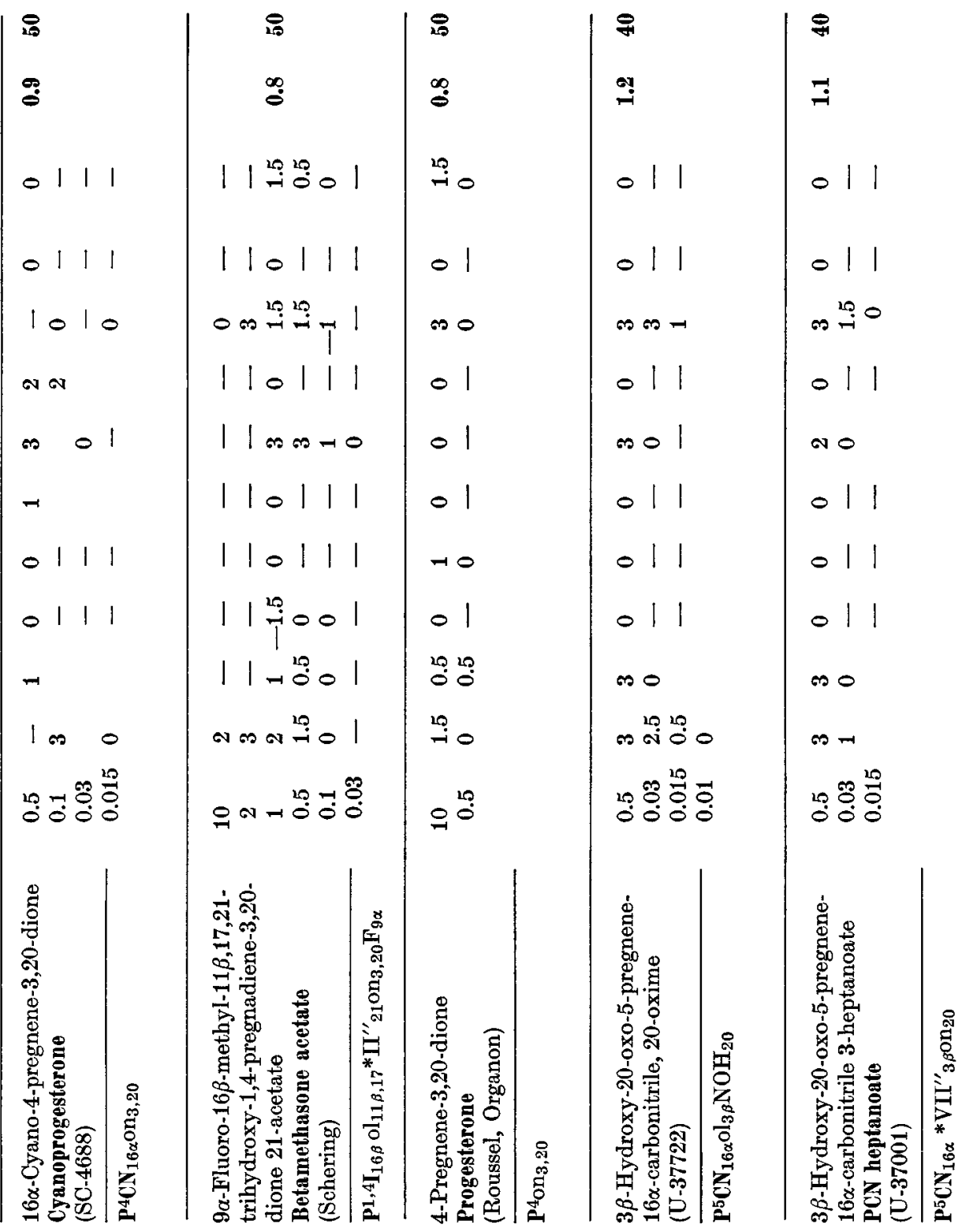

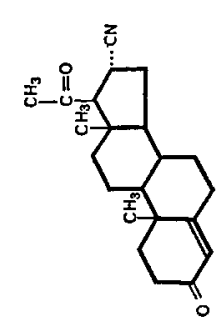

$\stackrel{\wp}{\circ}$

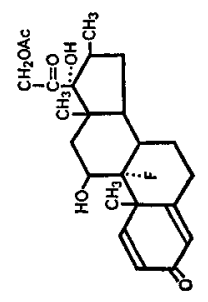

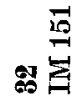

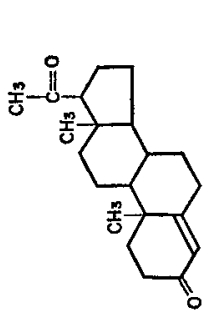

芯

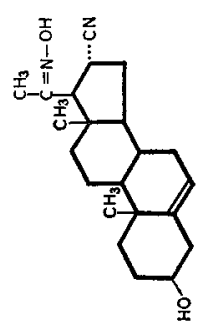

羿

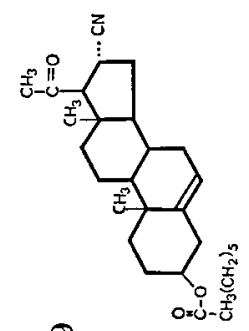

象龺 


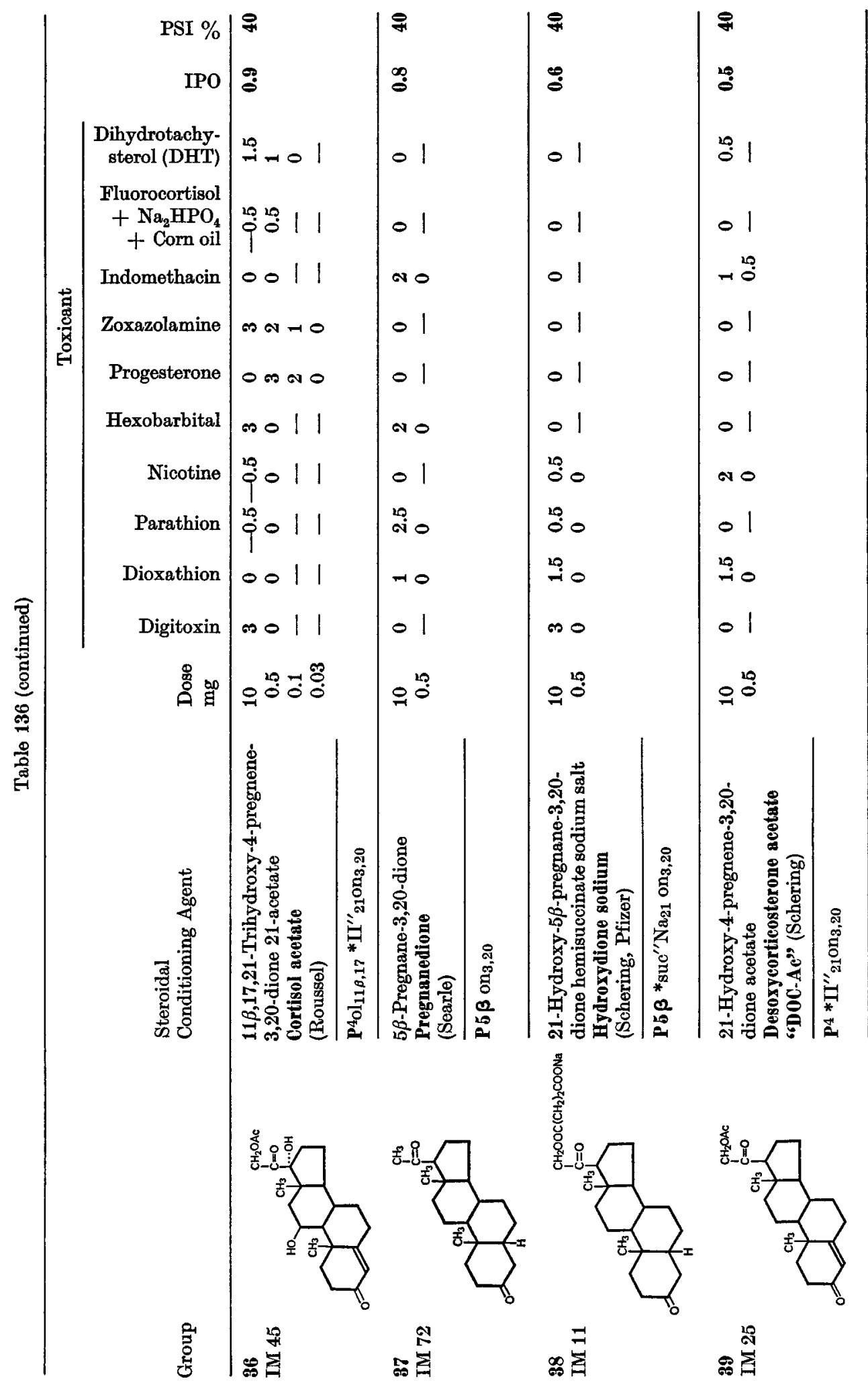




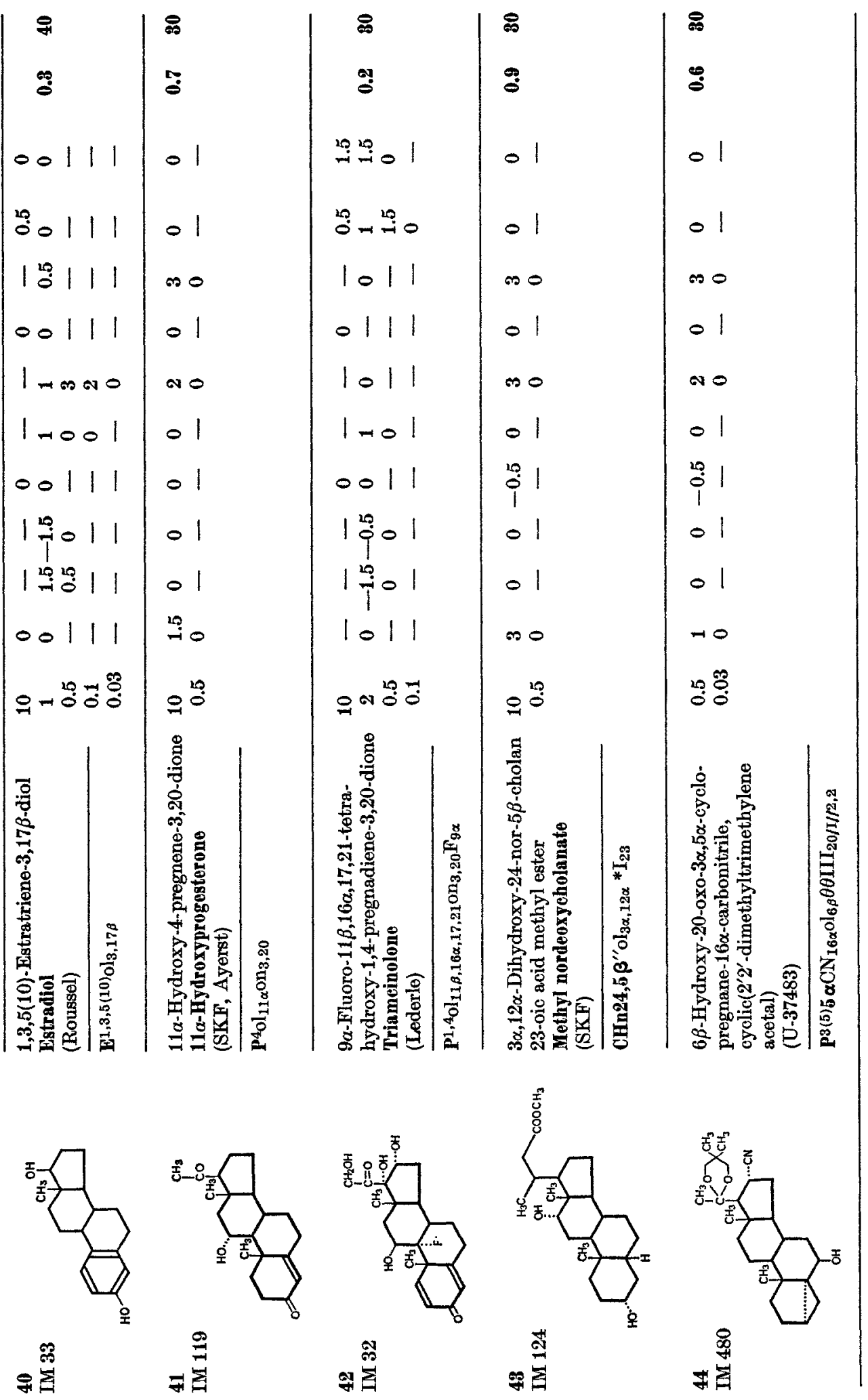




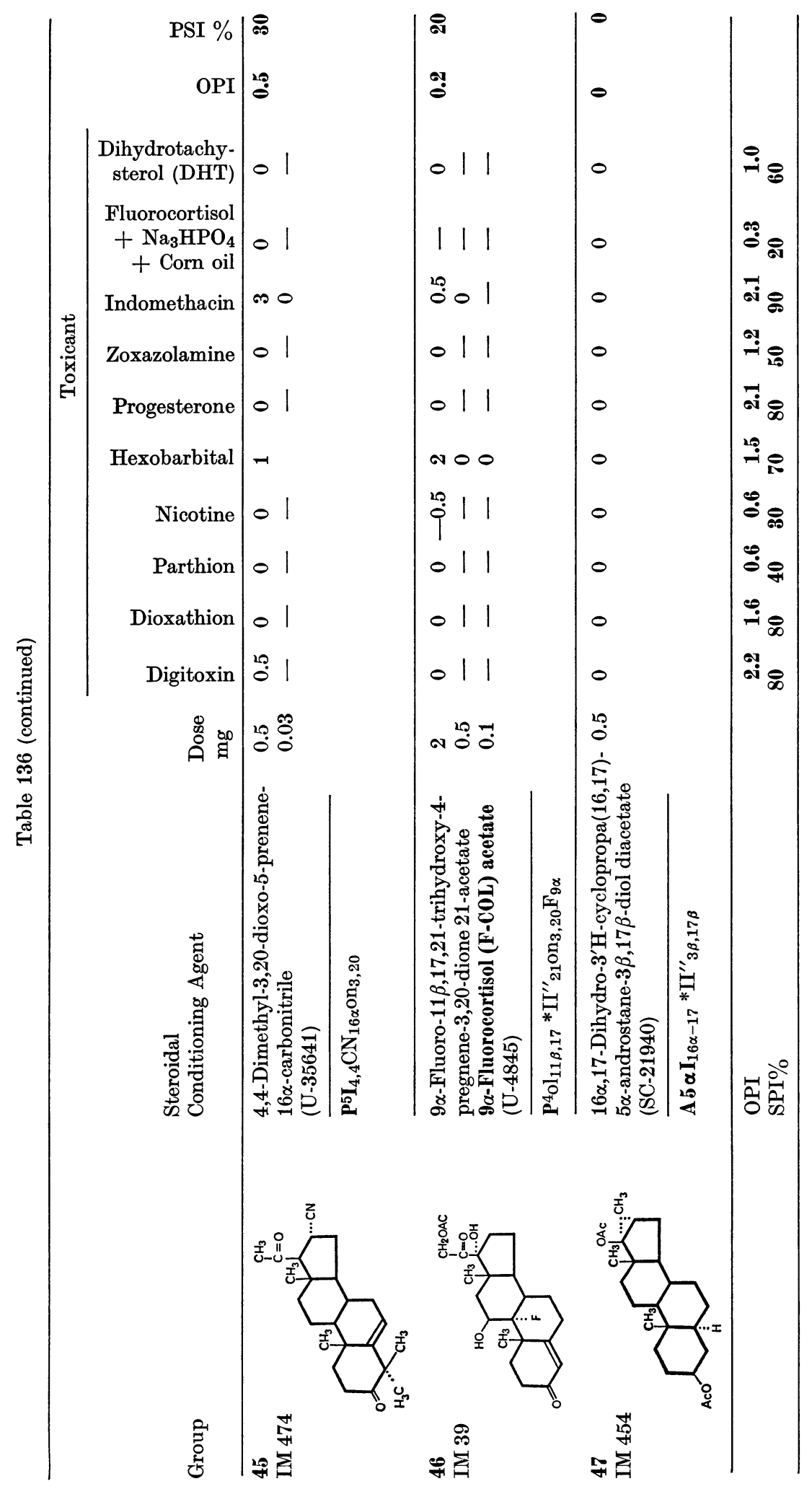


The infarctoid cardiopathy produced by fluorocortisol $+\mathrm{Na}_{2} \mathrm{HPO}_{4}+$ corn oil, which is inhibited by several steroids (particularly spironolactone and spiroxasone, among those listed in Table 136), was consistently resistant to prophylaxis by any of the nonsteroidal drugs in Table 137. Of course, potassium salts (e.g., KCl) or potassiumsparing agents (e.g., amiloride, triamterene) offer excellent protection against this cardiopathy, as shown by our previous investigations, and since spironolactone and spiroxasone likewise retain potassium, it is probable that here they also act primarily through this mechanism.

The relative amenability of the other toxicants to protection by nonsteroidal conditioning agents can be most readily appraised on the basis of the indexes listed in the last two horizontal lines of Table 137, p. 848. It will be seen that indomethacin and dioxathion have the highest PSI, but in general, the overall protective effect of these nonsteroidal agents falls far short of that of the steroids listed in Table 136 . Indeed, whatever overall protective values can be ascribed to the set of nonsteroidal agents are mainly due to the comparatively high efficacy of phenobarbital, phetharbital, diphenylhydantoin, phenylbutazone, and to a lesser extent, of tolbutamide and W-1372; the other agents in this list are either inactive or offer protection only against very few toxicants.

\section{Third Step: Identification of Damaging Agents Amenable to Prophylaxis}

As previously stated, this third step of the screening procedure was designed primarily to identify the types of compounds that can be detoxified by steroids. However, for comparative purposes, we have also tested thyroxine and phenobarbital under identical conditions, as examples of nonsteroidal agents previously shown to influence resistance against many toxicants. The steroids included in this battery of tests were purposely selected to comprise proven syntoxic or catatoxic substances, as well as compounds which had never been shown to protect against any toxic agent.

The prophylactic steroids were administered, as outlined on p. VIII, in $1 \mathrm{ml}$ water by a stomach tube, twice daily, from the first day until termination of the experiment, unless otherwise stated in the footnotes. Thyroxine was administered at the dose of $0.2 \mathrm{mg}$ in $0.2 \mathrm{ml}$ water s.c., once daily, and phenobarbital at the dose of $6 \mathrm{mg}$ in $1 \mathrm{ml}$ water p.o., twice daily, as described in Table 137. The treatment with the toxicants and the assessment of the lesions they produce was again expressed as outlined on p. 834. The results are summarized in Table 138, p. 850.

In this series of experiments, the "OPI" and "PSI" refer to the amenability of the individual damaging agents to the protective effect of the compounds listed in the caption of Table 138. In other words, in the two last vertical columns of Tables 135, 136, 137, these indexes were computed to express the protective action of many agents against a standard set of toxicants, whereas in Table 138 (as in the two last horizontal lines of Tables 136,137 ) they are meant to reflect the amenability of diverse toxicants to inactivation by a standard set of potential prophylactic agents.

In Table 137, the damaging agents are listed merely in alphabetic order but a glance at the OPI column reveals that the toxicants most amenable to prophylaxis by diverse agents are: cocaine, cyclobarbital, cycloheximide, digitoxin, EPN, ethion, ethylmorphine, glutethimide, hexobarbital, indomethacin, methyprylon, nicotine, 


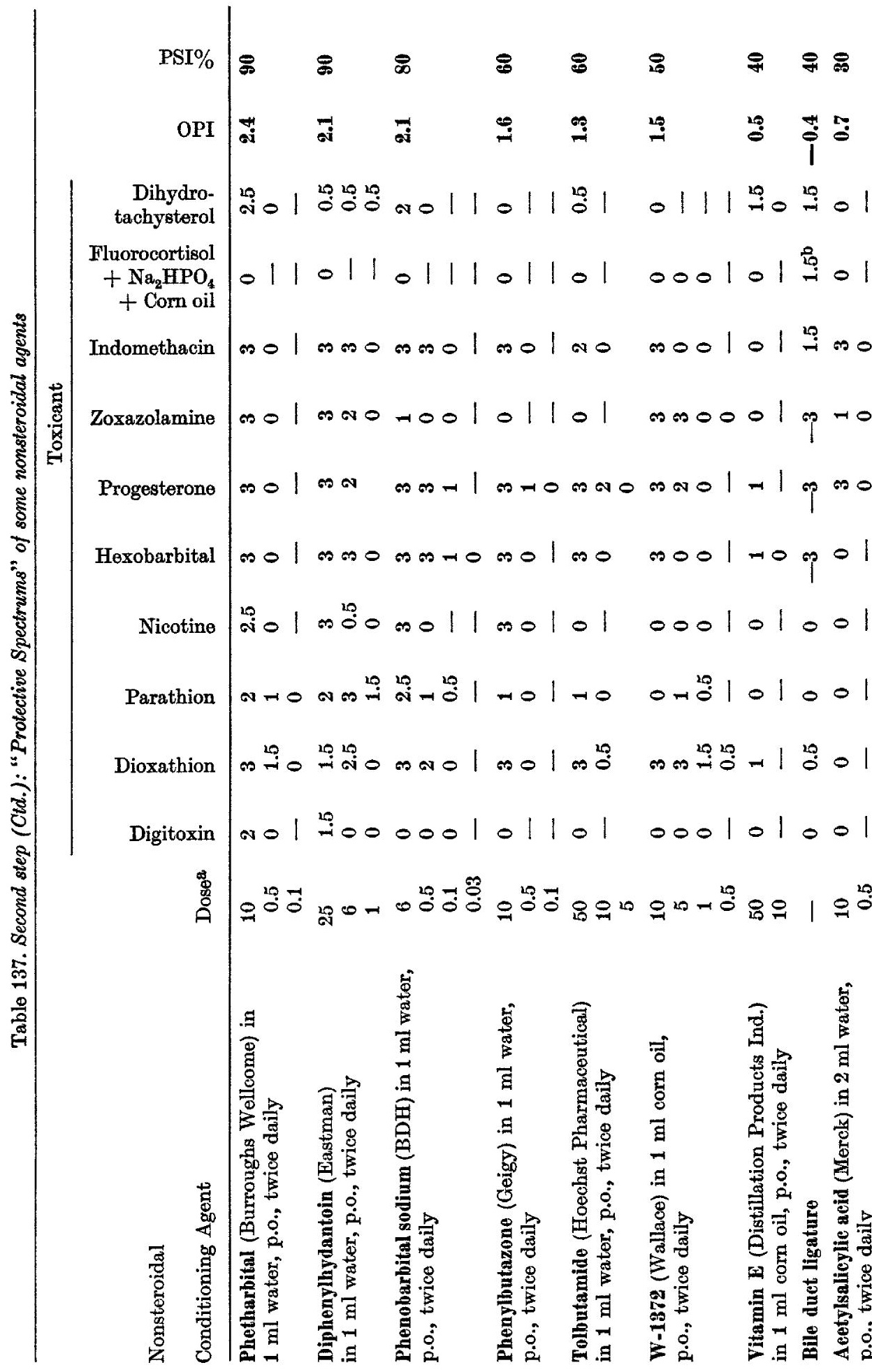


Second Step (Ctr.): "Protective Spectrum" of Some Nonsteroidal Agents

849

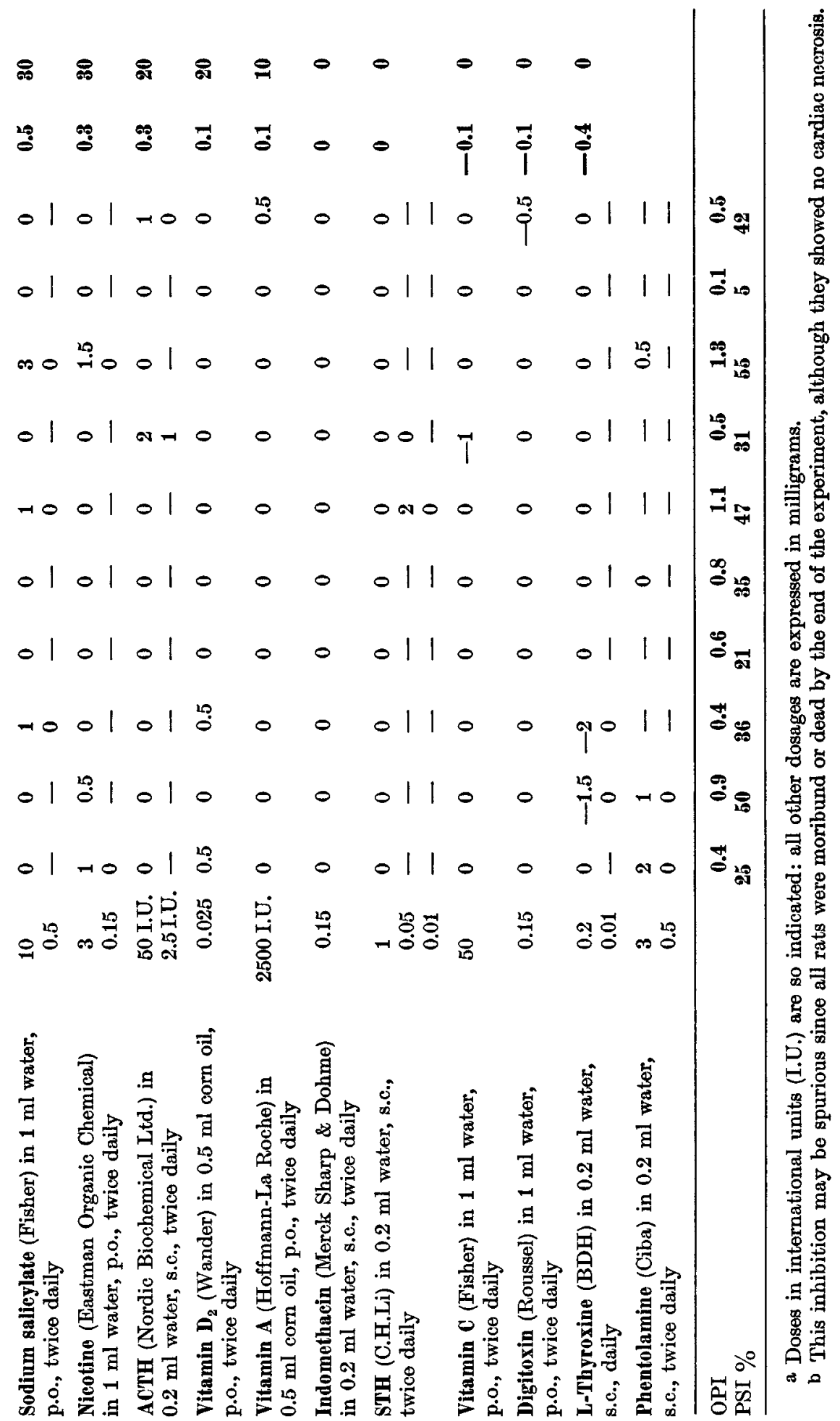




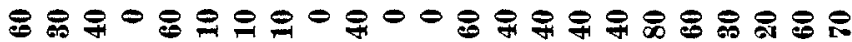

$\mathrm{OPI}^{2}$

웍 $\infty$ 익 염

MPI $^{1}$

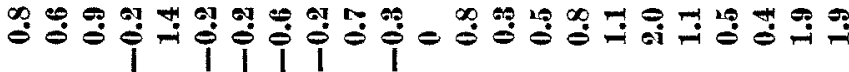

Thyroxine

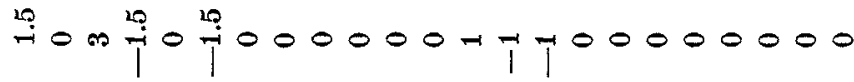

Estradiol

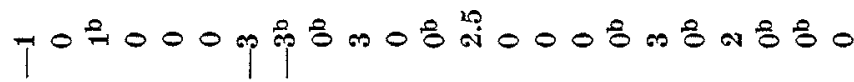

Hydroxydione $000 \stackrel{10}{0} 00 T^{0} 00000000-0000-$ DOC-AC

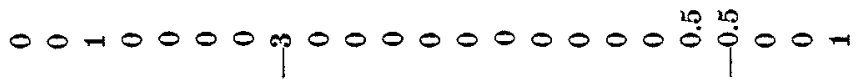

Triamci○ ○ 웅 ค nolone

Progesterone

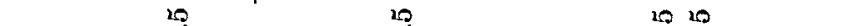

Prednisolone-Ac

Oxandrolone

Nor. bolethone

Spironolactone CS-1

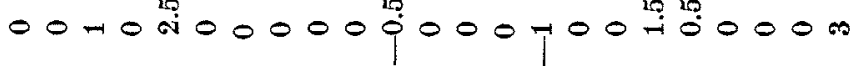
nomo $000000000 n 0000000 n$ n

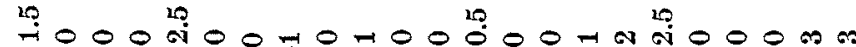

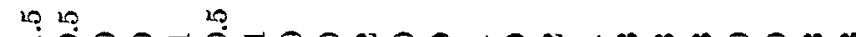
然

Ethylestrenol

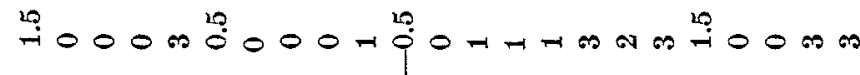
PCN 然央 0 |

Phenobarbital in 


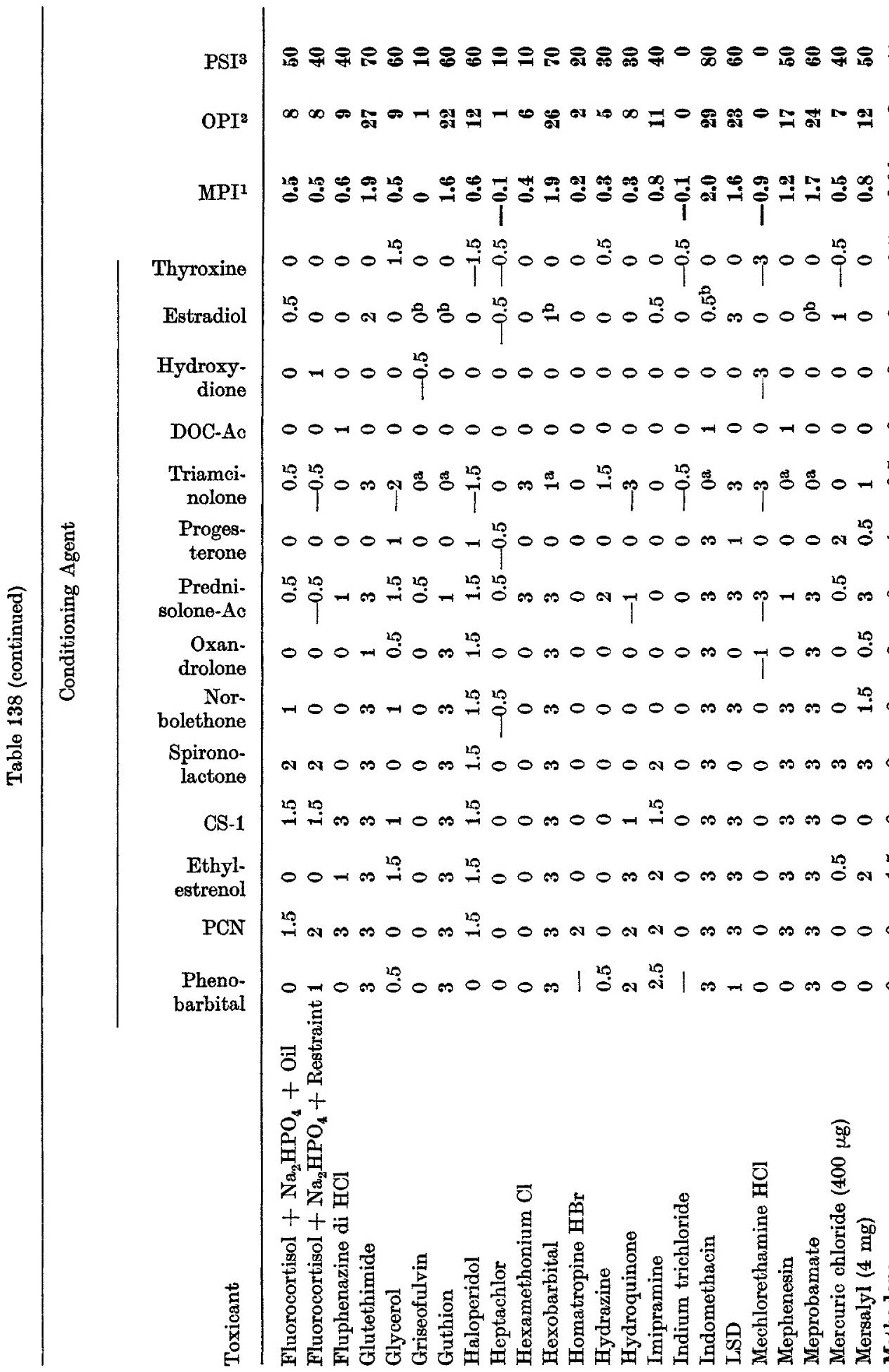




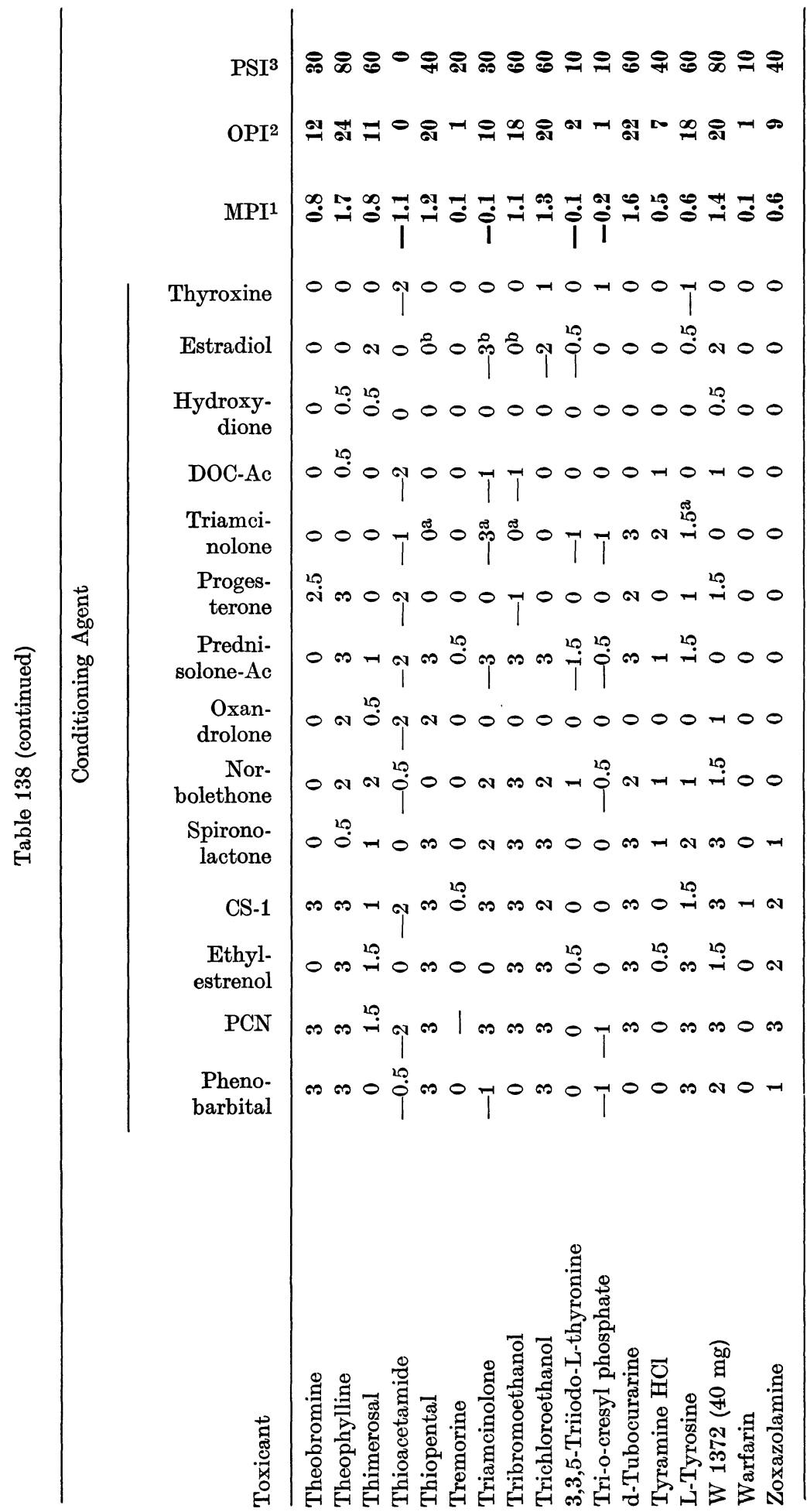


phenyramidol, picrotoxin, and piperidine. The PSI of these toxicants runs roughly parallel to their OPI, that is to say the agents whose toxicity is most significantly impeded by various prophylactics are, in general, also detoxified by the largest number of potentially prophylactic substances.

Several substrates in Table 138 are very amenable to detoxication but only by few compounds; hence, despite their great activity in one or two respects, they have extremely low general protective indexes. For example, mercuric chloride is almost completely detoxified by spironolactone, yet its overall amenability to protection is very low, because its detoxication depends upon a steroid-borne thioacetyl group. In this series of conditioners, such a substituent occurs only in this particular steroid. Similarly, the intoxications amenable to protection by glucocorticoids only (lathyrogens, ganglioplegics, croton oil, E. coli, pralidoxime, strychnine, ethylene glycol), give comparatively low overall protective indexes, because only two of the prophylactic substances tested possess strong glucocorticoid potency.

Reading the columns in Table 138 vertically, we confirmed that the best protection against the largest number of toxicants is offered by the typical catatoxic steroids: PCN, ethylestrenol, CS-1, spironolactone, norbolethone, and oxandrolone.

Furthermore, some systemic toxicants (e.g., cyclobarbital, methyprylon, SKF 525-A, d-tubocurarine) are combated both by catatoxic steroids and by the two glucocorticoids included in this series. Several other drugs (e.g., barbital, cinchophen, cocaine, ethion, meprobamate, picrotoxin, thiopental, tribromoethanol, trichloroethanol) are well detoxified by prednisolone but not by triamcinolone, although the latter is the more potent glucocorticoid. Presumably, prednisolone possesses both catatoxic and syntoxic properties. Yet, here again we must remember that such in vivo tests can only determine whether a compound is or is not amenable to detoxication by steroids that have syntoxic or catatoxic actions with respect to other substrates. Further investigations will be required to identify the underlying mechanism.

DOC, hydroxydione, estradiol and thyroxine are comparatively ineffective both as regards the intensity and the spectrum of protection. In fact, in many cases, pretreatment with thyroxine results in toxication rather than detoxication. In the computation of the OPI and PSI, the results of toxication are not deducted from those of detoxication, but merely considered as " $\mathrm{O}$ "; hence the aggravating effect of thyroxine emerges only from the MPI.

In general, intoxications that can be inhibited by catatoxic steroids are also amenable to prophylaxis by phenobarbital. Yet, here again, there are exceptions: chlordiazepoxide, cyclophosphamide, digitoxin, digitoxin $+\mathrm{Na}_{2} \mathrm{HPO}_{4}+$ corn oil, haloperidol, mephenesin, triamcinolone, tribromoethanol, and tubocurarine, though readily detoxified by most catatoxic steroids, are virtually resistant to phenobarbital. In several other instances, phenobarbital is effective, but much less so than the most potent catatoxic steroids. The converse is rarely if ever the case; among the intoxications tested, only strychnine and piperidine poisoning responded much better to phenobarbital than to catatoxic steroids, but perhaps here, the hypnotic effect of the drug played a special role.

It must be emphasized that we cannot draw far-reaching conclusions as to the specificity of catatoxic and syntoxic steroid actions from this experimental series, since in some groups, the number of experimental animals may have been too small to compensate for individual variations in susceptibility. Furthermore, the conditioners 
were administered in fixed amounts; dose effect curves would be required in each case to make more meaningful comparisons. Still even these data suffice to show that there are qualitative differences in the prophylactic actions of the various conditioning agents.

In surveying Table 138, it is striking how few conditioning agents induced a considerable decrease in resistance ( -2.5 or more) to the toxicants tested. This is all the more noteworthy since overdosage with two drugs (the toxicant and the conditioning agent) might be expected to be more difficult to resist than treatment with the toxicant alone. Most of the apparent decreases in resistance were seen after conditioning with prednisolone and triamcinolone, but of course here the toxic effect of heavy glucocorticoid overdosage (loss of body weight with a predisposition for spontaneous infections) was probably the decisive factor. In addition, when given in combination with DOC-Ac $+\mathrm{NaH}_{2} \mathrm{PO}_{4}$, the glucocorticoids notoriously sensitize to myocardial necrosis. Furthermore, when triamcinolone was used as a toxicant, it was obvious a priori that additional treatment with the same or another glucocorticoid would aggravate the overdosage syndrome. It is perhaps more remarkable that intoxication with hydroquinone was greatly accentuated by triamcinolone.

Among the other steroids, let us point out that PCN appears to sensitize to the toxic effects of propionitrile, whereas estradiol considerably aggravates poisoning with OMPA and triamcinolone. Thyroxine markedly diminishes resistance to epinephrine and propionitrile, but to a lesser extent, it also accentuates the toxicity of several other agents and rarely offers protection.

\section{Synoptic "Diagram Table"}

The "Diagram Table" (Table 139) graphically summarizes the highlights of Table 138 except that:

1. The results are registered only for inhibitions (not for aggravations) of intoxications.

2. Intermediates between the four basic grades $(0,1,2$ and 3$)$ are disregarded in that:

$$
\begin{aligned}
& \square=0.5 \text { or less } \\
& \square=1 \\
& \square=1.5 \text { to } 2 \\
& =2.5 \text { to } 3
\end{aligned}
$$

The absence of any sign indicates that the corresponding experiment has not been done.

3. Here, the toxicants are listed according to decreasing "Total OPI" values.

When thus arranged, it becomes particularly obvious that among the hormonal conditioning agents, PCN is effective against the largest number of toxicants and its protective potency roughly parallels that of phenobarbital at the dose levels employed here. However - as mentioned in discussing Table 138 - the parallelism in the protective value of these two compounds is not absolute. Tables 138 and 139 clearly show furthermore that (in addition to PCN) ethylestrenol, CS-1, spironolactone and oxandrolone have high protective potencies, prednisolone and progesterone are much less active, whereas triamcinolone, DOC, hydroxydione, estradiol and thyroxine protect only against very few toxicants. 
Table 139. "Diagram Table" a

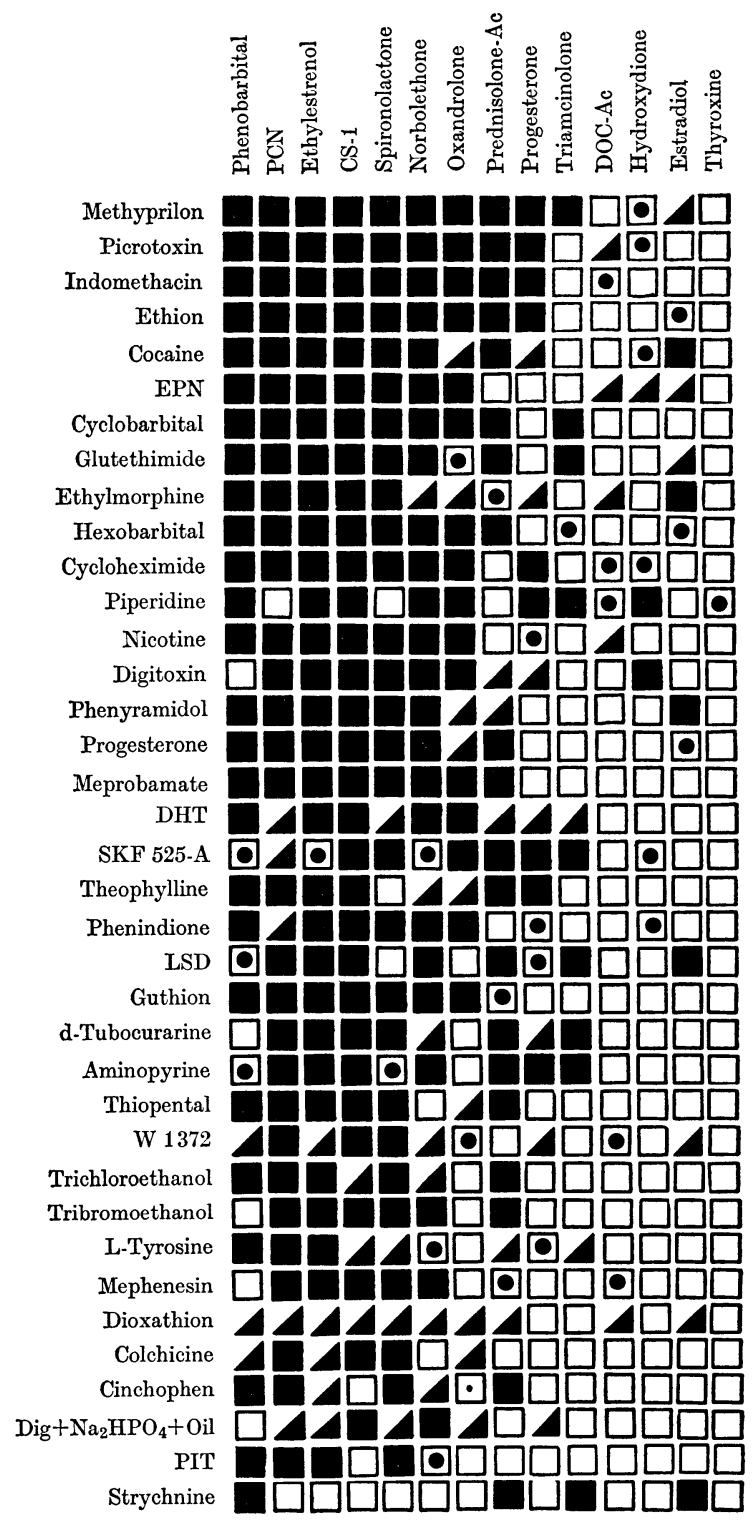

a In this Table the compounds are enumerated in the same order as in Table 138. However, in the latter, grades of 0.5 or less were also considered whereas here they were taken as $0(\square)$. Furthermore, no distinction is made here between 1.5 and 2 or 2.5 and 3. This explains the minor discrepancies between the grading judged by the pictorial symbols and the sequence in which the compounds are listed. 
Table 139 (continued)

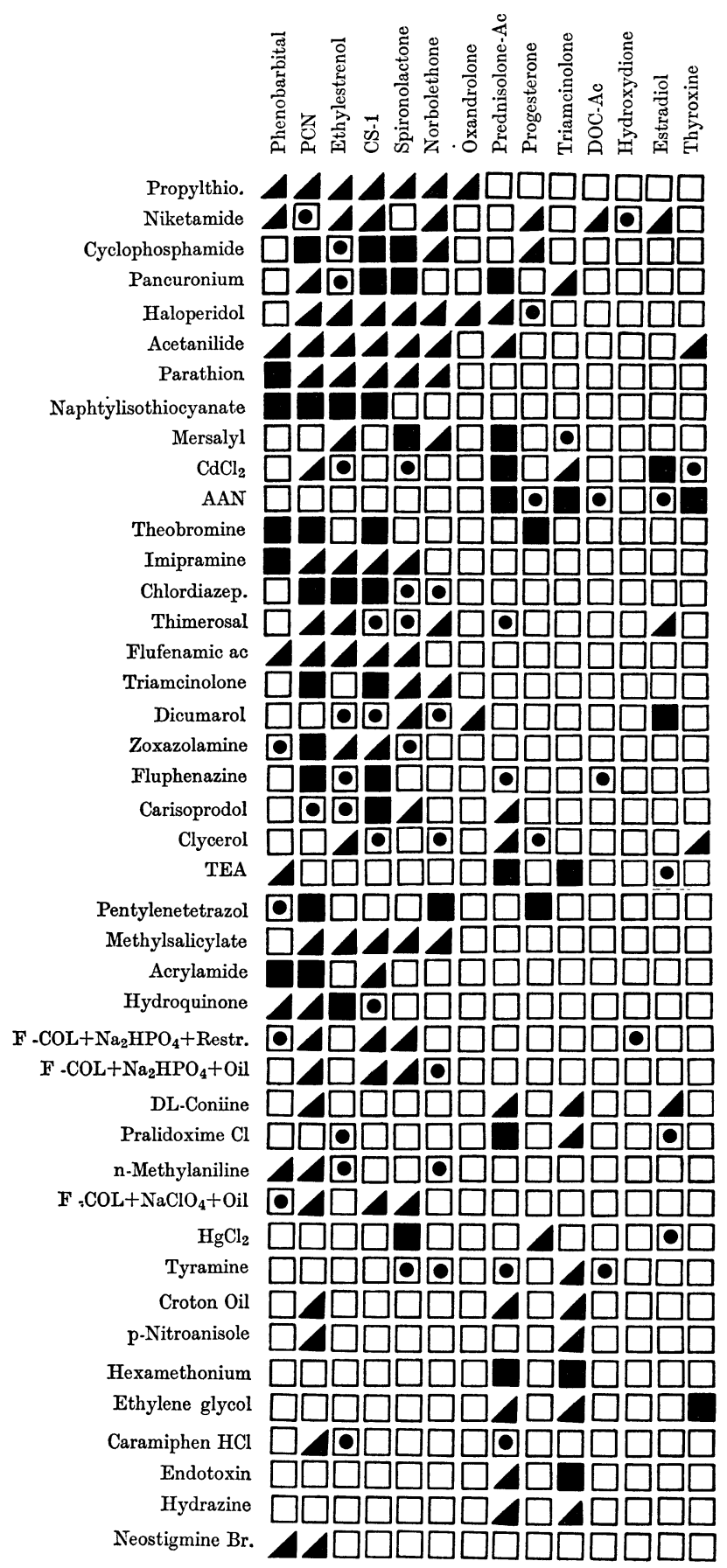


Table 139 (continued)

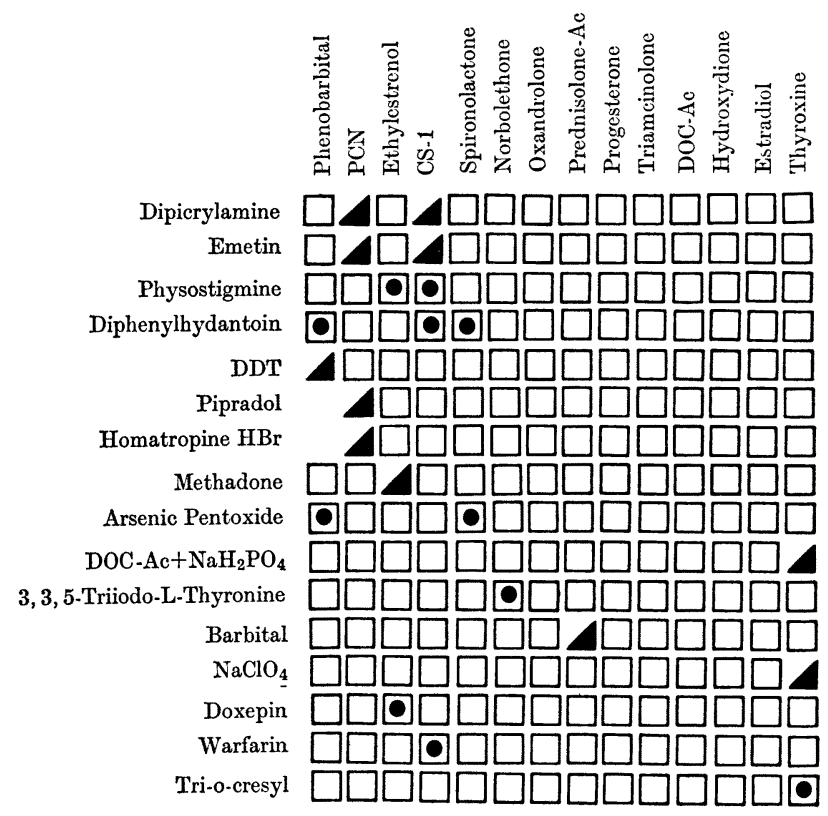

No significant protection was obtained by any of the conditioners against:

$\begin{array}{ll}\text { DFP } & \text { Bromobenzene } \\ \text { TICl } & \text { Brompheniramine } \\ \text { Propionitrile } & \text { Dimercaprol } \\ \text { Griseofulvin } & \text { Dinitrophenol } \\ \text { DL-Amphetamine } & \text { Endrophonium } \\ \text { Tremorine } & \text { Yellow phosphorus } \\ \text { Estradiol }+\mathrm{NaH}_{2} \mathrm{PO}_{4} \text { Ephedrine } \\ \text { Heptachlor } & \text { Ethyl alcohol } \\ \text { OMPA } & \text { Ethylene chlorohydrin } \\ \text { Epinephrine } & \text { Nephrectomy } \\ \text { Mechlorethamine } & \text { Methylphenidate } \\ \text { o-Aminophenol } & \text { InCl } 3 \\ \text { Fasting } & \text { Morphine } \\ \text { Bile duct ligature } & \text { Pyrilamine }\end{array}$

\section{Varia}

Conney F88,649/67: A review of the literature on more than 200 drugs leads to the conclusion that "there is no apparent relationship between either their actions or structure and their ability to induce enzymes. It is of interest that most of the inducers are soluble in lipid at a physiological $\mathrm{pH}$."

Moscona \& Piddington F90,487/67: In retinal explants of 12-day chick embryos, glutamine synthetase activity can be induced by the addition of various corticoids to the culture medium. Cortisol, corticosterone and aldosterone are particularly active in this respect, whereas pregnenolone, progesterone, DOC, 11-desoxycortisol, $17 \alpha$-hydroxyprogesterone, and $11 \alpha$-hydroxyprogesterone had little activity. 11 $\beta$-Hydroxyprogesterone and $11 \beta, 17 \alpha$-dihydroxyprogesterone exhibited intermediate degrees of activity. Apparently, "the $11 \beta$-position is of primary significance in the activity of these molecules in inducing retinal glutamine synthetase in this system. 
Table 140. Effect of the standard conditioners upon body and organ weights

\begin{tabular}{|c|c|c|c|c|}
\hline Treatmenta & $\begin{array}{l}\text { Final body } \\
\text { weight } \\
\text { (g) }\end{array}$ & $\begin{array}{l}\text { Liver } \\
\text { weight } \\
\text { (g) }\end{array}$ & $\begin{array}{l}\text { Kidney } \\
\text { weight } \\
\text { (mg) }\end{array}$ & $\begin{array}{l}\text { Preputial glands } \\
\text { weight } \\
\text { (mg) }\end{array}$ \\
\hline None & $131 \pm 2$ & $5.0 \pm 0.1$ & $533.1 \pm 8.9$ & $48.8 \pm 1.9$ \\
\hline PCN & $130 \pm 2 \mathrm{NS}$ & $7.4 \pm 0.2 * * *$ & $518.4 \pm 8.0 \mathrm{NS}$ & $51.4 \pm 2.3 \mathrm{NS}$ \\
\hline CS-1 & $140 \pm 3 *$ & $6.4 \pm 0.2 * * *$ & $528.7 \pm 10.6 \mathrm{NS}$ & $68.9 \pm 3.3 * * *$ \\
\hline Ethylestrenol & $142 \pm 3 * *$ & $5.8 \pm 0.1 * * *$ & 512.8 士 $6.9 \mathrm{NS}$ & $106.5 \pm 5.4 * * *$ \\
\hline Spironolactone & $138 \pm 2 * *$ & $5.9 \pm 0.1 * * *$ & $484.9 \pm 6.4 * * *$ & $47.1 \pm 2.9 \mathrm{NS}$ \\
\hline Norbolethone & $144 \pm 3 * * *$ & $5.6 \pm 0.2 * *$ & $529.0 \pm 10.7 \mathrm{NS}$ & $99.7 \pm 4.8 * * *$ \\
\hline Oxandrolone & $135 \pm 2 \mathrm{NS}$ & $5.1 \pm 0.1 \mathrm{NS}$ & $520.1 \pm 8.4 \mathrm{NS}$ & $88.0 \pm 3.1 * * *$ \\
\hline Prednisolone-Ac & $82 \pm 1 * * *$ & $7.1 \pm 0.2 * * *$ & $726.6 \pm 12.2 * * *$ & $43.3 \pm 2.9 \mathrm{NS}$ \\
\hline Triamcinolone ( $2 \mathrm{mg})$ & $90 \pm 2 * * *$ & $5.9 \pm 0.2 * * *$ & $609.6 \pm 10.4 * * *$ & $42.1 \pm 2.8 \mathrm{NS}$ \\
\hline Progesterone & $130 \pm 3 \mathrm{NS}$ & $5.3 \pm 0.1 \mathrm{NS}$ & $531.1 \pm 6.3 \mathrm{NS}$ & $66.3 \pm 2.6 * * *$ \\
\hline Estradiol & $90 \pm 3 * * *$ & $6.1 \pm 0.3 * * *$ & $666.3 \pm 17.0 * * *$ & $41.9 \pm 4.6 \mathrm{NS}$ \\
\hline DOC-Ac & $125 \pm 2 \overline{\mathrm{NS}}$ & $4.9 \pm 0.1 \mathrm{NS}$ & $546.7 \pm 8.3 \mathrm{NS}$ & $54.1 \pm 2.5 \mathrm{NS}$ \\
\hline Hydroxydione & $124 \pm 2$ * & $4.9 \pm 0.1 \mathrm{NS}$ & $546.5 \pm 13.7 \mathrm{NS}$ & $56.9 \pm 2.6 *$ \\
\hline Thyroxine & $127 \pm 2 \mathrm{NS}$ & $5.7 \pm 0.1 * * *$ & $618.7 \pm 8.3 * * *$ & $54.8 \pm 4.1 \mathrm{NS}$ \\
\hline Phenobarbital & $129 \pm 2 \mathrm{NS}$ & $6.8 \pm 0.2 * * *$ & $554.7 \pm 11.8 \mathrm{NS}$ & $62.0 \pm 3.2 * * *$ \\
\hline
\end{tabular}

a 25 ㅇ $100 \mathrm{~g}$ rats per group. All treatments were given at the standard dose levels ( $c f$. p. VIII) from the 1st to the 8 th day. Final body weights were registered on the 9 th day at which time the organs were fixed in formalin saturated with picric acid. All organ weights are listed as a percentage of the final body weight. (Student's t-test comparing all weights with the corresponding values of the untreated controls.)

For further details on technique of tabulation, $c f$. p. VIII.

This conclusion is further supported by the fact that cortisone, which has a ketone group in the 11-position, had no effect under these conditions."

Wattenberg et al. G71,805/68: In rats, the relationship between chemical structure and benzpyrene hydroxylase activity was studied on a large series of 2-phenylbenzothiazoles. "Introduction of an appropriate halogen into the $4^{\prime}$-phenyl position approximately doubles inducing activity compared to unsubstituted 2-phenylbenzothiazole. Other substitutions and modifications of the molecule result in either lesser increases in inducing activity or, in some instances, reduction or total loss of inducing activity. Most compounds show similar inducing effects on both lung and liver."

Selye G70,421/70: 304 Steroid were tested for their ability to protect rats against usually fatal intoxication with indomethacin or digitoxin. Using a "Simplified Activity Grading" system, 65 among these compounds were found to be active against indomethacin, 54 against digitoxin, and 23 against both substrates at a $10 \mathrm{mg}$ dose level. But only 4 of these steroids were still capable of inhibiting one or both of these substrates at the $0.5 \mathrm{mg}$ dose level. The only steroid still active against both substrates at the dose of $0.2 \mathrm{mg}$ was pregnenolone carbonitrile "PCN" ( $3 \beta$-hydroxy20-oxo-5-pregnene-16 $\alpha$-carbonitrile).

Selye G70,480/71: A review (28 pp., 111 refs.) on "Hormones and Resistance." The historic developments and present status of our concept of syntoxic and catatoxic steroids is summarized and the standard techniques for the in vivo bioassay of protective hormones are described at length.

Solymoss et al. G60,084/71: In rats, ethylestrenol, norbolethone, progesterone, triamcinolone, prednisolone and hydroxydione exhibited no antimineralocorticoid properties (Kagawa's test). Thus, the catatoxic effect of steroids appears to be unrelated to antimineralocorticoid potency.

Selye PROT. 43477: In otherwise untreated $100 \mathrm{~g}$ \% rats, the influence of the most commonly used conditioners upon the final body and organ weights (the latter expressed as a percentage of the body weight) has been determined for comparison with the experiments in which such conditioning agents were given conjointly with toxicants. After eight days of treatment, the final body weight was diminished 
Table 140 (continued)

\begin{tabular}{|c|c|c|c|c|}
\hline $\begin{array}{l}\text { Uterus } \\
\text { weight } \\
\text { (mg) }\end{array}$ & $\begin{array}{l}\text { Ovary } \\
\text { weight } \\
\text { (mg) }\end{array}$ & $\begin{array}{l}\text { Thymus } \\
\text { weight } \\
\text { (mg) }\end{array}$ & $\begin{array}{l}\text { Thyroid } \\
\text { weight } \\
\text { (mg) }\end{array}$ & $\begin{array}{l}\text { Adrenal } \\
\text { weight } \\
\text { (mg) }\end{array}$ \\
\hline $149.6 \pm 31.0$ & $11.3 \pm 0.8$ & $244.5 \pm 14.3$ & $6.8 \pm 0.2$ & $14.2 \pm 0.3$ \\
\hline $164.0 \pm 27.1 \mathrm{NS}$ & $7.9 \pm 0.8$ *** & $267.2 \pm 8.7 \mathrm{NS}$ & $9.0 \pm 0.4 * * *$ & $15.9 \pm 0.4 * *$ \\
\hline $133.8+13.0 \mathrm{NS}$ & $10.3 \pm 0.7 \mathrm{NS}$ & $234.7 \pm 19.4 \mathrm{NS}$ & $8.5 \pm 0.4 * *$ & $12.4 \pm 0.3 * * *$ \\
\hline $183.4 \pm 12.5 \mathrm{NS}$ & $8.5 \pm 0.6 * *$ & $137.6 \pm 9.2 * * *$ & $7.4 \pm 0.6 \mathrm{NS}$ & $10.4 \pm 0.3 * * *$ \\
\hline $147.0 \pm 26.3 \mathrm{NS}$ & $9.0 \pm 0.7 *$ & $253.2 \pm 12.1 \mathrm{NS}$ & $7.3 \pm 0.6 \mathrm{NS}$ & $12.2 \pm 0.3 * * *$ \\
\hline $168.6+13.2 \mathrm{NS}$ & $7.0 \pm 0.7 * * *$ & $157.5 \pm 11.6$ *** & $8.2 \pm 0.4 * *$ & $10.8+0.4 * * *$ \\
\hline $331.1 \pm 29.9 * * *$ & $9.5 \pm 0.5 \mathrm{NS}$ & $174.2 \pm 8.9$ *** & $7.4 \pm 0.4 \mathrm{NS}$ & $12.5 \pm 0.3 * * *$ \\
\hline $144.3 \pm 8.4 \mathrm{NS}$ & $10.6 \pm 0.6 \mathrm{NS}$ & $19.3 \pm 1.5 * * *$ & $10.0 \pm 0.6 * * *$ & $10.1 \pm 0.5 * * *$ \\
\hline $105.8+12.7 \mathrm{NS}$ & $13.1 \pm 0.9 \mathrm{NS}$ & $25.0 \pm 2.0 * * *$ & $8.2 \pm 0.4 *$ & $10.6 \pm 0.8 * * *$ \\
\hline $144.5 \pm 37.1 \mathrm{NS}$ & $7.8 \pm 0.7 * *$ & $249.4 \pm 16.8 \mathrm{NS}$ & $7.2 \pm 0.5 \mathrm{NS}$ & $12.4 \pm 0.3 * * *$ \\
\hline $535.2 \pm 98.4 * *$ & $14.7 \pm 1.6 \mathrm{NS}$ & $63.7 \pm 8.4 * * *$ & $8.3 \pm 0.3 * *$ & $19.6 \pm 0.8 * * *$ \\
\hline $144.9 \pm 37.1 \mathrm{NS}$ & $8.7 \pm 0.7$ * & $217.9 \pm 16.0 \mathrm{NS}$ & $8.0 \pm 0.4 *$ & $12.8 \pm 0.4$ * \\
\hline $155.3 \pm 46.3 \mathrm{NS}$ & $8.4 \pm 0.8 \underline{*}$ & $279.3 \pm 23.3 \mathrm{NS}$ & $8.2 \pm 0.5 *$ & $15.0 \pm 0.7 \mathrm{NS}$ \\
\hline $74.5+9.8 *$ & $6.7 \pm 0.7 * * *$ & $243.5+17.5 \mathrm{NS}$ & $6.2+0.4 \mathrm{NS}$ & $15.0 \pm 0.6 \mathrm{NS}$ \\
\hline $137.7 \pm 31.3 \mathrm{NS}$ & $10.4 \pm 0.8 \mathrm{NS}$ & $290.9 \pm 14.9 *$ & $10.0 \pm 0.4 * * *$ & $15.5 \pm 0.5 *$ \\
\hline
\end{tabular}

by prednisolone, triamcinolone and estradiol. To a lesser extent, hydroxydione also caused a decrease in body weight gain, but this may have been due to the prolonged daily anesthetic effect of this steroid. The rats treated with anabolics, particularly ethylestrenol and norbolethone, showed a body weight increase but this was not pronounced during this short time experiment. Although oxandrolone likewise proved to be anabolic in earlier experiments (in that it combated the catabolism produced by DHT or glucocorticoids) it did not cause an absolute increase in body weight. When organ weights were expressed as percentages of the final body weight, significant hepatic enlargement was obtained by PCN, CS-1, spironolactone, norbolethone, prednisolone, triamcinolone, estradiol and phenobarbital. This is of interest since triamcinolone and estradiol are virtually devoid of catatoxic potency. Among all steroids, PCN caused the greatest hepatic enlargement, exceeding even that elicited by phenobarbital. The percental increase in renal weight was especially conspicuous following treatment with prednisolone, triamcinolone, estradiol and thyroxine, although the glucocorticoids and estradiol markedly diminished the absolute final body weight of these same animals. Phenobarbital and PCN caused no renal enlargement. The preputial glands are only imperfect indicators of testoid activity. Our earlier experiments showed that ordinary pregnenolone (3 $\beta$-hydroxy-5-pregnen-20-one) possesses a pronounced preputial gland stimulating effect, although it is virtually devoid of typical testoid actions upon the capon's comb or the castrate rat's seminal vesicles. The insignificant increase in preputial gland weight, observed under our experimental conditions following treatment with PCN, suggests that the attachment of the carbonitrile group to this molecule decreases rather than increases its preputial gland stimulating action. In any event, the compound is much less "virilizing" under these conditions than is progesterone. The preputial glands were most markedly enlarged following treatment with ethylestrenol, norbolethone and oxandrolone, but to a lesser extent also by CS-1, progesterone and phenobarbital, perhaps owing to the endogenous production of testoid metabolites. As expected, uterine enlargement was greatest after treatment with estradiol, but some increase in uterine weight was noted also under the influence of oxandrolone, whereas thyroxine had an inverse effect. None of the conditioners tested caused ovarian enlargement, but PCN, ethylestrenol, norbolethone, progesterone and thyroxine induced significant ovarian atrophy. The thymus weight was most markedly diminished by prednisolone, triamcinolone and estradiol, but to a lesser extent also by ethylestrenol, norbolethone and oxandrolone. Curiously, phenobarbital appears to have caused a barely significant and PCN a nonsignificant increase in thymus weight. Phenobarbital, prednisolone, 
PCN, CS-1, norbolethone and estradiol also increased the weight of the thyroid approximately in decreasing order as enumerated. The most pronounced adrenal hypertrophy was elicited by estradiol, but minor degrees were also obtained by PCN and phenobarbital. Possibly, detoxication of endogenous corticoids might have led to a compensatory hypertrophy of this magnitude. On the other hand, CS-1, ethylestrenol, spironolactone, norbolethone, oxandrolone, prednisolone, triamcinolone, progesterone and DOC caused a diminution of the percental adrenal weight, $c f$. Table 140, p. 860 .

Selye PROT. 22393: There appears to be no obligatory relationship between glucocorticoid and catatoxic activity. Thus, large doses of prednisolone offer excellent protection against the ulcerogenic effect of indomethacin, whereas triamcinolone, a much more potent glucocorticoid, is devoid of this protective effect over a broad dose range cf. Table 141.

Solymoss PROT. 42234: As judged by the Kagawa test, PCN is practically devoid of antimineralocorticoid activity. In male adrenalectomized adult rats, $6 \mu \mathrm{g}$ of DOC s.c. produced a pronounced decrease in the urinary $\mathrm{Na} / \mathrm{K}$ excretion, which could not be counteracted by $1 \mathrm{mg}$ of PCN.

Table 141. Glucocorticoid potency not responsible for inactivation of indomethacin by prednisolone

\begin{tabular}{|c|c|c|}
\hline Treatment (mg) ${ }^{a}$ & $\begin{array}{l}\text { Intestinal } \\
\text { ulcers }(\%)^{b}\end{array}$ & $\begin{array}{l}\text { Mortality } \\
(\text { Dead/Total)b }\end{array}$ \\
\hline None & 100 & $5 / 5$ \\
\hline Triamcinolone 0.1 & 100 & $5 / 5$ \\
\hline Triamcinolone 0.5 & 100 & $5 / 5$ \\
\hline Triamcinolone 10 & 100 & $5 / 5$ \\
\hline Prednisolone $\quad 0.1$ & 100 & $5 / 5$ \\
\hline Prednisolone 0.5 & 100 & $4 / 5$ \\
\hline Prednisolone 10 & 0 & $0 / 5$ \\
\hline
\end{tabular}

a In addition to the treatments listed in this column, the rats (100 $\mathrm{g}$ \%) of all groups received indomethacin $1 \mathrm{mg}$ in $0.2 \mathrm{ml}$ water/ day, s.c., on 4th day ff. Triamcinolone and prednisolone were given at the doses indicated in $1 \mathrm{ml}$ water $\times 2 /$ day, p.o., 1st day $\mathrm{ff}$.

b Intestinal ulcers ( $\%$ positive) and mortality on 10th day.

\section{SUMMARY AND OUTLOOK}

This treatise attempts to outline the history and present status of research on the regulation of resistance by hormones. It would obviously be impossible to give a meaningful résumé of this vast field here, but it may be helpful to summarize the highlights of the research with which our group has had personal experience, namely: the effect of natural and artificial steroids upon comparatively nonspecific resistance phenomena.

The protective agents are classified, according to their mechanism of action, into two main groups: 1. "syntoxic" compounds which improve tissue tolerance by permitting a symbiotic type of coexistence with the pathogen (e.g., by suppressing inflammatory reactions); 2 . "catatoxic" substances which actually destroy the aggressor (e.g., through the induction of hepatic microsomal enzymes).

The syntoxic effects are virtually limited to glucocorticoids, and since these have received sufficient attention in the past, this monograph deals primarily with recent studies on catatoxic steroids.

We have tested more than 500 steroids, under comparable conditions, for their possible protective effect against numerous toxicants. The results of these studies are tabulated and their evaluation revealed the following principal facts:

1. The catatoxic effect can manifest itself independently of all classic hormonal actions, although it is frequently associated with anabolic, antimineralocorticoid or glucocorticoid properties.

2. Some of the most potent catatoxic steroids are carbonitriles; these also have an unusually broad "spectrum of activity", in that they protect against many toxicants. 
3. The $16 \alpha$-position of the - CN group appears to be particularly advantageous for catatoxic activity. Its introduction into a virtually ineffective steroid, e.g., 5-pregnenolone, endows the latter with sufficient catatoxic potency to protect a rat, at dose levels as low as $300 \mu \mathrm{g} / \mathrm{kg}$, against fatal digitoxin or indomethacin intoxication.

4. Steroids may serve as especially favorable carriers of pharmacologically active groups, for example of thioacetyl (for the detoxication of mercury), quaternary ammonium bases (for the induction of a neuromuscular block), oncolytic agents, etc.

5. Certain catatoxic steroids possess abortifacient properties and interfere with lactation.

6. It is not yet proven that effective amounts of catatoxic steroids are normally secreted in response to a need (as glucocorticoids are during stress). However, they certainly represent basic "soil-factors" determining normal resistance; for example testosterone in amounts secreted by the testis raises the resistance of male rats far above that of females or gonadectomized animals of either sex. Furthermore, corticosterone - the natural life-maintaining steroid of the rat - possesses catatoxic activity against several substrates and is undoubtedly secreted in response to a need during stress.

7. Certain substrates, which are not subject to inactivation by steroidal or nonsteroidal catatoxic compounds, can be "opsonized" (that is made amenable to this type of detoxication) by the addition of a radical. Thus, morphine is resistant, whereas ethylmorphine is highly sensitive, to inactivation by various compounds (catatoxic steroids, phenobarbital). This may well be due to a decrease in the polarity of the compound which may facilitate its penetration through membranes to the sites where enzymic detoxication can occur. It is interesting to speculate about the multitude of toxicants that might be made amenable to steroid-induced degradation if we learned how to stimulate their fat solubilization in vivo.

8. Many observations suggest that both syntoxic and catatoxic steroids may have important clinical applications in a variety of diseases caused by exogenous or endogenous toxicants. This is particularly true of maladies due to pathogens amenable to biotransformation by hepatic microsomal enzymes. In principle, here, enzyme induction would have to precede contact with the pathogen, and, hence, catatoxic steroids would be expected to have only prophylactic potency. Yet, if the pathogens act over a prolonged period (e.g., chronic indomethacin or digitoxin intoxication), curative effects have been obtained even when treatment was begun only after clinical manifestations of intoxication had become evident. Finally, if catatoxic steroids are important, "soil-factors" determining normal resistance, we should search for the possible existence of diseases caused by inadequate production of these compounds, or of disturbances in the responsiveness of the enzyme-inducing mechanisms which they regulate. Such maladies might be expected to result not only in deficient detoxication of exogenous pathogens but also in deficient or excessive degradation of endogenous chemical constituents of the body, such as hormones and metabolites.

As we have said in the Introduction to this monograph, animals are endowed with a complex hormonal defense system comparable in its scope to those based upon nervous, or immunologic reactions. Through conscious planning of defense, conditioned reflexes, or autonomic "emergency reactions," the body can adapt standard responses of its nervous system to defense against a multitude of specific injuries. Appropriate 
immunologic reactions can adjust the basic phenomenon of antibody formation to cope with a great variety of potential pathogens which possess antigenic properties.

The main purpose of this monograph was to show that there exists a third general adaptive system in which a group of hormones and hormone derivatives (particularly steroids) offer resistance to agents not easily combated through the first-mentioned two defensive mechanisms; here, syntoxic hormones help to tolerate a pathogen, whereas catatoxic substances destroy it.

The 35 years of research - from the first description of the defensive role of corticoids in combating stress, to the latest observations on the extraordinary catatoxic potency of steroid carbonitriles - represent only a rough outline of the introductory phase in the elucidation of the hormonal defense system. The many references cited in the preceding pages clearly show that even in this first sketch, our own observations provided only a small percentage of the established facts. We have raised more questions than we have answered; but perhaps, by providing an inventory of pertinent facts, this monograph will help others to clarify this new field, which appears to have implications in virtually all phases of homeostasis under physiologic and pathologic conditions. 


\section{REFERENCES}

Abbott, D. D., Harrisson, W. E.: Further study of the effect of salicylates upon the osseous tissue of young rats. Fed. Proc. 24, 640 (1965).

$[\mathrm{F} 36,510 / 65$

Abderhalden, E.: Weitere Beiträge zur Kenntnis von Nahrungsstoffen mit spezifischer Wirkung. XXIII. Vergleichende Versuche über das Verhalten von schilddrüsenlosen Meerschweinchen und solchen, die Schilddrüsen besitzen, gegenüber einer Nahrung, die zum Skorbut führt. Pflügers Arch. ges. Physiol. 198, 164-168 (1923).

$[13,399 / 23$

Abderhalden, E.: Der gegenwärtige Stand der Erforschung der Abwehrfermente (AbwehrProteinasen). In: Schweizerischen medizinischen Jahrbuch 1933. Basel: Benno Schwabe and Co. 1933.

$[67,622 / 33$

Abderhalden, E., Wertheimer, E.: Versuche über den Einfluß des Geschlechts auf die Alkoholwirkung. Biochem. Z. 186, 252 (1927).

$[\mathrm{A} 49,424 / 27$

Abderhalden, E., Wertheimer, E.: Studien über die Wirkung des Thyroxins auf den tierischen Organismus und insbesondere auf die Wärmeregulation des Gleichwarmblüters. Pflügers Arch. ges. Physiol. 219, 588-608 (1928).

$[19,292 / 28$

Abdul-Karim, R. W., Prior, J. T., Nesbitt, R. E. L. Jr.: Influence of maternal estrogen on fetal bone development in the rabbit. Obstet. and Gynec. 31, 346-353 (1968). [G55,510/68 Abe, M., Langendorfi, H.: Untersuchungen über einen biologischen Strahlenschutz. 60 . Mitteilg.: Das Verhalten des Hodengewebes von Mäusen bei einmaliger oder wiederholter lokaler Bestrahlung unter Serotonin-Schutz. Strahlentherapie 125, 358-370 (1964).

[G23,763/64

Abelin, I.: Über die Beziehungen zwischen Carotin (Vitamin A) und Thyroxin. Hoppe-Seylers Z. physiol. Chem. 217, 109-114 (1933). $[57,019 / 33$

Abelin, I., Schönenberger, A.: Utber den Antagonismus Dijodtyrosin: Thyroxin und über die Rolle der Diät bei der Hyperthyreose. Z. ges. exp. Med. 88, 528-542 (1933).

$[4,290 / 33$
Abernathy, R.: The effect of cortisone on experimental brucellosis. 43rd Meet. Amer. Soc. clin. Invest. p. 5 (1951).

[B57,911/51

Abernathy, R., Spink, W. W.: The influence of cortisone and adrenocorticotrophic hormone on brucellosis. I. Cortisone in experimentally infected animals. J. clin. Invest. 31, 947-957 (1952).

$[\mathrm{B} 75,468 / 52$

Abernathy, R. S., Spink, W. W.: Resistance to endotoxin after protection against initial lethal challenge with adrenocorticosteroids or chlorpromazine. Proc. Soc. exp. Biol. (N.Y.) 95, 580-581 (1957).

$[\mathrm{G} 68,366 / 57$

Abernathy, R. S., Spink, W. W.: Studies with brucella endotoxin in humans: the significance of susceptibility to endotoxin in the pathogenesis of brucellosis. J. clin. Invest. 37, 219-231 (1958).

$[\mathrm{C} 48,635 / 58$

Abraham, S., Kopelovich, L., Chaikoff, I. L.: Dietary and hormonal regulation of the hepatic citrate-cleavage enzyme. Biochim. biophys. Acta (Amst.) 93, 185-187 (1964). [G20,214/64

Abrams, H. L.: Influence of age, body weight, and sex on susceptibility of mice to the lethal effects of X-radiation. Proc. Soc. exp. Biol. (N.Y.) 76, 729-732 (1951). [B58,956/51

Adamkiewicz, V. W.: Insulin sensitization to the action of K-strophanthin. Canad. $J$. Biochem. 39, 9-13 (1961). $\quad[C 97,998 / 61$

Adamkiewiez, V. W.: Glycemia and immune responses. Canad. med. Ass. J. 88, 806-811 (1963).

$[\mathrm{D} 61,626 / 63$

Adamkiewiez, V. W., Adamkiewicz, L. M.: Alloxan diabetes and dextran 'anaphylactoid' inflammation. Amer. J. Physiol. 197, 377-379 (1959).

$[\mathrm{C} 73,760 / 59$

Adamkiewiez, V. W., Kopacka, B., Fredette, V.: Rôle du diabète alloxanique dans la gangrène gazeuse expérimentale de la souris blanche. Rev. canad. Biol. 26, 153-157 (1967).

[F99,983/67

Adamkiewicz, V. W., Langlois, Y.: Sensitization by insulin to the dextran 'anaphylactoid' reaction. Canad. J. Biochem. 35, 251-256 (1957). 
Adams, W. M., Wagner, W. C.: The role of corticoids in parturition. Biol. Reprod. 3, 223-228 (1970).

$[\mathrm{G} 80,309 / 70$

Adelman, R. C.: Reappraisal of biological ageing. Nature (Lond.) 228, 1095-1096 (1970).

$[\mathrm{H} 32,850 / 70$

Adlard, B. P. F., Lathe, G. H.: Breast milk jaundice: effect of $3 \alpha 20 \beta$-pregnanediol on bilirubin conjugation by human liver. Arch. Dis. Childh. 45, 186-189 (1970). [G74,759/70 Adler, T. K., Elliott, H. W., George, R.: Some factors affecting the biological disposition of small doses of morphine in rats. J. Pharmacol. exp. Ther. 119, 475-487 (1957). [G 79,852/57 Adlerereutz, H.: Oestrogen metabolism in liver disease. J. Endocr. 46, 129-163 (1970).

$[\mathrm{H} 21,321 / 70$

Adlersberg, D., Wang, C. I., Schaefer, L. E.: Extreme elevation of plasma lipids in the cholesterol-fed rabbit treated with cortisone and hydrocortisone. J. clin. Invest. 32,550 to 551 (1953).

[B 82,951/53

Adolph, E. F.: Lethal limits of cold immersion in adult rats. Amer. J. Physiol. 155, 378-387 (1948).

[B35,581/48

Agarkov, F. T., Maximovich, V. A., Namyatny, A. N.: The significance of adrenal glands for the thermal resistance of the body. (Russian text.) Probl. Endokr. Gormonoter. 8/15, 15-21 (1962).

$[\mathrm{D} 40,496 / 62$

Agarwal, M. K., Berry, L. J.: Effect of RESactive agents on tryptophan pyrrolase activity and endotoxin lethality. $J$. reticuloendoth. Soc. 3, 223-235 (1966).

[G66,479/66

Agarwal, M. K., Berry, L. J.: Influence of reticuloendothelial-active agents on inducible liver enzymes in mice. J. reticuloendoth. Soc. 4, 490-509 (1967).

$[\mathrm{G} 66,480 / 67$

Agarwal, M. K., Berry, L. J.: Reticuloendothelial response and liver enzyme induction in relation to endotoxicosis in mice. Biochem. Med. 2, 274-285 (1969).

$[\mathrm{G} 65,866 / 69$

Agarwal, M. K., Hoffman, W. W., Rosen, F.: The effect of endotoxin and thorotrast on inducible enzymes in the isolated, perfused rat liver. Biochim. biophys. Acta (Amst.) 177, 250-258 (1969).

[G65,716/69

Agduhr, E.: Ergosterin erhöht die Fruchtbarkeit bei den Versuchstieren, und die normalen sexuellen Funktionen steigern ihre Widerstandskraft gegenüber der Toxizität des Ergosterins. Z. mikr.-anat. Forsch. 36, 576 bis 588 (1934).

$[52,908 / 34$

Agduhr, E.: Ergosterol increases the prolific capacity of the experimental animals, and nor- mal sexual functions intensify their resisting power against the toxicity of the ergosterol. Z. Vitaminforsch. 4, 54-65 (1935). [70,849/35 Agduhr, E.: Sexual intercourse increases the resisting power of the organism against injurious factors. Skand. Arch. Physiol. 77, 2-4 (1937).

$[\mathrm{A} 51,257 / 37$

Agduhr, E.: Internal secretion and resistance to injurious factors. Acta med. scand. 99, $387-424$ (1939).

$[75,856 / 39$

Agduhr, E.: Till kännedomen om på hormonell väg åstadkommen resistensökning och mekanismen härvid (Swedish text with German summary: Studien über hormonale Resistenzsteigerung und ihren Mechanismus). Hygiea (Stockh.) 104, 1587-1598 (1941). [G37,252/41

Agduhr, E.: Einiges über Methoden und Ergebnisse bei Forschung über resistenzfördernde Wirkungen der Sexualfunktionen. Z. mikr.anat. Forsch. 49, 589-615 (1941). [A39,060/41 Agduhr, E.: Contributions to the knowledge of the mechanism behind the heightened resistance brought about by the normal sexual functions. Läk.-Fören. Förh. 47, 1-54 (1941).

[E 70,688/41

Aggeler, P. M., 0'Reilly, R. A.: Effect of heptabarbital on the response to bishydroxycoumarin in man. J. Lab. clin. Med. 74, 229-238 (1969).

$[\mathrm{G} 68,730 / 69$

Agnoli, R. T.: Study of pituitary hormones. IV. Relation between hypophysis hormones and vitamin C. J. Pharmacol. exp. Ther. 44, 47-53 (1932).

$[2,633 / 32$

Agostini, L., Giagheddu, M.: The effect of hormones on experimental catalepsy induced by reserpine. IV. On testosterone, follicular hormone, corticosteroids and adrenaline. Riv. Neurobiol. 9/1, 32-40 (1963). [G14,490/63

Aird, R. B.: The effect of desoxycorticosterone in epilepsy. J. nerv. ment. Dis. 99, 501 to 510 (1944).

[B $683 / 44$

Aitio, A., Hänninen, 0.: The activities of rat liver alanine, aspartate and tyrosine aminotransferases during the administration of cinchophen. Ann. Med. exp. Fenn. 45, 239 to 242 (1967).

$[\mathrm{G} 66,417 / 67$

Akerrén, Y.: Prolonged jaundice in the newborn associated with congenital myxedema. A syndrome of practical importance. Acta paediat. (Uppsala) 43, 411-425 (1954).

$[\mathrm{G} 76,866 / 54$

Akoev, I. G., Lagun, M. A., Klassovskii, Y. A.: Efficacy of hormone therapy of radiation effects. (Russian.) Radiobiologiya 5/6, 827-832 (1965).

$[\mathrm{F} 73,202 / 65$ 
Alam, S. Q., Boctor, A. M., Rogers, Q. R., Harper, A. E.: Some effects of amino acids and cortisol on tyrosine toxicity in the rat. J. Nutr. 93, 317-323 (1967). [G53,636/67

Albert, S.: Influence of testosterone on the morphogenetic actions of estradiol. Endocrinology 30, 454-458 (1942). [A37,132/42

Albert, S., Selye, H.: The effect of various pharmacological agents on the morphogenetic actions of estradiol. J. Pharmacol. exp. Ther. 75, 308-315 (1942).

[A37,637/42

Aldrete, J. A., Homatas, J., Boyes, R. N., Starzl, T. E.: Effects of hepatectomy on the disappearance rate of lidocaine from blood in man and dog. Anesth. Analg. Curr. Res. 49, 687-690 (1970).

[G78,399/70

Aldrete, J. A., Weber, M.: Le rôle du foie dans le métabolisme des agents anesthésiques; leur influence sur la physiopathologie hépatique. Anest. Analg. Réanim. 27, 297-314 (1970).

[G75,396/70

Aldridge, W. N., Barnes, J. M.: Some problems in assessing the toxicity of the 'organophosphorus' insecticides towards mammals. Nature (Lond.) 169, 345-347 (1952). [G41,307/52

Alexander, C. S., Hunt, V. R.: Inhibition of aminonucleoside nephrosis in rats. II. Effect of nucleic acid precursors and L-triiodothyronine. Proc. Soc. exp. Biol. (N.Y.) 108, 706-709 (1961).

[D20,284/61

Alexander, C. S., Hunt, V. R.: Evidence against immune mechanism in aminonucleoside nephrosis in rats. J. Lab. clin. Med. 62, 103-108 (1963).

[E20,128/63

Allardyce, J., Fitch, F., Semple, R.: Amelioration of experimental hypertension. Trans. roy. Soc. Can. Sect. 5, 42, 25-35 (1948).

[B29,416/48

Allegri, A., Campagnari, F., Paloschi, G.: Influenza del propionato di testosterone sulle lesioni epatiche indotte nei ratti da somministrazione prolongata di tetrachloruro di carbonio. Arch. Sci. med. 82, 118-141 (1957).

[C31,532/57

Allegri, A., Ferrari, V.: Ormoni sessuali maschili e steatosi epatica. II. Azione del propionato di testosterone sulla steatosi epatica da fosforo. Arch. Sci. med. 88, 440-453 (1949).

[B53,060/49

Allen, B. M., Ewell, L. M.: Resistance of $\mathrm{X}$-irradiation by embryonic cells of the limbbuds of tadpoles. J. exp. Zool. 142, 309-335 (1959).

$[\mathrm{C} 92,110 / 59$
Allison, A. C., Taylor, R. B.: Observations on thymectomy and carcinogenesis. Cancer Res. 27, 703-707 (1967).

[F 83,300/67

Alonso, A.: Efecto de la cicloheximida sobre la cancerizacion hepatica con dietilnitrosamina. Rev. esp. Fisiol. 26, 347-364 (1970).

[G81,092/70

Alper, R., Rubulis, A., Prior, J. T., Ruegamer, W. R.: Effects of methylprednisolone on plasma lipids and aortic mucopolysaccharides of normal and cholesterol-fed rabbits. Proc. Soc. exp. Biol. (N.Y.) 129, 623-627 (1968).

$[\mathrm{H} 5,589 / 68$

Alper, R., Ruegamer, W. R.: Hormonal effects on the acid mucopolysaccharide composition of the rat aorta. $J$. Atheroscler. Res. 10, 19-32 (1969).

[H 17,023/69

Altieri, N., Bazerque, P., Denti, A.: Influencia de la tiroides sobre la acción del aloxano en la rata. Rev. Soc. argent. Biol. 34, 331-334 (1958).

$[\mathrm{C} 71,565 / 58$

Altucci, P., Coraggio, F., Pecori, V.: L'ormone somatotropo in alcune infezioni virali sperimentali in culture di cellule e in vivo. G. Mal. infett. 14, 418-425 (1962). [D65,819/62

Altucei, P., Coraggio, F., Pecori, V.: Il prednisolone ed i suoi derivati nelle infezioni virali sperimentali in culture di cellule in vitro ed in vivo nel topo. G. Mal. infett. 14, 403-417 (1962).

[D $65,818 / 62$

Altura, B. M., Hsu, R., Mazzia, V. D. B., Hershey, S. C.: Effects of vasopressors on the microcirculation and on survival in bowel ischemia shock. Fed. Proc. 24, 340. (1965).

$$
\text { [F 36,124/65 }
$$

Altura, B. M., Hsu, R., Mazzia, V. D. B., Hershey, S. G.: Influence of vasopressors on survival after traumatic, intestinal ischemia and endotoxin shock in rats. Proc. Soc. exp. Biol. (N.Y.) 119, 389-393 (1965).

[F43,209/65

Amante, S.: Azione dell'ormone somatotropo ipofisario in condizioni sperimentali di shock o reazione di allarme. Arch. Sci. med. 106, $702-719$ (1958).

$[\mathrm{C} 62,537 / 58$

Amante, S., Mancini, M.: Antitiroidei e reazione d'allarme. (Ricerche sperimentali). Gazz. int. Med. Chir. 61, 1146-1158 (1956). [C21,222/56

Ambre, J. J.: The effect of prednisolone on the metabolism of 5-fluorouracil in vivo. (Abstr.). Fed. Proc. 29, 610 (1970). [H24,704/70

Ambrus, J. L., Ambrus, C. M., Leonard, C. A., Moser, C. E., Harrisson, J. W. E.: Synergism between histamine, antihistamines, and hyp- 
notic drugs. J. Amer. pharm. Ass. sci. Ed. 41, 606-608 (1952).

$[\mathrm{C} 16,607 / 52$

Amici, A.: Sul comportamento di Mus musculus trattati con iniezione contemporanea di dosi letali di stricnina e varie sostanze adrenalinosimili. Riv. Biol. 46, 273-293 (1954).

$[\mathrm{C} 5,836 / 54$

Anan, S.: Utber den Einfluß des Schilddrüsenhormons auf die Giftwirkung von verschiedenen Opiumalkaloiden. Folia pharmacol. jap., 8, 17-41 (1929).

$[24,228 / 29$

Anas, P., Neely, W. A., Hardy, J. D.: Effects of vasoactive drugs on oxygen consumption in endotoxin shock. Arch. Surg. 98, 189-193 (1969).

[G64,139/69

Anderson, B. G.: Potency and duration of action of triiodothyronine and thyroxine in rats and mice. Endocrinology 54, 659-665 (1954).

[B94,669/54

Anderson, R. E., Doughty, W. E., Leonard, L.: Parabiotic intoxication in neonatally thymectomized germ-free mice. Arch. Path. 87, $469-473$ (1969).

[H11,186/69

Anderson, T. A., Hubbert, F. Jr., Roubicek, C. B.: Effect of thyroxine, thiouracil and ambient temperature on the utilization of vitamin A by vitamin A-deficient rats. $J$. Nutr. 82, 457-462 (1964).

[G11,709/64

Andersson, B., Ekman, L., Hökfelt, B., Jobin, M., Olsson, K., Robertshaw, D.: Studies of the importance of the thyroid and the sympathetic system in the defence to cold of the goat. Acta physiol. scand. 69, 111-118 (1967).

[G45,246/67

Andervont, H. B., Dunn, T. B.: Effect of castration and sex hormones on the induction of tumors in mice with o-aminoazotoluene. J. nat. Cancer Inst. 7, 455-461 (1947).

$[\mathrm{A} 96,182 / 47$

Andervont, H. B., Grady, H. G., Edwards, J. E.: Induction of hepatic lesions, hepatomas, pulmonary tumors, and hemangioendotheliomas in mice with o-aminoazotoluene. $J$. nat. Cancer Inst. 3, 131-153 (1942). [A94,080/42 Andreani, D.: Inibizione del fenomeno di Halpern e Martin mediante somministrazione di ACTH. Boll. Soc. ital. Biol. sper. 26, 1603-1604 (1950).

$[\mathrm{B} 63,732 / 50$

Andreani, D., Marescotti, V., Giacomelli, F.: L'azione tossica della T.E.M. nei ratti trattati con corticotropina e cortisone. Boll. Soc. med.-chir. Pisa 23, 593-606 (1955).

$[\mathrm{C} 14,628 / 55$

Andrews, W. H. H.: The blood flow of the liver. Brit. med. Bull. 13, 82-86 (1957). [D94,471/57
Andriole, V. T., Cohn, G. L.: Estrogen and the pathogenesis of hematogenous pyelonephritis in the rat. Clin. Res. 11, 408 (1963). [G807/63 Angel, C., Burkett, M. L.: Adrenalectomy, stress and the bloodbrain barrier. Dis. nerv. Syst. 27, 389-393 (1966).

[G39,712/66

Angela, G. C., Nola, F. di: Effetto del cortisone sullo sviluppo della Coxiella burnetii nell'uovo fecondato e nelle cavie. G. Mal. infett. 6, 488-492 (1954).

$[\mathrm{C} 12,561 / 54$

Angelakos, E. T., Daniels, J. B.: Effect of catecholamine infusions on lethal hypothermic temperatures in dogs. J. appl. Physiol. 26, 194-196 (1969).

$[\mathrm{G} 64,739 / 69$

Anonymous: Phenobarbitone and dicophane in jaundice. Lancet 1969 II, 144 - 145. [H 19,246/69

Antona, G.: Rilievi preliminari sulle possibilità d'impiego della 5-ossitriptamina per la prevenzione del sanguinamento nel corso di interventi chirurgici. Farmaco $E d$. sci. 10, $86-90$ (1955).

$[\mathrm{C} 11,379 / 55$

Antopol, W.: Anatomic changes produced in mice treated with excessive doses of cortisone. Proc. Soc. exp. Biol. (N.Y.) 73, 262-265 (1950).

$[\mathrm{E} 50,253 / 50$

Appelmans, R.: Réponse à la note de Kepinow et Lanzenberg au sujet du phénomène de l'anaphylaxie chez les animaux thyroïdectomisés. C. R. Soc. Biol. (Paris) 88, 1216 (1923).

$[14,085 / 23$

Aragona, F.: La capacità oncogena degli ormoni sessuali. II. Effetto delle sostanze androgene iniettate in animali con fegato leso. Arch. De Vecchi Anat. pat. 13, 157-173 (1949).

$[\mathrm{B} 53,747 / 49$

Aragona, F.: Modificazioni ematiche e degli organi emopoietici in seguito a introduzione di ormoni estrogeni in animali con fegato leso. Arch. E. Maragliano Pat. Clin. 5, 245-258 (1950).

$[\mathrm{B} 53,056 / 50$

Aragona, F., Barone, P.: Tiroide ed epatiti croniche sperimentali. Arch. E. Maragliano Pat. Clin. 8, 511-534 (1953). [B92,455/53

Araki, T.: The beneficial influence of corticotrophin, cortisol and nicotinamide on male mice exposed to cold stress, with special reference to the mode of action of nicotinamide. J. Fac. Sci. (Tokyo) 10, 101-106 (1963).

$[\mathrm{G} 11,847 / 63$

Arcasoy, M. M., Smuckler, E. A.: Acute effects of digoxin intoxication on rat hepatic and cardiac cells. Structural and functional changes in the endoplasmic reticulum. Lab. Invest. 20, 190-201 (1969).

$[\mathrm{G} 63,705 / 69$ 
Arcuri, F., Fontana, G., de Lorenzi, F.: Considerazioni sull'associazione protidoanabolizzante alla terapia con steroidi di tipo cortisonico. Minerva gastroent. 8, 136-139 (1962).

[D 65,779/62

Arias, I. M.: Effects of a plant acid (icterogenin) and certain anabolic steroids on the hepatic metabolism of bilirubin and sulfobromophthalein (BSP). Ann. N.Y. Acad. Sci. 104, 1014-1025 (1963).

[D 63,323/63

Arias, I. M., Gartner, L. M.: Production of unconjugated hyperbilirubinaemia in fullterm new-born infants following administration of pregnane-3(alpha), 20(beta)-diol. Nature(Lond.) 203, 1292-1293 (1964).

[F 21,711/64

Arias, I. M., Gartner, L. M., Cohen, M., Ezzer, J. B., Levi, A. J.: Chronic nonhemolytic unconjugated hyperbilirubinemia with glucuronyl transferase deficiency. Clinical, biochemical, pharmacologic and genetic evidence for heterogeneity. Amer. J. Med. 47, 395-409 (1969).

[G72,103/69

Arias, I. M., Gartner, L. M., Seifter, S., Furman, M.: Neonatal unconjugated hyperbilirubinemia associated with breast-feeding and a factor in milk that inhibits glucuronide formation in vitro. (Abstr.). J. clin. Invest. 42, 913 (1963).

$[\mathrm{G} 76,756 / 63$

Arias, I. M., Gartner, L. M., Seifter, S., Furman, M.: Prolonged neonatal unconjugated hyperbilirubinemia associated with breast feeding and a steroid, pregnane-3(Alpha), 20(Beta)Diol, in maternal milk that inhibits glucuronide formation in vitro. J. clin. Invest. 43, 2037 to 2047 (1964).

[F 24,502/64

Ariëns, E. J.: Reduction of drug action by drug combination. Fortschr. Arzneimittelforschg. 14 11-58 (1970).

[G79,943/70

Arima, K.: Utber den Einfluß des Thymusdrüsenhormons auf die Giftwirkung von einigen Opiumalkaloiden. Folia Pharmacol. jap. 21, $41-47$ (1935).

$[60,156 / 35$

Ariyoshi, T., Takabatake, E.: Drug metabolism in ethionine induced fatty liver. Life Sci. 9, 371-377 (1970).

$[\mathrm{G} 75,246 / 70$

Arlander, T. R.: Actions of cortisone, vitamin $B_{12}$, and androgens on hearts, livers and kidneys of mice. Anat. Rec. 139, 203 (1961).

[D5,055/61

Arnold, H., Delbrïck, A., Hartmann, F.: Beitrag zur Biochemie einer experimentellen Lebercirrhose und zur Möglichkeit, sie pharmakologisch zu beeinflussen. Dtsch. Arch. klin. Med. 209, 92-116 (1963).

$[\mathrm{E} 27,627 / 63$
Arnould, P., Lamarche, M., Jochum, F.: Influence de la cortisone sur la résistance à l'anoxémie chez le Cobaye non anesthésié. C. R. Soc. Biol. (Paris) 149, 557 (1955).

$[\mathrm{C} 12,257 / 55$

Aronsen, K. F., Grundsell, H., Ohlsson, E. G., Waldeskog, B.: Studies of the functional changes in the reticulo-endothelial and parenchymal cells of the liver following partial hepatectomy in dogs. Acta chir. scand. 135, 165-169 (1969).

$[\mathrm{H} 22,143 / 69$

Arora, R. B., Wig, K. L., Somani, P.: Effectiveness of hydrocortisone and hydrocortisoneantivenene combination against Echis carinatus snake venom. Arch. int. Pharmacodyn. 137, 299-306 (1962).

[D 27,786/62

Arrigo, L., Pontremoli, S.: Azione dell'ormone corticotropo ipofisario sulla rigenerazione del fegato dopo parziale epatectomia. Boll. Soc. ital. Biol. sper. 26, 258-259 (1950).

[B $54,373 / 50$

Arrigo, L., Trasino, M.: Ormoni anteroipofisari e morfologia del pancreas esocrino. Ormonologia 15, 1-19 (1955).

$[\mathrm{C} 21,687 / 55$

Arrigoni-Martelli, E., Galimberti, P., Gerosa, V., Kramer, M., Melandri, M.: Synthesis and potentiating activity of some malonic and succinic derivatives. Farmaco, Ed. sci., 15, 19-28 (1960).

$[\mathrm{G} 74,653 / 60$

Arrigoni-Martelli, E., Kramer, M.: Einfluß von Iproniazid und von Beta-phenylisopropylhydrazin (JB 516) auf die narkotische Wirkung und den Abbau von Hexobarbital und Thiopental. Med. Exp. (Basel) 1, 45-51 (1959).

[G74,659/59

Asagoe, T.: Biochemical studies on the development of experimental cirrhosis in albino rats induced by carbon tetrachloride. II. Study on the influence of cortisone upon the collagen contents in experimentally induced cirrhotic liver. (Japanese text.) Jap. Arch. intern. Med. 6, 1059-1064 (1959).

[D 13,524/59

Asagoe, T.: Biochemical studies on the development of experimental cirrhosis in albino rats induced by carbon tetrachloride. III. Study on the influence of castration and testosterone propionate upon the collagen contents in experimentally induced cirrhotic liver. Jap. Arch. intern. Med. 7, 171-176 (1960).

$[\mathrm{D} 13,523 / 60$

Aschkenasy, A.: Protection exercée par la caséine contre l'ostéolathyrisme chez le rat mâle. Protection réduite chez le rat femelle et le rat mâle castré. J. Physiol. (Paris) 52, 10-11 (1960). 
Aschkenasy, A.: Protection par la caséine alimentaire contre les lésions osseuses du lathyrisme chez le rat mâle. Protection réduite chez le rat femelle et le rat mâle castré. $C . R$. Soc. Biol. (Paris) 154, 556-560 (1960).

$[\mathrm{C} 91,685 / 60$

Aschkenasy, A.: Action de la thyroxine et du propylthiouracile sur l'ostéolathyrisme du rat. C. R. Soc. Biol. (Paris) 156, $434-438$ (1962).

[D30,881/62

Aschkenasy, A.: Action de la surrénalectomie, de la cortisone et de l'hormone somatotrope sur l'ostéolathyrisme du rat. C. R. Soc. Biol. (Paris) 156, 470-475 (1962). [D30,892/62 Aschkenasy-Lelu, P.: L'hormone du sexe faible. Une étude critique des divers effets protecteurs des oestrogènes. Rev. franç. Étud. clin. biol. 9, 109-117 (1964). [G9,425/64

Asher, L., Wagner, H.: Untersuchungen über die Spezifität der Asherschen Methode der Prüfung der Schilddrüsenfunktion durch Sauerstoffmangel.Z. ges. exp. Med. 68, 32-81 (1929). $[23,903 / 29$

Ashford, A., Ross, J. W.: Toxicity of depressant and antidepressant drugs in hyperthyroid mice. Brit. med. J. 1968I, 217-218.

$[\mathrm{H} 2,686 / 68$

Askew, B. M.: Hyperpyrexia as a contributory factor in the toxicity of amphetamine to aggregated mice. Brit. J. Pharmacol. 19, 245-257 (1962).

$[\mathrm{G} 72,695 / 62$

Aspinall, R. L.: Differential effect of spironolactone on the ulcerogenic and antiinflammatory activities of indomethacin. Proc. Soc. exp. Biol. (N.Y.) 135, 561-564 (1970).

[H32,269/70

Astarabadi, T.: The regression in the size of the hypertrophic remaining kidney after hypophysectomy in rats. Quart. J. exp. Physiol. 47, 93-97 (1962).

$[\mathrm{D} 8,815 / 62$

Astarabadi, T. M., Essex, H. E.: Effect of epinephrine on male and female albino rats. Amer. J. Physiol. 171, 75-77 (1952). [B75,437/52 Astarabadi, T. M., Essex, H. E.: Effect of hypophysectomy on size of remaining kidney after ureteroduodenostomy and contralateral nephrectomy. Proc. Soc. exp. Biol. (N.Y.) 81, 25-28 (1952).

$[\mathrm{B} 75,446 / 52$

Astarabadi, T. M., Essex, H. E.: Effect of hypophysectomy on compensatory renal hypertrophy after unilateral nephrectomy. Amer, $J$. Physiol. 173, 526-536 (1953). [B86,411/53 Aterman, K.: Effect of cortisone on early fibrosis of the liver in rats. Lancet 1950II, $517-519$.

$[\mathrm{B} 52,265 / 50$
Aterman, K.: Studies in fibrosis of the liver induced by carbon tetrachloride. II. A quantitative study of the effect of cortisone on fibrosis of the liver in rats. Arch. Path. 57, 12-25 (1954).

[B92,038/54

Aterman, K.: The thyroid-adrenal relationship: the effect of cortisone and of thyroid hormone on hepatic necrosis of dietary origin in the rat. Endocrinology 60, 711-717 (1957).

$[\mathrm{C} 35,275 / 57$

Aterman, K.: Aldosterone and experimental hepatic necrosis. Nature (Lond.) 182, 1324 (1958).

$[\mathrm{C} 61,786 / 58$

Aterman, K.: Growth hormone and partial hepatectomy in diet-deficient rats. Effects on the hepatic necrosis produced in rats by a deficient diet. Arch. Path. 72, 666 (1961).

[D 15,536/61

Aterman, K., Ahmad, N. D.: Cortisone and liver function. Lancet 1953I, 71-73.

[B76,967/53

Aterman, K., Howell, J. S.: The bromsulphthalein excretion test in hypothyroid rats. $L a b$. Invest. 8, 19-28 (1959).

$[\mathrm{C} 63,343 / 59$

Atkinson, R. M., Pratt, M. A., Tomich, E. G.: A sex difference in sensitivity of GFF mice to an anaesthetic steroid. J. Pharm. Pharmacol. 14, 698 (1962).

[D33,188/62

Aubert, C., Bohuon, C.: Dépigmentation produite chez le hamster doré par l'administration d'une dose per os de 9-10 diméthyl-1, 2-benzanthracène. Rôle de l'épiphysectomie. C. R. Acad. Sci. (Paris) 271, 281-284 (1970).

$[\mathrm{G} 77,483 / 70$

Avant, W. E., Weatherby, J. H.: Effects of epinephrine on toxicities of several local anesthetic agents. Proc. Soc. exp. Biol. (N.Y.) 103, 353-356 (1960).

$[\mathrm{C} 81,325 / 60$

Avezzu, G.: Alterazioni muscolari in corso di diabete allossanico ed interferenza del cloruro di cobalto. Arch. Sci. med. 103, 510-530 (1957).

$[\mathrm{C} 46,134 / 57$

Avezzu, G., Fiaccadori, F., Searpioni, L.: Su di alcune alterazioni morfologiche ed enzimatiche indotte nel rene mediante allossana e cortisone. G. Clin. med. 35, 1551-1577 (1954).

$[\mathrm{C} 12,653 / 54$

Axelrod, J.: The enzymatic deamination of amphetamine (Benzedrine). J. biol. Chem. 214, 753-763 (1955).

$[\mathrm{E} 40,270 / 55$

Axelrod, J.: The enzymatic N-demethylation of narcotic drugs. J. Pharmacol. exp. Ther. 116, 322-330 (1956).

$[\mathrm{D} 28,544 / 56$ 
Axelrod, J.: The enzymic cleavage of aromatic ethers. Biochem. J., 63, 634-639 (1956).

$[\mathrm{G} 74,652 / 56$

Axelrod, J.: Demethylation and methylation of drugs and physiologically active compounds. In: Brodie and Erdös; Metabolic Factors Controlling Duration of Drug Action 6, p. 97 to 110. New York: The MacMillan Co. 1962.

$[\mathrm{G} 66,350 / 62$

Axelrod, J.: Enzymatic formation of adrenaline and other catechols from monophenols. Science 140, 499-500 (1963). [D64,159/63 Axelrod, J., Reichenthal, J., Brodie, B. B.: Mechanism of the potentiating action of $\beta$-diethylaminoethyl diphenylpropylacetate. $J$. Pharmacol. exp. Ther. 110, 49-54 (1954).

[D79,919/54

Aycock, W. L., Foley, G. E.: The enhancement of tuberculous infection in the guinea pig by steroid hormones. J. clin. Endocr. 5, 337-344 (1945).

[B773/45

Azarnoff, D. L., Grady, H. J., Svoboda, D. J.: The effect of DDD on barbiturate and steroidinduced hypnosis in the dog and rat. Biochem. Pharmacol.15, 1985-1993 (1966). [G42,999/66

Azarnoff, D. L., Svoboda, D. J.: Microbodies in experimentally altered cells. VI. Thyroxine displacement from plasma proteins and clofibrate effect. Arch. int. Pharmacodyn. 181, 386-393 (1969).

[H 19,856/69

Baader, H., Girgis, S., Kiese, M., Menzel, H., Skrobot, L.: Der Einfluß des Lebensalters auf Umsetzungen von Phenacetin, p-Phenetidin, $\mathrm{N}$-Acetyl-p-aminophenol, $\mathrm{p}$-Aminophenol und Anilin im Hunde. Naunyn-Schmiedebergs Arch. exp. pathol. Pharmak. 241, 317-334 (1961).

[D43,960/61

Bächtold, H.: Die Beeinflussung des experimentellen Hochdrucks an der Ratte durch Methylthiouracil, Jod und Thyroxin. Thesis. Universität Basel (1950).

$[\mathrm{B} 60,463 / 50$

Bačić, M., Engström, L., Johannisson, E., Leideman, T., Diczfalusy, E.: Effect of F-6103 on implantation and early gestation in women. Acta endocr. (Kbh.) 64, 705-717 (1970).

$[\mathrm{H} 28,711 / 70$

Backman, A.: The influence of induced hyperthyroidism on experimental tuberculosis in mice. Ann. Med. exp. Fenn. 38, Suppl. 3, 1-56 (1960).

$[\mathrm{C94}, 674 / 60$

Backus, B., Cohn, V. H.: Genetic influences in metabolism of hexobarbital in mice. Fed. Proc. 25, 531 (1966).

[D92,313/66

Baeon, J. A., Patrick, H., Hansard, S. L.: Some effects of parathyroid extract and cortisone on metabolism of strontium and calcium. Proc. Soc. exp. Biol. (N.Y.) 93, 349-351 (1956).

$[\mathrm{C} 26,675 / 56$

Bacq, Z. M.: The amines and particularly cysteamine as protectors against roentgen rays. Acta radiol. (Stockh.) 41, 47-55 (1954).

$[\mathrm{D} 77,006 / 54$

Bacq, Z. M., Beaumariage, M. L.: Propriété radioprotectrice d'une préparation synthétique d'ocytocine (Syntocinon Sandoz) chez la souris. Arch. int. Physiol. 68, 516-518 (1960).

$[\mathrm{C} 87,128 / 60$

Bacq, Z. M., Herve, A., Lecomte, J., Fischer, P., Blavier, J., Dechamps, G., Le Bihan, H., Rayet, P.: Protection contre le rayonnement X par la $\beta$-mercaptoéthylamine. Arch. int. Physiol. 59, 442-447 (1951). [E91,032/51 Badarau, L., Ristesco, G., Calinca, N.: L'effet nécrosant commun des stéroïdes ovariens et cortico-surrénaux sur le trophoblaste placentaire chez le rat, 'diminué ou annihilé' par l'injection des couples antagonistes des mêmes hormones. Bull. Féd. Soc. Gynéc. Obstét. franç. 20, 311-312 (1968).

$[\mathrm{G} 69,247 / 68$

Bader, G.: Elektronenmikroskopische Untersuchungen zur funktionellen Morphologie der regenerierenden Leberzelle nach partieller Hepatektomie. Acta hepato-splenol. (Stuttg.) 16, 281-297 (1969).

$[\mathrm{G} 70,347 / 69$

Baglioni, A., Console, V.: Insulina e beri-beri sperimentale del Colombo. Arch. Fisiol. 33, 564-577 (1934).

$[45,284 / 34$

Bahr, C. von, Sjöqvist, F., Orrenius, S.: The inhibitory effect of hydrocortisone and testosterone on the plasma disappearance of nortriptyline in the dog and the perfused rat liver. Europ. J. Pharmacol. 9, 106-110 (1970).

[H 21,089/70

Bailey, C. H.: The production of arteriosclerosis and glomerulonephritis in the rabbit by intravenous injections of diphtheria toxin. $J$. exp. Med. 25, 109-127 (1917). [A 1,154/17 Bailey, J. M., Butler, J., Macnamara, T., Roe, N.: Antiinflammatory steroids in experimental atherosclerosis. (Abstr.) Fed. Proc. 27, 440 (1968).

$[\mathrm{H} 450 / 68$

Baird, P. C. Jr., Cloney, E., Albright, F.: Effect of cortical hormone in preventing extreme drop in colonic temperature displayed by hypophysectomized rats upon exposure to cold with preliminary observations upon the effect of hypophyseal and other hormones. Amer. $J$. Physiol. 104, 489-501 (1933). [14,881/33

Baird, W. L. M.: Clinical experience with pancuronium. Proc. roy. Soc. Med. 63, 697 to 699 (1970).

$[\mathrm{H} 27,487 / 70$ 
Baird, W. L. M., Reid, A. M.: The neuromuscular blocking properties of a new steroid compound, pancuronium bromide. A pilot study in man. Brit. J. Anaesth. 39, 775-780 (1967).

[G51,827/67

Baïsset, A., Boer, A., Montastruc, P.: Action des extraits post-hypophysaires dans la surcharge sodique prolongée. C. R. Soc. Biol. (Paris) 151, 1253-1256 (1957). [C55,475/57

Baisset, A., Demonte, H., Montastruc, P.: Action des extraits post-hypophysaires et de la désoxycorticostérone dans la surcharge sodique. Path. et Biol. 7, 815-827 (1958).

$[\mathrm{C} 84,788 / 58$

Balsset, A., Montastrue, P.: Effet de l'hormone antidiurétique sur le besoin d'alcool créé par l'habitude. C. R. Soc. Biol. (Paris) 156, 945-948 (1962).

[D34,473/62

Baisset, A., Montastruc, P.: Effet de l'hormone antidiurétique sur la soif consécutive a l'ingestion d'alcool. Ann. Endocr. (Paris) 23, 425-429 (1962).

[D37,918/62

Bajusz, E., Selye, H.: Effect of various hormones upon the muscular contractions induced by sodium perchlorate. Acta pharmacol. (Kbh.) 15, 235-243 (1959).

$[\mathrm{C} 57,180 / 59$

Bajusz, E., Selye, H.: An experimental type of muscular dystrophy and role of chlorides in its prevention. Proc. 2nd ann. Meet. Canad. Fed. Biol. (Toronto) 2, 5 (1959). [C64,511/59

Baker, B. L., Ingle, D. J., Li, C. H., Evans, H.M.: The effect on liver structure of treatment with adrenocorticotropin under varied dietary conditions. Amer. J. Anat. 82, 75-104 (1948).

[B26,490/48

Baker, B. L., Kent, J. F., Pliske, E. C.: Histological response of the duodenum to X-irradiation in hypophysectomized rats. Radiat. Res. 9, 48-58 (1958).

[C56,998/58

Baker, R., Reaven, G., Sawyer, J.: Ground substance and calcification: the influence of dye binding on experimental nephrocalcinosis. J. Urol. (Baltimore) 71, 511-522 (1954).

$[\mathrm{C} 24,277 / 54$

Balabanski, L., Dachev, G.: Le rôle du foie dans le métabolisme des hormones oestrogènes. Rev. roum. Endocr. 3, 121-126 (1966).

$$
[\mathrm{F} 68,584 / 66
$$

Baldratti, G.: The biological evaluation of the anabolic activity. In: Martini and Pecile; Hormonal Steroids, Biochemistry, Pharmacology and Therapeutics 2, p. 173-180. New York, London: Academic Press Inc. 1965.

$[\mathrm{E} 5,460 / 65$
Baldratti, G., Sala, G., Mars, G.: Azione del 4-clorotestosterone acetato e del 4-cloro-19nortestosterone acetate sull'ipotrofia surrenale indotta da cortisone. Boll. Soc. ital. Biol. sper. 33, 342-345 (1957).

[C45,101/57

Bálint, R., Molnár, B.: Experimentelle Untersuchungen über gegenseitige Wechselwirkung innerer Secretionsprodukte. Berl. klin. Wschr. 48, 289-292 (1911).

$[34,586 / 11$

Ball, H. A., Samuels, L. T.: Hypophysis and detoxification. Proc. Soc. exp. Biol. (N.Y.) 30, 26-27 (1932).

$[7,404 / 32$

Ball, J. K., Dawson, D. A.: Biological effects of the neonatal injection of 7,12-dimethylbenz $[\alpha]$ anthracene. J. nat. Cancer Inst. 42, 579-591 (1969).

$[\mathrm{G} 67,723 / 69$

Ballerini, G., Bosi, L.: Effects of serotonin, anti-serotonin and anti-histamine drugs on uracil-mustard intoxication. Experientia ( $B a$ sel) 21, 377-378 (1965).

$[\mathrm{G} 31,956 / 65$

Balner, H., Dersjant, H.: Neonatal thymectomy and tumor induction with methylcholanthrene in mice. J. nat. Cancer Inst. 36, 513-521 (1966).

$[\mathrm{G} 37,980 / 66$

Baraldi, M.: Azione dell'elettrourto sul quadro isto-patologico prodotto dai 'tioureici' nei conigli. Riv. sper. Freniat. 74, 3-14 (1950).

[B52,651/50

Barbazzo, M.: Tossina tifica e 17-idrossicorticosterone. Ormonologia 15, 401 (1955).

$[\mathrm{C} 13,021 / 55$

Barbe, M.: Influence de la $\Delta^{\prime}$-déhydrocortisone sur le développement de l'oedème adrénalique expérimental. C. R. Soc. Biol. (Paris) 151, 247-249 (1957).

$[\mathrm{C} 46,902 / 57$

Barbour, J. H., Seevers, M. H.: Narcosis induced by carbon dioxide at low environmental temperatures. J. Pharmacol. exp. Ther. 78, 296 to 303 (1943).

$[84,296 / 43$

Bardin, C. W., Bullock, L., Gram, T. E., Schroeder, D. H., Gillette, J. R.: End organ insensitivity to testosterone (T) in the pseudohermaphrodite rat (PS) (Abstr.). Program 51st Meet. Endocr. Soc. New York, N.Y., p. 40 (1969).

$[\mathrm{H} 12,120 / 69$

Bardier, E., Stillmunkès, A.: Intoxication scorpionique et syncope adrénalino-chloroformique. C. R. Soc. Biol. (Paris) 88, 559 a 561 (1923).

$[13,522 / 23$

Bardier, E., Stillmunkès, A.: Syncope adrenaline-chloroformique et envenimations. (Venins de vipère et de scorpion.). $C$. R. Soc. Biol. (Paris) 94, 1063-1064 (1926). $\quad[25,803 / 26$ Barella, A.: Influenza della castrazione nell' ipertemia passiva. Folia endocr. (Roma) 18, 
$121-129,145-151,169-175$ (1940).

$[\mathrm{B} 3,397 / 40$

Bargeton, D., Krumm-Heller, C., de Fombelle, F.: Etude des conditions de dosage d'activité des corps à action antithyroidienne. J. Physiol. 41, 125-136 (1949).

[B50,869/49

Bargon, G., Eger, W., Jr., Rittmeyer, K.: Die experimentelle Bestrahlungsnephritis unter Prednisolonbehandlung. Strahlentherapie 140, 192-203 (1970).

$[\mathrm{G} 78,255 / 70$

Bar-Hay, J., Benderly, A., Rumney, G.: Treatment of a case of nontumorous Cushing's syndrome with o, $\mathrm{p}^{\prime} \mathrm{DDD}$. Pediatrics 33, 239 to 244 (1964).

[G1,283/64

Barker, E. A., Arcassoy, M., Smuckler, E. A.: A comparison of the effects of partial surgical and partial chemical $\left(\mathrm{CCl}_{4}\right)$ hepatectomy on microsomal cytochrome $b_{5}$ and $P_{450}$ and oxidative $\mathrm{N}$-demythylation. Agents and Actions 1, 27-34 (1969).

$[\mathrm{H} 13,059 / 69$

Barksdale, B., Henson, E. C., Brunson, J. G.: Effects of epinephrine on the generalized Shwartzman reaction. Arch. Path. 89, 259-265 (1970).

$[\mathrm{H} 21,684 / 70$

Barlow, J. C., Sellers, E. A.: The effect of growth hormone on recovery from exposure to X-radiation. Radiat. Res. 2, 461-466 (1955).

$[\mathrm{C} 21,626 / 55$

Bar-Maor J. A., Ungar, J.: Effect of alphanaphthyl -isothiocyanate (ANIT) on the mitotis rate of liver cells following partial hepatectomy. Bull. Res. Coun. Israel E, 9E, 79-96 (1961).

[D41,800/61

Barnes, J. H., Lowman, D. M. R.: The effect of a monoamine oxidase inhibitor on radiation protection by 5-hydroxytryptophan. Int. $J$. Radiat. Biol. 14, 389-390 (1968). [G63,518/68

Barnes, J. H., Lowman, D. M. R.: Relative radioprotective abilities of 5-hydroxytryptophan and 5-hydroxytryptamine. Int. J. Radiat. Biol. 14, 87-88 (1969).

[G64,917/69

Barnett, G. 0., Teague, R. S.: The antagonism of salicylate to diethylstilbestrol upon liver glycogen in the rat. Endocrinology 63, 205-211 (1958).

$[\mathrm{C} 56,641 / 58$

Baronofsky, I. D., Canter, J. W.: The effect of endocrinectomy on ascites with especial reference to adrenalectomy and thyroidectomy. Amer. J. Surg. 99, 512-518 (1960).

$[\mathrm{C} 85,341 / 60$

Barral, P., d'Arrac, C. H., Vairel, J.: Modifications de l'intensité du choc anaphylactique et du choc peptonique chez le cobaye préalablement insulinisé. C. R. Soc. Biol. (Paris) 109, 1363-1364 (1932).

$[8,858 / 32$
Barral, P., Seguin, H., d'Arrac, C. H.: Importance de l'état glycémique préalable sur l'intensité du choc anaphylactique et du choc peptonique. Le glucose agent protecteur contre le choc. C. R. Soc. Biol. (Paris) 109, 1365-1366 (1932).

$[8,860 / 32$

Barron, D. H.: Some factors influencing the susceptibility of albino rats to injections of sodium amytal. Science 77, 372-373 (1933).

$[\mathrm{A} 42,858 / 33$

Barta, L., Beregi, E.: Utber Nebennierenblutung bei Alkoholintoxikation. Z. ges. inn. Med. 19, 785-787 (1964).

[F 24,783/64

Bartók, I., Varga, L., Varga, G.: Elektronenmikroskopische Veränderungen in der Rattenleber nach Verabreichung von dem oralen Antikonzeptionsmittel Lynestrenol. Acta hepatosplenol. (Stuttg.) 17, 1-10 (1970).

[G74,513/70

Basil, B., Somers, G. F., Woollett, E. A.: Measurement of thyroid activity by the mouse anoxia method. Brit. J. Pharmacol. 5, 315-322 (1950).

$[\mathrm{B} 53,039 / 50$

Bates, R. R.: Sex hormones and skin tumorigenesis. I. Effect of the estrous cycle and castration on tumorigenesis by 7,12-dimethylbenz(a)anthracene. J. nat. Cancer Inst. 41, 559 to 563 (1968).

$[\mathrm{H} 13,409 / 68$

Batliwalla, R. K., Deshpande, C. K.: Effects of cortisone in experimental diphtheritic myocarditis and diphtheritic intoxication in guineapigs. Indian J. med. Sci. 20, 780-789 (1966).

$[\mathrm{G} 43,844 / 66$

Batten, J. C., MeCune, R. M. Jr.: The influence of corticotrophin and certain corticosteroids on populations of mycobacterium tuberculosis in tissues of mice. Brit. J. exp. Path. 38, 413-423 (1957).

$[\mathrm{C} 53,554 / 57$

Baumann, C. A., Moore, T.: Thyroxine and hypervitaminosis-A. Biochem. J. 33, 1639 to 1644 (1939).

$[\mathrm{C} 38,599 / 39$

Bauman, T. R., Turner, C. W.: The effect of varying temperatures on thyroid activity and the survival of rats exposed to cold and treated with L-thyroxine or corticosterone. J. Endocr. 37, 355-359 (1967).

[F 81,331/67

Bavetta, L. A., Bekhor, I., Nimni, M. E.: Effects of hormone administration on collagen biosynthesis in the rat. Proc. Soc. exp. Biol. (N.Y.) 110. 294-297 (1962). [D29,064/62

Bavetta, L. A., Bekhor, I., Shah, R., 0'Day, P., Nimni, M. E.: Metabolic and anti-inflammatory properties of 6-methyl prednisolone alone and in combination with anabolic hormones. Endocrinology 71, 221-226 (1962).

$[\mathrm{D} 29,035 / 62$ 
Bavetta, L. A., Bernick, S., Ershoff, B. H.: Selective effects of growth hormone on rats fed a tryptophan-low diet. Endocrinology 59, 701 to 707 (1956).

$[\mathrm{C} 17,656 / 56$

Bavetta, L. A., Bernick, S., Ershofi, B. H.: The influence of dietary thyroid on the bones and periodontium of rats on total and partial tryptophan deficiencies. $J$. dent. Res. 36, 13 to 20 (1957).

$[\mathrm{C} 47,327 / 57$

Bavetta, L. A., Bernick, S., Ershoff, B. H.: Effects of growth hormone on the bone and periodontium of vitamin A-depleted rats. Arch. Path. 66, 610-617 (1958). [C60,277/58

Beach, E. F., Bradshaw, P. J., Blatherwick, N. R.: Alloxan diabetes in the albino rat as influenced by sex. Amer. J. Physiol. 166, 364-373 (1951).

$[\mathrm{B} 61,498 / 51$

Bean, J. W., Bauer, R.: Thyroid in pulmonary injury induced by $\mathrm{O}_{2}$ in high concentration at atmospheric pressure. Proc. Soc. exp. Biol. (N.Y.) 81, 693-694 (1952). [B76,951/52 Bean, J. W., Johnson, P.: Hypophyseal involvement in response to $\mathrm{O}_{2}$ at high pressure. Fed. Proc. 11, 9 (1952).

[B68,165/52

Bean, W. B., Ponseti, I. V.: Dissecting aneurysm produced by diet. Circulation 12, 185 to 192 (1955).

$[\mathrm{C} 29,403 / 55$

Beaton, G. H., Beare, J., Ryu, M. H., McHenry, E. W.: Protein metabolism in the pregnant rat. J. Nutr. 54, 291-304 (1954).

[A49,354/54

Beaton, G. H., Curry, D. M.: The resistance of pregnant rats to cortisone treatment. Rev. canad. Biol. 16, 465 (1957). [ [C42,333/57

Beaton, G. H., Curry, D. M., Veen, M. J.: Alanine-glutamic transaminase activity and protein metabolism. Arch. Biochem. 68, 288-290 (1957).

[D83,636/57

Beaton, G. H., Ozawa, G., Beaton, J. R., MeHenry, E. W.: Effect of anterior pituitary growth hormone on certain liver enzymes. Proc. Soc. exp. Biol. (N.Y.) 83, 781-784 (1953).

$[\mathrm{B} 86,367 / 53$

Beaton, G. H., Ryu, M. H., MeHenry, E. W.: Studies on the role of growth hormone in pregnancy. Endocrinology 57, 748-754 (1955).

$[\mathrm{C} 10,012 / 55$

Beaton, J. R.: Previous dietary protein level and survival of starving rats in the cold. Canad. J. Biochem. 41, 171-178 (1963).

[D55,998/63

Beatson, G. T.: On the treatment of inoperable cases of carcinoma of the mamma: suggestion for a new method of treatment with illustrative cases. Lancet 104, 162-165 (1896).

$[\mathrm{A} 50,749 / 1896$

Beck, L. V.: Lethal and tumor-damaging effects of certain trivalent arsenicals, as modified by 2,3-dimercaptopropanol (BAL) and by adrenal extracts (Abstr.). Cancer Res. 10, 202 (1950).

[B58,869/50

Beck, L. V.: Action of adrenal hormones on lethal toxicities of certain organic compounds. Proc. Soc. exp. Biol. (N.Y.) 78, 392-397 (1951).

[B64,609/51

Beck, L. V., Voloshin, T.: Influence of adrenal hormones on toxic and tumor-damaging effects of certain substances. Amer. J. Physiol. 163, 696 (1950).

$[\mathrm{B} 58,271 / 50$

Becker, F. F., Brenowitz, J. B.: The concentration of actinomycin D in hepatocyte nuclei as related to inhibition of ribonucleic acid synthesis. Biochem. Pharmacol. 19, 1457-1462 (1970).

[G75,528/70

Becker, K.: Biochemische Untersuchungen zum Bindegewebsstoffwechsel bei menschlicher und experimenteller Leberzirrhose. Dtsch. Z. Verdau.- u. Stoffwechselkr. 28, 161 bis 162 (1968).

[H 22,471/68

Becker, K.: Der Einfluß von Cortison auf Proliferation und Stoffwechsel des Bindegewebes bei der experimentellen Leberzirrhose. Ztschr. gesamt. exp. Med. 151, 10-17 (1969).

[H17,711/69

Beckett, A. H., Triggs, E. J.: Enzyme induction in man caused by smoking. Nature (Lond.) 216, 587 (1967).

[G70,154/67

Behrman, R. E., Fisher, D. E.: Phenobarbital for neonatal jaundice. $J$. Pediat. 76, 945-948 (1970).

[G75,312/70

Bein, H. J.: Aldosterone and alterations in circulatory reactivity following endotoxins. In: Shock; An International Symposium, p. 162-168. Berlin, Göttingen, Heidelberg: Springer-Verlag 1962.

[D37,982/62

Bein, H. J., Desaulles, P. A., Loustalot, P.: Endokrine Faktoren bei der experimentellen renalen Hypertonie. Bull. schweiz. Akad. med. Wiss. 14, 223-230 (1958).

$[\mathrm{C} 57,714 / 58$

Bein, H. J., Jaques, R.: The antitoxic effect of aldosterone. Experientia (Basel) 16, 24-26 (1960).

$[\mathrm{D} 41,862 / 60$

Bekemeier, H.: Nephrocalcitopotrope Wirkung von Äthinylnortestosteron und Progesteron. Naturwissenschaften 52, 397 (1965).

$[\mathrm{G} 31,719 / 65$ 
Bekemeier, H.: Beeinflussung von Kalkablagerungen in der Rattenniere durch Androgene. Acta biol. med. germ. 14, 863-864 (1965).

[F 53,774/65

Bekemeier, H.: Lokalisation des Kalkes in der Niere von Maus, Kaninchen, Hund und Mensch bei mit Östrogenen behandelter D-Hypervitaminose. Z. Urol. 60, 145-148 (1967).

$[\mathrm{F} 80,690 / 67$

Bekemeier, H., Leiser, H.: Beeinflussen endogene Oestrogene und Androgene den Ort der durch Calcinosefaktor erzeugten Kalkablagerungen in der Niere? Z. ges. exp. Med. 135, 281-284 (1961).

[D76,990/61

Bekemeier, H., Leiser, H.: Verschiebung des Ortes experimentell bedingter Kalkablagerungen in der Niere unter dem Einfluß von Oestrogenen. Naunyn-Schmiedebergs Arch. Pharmak. 241, 146-148 (1961). [D76,994/61

Bekemeier, H., Leiser, H.: Der Einfluß von Nebennieren- und Hypophysenentfernung auf das durch Calcinosefaktor erzeugte Verkalkungsbild der Rattenniere. Naunyn-Schmiedebergs Arch. Pharmak. 245, 115-116 (1963).

[D 65,289/63

Bekemeier, H., Leiser, H., Schottek, W.: The influence of testosterone on the location of renal calcification induced by a calcinosing factor. Z. ges. exp. Med. 135/6, 541-544 (1962).

$[\mathrm{E} 97,156 / 62$

Bélanger, L. F., Migicovsky, B. B.: Comparative effects of vitamin $D$, calcium, cortisone, hydrocortisone, and norethandrolone on the epiphyseal cartilage and bone of rachitic chicks. Develop. Biol. 2, 329-342 (1960).

$[\mathrm{C} 95,269 / 60$

Belaval, G. S., Widen, A. L.: Meprobamate toxicity. U. S. armed Forces med. J. 9, 1691-1702 (1958).

$[\mathrm{C} 76,528 / 58$

Belding, D. L., Wyman, L. C.: The role of the suprarenal gland in the natural resistance of the rat to diphtheria toxin. Amer. J. Physiol. 78, 50-55 (1926).

$[3,915 / 26$

Bella, D. D., Rognoni, F., Teotino, U.: Effect of $\beta$-diethylaminoethyl 3,3-diphenylpropylacetate on the action of suxamethonium and other neuromuscular blocking drugs. Brit. J. Pharmacol. 18, 563-571 (1962).

[G77,568/62

Benacerraf, B., Thorbecke, G. J., Jacoby, D.: Effect of zymosan on endotoxin toxicity in mice. Proc. Soc. exp. Biol. (N.Y.) 100, 796 to 799 (1959).

$[\mathrm{C} 67,852 / 59$

Bendoc, C. C., Beskid, G., Wolferth, C. C. Jr., Howard, J. M., 0'Malley, J. F.: Cardiovascular and antitoxic effects of aldosterone on cats in endotoxin shock. Surg. Gynec. Obstet. 114, 43-46 (1962).

[D24,577/62

Benes, J., Zicha, B.: Effect of ionizing radiation on tryptophan oxygenase of rat liver. Strahlentherapie 137, 612-619 (1969).

$[\mathrm{G} 67,159 / 69$

Benetato, G., Gaina, I., Oprisiu, C.: Influence de l'hypertrophie provoquée de la corticosurrénale et de l'extrait cortical sur la résistance à certaines intoxications. C. R. Soc. Biol. (Paris) 120, 353-355 (1935).

$[33,773 / 35$

Bengmark, S.: Liver regeneration. In: Pack, G. T., Islami, A. H.; Tumor of the Liver. Recent Results in Cancer Research, p. 187-212. Berlin, Heidelberg, New York: SpringerVerlag 1969. [G74,917/69

Bengmark, S., Ekdahl, P.-H., Gottfries, A., Mobacken, H., Olsson, R., Rehnström, B., Schersten, T.: Influence of testosterone treatment in experimental nutritional hepatic cirrhosis in the rat. Gastroenterologia 105, 301-315 (1966).

$[\mathrm{F} 67,484 / 66$

Bengmark, S., Haiström, L. O., Loughridge, B.: Studies of the influence of hepatic artery ligation on liver regeneration in partially hepatectomized rats. Acta hepato.-splenol. (Stuttg.) 16, 349-355 (1969).

[G71,689/69

Bengmark, S., Olsson, R.: The effect of sex and of testosterone on toxic liver damage. $J$. Endocr. 25, 293-297 (1962). [D48,932/62

Bengmark, S., Olsson, R.: Effect of testosterone upon liver regeneration. Bull. Soc. int. Chir. No. 5-6, 451-457 (1963). [D14,663/63 Bengmark, S., Olsson, R.: Experimental study of liver healing after partial hepatectomy. Special regard to the changes in content of liver glutamic pyruvic transaminase. Acta hepato-splenol. (Stuttg.) 10, 282-293 (1963).

$[\mathrm{E} 34,627 / 63$

Bengmark, S., Olsson, R.: Effect of vitamin $\mathrm{B}_{12}$ on liver regeneration after partial hepatectomy. Gastroenterologia (Basel) 100, 75-86 (1963).

$[\mathrm{E} 34,736 / 63$

Bengmark, S., Olsson, R.: The effect of testosterone on liver healing after partial hepatectomy. Acta chir. scand. 127, 93-100 (1964).

$[\mathrm{D} 6,135 / 64$

Bengmark, S., Olsson, R.: The effect of castration and testosterone treatment on liver healing in male rats after carbon tetrachloride injury. Path. et Microbiol. (Basel) 27, 167-174 (1964).

$[\mathrm{G} 13,853 / 64$

Benkö, A.: Die gemeinsame Wirkung des Nikotinsäureamids und Cortigens auf die Por- 
phyrinurie bei Bleivergiftung. Dtsch. med. Wschr. 68, 271-272 (1942). $[95,966 / 42$

Bennett, I. L., Jr., Beeson, P. B.: The effect of cortisone upon reactions of rabbits to bacterial endotoxins with particular reference to acquired resistance. Bull. Johns Hopk. Hosp. 93, 290-308 (1953).

[B $95,351 / 53$

Bennette, J. G.: Amethopterin: a toxic tumour growth inhibitor. Brit. J. Cancer 6, 377-388 (1952).

$[\mathrm{D} 77,417 / 52$

Bennison, B. E., Coatney, G. R.: The sex of the host as a factor in plasmodium gallinaceum infections in young chicks. Science 107, 147-148 (1947).

[B 17,600/47

Benoit, J., Clavert, J.: Rôle de la glande thyroide dans l'ostéogénèse folliculinique chez les oiseaux. Congr. Anat. (Strasbourg), No. 68, p. $68-75$ (1948).

$[\mathrm{B} 27,669 / 48$

Benton, D. A.: Regression of 3,4,9,10-dibenzpyrene induced tumors in mice following adrenalectomy. (Abstr.) Proc. Amer. Ass. Cancer Res. 3, 303 (1962).

[D 22,526/62

Benveniste, J., Higounet, F., Salomon, J. C.: Effects of various doses of prednisolone on the phagocytic activity in axenic and holoxenic mice. J. reticuloendothel. Soc. 8, 499-507 (1970).

$[\mathrm{G} 80,804 / 70$

Berde, B., Takács, L.: Heat tolerance of castrated female rabbits. $Z$. Vitamin-, Hormonu. Fermentforsch. 1, 480-483 (1948).

[B31,943/48

Berde, B. I., Takáes, L.: Heat tolerance of castrated male rabbits. Z. Vitamin-, Hormonu. Fermentforsch. 2, 23-25 (1948).

$[\mathrm{B} 38,366 / 48$

Berdjis, C. C.: Cortisone and radiation. III. Histopathology of the effect of cortisone on the irradiated rat kidney. Arch. Path. 69, $431-439$ (1960).

$[\mathrm{C} 83,954 / 60$

Berdjis, C. C.: Influence of cortisone on hepatotoxic agents. Fed. Proc. 26, 575 (1967).

[F 79,528/67

Berdjis, C. C., Brown, R. F.: Histopathology of the effect of cortisone on the irradiated rat lung. Dis. Chest 32, 481 (1957). [C45,470/57

Berenesi, G., Krompecher, S.: Recent data concerning the connexion between thyroid and hepatic functions. Acta anat. (Basel) 64, 235-244 (1966).

[G43,712/66

Berenesi, G., Krompecher,S., Märcz, I.: Experimental data on the correlation between hepatic and thyroid functions. Acta anat. (Basel) 60, 507-515 (1965). [G33,802/65
Bergen, J. R., Beisaw, N. E., Krus, D. M., Koella, W. P., Pincus, G.: Central nervous system and behavior: some properties of progesterone. In: Martini and Pecile; Hormonal Steroids. Biochemistry, Pharmacology, and Therapeutics 2, p. 483-490. New York, London: Academic Press 1965. [E 5,492/65

Bergen, J. R., Krus, D., Pincus, G.: Suppression of LSD-25 effects in rats by steroids. Proc. Soc. exp. Biol. (N.Y.) 105, 254-256 (1960).

$[\mathrm{C} 97,551 / 60$

Bergen, J. R., Pincus, G. G.: Steroid suppression of LSD induced behavior changes in rats. Fed. Proc. 19, 20 (1960). [C $82,720 / 60$

Bergenstal, D. M., Hertz, R., Lipsett, M. B., Moy, R. H.: Chemotherapy of adrenocortical cancer with o, p'DDD. Ann. intern. Med. 53, 672-682 (1960).

$[\mathrm{C} 94,436 / 60$

Bergenstal, D. M., Lipsett, M. B., Moy, R. H., Hertz, R.: Regression of adrenal cancer and suppression of adrenal function in man by $\mathrm{o}, \mathrm{p}^{\prime}$ DDD. Trans. Ass. Amer. Phycns 72, 341350 (1959).

$[\mathrm{G} 74,073 / 59$

Berger, E.: Die experimentellen Voraussetzungen einer Behandlung der Diphtherie mit Vitamin $\mathrm{C}$ und Nebennierenrindenhormon. Klin. Wschr. 16, 1177-1180 (1937).

$[95,075 / 37$

Berglund, K.: Studies on factors which condition the effect of cortisone on antibody production. I. The significance of time of hormone administration in primary hemolysin response. Acta pathol. microbiol. scand. 38, 311-328 (1956).

$[\mathrm{C} 16,832 / 56$

Bergman, F., Linden, W. van der: Influence of D-thyroxine on gallstone formation in hamsters. Acta chir. scand. 129, 547-552 (1965).

[G30,642/65

Bergman, F., Linden, W. van der: Further studies on the influence of thyroxine on gallstone formation in hamsters. Acta chir. scand. 131, 319-328 (1966).

$[\mathrm{G} 39,200 / 66$

Bergman, F., Linden, W. van der: Influence of cholestyramine, a bile acid sequestrant, on gallstone formation in hamsters. Acta chir. scand. 132, 724-730 (1966). $\quad[\mathrm{G} 43,913 / 66$

Bergman, H. C., Rosenfeld, D. D., Hechter, O., Prinzmetal, M.: Ineffectiveness of adrenocortical hormones, thiamine, ascorbic acid, nupercaine, and post-traumatic serum in shock due to scalding burns. Amer. Heart J. 29, 506-512 (1945).

$[\mathrm{B} 2,009 / 45$

Berkovich, S., Ressel, M.: Effect of gonadectomy on susceptibility of the adult mouse to 
coxsackie B1 virus infection. Proc. Soc. exp. Biol. (N.Y.) 119, 690-694 (1965).

[F46,105/65

Berlin, C. M., Sehimke, R. T.: Influence of turnover rates on the responses of enzymes to cortisone. Molec. Pharmacol. 1, 149-156 (1965).

[G37,616/65

Berliner, D. L., Keller, N., Dougherty, T. F.: Tissue retention of cortisol and metabolites induced by ACTH: an extra-adrenal effect. Endocrinology 68, 621-632 (1961).

$[\mathrm{G} 75,988 / 61$

Berliner, D. L., Keller, N., Dougherty, T. F.: Medicated and direct effects of ACTH and corticosteroids in stress. In: Bajusz; Physiology and Pathology of Adaptation Mechanisms: Neural-Neuroendocrine-Humoral, p. 204-213. Oxford, London, Edingburgh: Pergamon Press 1969.

$[\mathrm{E} 8,170 / 69$

Berliner, D. L., Wiest, W. G.: The extrahepatic metabolism of progesterone in rats. J. biol. Chem. 221, 449-459 (1956).

$[\mathrm{C} 22,807 / 56$

Berman, D.: Hormonal effects on fat deposition in the liver. Thesis. University of McGill (1946).

$[\mathrm{A} 46,758 / 46$

Berman, D., Sylvester, M., Hay, E. C., Selye, H.: The adrenal and early hepatic regeneration. Endocrinology 41, 258-264 (1947).

$[97,700 / 47$

Berman, L. B.: Modification of protein catabolism in the anuric dog. Proc. Soc. exp. Biol. (N.Y.) 101, 809-811 (1959). [C74,922/59

Berman, M. L., Bochantin, J. F.: Nonspecific stimulation of drug metabolism in rats by methoxyflurane. Anesthesiology 32, 500-506 (1970).

$[\mathrm{G} 75,502 / 70$

Bernard, C.: Leçons sur les phénomènes de la vie communs aux animaux et aux végétaux. Paris: Librairie J.-B. Baillière et Fils 1, 1878; 2, 1879.

[E 719/1878/79

Bernick, S., Ershoff, B. H., Sobel, H.: The effects of various hormones upon the bone changes induced by toxic doses of cortisone in rats. Anat. Rec. 139, 207 (1961). [D5,063/61 Bernick, S., Hyman, C., Paldino, R. L.: Histological studies of the sex difference in intrahepatic distribution of thorotrast and T-1824 in rabbits. Anat. Rec. 126, 213-223 (1956).

$[\mathrm{C} 39,526 / 56$

Berry, L. J.: Endotoxin lethality and tryptophan pyrrolase induction in cold-exposed mice. Amer. J. Physiol. 207, 1058-1062 (1964).

[F 24,603/64

Berry, L. J.: Effects of endotoxins on the level of selected enzymes and metabolites. In: Landy and Braun; Bacterial Endotoxins, p. 151-159. New Brunswick, N.J.: Rutgers, State University 1964.

[G68,858/64

Berry, L. J.: Effect of environmental temperature on lethality of endotoxin and its effect on body temperature in mice. Fed. Proc. 25, 1264-1270 (1966).

$[\mathrm{F} 69,416 / 66$

Berry, L. J., Agarwal, M. K., Snyder, I. S.: Comparative effect of endotoxin and reticuloendothelial "blocking" colloids on selected inducible liver enzymes. In: Di Luzio and Paoletti; The Reticuloendothelial System and Atherosclerosis, p. 266-274. New York: Plenum Press 1967.

$[\mathrm{E} 7,069 / 67$

Berry, L. J., Smythe, D. S.: Effects of bacterial endotoxin on metabolism. II. Protein-carbohydrate balance following cortisone. Inhibition of intestinal absorption and adrenal response to ACTH. J. exp. Med. 110, 407-418 (1959). $[\mathrm{C} 73,199 / 59$

Berry, L. J., Smythe, D. S.: Effects of bacterial endotoxin on metabolism. VI. The role of tryptophan pyrrolase in response of mice to endotoxin. J. exp. Med. 118, 587-603 (1963).

$[\mathrm{E} 28,203 / 63$

Berry, L. J., Smythe, D. S.: Effects of bacterial endotoxins on metabolism. VII. Enzyme induction and cortisone protection. J. exp. Med. 120, 721-732 (1964). [D19,640/64

Berry, L. J., Smythe, D. S., Colwell, L. S.: Inhibition of inducible liver enzymes by endotoxin and actinomycin D. J. Bact. 92, 107-115 (1966). $[\mathrm{G} 67,237 / 66$

Berry, L. J., Smythe, D. S., Colwell, L. S., Chu, P. H. C.: Influence of hypoxia, glucocorticoid, and endotoxin on hepatic enzyme induction. Amer. J. Physiol. 215, 587-592 (1968).

$[\mathrm{H} 2,124 / 68$

Berry, L. J., Smythe, D. S., Young, L. G.: Effects of bacterial endotoxin on metabolism. I. Carbohydrate depletion and the protective role of cortisone. J. exp. Med. 110, 389-405 (1959).

$[\mathrm{C} 73,198 / 59$

Bertolotti, E., Giordano, S.: Il fenil-propionato di norandrostenolone nella intossicazione da vitamina "D." Minerva pediat. 14, 1175-1178 (1962).

[D57,171/62

Besendori, H., Pletscher, A.: Beeinflussung zentraler Wirkungen von Reserpin und 5-Hydroxytryptamin durch Isonicotinsäurehydrazide. Helv. physiol. pharmacol. Acta 14, 383 bis 390 (1956).

$[\mathrm{C} 31,623 / 56$

Best, C. H., Solandt, D. Y.: Concentrated serum in treatment of traumatic and histamine shock in experimental animals. Brit. med. $J .1940 \mathrm{I}$, $799-802$.

$[\mathrm{A} 33,635 / 40$ 
Bettini, S., Cantore, G.: Sull'azione protettiva dell'ACTH, del cortisone, del gluconato di calcio, della pirilamina (Neoantergan), della prometazina (Fargan), della cloropromazina (Largactil) nel latrodectismo indotto nella cavia. R. C. Ist. sup. Sanita 18, 488-495 (1955).

[C21,801/55

Betz, E. H.: Contribution a l'étude du syndrome endocrinien provoqué par l'irradiation totale de l'organisme. Thesis. Université de Liège (1955).

$[\mathrm{C} 13,907 / 55$

Bevan, B. R., Holton, J. B., Lathe, G. H.: The effect of pregnanediol and pregnanediol glucuronide on bilirubin conjugation by rat liver slices. Clin. Sci. 29, 353-361 (1965).

[G35,435/65

Bhagat, B.: The effects of a deficiency in thiamine and an excess of thyroid hormone on the analgesic action of morphine. Arch. int. Pharmacodyn. 148, 536-544 (1964).

$[$ F9,444/64

Bianchi, A., Maio, M. de: Ricerche sperimentali sul potenziamento della narcosi da 21idrossipregnandione ad opera della serotonina, della reserpina e dell'esametonio. G. ital. Chir. 14, 280-289 (1958).

$[\mathrm{C} 54,169 / 58$

Biancifiori, C., Caschera, F., Giornell-Santilli, F. E., Bucciarelli, E.: The action of oestrone and four chemical carcinogens in intact and ovariectomised BALB $/ \mathrm{c} / \mathrm{Cb} / \mathrm{Se}$ mice. Brit. J. Cancer 21, 452-459 (1967).

[F 98,833/67

Bickel, M. H., Minder, R.: Metabolism and biliary excretion of the lipophilic drug molecules, imipramine and desmethylimipramine in the rat. I. Experiments in vivo and with isolated perfused livers. Biochem. Pharmacol. 19, 2425-2435 (1970).

$[\mathrm{G} 77,613 / 70$

Bickel, M. H., Minder, R.: Metabolism and biliary excretion of the lipophilic drug molecules, imipramine and desmethylimipramine in the rat. II. Uptake into bile micelles. Biochem. Pharmacol. 19, 2437-2443 (1970). $[\mathrm{G} 77,614 / 70$

Bidleman, K., Mannering, G. J.: Induction of drug metabolism $\mathrm{V}$. Independent formation of cytochromes P-450 and $\mathrm{P}_{\mathbf{1}}-450$ in rats treated with phenobarbital and 3-methylcholanthrene simultaneously. Molec. Pharmacol. 6, 697-701 (1970).

[G80,042/70

Biebl, M., Essex, H. E., Mann, F. C.: Studies on the physiology of the liver. Amer. J. Physiol. 100, 167-172 (1932).

$[44,898 / 32$

Biedl, A., Winterberg, H.: Beiträge zur Lehre von der Ammoniakentgiftenden Funktion der
Leber. Pflügers Arch. ges. Physiol. 88, 140-200 (1901).

$[47,485 / 01$

Bielschowski, F.: The role of hormonal factors in the development of tumours induced by 2-aminofluorene and related compounds. Acta Un. int. Cancr. 17, 121-130 (1961).

[D 10,255/61

Bielschowsky, F., Hall, W. H.: Carcinogenesis in parabiotic rats. Tumours of the ovary induced by acetylaminofluorene in intact females joined to gonadectomized litter-mates and the reaction of their pituitaries to endogenous oestrogens. Brit. J. Cancer 5, 331-344 (1951).

$[\mathrm{G} 71,797 / 51$

Bielschowsky, F., Hall, W. H.: Carcinogenesis in the thyroidectomized rat. Brit. J. Cancer 7, 358-366 (1953).

[C194/53

Biezunski, N.: Action of warfarin injected into rats on protein synthesis in vitro by liver microsomes as related to its anticoagulating action. Biochem. Pharmacol. 19, 2645-2652 (1970).

[G78,643/70

Biozzi, G.o, Benacerraf, B., Halpern, B. N.: The effect of Salm. typhi and its endotoxin on the phagocytic activity of the reticulo-endothelial system in mice. Brit. J. exp. Path. 36, 226-235 (1955).

$[\mathrm{E} 22,483 / 55$

Birchall, K., 0'Day, W. G., Fajer, A. B., Burstein, S.: Urinary cortisol and $6 \beta$-hydroxycortisol in the monkey, Cebus albifrons: normal variation and the effects of ACTH and phenobarbital. Gen. comp. Endocr. 7, 352-362 (1966).

[F76,581/66

Birchmeier, P. J.: Quantitative changes in mouse liver ultrastructure following cortisone and insulin administration. Austral. J. biol. Sci. 22, 965-978 (1969).

[G69,512/69

Bird, C. C., Crawford, A. M., Currie, A. R.: Foetal adrenal necrosis induced by 7-hydroxymethyl-12-methylbenz(a)-anthracene and its prevention. Nature (Lond.) 228, 72-73 (1970).

$[\mathrm{H} 30,425 / 70$

Bisetti, A., Barbolini, G.: Effetto degli ormoni corticotropo e somatotropo nella tubercolosi sperimentale del ratto ipofisectomizzato. Rass. Fisiopat. clin. ter. 33, 406-422 (1961).

[D12,624/61

Bishop, R. F., Marshall, V.: The enhancement of Clostridium welchii infection by adrenalinein-oil. Med. J. Austral. 2, 656-657 (1960).

$[\mathrm{C} 95,338 / 60$

Biskind, G. R.: Inactivation of methyl testosterone in castrate male rats. Proc. Soc. exp. Biol. (N.Y.) 43, 259-261 (1940). [A31,848/40 
Biskind, G. R.: Inactivation of testosterone propionate by normal female rats. Proc. Soc. exp. Biol. (N.Y.) 46, 452-453 (1941).

$[\mathrm{A} 35,907 / 41$

Biskind, G. R.: The inactivation of estradiol and estradiol benzoate in castrate female rats. Endocrinology 28, 894-896 (1941).

$[\mathrm{A36,315/41}$

Biskind, G. R.: Inactivation of estrone in normal adult male rats. Proc. Soc. exp. Biol. (N.Y.) 47, 266-268 (1941). [A36,481/41 Biskind, G. R., Mark, J.: The inactivation of testosterone propionate and estrone in rats. Bull. Johns Hopk. Hosp. 65, 212-217 (1939).

$[A 31,656 / 39$

Biskind, M. S., Biskind, G. R.: Effect of vitamin $\mathrm{B}$ complex deficiency on inactivation of estrone in the liver. Endocrinology 31, 109-114 (1942). [A38,221/42

Bixler, D., Muhler, J. C., Shafer, W. G.: The effect of radioactive iodine on dental caries in the rat. $J$. Amer. dent. Ass. 53, 667-671 (1956).

[E99,118/56

Black, M., Sherlock, S.: Treatment of Gilbert's syndrome with phenobarbital. Lancet 1970I, 1359-1362.

[H26,290/70

Blackham, A., Spencer, P. S. J.: The effects of oestrogens and progestins on the response of mice to barbiturates. Brit. J. Pharmacol. 37, 129-139 (1969).

[G69,913/69

Blackham, A., Spencer, P. S. J.: Interactions of oestrogenic and progestational steroids with dexamphetamine and fencamfamin in mice. Brit. J. Pharmacol. 37, 508-509 (1969).

[G76,301/69

Blackham, A., Spencer, P. S. J.: Response of female mice to anticonvulsants after pretreatment with sex steroids. J. Pharm. Pharmacol. 22, 304-305 (1970).

[G 73,813/70

Black-Schaffer, B., Johnson, D. S., Gobbel, W. G., Jr.: Experimental total midzonal hepatic necrosis. Amer. J. Path. 26, 397-409 (1950).

[B55,142/50

Blackwell, B.: Tranylcypromine. Lancet 1963II, 414.

[E65,708/63

Blatt, L. M., Slickers, K. A., Kim, K. H.: Effect of prolactin on thyroxine-induced metamorphosis. Endocrinology 85, 1213-1215 (1969).

$[\mathrm{H} 19,832 / 69$

Blaw, M. E., Good, R. A., Peterson, R. D. A.: Curare sensitivity in neonatally thymectomized mice. Nature (Lond.) 210, 129-130 (1966).

$[\mathrm{F} 65,571 / 66$
Bledsoe, T., Island, D. P., Ney, R. L., Liddle, G. W.: An effect of $o, p^{\prime} D D D$ on the extraadrenal metabolism of cortisol in man. J. clin. Endocr. 24, 1303-1311 (1964). [E20,690/64

Bloch, E., Lew, M., Klein, M.: Studies on the inhibition of fetal androgen formation: testosterone synthesis by fetal and newborn mouse testes in vitro. Endocrinology 88, 41-46 (1971).

$[\mathrm{H} 34,907 / 71$

Bloch, R. G.: The effect of hyperthyroidism on tuberculosis in the guinea pig. Amer. Rev. resp. Dis. 87, 525-528 (1963). [D61,174/63

Block, L. H., Lamy, P. P.: Therapeutic incompatibilities. J. Amer. pharm. Ass. 8, 66-68, 82-84 (1968).

[G 81,054/68

Block, L. H., Lamy, P. P.: Drug interactions. J. Amer. pharm. Ass. 9, 202-206 (1969).

[G 81,052/69

Blood, F. R., Glover, R. M., Henderson, J. B., D'Amour, F. E.: Relationship between hypoxia, oxygen consumption and body temperature. Amer. J. Physiol. 156, 62-66 (1949).

$[\mathrm{B} 48,970 / 49$

Bloodworth, J. M. B. Jr., Arscott, P., Hamwi, G. J., Morton, J. L.: Effect of somatotrophic hormone and chlortetracycline on weight and mortality of irradiated rats. Fed. Proc. 15, 508 (1956).

$[\mathrm{C} 14,328 / 56$

Blount, H. C., Jr., Smith, W.: The influence of thyroid and thiouracil on mice exposed to roentgen radiation. Science 109, 83-84 (1949).

$[\mathrm{B3} 0,000 / 49$

Blum, F.: Neue, experimentell gefundene Wege zur Erkenntnis und Behandlung von Krankheiten, die durch Auto-Intoxicationen bedingt sind. Virchows Arch. path. Anat. 162, 375-406 (1900).

$[38,401 / 1900$

Blum, F.: Neues und Altes zur Physiologie und Pathologie der Schilddrüse. Verhandl. 23. Kongr. inn. Med. München, p. 183-218 (1906).

$[38,405 / 06$

Boatman, J. B.: Response of the normal and thyroidectomized cat to severe cold. Amer. J. Physiol. 196, 983-986 (1959). [C68,449/59

Bóbr, J.: The effect of alloxan diabetes on experimental staphylococcal infection in mice. J. Path. Bact. 89, 749-752 (1965). [G30,418/65

Bóbr, J., Ptak, W.: Hormones influencing resistance to crude staphylococcal $\alpha$-toxin. Postȩpy Mikrobiol. 5, 309-312 (1966).

$[\mathrm{G} 47,053 / 66$

Bochner, F., Lloyd, H. M., Roeser, H. P., Thomas, M. J.: Effects of $0, p^{\prime} \mathrm{DDD}$ and amino- 
glutethimide on metastatic adrenocortical carcinoma. Med. J. Austral. 56, 809-812 (1969).

$[\mathrm{H} 31,656 / 69$

Bock, F. G., Dao, T. L.: Factors affecting the polynuclear hydrocarbon level in rat mammary glands. Cancer Res. 21, 1024-1029 (1961).

[D 11,892/61

Boctor, A. M., Rogers, Q. R., Harper, A. E.: The influence of thyroxine and thiouracil on rats fed excess tyrosine. Proc. Soc. exp. Biol. (N.Y.) 133, 821-825 (1970). [H22,509/70

Bodaiji, S., Mori, Y.: Effect of cortisone on the experimental tuberculosis in rabbit. Kobe $J$. med. Sci. 3, 89 (1957).

[C35,586/57

Bodansky, M., Duff, V. B.: The influence of pregnancy on resistance to thyroxine, with data on the creatine content of the maternal and fetal myocardium. Endocrinology 20, 537-540 (1936).

$[63,084 / 36$

Bodo, R. D. de, Prescott, K. F.: The antidiuretic action of barbiturates (phenobarbital, amytal, pentobarbital) and the mechanism involved in this action. J. Pharmacol. exp. Ther. 85, 222-233 (1945).

$[88,791 / 45$

Boer, B. de: Factors affecting pentothal anesthesis in dogs. Anesthesiology 8, 375-381 (1947).

$[\mathrm{A} 52,450 / 47$

Boer, B. de: The effects of thiamine hydrochloride upon pentobarbital sodium ("Nembutal") hypnosis and mortality in normal, castrated, and fasting rats. J. Amer. pharm. Ass., sci. Ed. 37, 302-307 (1948).

$[\mathrm{A} 48,817 / 48$

Boer, B. de, Mukomela, A. E.: Thiopental and pentobarbital hypnosis in normal and castrate rats as modified by ACTH and cortisone. Fed. Proc. 14, 332 (1955).

$[\mathrm{C} 5,245 / 55$

Boeri, R.: Ormoni ipofiso-surrenalici e soglia convulsiva. Minerva med. 50, 2813-2815 (1958).

[C78,610/58

Bogdanovitch, S. B.: The effect of methylthiouracil on the toxicity of oxophenarsine. Arch. int. Pharmacodyn. 106, 307-311 (1956).

$[\mathrm{C} 18,912 / 56$

Bogdanovitch, S. B., Varagitch, V. M.: Influence of thyroidea hormone on the toxicity of dichlormapharsen. Acta med. iugosl. 8, 196 to 199 (1954).

[G71,534/54

Boggs, T. R., Jr., Hardy, J. B., Frazier, T. M.: Correlation of neonatal serum total bilirubin concentrations and developmental status at age eight months. A preliminary report from the collaborative project. $J$. Pediat. 71, 553 to 560 (1967).

$[\mathrm{G} 71,887 / 67$
Bois, P., Bélanger, L. F., Le Buis, J.: Effect of growth hormone and aminoacetonitrile on the mitotic rate of epiphysial cartilage in hypophysectomized rats. Endocrinology 73, 507 to 509 (1963).

$[\mathrm{E} 29,177 / 63$

Bojesen, E., Egense, J.: Elimination of endogenous corticosteroids in vivo. The effects of hepatectomy and total abdominal evisceration in the acutely adrenalectomized cat, and the effect of muscular exercise and insulin administration on the isolated hindquarter preparation. Acta endocr. (Kbh.) 33, 347-369 (1960).

$[\mathrm{G} 75,996 / 60$

Boler, R. K., Bibighaus, A. J., Brunson, J. G.: An electron microscopic study of the liver of endotoxin-shocked dogs treated with a combination of propiomazine and levarterenol. Lab. Invest. 20, 319-325 (1969). [G65,722/69

Bolis, L.: Cardiovasculopatie sperimentali e gonadotropine. Atti Soc. lombarda Sci. med.biol. 2, 254-259 (1956). [E50,716/56

Bomskov, C., Hölscher, B., Hartmann, J.: Der Thymustod. Pflügers Arch. ges. Physiol. 245, 483-492 (1942).

$[\mathrm{A} 56,954 / 42$

Bond, E. J., Butler, W. H., Matteis, F. de, Barnes, J. M.: Effects of carbon disulphide on the liver of rats. Brit. J. industr. Med. 26, 335-337 (1969).

[H 18,559/69

Bondoc, C. C., Beskid, G., Wolferth, C. C. Jr., Howard, J. M., O'Malley, J. F.: Cardiovascular and antitoxic effects of aldosterone on cats in endotoxin shock. Surg. Gynec. Obstet. 114, $43-46$ (1962).

[D $69,984 / 62$

Bondurant, C. P., Campbell, C.: Adrenal cortex extract in the treatment of bromide eruption and bromide intoxication. J. Amer. med. Ass. 116, 100-104 (1941).

[A 36,066/41

Bonetti, E., Guerzon, A. P., Stirpe, F.: Induction of tryptophan pyrrolase in rats after early injections of tryptophan or neonatal thymectomy. Experientia (Basel) 23, 436-437 (1967).

$[\mathrm{G} 48,030 / 67$

Bongiovanni, A. M., Eberlein, W. R., Goldman, A. S., New, M.: Disorders of adrenal steroid biogenesis. In: Pincus, G.; Recent Progress in Hormone Research, p. 375-449. New York, London: Academic Press 1967. [E7,039/67

Bonino, A.: Ovariectomia e tossicosi ganglioplegica. Ormologia 15, 362-364 (1955).

$[\mathrm{C} 13,016 / 55$

Bonino, A.: Sesso e tossicosi acetilcolinica. Ormonologia 16, 174-177 (1956). [C30,089/56

Bonino, A.: Sesso e ganglioplegici. Ormonologia 16, 256-260 (1956).

$[\mathrm{C} 30,099 / 56$ 
Bonino, A.: Spasmo morfinico e gestazione. Ormonologia 17, 195-199 (1957). [C64,366/57

Bonmassar, E., Melan, F., Montagnani-Marelli, A.: Influsso di un ormone anabolizzante (dimetazina) sullo stato immunitario del topo verso il cancro ascite di Ehrlich. Arch. ital. Pat. 10, 37-40 (1967).

[F 85,891/67

Bonnycastle, D. D., Giarman, N. J., Paasonen, M. K.: Anticonvulsant compounds and 5-hydroxytryptamine in rat brain. Brit. J. Pharmacol. 12, 228-231 (1957).

$[\mathrm{C} 37,036 / 57$

Bonta, I. L., Goorissen, E. M.: Different potency of pancuronium bromide on two types of skeletal muscle. Europ. J. Pharmacol. 4, 303-308 (1968).

[G75,052/68

Bonta, I. L., Overbeek, G. A.: Experimental design for studying the pattern of central nervous activity of steroids. In: Martini and Pecile; Hormonal Steroids, Biochemistry, Pharmacology and Therapeutics. New York: Academic Press 1965.

$[\mathrm{E} 5,494 / 65$

Bonta, I. L., Vargaftig, B. B., de Vos, C. J., Grijsen, H.: Haemorrhagic mechanisms of some snake venoms in relation to protection by estriol succinate of blood vessel damage. Life Sci. 8, 881-888 (1969).

$[\mathrm{G} 69,044 / 69$

Bonta, I. L., de Vos, C. J., Delver, A.: Inhibitory effects of estriol-16,17-disodium succinate on local haemorrhages induced by snake venom in canine heart-lung preparations. Acta endocr. (Kbh.) 48, 137-146 (1965).

[F 28,544/65

Booth, J., Gillette, J. R.: The effect of anabolic steroids on drug metabolism by microsomal enzymes in rat liver. J. Pharmacol. exp. Ther. 137, 374-379 (1962).

[D34,656/62

Boquet, P., Izard, Y., Grave, F., Delpuech, M.: Influence de l'acide ascorbique et de la cortisone sur les réactions homéostatiques des petits rongeurs expérimentalement intoxiqués par l'antigène typhique 0 . Ann. Inst. Pasteur 91, 292-311 (1956).

[E52,759/56

Boquoi, E., Kreuzer, G.: Der Einfluß von östrogen und gestagen wirkenden Hormonen auf die durch Diäthylnitrosamin erzeugten Leberveränderungen und Tumoren bei der Ratte. Arch. Geschwulstforsch. 26, 223-233 (1965).

$[\mathrm{F} 82,383 / 65$

Borberg, H., Lücker, P.: Tierexperimentelle Untersuchungen über die antikatabole Wirkung des 1-Methyl-androst-1-en-17 $\beta$-ol-3-on. (Primobolan Schering). Acta endocr. (Kbh.) 47, 231-236 (1964).

$[\mathrm{F} 24,271 / 64$

Borchardt, W.: Fieber, Schilddrüse und Nebennieren. (Nach Versuchen an Katzen.) Klin. Wschr. 2, 1507-1509 (1928).

$[23,683 / 28$
Borglin, N. E.: Oral contraceptives and liver damage. Brit. med. J. 1965I, 1289-1290.

$[\mathrm{F} 40,990 / 65$

Borglin, N. E., Mansson, B.: The effect of natural oestrogen on the toxic action of amidopyrine. Acta endocr. (Kbh.) 8, 81-89 (1951).

$[\mathrm{B} 62,206 / 51$

Borgman, R. F.: Increased survival-time in dystrophic mice treated with methylandrostenediol dienanthoylacetate. Nature (Lond.) 197, 1304 (1963).

$[\mathrm{D} 62,710 / 63$

Borgman, R. F., Haselden, F. H.: Cholelithiasis in rabbits: effects of bile constituents and hormones on dissolution of gallstones. Amer. J. vet. Res. 30, 107-112 (1969). [H29,947/69 Börner, H., Klinkmann, H., Tessmann, D., Wüstenberg, P. W.: Zur Testosteronbehandlung der Urämie. Kasuistik und tierexperimenteller Beitrag. Wiss. Z. Univ. Rostock 15, 157-161 (1966).

$[\mathrm{E} 85,972 / 66$

Boroff, D. A.: Studies of the toxin of Clostridium botulinum. IV. Fluorescence of Clostridium botulinum toxin and its relation to toxicity. Int. Arch. Allergy 15, 74-90 (1959).

$[\mathrm{C} 75,371 / 59$

Boroff, D. A., Fleck, U.: Effects of serotonin on the toxin of Clostridium botulinum. J. Pharmacol. exp. Ther. 157, 427-431 (1967).

$[\mathrm{F} 87,254 / 67$

Borowsky, B. A., Kessner, D. M., Hartroft, W. S., Recant, L., Koch, M. B.: Aminonucleosideinduced chronic glomerulonephritis in rats. $J$. Lab. clin. Med. 57, 512-521 (1961). [D2,508/61

Borzelleca, J. F., Manthei, R. W.: Factors influencing pentobarbital sleeping time in mice. Arch. int. Pharmacodyn. 111, 296-307 (1957).

$[\mathrm{C} 40,953 / 57$

Bosányi, A. de: Experimental studies on rickets. III. Protein substances as a factor in normal osteogenesis and in the healing of rickets. Amer. J. Dis. Child. 30, 780-798 (1925).

$[367 / 25$

Bose, B. C., Saifi, A. Q., Bhagwat, A. W.: Effect of Cannabis indica on hexobarbital sleeping time and tissue respiration of rat brain. Arch. int. Pharmacodyn. 141, 520-524 (1963).

[D58,773/63

Both, P. C. J.: Sur l'action préventive d'un dérivé de l'hormone mâle, dans la cancérisation des souris provoquée par des implants d'hormone femelle (action du pH). Ann. Endocr. (Paris) 25, Sup.119-121 (1964). [F 29,450/64 Bottiglioni, E., Orlandi, G., Sturani, P. L.: Aspetti istologici ed istochimici dell'apparato cardiovascolare e dei muscoli dell'attivà 
volontaria nel ratto in carenza di vitamina $A$; effetto della somministrazione di ormone somatotropo e di una frazione lipidica diencefalica. Musc. Dystrophy Abstr. 3, 117 (1959).

$[\mathrm{C} 70,889 / 59$

Bottiglioni, F., Pedrelli, P., Savorelli, M.: Studio dell'influenza di un antiandrogeno (il cyproterone) sull'attività steroidogenetica del testicolo di ratto in vitro. Boll. Soc. ital. Biol. sper. 45, 993-996 (1969).

[G76,203/69

Bourque, J. E., Haterius, H. 0., Glasseo, E.: Treatment of circulatory collapse of experimental venous occlusion: use of adrenal cortical extract and saline solution. Proc. Soc. exp. Biol. (N.Y.) 52, 313-314 (1943).

$[\mathrm{A} 57,912 / 43$

Bousquet, W. F.: Pharmacology and biochemistry of drug metabolism. J. pharm. Sci. 51, 297-309 (1962).

[H11,613/62

Bousquet, W. F., Rupe, B. D., Miya, T. S.: Morphine inhibition of drug metabolism in the rat. Biochem. Pharmacol. 13, 123-125 (1964).

[E39,107/64

Bousquet W. F., Rupe, B. D., Miya, T. S.: Endocrine modification of drug responses in the rat. J. Pharmacol. Exp. Ther. 147/3, 376 to 379 (1965).

[F 35,073/65

Bouyard, P., Klein, M.: Action musculaire de l'ouabaïne chez le rat traité par la 9- $\alpha$-fluoro, 16- $\beta$-méthyl, $\Delta$-hydrocortisone. $C . R$. Soc. Biol. (Paris) 157, 342-344 (1963).

[D $69,070 / 63$

Bouyard, P., Klein, M.: Actions de divers corticoïdes anti-inflammatoires dans le "choc hémorragique irréversible' expérimental. $A n n$. Anesth. franç. 7, 569-573 (1966). [G41,843/66

Bowen, S. T., Gowen, J. W., Tauber, O. E.: Cortisone and mortality in mouse typhoid. I. Effect of hormone dosage and time of injection. Proc. Soc. exp. Biol. (N.Y.) 94, 476-479 (1957).

$[\mathrm{C} 31,414 / 57$

Bowen, S. T., Gowen, J. W., Tauber, O. E.: Cortisone and mortality in mouse typhoid. II. Effect of environmental temperature. Proc. Soc. exp. Biol. (N.Y.) 94, 479-482 (1957).

$[\mathrm{C} 31,415 / 57$

Bowen, S. T., Gowen, J. W., Tauber, O. E.: Cortisone and mortality in mouse typhoid. III. Effect of natural and acquired immunity. Proc. Soc. exp. Biol. (N.Y.) 94, 482-485 (1957).

$[\mathrm{C} 31,416 / 57$

Bowman, W. C., Osuide, G.: Interaction between the effects of tremorine and harmine and of other drugs in chicks. Europ. J. Pharmocol. 3, 106-111 (1968).

$[\mathrm{F} 98,712 / 68$
Bowman, W. C., Rand, M. J., West, G. B.: Textbook of Pharmacology, p. 1025. Oxford, Edinburgh: Blackwell Scientific Publ. 1968.

[E714/68

Boyer, F., Chedid, L.: La cortisone dans les infections expérimentales de la souris. Ann. Inst. Pasteur 84, 453-457 (1953). [C624/53

Boyland, E. and Jondorf, W. R.: The stimulation of ascorbic acid excretion in rats. Brit. J. Cancer 16, 489-493 (1962). [D [ $47,605 / 62$ Bozzo, G. B.: Ricerche sperimentali sulla epatosteatosi dietetica in gravidanza. Quad. Clin. ostet. ginec. 4, 206-213 (1949). [B50,296/49 Bracharz, H., Laas, H., Beitzien, G.: Die Wirkung von Aldactone auf die arterielle Hypertension. In: Klinische Anwendung der Aldosteron-Antagonisten, p. 89. Stuttgart: Georg Thieme Verlag 1962.

[D37,973/62

Brachet, J., Jeener, R.: Phosphatase alcaline des noyaux et vitesse de remplacement du phosphore de l'acide thymonucléique. $C$. $R$. Soc. Biol. (Paris) 140, 1121-1122 (1946).

[B23,118/46

Bradiord, R. H., Howard, R. P., Joel, W., Shetlar, M. R.: Antagonistic effects of parathyroid extract and cortisone. Effects on serum protein and glycoprotein fractions and on renal calcification. Arch. Path. 69, 382-389 (1960).

$[\mathrm{D} 76,315 / 60$

Bradley, G. M., Spink, W. W.: Acute hepatic necrosis induced by brucella infection in hyperthyroid mice. $J$. exp. Med. 110, 791-800 (1959).

$[\mathrm{C} 76,042 / 59$

Bradlow, H. L., Hellman, L., Zumofi, B., Gallagher, T. F.: Interaction of hormonal effects: influence of triiodothyronine on androgen metabolism. Science 124, 1206-1207 (1956).

$[\mathrm{C} 27,897 / 56$

Brainerd, H., Scaparone, M.: The effect of cortisone on the fixation and neutralization of diphtheria toxin. Antibiot. et Chemother. (Basel) 3, 693-697 (1953).

$[\mathrm{B} 87,957 / 53$

Braun-Menéndez, E.: Tiroides e hipertensión nefrógena experimental. Rev. Soc. argent. Biol. 30, 138-147 (1954).

$[\mathrm{C} 4,927 / 54$

Braun-Menéndez, E., Houssay, H. E. J.: Hipertrofia compensadora del riñon en la rata hipofisopriva. Rev. Soc. argent. Biol. 25, 55-62 (1949).

$[\mathrm{B} 45,945 / 49$

Brazda, F. G., Baucum, R.: The effect of nikethamide on the metabolism of pentobarbital by liver microsomes of the rat. J. Pharmacol. exp. Ther. 132, 295-298 (1961). [D48,613/61 
Brazda, F. G., Coulson, R. A.: The influence of coramine on the liver of the young rat. Proc. Soc. exp. Biol. (N.Y.) 67, 37-40 (1948).

[B32,015/48

Bremer, F., Titeca, J.: Action de l'adrénaline sur l'atonie musculaire du stade initial de la curarisation. C. R. Soc. Biol. (Paris) 99, 624-627 (1928).

$[23,673 / 28$

Brena, S., D'Agostino, A.: Narcosi barbiturica e orchiectomia. Ormonologia 14, $1-8$ (1954).

$[\mathrm{C} 11,921 / 54$

Brenk, H. A. S. van den: Radiation lethality in histamine depleted rats. Brit. J. exp. Path. 39, 300-306 (1958).

$[\mathrm{C} 57,624 / 58$

Brenk, H. A. S. van den, Elliott, K.: Radioprotective action of 5-hydroxytryptamine. Nature (Lond.) 182, 1506-1507 (1958).

$[\mathrm{C} 76,268 / 58$

Brenk, H. A. S. van den, Moore, R.: Effect of high oxygen pressure on the protective action of cystamine and 5-hydroxytryptamine in irradiated rats. Nature (Lond.) 183, 1530 to 1531 (1959).

$[\mathrm{C} 71,353 / 59$

Brenner, G., Korte, W., Puck, A.: Die Wirkung von Oestradiol-17 und Oestriol auf die experimentelle diätetische Lebernekrose der Ratte. Endokrinologie 42, 212-222 (1962).

[D24,411/62

Bresnick, E., Stevenson, J. G.: Microsomal Ndemethylase activity in developing rat liver after administration of 3-methylcholanthrene (3MC). (Abstr.) Biochem. Pharmacol. 17, 1815 to 1822 (1968).

[H $215 / 68$

Brewster, W. R. Jr., Isaaes, J. P., Osgood, P. F., King, T. L.: The hemodynamic and metabolic interrelationships in the activity of epinephrine, norepinephrine and the thyroid hormones. Circulation 13, 1-20 (1956).

$[\mathrm{C} 11,771 / 56$

Brin, M., MeKee, R. W.: Effects of X-irradiation, nitrogen mustard, fasting, cortisone and adrenalectomy on transaminase activity in the rat. Arch. Biochem. 61, 384-389 (1956).

$[\mathrm{C31}, 261 / 56$

Britton, S. W., Kline, R. F.: Age, sex, carbohydrate, adrenal cortex and other factors in anoxia. Amer. J. Physiol. 145, 190-202 (1945).

$[93,980 / 45$

Britton, S. W., Myers, W. K.: The thyroid gland and the sensitivity of animals to insulin. Amer. J. Physiol. 84, 132-140 (1928).

$[18,695 / 28$

Broek, N., Hohorst, H. J.: Utber die Aktivierung von Cyclophosphamid im Warmblüterorganis- mus. Naturwissenschaften 49, 610-611 (1962).

$[\mathrm{G} 71,533 / 62$

Brodeur, J., Côté, J.-Y., Nantel, J., Auger, P.: Effects de l'âge, du sexe et de divers traitements hormonaux sur l'activité de la procaïnestérase du foie de rat in vitro. Rev. canad. Biol. 26, 135-140 (1967).

[F99,981/67

Brodeur, J., Du Bois, K. P.: Comparison of acute toxicity of anticholinesterase insecticides to weanling and adult male rats. Proc. Soc. exp. Biol. (N.Y) 114, 509-511 (1963).

$[\mathrm{E} 33,487 / 63$

Brodeur, J., DuBois, K. P.: Mechanisms of age difference in malathion toxicity. Proc. canad. Fed. biol. Soc. 8, 18 (1965). [F 40,590/65 Brodeur, J., DuBois, K. P.: Studies on factors influencing the acute toxicity of malathion and malaoxon in rats. Canad. J. Physiol. Pharmacol. 45, 621-631 (1967). [F 85,072/67 Brodie, B. B.: Pathways of drug metabolism. J. Pharm. Pharmacol. 8, 1-17 (1956).

$[\mathrm{C} 12,157 / 56$

Brodie, B. B.: Drug metabolism-subcellular mechanisms. In: Mongar and de Reuck; Ciba Foundation Symposium on Enzymes and Drug Action, p. 317-343. London: J. \& A. Churchill Ltd. 1962.

[G55,013/62

Brodie, B. B.: Some prospects in toxicology. Environm. Res. 2, 368-372 (1969).

$[\mathrm{G} 72,492 / 69$

Brodie, B. B., Axelrod J., Cooper, J. R., Gaudette, L., La Du, B. N., Mitoma C., Udenfriend, S.: Detoxication of drugs and other foreign compounds by liver microsomes. Science 121, 603-604 (1955). [G66,772/55

Brodie, B. B., Cosmides, G. J., Rall, D. P.: Toxicology and the biomedical sciences. Science 148, 1547-1554 (1965).

$[\mathrm{F} 42,949 / 65$

Brodie, B. B., Gillette, J. R., La Du, B. N.: Enzymatic metabolism of drugs and other foreign compounds. Ann. Rev. Biochem. 27, 427-454 (1958).

$[\mathrm{E} 92,717 / 58$

Brodie, B. B., Maickel, R. P.: Comparative biochemistry of drug metabolism. In: Brodie and Erdös; Metabolic Factors Controlling Duration of Drug Action 6, p. 299-324. New York: The Macmillan Co. 1962. [G67,800/62

Brodie, B. B., Maickel, R. P., Jondori, W. R.: Termination of drug action by enzymatic inactivation. Fed. Proc. 17, 1163-1174 (1958).

$[\mathrm{E} 92,716 / 58$

Brodie, B. B., Reid, W. D., Cho, A. K., Sipes, G., Krishna, G., Gillette, J. R.: Possible mechanism 
of liver necrosis caused by aromatic organic compounds. Proc. nat. Acad. Sci. (Wash.) 68, 160-164 (1971).

$[\mathrm{G} 80,473 / 71$

Brodie, D. A., Cook, P. G., Bauer, B. J., Dagle, G. E.: Indomethacin-induced intestinal lesions in the rat. Toxicol. appl. Pharmacol. 17, 615 to 624 (1970).

$[\mathrm{G} 67,797 / 70$

Brody, S.: Mechanism of growth. II. The influence of $p$-dimethylaminoazobenzene on rat liver regeneration after partial hepatectomy. Cancer Res. 20, 1469-1473 (1960).

[G71,680/60

Brooke, M. S., Hechter, O., Kass, E. H.: Antiendotoxic activity of corticosteroids. Endocrinology 69, 867-869 (1961). [D11,627/61

Brooks, G. T., Harrison, A.: The oxidative metabolism of aldrin and dihydroaldrin by houseflies, housefly microsomes and pig liver microsomes and the effect of inhibitors. Biochem. Pharmacol. 18, 557-568 (1969).

$[\mathrm{G} 65,297 / 69$

Brouet, G., Marche, J., Chrétien, J., Mallet, J., Quichaud, J.: Hormone somatotrope et infection tuberculeuse. Données expérimentales et cliniques. Therapie 11, 584-631 (1956).

[G72,418/56

Brown, A. K.: Studies on the neonatal development of the glucuronide conjugating system. J. Dis. Child. 94, 510-512 (1957). [H28,215/57 Brown, B. B.: Lysergic acid diethylamide antagonism of certain drugs. Ann. N.Y. Acad. Sci. 66, 677-685 (1957).

$[\mathrm{C} 31,328 / 57$

Brown, I. N., Allison, A. C., Taylor, R. B.: Plasmodium berghei infections in thymectomized rats. Nature (Lond.) 219, 292-293 (1968).

$[\mathrm{H} 1,304 / 68$

Brown, J. H., Schwartz, N. L.: Interaction of lysosomes and anti-inflammatory drugs. Proc. Soc. exp. Biol. (N.Y.) 131, 614-620 (1969).

$[\mathrm{H} 14,096 / 69$

Brown, J. H. U., Smith, R. B., Griffin, J. B., Jacobs, J.: The influence of cortisone on the action of an adrenocorticolytic drug. Endrocrinology 61, 106-109 (1957). [C37,523/57

Brown, J. R.: The effect of environmental and dietary stress on the concentration of 1,1-bis(4chlorophenyl)-2,2,2-trichloroethane in rats. Toxicol. appl. Pharmacol. 17, 504-510 (1970).

$[\mathrm{G} 78,684 / 70$

Brown, P. S., Wells, M.: Factors which influence assays of gonadotrophin based on the induction of ovulation in mice. $J$. Endocr. 33, 507-514 (1965).

$[\mathrm{F} 57,759 / 65$

Brown, R. R., Miller, J. A., Miller, E. C.: The metabolism of methylated aminoazo dyes. IV.
Dietary factors enhancing demethylation in vitro. J. biol. Chem. 209, 211-222 (1954).

$[\mathrm{G} 57,030 / 54$

Brown, T. G. Jr., Evangelista, B. S., Green, T. J., Gwilt, D. J.: Experimental study of current therapeutic approaches to endotoxin shock. (Abstr.). Fed. Proc. 27, 447 (1968).

[H456/68

Brown, W. D., Johnson, A. R., O'Halloran, M. W.: The effect of the level of dietary fat on the toxicity of phenolic antioxidants. Austral. J. exp. Biol. med. Sci. 37, 533-547 (1959).

$[\mathrm{G} 69,691 / 59$

Brown, W. R., Boon, W. H.: Ethnic group differences in plasma bilirubin levels of full-term, healthy Singapore newborns. Pediatrics 36, 745 to 751 (1965).

$[\mathrm{G} 78,957 / 65$

Bruce, J. A., Brunson, J. G.: Use of propiomazine and levarterenol in endotoxin shock. Fed. Proc. 26, 690 (1967).

[F 79,682/67

Brück, K., Wünnenberg, W., Zeisberger, E.: Comparison of cold adaptive metabolic modifications in different species, with special reference to the miniature pig. Fed. Proc. 28, 1035-1041 (1969).

[H 13,180/69

Bruckner, W. L., Barenfus, M., Snow, H. D., Longmire, W. P., Jr.: Abrasive ablation: a new experimental surgical technique to study nonparenchymal aspects of hepatic regeneration. J. surg. Res. 9, 461-469 (1969). [H34,704/69 Brues, A. M., Drury, D. R., Brues, M. C.: A quantitative study of cell growth in regenerating liver. Arch. Path. 22, 658-673 (1936).

$[\mathrm{A} 45,962 / 36$

Brues, A. M., Marble, B. B.: An analysis of mitosis in liver restoration. $J$. exp. Med. 65, 15-28 (1937).

$[\mathrm{A} 47,729 / 37$

Bruger, M., Fitz, F.: Experimental atherosclerosis. I. Effect of prolonged administration of the thyrotropic factor of the anterior lobe of the pituitary on experimental atherosclerosis in rabbits. Arch. Path. 65, 637-642 (1938).

$[\mathrm{A} 15,324 / 38$

Brühl, P., Schmidt, H. J.: Die Wirkung von Nalidixinsäure auf den Ablauf der experimentellen Pyelonephritis unter dem Einfluß resistenzbeeinflussender Pharmaka. Zbl. Bakt., I. Abt. Ref. 212, 517-526 (1970). [G 76,086/70 Brunson, J. G., Kalina, R. E., Eckman, P. L.: Studies on experimental shock. Effects of vasopressor amines and phenothiazine derivatives. Amer. J. Path. 35, 1149-1167 (1959). $[\mathrm{C} 78,005 / 59$

Brust, A. A., Assali, N. S., Ferris, E. B.: Evaluation of neurogenic and humoral factors 
in blood pressure maintenance in normal and toxemic pregnancy using tetraethylammonium chloride. J. clin. Invest. 27, 717-726 (1948).

[B 18,590/48

Brust, A. A., Ransohoff, W., Reiser, M. F.: Blood pressure responses to ACTH and cortisone in normotensive and hypertensive subjects in the resting state and during autonomic blockade with tetraethylammonium chloride. Program 43rd Meet. Amer. Soc. clin. Invest., p. 9 (1951).

$[\mathrm{B} 57,917 / 51$

Brust, A. A., Ransohofi, W., Reiser, M. F., Ferris, E. B.: Vascular response to ACTH and alterations in sodium intake. In: Mote, J. R.; Proceedings of the second clinical ACTH conference. I. Research, p. 177-195. New York, Philadelphia, Toronto: The Blakiston Co. 1951.

[B58,739/51

Buchel, L.: Influence de l'âge des rats sur leur sensibilité à quelques hypnotiques. Anesth. et Analg. 10, 526-545 (1953).

[D 59,654/53

Buchel, L.: Influence des glandes sexuelles sur la sensibilité des rats blancs à quelques hypnotiques. Anesth. et Analg. 11, 229-251 (1954).

[D 73,669/54

Buchel, L.: Influence des hormones sexuelles sur l'activité de l'hexobarbital chez le rat. Durée du séjour de cet hypnotique dans l'organisme du rat. Anesth. et Analg. 11, 268-279 (1954).

$[\mathrm{G} 67,326 / 54$

Buchel, L., Levy, J.: Induction des hydroxylases des microsomes du foie. I. Présence, reversibilité, reproductibilité de l'induction chez la souris prétraitée par le phénobarbital. Thérapie 25, 91-106 (1970).

[G74,850/70

Buchel, L., Levy, J.: Induction des hydroxylases des microsomes du foie. II. Reversibilité, reproductibilité de l'induction chez le rat, prétraité par le phénobarbital. Thérapie 25, 107-123 (1970).

[G74,851/70

Buchel, L., Liblau, L.: Contribution à l'étude du métabolisme de l'hexobarbital chez le rat blanc, suivant le sexe. Arch. Sci. physiol. 16, 227-235 (1962).

[E 87,108/62

Buchel, L., Liblau, L.: Contribution à l'étude du métabolisme de l'hexobarbital chez la souris. Arch. Sci. physiol. 17, 255-259 (1963).

[E 89,233/63

Bucher, N. L. R.: Regeneration of mammalian liver. Int. Rev. Cytol. 15, 245-300 (1963).

[G68,621/63

Bucher, N. L. R., MeGarrahan, K.: The biosynthesis of cholesterol from acetate-1-C ${ }^{14}$ by cellular fractions of rat liver. J. biol. Chem. 222, 1-15 (1956).

$[\mathrm{G} 67,470 / 56$
Bucher, N. L. R., Swaffield, M. N.: Ribonucleic acid synthesis in relation to precursor pools in regenerating rat liver. Biochim. biophys. Acta (Amst.) 174, 491-502 (1969).

$[\mathrm{H} 21,579 / 69$

Bucher, N. L. R., Schrock, T. R., Moolten, F. L.: An experimental view of hepatic regeneration. Johns Hopk. med. J. 125, 250-257 (1969).

$[\mathrm{G} 72,546 / 69$

Bucher, N. I. R., Scott, J. F., Aub, J. C.: Regeneration of the liver in parabiotic rats. Cancer Res. 11, 457-465 (1951). [ [D42,066/51

Buckett, W. R.: The pharmacology of pancuronium bromide: a new non-depolarising neuromuscular blocking agent. Irish J. med. Sci. 1, 565-568 (1968).

[G 75,531/68

Buckett, W. R., Marjoribanks, C. E. B., Marwick, F. A., Morton, M. B.: The pharmacology of pancuronium bromide (Org. NA 97), a new potent steroidal neuromuscular blocking agent. Brit. J. Pharmacol. 32, 671-682 (1968).

$[\mathrm{G} 56,175 / 68$

Bugbee, L. M., Like, A, A., Stewart, R. B.: The effects of cortisone on intradermally induced vaccinia infection in rabbits. J. infect. Dis. 106, 166-173 (1960).

$[\mathrm{C} 84,115 / 60$

Bull, L. B., Dick, A. T., McKenzie, J. S.: The acute toxic effects of heliotrine and lasiocarpine, and their N-oxides, on the rat. J. Path. Bact. 75, 17-25 (1958).

$[\mathrm{C} 49,278 / 58$

Bullock, G. R., Delaney, V. B., Sawyer, B. C., Slater, T. F.: Biochemical and structural changes in rat liver resulting from the parenteral administration of a large dose of sodium salicylate. Biochem. Pharmacol. 19, 245-253 (1970).

$[\mathrm{G} 73,358 / 70$

Burberi, S., Cioli, V., Piccinelli, D.: Effects of benzydamine on experimental gastric ulcers produced by indomethacin and reserpine. Pharmacol. Res. Commun. 2, 91-95 (1970).

[G 80,224/70

Burckhardt, D., LaDue, J. S.: Östrogenähnliche Wirkung von Digitalis. Seine Wirkung auf die Gonadotropinausscheidung bei postklimakterischen Frauen. Schweiz. med. Wschr. 98, 1250-1252 (1968).

$[\mathrm{H} 15,071 / 68$

Burger, A., Laudat, P., Bricaire, H.: Determination de la transcortine plasmatique au cours de diverses endocrinopathies. Acta endocr. (Kbh.) 64, 602-609 (1970). [H28,702/70

Burger, P. C., Herdson, P. B.: Phenobarbitalinduced fine structural changes in rat liver. Amer. J. Path. 48, 793-809 (1966).

$[\mathrm{G} 66,499 / 66$ 
Burns, J. J.: Implications of enzyme inductions for drug therapy. Amer. J. Med. 37, 327-331 (1964).

$[\mathrm{G} 41,546 / 64$

Burns, J. J., Conney, A. H.: Therapeutic implications of drug metabolism. Semin. Hemat. 1, 375-400 (1964).

$[$ G71,448/64

Burns, J. J., Conney, A. H.: Enzyme stimulation and inhibition in the metabolism of drugs. Proc. Roy. Soc. Med. 58, 955-960 (1965).

$[\mathrm{F} 56,503 / 65$

Burns, J. J., Welch, R. M., Conney, A. H.: Drug effects on enzymes. In: Siegler and Moyer; Animal and Clinical Pharmacologic Techniques in Drug Evaluation 2, p. 67-75. Chicago, Ill.: Year Book Medical Publication Inc. 1967.

[G66,103/67

Burrill, M. W., Greene, R. R.: The liver and endogenous androgens. Proc. Soc. exp. Biol. (N.Y.) 44, 273-276 (1940). [A32,956/40

Burrill, M. W., Greene, R. R.: Effect of rat's liver on activity of testosterone and methyl testosterone. Endocrinology 31, 73-77 (1942).

[A38,214/42

Burstein, S.: Determination of initial rates of cortisol $2 \alpha$ - and $6 \beta$-hydroxylation by hepatic microsomal preparations in guinea pigs: effect of phenobarbital in two genetic types. Endocrinology 82, 547-554 (1968). [F95,565/68

Burstein, S., Bhavnani, B. R.: Effect of phenobarbital administration of the in vitro hydroxylation of cortisol and on over-all substrate and product metabolism in the guinea pig and rat. Endocrinology 80, 351-356 (1967).

[F 77,040/67

Burstein, S., Klaiber, E. L.: Phenobarbitalinduced increase in $6 \beta$-hydroxycortisol excretion: clue to its significance in human urine. J. clin. Endocr. 25, 293-296 (1965).

[F31,533/65

Burton, R. R., Smith, A. H., Carlisle, J. C., Sluka, S. J.: Role of hematocrit, heart mass, and high-altitude exposure in acute hypoxia tolerance. J. appl. Physiol. 27, 49-52 (1969).

$[\mathrm{G} 67,617 / 69$

Buschke, A.: Thallium und thymus. Klin. Wschr. 12, 311 (1933).

$[4,823 / 33$

Buschke, A., Spanier, F., Pleger: Versuche zu einer Modifikation der Thalliumepilation. Dermat. Wschr. 96, 226-229 (1933). [43,284/33

Busfield, D., Child, K. J., Basil, B., Tomich, E. G.: The influence of sex on the catabolism of griseofulvin. J. Pharm. 12, 539-543 (1960).

[D10,983/60
Busfield, D., Child, K. J., Tomich, E. G.: An effect of phenobarbitone on griseofulvin metabolism in the rat. Brit. J. Pharmacol. 22, 137-142 (1964).

[G74,680/64

Bush, G. H., Stead, A. L.: The use of d-tubocurarine in neonatal anaesthesia. Brit. $J$. Anaesth. 34, 721-728 (1962). $\quad$ [G78,967/62

Busso, R.-R.: Sensibilité des animaux éthyroïdés a l'égard de certains toxiques. $C$. $R$. Soc. Biol. (Paris) 92, 820-821 (1925). [26,684/25 Butler, T. C., Mahaffee, D., Mahaffee, C.: The role of the liver in the metabolic disposition of mephobarbital. J. Pharmacol. exp. Ther. 106, 364-369 (1952).

$[\mathrm{G} 76,364 / 52$

Buttle, G. A. H., Squires, S.: A method of assessing ACTH by means of the antagonism of histamine intoxication. J. Endocr. 7, xxvii to $x x v i i i(1951)$.

[B59,985/51

Buu-Hoi, N. P., Hien, D. P.: Zoxazolaminehydroxylase inducing effect of polycyclic aromatic hydrocarbons; relationships between structure and activity, and degree of correlation with carcinogenicity. Biochem. Pharmacol. 18, 741-748 (1969).

$[\mathrm{G} 66,135 / 69$

Byerrum, R. U.: Influence of dietary iodine on Susceptibility of rats to alpha naphthylthiourea poisoning. Proc. Soc. exp. Biol. (N. Y.) 62, 328-330 (1946). [B1,322/46

Byerrum, R. U., DuBois, K. P.: The influence of Diet on the Susceptibility of rats to AlphaNaphathylthiourea. J. Pharmacol. Exp. Ther. 90, 321-329 (1947).

$[\mathrm{B3}, 076 / 47$

Byrne, J. J.: The sympathetic nervous system and pulmonary embolism. Arch. Surg. 73, 936-938 (1956).

$[\mathrm{C} 46,341 / 56$

Byrom, F. B.: The effect of oestrogenic and other sex hormones: on the response of the rat to vasopressin. Lancet 1839 I, 129-131.

$[\mathrm{A} 9,905 / 38$

Cabibbe, F., Paracchi, G., Lanzara, D.: Azione di alcuni psicofarmaci sulla triptofano-pirrolasi epatica di ratti in stato di stress postoperatorio. Boll. Soc. ital. Biol. sper. 43, 1183-1186 (1967).

[G52,346/67

Cahn, J., Georges, G., Herold, M., Pierre, R.: Influence de la sérotonine sur le métabolisme cérébral et la narcose barbiturique au cours des 24 heures suivant l'injection intraveineuse de $12,5 \mathrm{mg} / \mathrm{kg}$ chez le lapin in vivo. Therapie 13, 62-65 (1958).

$[\mathrm{C} 64,625 / 58$

Cahn, J., Georges, G., Pierre, R.: Essais d'anesthésie prolongée par la 5-hydroxytryptamine (séronine) et contrôlée des drogues à action 
neurovégétative. II. Etude chez le rat. $C . R$. Soc. Biol. (Paris) 150, 162-164 (1956).

$[\mathrm{C} 19,722 / 56$

Cahn, J., Herold, M.: Importance des groupes sulfhydryles en biologie. Physiopathologie des dérivés sulfhydryles. Agressologie 1, 157-171 (1960).

$[\mathrm{G} 72,124 / 60$

Cahn, J., Pierre, R., Georges, G.: Essais d'anesthésie prolongée par la 5-hydroxytryptamine (sérotonine) et contrôlée par des drogues à action neurovégétative. II. Etude chez le lapin. C. R. Soc. Biol. (Paris) 150, 290-292 (1956).

[G71,537/56

Calabro, G.: Richerche sperimentali e considerazioni sull'azione epatoprotettiva della colina in gravidanza. Quad. Clin. ostet. ginec. 4, 228-232 (1949).

[B48,121/49

Calandi, C., Calzolari, C., Di Maria, M., Pierro, U.: Poisoning due to vitamin $\mathrm{D}$ in early infancy. (12 case reports). Riv. Clin. pediat. 77/1, 3-18 (1966).

$[\mathrm{F} 75,662 / 66$

Calcagno, A., Quercio, M.: Modificazioni della reattività alla ibernazione in rapporto al tipo di trauma sperimentale chirurgico. Pathologica 57, 367 (1965).

[G46,022/65

Caldwell, W. L., Thomassen, R. W., Bosch, A.: Unfavourable response of radiation nephritis to administration of L-triiodothyronine. Nature (Lond.) 197, 200-201 (1963). [D54,096/63

Calhoun, F. J., Tolson, W. W., Schrogie, J. J.: Effects of various drugs on the uterotropic response to mestranol and norethynodrel in the rat. Proc. Soc. exp. Biol. (N.Y.) 136, 47-50 (1971).

$[\mathrm{H} 34,806 / 71$

Caloi, N. S., Smith, C. M.: Effect of $\alpha$ and $\beta$ adrenergic agonists on traumatic shock in the rat. (Abstr.). Fed. Proc. 28, 611 (1969).

[H10,412/69

Calvert, D. N., Brody, T. M.: Role of the sympathetic nervous system in $\mathrm{CCl}_{4}$ hepatotoxicity. Amer. J. Physiol. 198, 669-676 (1960).

$[\mathrm{C} 82,653 / 60$

Calvert, D. N., Brody, T. M.: The effects of hyperthyroidism and hypothyroidism on the hepatotoxicity produced by $\mathrm{CCl}_{4}$. Fed. Proc. 19, 133 (1960).

$[\mathrm{C} 82,829 / 60$

Calvert, D. N., Brody, T. M.: The effects of thyroid function upon carbon tetrachloride hepatotoxicity. J. Pharmacol. exp. Ther. 134, 304-310 (1961).

[D 61,412/61

Camargo, A. C. M., Cornicelli, J., Cardoso, S. S.: Alteration in lipid content of the liver in the rat after partial hepatectomy. Proc. Soc. exp. Biol. (N.Y.) 122, 1151-1154 (1966).

$[\mathrm{F} 72,052 / 66$
Cameron, A. T., Carmichael, J.: A note on tetany in thyroid-fed rats and the supposed antagonism between thymus and parathyroid. Trans. Roy. Soc. Can. Sect. V 19, 53-56 (1925).

$[27,015 / 25$

Cameron, A. T., Carmichael, J.: Sudden atmospheric changes as contributory factors in the production of tetany. Trans. Roy. Soc. Can., Sect. V 20, 277-296 (1926).

$[42,188 / 26$

Cameron, A. T., Moore, A.: The effect of thyroid feeding on rats on a vitamin-deficient diet. Trans. Roy. Soc. Can., Sect. V 15, 29-36 (1921).

$[57,815 / 21$

Cameron, G. R.: Liver regeneration and biliary obstruction. J. Path. Bact. 41, 283-288 (1935).

$[\mathrm{A} 48,168 / 35$

Cameron, G. R.: Some recent work on barbiturates. Proc. Roy. Soc. Med. (Sect. Anaesth.) 32, 309-314 (1939).

$[\mathrm{A34}, 503 / 39$

Cameron, G. R., Cooray, G. H., De, S. N.: The effect of castration on the action of some barbiturates. J. Path. Bact. 60, 239-246 (1948).

$[\mathrm{B} 45,221 / 48$

Cameron, G. R., Saram, G. S. W. de: The effect of liver damage on the action of some barbiturates. J. Path. Bact. 48, 49-54 (1939).

[G72,101/39

Cameron, J. M., Pirie, T. G., Robb, R. A.: The protective action of certain hormones and vitamins against lathyrogenic drugs. Brit. J. exp. Path. 43, 496-505 (1962).

[D38,527/62

Campanacci, L. Jr., Pieragnoli, E., Tura, S.: Neurosecreto, epatopatia sperimentale ed ormone somatotropo. Azione dell'STH sulla neurosecrezione ipotalamo-ipofisaria e sul fegato, nel ratto, in condizioni normali e nell intossicazione cronica sperimentale da $\mathrm{CCl}_{4}$. (Ricerche istochimiche). Folia endocr. (Roma) 9, 381-401 (1956).

$[\mathrm{C} 20,086 / 56$

Campbell, J. A.: Oxygen poisoning and the thyroid gland. J. Physiol. (Lond.) 90, $91 \mathrm{P}-92 \mathrm{P}$ (1937).

$[\mathrm{A} 14,903 / 37$

Campbell, J. G.: Studies on the influence of sex hormones on the avian liver. III. Oestrogeninduced regeneration of the chronically damaged liver. J. Endocr. 15, 351-354 (1957).

$[\mathrm{C} 38,327 / 57$

Campbell, R. A., Bern, H. A., DeOme, K. B.: The adverse effect of oestrogen on the resistance of mice to stress. Acta endocr. (Kbh.) 23, 49-59 (1956). [C23,145/56 Campbell, R. M., Cuthbertson, D. P., Pullar, J. D.: The effects of betamethasone and fracture on nitrogen metabolism. Quart. J. exp. Physiol. 49, 141-150 (1964). [G9,081/64 
Campbell, W. C., Collette, J. V.: Effect of cortisone upon infection with Trichuris muris in albino mice. J. Parasit. 48, 933-934 (1962).

[D61,500/62

Câmpeanu, L., Vrăbiescu, A., Comsa, E.: Induced arteriosclerosis in female white rats related to age. Excerpta med. (Amst.), Int. Congr. Ser. No. 57, p. 10 (1963).

$[\mathrm{G} 21,413 / 63$

Canadell, J. M., Valdecasas, F. G.: Action inhibitrice du thiouracil sur la carotine. Experientia (Basel) 3, 35 (1947).

$[\mathrm{B} 25,697 / 47$

Canal, N., Maffei-Faccioli, A.: Induction of tryptophan-peroxydase-oxydase in rat liver by reserpine. Naturwissenschaften 46, 494 (1959).

$[\mathrm{G} 66,306 / 59$

Candole, C. A. de: Successful use of pressor drugs in paraoxon poisoning. Proc. Canad. Physiol. Soc. 20th Ann. Meet. Montreal, p. 13 (1956).

$[\mathrm{C} 25,237 / 56$

Cannon, W. B.: The Wisdom of the Body. New York: W. W. Norton and Co. 1939.

[B14,905/39

Cantarow, A., Pasehkis, K. E., Stasney, J., Rothenberg, M. S.: The influence of sex hormones upon the hepatic lesions produced by 2-acetaminofluorene. Cancer Res. 6, 610-616 (1946).

[B18,774/46

Canter, J. W., Kreel, I., Segal, R. L., Frankel, A., Baronofsky, I. D.: Influence of thyroidectomy on experimental ascites. Proc. Soc. exp. Biol. (N.Y.) 100, 771-774 (1959).

$[\mathrm{C} 67,855 / 59$

Cantin, M.: Inhibition de la néphrocalcinose expérimentale par la parathyroïdectomie. Proc. 30th Congress ACFAS Montreal, p. 37 (1962).

$[\mathrm{D} 36,815 / 62$

Cantin, M.: Role of the parathyroid and of the thyroid in the production of experimental nephrocalcinosis. Fed. Proc. 23, 545 (1964).

$[\mathrm{F} 5,681 / 64$

Cantrell, W.: Cortisone and the course of trypanosoma equiperdum infection in the rat. $J$. infect. Dis. 104, 71-77 (1959). $\quad$ [C64,728/59

Canzanelli, A., Guild, R., Rapport, D.: Pituitary and adreno-cortical relationships to liver regeneration and nucleic acids. Endocrinology $\mathbf{4 5}$, 91-95 (1949).

[B37,729/49

Capek, R.: Some effects of bradykinin on the central nervous system. Biochem. Pharmacol. 10, 61-64 (1962).

[D54,290/62

Capitolo, G.: Sugli effetti della tiroparatiroidectomia nel colpo di calore. Resistenza dell'organismo e andamento termico. Arch. Sci. med. 62, 587-595 (1936).

$[\mathrm{A} 1,730 / 36$
Caprino, G., Gallina, F.: Azione del 19-norandrostenolone fenilpropionato sul recupero negli animali panirradiati. Boll. Soc. ital. Biol. sper. 39, 1687-1691 (1963). [G10,521/63 Caprino, G., Gallina, F.: Effetto del propiltiouracile nell'animale panirradiato. Boll. Soc. ital. Biol. sper. 39, 1691-1692 (1963).

[G13,680/63

Carbone, J. V., Grodsky, G. M., Hjelte, V.: Effect of hepatic dysfunction on circulating levels of sulfobromophthalein and its metabolites. J. Clin. Invest. 38, 1989-1995 (1959).

$[\mathrm{C} 77,294 / 59$

Careddu, P., Sereni, L. P., Giunta, A., Sereni, F.: Sulla possibilità di attivare i processi di coniugazione e di escrezione epatica della bilirubina mediante alcuni farmaci. Ricerche sperimentali con la dietilamide dell'acido nicotinico (Coramina) e con l'acido fenil-etil-barbiturico (Gardenale). Minerva med. 55, 2559-2562 (1964).

[G21,332/64

Caren, L. D., Rosenberg, L. T.: The role of complement in resistance to endogenous and exogenous infection with a common mouse pathogen, Corynebacterium kutscheri. J. exp. Med. 124, 689-699 (1966).

$[\mathrm{G} 41,288 / 66$

Caridroit, F., Arvy, L.: Action favorisante de la thyroxine sur le développement des vésicules séminales des souris castrées traitées par le propionate de testostérone. C. R. Soc. Biol. (Paris) 136, 3-5 (1942). [A57,397/42

Carlo, F. J. Di, Haynes, L. J., Coutinho, C. B., Phillips, G.: Pentobarbital sleeping time and RES stimulation in mice. $J$. reticuloendoth. Soc. 2, 360-361 (1965).

[F 74,536/65

Carlson, G. P., DuBois, K. P.: Studies on the toxicity and biochemical mechanism of action of 6-methyl-2,3-quinoxalinedithiol cyclic carbonate (Morestan). J. Pharmacol. exp. Ther. 173, 60-70 (1970).

$[\mathrm{H} 24,653 / 70$

Carmichael, E. B.: Nembutal anesthesia. III. The median lethal dose of nembutal (pentobarbital sodium) for young and old rats. $J$. Pharmacol. exp. Ther. 62, 284-291 (1938).

$[\mathrm{D} 68,076 / 38$

Carmichael, R. H., Wilson, C., Martz, B. L.: Effect of anabolic steroids on liver function tests in rabbits. Proc. Soc. exp. Biol. (N.Y.) 113, 1006-1008 (1963).

[E28,041/63

Carraseo, R., Vargas, L.: Hormonas esteroideas y estilbestrol en el tratamiento de la diabetes aloxánica. Bol. Soc. Biol. Santiago 6, 61-62 (1949).

$[\mathrm{B} 50,792 / 49$

Carrasco-Formiguera, R., Eseobar, I.: Influence of previous injection of epinephrine upon dia- 
betogenic effect of alloxan in rabbits. Amer. $J$. Physiol. 152, 609-614 (1948). [B19,877/48 Carrier, R. N., Buday, P. V.: Augmentation of toxicity of monoamine oxidase inhibitor by thyroid feeding. Nature (Lond.) 191, 1107 (1961).

[D 11,237/61

Carrier, R. N., Buday, P. V.: The influence of thyroid feeding on the pharmacologic actions of some monoamine oxidase inhibitors. Arch. int. Pharmacodyn. 145, 18-35 (1963).

$[\mathrm{E} 28,887 / 63$

Carroll, K. K., Noble, R. L.: Resistance induced by anti-thyroid compounds and by goitrogenic diets against experimental pulmonary edema in rats. Fed. Proc. 8, 22 (1949). [B32,718/49 Carroll, R.: Temporary hepatic ischaemia in the rabbit. J. Path. Bact. 85, 67-75 (1963).

[G71,190/63

Carroll, R.: The extent and distribution of experimental hepatic infarcts. J. Path. Bact. 85, 349-355 (1963).

[G71,191/63

Carstensen, B., Paulsen, F., Rudberg-Roos, I.: Some experiments with somatotropin (STH) and insulin in tuberculosis. Preliminary report. Acta tuberc. scand. 31, 225-235 (1955).

$[\mathrm{C} 12,300 / 55$

Cartner, L. M., Arias, I. M.: Developmental pattern of glucuronide formation in rat and guinea pig liver. Amer. J. Physiol. 205, 663 to 666 (1963).

$[\mathrm{E} 28,857 / 63$

Caskey, M. W.: Effect of adrenalin on the temperature of skeletal muscle before and after ligation of the hepatic artery and the portal vein. Amer. J. Physiol. 80, 381-390 (1927).

$[20,936 / 27$

Cassidy, G. J., Dworkin, S., Finney, W. H.: Insulin and the mechanism of hibernation. Amer. J. Physiol. 73, 417-428 (1925).

$[24,604 / 25$

Cassidy, G. J., Dworkin, S., Finney, W. H.: The action of insulin on the domestic fowl. Amer. J. Physiol. 75, 609-615 (1926).

$[26,459 / 26$

Castells, S., Bransome, E. D., Jr.: Effects of ACTH and an inhibitor of $3 \beta$-hydroxysteroid dehydrogenase on the synthesis of adrenocortical mitochondrial proteins. Endocrinology 86, 444-447 (1970).

[H21,283/70

Caster, W. 0., Wade, A. E., Greene, F. E., Meadows, J. S.: Effect of different levels of corn oil in the diet upon the rate of hexobarbital, heptachlor and aniline metabolism in the liver of the male white rat. Life Sci. 9, 181-190 (1970).

$[\mathrm{G} 73,426 / 70$
Castro, J. A., Gillette, J. R.: Species and sex differences in the kinetic constants for the $\mathrm{N}$-demethylation of ethyl-morphine by liver microsomes. Biochem. biophys. Res. Commun. 28, 426-430 (1967).

[G77,558/67

Castro, J. A., Greene, F. E., Gigon, P., Sasame, H., Gillette, J. R.: Effect of adrenalectomy and cortisone administration on components of the liver microsomal mixed function oxygenase system of male rats which catalyzes ethylmorphine metabolism. Biochem. Pharmacol. 19, 2461 to 2467 (1970).

$[\mathrm{G} 77,615 / 70$

Catton, D. V.: The injection of epinephrine during methoxyflurane anesthesia. Anesth. Analg. Curr. Res. 48, 900-905 (1969).

$[\mathrm{G} 71,124 / 69$

Catz, C., Yaffe, S. J.: Individual variation in drug response. J. Dis. Child. 102, 579-580 (1961).

[G37,059/61

Catz, C., Yaffe, S. J.: Pharmacological modification of bilirubin conjugation in the newborn. J. Dis. Child. 104, 516-517 (1962).

$[\mathrm{G} 71,888 / 62$

Catz, C., Yaffe, S. J.: Barbiturate enhancement of bilirubin conjugation and excretion in young and adult animals. Pediat. Res. (Basel) 2,361 to 370 (1968).

$[\mathrm{H} 14,471 / 68$

Cauwenberge, H. van, Jaques, L. B.: Haemorrhagic effect of ACTH with anticoagulants. Canad. med. Ass. J. 79, 536-540 (1958).

$[\mathrm{C} 58,521 / 58$

Cauwenberge, H. van, Jaques, L. B.: Prothrombin time and hemorrhagic death in dicumarolized rats receiving pituituary and adrenal hormones. Thrombos. Diathes. haemorrh. (Stuttg.) $3,45-58(1959)$.

$[\mathrm{C} 72,748 / 59$

Cauwenberge, H. van, Lecomte, J., Palem Vliers, M.: Effects de l'amino-acétonitrile administré chez le rat adulte seul ou en association avec des médications anti-inflammatoires. Path. et Biol. 7, 547-551 (1959). [C78,726/59 Cauwenberge, H. van, Lefebvre, P.: De l'étude des médications anti-inflammatoires à celle des propriétés biologiques du glucagon. Bull. Acad. Roy. Méd. Belg., Ser. 7 4, 267-311 (1964).

[G58,189/64

Cavalea, G.-G.: Experimentelle Myopathien nach Behandlung mit Prednisolon und Schilddrüsenpräparaten. Wien. klin. Wschr. 79, 308 bis 313 (1967).

[F83,698/67

Cavallero, C.: Influence of hormones on infection. In: Asboe-Hansen, G.; Connective Tissue in Health and Disease, p. 214-224. Copenhagen: Ejnar Munksgaard Publ. 1954.

$[\mathrm{C} 829 / 54$ 
Cavallero, C., Sala, G., Amira, A. Borasi, M.: Effects of cortisone on early fibrosis of the liver in rats. Lancet 1951 I, 55. [B54,229/51 Cavallero, C., Sala, G., Ballabio, C. B.: Experimental studies with cortisone. Bull. schweiz. Akad. med. Wiss. 8, 116-118 (1952).

[B69,181/52

Cavallot, A., Einaudi, G.: Estratto pancreatico desulinizzato e roentgen irradiazione a dose letale. Ormonologia 16, 118-127 (1956).

$[\mathrm{C} 30,084 / 56$

Caviles, A., Jr.: Abnormalities in liver function in the course of massive dosage of stanozolol. (Abstr.) Excerpta med. (Amst.) 24, Sect. 6, 163 (1970).

[H30,761/70

Cawthorne, M. A., Bunyan, J., Sennitt, M. V., Green, J., Grasso, P.: Vitamin E and hepatotoxic agents. 3. Vitamin $\mathrm{E}$, synthetic antioxidants and carbon tetrachloride toxicity in the rat. Brit. J. Nutr. 24, 357-384 (1970).

[H26,441/70

Cedrangolo, F.: L'adattamento come problema di enzimologia. Pubb. Staz. Zool. Napoli 21, Sup., 28-59 (1949).

$[\mathrm{B} 46,622 / 49$

Cervini, C., Longo, C.: L'influenza del cortisone sugli effetti della pan-irradiazione sperimentale. Nunt. radiol. (Roma) 21, 348-359 (1955).

$[\mathrm{C} 9,357 / 55$

Chaffee, R. R. J., Tichy, R., Foucrier, J.: A comparison of cold resistance between thyroidectomized hamsters (Mesocricetus auratus) and rats. (Abstr.). Amer. Zool. 3, 538-539 (1963).

[G71,307/63

Chahoviteh, X.: Béribéri experimental et insuline. C. R. Soc. biol. (Paris) 93, 652-655 (1925).

$[26,462 / 25$

Chahovitch, X.: Action de l'insuline sur le béribéri expérimental du pigeon. $C$. $R$. Soc. Biol. (Paris) 93, 1333-1335 (1925). [26,685/25 Chamberlin, P. E., Hall, V. E.: Sex-difference in susceptibility to dinitrophenol intoxication in anesthetized cats. Proc. Soc. exp. Biol. (N.Y.) 34, 385-388 (1936). $\quad[66,611 / 36$

Chambon, M., Bouvet, G.: Sur l'action de l'hyposulfite de soude dans l'intoxication oxycarbonée. C. R. Soc. Biol. (Paris) 114, 45-46 (1933).

[A48,279/33

Chambon, Y., Picard, F., Gourvès, M.: Influence du sexe et des glandes sexuelles sur l'hyperplasie régénératrice du foie chez le rat. $C . R$. Soc. Biol. (Paris) 160, 2415 (1966).

$[\mathrm{F} 80,788 / 66$

Chamorro, A.: Action narcotique de la progestérone et de l'acétate de désoxycorticosté- rone. C. R. Soc. Biol. (Paris) 136, 391-392 (1942).

$[\mathrm{A} 57,215 / 42$

Chan, S.-K., Cohen, P. P.: A comparative study of the effect of hydrocortisone injection on tyrosine transaminase activity of different vertebrates. Arch. Biochem. 104, 335-337 (1964).

[D 18,552/64

Chandler, A. B., Nordöy, A.: Adenosine diphosphate induced thrombosis in hypothyroid rats. Scand. J. Haemat. 1, 89-93 (1964).

[G 22,017/64

Chandler, H. L., Collins, W. V., Minsky, G. R., Athans, J. C., Mallory, K. C., Byrne, J. J.: Cortisone in experimental obstructive jaundice. Ann. Surg. 146, 195-206 (1957). [C39,998/57 Chandler, R. L.: Infection of laboratory animals with Mycobacterium johnei. I. Infection in Swiss white mice and its modification by suramin and cortisone. J. comp. Path. 71, 118 to 130 (1961).

$[\mathrm{D} 5,239 / 61$

Chandler, R. L.: Infection of laboratory animals with Mycobacterium johnei. II. Infection in white rats; effect of cortisone treatment. $J$. comp. Path. 71, 131-134 (1961). [D5,240/61 Chang, C. T., Lei, H. P.: Pharmacology of 17 $\alpha$-methyl-5 $\alpha$-androstan-17 $\beta$-ol. (Chinese.) $A c t a$ pharm. sin. 12/11, 734-739 (1965).

[F 78,943/65

Chang, S. I., MeGinnis, J.: Vitamin D deficiency in adult quail and chickens and effects of estrogen and testosterone treatments. Proc. Soc. exp. Biol. (N.Y.) 124, 1131-1135 (1967).

$[\mathrm{F} 83,363 / 67$

Chany, E., Boy, J.: Influence de la cortisone sur le délai de cancérisation du foie chez le rat normal ou surrénaloprivé. C. R. Acad. Sci. (Paris) 250, 3752-3754 (1960). [D2,278/60

Chaouki, K., Viljoen, J. F., Kellner, G. A.: Pancuronium bromide. A new non-depolarizing muscle relaxant. Preliminary report on its use in fifty patients. Cleveland Clin. Quart. 37, 133-137 (1970).

$[\mathrm{G} 77,223 / 70$

Chaplin, H., Jr., Cassell, M.: Studies on the possible relationships of tolbutamide to dicumarol in anticoagulant therapy. Amer. J. med. Sci. 235, 706-716 (1958).

[D 99,463/58

Chaplin, M. D., Mannering, G. J.: Role of phospholipids in the hepatic microsomal drug metabolizing system. Molec. Pharmacol. 6, 631-640 (1970).

$[\mathrm{G} 75,976 / 70$

Chappel, C. I., Rona, G., Gaudry, R.: Relationship between thyroid function and cardiotoxic properties of isoproterenol. Endocrinology 65, 208-215 (1959).

$[\mathrm{C} 71,409 / 59$ 
Chappel, C. I., Rona, G., Gaudry, R.: The influence of adrenal cortical steroids on cardiac necrosis produced by isoproterenol. Acta endocr. (Kbh.) 32, 419-424 (1959). [C76,910/59 Charbon, G. A.: The development of resistance to tolbutamidum in dogs. Arch. int. Pharmacodyn. 130, 207-210 (1961). [G76,685/61 Chase, R. E., Saidman, L. J.: The effect of spironolactone on altering the anesthetic action of cyclopropane in the rat. (Abstr.) Fed. Proc. 30, 541 (1971).

[H35,774/71

Chatterjee, A.: The role of cortisone in the prevention of gonadal inhibition in chlorpromazinized female rats. Acta anat. (Basel) 65, 606 to 609 (1966).

[G48,145/66

Chatterton, R. T., Jr., Chatterton, A. J., Hellman, L.: Metabolism of progesterone by the rabbit liver. Endocrinology 87, 941-950 (1970).

[H31,456/70

Chaturvedi, U. C.: Influence of sex on hepatic injury in albino rats. Indian J. med. Sci. 23, $374-379$ (1969).

[G69,350/69

Chedid, L.: Actions comparées de la prométhazine, de la chlorpromazine et de la cortisone chez la souris recevant des doses mortelles d'une endotoxine bactérienne. C. R. Soc. Biol. (Paris) 148, 1039-1043 (1954). [C622/54

Chedid, L.: Disparition de l'action antiendotoxique de la cortisone chez la souris immunisée par le bacille de Bordet-Gengou (Hemophilus Pertussis). Ann. Endocr. (Paris) 15, 746 -750 (1954).

$[\mathrm{C} 1,930 / 54$

Chedid, L., Boyer, F.: Hypercorticisme gravidique et résistance aux salmonelloses expérimentales. Ann. Endocr. (Paris) 16, 467-471 (1955).

[C10,098/55

Chedid, L., Boyer, F.: Etude comparative du pouvoir antitoxique de la cortisone et de la chlorpromazine. Ann. Inst. Pasteur 88, 336 a 346 (1955).

[C17,612/55

Chedid, L., Boyer, F., Pophillat, F., Parant, M.: Etude de la toxicité d'une endotoxine radioactive $\left({ }^{51} \mathrm{Cr}\right)$ injectée à des parabiontes normaux et hypophysectomisés. Ann. Inst. Pasteur 104, 197-207 (1963).

[D 57,924/63

Chedid, L., Boyer, F., Saviard, M.: Action de la cortisone vis-à-vis de l'infection expérimentale avec Salmonella typhi chez la souris. $C$. $R$. Acad. Sci. (Paris) 233, 713-716 (1951).

[B91,160/51

Chedid, L., Boyer, F., Saviard, M.: Surrénales et infection. Ann. Inst. Pasteur 83, 213-231 (1952).

[B91,161/52
Chedid, L., Boyer, F., Saviard, M.: Nouveaux aspects de l'action antitoxique de la cortisone. Ann. Inst. Pasteur 86, 347-355 (1954).

[B 99,547/54

Chedid, L., Boyer, F., Saviard, M.: Disparition de différents effets de la cortisone chez la femelle gestante du rat. C. R. Acad. Sci. 238, 156-158 (1954).

[C621/54

Chedid, M. L., Parant, M.: Effets de la reserpine sur la résistance aux endotoxines bactériennes du rat et de la souris traités à la cortisone. Influence de la surrénalectomie et de l'hypophysectomie. Ann. Endocr. 22, 117-125 (1961).

[D $6,761 / 61$

Chedid, L., Parant, M., Boyer, F., Skarnes, R. C.: Nonspecific host responses in tolerance to the lethal effect of endotoxins. In: Landy and Braun; Bacterial Endotoxins, p. 500-516. New Brunswick, N. J.: Institute of Microbiology, Rutgers, The State University 1964.

$[\mathrm{E} 8,476 / 64$

Chen, G., Wickel, A.: Protective effect of steroids against acute egg-white toxicity in adrenalectomized rats. Endocrinology 51, 21 to 25 (1952).

[B 74,534/52

Chenderovitch, J.: Stop-flow analysis of bile secretion. Amer. J. Physiol. 214, 86-93 (1968).

[G80,059/68

Cheng, K. K.: A technique for total hepatectomy in the rat and its effect on toxicity of octamethyl pyrophosphoramide. Brit. J. exp. Path. 32, 444-447 (1951).

$[\mathrm{G} 71,450 / 51$

Chernozemski, I. N., Warwick, G. P.: Liver regeneration and induction of hepatomas in

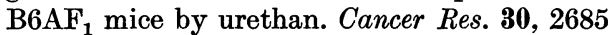
to $2690(1970)$.

$[\mathrm{H33}, 929 / 70$

Cherrick, G. R., Stein, S. W., Leevy, C. M., Davidson, C. S.: Indocyanine green: observations on its physical properties, plasma decay, and hepatic extraction. J. clin. Invest. 39, 592-600 (1960).

[E98,251/60

Cherry, J. W.: Endotoxin shock. Surg. Clin. N. Amer. 50, $403-408$ (1970). [G74,846/70 Chesler, A., LaBelle, G. C., Himwich, H. E.: A study of the compararative toxic effects of morphine on the fetal, newborn and adult rats. J. Pharmacol. exp. Ther. 75, 363-366 (1942).

[A 52,010/42

Cheverie, J. C., Lynn, W. G.: High temperature tolerance and thyroid activity in the teleost fish, tanichthys albonubes. Biol. Bull. 124, 153-162 (1963).

[D 68,411/63

Cheymol, J., Pfeiffer, A.: Atteinte de la surrénale au cours de l'intoxication phalloïdienne. Essai de traitement par les hormones 
cortico-surrénales. Arch. int. Pharmacodyn. 79, 273-281 (1949).

$[\mathrm{B} 54,350 / 49$

Cheymol, J., Quinquaud, A.: Sur la baisse de la calcemie du chien privé d'appareil thyroidien. Influence de l'anesthésie au chloralosane. C. R. Soc. Biol. (Paris) 110, 528-530 (1932). $[3,531 / 32$

Chiancone, F. M.: I dati piu recenti sulla triptofano pirrolasi epatica. Acta vitamin. (Milano) 21, 37-62 (1967). [F 85,259/67 Chiesara, E., Conti, F., Meldolesi, J.: Influence of partial hepatectomy on the induction of liver microsomal drug-metabolizing enzymes produced by phenobarbital. A biochemical and ultrastructural study. Lab. Invest. 22, 329 to 338 (1970).

[G75,314/70

Chiodi, H., Sammartino, R.: Renotrophic action of lead in the rat. Acta physiol. lat.-amer. 1, 33-45 (1950).

$[\mathrm{B} 52,225 / 50$

Chirico, G.: Données expérimentales sur quelques activités biologiques de l'hormone somatrope. Rev. Path. gen. 56, 1041-1072 (1956).

$[\mathrm{C} 24,381 / 56$

Chirico, G., Zangaglia, o., Petronio, L.: Influenza della tiroxina sulla malattia tbc. del 'Mus musculus' albino. Arch. Sci. med. 107, 225-240 (1959).

$[\mathrm{C} 67,012 / 59$

Chirico, G., Zangaglia, O., Viola, S.: Somatotropina (STH) e tubercolosi. Ricerche sperimentali. Arch. Sci. med. 98, 1-20 (1954).

$$
[\mathrm{C} 5,040 / 54
$$

Chivers, B. R., Raick, A. N., Ritehie, A. C.: Some effects of 9,12-dimethyl $(\alpha)$ benzanthracene and corn oil on mitoses in mouse liver after partial hepatectomy. (Abstr.) Proc. Canad. Fed. biol. Soc. Montreal, Que. 13, 110 (1970).

$[\mathrm{H} 25,819 / 70$

Choi, Y., Thrasher, K., Werk, E., Sholiton, L., Olinger, C.: Enhancement of tissue uptake and turnover of cortisol by diphenylhydantoin (DPH). Program 51st Meet. Endocr. Soc., New York, N.Y., p. 130 (1969).

$[\mathrm{H} 12,299 / 69$

Choisy, H., Potron, G.: Etude comparée de l'action de la thyroxine et du métronidazole sur la vitesse de disparition de l'éthanol dans le sang du lapin. Thérapie 23, 903-918 (1968).

[H 28,010/68

Christensen, B. G., Jacobsen, E.: Studies on liver regeneration. Acta med. scand. Sup. 243, 103-108 (1949).

$[A 49,204 / 49$

Christian, H. A.: Study XV. Hepatic lesions associated with experimental cardiac lesions. Arch. intern. Med. 8, 547-551 (1911).

$[D 1,675 / 11$
Christian, H. A., Smith, R. M., Walker, I. C.: Experimental cardiorenal disease. Arch. intern. Med. 8, 468-551 (1911). [ [C81,653/11

Christoforov, B., Deraedt, R., Foliot, A., Petite, J. P.: Effets du phénobarbital sur l'hyperbilirubinémie provoquée chez les rats Gunn hétérozygotes et Wistar. Path. et Biol. 18, 663-667 (1970).

$[\mathrm{G} 77,086 / 70$

Chury, Z., Kasparek, M.: Syndrom podobny progerii po DHT u kastrovanych krysich samecku. (Progeria-like syndrome occurring after DHT administration in castrated male rats.) Cs. Pat. 5, 23-28 (1969).

[H 29,730/69

Chury, Z., Nevrtal, M.: Die Herz- und Ekg-Veränderungen bei dem progerieähnlichen Syndrom der Ratte. Ztschr. gesamt. inn. Med. 25, 923-928 (1970).

$[\mathrm{H} 33,801 / 70$

Ciampolini, M.: Terapia con barbiturici degli itteri da difettosa coniugazione della bilirubina. Minerva pediat. 21, 2440-2446 (1969).

$[\mathrm{G} 81,416 / 69$

Cicardo, V. H.: Sensibilidad convulsivante de los animales adrenoprivos, hipofisoprivos e inyectados con desoxicorticoesterona. Rev. Soc. argent. Biol. 12, 207-213 (1945).

[B964/45

Cicchini, T., Cao-Pinna, M., De Carlo, M.: Azione del 4-clorotestosterone acetato sulle lesioni epatiche degenerative provocate nei ratti dalla dieta di Handler. (Abstr.) Minerva med. 49, 1848 (1958).

$[\mathrm{C} 57,934 / 58$

Cier, A., Maigrot, J. C., Nofre, C.: Effets synergiques de quelques substances douées d'une activité radioprotectrice. $C . R$. Soc. Biol. (Paris) 161, 360-363 (1967).

$[\mathrm{F} 85,815 / 67$

Cilli, V., Scuro, L. A., Castrucei, G., Barboni, E., Guercio, P. del, Ippolito, A.: Ormoni ipofisari (STH e ACTH) e desametazone nell fisiopatologia delle infezioni virale. Contributo sperimentale sulla infezione da virus del vaiolo ovino. G. Mal. infett. 13, 225-250 (1961).

[D 12,192/61

Cîrstea, M., Suhaciu, G.: Incercări de terapie experimentală în şocul anafilactic la cîine. (Essais de thérapie expérimentale du choc anaphylactique du chien.) Stud. Cercet. Fiziol. $8,631-641$ (1963).

[G2,471/63

Cittadini, G., Lanfredini, L., Mancini, G.: Fattori che influenzano la formazione di colonie ematopoietiche endogene nella milza del topo dopo panirradiazone. II. Effetti dello stress da freddo e dell'ormone adrenocorticotropo. Boll. Soc. ital. Biol. sper. 46, 91-94 (1970).

$[\mathrm{G} 76,028 / 70$ 
Ciulla, U., Razzini, M.: Ormoni gonadotropi urinari ed intossicazione da tossina difterica. Atti 36 Congr. Soc. ital. Ostet. Ginec. Torino, p. 3-10 (1939).

[B50,987/39

Civen, M., Knox, W. E.: Induced synthesis of tryptophan peroxidase in rat liver slices. Fed. Proc. 16, 165 (1957).

[E53,175/57

Civen, M., Knox, W. E.: The independence of hydrocortisone and tryptophan inductions of tryptophan pyrrolase. J. Biol. Chem. 234, 1787-1790 (1959).

$[\mathrm{E} 64,178 / 59$

Civen, M., Wilson, C., Brown, C. B., Granner, D.: Diurnal variations in liver tyrosine $a$-ketoglutarate transaminase: the relationship between changes in catalytic and antigenic activity. Program 51st Meet. Endocr. Soc. New York, N.Y., p. 65 (1969). [H12,169/69 Clark, J. H., Jr., Pesch, L. A.: Effects of cortisone upon liver enzymes and protein synthesis. J. Pharmacol. exp. Ther. 117, $202-207$ (1956).

[C18,864/56

Clark, J. M., Higginbotham, R. D.: Influence of adrenalectomy and/or cortisol treatment on resistance to moccasin (Agkistrodon $P$. piscivorous) venom. Toxicon (Oxford) 8, 25-32 (1970).

$[\mathrm{G} 77,169 / 70$

Clark, M. B., Pennock, J., Kalu, D. N., Bordier, P., Doyle, F. H., Foster, G. V.: Effects of calcitonin on metabolically-induced bone changes in rats. (Abstr.) Calc. Tiss. Res. 2, Sup. 18 (1968).

[H5,009/68

Clark, W. C., Blackman, H. J., Preston, J. E.: Certain factors in aggregated mice damphetamine toxicity. Arch. int. Pharmacodyn. 170, $350-363$ (1967).

[F 92,621/67

Clark, W. G., Barnes, R. H.: Effects of salts and adrenal cortical extracts upon toxicity of drugs. Proc. Soc. exp. Biol. (N.Y.) 44, 340 to 344 (1940).

[A33,441/40

Clark, W. G., MacKay, E. M.: Effect of $l$-epinephrine and $l$-arterenol on egg white edema in the rat. Proc. Soc. exp. Biol. (N.Y.) 71, 86-87 (1949).

[B36,925/49

Clarke, E. L.: The antagonism between steroid anesthesia and picrotoxin. Proc. canad. physiol. Soc. (7th Ann. Meet., Montebello), p. 5 (1941).

[A36,747/41

Claude, A.: Microsomes, endoplasmic reticulum and interactions of cytoplasmic membranes. In: Gillette, J. R., Conney, A. H., et al.; Microsomes and Drug Oxidations, p. 3 to 39. New York, London: Academic Press Inc. 1969.

[E 8,217/69

Claus, J. L., Trunnell, J. B., Llaurado, J. G.: Thyroid and adrenal changes in rats bearing an experimentally induced fibrosarcoma and their influences upon the growth of the tumour. Acta endocr. (Kbh.) 40, 584-603 (1962).

[D29,754/62

Cleghorn, R. A.: Studies of shock produced by muscle trauma. III. The effect of serum isinglass, glucose, certain salts, and adrenal cortical hormones on survival. Canad. J. Res. 25, 86-99 (1947).

[B2,571/47

Clodi, P. H., Schnack, H.: Tierexperimentelle Untersuchungen über den sekretionshemmenden Einfluß anabol wirkender Steroide auf die Bromsulphophthaleinausscheidung durch die Leber. Wien. Z. inn. Med., 43, 50-59 (1962).

[D41,569/62

Clouet, D. H., Ratner, M.: The effect of altering liver microsomal $\mathrm{N}$-demethylase activity on the development of tolerance to morphine in rats. J. Pharmacol. exp. Ther. 144, 362-372 (1964).

[F 14,837/64

Cochin, J., Axelrod, J.: Biochemical and pharmacological changes in the rat following chronic administration of morphine, nalorphine and normorphine. J. Pharmacol. exp. Ther. 125, 105-110 (1959).

$[\mathrm{G} 67,795 / 59$

Cochin, J., Sokoloff, L.: Effects of administration of L-thyroxin on liver $\mathrm{N}$-demethylating activity in normal and morphine-treated rats. Proc. Soc. exp. Biol. (N.Y.) 104, 504-506 (1960).

$[\mathrm{D} 29,487 / 60$

Cody, D. T. R., Code, C. F.: Protection of the rat against anaphylaxis by removal of the spleen and thymus. Fed. Proc. 22, 379 (1963).

$[\mathrm{G4,417/63}$

Cohen, J. L., Jao, J. Y.: Enzymatic basis of cyclophosphamide activation by hepatic microsomes of the rat. J. Pharmacol. exp. Ther. 174, 206-210 (1970).

$[\mathrm{H} 27,933 / 70$

Cohen, M. B., Wasserman, P., Rudolph, J. A.: Observations on the influence of certain drugs on edema of paraphenylenediamine. J. Pharmacol. exp. Ther. 48, 235-239 (1933).

$[92,880 / 33$

Cohen, P. P., Hekhuis, G. L.: Transamination in tumors, fetal tissues, and regenerating liver. Cancer Res. 1, 620-626 (1941). [93,220/41

Cohn, K. E., Agmon, J., Gamble, 0. W.: The effect of glucagon on arrhythmias due to digitalis toxicity. Amer. J. Cardiol. 25, 683-689 (1970).

$[\mathrm{H} 26,723 / 70$

Coker, C. M.: Cellular factors in acquired immunity to Trichinella spiralis as indicated by cortisone treatment of mice. $J$. infect. Dis. 98, 187-197 (1956).

$[\mathrm{C} 48,693 / 56$ 
Coker, C. M.: Effect of cortisone on natural immunity to Schistosoma mansoni in mice. Proc. Soc. exp. Biol. (N.Y.) 96, 1-3 (1957).

$[\mathrm{C} 42,296 / 57$

Colafranceschi, M., Tosi, P.: Sull'azione adrenocorticolitica nel ratto del 7,12-dimetilbenz (alfa)antracene. I. Può la funzione gonadica influenzare la suscettibilità surrenalica al tossico? Arch. De Vecchi Anat. pat. 49, 541 a 564 (1967).

[G59,115/67

Colafranceschi, M., Tosi, P.: Sull'azione adrenocorticolitica nel ratto del 7,12-dimetilbenz $(\alpha)$ antracene. II. Influenza dell'intossicazione acuta da $\mathrm{CCl}_{4}$, dell'epatectomia parziale e di una dieta steatogena sulla suscettibilità corticosurrenalica al tossico. Arch. De Vecchi Anat. pat. 50, 681 (1967). $\quad[\mathrm{G} 61,860 / 67$ Colás, A.: The 16a-hydroxylation of dehydroepiandrosterone (3 $\beta$-hydroxyandrost-5-en-17one) by rat-liver slices. Biochem. J. 82/3, 390-394 (1962).

[D20,925/62

Colby, H. D., Brownie, A. C.: In vivo interaction of metyrapone with adrenal cortical mitochondrial cytochrome P-450. Arch. Biochem. 138, 632-639 (1970).

$[\mathrm{G} 75,695 / 70$

Cole, L. J., Foley, W. A.: Modification of urethan-lung tumor incidence by low X-radiation doses, cortisone, and transfusion of isogenic lymphocytes. Radiat. Res. 39, 391-399 (1969).

[H35,251/69

Cole, L. J., Habermeyer, J. G., Bond, V. P.: Recovery from acute radiation injury in mice following administration of rat bone marrow. J. nat. Cancer Inst. 16, 1-9 (1955).

$[\mathrm{C} 14,411 / 55$

Cole, V. V.: A possible method for the determination of prolonged action of barbiturates. J. Pharmacol. exp. Ther. 78, 170-173 (1943). $[\mathrm{A} 30,204 / 43$

Cole, V. V., Hulpieu, H. R.: Effect of epinephrine on toxicity of procaine. Fed. Proc. 8, 283 (1949).

[B32,910/49

Cole, V. V., Hulpieu, H. R.: Influence of epinephrine and related drugs on toxicity of procaine used intravenously in dogs. Curr. Res. Anesth. 29, 235-238 (1950).

[B57,578/50

Colier, H. F.: Studies of the relationship between electrolyte of the cerebral cortex and the mechanism of convulsions. Res. Publ. Ass. nerv. ment. Dis. 26, 98-117 (1947).

$[\mathrm{A} 47,355 / 47$

Collins, E. J.: Steroid-induced adrenal-pituitary hypofunction. Proc. Soc. exp. Biol. (N.Y.) 89, 443-445 (1955). [C7,486/55
Collins, E. J.: Steroid-induced adrenal-pituitary hypofunction II. Proc. Soc. exp. Biol. (N.Y.) 91, 336-338 (1956). [C12,721/56

Collins, E. J.: Steroid-induced adrenal-pituitary hypofunction. Endocrinology 58, 777-780 (1956).

$[\mathrm{C} 17,662 / 56$

Collip, J. B., Kutz, R. L., Long, C. N. H., Thomson, D. L., Toby, G., Selye, H.: Acute fatty liver following partial hepatectomy. Canad. med. Ass. J. 33, 689 (1935). [36,231/35 Collip, J. B., Selye, H., Thomson, D. L.: The antihormones. Biol. Rev. 15, 1 (1940).

$[\mathrm{A} 32,156 / 40$

Combes, B., Shibata, H., Adams, R., Mitchell, B. D., Trammell, V.: Alterations in sulfobromophthalein sodium-removal mechanisms from blood during normal pregnancy. J. clin. Invest. 42, 1431-1442 (1963).

[E 26,415/63

Common, R. H., Bolton, W., Rutledge, W. A.: The influence of gonadal hormone on the composition of the blood and liver of the domestic fowl. J. Endocr. 5, 263-273 (1948).

$[\mathrm{B} 23,003 / 48$

Common, R. H., Keefe, T. J., Burgess, R., Maw, W. A.: Modification of the biochemical responses of the immature pullet to oestrogen by means of dietary aureomycin. Nature (Lond.) 166, 992 (1950).

[B59,914/50

Common, R. H., Moo-Young, A. J., MeCully, K. A.: Some effects of dietary thiouracil and dietary iodine supplementation on the responses of the immature pullet to estrogen. Canad. J. biochem. 39, 1441-1450 (1961).

[D $12,509 / 61$

Conney, A. H.: Enzyme induction and drug toxicity. In: Brodie and Gillette; Drugs and Enzymes (Proc. 2nd int. pharmacol. Meet.) 4, p. 277. New York: MacMillan Co. 1965.

$[\mathrm{G} 41,879 / 65$

Conney, A. H.: Pharmacological implications of microsomal enzyme induction. Pharmacol. Rev. 19, 317-366 (1967).

[F 88,649/67

Conney, A. H.: Stimulatory effect of drugs on drug metabolism. (Abstr.) Pharmacologist 9, 77 (1967).

$[\mathrm{G} 69,760 / 67$

Conney, A. H.: Drug metabolism and therapeutics. New Engl. J. Med. 280, 653-660 (1969).

$[\mathrm{H} 8,988 / 69$

Conney, A. H.: Environmental factors influencing drug metabolism. In: Fundamentals of Drug Metabolism and Drug Disposition (in press).

$[\mathrm{G} 70,316$

Conney, A. H., Burns, J. J.: Factors influencing drug metabolism. Advanc. Pharmacol. 1, 31-38 (1962).
$[\mathrm{G} 67,166 / 62$ 
Conney, A. H., Burns, J. J.: Induced synthesis of oxidative enzymes in liver microsomes by polycyclic hydrocarbons and drugs. In: Weber; Advances in Enzyme Regulation, 1, p. 189-214. New York: The MacMillan Co. 1963.

$[\mathrm{G} 66,473 / 63$

Conney, A. H., Garren, L.: Effects of thyroxin on the metabolism of zoxazolamine and hexobarbital (Abstr.). Pharmacologist 2, 82 (1960).

[D 78,956/60

Conney, A. H., Garren, L.: Contrasting effects of thyroxin on zoxazolamine and hexobarbital metabolism. Biochem. Pharmacol. 6, 257-262 (1961).

[D93,666/61

Conney, A. H., Ikeda, M., Levin, W., Cooper, D., Rosenthal, 0., Estabrook, R.: Carbon monoxide inhibition of steroid hydroxylation in rat liver microsomes. Fed. Proc. 26, 462 (1967).

$[\mathrm{F} 79,331 / 67$

Conney, A. H., Jacobson, M., Levin, K., Scheidman, K., Kuntzman, R.: Decreased central depressant effect of progesterone and other steroids in rats pretreated with drugs and insecticides. J. Pharmacol. exp. Ther. 154, 310-318 (1966).

$[\mathrm{F} 73,731 / 66$

Conney, A. H., Jacobson, M., Schneidman, K., Kuntzman, R.: Induction of liver microsomal cortisol $6 \beta$-hydroxylase by diphenylhydantoin or phenobarbital: an explanation for the increased excretion of 6-hydroxycortisol in humans treated with these drugs. Life Sci. 4, 1091-1098 (1965).

$[\mathrm{G} 29,083 / 65$

Conney, A. H., Klutch, A.: Increased activity of androgen hydroxylases in liver microsomes of rats pretreated with phenobarbital and other drugs. J. biol. Chem. 238, 1611-1617 (1963).

[D 65,813/63

Conney, A. H., Kuntzman, R.: Metabolism of normal body constituents by drug-metabolizing enzymes in liver microsomes. In: Concepts in Biochem. Pharmacol. (in press). [G70,540

Conney, A. H., Levin, W., Ikeda, M., Kuntzman, R., Cooper, D. Y., Rosenthal, 0.: Inhibitory effect of carbon monoxide on the hydroxylation of testosterone by rat liver microsomes. J. biol. Chem. 243, 3912-3915 (1968).

[G67,773/68

Conney, A. H., Levin, W., Jacobson, M., Kuntzman, R., Cooper, D. Y., Rosenthal, 0.: Specificity in the regulation of the $6 \beta, 7 \alpha$ and $16 \alpha$-hydroxylation of testosterone by rat liver microsomes. In: Gillette, J. R., Conney, A. H. et al.; Microsomes and Drug Oxidations, p. 279-302. New York, London: Academic Press Inc. 1969.

$[\mathrm{E} 8,232 / 69$
Conney, A. H., Michaelson, I. A., Burns, J. J.: Stimulatory effect of chlorcyclizine on barbiturate metabolism. J. Pharmacol. exp. Ther. 132, 202-206 (1961).

[D 52,543/61

Conney, A. H., Miller, E. C., Miller, J. A.: The metabolism of methylated aminoazo dyes. V. Evidence for induction of enzyme synthesis in the rat by 3-methyl-cholanthrene. Cancer Res. 16, 450-459 (1956).

[D 87,867/56

Conney, A. H., Schneidman, K.: Enhanced androgen hydroxylase activity in liver microsomes of rats and dogs treated with phenylbutazone. J. Pharmacol. exp. Ther. 146, 225-235 (1964).

[F 24,913/64

Conney, A. H., Schneidman, K.: Decreased hypnotic action of progesterone and other steroids in rats pretreated with drugs that stimulate steroid metabolism. Fed. Proc. 24, 152 (1965).

[F 35,870/65

Conney, A. H., Schneidman, K., Jacobson, M., Kuntzman, R.: Drug-induced changes in steriod metabolism. Ann. N.Y. Acad. Sci. 123, 98-109 (1965). [G65,135/65

Conney, A. H., Welch, R. M., Kuntzman, R., Burns, J. J.: Effects of pesticides on drug and steroid metabolism. Clin. Pharmacol. Ther. 8, 2-10 (1967).

[G43,018/67

Connolly, J. E.: The use of adrenal cortical compounds in hemorrhagic shock. Lancet 1959I, $460-463$.

[C78,861/59

Connolly, J. E., Bruns, D. L., Stofer, R. C.: The use of intravenous hydrocortisone in hemorrhagic shock. Surg. Forum 9, 17-22 (1958).

[D $57,333 / 58$

Connor, R. C. R.: Causes of disseminated sclerosis. Lancet 1970I, 724-725.

$[\mathrm{H} 23,400 / 70$

Connors, T. A., Elson, L. A.: Reduction of the toxicity of 'radiomimetic' alkylating agents in rats by thiol pretreatment. Biochem. Pharmacol. 11, 1221-1232 (1962). [G2,440/62

Connors, T. A., Elson, L. A., Leese, C. L.: The effect of glucose pretreatment on the antitumour action of Mannitol Myleran. Biochem. Pharmacol. 13, 963-968 (1964). [G17,080/64

Constantin, B., Bouyard, P.: Relations du bichlorhydrate de diallylnortoxiférine avec l'effet anticurare de l'adrénaline chez le lapin anesthésié. C. R. Soc. Biol. (Paris) 163, 478-481 (1969).

[H15,750/69

Constantinides, P., Gordon, M. L.: The effect of some synthetic steroids on the morphogenetic action of stilbestrol, in the rat. Rev. Canad. Biol. 9, 107-112 (1950). [B41,764/50 
Constantinides, P., Gutmann-Auersperg, N., Hospes, D., Williams, K.: Estriol and prednisolone in rabbit atherosclerosis. Arch. Path. 73, 277-280 (1962).

[D21,813/62

Conti, M., Neglia, V.: Funzionalità epatica e ovulostatici orali. Ann. ostet. Ginec. 90, 554 to 560 (1968).

$[\mathrm{H} 30,753 / 68$

Contreras, E., Tamayo, L., Quijada, L.: Analgesic effect of ergonovine in male and female rats. Med. Pharmacol. exp. (Basel) 16, 159 to 164 (1967).

$[\mathrm{F} 81,599 / 67$

Cook, J. W., Blake, J. R., Williams, M. W.: The enzymic hydrolysis of malathion and its inhibition (ethyl p-nitrophenyl phenyl- and other organic phosphorus phosphonothionate) compounds. J. Ass. Offic. Agricult. Chem. 40, 664-665 (1957).

[G74,655/57

Cook, L., Macko, E., Fellows, E. J.: The effect of $\beta$-diethylaminoethyldiphenylpropylacetate hydrochloride on the action of a series of barbiturates and C.N.S. depressants. J. Pharmacol. exp. Ther. 112, 382-386 (1954). [E 34,395/54

Cook, L., Navis, G., Fellows, E. J.: Enhancement of the action of certain analgetic drugs by $\beta$-diethylaminoethyldiphenylpropylacetate hydrochloride. J. Pharmacol. exp. Ther. 112, 473-479 (1954).

[D94,204/54

Cook, L., Toner, J. J., Fellows, E. J.: The effect of $\beta$-diethylaminoethyldiphenylpropylacetate hydrochloride (SKF No. 525-A) on hexobarbital. J. Pharmacol. exp. Ther. 111, 131-141 (1954).

[D23,923/54

Cooper, D. Y., Rosenthal, 0.: Acceleration by noradrenaline of hydroxylation of steroids by adrenocortical homogenates. Arch. Biochem. 96, 327-330 (1962).

[D20,337/62

Cooper, D. Y., Rosenthal, 0.: Action of noradrenaline and ascorbic acid on C-21 hydroxylation of steroids by adrenocortical microsomes. Arch. Biochem. 96, 331-335 (1962).

[D20,338/62

Cooper, J., Gutstein, W. H.: Calcific aortic atherosclerosis of the rabbit after cholesterol and pitressin treatment. J. Atheroscler. Res. 6, 75-86 (1966).

[F61,290/66

Cooper, J. R., Axelrod, J., Brodie, B. B.: Inhibitory effects of $\beta$-diethylaminoethyl diphenylpropylacetate on a variety of drug metabolic pathways in vitro. J. Pharmacol. exp. Ther. 112, 55-63 (1954).

[H25,117/54

Cope, 0., Graham, J. B., Mixter, G., Jr., Ball, M. R.: Threshold of thermal trauma and influence of adrenal cortical and posterior pituitary extracts on the capillary and chemical changes. An experimental study. Arch. Surg. 59, 1015-1069 (1949).

[B52,084/49

Coppo, M.: Ricerche sperimentali sui rapporti tra ormoni e vitamine, con speciale riguardo al timo e all'ergosterina irradiata. Arch. int. Pharmacodyn. 43, 123-185 (1932).

$[3,642 / 32$

Coraggio, F., Coto, V., Oriente, P., Longis, G. de, Galeota, C. A.: Influenza del 19-nor-androstenolone sulla produzione di anticorpi antimorbillosi nel coniglio. Boll. Soc. ital. Biol. sper. 38, 1316-1317 (1962). [ [D 58,058/62

Coraggio, F., Pecori, V., Altucei, P., de Marco, G.: L'aldosterone nelle infezioni virali sperimentali. - III) Attività nell'infezione da virus vaccinico in culture di cellule di rene umano. Boll. Soc. ital. Biol. sper. 37, 714-717 (1961).

$[\mathrm{D} 12,550 / 61$

Cori, G.: Utber den Einfluß der Schilddrüse auf die Wärmeregulation. Zugleich eine Bemerkung zu P. Schenk: Über den Einfluß der Schilddrüse auf den Stoffwechsel mit besonderer Berücksichtigung des Wärmehaushaltes. Naunyn-Schmiedebergs Arch. Pharmak. 95, 378 bis 380 (1922).

$[17,210 / 22$

Corn, M.: Effect of phenobarbital and glutethimide on biological half-life of warfarin. Thrombos. Diathes. haemorrh. (Stuttg.) 16, 606 to 612 (1966).

$[\mathrm{H} 33,065 / 66$

Cornelius, C. E.: Studies on ovine urinary biocolloids and phosphatic calculosis. Ann. N.Y. Acad. Sci. 104, 638-657 (1963).

$[\mathrm{D} 58,739 / 63$

Cornforth, J. W., Long, D. A.: Influence of carbohydrate metabolism on bacterial allergy. Its relation to cortisone desensitisation. Lancet 1953 I, 160-164. [B77,176/53

Correll, J. T., Lyth, L. F., Long, S., Vanderpoel, J. C.: Some physiologic responses to 5-hydroxytryptamine creatinine sulfate. Amer. J. Physiol. 169, 537-544 (1952).

$[\mathrm{E} 57,669 / 52$

Cort, J. H., Hammer, J., Ulrych, M., Piša, Z., Douša, T., Rudinger, J.: Synthetic extendedchain analogues of vasopressin and oxytocin in the treatment of experimental haemorrhagic shock. Lancet 1964II, 840-841.

$[\mathrm{F} 23,086 / 64$

Cort, J. H., Jeanjean, M. F., Thomson, A. E., Nickerson, M.: Effects of 'hormonogen' forms of neurohypophysial peptides in hemorrhagic shock in dogs. Amer. J. Physiol. 214, 455-462 (1968).

$[\mathrm{F} 96,105 / 68$

Cosmides, G. J., Miya, T. S., Carr, C. J.: A study of the effects of certain lactones on digi- 
toxin toxicity. J. Pharmacol. Exp. Ther. 118, 286-295 (1956).

[G45,832/56

Costa, A., Smorlesi, L.: Il ripristino del fegato e la reversione rapida della cirrosi da $\mathrm{CCl}_{4}$ dopo asportazione di larga parte del fegato cirrotico. Arch. De Vecchi Anat. pat. 16, 49-70 (1951).

[E34,570/51

Côté, G., Gabbiani, G., Tuchweber, B.: Inhibition de l'hyperparathyroïdisme expérimental. Un. méd. Can. 96, 1489-1501 (1967).

[G46,713/67

Côté, G., Gabbiani, G.o, Tuchweber, B., Déziel, C.: Effect of thyrocalcitonin and thyroxine on experimental metastatic calcification. Acta endocr. (Kbh.) 59, 362-370 (1968).

$[\mathrm{G} 46,741 / 68$

Cournot, L., Halpern, B. N.: La testostérone a-t-elle une action protectrice contre la néphrite mercurielle chez la souris ? C. R. Soc. Biol. (Paris) 144, 936-938 (1950).

$[\mathrm{B} 54,669 / 50$

Courrier, R.: Endocrinologie de la gestation. Paris: Masson et Co. pp. 396 (1945).

$[86,924 / 45$

Cox, E., Wright, S. E.: The hepatic excretion of digitalis glycosides and their genins in the rat. $J$. Pharmacol. exp. Ther. 126, 117-122 (1959).

$[\mathrm{G} 66,614 / 59$

Cox, F. E. G.: The effect of betamethasone on acquired immunity to Plasmodium vinckei in mice. Ann. trop. Med. Parasit. 62, 295-300 (1968).

[G64,797/68

Crabtree, D. G., Ward, J. C., Welch, J. F.: Sex differences in albino rats to toxic doses of powdered red squill. Endocrinology $25,629-632$ (1939).

[A 19,999/39

Craig, C. R.: Anticonvulsant activity of steroids: separability of anticonvulsant from hormonal effects. $J$. Pharmacol. exp. Ther. 153, 337-343 (1966).

$[\mathrm{F} 69,385 / 66$

Craig, C. R., Deason, J. R.: Anticonvulsant activity of steroids, specificity of structure. Arch. int. Pharmacodyn. 172, 366-372 (1968).

[F99,058/68

Crainiceanu, A., Copelman, L.: Recherches expérimentales sur l'action antitoxique de la sécrétion interne de l'ovaire. Bull. Mem. Sect. Endocr. 1, 92 (1935).

$[67,918 / 35$

Crane, M., Loring, J., Villee, c. A.: Progesterone metabolism in regenerating rat liver. Endocrinology 87, 80-83 (1970). [H 25,068/70

Crawiord, J. S., Rudofsky, S.: Placental transmission and neonatal metabolism of promazine. Brit. J. Anaesth. 37, 303-309 (1965).

$[\mathrm{G} 78,958 / 65$
Crawiord, J. S., Rudofsky, S.: The mode of administration of promazine as a factor in determining the extent of placental transmission. Brit. J. Anaesth. 37, 310-313 (1965).

$[\mathrm{G} 78,959 / 65$

Crawford, J. S., Rudofsky, S.: Some alterations in the pattern of drug metabolism associated with pregnancy, oral contraceptives, and the newly-born. Brit. J. Anaesth. 38, $446-454$ (1966).

$[\mathrm{G} 42,454 / 66$

Creaven, P. J., Parke, D. V., Williams, R. T.: Differential stimulation of the o- and p-hydroxylation of biphenyl by liver microsomes. Biochem. J. 91, 12P-13P (1964).

$[\mathrm{G} 77,565 / 64$

Cremer, N., Watson, D. W.: Influence of stress on distribution of endotoxin in RES determined by fluorescein antibody technic. Proc. Soc. exp. Biol. (N.Y.) 95, 510-513 (1957).

$[\mathrm{C} 37,986 / 57$

Crevier, M., d'Iorio, A., Robillard, E.: Influence des glandes sexuelles sur la désintoxication du pentobarbital par le foie. Rev. canad. Biol. 9, 336-343 (1950).

[B54,151/50

Crigler, J. F., Jr.: Phenobarbital, hormones, and bilirubin. Johns Hopk. med. J. 125, 245-249 (1969).

$[\mathrm{G} 72,545 / 69$

Crigler, J. F., Jr., Gold, N. I.: Sodium phenobarbital-induced decrease in serum bilirubin in an infant with congenital nonhemolytic jaundice and kernicterus. (Abstr.) J. clin. Invest. 45, 998-999 (1966). [G68,552/66

Crigler, J. F., Jr., Gold, N. I.: Effect of sodium phenobarbital on the metabolism of bilirubin- ${ }^{3} \mathrm{H}$ and ${ }^{14} \mathrm{C}$ in an infant with congenital nonhemolytic jaundice and kernicterus. (Abstr.). J. clin. Invest. 46, 1047 (1967).

$[\mathrm{G} 68,705 / 67$

Crigler, J. F., Jr., Gold, N. I.: Effect of sodium phenobarbital on bilirubin metabolism in an infant with congenital, nonhemolytic, unconjugated hyperbilirubinemia, and kernicterus. J. clin. Invest. 48, 42-55 (1969).

$[\mathrm{H} 7,119 / 69$

Crispens, C. G., Rey, I. F.: Additional studies on the effects of neonatal thymectomy and lactate dehydrogenase virus infection on mice. Experientia (Basel) 23, 681-683 (1967).

[F 87,332/67

Cronin, R. F. P., Tan, E. H.: The inotropic effect of 1-noradrenaline in experimental cardiogenic shock. Canad. J. Physiol. Pharmacol. 43, 55-68 (1965). [F 29,408/65

Cronkite, E. P., Shellabarger, C. J., Bond, V. P., Lippincott, S. W.: Studies on radiationinduced mammary gland neoplasia in the rat. 
I. The role of the ovary in the neoplastic response of the breast tissue to total- or partialbody-X-irradiation. Radiat. Res. 12, 81-93 (1960).

$[\mathrm{C} 81,609 / 60$

Cruickshank, E. M., Kodicek, E.: The antagonism between cortisone and vitamin $\mathrm{D}$ : experiments on hypervitaminosis $\mathrm{D}$ in rats. J. Endocr. 17, 35-40 (1958). [C53,881/58 Cruveilhier, J.: Anatomie pathologique du corps humain. Bailliere, Paris (1933).

[A 73,454/33

Cucinell, S. A., Conney, A. H., Sansur, M., Burns, J. J.: Drug interactions in man. I. Lowering effect of phenobarbital on plasma levels of bishydroxycoumarin (Dicumarol) and diphenylhydantoin (Dilantin). Clin. Pharmacol. Ther. 6, 420-429 (1965).

$[\mathrm{G} 66,286 / 65$

Cueto, C., Jr.: Cardiovascular effects of o, $\mathrm{p}^{\prime}-\mathrm{DDD}$. Industr. Med. Surg. 39, 31-32 (1970).

[G72,544/70

Cullberg, G., Lundström, R., Stenram, U.: Jaundice during treatment with an oral contraceptive, Lyndiol. Brit. med. J. 1965 I, 695-697.

[F 34,942/65

Cullen, S. I., Catalano, P. M.: Griseofulvinwarfarin antagonism. J. Amer. med. Ass. 199, 582-583 (1967).

$[\mathrm{G} 68,707 / 67$

Culliford, D., Hewitt, H. B.: The influence of sex hormone status on the susceptibility of mice to chloroform-induced necrosis of the renal tubules. J. Endocr. 14, 381-393 (1957).

$[\mathrm{C} 28,738 / 57$

Cummings, M. M., Hudgins, P. C.: Symposium on cortisone and ACTH. The influence of cortisone on experimental tuberculosis. Trans. 47. Ann. Meet. nat. Tuberc. Ass., p. 1-11 (1951).

$[\mathrm{B} 66,423 / 51$

Cunningham, M. D., Mace, J. W., Peters, E. R.: Clinical experience with phenobarbitone in icterus neonatorum. Lancet 1969I, 550-551. $[\mathrm{G} 77,715 / 69$

Curreri, P. W., Kothari, H. V., Bonner, M. J., Miller, B. F.: Increased activity of lysosomal enzymes in experimental atherosclerosis, and the effect of cortisone. Proc. Soc. exp. Biol. (N.Y.) 130, 1253-1256 (1969). [H11,525/69

Currie, A. R., Helfenstein, J. E., Young, S.: Massive adrenal necrosis in rats caused by 9,10-dimethyl-, 2-benzanthracene and its inhibition by metyrapone. Lancet 1962II, 1199 to 1200.

[D $48,292 / 62$

Curry, D. M., Beaton, G. H.: Glucagon administration in pregnant rats (Abstr.). Endocrinology 63, 252-254 (1958).

[C56,647/58
Cutts, J. H.: Protective action of diethylstilbestrol on the toxicity of vinblastine in rats. J. nat. Cancer Inst. 41, 919-922 (1968).

$[\mathrm{H} 22,100 / 68$

Czarnecki, E., Kiersz, J.: Der Verlauf des experimentellen Schocks nach Schilddrüsenund Nebenschilddrüsenentfernung. Arch. int. Pharmacodyn. 134, 189-197 (1961).

[D 15,579/61

Czeizel, E., Palkovits, M., Palkovich, I.: Die Wirkung der natürlichen Oestrogene auf die Funktion der gesunden und geschädigten Leber der Ratten. Endocrinologie 46, 288-298 (1964).

[F 23,802/64

Dagradi, A., Candia, G. de: In tema di biologia comparata della rigenerazione epatica dopo resezione del fegato. Chir. Pat. sper. 10, 351-366 (1962).

[D $56,609 / 62$

Dagradi, A., Galanti, G.: Esperimenti di resezioni epatiche ripetute. Chir. Pat. sper. 10, 447-467 (1962).

[D $62,332 / 62$

Dairman, W., Balazs, T.: Comparison of liver microsome enzyme systems and barbiturate sleep times in rats caged individually or communally. Biochem. Pharmacol. 19, 951 to 955 (1970).

$[\mathrm{G} 78,636 / 70$

Dallemagne, M. J.: L'accoutumance expérimentale a l'évipan et au numal. Arch. int. Pharmacodyn. 65, 52-62 (1941). [A47,748/41

Dallner, G., Siekevitz, P., Palade, G. E.: Phospholipids in hepatic microsomal membranes during development. Biochem. biophys. Res. Commun. 20, 142-148 (1965). [G74,691/65 Dallner, G., Siekevits, P., Palade, G. E.: Synthesis of microsomal membranes and their enzymic constituents in developing rat liver. Biochem. biophys. Res. Commun. 20, 135-141 (1965).

[G74,693/65

Dallner, G., Siekevits, P., Palade, G. E.: Biogenesis of endoplasmic reticulum membranes. II. Synthesis of constitutive microsomal enzymes in developing rat hepatocyte. $J$. Cell. Biol. 30, 97-117 (1966). [G78,599/66

Danielsson, H., Tehen, T. T.: Steroid metabolism. In: Greenberg, D. M.; Metabolic Pathways. II. Lipids, Steroids, and Carotenoids, p. 117-168. New York, London: Academic Press Inc. 1968.

[G 72,327/68

Danysz, A., Kocmierska-Grodzka, D.: The investigations on the new ways of chemical radioprotection. Agressologie 8,277-290(1967).

$[\mathrm{F} 84,845 / 67$

Danysz, A., Panek, R.: Ocena działania radioochronnego metyloandrostenolonu $w$ prze- 
biegu choroby popromiennej wywołanej róźnymi dawkami promieni RTG. Acta physiol. pol. 16, 893-902 (1965).

$[\mathrm{F} 61,858 / 65$

Danysz, A., Panek, R.: Untersuchungen über die Strahlenschutzwirkung des Methandrostenolon bei Rattenweibchen. Strahlentherapie 135/4, 459-463 (1968).

[G57,847/68

Danysz, A., Panek, R., Proniewski, H., Kruszewska, J.: Untersuchungen über den Wirkungsmechanismus der Strahlenschutzsubstanz Methandrostenolon. Teil I und II. Strahlentherapie 128, 419-424, 610-616 (1965).

[G38,389/65

Da0, T. L.: The role of ovarian hormones in initiating the induction of mammary cancer in rats by polynuclear hydrocarbons. Cancer Res. 22, 973-981 (1962).

[D36,011/62

Dao, T. L.: Some considerations on molecular structures of polynuclear hydrocarbons and inhibition of adrenal necrosis in rats. Cancer Res. 24, 1238-1242 (1964). [ [F 19,168/64

Dao, T. L.: Carcinogenesis of mammary gland in rat. Progr. exp. Tumor Res. (Basel) 5, 157-216 (1964).

[G37,357/64

Da0, T. L., Bock, F. G., Greiner, M. J.: Mammary carcinogenesis by 3-methylcholanthrene. II. Inhibitory effect of pregnancy and lactation on tumor induction. J. nat. Cancer Inst. 25, 991-1003 (1960).

$[\mathrm{E} 57,368 / 60$

Dao, T. L., Greiner, M. J.: Mammary carcinogenesis by 3-methylcholanthrene. III. Induction of mammary carcinoma and milk secretion in male rats bearing ovarian grafts. $J$. nat. Cancer Inst. 27, 333-349 (1961). [D91,850/61

Dao, T. L., Sunderland, H.: Mammary carcinogenesis by 3-methylcholanthrene. I. Hormonal aspects in tumor induction and growth. $J$. nat. Cancer Inst. 23, 567-585 (1959).

[D79,860/59

Da0, T. L., Tanaka, Y.: Inhibitory effect of 3-methylcholanthrene on induction of massive necrosis of adrenal cortex by 7,12-dimethylbenz(a)anthracene. Proc. Soc. exp. Biol. (N.Y.) 113, 78-81 (1963). [ [D67,132/63

Dao, T. L., Tanaka, Y.: Inhibitory effect of polynuclear hydrocarbons and amphenone analogs on induction of acute adrenal necrosis by 7,12-dimethylbenz(a)anthracene. Cancer Res. 23, 1148-1152 (1963).

$[\mathrm{E} 29,709 / 63$

Dao, T. L., Yogo, H.: Effects of polynuclear aromatic hydrocarbons on benzpyrene hydroxylase activity in rats. Proc. Soc. exp. Biol. (N.Y.) 116, 1048-1050 (1964). [F21,633/64
Darcis, L., Brisbois, A.-M.: Influence de la thyroxine et du propionate de testostérone sur la réponse de l'intestin grêle du rat à une irradiation roentgénienne localisée. $A n n$. Endocr. (Paris) 18, 1042-1045 (1957).

$[\mathrm{C} 50,953 / 57$

D'Arey-Hart, P., Rees, R. J. W.: Enhancing effect of cortisone on tuberculosis in the mouse. Lancet 1950 II, 391-395.

$[\mathrm{B} 50,249 / 50$

D'Arey, P. F., Spurling, N. W.: The effect of cortisol and corticotrophin on amphetamine toxicity in mice under crowded and noncrowded conditions. J. Endocr. $22, \mathrm{xxxv}-\mathrm{xxxvi}$ (1961).

$[\mathrm{D} 8,818 / 61$

Dardachti, D., Garg, B. D., Khandekar, J. D., Kovaes, K.: L'effet du metyrapone sur l'ultrastructure hépatique chez le rat surrénalectomisé. Ann. Anat. path. (in press). [G79,006/ Da Rocha Lagoa, F., cf. Rocha Lagoa, F. da $[\mathrm{B} 49,008 / 47$

Das, R. P., Kar, A. B.: Effect of corticoids on the testis of cadmium chloride treated rats. Proc. nat. Inst. Sci. India B, 27, 46-51 (1961).

[D 14,801/61

Dashputra, P. G., Sharma, M. L., Rajapurkar, M. V.: Modification of metrazol induced convulsions in rats by adrenal cortical steroids. Arch. int. Pharmacodyn. 150, 483-488 (1964).

[F 19,871/64

Dasler, W.: Protective action of glutamine, cysteine and other substances against experimental lathyrism in the rat. Proc. Soc. exp. Biol. (N.Y.) 91, 554-557 (1956).

$[\mathrm{C} 15,943 / 56$

Dasler, W.: Experimental lathyrism. Chic. Med. Sch. Quart. 18, 1-10 (1957).

$[\mathrm{C} 36,068 / 57$

D'Aste, G., Ardau, B.: Sulfotiazolo, penicillina, streptomicina, metiltiouracile, neoantergan $\theta$ loro influenza sullo shock sperimentale. Riv. Chir. Med. 1, 91-123 (1949). [ [B56,421/49

Datta, D. V., Isselbacher, K. J.: Effect of corticosteroids on mouse hepatitis virus infection. Gut 10, 522-529 (1969).

$[\mathrm{G} 68,822 / 69$

Datta, P. R.: In vivo detoxication of $\mathrm{p}, \mathrm{p}^{\prime}-\mathrm{DDT}$ via $\mathrm{p}, \mathrm{p}^{\prime}-\mathrm{DDE}$ to $\mathrm{p}, \mathrm{p}^{\prime}-\mathrm{DDA}$ in rats. Industr. Med. Surg. 39, 190-194 (1970).

$[\mathrm{G} 75,362 / 70$

Dau, W., Weber, H. G.: Chemisch-hormonelle Stoffwechselbeeinflussung und Verlängerung der Wiederbelebungszeit. Langenbecks Arch. klin. Chir. 302, 779-784 (1963). [G20,433/63 
Daugharty, D. A., Sullivan, J. F., Gantner, G. E.: Effect of cortisone on ethionine-induced pancreatitis in the rat. Proc. Soc. exp. Biol. (N.Y.) 101, 826-829 (1959). [C74,925/59

Dautrebande, L.: L'action du benzol sur le système vaso-moteur. La syncope adrénalinobenzolique. C. R. Soc. Biol. (Paris) 111, 218-220 (1932).

$[8,083 / 32$

da Vanzo, J. P., cf. Vanzo, J. P. da

[F 19,865/64

Davenport, V. D.: Relation between brain and plasma electrolytes and electroshock seizure thresholds in adrenalectomized rats. Amer. J. Physiol. 156, 322-327 (1949). [B36,663/49

Davidow, B., Frawley, J. P.: Tissue distribution, accumulation and elimination of the isomers of benzene hexachloride. Proc. Soc. exp. Biol. (N.Y.) 76, 780-783 (1951).

$[\mathrm{H} 27,655 / 51$

Davidson, A., Owen, J., Thomas, C. G., Jr.: Further studies on the role of altered thyroid function on experimentally induced breast cancer in Sprague-Dawley rats. (Abstr.) Proc. Amer. Ass. Cancer Res. 10, 17 (1969). [H 10,206/69

Davies, D. S., Gigon, P. L., Gillette, J. R.: Sex differences in the kinetic constants for the $\mathrm{N}$ demethylation of ethylmorphine by rat liver microsomes. Biochem. Pharmacol. 17, 1865 to 1872 (1968).

[H 22,054/68

Davies, D. S., Gigon, P. L., Gillette, J. R.: Species and sex differences in electron transport systems in liver microsomes and their relationship to ethylmorphine demethylation. Life Sci. 8, 85-91 (1969).

[G76,865/69

Davies, J. E., Edmundson, W. F., Carter, C. H., Barquet, A.: Effect of anticonvulsant drugs on dicophane (D.D.T.) residues in man. Lancet 1969 II, 7-9.

$[\mathrm{G} 77,532 / 69$

Davis, D. A., Medline, N. M.: Spironolactone (aldactone) bodies: concentric lamellar formations in the adrenal cortices of patients treated with spironolactone. Amer. J. clin. Path. 54, 22-32 (1970).

[G76,611/70

Davis, N. C., Whipple, G. H.: The influence of drugs and chemical agents on the liver necrosis of chloroform anesthesia. Paper II. Arch. intern. Med. 23, 636-654 (1919).

$[58,731 / 19$

Davis, V. E.: Effect of cortisone and thyroxine on aromatic amino acid decarboxylation. Endocrinology 72, 33-38 (1963). [D92,322/63

Davis, W. M., Su, M. Q.: Effects of adrenalectomy and repeated convulsions on responses of rats to flurothyl. Int. J. Neuropharmacol. 8, $55-59$ (1969).

$[\mathrm{H} 31,927 / 69$
Davison, A. N.: The conversion of schradan (OMPA) and parathion into inhibitors of cholinesterase by mammalian liver. Biochem. $J .61,203-209$ (1955). [A49,341/55 Davydova, S. A.: Effect of sex hormones on course of acute radiation sickness. Fed. Proc. 23/2, T1166-T1168 (1964). [F23,736/64

Dayton, P. G., Tarcan, Y., Chenkin, T., Weiner, M.: The influence of barbiturates on coumarin plasma levels and prothrombin response. J. clin. Invest. 40, 1797-1802 (1961).

[D42,366/61

Dearing, W. H., Barnes, A. R., Essex, H. E.: Experiments with calculated therapeutic and toxic doses of digitalis. I. Effects on the myocardial cellular structure. Amer. Heart $J$. 25, 648-664 (1943).

$[\mathrm{C} 41,482 / 43$

Dearing, W. H., Barnes, A. R., Essex, H. E.: Myocardial lesions produced by digitalis in the presence of hyperthyroidism; an experimental study. Circulation 1, 394-403 (1950).

[B53,571/50

De Baun, J. R., Miller, E. C., Miller, J. A.: Nhydroxy-2-acetylaminofluorene sulfotransferase: its probable role in carcinogenesis and in protein-(methion-S-yl) binding in rat liver. Cancer Res. 30, 577-595 (1970). [H26,701/70 Debias, D. A.: Hormonal factors in the rat's tolerance to altitude. Amer. J. Physiol. 203, 818-820 (1962).

[D41,419/62

Debias, D. A.: Thyroid-adrenal relationship in altitude tolerance. Fed. Proc. 25, 1227-1229 (1966).

$[\mathrm{F} 69,410 / 66$

Debias, D. A., Wang-Yen: The effect of hormones on the rat's tolerance to simulated altitude. Fed. Proc. 21, 186 (1962).

$[\mathrm{D} 22,848 / 62$

de Boer, B., cf. Boer, B. de

$[\mathrm{A} 48,817 / 48$

de Boer, B., Mukomela, A. E., cf. Boer, B. de, Mukomela, A. F.

$[\mathrm{C} 5,245 / 55$

Debry, G.: Influence du terrain endocrinien sur les infections. (Etudes clinique et expérimentale). Ses conséquences en médecine sociale. Tome II. Thèse, Université de Nancy 1956.

$[\mathrm{C} 30,870 / 56$

Debry, G., Berger, H., Jolibois, C.: Le rôle de la thyroïde dans l'infection tuberculeuse expérimentale. Rev. Tuberc. (Paris) 26, 311-325 (1962).

$[\mathrm{D} 34,828 / 62$

Decken, A. von der, Hultin, T.: The enzymatic composition of rat liver microsomes during liver regeneration. Exp. Cell. Res. 19, 591-604 (1960).

[G37,124/60 
Decken, A. von der, Hultin, T.: Inductive effects of 3-methylcholanthrene on enzyme activities and amino acid incorporation capacity of rat liver microsomes. Arch. Biochem. 90, 201-207 (1960).

[G68,039/60

De Dominicis, G., cf. Dominicis, G. De

$$
[\mathrm{B} 3,412 / 42
$$

De Feo, J. J., Baumel, I., Lal, H.: Drug environment interactions: acute hypoxia and chronic isolation. Fed. Proc. 29, 1985-1990 (1970).

$[\mathrm{H} 32,863 / 70$

Dehnen, W., Tomingas, R., Schagholi, H.: Abbau von Benzo(a)pyren durch Enzyme der Rattenlebermikrosomen in vitro in Abhängigkeit vom Alter und Geschlecht der Versuchstiere. Z. Krebsforsch. 73, 363-370 (1970).

$[\mathrm{G} 74,165 / 70$

Deichmann, W. B., Dees, J. E., Keplinger, M. L., Farrell, J. J., MacDonald, W. E., Jr.: Toxicity of crotalus adamanteus (Rattlesnake) venom and the antidotal effects of hydrocortisone. Fed. Proc. 16, 291 (1957).

$[\mathrm{C} 33,188 / 57$

Deichmann, W. B., Radomski, J. L., Farrell, J. J., MacDonald, W. E., Keplinger, M. L.: Acute toxicity and treatment of intoxications due to crotalus adamanteus (Rattlesnake venom). Amer. J. med. Sci. 236, 204-207 (1958).

$[\mathrm{C} 73,854 / 58$

Deichmann, W. B., Witherup, S., Kitzmiller, K. V.: The toxicity of DDT. Experimental observations. Prev. Med. and Industr. Health, Coll. Med., p. 71 (1950).

$[\mathrm{D} 98,307 / 50$

DeLeon, A., Gartner, L. M., Arias, I. M.: The effect of phenobarbital on hyperbilirubinemia in glucuronyl transferase deficient rats. $J$. Lab. clin. Med. 70, 273-278 (1967).

[G71,826/67

Delfini, C.: Influenza dell'elettro-schok sull'arteriosclerosi sperimentale da adrenalina. $G$. Psichiat. Neuropat. 78, 305-325 (1950).

[B52,659/50

DeLorimier, A. A., Gordan, G. S., Lowe, R. C., Carbone, J. V.: Methyltestosterone, related steroids, and liver function. Arch. intern. Med. 116, 289-294 (1965).

[G31,525/65

DeLuea, H. F.: Vitamin D. New Engl. J. Med. 281, 1103-1104 (1969).

$[\mathrm{H} 17,327 / 69$

De Marchi, G., cf. Marchi, G. De $\quad[$ A30,837/38

De Mitri, T., cf. Mitri, T. De [D64,042/63

Denef, C., de Moor, P.: The "puberty" of the rat liver. II. Permanent changes in steroid metabolizing enzymes after treatment with a single injection of testosterone propionate at birth. Endocrinology 83, 791-798 (1968).

$[\mathrm{H} 3,569 / 68$
Denef, C., de Moor, P.: "Puberty" of the rat liver. IV. Influence of estrogens upon the differentiation of cortisol metabolism induced by neonatal testosterone. Endocrinology $\mathbf{8 5}$, 259-269 (1969).

$[\mathrm{H} 15,811 / 69$

Denison, M. E., Zarrow, M. X.: The effect of cold on survival and reproductive activities in the rat. Anat. Rec. 113, 531 (1952).

[B 77,713/52

Dent, C. E., Richens, A., Rowe, D. J. F., Stamp, T. C. B.: Osteomalacia with long-term anticonvulsant therapy in epilepsy. Brit. med. J. 1970II, 69-72.

$[\mathrm{H} 30,946 / 70$

Deplano, P.: Il comportamento degli acidi nucleinici nel fegato dopo epatectomia parziale nel ratto normale e nel ratto sottoposto a trattamento cortisonico. Atti Acad. med. lombarda 23, 741-748 (1968). $\quad$ [H23,483/68

Deplano, P., Fornara, C. F.: Il comportamento della fosfatasi alcalina nel fegato dopo epatectomia parziale nel ratto normale e nel ratto sottoposto a trattamento cortisonico. Atti Acad. med. lombarda 28, 749-754 (1968).

$[\mathrm{H} 23,484 / 68$

Deppe, H. D., Lutzmann, L.: Einfluß eines anabolen Steroids auf die cytostatisch gehemmte Antikörperbildung bei der Ratte. Z. Hyg. Infekt.-Kr. 149, 401-406 (1964).

[G14,653/64

Deringer, M. K., Dunn, T. B., Heston, W. E.: Results of exposure of strain $\mathrm{C} 3 \mathrm{H}$ mice to chloroform. Proc. Soc. exp. Biol. (N.Y.) 83, $474-479$ (1953).

$[\mathrm{G} 64,723 / 53$

Derom, P., van Hoydonck, J.: Influence de l'A.C.T.H. et de la cortisone sur la leptospirose expérimentale du cobaye. Rev. belge Path. 24, 207-208 (1955).

$[\mathrm{C} 17,095 / 55$

Dérot, M., Tutin, M.: Néphropathie aiguë après ingestion de nitrate mercurique. (Considérations sur le traitement des néphropathies mercurielles). Bull. Soc. méd. Hôp. Paris 73, 1039-1044 (1957).

$[\mathrm{C} 67,130 / 57$

Dési, I., Szold, E., Olasz, J.: Die Verlängerung der Lebensdauer urämischer Tiere mit einem neuen Hormonpräparat. Z. Urol. 54, 161-164 (1961).

[D11,138/61

Dési, I., Szold, A., Weisz, P., Kádas, T., Zalán, J.: Wirkung des somatotropen Hormons auf experimentelle Urämie. Z. ges. inn. Med. 14, 299-300 (1959).

$[\mathrm{C} 69,045 / 59$

DesMarais, A., Dugal, L. P.: Circulation périphérique et teneur des surrénales en adrénaline et en artgrénol (nor-adrénaline) chez le rat blanc exposé au froid. Proc. Canad. 
Physiol. Soc., 14th Ann. Meet., Ottawa, p. 11 (1950).

$[\mathrm{B} 51,093 / 50$

DesMarais, A., Dugal, L. P.: Influence de l'administration d'adrénaline et d'artérénol, sur l'hypertrophie de la surrénale au froid. Canad. J. med. Sci. 29, 104-107 (1951).

$[\mathrm{B} 64,359 / 51$

Despopoulos, A.: Excretion of sulfobromophthalein by perfused rat liver as influenced by steroidal hormones. J. Pharmacol. exp. Ther. 173, 37-42 (1970).

$[\mathrm{H} 24,651 / 70$

Despopoulos, A.: Hepatic and renal excretory metabolism of bile salts a background for understanding steroid-induced cholestasis. $J$. Pharmacol. exp. Ther. 176, 273-283 (1971).

[H35,471/71

Dessau, F.: Nebennierenwirkungen bei der akuten Acetonitrilvergiftung der Ratte. Acta brev. neerl. Physiol. 5, 1-2 (1935).

$[34,845 / 35$

de Valderrama, J. A. F., Munuera, L. M., $c f$. Valderrama, J. A. F. de, Munuera, L. M.

$[\mathrm{E} 6,008 / 66$

Dewaide, J. H.: Species differences in hepatic drug oxidation in mammals and fishes in relation to thermal acclimation. Comp. gen. Pharmacol. 1, 375-384 (1970). [G80,406/70

Dewar, A. D.: The nature of the weight gain induced by progesterone in mice. Quart. $J$. exp. Physiol. 49, 151-161 (1964). [G9,079/64

Dewhurst, F.: The effect of 1:2:5:6 dibenzanthracene (D.B.A.) upon the metabolism of $\beta$-naphthylamine in the rat. Naturwissenschatten 50, 404-405 (1963).

$[\mathrm{G} 76,687 / 63$

Dewhurst, F., Kitehen, D. A.: The effect of prolonged pretreatment with 6-substituted benzo pyrene derivatives upon zoxazolamine paralysis times in mice. Biochem. Pharmacol. 19, 615-617 (1970).

[G73,848/70

Dhunèr, K. G., Nordqvist, P.: Sleep reinduced by cortisone and glucose in patients intoxicated with barbiturates and related drugs. Acta anaesth. scand. 1, 55-62 (1957).

[D98,693/57

Diaz, C. J., Vivanco, F., Ramos, F., Martin, J. A. S.: Ulteriores estudios sobre el latirismo experimental de la rate (odoratismo). Rev. clin. exp. 67, 295-304 (1957). [C50,497/57

Diaz, C. J., Vivanco, F., Ramos, F., Martin, J. A. S.: Further studies of experimental lathyrism in rats (odoratism). Bull. Inst. med. Res. (Madr.) 11, 23-40 (1958). [D99,329/58

Di Carlo, F. J., et al., cf. Carlo, F. J. Di, et al.

$[$ F 74,536/65
Dick, E. C., Greenberg, S. M., Herndon, J. F., Jones, M., van Loon, E. J.: Hypocholesteremic effect of $\beta$-diethylaminoethyl diphenylpropylacetate hydrochloride (SKF No. 525-A) in the dog. Proc. Soc. exp. Biol. (N.Y.) 104, 523-526 (1960).

[G74,672/60

Dick, W., Droh, R., Frey, R., Hadjidimos, M., Halmagyi, M., Heymer, G., Oettel, P.: Experimentelle und klinische Untersuchungen mit dem Muskelrelaxans Pancuroniumbromid. Anaesthesist 19, 248-250 (1970). [G77,777/70

Dieckhoff, J., Bartel, J., Hoppe, E.: Zur Pathogenese und Therapie des WaterhouseFriderichsen-Syndroms. Dtsch. med. Wschr. 93, 1397-1401 (1968).

[H1,991/68

Diengott, D., Ungar, H.: Effect of cortisone on carbon tetrachloride cirrhosis in rats. Arch. Path. 58, 449-454 (1954). [ [E 84,645/54

Dietrich, L. S.: Effect of hyperphysiological levels of steroid hormones on nicotinamide deamidase and NAD synthesis in mouse liver tissue. Biochem. Pharmacol. 14, 467-472 (1965). [G28,103/65

Dietrich, L. S., Franklin, L., Farinas, B.: Effect of hyperphysiological levels of hexestrol on the hepatic metabolism of nicotinate in the mouse. Proc. Soc. exp. Biol. (N.Y.) 133, 160-163 (1970).

[H19,763/70

Dietrich, L. S., Yero, I. L.: Endocrine involvement in the suppression of NAD synthesis produced by hyperphysiological levels of steroid hormones. Biochim. biophys. Acta (Amst.) 97, 385-388 (1965).

[G26,959/65

Dietrich, W. C., Beutner, R.: The mechanism of action of thiouracil. Proc. Soc. exp. Biol. (N.Y.) 57, 35-36 (1944). [B [ [

Dille, J. M.: Studies on barbiturates. IX. The effect of barbiturates on the embryo and on pregnancy. J. Pharmacol. exp. Ther. 52, 129 to 136 (1934).

$[45,154 / 34$

Dille, J. M., Seeberg, V. P.: Preliminary report on the elimination of metrazol. Pharm. Arch. 12, 9 (1941).

$[84,277 / 41$

Dingell, J. V., Heimberg, M.: The effect of aliphatic halogenated hydrocarbons on hepatic drug metabolism. Biochem. Pharmacol. 17, 1269-1278 (1968).

$[\mathrm{G} 72,112 / 68$

Discher, R., Laafi, H., Creutzieldt, W., Kühn, H. A.: Untersuchungen über die therapeutische Beeinflußbarkeit experimenteller Lebercirrhosen bei der Ratte. III. Die Tetrachlorkohlenstoff-Cirrhose der Ratte und ihre therapeutische Beeinflussung durch Glucocorticoide mit und ohne gleichzeitige Verabreichung von 
Antibiotica und Androgenen. $Z$. ges. exp. Med. 136, 500-516 (1963). [D $64,428 / 63$

Dixon, R. L., Fouts, J. R.: Inhibition of microsomal drug metabolic pathways by chloramphenicol. Biochem. Pharmacol. 11, 715-720 (1962).

[E53,752/62

Dixon, R. L., Hart, L. G., Fouts, J. R.: The metabolism of drugs by liver microsomes from alloxan diabetic rats. $J$. Pharmacol. Exp. Ther. 133/1, 7-11 (1961).

$[\mathrm{D} 9,331 / 61$

Dixon, R. L., Hart, L. G., Rogers, L. A., Fouts, J. R.: The metabolism of drugs by liver microsomes from alloxan-diabetic rats: long term diabetes. J. Pharmacol. exp. Ther. 142, 312-317 (1963).

[E35,705/63

Dixon, R. L., Rogers, L. A., Fouts, J. R.: The effects of norepinephrine treatment on drug metabolism by liver microsomes from rats. Biochem. Pharmacol. 13, 623-631 (1964).

[G11,757/64

Dixon, R. L., Shultice, R. W., Fouts, J. R.: Factors affecting drug metabolism by liver microsomes. IV. Starvation. Proc. Soc. exp. Biol. (N.Y.) 103, 333-335 (1960).

$[\mathrm{G} 65,886 / 60$

Dixon, R. L., Willson, V. J.: Metabolism of hexobarbital and zoxazolamine by placentae and fetal liver supernatant fraction and response to phenobarbital and chlordane treatment. Arch. int. Pharmacodyn. 172, 453-466 (1968).

[H30,692/68

Dmitriev, V. N.: The hormone prophylaxis of dyshormonal hyperplasias of the mammary glands in mice. (Russian text.) Vop. Onkol. 15/1, 59-61 (1969).

[H28,154/69

Dmowski, W. P., Scholer, H. F. L., Mahesh, V. B., Greenblatt, R. B.: Danazol: a synthetic steroid derivative with interesting physiologic properties. Fertil. and Steril. 22, 9-18 (1971).

[G80,777/71

Dobrescu, D., Coeugniet, E., Coeugniet, A.: Influenţa prednisolonului şi testosteronului asupra toleranței la morfină. (Influence de la prednisolone et de la testostérone sur la tolérance envers la morphine.) Stud. Cercet. Fiziol. 15, 163-169 (1970).

[H 26,899/70

Dobrev, P.: Experimentelle Studien zur Pathogenese der Tuberkulose bei Diabetikern. Beitr. Klin. Tuberk. 129, 153-157 (1964).

[G 23,362/64

Dobrokhotova, L. P.: Effect of methylthiouracil on haemorrhagic shock under the influence of trauma to the nervous system.
(Russian text with Engl. summary.) Doklady Akad. nauk. SSSR. 114, 1320-1321 (1957).

$[\mathrm{C} 55,431 / 57$

Dobrolvolskaīa-Zavadskaīa, N., Vérotennikoff, M. S., Rodzévitch, M.: La survie des souris, de lignée et d'âge differents, aprés une seule irradiation totale par les rayons X. C. R. Acad. Sci. 213, $704-706$ (1941).

$[86,799 / 41$

Dodd, J. M., Dent, J. N.: Thyroid gland and temperature tolerance relationships in coldblooded vertebrates. Nature (Lond.) 199, 299 (1963).

[E21,585/63

Dolfini, E., Kobayashi, M.: Studies with amphetamine in hyper- and hypothyroid rats. Europ. J. Pharmacol. 2, 65-66 (1967).

$[\mathrm{F} 91,611 / 67$

Dolgova, Z. Y., Dolgov, E. G.: Effect of thyroid hormone on the internal organs in rats as revealed by vital staining of the tissues. (Russian text.) Bull. exp. Biol. Med. 58, 1246-1248 (1964).

[G33,058/64

Dominicis, G. De: Tricloroetilene, estratti corticali e vitamina C. Folia endocr. (Roma) 20, 97-106 (1942).

$[\mathrm{B3}, 412 / 42$

Domschke, W., Domagk, G. F., Domschke, S., Erdmann, W. D.: Hemmung der Somaninduzierten Enzymbiosynthese in der Rattenleber durch Äthionin. Arch. Toxikol. 26, 142-148 (1970).

[G74,897/70

Donatelli, L.: Età, sesso e barbiturismo acuto. Contributo clinico e sperimentale. Arch. int. Pharmacodyn. 74, 90-111 (1947).

[B38,172/47

Donatelli, L.: Età, sesso ed idrargirismo acuto. Contributo clinico e sperimentale. Arch. int. Pharmacodyn. 74, 193-211 (1947).

[B38,554/47

Done, A. K.: Developmental pharmacology. Clin. Pharmacol. Ther. 5, 432-479 (1964).

[G81,518/64

Done, A. K.: Perinatal pharmacology. Ann Rev. Pharmacol. 6, 189-208 (1966).

[G81,512/66

Donomae, I., Hori, M., Hattori, S., Mishima, J.: Histochemical studies on the experimental tuberculous cavity formation of the rabbit lung: effect of ACTH administration on the cavity formation. Med. J. Osaka Univ. 6, $463-478$ (1955).

$[\mathrm{C} 22,935 / 55$

Dontenwill, W., Mancini, A. M.: IV. Experimentelle Untersuchungen über hormonale Beeinflussung des Knochenwachstums beim Kaninchen. Beitr. pathol. Anat. 117, 50-64 (1957). $[\mathrm{C} 35,119 / 57$ 
Dooley, E. S., Holtman, D. F.: Effect of the administration of cortisone on the response of chicks to the endotoxin of salmonella pullorum. J. Bact. 78, 562-566 (1959). [C84,689/59

Dorfman, R. I.: Steroids and tissue oxidation. In: Harris, R.S., Vitamins and Hormones, p. 331. New York: Academic Press Inc. Publ. 1952.

$[\mathrm{B} 76,571 / 52$

Dorrance, S. S., Thorn, G. W., Tyler, F. H., Katzin, B.: Work performance of normal rats under conditions of anoxia. Endocrinology 31, 209-216 (1942).

$[\mathrm{A} 38,460 / 42$

Dosne, C.: The effect of dosage and duration of administration on the anti-uremic effect of desoxycorticosterone. Amer. J. Physiol. 134, 71-73 (1941).

[A35,924/41

Dossena, P.: Recherches sur l'influence des hormones sexuelles dans l'intoxication expérimentale par le venin de naja flava (Cape cobra). Acta trop. (Basel) 6, 263-267 (1949).

[B47,510/49

Dotti, L. B.: The response of the rabbit to insulin. Amer. J. Physiol. 114, 538-550 (1936).

$[34,994 / 36$

Dougherty, J. H., Dougherty, T. F.: Acute effect of 4-aminopteroylglutamic acid on blood lymphocytes and the lymphatic tissue of intact and adrenalectomized mice. J. Lab. clin. Med. 35, 271-279 (1950). [G77,517/50

Douglas, A. C.: Treatment of radiation pneumonitis with prednisolone. Brit. J. Dis. Chest 53, 346-355 (1959).

$[\mathrm{C} 78,775 / 59$

Douglas, B.: Action protectrice de l'adrénaline. Syncope adrénalino-chloro-formique. C. R. Soc. Biol. (Paris) 91, 1419-1420 (1924).

$[20,147 / 24$

Douglas, B.: Action empêchante de l'adrénaline sur l'absorption du venin de cobra par la peau. C. R. Soc. Biol. (Paris) 91, 1223-1224 (1924).

$[21,321 / 24$

Douglas, B. H., Clower, B. R.: Hepatotoxic effect of carbon tetrachloride during pregnancy. Amer. J. Obstet. Gynec. 102, 236-239 (1968).

[H $20,791 / 68$

Doull, J., Tricou, B. J.: Studies on the radioprotective effect of serotonin in mice. Fed. Proc. 20, 400 (1961).

$[\mathrm{D} 4,271 / 61$

Dowben, R. M.: Prolonged survival of dystrophic mice treated with $17 \alpha$-ethyl-19-nortestosterone. Nature (Lond.) 184, 1966-1967 (1959).

$[\mathrm{C} 79,563 / 59$

Dowben, R. M.: Anabole Steroide bei Myopathien. In: Beckmann; Myopathien, p. 242-251. Stuttgart: Georg Thieme Verlag 1965.

$[\mathrm{E} 80 / 65$
Dowben, R. M., Gordon, P.: Effects of steroids on the survival of dystrophic mice. Fed. Proc. 20, 302 (1961).

$[\mathrm{D} 4,188 / 61$

Dowben, R. M., Zuckerman, L., Gordon, P., Sniderman, S. P.: Effect of steroids on the course of hereditary muscular dystrophy in mice. Amer. J. Physiol. 206, 1049-1056 (1964).

[F 10,902/64

Dowling, J. N., Feldman, H. A.: Quantitative biological assay of bacterial endotoxins. Proc. Soc. exp. Biol. (N.Y.) 134, 861-864 (1970).

[H31,139/70

Downs, A. W., Eddy, N. B.: The effect of repeated doses of cocaine on the rat. J. Pharmacol. exp. Ther. 46, 199-200 (1932).

$[58,426 / 32$

Drabkin, D. L.: The effect of thyroidectomy and of thiouracil on cytochrome c metabolism and liver regeneration. Fed. Proc. 7, 151 (1948).

$[\mathrm{B} 17,795 / 48$

Drabkin, D. L.: Cytochrome c metabolism and liver regeneration. Influence of adrenalectomy. J. biol. Chem. 182, 351-357 (1950).

[B53,844/50

Drabkin, D. L.: Cytochrome c metabolism and liver regeneration. Influence of thyroid gland and thyroxine. J. biol. Chem. 182, 335-349 (1950).

[D $18,388 / 50$

Drachman, R. H., Root, R. K., Wood, W. B. Jr.: Studies on the effect of experimental nonketotic diabetes mellitus on antibacterial defense. I. Demonstration of a defect in phagocytosis. J.exp.Med.124, 227-240 (1966). [F 81,617/66 Dragstedt, L. R., Peacock, S. C.: Studies on the pathogenesis of tetany. I. The control and cure of parathyroid tetany by diet. Amer. J. Physiol. 64, 424-434 (1923). $\quad[17,556 / 23$

Dragstedt, L. R., Phillips, K., Sudan, A. C.: Studies on the pathogenesis of tetany. II. The mechanism involved in recovery from parathyroid tetany. Amer. J. Physiol. 65, 368-378 (1923).

$[17,561 / 23$

Draize, J. H., Tatum, A. L.: A method for the study of the biological potency of thyroid preparations. J. Pharmacol. exp. Ther. 42, 262 (1931).

$[3,901 / 31$

Draize, J. H., Tatum, A. L.: Experimental thyrotoxicosis. Arch. int. Pharmacodyn. 43, 237-245 (1932).

$[3,657 / 32$

Drawkins, M. J. R.: Carbon tetrachloride poisoning in the liver of the new-born rat. J. Path. Bact. 85, 189-196 (1963).

$[\mathrm{G} \mathrm{78,605/63}$

Drews, J.: Klinische und biochemische Wirkungen der Glukokortikoide, dargestellt am 
Beispiel des Cushing-Syndroms. Med. Klin. 64, 773-789 (1969).

[H 12,100/69

Drews, J., Brawerman, G.: Alterations in the nature of ribonucleic acid synthesized in rat liver during regeneration and after cortisol administration. J. biol. Chem. 242, 801-808 (1967).

[G52,150/67

Driever, C. W., Bousquet, W. F.: Stress drug interactions: evidence for rapid enzyme inductions. Life Sci. 4, 1449-1454 (1965).

[G31,872/65

Driever, C. W., Bousquet, W. F., Miya, T. S.: Stress stimulation of drug metabolism in the rat. Int. J. Neuropharmacol. 5, 199-205 (1966).

$[\mathrm{F} 73,812 / 66$

Druskemper, H. L.: Anabolic Steroids, pp. 236. New York, London: Academic Press Inc. 1968. (Originally published in German) Stuttgart: George Thieme Verlag 1963. [E933/63 Dryden, L. P., Hartman, A. M.: Unidentified nutrients required by the hyperthyroid rat. Fed. Proc. 18, 523 (1959).

$[\mathrm{C} 66,416 / 59$

DuBois, K. P.: Inhibition by radiation of the development of drug-detoxification enzymes. Radiat. Res. 30, 342-350 (1967). [G77,578/67

DuBois, K. P., Doull, J., Coon, J. M.: Studies on the toxicity and pharmacological action of octamethyl pyrophosphoramide (OMPA: Pestox III). J. Pharmacol. exp. Ther. 99, 376 to 393 (1950).

$[\mathrm{D} 92,992 / 50$

DuBois, K. P., Doull, J., Salerno, P. R., Coon, J. M.: Studies on the toxicity and mechanism of action of p-nitrophenyl diethyl thionophosphate (parathion). J. Pharmacol. exp. Ther. 95, 79-91 (1949).

$[\mathrm{G} 66,495 / 49$

DuBois, K. P., Herrmann, R. G., Erway, W. F.: Studies on the mechanism of action of thiourea and related compounds. III. The effect of acute poisoning on carbohydrate metabolism. J. Pharmacol. exp. Ther. 89, 186-195 (1947).

$[\mathrm{B} 3,089 / 47$

DuBois, K. P., Holm, L. W., Doyle, W. L.: Studies on the mechanism of action of thiourea and related compounds. I. Metabolic changes after acute poisoning by alpha-naphthylthiourea. J. Pharmacol. exp. Ther. 87, 53-62 (1946).

$[\mathrm{B} 3,103 / 46$

DuBois, K. P., Kinoshita, F.: Modification of the anticholinesterase action of 0,0-diethyl 0-(4-methylthio-m-tolyl) phosphorothioate (DMP) by drugs affecting hepatic microsomal enzymes 1. Arch. int. Pharmacodyn. 156, 418-431 (1965).

$[\mathrm{G} 66,247 / 65$

DuBois, K. P., Kinoshita, F.: Stimulation of detoxification of 0-ethyl 0-(4-nitrophenyl) phenylphosphonothioate (EPN) by nikethamide and phenobarbital. Proc. Soc. exp. Biol. (N.Y.) 121, 59-62 (1966).

$[\mathrm{H} 24,226 / 66$

DuBois, K. P., Kinoshita, F. K.: Influence of induction of hepatic microsomal enzymes by phenobarbital on toxicity of organic phosphate insecticides. Proc. Soc. exp. Biol. (N.Y.) 129, 699-702 (1968).

$[\mathrm{G} 66,349 / 68$

DuBois, K. P., Puchala, E.: Studies on the sex difference in toxicity of a cholinergic phosphorothioate. Proc. Soc. exp. Biol. (N.Y.) 107, 908-911 (1961).

[D43,878/61

Dubos, R. J.: Effect of metabolic factors on the susceptibility of albino mice to experimental tuberculosis. J. exp. Med. 101, 59-84 (1955).

[D93,317/55

Dubos, R. J.: Biochemical determinants of infection. Bull. N. Y. Acad. Med. 31, 5-19 (1955).

$[\mathrm{G} 71,484 / 55$

Dubos, R. J., Smith, J. M., Schaedler, R. W.: Metabolic disturbances and infection. Proc. Roy. Soc. Med. 48, 911-918 (1955).

$[\mathrm{C} 21,520 / 55$

Ducheneau, L.: Action de l'insuline sur les lapins ethyroidés. C. R. Soc. Biol. (Paris) 90, 248-249 (1924).

$[20,846 / 24$

Ducommun, P., Ducommun, S.: Sur l'action de la somatotrophine hypophysaire dans la prévention des infections favorisées par le surdosage en cortisone. Ann. Endocr. (Paris) 14, 765-771 (1953).

$[\mathrm{B} 70,251 / 53$

Ducommun, P., Ducommun, S., Baquiche, M.: Comparaison entre l'action du 17-ethyl-19-nortestosterone et $\mathrm{du}$ propionate de testosterone chez le rat adulte et immature. Acta endocr. (Kbh.) 30, 78-92 (1959). [C62,099/59

Ducommun, P., Ducommun, S., Baquiche, M.: Etude expérimentale des actions antagonistes d'un spirolactone (Aldactone) et de la désoxycorticostérone. Schweiz. med. Wschr. 90, 607-611 (1960).

$[\mathrm{C} 91,529 / 60$

Duffy, B. J., Jr., Morgan, H. R.: ACTH and cortisone aggravation or suppression of the febrile response of rabbits to bacterial endotoxin. Proc. Soc. exp. Biol. (N.Y.) 78, 687 to 689 (1951).

$[\mathrm{B} 65,399 / 51$

Dufour, D., Dugal, L. P.: Effet de l'hormone somatotrope sur la résistance du rat exposé au froid. C. R. Soc. Biol. (Paris) 149, 2056 à 2060 (1955).

$[\mathrm{C} 15,508 / 55$

Dufour, D., Dugal, L. P.: Effet de l'association STH-vitamine $\mathrm{C}$ sur la résistance du rat blanc au froid. $A n n . A C F A S 23,83$ (1957).

$[\mathrm{C} 26,092 / 57$ 
Dufour, D., Dugal, L. P., Desmarais, A.: Effet de l'hormone somatotrope chez le rat surrénalectomisé exposé au froid. C. R. Soc. Biol. (Paris) 149, 1722-1725 (1955). [C12,151/55 Dugal, L. P., Dufour, D.: Maintien, par l'hormone somatotrope, de la croissance normale du rat exposé au froid. C. R. Soc. Biol. (Paris) 148, 1521-1523 (1954). [C8,603/54 Dugal, L. P., Ross, S.: Effet de l'ablation partielle du foie sur l'activité spontanée du rat blanc. Rev. Canad. Biol. 2, 435-441 (1943).

$[84,992 / 43$

Dugal, L. P., Saucier, G.: Cryptorchidisme et effet nocif du testostérone chez le rat mâle, après une longue exposition au froid. Proc. Canad. Fed. Biol. Soc., First Ann. Meet., Kingston, p. 15 (1958).

$[\mathrm{C} 53,333 / 58$

Dugal, L. P., Saucier, G.: Cryptorchidisme et toxicité du testostérone chez le rat mâle, longuement exposé au froid. Ann. $A C F A S \mathbf{2 4}$, 70-71 (1958).

$[\mathrm{C} 77,621 / 58$

Duncan, G. W., Lyster, S. C., Clark, J. J., Lednicer, D.: Antifertility activities of two diphenyldihydronaphthalene derivatives. Proc. Soc. exp. Biol. (N.Y.) 112, 439-442 (1963).

[D 58,473/63

Dunn, T. B.: Morphologic changes preceding virus-induced leukemia in rodents. Acta Un. int. Cancr. 19, 665-667 (1963). [E29,253/63

Dunn, T. B., Green, A. W.: Morphology of BALB/c mice inoculated with Rauscher virus. J. nat. Cancer Inst. 36, 987-1001 (1966).

[G40,311/66

Dunning, W. F., Curtis, M. R., Friedgood, C. E.: The incidence of benzpyrene-induced sarcomas in alloxan-diabetic rats. Cancer Res. 8, 83-89 (1948).

[A 48,770/48

Dunphy, T. W.: The pharmacist's role in the prevention of adverse drug interactions. Amer. J. Hosp. Pharm. 26, 367-377 (1969).

$[\mathrm{G} 77,712 / 69$

Duran, M.: Beiträge zur Physiologie der Drüsen. Nr. 44. Das Verhalten von normalen, mit Schilddrüsensubstanz gefütterten und schilddrüsenlosen Ratten gegen reinen Sauerstoffmangel. Biochem. Z. 106, 254-274 (1920).

$[\mathrm{A} 10,045 / 20$

Duran-Reynals, M. L.: Combined effects of methylcholanthrene and vaccinia virus in cortisone-treated and untreated mice. Acta Un. int. Cancr. 19, 792-796 (1963). [E 29,252/63

Durham, W. F., Cueto, C., Jr., Hayes, W. J., Jr.: Hormonal effects on DDT storage in the white rat. Fed. Proc. 15, 419 (1956). $\quad[$ C14,264/56
Durham, W. F., Cueto, C., Jr., Hayes, W. J., Jr.: Hormonal influences on DDT metabolism in the white rat. Amer. J. Physiol. 187, 373 to 377 (1956).

$[\mathrm{C} 27,425 / 56$

Durham, F. M., Gaddum, J. H., Marchal, J. E.: Toxicity tests for novarsenobenzene (neosalvarsan). Spec. Rep. Ser. med. Res. Counc. (Lond.) 128, 6- 40 (1929). [A49,445/29

Duru, S., Türker, R. K.: Effect of prostaglandin $\mathrm{E}_{1}$ on the strychnine-induced convulsion in the mouse. Experientia (Basel) 25, 275 (1969).

[H 10,307/69

Dury, A.: Effect of cortisone on lipid metabolism of plasma, liver and aorta and on retrogression of atherosclerosis in the rabbit. Amer. J. Physiol. 187, 66-74 (1956). [C25,675/56 Dutta, S., Marks, B. H.: Distribution of ouabain and digoxin in the rat and guinea pig. Life Sci. 5, 915-920 (1966).

$[\mathrm{G} 73,208 / 66$

Dutton, G. J.: Glucuronide synthesis in foetal liver and other tissues. Biochem. J. 71, 141 to 148 (1959).

$[\mathrm{G} 70,064 / 59$

Dutton, G. J.: Variations in glucuronide formation by perinatal liver. Biochem. Pharmacol. 15, 947-951 (1966).

$[\mathrm{G} 78,598 / 66$

Dutz, H., Voigt, K., Wendler, J.: Utber die Beeinflußbarkeit der experimentellen Rattennephritis durch Testosteron, Oestradiol, Kastration und somatotropes Hormon. Z. ges. inn. Med. 11, 1115-1120 (1956). [C31,646/56

Dworetzky, M., Code, C. F., Higgins, G. M.: Effect of cortisone and ACTH on eosinophils and anaphylactic shock in guinea pigs. Proc. Soc. exp. Biol. (N.Y.) 75, 201-206,(1950).

$[\mathrm{B} 52,246 / 50$

Dzyubinskaya, T. K.: Nonspecific changes in the course of tuberculosis due to administration of 6-methylthiouracil. (Russian text). Probl. Endokr. Gormonoter. 6/5, 14-20 (1960).

$[\mathrm{C} 97,348 / 60$

Eades, C. H., Jr., Hsu, I. C., Ekholm, C. A., Harrsch, F.: Antithyroid agents as antihypertensive agents in unilaterally nephrectom. ized meat-fed rats. (Abstr.) Fed. Proc. 28, 394 (1969).

$[\mathrm{H} 9,590 / 69$

Eades, C. H., Jr., Hsu, I. C., Ekholm, C. A., Harrsch, F., Phillips, G. E.: Prevention of coronary atherosclerosis by propylthiouracil in unilaterally nephrectomized meat-fed rats. (Abstr.) Circulation 36, Sup. 2, II-9-II-10 (1967).

$[\mathrm{F} 89,204 / 67$

East, J., Parrott, D. M. V., Seamer, J.: The ability of mice thymectomized at birth to 
survive infection with lymphocytic choriomeningitis virus. Virology 22, 160-162 (1964).

[E38,279/64

Ebert, R. V., Borden, c. W., Hall, W. H., Gold, D.: A study of hypotension (shock) produced by meningococcus toxin. Circulat. Res. 3, 378-384 (1955).

[E56,239/55

Eckhardt, E. T.: The influence of methylphenidate (MP) on the capacity of the liver to limit DL-7-H ${ }^{3}$-norepinephrine (NE) pressor responses in the rat. (Abstr.) Fed. Proc. 24, 265 (1965).

[F 36,030/65

Eckhardt, E. T., Armstrong, C. B.: Some effects observed following an acute liver bypass in the rat. (Abstr.) Fed. Proc. 26, 682 (1967).

[F 79,670/67

Eddy, N. B.: Studies of morphine, codeine and their derivatives. XIV. The variation with age in the toxic effects of morphine, codeine and some of their derivatives. J. Pharmacol. exp. Ther. 66, 182-201 (1939). [A50,050/39

Edgren, R. A.: On the endocrine basis of sexual-differences in hexobarbital sleepingtime in rats. Experientia 13, 86-87 (1957).

$[\mathrm{C} 45,010 / 57$

Efron, D. H.: Reserpine toxicity and 'nonspecific stress'. Life Sci. 1, 561-564 (1962).

[D $59,758 / 62$

Eger, W.: Osteodystrophia fibrosa generalisata, Epithelkörperchen und Nieren. Frankfurt. Z. Path. 56, 369-450 (1942).

[B35,694/42

Eger, W., Schulz, E., Stratakis, K.: Die durch Allylalkohol oder Thiocetamid experimentell erzeugte Leberzirrhose unter dem Einfluß von Prednisolon. Medizinische 28, 871—872 (1959).

[E58,108/59

Eger, W., Stratakis, K.: Utber den Einfluß des Prednisolon auf die Bindegewebsentwicklung der experimentell erzeugten Leberzirrhose. Z. ges. exp. Med. 129, 559-572 (1958).

[D 89,546/58

Ehrlich, H. P., Hunt, T. K.: Effects of cortisone and vitamin A on wound healing. Ann. Surg. 167, $324-328$ (1968).

[G55,237/68

Ehrlich, H. P., Hunt, T. K.: The effects of cortisone and anabolic steroids on the tensile strength of healing wounds. Ann. Surg. 170, 203-206 (1969).

[G68,785/69

Eichholtz, F.: Utber rektale Narkose mit Avertin (E 107). Pharmakologischer Teil. Dtsch. med. Wschr. 53, 710-712 (1927).

[A27,018/27

Eichholtz, F., Hotovy, R., Collischonn, P., Knauer, H.: Beeinflussung der Entgiftungs- zeiten von Avertin und Pentothal-Natrium an der nebennierenlosen Ratte durch Nebennieren-Rindenhormon (Pentothal-Natriumtest). Arch. exp. Pathol. Pharmacol. 207, $576-585$ (1949).

[B 45,516/49

Einer-Jensen, N.: Antifertility properties of two diphenylethenes. Acta pharmacol. (Kbh.) 26, Sup. 1, 97 (1968).

[G75,787/68

Einhauser, M.: Giftwirkung der Schlafmittel und Nebennierenrinde. Klin. Wschr. 18, $423-427$ (1939).

[A 19,483/39

Einheber, A., Munan, L. P., Leese, C. E.: Survival rates in experimental burn shock. Fed. Proc. 11, 42 (1952).

[B68,195/52

Einheber, A., Wren, R. E., Klobukowski, C. J.: Interference of hepatic drug metabolism in plasmodium berghei-infected mice and its therapeutic modification: a study of hexobarbital sleeping time and phenobarbitalinduced liver stimulation. Exp. Parasit. 27, $424-443$ (1970).

[G75,665/70

Einhorn, S. L., Hirschberg, E., Gellhorn, A.: Effects of cortisone on regenerating rat liver. J. gen. Physiol. 37, 559-573 (1954).

[E 55,369/54

Eisalo, A.: Liver function tests during treatment with contraceptive pills. (Abstr.) $E x$ cerpta med. (Amst.), Int. Congr. Ser. No. 210, p. 67. (1970) 3rd Int. Congr. on Hormonal steroids, Hamburg.

[H 29,326/70

Eisalo, A., Järvinen, P. A., Luukkainen, T.: Hepatic impairment during the intake of contraceptive pills: clinical trial with postmenopausal women. Brit. med. J. 1964II, 426-427.

[F 18,828/64

el-Denshary, E. S. M., Scott, P. M., el-Masri, A. M.: Studies on the protective effectiveness of drugs against the hepatic toxicity of primaquine diphosphate in rabbits. $J$. Egypt. med. Ass. 52, 552-560 (1969).

[G77,356/69

Elder, T. D., Baker, R. D.: Pulmonary mucormycosis in rabbits with alloxan diabetes. Increased invasiveness of fungus during acute toxic phase of diabetes. Arch. Path. 61, 159 to 168 (1956).

$[\mathrm{C} 12,831 / 56$

Elgee, N. J., Williams, R. H.: Degradation of insulin- $\mathrm{I}^{\mathbf{1 3 1}}$ by liver and kidney in vivo. Proc. Soc. exp. Biol. (N.Y.) 87, 352-355 (1954).

[C430/54

Eling, T. E., Harbison, R. D., Becker, B. A., Fouts, J. R.: Kinetic changes in microsomal drug metabolism with age and diphenylhydantoin treatment. Europ. J. Pharmacol. 11, 101 to 108 (1970).
[H 27,047/70 
Ellinger, F.: Acetonitril test for thyroid according to Reid Hunt and irradiation with ultraviolet light. Radiologica 3, 195-200 (1938).

$[78,163 / 38$

Ellinger, F.: Protective action of desoxycorticosterone acetate against $\mathrm{X}$-ray-induced liver changes. Science 104, 502-503 (1946).

$[93,367 / 46$

Ellinger, F.: Some effects of desoxycorticosterone acetate on mice irradiated with X-rays. Proc. Soc. exp. Biol. (N.Y.) 64, 31-35 (1947).

$[93,953 / 47$

Ellinger, F.: Influence of pharmacological agents on effects of irradiation. Radiology 50, 234-243 (1948).

$[\mathrm{B} 24,015 / 48$

Ellinger, F.: The use of adrenal cortical hormone in radiation sickness. Radiology 51, $394-399$ (1948).

[B 57,402/48

Ellinger, F.: Some effects of testosterone propionate on mice irradiated with X-rays. Proc. Soc. exp. Biol. (N.Y.) 74, 616-619 (1950).

[B49,654/50

Ellinger, F.: Endocrine influences on radiosensitivity. Radiol. clin. (Basel) 23, 182-190 (1954).

[B95,888/54

Ellinger, F., Roswit, B., Glasser, S. M.: The treatment of radiation sickness with adrenal cortical hormone (desoxycorticosterone acetate): A preliminary report on fifty cases. Amer. J. Roentgenol. 61, 387-396 (1949).

$[\mathrm{B} 44,439 / 49$

Ellinwood, E. H.: Paradoxical effect of dichloroisoproterenol on pentobarbital sleep time in hyperthyroid mice. Nature (Lond.) 209, 1250-1251 (1966).

$[\mathrm{F} 64,417 / 66$

Ellinwood, E. H., Jr., Prange, A. J., Jr.: Effect of epinephrine pretreatment on pentobarbital sleeping time of mice with altered thyroid status. Nature (Lond.) 201, 305-306 (1964).

$[\mathrm{E} 39,187 / 64$

Emans, J. B., Jones, A. L.: Hypertrophy of liver cell smooth surfaced reticulum following progesterone administration. J. Histochem. Cytochem. 16, 561-571 (1968).

[H20,754/68

Emerson, W. J., Zamecnik, P. C., Nathanson, I. T.: The effect of sex hormones on hepatic and renal lesions induced in rats by a cholinedeficient diet. Endocrinology 48, 548-559 (1951).

[B59,636/51

Emmens, C. W.: Steroid anaesthesia. $J$. Endocr. 5, xii (1946).

[A46,574/46

Emmens, C. W., Cox, R. I., Martin, L.: Antiestrogens. In: Pincus; Recent Progr. Hormone
Res. 18, 415- 466 (1962). (The Proceedings of the Laurentian Hormone Conference, 1961.) New York, London: Academic Press.

[D25,360/62

Emmens, C. W., Parkes, A. S.: Assay of thyroidal activity by a closed vessel technique. J. Endocr. 5, 186-206 (1947). [ [B4,928/47

Englhardt-Gölkel, A.: Untersuchungen über die antagonistischen Wirkungen von Methylandrostendiol und Cortisonacetat auf den Eiweißhaushalt beim Menschen. Z. klin. Med. 153, 222-229 (1955).

[C42,792/55

English, J. M.: A case of probable phosgene poisoning. Brit. med. J. 1964 I, 38.

[F 399/64

Epple, A., Jørgensen, c. B., Rosenkilde, P.: Effect of hypophysectomy on blood sugar, fat, glycogen, and pancreatic islets in starving toads (Bufo bufo L.). Gen. comp. Endocr. 7, 197-202 (1966).

[F76,569/66

Epstein, S. S., Andrea, J., Clapp, P., Mackintosh, D.: Enhancement by piperonyl butoxide of acute toxicity due to Freons, benzo $(\alpha)$ pyrene, and griseofulvin in infant mice. Toxicol. appl. Pharmacol. 11, 442-448 (1967). [G77,545/67

Epstein, S. S., Andrea, J., Joshi, S., Mantel, N.: Hepatocarcinogenicity in griseofulvin following parenteral administration to infant mice. Cancer Res. 27, 1900-1906 (1967).

[H30,997/67

Epstein, S. S., Joshi, S., Andrea, J., Clapp, P., Falk, H., Mantel, N.: Synergistic toxicity and carcinogenicity of 'Freons' and piperonyl butoxide. Nature (Lond.) 214, 526-528 (1967).

$[\mathrm{H} 29,385 / 67$

Eriksson, M.: Salicylate-induced foetal damage during late pregnancy in mice. The modifying effect of repeated administration and dosage. Acta paediat. scand. 59, 517-522 (1970).

$[\mathrm{H} 30,468 / 70$

Ershofi, B. H.: Deleterious effects of pancreas in the hyperthyroid rat. Proc. Soc. exp. Biol. (N.Y.) 69, 122-124 (1948). [B24,883/48
[B

Ershoff, B. H.: Potentiating effects of reserpine on thyrotoxicity in the rat. Proc. Soc. exp. Biol. (N.Y.) 99, 189-192 (1958).

$[\mathrm{C} 60,006 / 58$

Ershoff, B. H.: Unidentified nutritional factors and resistance to stress. J. dent. Med. 16, $71-75$ (1961).

[D5,818/61

Ershofi, B. H., Deuel, H. J., Jr.: The effect of growth hormone on the vitamin A-deficient rat. Endocrinology 36, 280-282 (1945).

[B14,516/45 
Erspamer, V.: Influence of 5-hydroxytryptamine (enteramine) on the course of the acute lethal sublimate intoxication in the rat. Experientia (Basel) IX/5, 186 (1953).

[B 84,587/53

Erspamer, V.: Peripheral physiological and pharmacological actions of indolealkylamines. In: Eichler, O., Farah, A,: Handbuch der experimentellen Pharmakologie, p. 245-359. Berlin, Heidelberg, New York: SpringerVerlag 1966.

[E 5,915/66

Ertel, I. J., Newton, W. A., Jr.: Therapy in congenital hyperbilirubinemia: phenobarbital and diethylnicotinamide. Pediatrics 44, 43-48 (1969).

[G68,390/69

Ertuganova, Z. A.: The influence of cortisone, desoxicorticosterone, largactyl and phenergan on the course and issue of pneumococcal infection. (Russian text.) Farmakol. i. Toksikol. 23, 348-349 (1960).

$[\mathrm{C} 97,404 / 60$

Eschenbrenner, A. B.: Induction of hepatomas in mice by repeated oral administration of chloroform, with observations on sex differences. J. nat. Cancer Inst. 5, 251-255 (1945).

$[93,202 / 45$

Eschenbrenner, A. B., Miller, E.: Sex differences in kidney morphology and chloroform necrosis. Science 102, 302-303 (1945).

$[94,309 / 45$

Estabrook, R. W., Franklin, M. R., Cohen, B., Shigamatzu, A., Hildebrandt, A. G.: Influence of hepatic microsomal mixed function oxidation reactions on cellular metabolic control. Metabolism 20, 187-199 (1971). [H34,125/71

Estabrook, R. W., Hildebrandt, A. G., Baron, J., Netter, K. J., Leibman, K.: A new spectral intermediate associated with cytochrome P-450 function in liver microsomes. Biochem. biophys. Res. Commun. 42, 132-139 (1971).

$[\mathrm{G} 81,261 / 71$

Etoh, H., Egami, N.: Effect of hypophysectomy and adrenalectomy on the length of survival time after $\mathrm{X}$-irradiation in the goldfish, Carassius auratus. Proc. Jap. Acad. 39, 503-506 (1963).

$[\mathrm{G} 11,664 / 63$

Eufinger, H., Wiesbader, H.: Reid Huntsche Reaktion und Schwangerschaft. II. Mitt. Arch. Gynäk. 142, 662-667 (1930).

$$
[4,663 / 30
$$

Eufinger, H., Wiesbader, H., Focsaneanu, L.: Reid Huntsche Reaktion und Schwangerschaft. Arch. Gynäk. 136, $12-18$ (1929). $\quad$ [22,082/29 Euler, H. von, Klussmann, E.: Carotin (Vitamin A) und Thyroxin. Hoppe-Seylers Z. physiol. Chem. 213, 21-34 (1932). [4,928/32
Evangelista, B. S., Green, T. J., Gwilt, D. J., Brown, T. G., Jr.: An experimental study of current therapeutic approaches to endotoxin shock. Arch. int. Pharmacodyn. 180, 57-67 (1969).

[H16,824/69

Evans, D. G., Miles, A. A., Niven, J. S. F.: The enhancement of bacterial infections by adrenaline. Brit. J. exp. Path. 29, 20-39 (1948).

$[\mathrm{B} 65,652 / 48$

Evans, E. A., Eisenlord, G., Hine, C. H.: Studies in detoxication by means of the isolated perfused liver. Toxicol. appl. Pharmacol. 5, 129-141 (1963). [ [G65,279/63

Eversole, W. J.: Inhibition of Azo dye carcinogenesis by adrenalectomy and treatment with desoxycorticosterone trimethylacetate. Proc. Soc. exp. Biol. (N.Y.) 96, 643-646 (1957).

$[\mathrm{C} 45,823 / 57$

Eversole, W. J., Edelmann, A., Gaunt, R.: Effect of adrenal cortical transplants on lifemaintenance and "water intoxication." Anat. Rec. 76, 271-281 (1940).

$[78,679 / 40$

Eversole, W. J., Gaunt, R.: Methods of administering desoxycorticosterone and the problem of its inactivation by the liver. Endocrinology 32, 51-56 (1943).

[A56,551/43

Evonuk, E., Hannon, J. P.: Cardiovascular and pulmonary effects of noradrenaline in the coldacclimatized rat. Fed. Proc. 22, 911-916 (1963).

[E21,027/63

Evropeitzeva, N. V.: The effect of thiourea on development of the thyroid in coregonous lafaretus ludoga. Dokl. Akad. Nauk. SSSR, Otd. Biokh. 68, 977-980 (1949). [A49,151/49

Ewing, P. L., Tree, H. G., Emerson, G. A.: Nonspecific factors in chemotherapy of trypanosomiases. Fed. Proc. 9, 270 (1950).

[B 50,244/50

Faber, H. von: Utber die Beeinflussung der Nebenschilddrüse durch Verabreichung von Stilboestrol allein und kombiniert mit Thyroxin, bzw. Testosteronpropionat an Hähne. Endokrinologie 32, 295-302 (1955).

$[\mathrm{C} 6,925 / 55$

Fabrikant, J. I.: Cell proliferation in the regenerating liver of continuously irradiated mice; effect of a radiation-free interval. Brit. J. Radiol. 41, 369-374 (1968).

[H8,091/68

Fahim, M.S., Dement, G., Hall, D. G., Fahim, Z.: Induced alterations in the hepatic metabolism of androgens in the rat. Amer. J. Obstet. Gynec. 107, 1085-1091 (1970). [G77,345/70

Fahim, M. S., Hall, D. G., Jones, T. M., Fahim, Z., Whitt, F. D.: Drug-steroid interac- 
tion in the pregnant rat, fetus, and neonate. Amer. J. Obstet. Gynec. 107, 1250-1258 (1970).

$[\mathrm{G} 77,383 / 70$

Fahim, M. S., Ishaq, J., Hall, D. G., Jones, T.: Induced alteration in the biologic activity of estrogen by DDT. Amer. J. Obstet. Gynec. 108, 1063-1067 (1970).

[G81,358/70

Fahim, M. S., King, T. M., Hall, D. G.: Induced alterations in the biologic activity of estrogen. Amer. J. Obstet. Gynec. 100, 171-175 (1968).

$[\mathrm{G} 67,772 / 68$

Fahim, M. S., King, T. M., Venson, V., Norwich, C., Bolt, D. J.: Uterotropic action of estrogens in phenobarbital-treated mice. Fertil. and Steril. 20, 344-350 (1969).

$[\mathrm{G} 65,075 / 69$

Fairchild, E. J.: Neurohumoral factors in injury from inhaled irritants. Arch. environm. Hlth. 6, 79-86 (1963).

$[\mathrm{G} 71,531 / 63$

Fairchild, E. J., Graham, S. L.: Thyroid influence on the toxicity of respiratory irritant gases, ozone and nitrogen dioxide. J. Pharmacol. exp. Ther. 139, 177-184 (1963).

[D56,574/63

Fairchild, E. J., Graham, S. L., Stokinger, H. E.: Pharmacologic aspects of humoral mechanisms in the toxic response to pulmonary irritant gases. Biochem. Pharmacol. 12, Suppl. 158 (1963).

$[$ E32,187/63

Fairchild, E. J., Stokinger, H. E.: The thyroid in pulmonary injury of acute ozone poisoning. Fed. Proc. 20, 203 (1961).

[D4,088/61

Falk, R.: Antagonisme entre les extraits testiculaires et certaines substances hypnoanesthésiques. C. R. Soc. Biol. (Paris) 123, $779-781$ (1936).

[A337/36

Falta, W., Jveovic, L.: Adrenalin als Antidot. Berl. klin. Wschr. 46, 1929-1930 (1909).

$[\mathrm{A} 1,273 / 09$

Falutz, S. E.: Action of catecholamines and some precursors on tremorine-induced tremor in cats. Proc. Canad. Fed. biol. Soc. (Montreal) 10, 139 (1967).

$[\mathrm{F} 85,463 / 67$

Fanfani, M., Dini, S.: Le modificazioni istopatologiche del miocardio nella paramiloidosi sperimentale da caseinato sodico. Arch. De Vecchi Anat. pat. 26, 327-363 (1957).

$[\mathrm{C} 48,253 / 57$

Farah, A., Smuskowicz, E.: The effect of liver damage on the activity of $\mathrm{g}$-strophanthin in the rat. J. Pharmacol. exp. Ther. 96, 139-144 (1949).

[A49,134/49

Farber, E., Koch-Weser, D., Popper, H.: Influence of steroid hormone on fatty livers. Fed. Proc. 9, 329 (1950).

$[\mathrm{B} 47,283 / 50$
Farber, E., Koch-Weser, D., Popper, H.: The influence of sex and of testosterone upon fatty liver due to ethionine. Endocrinology 48, 205-212 (1951).

[D24,923/51

Farber, E., Segaloff, A.: Effect of androgens and growth and other hormones on ethionine fatty liver in rats. J. biol. Chem. 216, 471-477 (1955).

[D95,996/55

Farese, R. V.: Inhibition of cholesterol side chain cleavage by cyanoketone (2a-cyano$4,4,17 \alpha$-trimethyl-17 $\beta$-hydroxyandrost-5-en-3one). Steroids 15, 245-250 (1970).

$[\mathrm{H} 27,025 / 70$

Farnell, D. R.: Functional and structural effects of magnesium deficiency and cortisone treatment in mice. Amer. J. vet. Res. 29, 1695-1706 (1968).

$[\mathrm{H} 15,528 / 68$

Farrar, W. E., Jr., Magnani, T. J.: Endotoxin susceptibility following hepatic injury by carbon tetrachloride. Proc. Soc. exp. Biol. (N.Y.) 115, 596-601 (1964). [F6,647/64

Farson, D. B., Carr, C. J., Krantz, J. C., Jr.: Anesthesia. XXIV. The effect of cholesterol on pentothal and ether anesthesia. J. Pharmacol. exp. Ther. 89, 222-226 (1947).

$[\mathrm{A} 49,680 / 47$

Fasold, H., Heidemann, E. R.: Utber die Gelbfärbung der Milch thyreopriver Ziegen. $Z$. ges. exp. Med. 92, 53-56 (1933). [16,518/33

Fasold, H., Peters, H.: Utber den Antagonismus zwischen Thyroxin und Vitamin. Z. ges. exp. Med. 92, 57-62 (1933).

$[\mathrm{A} 54,337 / 33$

Fastier, F. N.: Prolongation of hypnosis by 5-hydroxytryptamine (serotonin). Experientia (Basel) 12, 351 (1956).

[D95,950/56

Fastier, F. N., Speden, R. N., Waal, H.: Prolongation of chloral hydrate sleeping time by 5 -hydroxytryptamine and by certain other drugs. Brit. J. Pharmacol. 12, 251-256 (1957).

$[\mathrm{C} 37,038 / 57$

Fautrez, J., Pisi, E., Cavalli, G.: Activité mitotique provoquée par la thiourée et teneur en acide désoxyribonucléique de la cellule hépatique. Exp. Cell. Res. 9, 189-192 (1955).

$[\mathrm{C} 23,124 / 55$

Fazekas, I. G.: Die Wirkung von Corticosteoridfraktionen auf die Alkoholdehydrogenaseaktivität der Leber. Arch. Toxikol. 19, 388-395 (1962).

[D55,397/62

Fazekas, I. G.: Corticosterone content of peripheric blood and alcoholdehydrogenase activity of the liver after adrenalectomy. Folia endocr. (Roma) 16, 600-607 (1963).

$[\mathrm{G} 9,347 / 63$ 
Fazekas, I. G.: Alkoholabbau und Nebennierenrinde. Acta Med. leg. soc. (Liège) 17, 77-80 (1964).

[F 71,641/64

Fazekas, I. G., Rengei, B.: Die Wirkung von Adrenalektomie und Alkohol auf die Alkoholdehydrogenase-Aktivität von Rattenorganen. Enzymologia 34, 226-230 (1968). [G58,271/68

Fazekas, I. G., Rengei, B.: Utber den NAD- und $\mathrm{NADH}_{2}$-Gehalt in Leber, Herz und Nieren adrenalektomierter und alkoholbehandelter Ratten. Enzymologia 36, 59-64 (1969).

$[\mathrm{G} 64,534 / 69$

Fazekas, I. G., Rengei, B., Fazekas, A. G.: Die Wirkung der Nebennierenrindenfunktion auf die Aktivität der Alkoholdehydrogenase der Leber. Arch. Toxicol. 19, 229-236 (1961).

[D22,442/61

Fazio, M., Oddone, I., Boglione, F.: Ricerche sperimentali sull'influenza dell'ACTH e del cortisone sui processi infettivi. II. Infezione streptococcica del ratto. G. Mal. infett. 8, 168-173 (1956).

$[\mathrm{C} 34,111 / 56$

Feigelson, M., Gross, P. R., Feigelson, P.: Early effects of cortisone on nucleic acid and protein metabolism of rat liver. Biochim. biophys. Acta (Amst.) 55, 495-504 (1962).

[G68,042/62

Feigelson, P.: Comparison of the mechanisms of substrate and hormonal induction of rat liver tryptophan pyrrolase. Fed. Proc. 20, 223 (1961).

$[\mathrm{D} 4,122 / 61$

Feigelson, P., Dashman, T., Margolis, F.: The half-lifetime of induced tryptophan peroxidase in vivo. Arch. Biochem. 85, 478-482 (1959).

[G67,768/59

Feigelson, P., Feigelson, M.: Studies on the mechanism of regulation by cortisone of the metabolism of liver purine and ribonucleic acid. J. Biol. Chem. 238, 1073-1077 (1963).

[D59,123/63

Feigelson, P., Feigelson, M., Greengard, 0.: Comparison of the mechanisms of hormonal and substrate induction of rat liver tryptophan pyrrolase. In: Pincus; Recent Progr. Hormone Res. 18, 491-512 (1962). (The Proceedings of the Laurentian Hormone Conference, 1961.) New York, London: Academic Press.

[D 25,364/62

Feigelson, P., Greengard, 0.: Immuno chemical evidence for increased titers of liver tryptophan pyrrolase during substrate and hormonal enzyme induction. J. biol. Chem. 237, 3714 to 3717 (1962).

$[\mathrm{D} 46,319 / 62$
Feinstein, R. N., Seaholm, J. E.: Effect of a serotonin antagonist on radiation lethality. Proc. Soc. exp. Biol. (N.Y.) 114, 247-248 (1963).

$[\mathrm{E} 29,638 / 63$

Feldman, S. A., Tyrrell, M. F.: A new steroid muscle relaxant Dacuronium-NB. 68 (Organon). Anaesthesia 25, 349-355 (1970). [G76,666/70

Fell, H. B.: The direct action of cortisol on skeletal tissue in organ culture. In: Proc. 2nd int. Congr. Endocr. Part II, p. 922-927. London: Excerpta Medica Foundation 1964.

[F 48,679/64

Fell, H. B., Thomas, L.: The influence of hydrocortisone on the action of excess vitamin A on limb bone rudiments in culture. J. exp. Med. 114, 343-361 (1961). [D 10,358/61 Feller, D. R., Gerald, M. C.: Possible liver microsomal induction in mice by spironolactone. (Abstr.) Fed. Proc. 29, 346 (1970).

$[\mathrm{H} 22,744 / 70$

Fellinger, K., Hochstädt, 0.: Ưber die Beeinflussung des Reid-Huntschen Versuches durch Antithyreoidale Schutzstoffe. Klin. Wschr. 14, 1250-1251 (1935).

$[63,744 / 35$

Felsher, B. F., Barretto, F. T., Redeker, A. G.: Effect of caloric intake and phenobarbital on serum bilirubin (SB). (Abstr.) Clin. Res. 19, 175 (1971).

[H34,479/71

Felsher, B. F., Craig, J. R., Carpio, N. M.: Hepatic glucuronyl transferase (GT) and betaglucuronidase (BG) in Gilbert's syndrome (GS). (Abstr.) Clin. Res. 19, 175 (1971). [H34,480/71

Fenu, G.: Intorno alla capacità dell'adrenalina di potenziare l'azione narcotica del pentotal. Minerva otorinolaring. 4, 91-93 (1954).

$[\mathrm{C} 17,650 / 54$

Ferguson, C. C., Rogers, C. S., Vars, H. M.: Liver regeneration in the presence of common bile duct obstruction. Amer. J. Physiol. 159, 343-350 (1949).

[G71,528/49

Ferraris, F.: Ovariectomia e tossicosi isoniazidica. Chemoterapia 8 (1954). $\quad[C 27,552 / 54$

Ferraris, F.: Ovariectomia e tossicosi isoniazidica. Ormonologia 16, 235-238 (1956).

$[\mathrm{C} 30,097 / 56$

Ferret, P.: The effect of diet on oestrogen inactivation by the liver. Brit.J. exp. Path. 31, $590-596$ (1950).

[E50,456/50

Ferris, B. G., Jr., Affeldt, J. E., Kriete, H. A., Whittenberger, J. L.: Pulmonary function in patients with pulmonary disease treated with ACTH. Arch. industr. Hyg. 3, 603-616 (1951).

$[\mathrm{B} 65,475 / 51$ 
Ferrucio, S.: Eliminazione urinaria dei 17-chetosteroidi nella steatosi sperimentale da colesterina e nella steatosi da colesterina trattata con sostanze metilanti, testosterone e vit. E (Ricerche sperimentali). Chir. Pat. sper. 12, 695-711 (1964).

$[\mathrm{F} 62,336 / 64$

Feuer, G.: Induction of drug-metabolising enzymes of rat liver by derivatives of coumarin. Canad. J. Physiol. Pharmacol. 48, 232-240 (1970).

$[\mathrm{H} 24,218 / 70$

Feuer, G., Golberg, L.: Stimulation of liver processing enzymes by derivatives of coumarin. Biochem. J. 103, 13P (1967).

[G76,853/67

Feuer, G., Liscio, A.: Origin of delayed development of drug metabolism in the newborn rat. Nature (Lond.) 223, 68-70 (1969).

[H14,579/69

Feyel, P.: L'action trophique des hormones sexuelles sur le rein chez la souris. Ann. Endocr. 4, 93-110 (1943).

$[99,416 / 43$

Fiala, S., Fiala, A. E.: Hormonal dependence of cytotoxic action of actidione (cycloheximide). Proc. Amer. Ass. Cancer Res. 6, 18 (1965).

$[\mathrm{F} 33,398 / 65$

Fiala, S., Fiala, E.: Hormonal dependence of actidione (cycloheximide) action. Biochim. biophys. Acta (Amst.) 103, 699-701 (1965).

$[\mathrm{F} 70,819 / 65$

Fiala, S., Fiala, E.: Induction of tyrosine transaminase in rat liver by actidione. Nature (Lond.) 210, 530-531 (1966). [ [F 65,983/66

Fiegelson, E. B., Drake, J. W., Recant, L.: Experimental aminonucleoside nephrosis in rats. J. Lab. clin. Med. 50, 437-446 (1957).

[D96,580/57

Field, J. B., Ershoff, B. H., Dolendo, E., Mireles, A.: The effect of endocrine agents on the toxicity of anti-cancer drugs. (Abstr.) Proc. Amer. Ass. Cancer Res. 8, 17 (1967).

$[\mathrm{F} 78,812 / 67$

Field, J. B., Mireles, A., Dolendo, E. C.: Effect of androgens on survival of mice treated with anti-cancer drugs. Proc. Amer. Ass. Cancer Res. 6, 19 (1965).

[F 33,399/65

Figueroa, M. A., Yañez, J. A.: Hepatectomía parcial experimental. Técnica en dos tiempos operatorios. Pren. méd. argent. 56, 925-927 (1969).

$[\mathrm{H} 18,495 / 69$

Filipp, G., Mess, B.: Role of the adrenocortical system in suppressing anaphylaxis after hypothalamic lesion. Ann. Allergy 27, 607-610 (1969).

$[\mathrm{G} 71,129 / 69$

Filner, P., Wray, J. L., Varner, J. E.: Enzyme induction in higher plants. Environmental or developmental changes cause many enzyme activities of higher plants to rise or fall. Science 165, 358-367 (1969). [H15,309/69 Finch, C. E., Foster, J. R., Mirsky, A. E.: Ageing and the regulation of cell activities during exposure to cold. J. gen. Physiol. 54, 690-712 (1969).

[G71,208/69

Finch, C. E., Huberman, H. S., Mirsky, A. E.: Regulation of liver tyrosine aminotransferase by endogenous factors in the mouse. J. gen. Physiol. 54, 675-689 (1969). $\quad$ [G71,207/69

Findlay, G. M., Howard, E. M.: The effects of cortisone and adrenocorticotrophic hormone on poliomyelitis and on other virus infections. J. Pharm. Pharmacol. 4, 37-42 (1952).

$[\mathrm{B} 81,142 / 52$

Fine, J., Fishmann, J., Frank, H. A.: The effect of adrenal cortical hormones in hemorrhage and shock. Surgery 12, 1-13 (1942).

$[\mathrm{A} 56,268 / 42$

Fine, J., Palmerio, C., Rutenburg, S.: New developments in therapy of refractory traumatic shock. Arch. Surg. 96, 163-175 (1968).

[G53,608/68

Finger, H.: Möglichkeiten der Unterdrückung paralytischer Komplikationen nach antirabischer Schutzimpfung. Arb. Paul-Ehrlich-Inst. 57, 63-79 (1962).

[E26,273/62

Fingl, E., Olsen, L. J., Harding, B. W., Cockett, A. T., Goodman, L. S.: Effects of chronic anticonvulsant administration upon cortisone-induced brain hyperexcitability. $J$. Pharmacol. exp. Ther. 105, 37-45 (1952).

[D38,091/52

Finney, D. J.: The Fischer-Yates test of significance in $2 \times 2$ contingency tables. Biometrika 35, 145-156 (1948). [D31,291/48

Fiore-Donati, L., Chieco-Bianchi, L., Bertaccini, G.: Effetto protettivo della 5-idrossitriptamina sul danno epatocellulare da tetracloruro di carbonio nel ratto. Arch. int. Pharmacodyn. 123, 115-131 (1959). [C78,953/59

Fiore-Donati, L., Maiorano, G., Chieco-Bianchi, L.: Interferenza della 5-idrossitriptamina sullo sviluppo della cirrosi sperimentale da $\mathrm{CCl}_{4}$. Boll. Soc. ital. Biol. sper. 34, 1493-1494 (1958).

$[\mathrm{C} 62,200 / 58$

Fiorentino, M.: Diagnosi biologica di tubercolosi, accelerata con ormone corticotropo. Riv. Anat. pat. 16, 78-84 (1959). [D8,379/59

Firkin, F. C., Linnane, A. W.: Biogenesis of mitochondria. 8. The effect of chloramphenicol on regenerating rat liver. Exp. Cell. Res. 55, $68-76$ (1969).

[H31,607/69 
Firschein, H. E., DeVenuto, F., Fitch, W. M., Pearce, E. M., Westphal, U.: Distribution of injected cortisol-4-C $\mathrm{C}^{14}$ in normal and shocked rats. Endocrinology 60, 347-358 (1957).

$[\mathrm{C} 30,553 / 57$

Fishel, C. W., Szentivanyi, A., Talmage, D. W.: Adrenergic factors in Bordetella pertussisinduced histamine and serotonin hypersensitivity of mice. In: Landy, M., Braun, W.; Bacterial Endotoxins, p. 474-481. New Brunswick, N.J.: Institute of Microbiology, Rutgers, The State University 1964 . [E8,474/64 Fischer, E., Ludmer, R. I., Sabelli, H. C.: The antagonism of phenylethylamine to catecholamines on mouse motor activity. Acta physiol. lat.-amer. 17, 15-21 (1967).

$[\mathrm{G} 48,517 / 67$

Fischer, E. R., Fisher, B.: Experimental studies of factors influencing development of hepatic metastases. XVII. Role of thyroid. Cancer Res. 26, 2248-2253 (1966).

[F 74,176/66

Fischer, H.: Zum Ausbau der tierexperimentellen Forschung in der Psychiatrie. Mschr. Psychiat. Neurol. 48, 181-192 (1920).

$[50,723 / 20$

Fisher, B., Fisher, E. R.: Experimental studies of factors influencing hepatic metastases. II. Effect of partial hepatectomy. Cancer 12, 929-932 (1959).

$[\mathrm{G} 72,106 / 59$

Fisher, E. R., Fisher, B.: Nephrotoxic serum nephritis in thymectomized rats. Proc. Soc. exp. Biol. (N.Y.) 115, 156-160 (1964).

[E690/64

Fisher, E. R., Gruhn, J.: Aminonucleoside nephrosis. Effect of adrenalectomy, cortisone, hypophysectomy and saline ingestion. Arch. Path. 71, 23-30 (1961).

[D 12,898/61

Fister, V.: Effect of carbutamide BZ-55 treatment on the resistance to hypoxia in albino rats. Rev. argent. Endocr. 5, 191 (1959).

$[\mathrm{C} 97,077 / 59$

Fitzhugh, 0. G., Nelson, A. A.: The chronic oral toxicity of DDT (2,2-bis (p-Chlorophenyl-1,1,1-Trichloroethane). J. Pharmacol. exp. Ther. 89, 18-30 (1947). [A47,885/47

Fitzhugh, 0. G., Nelson, A. A., Bliss, C. 1.: The chronic oral toxicity of selenium. J. Pharmacol. exp. Ther. 80, 289-299 (1944). [A45,940/44

Fitzhugh, 0. G., Nelson, A. A., Calvery, H. 0.: The chronic toxicity of ergot. J. Pharmacol. exp. Ther. 82, 364-376 (1944). [ [A46,537/44

Fiumara, A., Nuciforo, G., Gaia, L., Condorelli, B.: Differente intensita' delle lesioni arteriose da intossicazione acuta con di-idrotachisterolo nei ratti giovani maschi e femmine. Riv. Anat. pat. 33, XXXVIII-XLVI (1968).

$[\mathrm{H34}, 170 / 68$

Flaks, A.: Observation of the action of the thymus on the induction of lung tumours by 9,10-dimethyl-1,2-benzanthracene (DMBA) in new-born A mice. Brit. J. Cancer 21, 390-392 (1967).

[F95,414/67

Flaks, J.: Influence of testosterone propionate on the induction of subcutaneous tumours in mice by 20 -methylcholanthrene. Brit. J. Cancer 2, 386-394 (1948).

[B35,572/48

Fleischer, J., Riedel, H.: Histologische Organveränderungen beim Kaninchen nach Gaben von Prednisolon und Endoxan. Folia haemat. (Frankfurt) 82, 23-39 (1964). [G20,778/64

Fleischmann, W., Kann, S.: Untersuchungen über die Beziehungen zwischen dem Schilddrüsenhormon und dem Vitamin A. Wien. klin. Wschr. 49, 1488-1489 (1936).

$[67,360 / 36$

Fleisher, M. S., Wilhelmj, C. M.: The influence of thyroidectomy on anaphylaxic shock. $Z$. Immun.-Forsch. 51, 115-125 (1927).

$[23,337 / 27$

Flemming, K., Langendorif, M.: Untersuchungen über einen biologischen Strahlenschutz. 66. Mitteilung: Das Pro-Östrogen Chlortrianisen (Tace) als Strahlenschutzsubstanz. Strahlentherapie 128, 109-118 (1965).

[G38,381/65

Fleteher, H. P., Miya, T. S., Bousquet, W. F.: Influence of estradiol on the disposition of chlorpromazine in the rat. $J$. pharm. Sci. 54, 1007-1009 (1965).

$[\mathrm{F} 44,604 / 65$

Flint, M., Lathe, G. H., Ricketts, T. R., Silman, G.: Development of glucuronyl transferase and other enzyme systems in the newborn rabbit. Quart. J. exp. Physiol. 49, 66-73 (1964).

[G78,603/64

Flückiger, E., Verzar, F.: Senkung und Restitution der Körpertemperatur bei niedrigem atmosphärischem Druck und der Einfluß von Thyreoidea, Hypophyse und Nebennierenrinde auf dieselbe. Helvet. physiol. pharmacol. Acta 10, 349-359 (1952).

[B86,489/52

Fogelman, M. J., Ivy, A. C.: Effect of thiouracil on liver regeneration. Amer. $J$. Physiol. 153, 397-401 (1948). [B23,357/48

Foglia, V. G., Penhos, J. C.: Diferencia sexual en la diabetes pancreática de ratas castradas al nacer. Rev. Soc. argent. Biol. 28, 143-148 (1952).
[B 79,957/52 
Földes, P., Szeri, I., Bános, Z., Anderlik, P., Balázs, M.: LCM infection of mice thymectomized in newborn age. Acta microbiol. Acad. Sci.hung. 11, 277-282 (1965). [G29,263/65

Foley, E. J.: Therapeutic effect of chlortetracycline and oxytetracycline in immunized mice treated with cortisone. Antibiot. and Chemother. 5, 1-5 (1955).

$[\mathrm{C} 13,263 / 55$

Foley, E. J., Morgan, W. A., Greco, G.: Effect of prednisone and prednisolone on Streptococcus infections in mice treated with chlortetracycline. Antibiot. and Chemother. 7, 65-69 (1957).

$[\mathrm{C} 31,073 / 57$

Foley, G. E., Aycock, W. L.: Alterations in the autarceologic susceptibility of the mouse to experimental poliomyelitis by estrogenic substances. Endocrinology 37, 245-251 (1945).

[B764/45

Fontan, M., Cotlenko, V., Barberis, D.: Effet protecteur du noyau cyclo-pentano-phénantrène vis-à-vis de l'intoxication par le Di-isopropyl-fluoro-phosphate (D.F.P.). Lille méd. 13, 299-302 (1968).

[F98,752/68

Fontan, M., Cotlenko, V., Cheval, P., Barberis, D.: Interactions spironolactone/di-iso-propylfluoro-phosphate (D.F.P.). Lille méd. 10, 780-784 (1965). [F55,419/65

Fonts, J. M., Martinez, J. M., D'Angeli, S. R.: Contribución al estudio de la acción anestésica de la progesterona y del acetato de desoxicorticoesterona. An. Med. Cir. (Barcelona) 27, 353-356 (1950).

[B54,459/50

Fonzo, D., Bosso, P., Dogliotti, L., Lauro, R., Martinis, C. de: Osservazioni preliminari sulle differenze della distribuzione e deiodazione della tiroxina-1-125 tra ratti maschi e femmine di razza wistar. Boll. Soc. ital. Biol. sper. 46, 328 to 331 (1970).

[G 77,635/70

Foraboseo, A., Bratina, F., Narducei, P.: Sulla rigenerazione epatica nel ratto timectomizzato in età adulta. V. Attività istochimica di alcune deidrogenasi alla $30^{\mathrm{a}}$ ora di rigenerazione. Boll. Soc. ital. Biol. sper. 45, 363-365 (1969).

[G70,749/69

Forabosco, A., Guli, F.: Sulla rigenerazione epatica nel ratto timectomizzato in età adulta. IV. La ricostituzione della massa epatica alla $30^{\mathrm{a}}$ ora del processo rigenerativo. Boll. Soc. ital. Biol. sper. 45, 361-363 (1969).

$[\mathrm{G} 70,748 / 69$

Forabosco, A., Narducci, P.: Sulla rigenerazione epatica nel ratto timectomizzato in età adulta. II. L'attività mitotica alla $30^{\mathrm{a}}$ ora di rigenerazione. Boll. Soc. ital. Biol. sper. 45, 356-359 (1969).

$[\mathrm{G} 70,746 / 69$
Foraboseo, A., Toni, G.: Sulla rigenerazione epatica nel ratto timectomizzato in età adulta. III. L'attività di sintesi di DNA alla $30^{\mathrm{a}}$ ora di rigenerazione. Boll. Soc. ital. Biol. sper. 45, 359-361 (1969).

$[\mathrm{G} 70,747 / 69$

Forbes, R. M.: Mineral utilization in the rat. V. Effects of dietary thyroxine on mineral balance and tissue mineral composition with special reference to magnesium nutriture. J. Nutr. 86, 193-200 (1965). [G30,402/65

Forchielli, E., Brown-Grant, K., Doriman, R. I.: Steroid 4-hydrogenases of rat liver. Proc. Soc. exp. Biol. (N.Y.) 99, 594-596 (1958).

[D75,874/58

Forchielli, E., Doriman, R. I.: Separation of $\Delta^{4}-5 \alpha$ - and $\Delta^{4}-5 \beta$-hydrogenases from rat liver homogenates. $J$. biol. Chem. 223, 443-448 (1956).

$[\mathrm{G} 66,498 / 56$

Ford, E. J. H.: The fate of mycobacterium johnei in young mice and guinea-pigs. $J$. Path. Bact. 73, 363-374 (1957).

$[\mathrm{G} 67,455 / 57$

Ford, E., Huggins, C.: Selective destruction in testis induced by 7,12-dimethylbenz(a) anthracene. J. exp. Med. 118, 27-40 (1963).

$[\mathrm{D} 69,790 / 63$

Fornaroli, P.: Sull'effetto potenziante l'attività dei narcotici della 5-ossitriptamina. In: Various Authors; , Scritti Medici in Onore di Luigi Villa, p. 363-374. Milano: C.E.A. 1957.

$[\mathrm{C} 47,728 / 57$

Forsander, O. A., Hillbom, M. E., Lindros, K. O.: Influence of thyroid function on the acetaldehyde level of blood and liver of intact rats during ethanol metabolism. Acta pharmacol. (Kbh.) 27, 410-416 (1969). [G71,697/69

Fortune, P. Y.: Comparative studies of the thyroid function in teleosts of tropical and temperate habitats. J. exp. Biol. 32, 504-513 (1955).

$[\mathrm{C} 17,485 / 55$

Fortune, P. Y.: An inactive thyroid gland in Carassius auratus. Nature (Lond.) 178, 98 (1956).

$[\mathrm{C} 21,670 / 56$

Fournier, G.: Détoxification du métrazol. $J$. Hôtel-Dieu Montréal 2, 112-115 (1943).

$[84,151 / 43$

Fournier, G., Selye, H.: Concerning the site of pentamethylenetetrazol (metrazol) detoxification. (Abstr.) Fed. Proc. 1, 25 (1942).

$[81,980 / 42$

Fouts, J. R.: The metabolism of drugs by subfractions of hepatic microsomes. Biochem. biophys. Res. Commun. 6, 373-378 (1961).

$[\mathrm{G} 79,654 / 61$ 
Fouts, J. R.: Interaction of drugs and hepatic microsomes. Fed. Proc. 21, 1107-1111 (1962).

[D43,347/62

Fouts, J. R.: Physiological impairment of drug metabolism. In: Brodie, B. B., Erdös, E. G.; Metabolic Factors Controlling Duration of Drug Action, p. 257-275. New York: MacMillan Co. 1962.

[G77,514/62

Fouts, J. R.: Factors affecting hepatic microsomal enzyme systems involved in drug metabolism. In: Weber, G.; Advances in Enzyme Regulation, p. 225-233. New York: MacMillan Co. 1963.

[G76,304/63

Fouts, J. R.: Drug interactions: effects of drugs and chemicals on drug metabolism. Gastroenterology 46, 486-490 (1964). [G77,566/64

Fouts, J. R.: Some effects of insecticides on hepatic microsomal enzymes in various animal species. Rev. Canad. Biol. 29, 377-389 (1970).

$[\mathrm{G} 76,868 / 70$

Fouts, J. R.: The stimulation and inhibition of hepatic microsomal drug-metabolizing enzymes with special reference to effects of environmental contaminants. Toxicol. appl. Pharmacol.17, 804-809 (1970).

[G 79,537/70

Fouts, J. R., Adamson, R. H.: Drug metabolism in the newborn rabbit. Science 129, 897-898 (1959).

$[\mathrm{H} 24,325 / 59$

Fouts, J. R., Brodie, B. B.: Inhibition of drug metabolic pathways by the potentiating agent, 2,4-dichloro-6-phenylphenoxyethyl diethylamine. J. Pharmacol. exp. Ther. 113, 68-73 (1955).

[D 83,597/55

Fouts, J. R., Brodie, B. B.: On the mechanism of drug potentiation by iproniazid (2-isopropyl-1-isonicotinyl hydrazine). J. Pharmacol. exp. Ther. 116, $480-485$ (1956).

[D95,674/56

Fouts, J. R., Dixon, R. L., Shultice, R. W.: The metabolism of drugs by regenerating liver. Biochem. Pharmacol. 7, 265-270 (1961).

[G68,041/61

Fouts, J. R., Rogers, L. A.: Morphological changes in the liver accompanying stimulation of microsomal drug metabolizing enzyme activity by phenobarbital, chlordane, benzpyrene or methylcholanthrene in rats. $J$. Pharmacol. exp. Ther. 147, 112-119 (1965).

[F 29,497/65

Fowler, J. S. L.: Carbon tetrachloride metabolism in the rabbit. Brit. J. Pharmacol. 37, 733-737 (1969).

[G70,865/69

Fox, S. L.: Potentiation of anticoagulants caused by pyrazole compounds. J. Amer. med. Ass.j188, 320-321 (1964).

$[\mathrm{F} 8,079 / 64$
Franchimont, P., Lefebvre, P., Cauwenberge, H. van: Effets de la sérotonine, d'un de ses inhibiteurs, l'UML 491, et du glucagon sur l'ostéolathyrisme expérimental du rat. $C . R$. Soc. Biol. 155, 427-431 (1961). [D13,136/61

Franco, M.: Edema polmonare sperimentale adrenalinico e testosterone. Ormonologia 14, $389-403$ (1954).

$[\mathrm{C} 27,538 / 54$

Franke, H., Klinger, W.: Untersuchungen zum Mechanismus der Enzyminduktion. IX. Die Wirkung von Barbital auf die Substruktur der Leberzellen gravider Ratten und ihrer Foeten. Acta biol. med. Germanica 17, 507-526 (1966).

$[\mathrm{H} 31,874 / 66$

Franken, F. H., Hagelskamp, W.: Barbiturate und Leber. Dtsch. med. Wschr. 95, 1613-1616 (1970).

$[\mathrm{H} 28,823 / 70$

Franklin, M.: Studies on the N-demethylation of morphine and other compounds. Canad. J. Biochem. 43, 1053-1062 (1965).

$[\mathrm{G} 32,826 / 65$

Fraser, H. F., Isbell, H., Wikler, A., Eisenman, A. I., Kornetsky, C. H.: Cortisone therapy in barbiturate abstinence syndrome. Fed. Proc. 10, 296-297 (1951).

$[\mathrm{B} 57,226 / 51$

Frawley, J. P., Hagan, E. C., Fitzhugh, 0. G.: A comparative pharmacological and toxicological study of organic phosphate-anticholinesterase compounds. J. Pharmacol. exp. Ther. 105, 156-165 (1952). [ [G69,644/52

Frawley, T. F., Roche, M., Jenkins, D., Thorn, G. W.: The role of the pituitary adrenocortical system in the response to anoxia. 43rd Meet. Amer. Soc. clin. Invest., p. 17 (1951).

$[\mathrm{B} 57,930 / 51$

Fredericq, L.: Influence du milieu ambiant sur la composition du sang des animaux aquatiques. Arch. Zool. exp. gén. 3, XXXIV à XXXVIII (1885).

$[\mathrm{A} 5,288 / 1885$

Freedland, R. A.: Urea cycle adaptations in intact and adrenalectomized rats. Proc. Soc. exp. Biol. (N.Y.) 116, 692-696 (1964).

[F 17,044/64

Freedland, R. A.: Effects of thyroid hormones on metabolism. Effect of thyroxine and iodinated casein on liver enzyme activity. Endocrinology 77, 19-27 (1965). [F 46,702/65

Freedland, R. A.: Effect of hypophysectomy on urea cycle enzyme adaptations. Life Sci. 4, 899 (1965).

[G 28,270/65

Freedland, R. A., Avery, E. H.: Studies on threonine and serine dehydrase. J. biol. Chem. 239, 3357-3360 (1964).

[G67,766/64 
Freedland, R. A., Avery, E. H., Taylor, A. R.: Effect of thyroid hormones on metabolism. II. The effect of adrenalectomy or hypophysectomy on responses of rat liver enzyme activity to L-thyroxine injection. Canad. J. Biochem. 46, 141-150 (1968).

[G55,808/68

Freedland, R. A., Krakowski, M. C., Waisman, H. A.: Effect of age, sex, and nutrition on liver phenylalanine hydroxylase activity in rats. Amer. J. Physiol. 202, 145-148 (1962).

$[\mathrm{G} 66,662 / 62$

Freedland, R. A., Murad, S., Hurvitz, A. I.: Relationship of nutritional and hormonal influences on liver enzyme activity. Fed. Proc. 27, 1217-1222 (1968).

$[\mathrm{H} 2,949 / 68$

Freeman, S., Svec, M.: Effect of complete hepatectomy upon plasma concentration and urinary excretion of eighteen amino acids. Amer. J. Physiol. 167, 201-205 (1951).

[B 64,175/51

Fregly, M. J.: Prevention of salt hypertension by propylthiouracil treatment in rats. Proc. Soc. exp. Biol. (N.Y.) 102, 299-302 (1959).

$[\mathrm{C} 77,939 / 59$

Fregly, M. J.: Effect of changes of ambient temperature on spontaneous activity of hypothyroid rats. Canad. J. Biochem. 39, 1085-1096 (1961).

[D5,800/61

Fregly, M. J.: Effect of chlorothiazide and hydrochlorothiazide on blood pressure and thyroid activity of hypertensive rats. Amer. J. Cardiol. 8, 890-898 (1961). [D15,796/61

Fregly, M. J.: Comments on cross-adaptation. Environm. Res. 2, 435-441 (1969).

$[\mathrm{G} 72,594 / 69$

Fregly, M. J., Baker, M. I., Gennaro, J. F., Jr.: Effect of certain anti-thyroid treatments on development or renal hypertension in rats. Fed. Proc. 18, 48 (1959).

[C66,042/59

Fregly, M. J., Baker, M. I., Gennaro, J. F., Jr.: Comparison of effects of thyroidectomy with propylthiouracil treatment on renal hypertension in rats. Amer. J. Physiol. 198, 4-12 (1960).

$[\mathrm{C} 80,398 / 60$

Fregly, M. J., Black, B. A.: Effect of methylphenidate on spontaneous activity, food intake, and cold tolerance of propylthiouracil-treated rats. Canad. J. Physiol. Pharmacol. 42, 415-429 (1964).

[F 15,674/64

Fregly, M. J., Cook, K. M.: Role of the thyroid gland in development and maintenance of renal hypertension in rats. Acta endocr. (Kbh.) 34, $411-429$ (1960).

$[\mathrm{C88,371/60}$
Frenkel, J. K.: Effects of hormones on the adrenal necrosis produced by besnoitia jellisoni in golden hamsters. J. exp. Med. 108, 375-398 (1956).

$[\mathrm{C} 13,371 / 56$

Frenkel, J. K.: Effects of cortisone, total body irradiation and nitrogen mustard on chronic, latent toxoplasmosis. Amer. J. Path. 33, 618-619 (1957).

$[\mathrm{C} 34,875 / 57$

Frenkel, J. K.: Evaluation of immunitydepressing effects of anti-inflammatory corticoids. Fed. Proc. 17, 437 (1958). [ [C52,043/58

Frenkel, J. K.: Evaluation of infectionenhancing activity of modified corticoids. Proc. Soc. exp. Biol. (N.Y.) 103, 552-555 1960).

$[\mathrm{C} 84,036 / 60$

Freund, H.: Digitaliswirkung und Stoffwechsel. Naunyn-Schmiedebergs Arch. Pharmak. 167, 73-76 (1932).

$[\mathrm{A} 26,153 / 32$

Friedgood, C. E., Vars, H. M., Zerbe, J. W.: Role of adrenal cortex in liver regeneration. Amer. J. Physiol. 163, 354-363 (1950).

$[\mathrm{B} 52,238 / 50$

Friedlaender, S., Friedlaender, A. S.: The effect of pituitary adrenocorticotrophic hormone (ACTH) on histamine intoxication and anaphylaxis in the guinea pig. J. Allergy 21, 303-309 (1950).

[B55,467/50

Friedman, M., Bine, R., Jr., Byers, S. 0.: Urinary excretion of digitoxin in the rat. Proc. Soc. exp. Biol. (N.Y.) 71, 406-407 (1949).

$[\mathrm{A} 49,249 / 49$

Friedman, S. M., Friedman, C. L.: A screening test to indicate opposition to the cardiovascular-renal effects of desoxycorticosterone acetate in the rat: the effect of adrenal cortical extract. Endocrinology 46, 367-374 (1950).

$[\mathrm{B} 48,306 / 50$

Friedrich, F., Kovac, W., Swoboda, W.: Die Beeinflussung der Vitamin-D-Wirkung auf die experimentelle Rattenrachitis durch Durabolin. Z. Kinderheilk. 92, 249-263 (1965).

[F 39,223/65

Frölén, H.: Effects of some radioprotective substances upon prenatal survival of offspring to roentgen irradiated male mice. Acta radiol. (Stockh.) -Therapy- 4, 373-384 (1966).

[G43,045/66

Frommel, E. von, Ledebur, I., Béguin, M.: De l'action pseudomorphinique de la cortisone en administration unique et de son effet amphétaminolike en administration répétée. Expérimentation animale. Schweiz. med. Wschr. 92, 1265-1269 (1962).

[E37,967/62

Fudema, J. J., Oester, Y. T., Proctor, C. D.: Effect of $I^{131}$ thyroid suppression on nutri- 
tional muscular dystrophy in rabbits. Fed. Proc. 21, 313 (1962).

[D 23,102/62

Fujii, K., Jaffe, H., Bishop, Y., Arnold, E., MacKintosh, D., Epstein, S. S.: Structureactivity relations for methylenedioxyphenyl and related compounds on hepatic microsomal enzyme function as measured by prolongation of hexobarbital narcosis and zoxazolamine paralysis in mice. Toxicol. appl. Pharmacol. 16, $482-494$ (1970).

[G77,242/70

Fujii, K., Jaffe, H., Epstein, S. S.: Factors influencing the hexobarbital sleeping time and zoxazolamine paralysis time in mice. Toxicol. Appl. Pharmacol. 13, 431-438 (1968).

[H28,618/68

Fujimoto, J. M., Blickenstaff, D. E., Schueler, F. W.: Urethan induced acceleration of hexobarbital metabolism. Proc. Soc. exp. Biol. (N.Y.) 103, 463-465 (1960). [D78,955/60 Fujimoto, J. M., Eich, W. F., Nichols, H. R.: Enhanced sulfobromophthalein disappearance in mice pretreated with various drugs. Biochem. Pharmacol. 14, 515-524 (1965).

[G30,289/65

Fujita, T., Orimo, H., Ohata, M., Yoshikawa, M., Kataumi, S., Lehr, D.: Effect of age and thyrocalcitonin on myocardial changes induced by sodium sulfaacetylthiazole. Endocr. jap. 15, 247-249 (1968).

[H2,733/68

Fujiwara, K., Takagaki, Y., Maejima, K., Kato, K., Naiki, M., Tajima, Y.: Tyzzer's disease in mice: pathologic studies on experimentally infected animals. Jap. J. exp. Med. 33, $183-202$ (1963).

[E34,642/63

Fujiwara, K., Takagaki, Y., Naiki, M., Maejima, K., Tajima, Y.: Tyzzer's disease in mice. Effects of corticosteroids on the formation of liver lesions and the level of blood transaminases in experimentally infected animals. Jap. J. exp. Med. 34, 59-75 (1964).

[F 17,247/64

Fukui, G. M.: Some factors affecting endotoxin-induced "nonspecific" resistance. In: Landy, Braun; Bacterial Endotoxin, p. 373 to 381. New Brunswick, N. J.: Institute of Microbiology, Rutgers, The State University 1964.

$[\mathrm{E} 8,467 / 64$

Fuller, G. C., Olshan, A., Puri, S. K., Lal, H.: Induction of hepatic drug metabolism in rats by methylchloroform inhalation. J. Pharmacol. exp. Ther. 175, 311-317 (1970). [H31,807/70

Fuller, R. W.: Differences in the regulation of tyrosine aminotransferase in brain and liver. J. Neurochem. 17, 539-543 (1970).

$[\mathrm{G} 75,131 / 70$
Fumarola, D., Giordano, D.: Influenza della timectomia e della ipertimizzazione sulla insorgenza e sullo sviluppo del sarcoma da 3,4-benzopirene nel ratto. Tumori 48, 5-12 (1962).

[D33,779/62

Funahashi, H.: Ultrastructural changes in liver cells. I. Electronmicroscopic observations on human and rat liver in hyperthyroidism (Jap. text). Jap. Arch. intern. Med. 14, 1-16 (1967).

$[\mathrm{F} 98,400 / 67$

Furner, R. L., MeCarthy, J. S., Stitzel, R. E., Anders, M. W.: Stereoselective metabolism of the enantiomers of hexobarbital. J. Pharmacol. exp. Ther. 169, 153-158 (1969). [H17,931/69

Furner, R. L., Stitzel, R. E.: Stress-induced alterations in microsomal drug metabolism in the adrenalectomized rat. Biochem. Pharmacol. 17, 121-127 (1968).

[G54,558/68

Furstman, L., Bernick, S., Zipkin, I.: The effect of hydrocortisone and fluoride upon the rat's mandibular joint. J. oral Therap. Pharmacol. 1, 515-525 (1965).

[G31,603/65

Furukawa, T.: Role of endocrine glands and sympathetic nerves in fatty liver due to carbon tetrachloride. Wakayama med. Rep. 9, 203 to 210 (1965).

[F 71,711/65

Fuwa, M., Waugh, D.: Experimental renal papillary necrosis. Effects of diuresis and antidiuresis. Arch. Path. 85, 404-409 (1968).

[F 96,546/68

Gabay, S., Vivanco, F., Ramos, F., Diaz, C. J.: Influence of DL-thyroxine and cortisone on femurs of rats with odoratism. Arch. Biochem. 92, 87-93 (1961).

[D98,867/61

Gabbiani, G.: Inibizione della calcifilassi per mezzo del metiltestosterone. Sperimentale 112, 457-466 (1962).

[D32,379/62

Gabbiani, G., Selye, H., Tuchweber, B.: Adrenal localization of a thrombohemorrhagic phenomenon. Endocrinology 77, 177-182 (1965).

[G19,450/65

Gabbiani, G., Tuchweber, B.: Prevention by calcitonin of metallic salt intoxications. Calc. Tiss. Res. 4, Sup., 144-145 (1970).

$[\mathrm{G} 70,453 / 70$

Gabbiani, G., Tuchweber, B., Côté, G.: Action of thyroxine on experimental parathyroid extract overdosage. Endocrinology 81, 798 to 802 (1967).

[G39,934/67

Gabbiani, G., Tuchweber, B., Côté, G., Lefort, P.: Action of thyroxine and calcitonin on experimental soft-tissue calcification. Calc. Tiss. Res. 2, 30-37 (1968).

[G46,731/68

Gabbiani, G., Tuchweber, B., Côté, G., Pahk, U. S., Selye, H.: Influence of thyroparathyroid 
apparatus on experimental soft-tissue calcification. Int. Congr. Ser. No. 159 p. 485-498 (1968).

[G46,730/68

Gabler, E.: Die therapeutische Wirkung von Adrenalin und Alupent nach letaler Röntgenganzkörperbestrahlung. Experientia (Basel) 22, 542-543 (1966).

[G $40,828 / 66$

Gaddum, J. H.: Recent work on 5-hydroxytryptamine and lysergic acid derivatives. 20th Congr. int. Physiol., Brussels, p. 442-455 (1956).

$[\mathrm{C} 25,117 / 56$

Gaetani, G. F. de: Modificazioni della pressione arteriosa e del ritmo cardiaco e respiratorio nell'assideramento sotto l'influenza della adrenalina. Riv. Pat. sper. 15, 201-211 (1935).

$[33,111 / 35$

Gaines, T. B.: Acute toxicity of pesticides. Toxicol. appl. Pharmacol. 14, 515-534 (1969).

[G67,102/69

Gallagher, T. F., Kappas, A.: Estrogen effects on BSP metabolism in rats. (Abstr.) Fed. Proc. 24, 144 (1965).

[F] 35,850/65

Gallagher, T. F., Mueller, M. N., Kappas, A.: Estrogen pharmacology. IV. Studies on the structural basis for estrogen-induced impairment of liver function. Medicine (Baltimore) 45, 471-479 (1966).

[F 86,156/66

Galletti, F., Bruni, G.: Eteri steroidali; effetto anticatabolico di uno steroide anabolizzante non $17 \alpha$-alchilato in ratti trattati con prednisone. Boll. Soc. ital. Biol. sper. 39, 1898-1902 (1963).

$[\mathrm{G} 16,710 / 63$

Galliard, H., Buttner, A., Bourcart, N.: Effet de l'hormone somatotrope sur une trypanosomose mortelle pour Rana esculenta L., due au Trypanosoma inopinatum sergent, 1904 (souche algérienne). C. R. Soc. Biol. (Paris) 147, 1695-1698 (1953).

$[\mathrm{G} 70,892 / 53$

Galliard, H., Lapierre, J.: Effets neutralisants de la somatotrophine hypophysaire, dans les infections à Plasmodium berghei chez la souris. C. R. Acad. Sci. (Paris) 237, 477-479 (1953).

$[\mathrm{E} 82,642 / 53$

Galliard, H., Lapierre, J., Murard, J.: Inhibition de l'infection à Plasmodium berghei chez la souris et le rat par l'hormone hypophysaire de croissance (S.T.H.). Ann. Parasit. hum. comp. 29, 167-178 (1954). [D89,408/54 Gallut, J.: Du rôle de la glande surrénale dans l'intoxication cholérique expérimentale de la souris. C. R. Soc. Biol. (Paris) 149, 1414 (1955).

$[\mathrm{C} 14,519 / 55$

Gandini, S., Gandini-Collodel, E.: Azione del 4-Clorotestosterone sul metabolismo proteico della cellula nervosa. Studio istochimico delle fosfatasi alcaline in animali affaticati. Boll. Soc. ital. Biol. sper. 38, 1329-1331 (1962).

[D 58,657/62

Ganesan, D.: Influence of female sex hormones on pentobarbitone sodium anaesthesia in rats. Arch. int. Pharmacodyn. 177, 88-91 (1969).

$[\mathrm{H} 12,504 / 69$

Ganguli, N. C., Roy, S. C., Guha, B. C.: Studies on the biosynthesis of L-ascorbic acid by the rat. I. Effect of adenosine triphosphate and other compounds on the synthesis stimulated by chloretone. Arch. Biochem. 61, 211-219 (1956).

[G71,669/56

Ganley, 0. H.: Studies of the prevention of sensitization by Bordetella pertussis in alloxan diabetic mice. Canad. J. Biochem. 40, 1179 to 1183 (1962).

$[\mathrm{D} 31,168 / 62$

Ganley, 0. H., Balch, H. H., Pulaski, E. J.: Effect of ACTH and adrenocortical hormones on experimental gas gangrene toxemia. Proc. Soc. exp. Biol. (N.Y.) 89, 485-487 (1955).

$[\mathrm{C} 7,489 / 55$

Ganley, 0. H., Robinson, H. J.: Influence of alloxan on sensitizing properties of $B$. pertussis in the mouse. Fed. Proc. 18, 392 (1959).

$[\mathrm{C} 66,305 / 59$

Ganong, W. F.: Review of Medical Physiology, p. 298. Los Altos, Calif.: Lange Medical Publ., 3rd ed. (1967).

[G74,587/67

Ganong, W. F.: Review of Medical Physiology, Los Altos, Calif.: Lange Medical Publ., 4th ed., Sect. IV (1969).

$[\mathrm{G} 74,400 / 69$

Gans, H., Stern, R., Tan, B. H.: Effect of hepatectomy on thrombin clearance. Ann. Surg. 170, 937-946 (1969).

$[\mathrm{G} 71,042 / 69$

Garattini, S., Gaiardoni, P., Mortari, A., Palma, V.: Increased toxicity of serotonin in adrenalectomized animals. Nature (Lond.) 190, $540-541$ (1961).

[D4,913/61

Garattini, S., Valzelli, L.: Sostanze interferenti sulla attività potenziante gli ipnotici svolta dalla serotonina. Boll. Soc. ital. Biol. sper. 32, 292-295 (1956).

$[\mathrm{G} 71,229 / 56$

Gardell, C., Blascheck, J. A., Kováes, K.: Action de la norboléthone sur le réticulum endoplasmique hépatique du rat. J. Micr. 9, 133-138 (1970).

$[\mathrm{G} 60,062 / 70$

Gardell, C., Blaseheck, J. A., Kovács, K.: Protection par la spironolactone contre la cardiopathie expérimentale causée par la digitoxine, le phosphate disodique et l'huile. Path. et Biol. 18, 141-146 (1970).

$[\mathrm{G} 60,065 / 70$ 
Gardell, C., Somogyi, A., Kovács, K.: Influence de la dl-méthionine sur l'action protectrice de la spironolactone lors d'intoxication à la digitoxine chez le rat. Europ. J. Toxicol. 3, No. 2, 107 a 109 (1970).

[G60,076/70

Gardell, C., Tuchweber, B., Hatakeyama, S., Kovács, K.: Steroïdes et cardiopathie de néphrectomie. Rev. Canad. Biol. 29, No. 2, 181-185 (1970).

[G70,430/70

Gardner, W. U., Pfeiffer, c. A.: Inhibition of estrogenic effects on the skeleton by testosterone injections. Proc. Soc. exp. Biol. (N.Y.) 38, 599-602 (1938).

$[72,281 / 38$

Garg, B. D., Blascheck, J. A., Kováes, K.: A comparative ultrastructural study on druginduced proliferation of smooth-surfaced endoplasmic reticulum in hepatocytes. Tohoku $J$. exp. Med. (in press).

[G70,495/

Garg, B. D., Khandekar, J. D., Dardachti, D. F., Kovaes, K.: Effect of betamethasone and dexamethasone on the liver ultrastructure in rats. Indian J. med. Res. (in press). [G79,011/

Garg, B. D., Khandekar, J. D., Tuchweber, B., Kovacs, K.: Influence of dactinomycin on the ultrastructural changes induced in rat hepatocytes by spironolactone and pregnenolone-16 $\alpha$ carbonitrile. Agressologie (in press).

[G79,030/

Garg, B. D., Kováes, K., Blascheck, J. A., Selye, H.: Ultrastructural changes in hepatocytes induced by a steroid carbonitrile. Folia endocr. (Roma) 23, 357-363 (1970).

[G60,031/70

Garg, B. D., Kováes, K., Blascheck, J. A., Selye, H.: Ultrastructural changes induced by pregnenolone nitrile in the rat liver. J. Pharm. Pharmacol. 22, 872-873 (1970). [G70,474/70

Garg, B. D., Solymoss, B., Tuchweber, B.: Effect of spironolactone on the distribution and excretion of ${ }^{203} \mathrm{HgCl}_{2}$ in the rat. Arzneimittel-Forsch. 22, 872-873 (1970).

$[\mathrm{G} 60,078 / 70$

Garg, B. D., Szabo, S., Khandekar, J. D., Kovacs, K.: Effect of hypophysectomy on pregnenolone-16 $\alpha$-carbonitrile-induced ultrastructural changes in rat liver. Naunyn-Schmiedebergs Arch. Pharmak. 269, 7-14 (1971).

[G79,002/71

Garg, B. D., Szabo, S., Khandekar, J. D., Kovaes, K.: Ultrastructural changes caused by pregnenolone-16 $\alpha$-carbonitrile in the liver of hypophysectomized rats. (Abstr.) 8th Acta endocr. Congr. Copenhagen, July 4-8, 1971.

$[\mathrm{G} 79,008 / 71$
Garren, L. D., Conney, A. H., Tomkins, G. M.: Stimulatory effect of phenobarbital on steroid metabolism. J. clin. Invest. 40, 1041 (1961).

[G66,660/61

Garren, L. D., Howell, R. R., Tomkins, G. M.: Mammalian enzyme induction by hydrocortisone. The possible role of RNA. J. molec. Biol. 9, 100-108 (1964).

[G 19,151/64

Garren, L. D., Howell, R. R., Tomkins, G. M., Crocco, R. M.: A paradoxical effect of actinomycin $\mathbf{D}$ : the mechanism of regulation of enzyme synthesis by hydrocortisone. Proc. nat. Acad. Sci. (Wash.) 52, 1121-1129 (1964).

[G28,021/64

Garrido, C. M.: Acción de distintas substancias en la resistencia al frío de ratas blancas suprarrenoprivas y normales. Rev. Soc. argent. Biol. 35, 96-102 (1959).

$[\mathrm{C} 77,562 / 59$

Garrido, C. M.: Thyroïde et résistance au froid. C. R. Soc. Biol. (Paris) 154, 2378 (1960).

[D 8,112/60

Garvin, P. J., Jr., Jennings, R. B., Gesler, R. M.: Some comparative effects of sodium $D$ - and sodium L-thyroxine administered chronically to rats and dogs. Toxicol. appl. Pharmacol. 4, 276-285 (1962).

[D 21,160/62

Gasic, G.: Local resistance to a lethal dose of formalin. Proc. Soc. exp. Biol. (N.Y.) 66, $579-582$ (1947).

[B17,561/47

Gass, G. H., Umberger, E. J.: Lack of effect of two 17-substituted testosterones on hepatic sulfobromophthalein clearance in dogs. Toxic. appl. Pharmac. 1, 545-547 (1959).

[C94,624/59

Gastinel, P., Collart, P., Vaisman, A., Hamelin, A., Dunoyer, F.: A propos des résultats obtenus par l'emploi de la cortisone en syphilis expérimentale. Ann. Derm. Syph. (Paris) 87, 612-617 (1960).

[D 8,309/60

Gaudette, L. E., Brodie, B. B.: Relationship between the lipid solubility of drugs and their oxidation by liver microsomes. Biochem. Pharmacol. 2, 89-96 (1959). [E90,437/59

Gaunt, R.: Protection of normal rats against death from water intoxication with adrenal cortical substances. Proc. Soc. exp. Biol. (N.Y.) 54, 19-21 (1943).

[A 63,323/43

Gaunt, R.: The effect of thyroxin on water diuresis and water intoxication in the rat. Fed. Proc. 3, 12 (1944).

$[84,566 / 44$

Gaunt, R., Howell, C., Antonchek, N.: The effect of other steroids on the response to cortisone. J. clin. Endocr. 12, 957 (1952).

$[\mathrm{B} 71,987 / 52$ 
Gaunt, R., Steinets, B. G., Chart, J. J.: Pharmacologic alteration of steroid hormone functions. Clin. Pharmacol. Ther. 9, 657-681 (1968).

$[\mathrm{G} 63,202 / 68$

Gaunt, R., Tuthill, C. H., Antonchak, N., Leathem, J. H.: Antagonists to cortisone: an ACTH-like action of steroids. Endocrinology 52, 407-423 (1953).

[B 82,200/53

Gautieri, R. F., Mann, D. E., Jr.: Effect of gonadectomy and estradiol benzoate administration on the minimal carcinogenic dose 50 of methylcholanthrene on mouse epidermis. J. Pharm. Sci. 50, 556-560 (1961).

[H30,506/61

Gavosto, F., Pileri, A., Brusca, A.: Increased transaminase activity in the liver after administration of cortisone. Biochim. biophys. Acta (Amst.) 24, 250-254 (1957).

$[\mathrm{C} 34,243 / 57$

Gayet-Hallion, T., Bouvet, P.: Action du sang de cheval éthyroïdé sur la toxicité de groupe de l'amphétamine. Comparaison avec le sang de cheval normal et avec la réserpine. $C$. $R$. Soc. Biol. (Paris) 158, 269-271 (1964).

[F 16,484/64

Gaylord, C., Hodge, H. C.: Duration of sleep produced by pentobarbital sodium in normal and castrate female rats. Proc. Soc. exp. Biol. (N.Y.) 55, 46-48 (1944).

[B 11,425/44

Gedalia, I., Frumkin, A., Zukerman, H.: Effects of estrogen on bone composition in rats at low and high fluoride intake. Endocrinology 75, 201-205 (1964).

[F 17,787/64

Gelboin, H. V.: Drugs and protein synthesis. Exp. Med. Surg. 23, 85-103 (1965).

$[\mathrm{F} 62,759 / 65$

Gelboin, H. V.: Carcinogens, enzyme induction, and gene action. Advanc. Cancer Res. 10, 1-81 (1967).

$[\mathrm{G53}, 802 / 67$

Gelboin, H. V., Miller, J. A., Miller, E. C.: Studies on hepatic protein-bound dye formation in rats given single large doses of 3'-methyl-4-dimethylaminoazobenzene. Cancer Res. 18, 608-617 (1958).

[D81,074/58

Gelehrter, T. D., Tomkins, G. M.: The role of RNA in the hormonal induction of tyrosine aminotransferase in mammalian cells in tissue culture. J. molec. Biol. 29, 59-76 (1967).

$[\mathrm{G} 51,315 / 67$

Geller, E., Yuwiler, A., Schapiro, S.: Comparative effects of a stress and cortisol upon some enzymatic activities. Biochim. biophys. Acta (Amst.) 93, 311-315 (1964). [ [G22,722/64
Geller, E., Yuwiler, A., Schapiro, S.: Tyrosine aminotransferase: activation or repression by a stress. Proc. Soc. exp. Biol. (N.Y.) 130, 458-461 (1969).

$[\mathrm{H} 8,414 / 69$

Geller, P., Merrill, E. R., Jawetz, E.: Effects of cortisone and antibiotics on lethal action of endotoxins in mice. Proc. Soc. exp. Biol. (N.Y.) 86, 716-719 (1954). [B98,147/54

Gellhorn, E.: Schilddrüse und Nitrilvergiftung. Pflügers Arch. ges. Physiol. 200, 571-582 (1923).

$[16,839 / 23$

Gemmill, C. L.: Comparison of activity of thyroxine and 3,5, $3^{\prime}$-triiodothyronine. Amer. $J$. Physiol. 172, 286-290 (1953). [B 85,291/53

Genitis, V. E., Borkon, E. L., Templeton, R. D.: The influence of temperature on parathyroid tetany in the albino rat. Amer. J. Physiol. 113, 48 (1935).

$[68,723 / 35$

Georgii, A., Mehnert, H., Prosiegel, R., Kastein, H., Stock, G.: Tierexperimentelle Leberbefunde nach langfristigen Sulfonylharnstoffgaben (D 860) und gleichzeitiger Leberschädigung mit Thioacetamid. Z. ges. exp. Med. 131, 181-190 (1959). [C69,388/59

Gerald, M. C., Feller, D. R.: Evidence for spironolactone as a possible inducer of liver microsomal enzymes in mice. Biochem. Pharmacol. 19, 2529-2532 (1970). [G74,092/70

Gerald, M. C., Feller, D. R.: A comparison of spironolactone (SL) and a major metabolite (SC-9376) as inducers of hepatic microsomal enzyme systems in male and female mice. Pharmacologist 12, 279 (1970). $\quad$ [G74,396/70

Gerald, M. C., Feller, D. R.: Stimulation of barbiturate metabolism by spironolactone in mice. Arch. int. Pharmacodyn. 187, 120-124 (1970).

$[\mathrm{G} 78,804 / 70$

Gerber, W., Cottier, P.: Zur Wirkung anaboler Hormone auf die Azotämie bei Nierenversagen. Helv. med. Acta 28/3, 197-215 (1961).

$[\mathrm{D} 12,775 / 61$

Gerlich, N.: Experimentelle Studien über die Beziehungen zwischen Schilddrüse und Krampfbereitschaft. Naunyn-Schmiedebergs Arch. Pharmak. 207, 159-172 (1949).

[B $49,124 / 49$

Germer, W. D., Regoeczi, E.: Ein experimenteller Beitrag zur Testosteron-Wirkung bei toxischen Leberschäden. Dtsch. Arch. klin. Med. 205, 343-361 (1958).

$[\mathrm{C} 64,975 / 58$

Germuth, F. G., Jr., Ottinger, B., Oyama, J.: The influence of cortisone on the evolution of acute infection and the development of immunity. Bull. Johns Hopk. Hosp. 91, 22-48 (1952).

$[\mathrm{D} 77,106 / 52$ 
Gersh, I., Wagner, C. E.: Metabolic factors in oxygen poisoning. Amer. J. Physiol. 144, $270-277$ (1945).

[B1,140/45

Gershbein, L. L.: Pregnancy and liver regeneration in partially hepatectomized rats. Proc. Soc. exp. Biol. (N.Y.) 99, 716-717 (1958).

[G71,666/58

Gershbein, L. L.: Effect of carcinogenic and noncarcinogenic hydrocarbons and hepatocarcinogens on rat liver regeneration. $J$. nat. Cancer Inst. 21, 295-310 (1958). [G71,667/58 Gershbein, L. L.: Transplanted tumor growth and liver regeneration in the rat. $J$. nat. Cancer Inst. 31, 521-528 (1963). [E 71,030/63 Gershbein, L. L.: Effects of various agents on liver regeneration and Walker tumor growth in partially hepatectomized rats. Cancer Res. 26, 1905-1908 (1966).

[F 71,304/66

Gershbein, L. L.: Effect of insecticides on rat liver regeneration. Res. Commun. chem. Path. Pharmacol. 1, 740-748 (1970). [H31,893/70

Gershoff, S. N., Vitale, J. J., Antonowicz, I., Nakamura, M., Hellerstein, E. E.: Studies of interrelationships of thyroxine, magnesium and vitamin $\mathrm{B}_{12}$. J. biol. Chem. 231, 849-854 (1958).

[C54,255/58

Geschwind, I. I., Li, C. H.: Influence of hypophysectomy and of adrenocorticotropic hormone on a mammalian adaptive enzyme system. Nature 172, 732-733 (1953).

[B95,517/53

Geschwind, I. I., Li, C. H.: Endocrine control of an induced hepatic enzyme system. J. clin. Endocr. 14, 789-790 (1954). [B93,277/54

Gessner, T., Acara, M., Baker, J. A., Edelman, L. L.: Effects of sex hormones on the duration of drug action in mice. J. pharm. Sci. 56, 405-407 (1967).

[F 77,776/67

Geyer, G.: Erfolgreiche Behandlung eines Falles von Cushing-Syndrom mit o,p-DDD [2,2-bis (2-chlorophenyl-4-chlorophenyl)-1,1-Dichloroäthan.] Acta endocr. (Kbh.) 40, 332-348 (1962).

[D27,915/62

Geyer, G., Schüller, E.: Ưber den Einfluß von o,p-DDD [2,2-bis (2-chlorphenyl-4-chlorphenyl)-1,1-Dichloräthan] auf die Steroidausscheidung im Harn bei Nebennieren-gesunden und bei einigen Fällen typischer adrenocorticaler Funktionsstörung. Klin. Wschr. 40, 734-740 (1962).

[D $38,170 / 62$

Geyer, R. P., Bryant, J. E., Bleisch, V. R., Peirce, E. M., Stare, F. J.: Effect of dose and hormones on tumor production in rats given emulsified 9,10-dimethyl-1,2-benzanthracene intravenously. Cancer Res. 13, 503-506 (1953).

[H31,923/53

Ghedini, Ollino: Influence de la situation endocrinique sur l'action des médicaments cardio-vasculaires. C. R. Soc. Biol. (Paris) 76, $659-660$ (1914).

$[\mathrm{A} 21,128 / 14$

Ghione, M.: Azione antiinfettiva di steroidi anabolizzanti. Sperimentale 107, 182-195 (1957).

[D 87,868/57

Ghione, M.: Anti-infective action of an anabolic steroid. Proc. Soc. exp. Biol. (N.Y.) 97, 773 -775 (1958).

[C51,954/58

Ghione, M., Turolla, E.: Steroidi anabolizzanti e processi infettivi. G. ital. Chemioter. 10, 290-302 (1964).

[G18,525/64

Ghiringhelli, L.: Influenza dell'ormone somatropo sulla produzione di anticorpi antiovalbumina in animali da esperimento. Folia endocr. (Roma) 13, 416-421 (1960).

$[\mathrm{C} 90,609 / 60$

Ghys, R.: Action radiomodificatrice de la testostérone chez des rats soumis à l'action de neutrons rapides ou à l'irradiation interne par rayons béta du 32 P. Rev. canad. Biol. 21, 95-103 (1962).

[D30,012/62

Ghys, R.: Action radiomodificatrice des hormones sexuelles chez le rat. II. Influence du traitement hormonal combiné à l'irradiation chez le rat hypophysectomisé. $J$. belge Radiol. 45, 67-82 (1962).

[D70,483/62

Ghys, R.: L'influence des facteurs métaboliques sur la radiosensibilité. Laval méd. 34, 69-79 (1963).

[D 54,640/63

Ghys, R., Loiselle, J. M.: Les facteurs influençant les réactions des animaux soumis à une irradiation totale non fractionnée. Rev. canad. Biol. 19, 53-79 (1960).

[C83,564/60

Giberti, A., Ponzoni, R., Spampinato, V.: Sulla morte precoce delle cavie in corso di trattamento aureomicinico. Tentativi di protezione con vitamine dei gruppi B e C e con cortisone. Nota II. Ricerche istologiche. Boll. Ist. sieroter. Milan 32, 246-255 (1953).

[B90,116/53

Giberti, A., Vecchiati, R., Belluzzi, V.: Il propiltiuracile sulla rigenerazione epatica. Folia endocr. (Roma) 6, 267-272 (1953).

[B 82,948/53

Gibson, J. E., Becker, B. A.: Demonstration of enhanced lethality of drugs in hypoexcretory animals. J. pharm. Sci. 56, 1503-1505 (1967).

$[\mathrm{E} 65,709 / 67$ 
Gigante, D., Scopinaro, D.: Sulla fisiopatologia dei vasi sanguigni nei congelamenti. III. Azione del propionato di testosterone sulla pressione arteriosa e venosa, sull'osciliometria e sulla temperatura cutanea nei congelati. Ormonologia 4, 65-76 (1946). $\quad[\mathrm{B} 67,617 / 46$ Gigon, P. L., Gram, T. E., Gillette, J. R.: Effect of drug substrates on the reduction of hepatic microsomal cytochrome P-450 by NADPH. Biochem. biophys. Res. Commun. 31, 558-562 (1968).

$[\mathrm{G} 76,365 / 68$

Gigon, P. L., Gram, T. E., Gillette, J. R.: Studies on the rate of reduction of hepatic microsomal cytochrome P.450 by reduced nicotinamide adenine dinucleotide phosphate: effect of drug substrates. Molec. Pharmacol. 5. 109-122 (1969).

[G66,216/69

Gilger, A. P., Potts, A. M., Johnson, L. V.: Studies on the visual toxicity of methanol. II. The effect of parenterally administered substances on the systemic toxicity of methyl alcohol. Amer. J. Ophthal. 35, 113-126 (1952).

[B 73,737/52

Gillett, J. W.: Microsomal epoxidation: effect of age and duration of exposure to dietary DDT on induction. Bull. environm. Contam. Toxicol. 4, 160-168 (1969). [G74,480/69 Gillette, J. R.: Oxidation and reduction by microsomal enzymes. In: Brodie and Erdös; Metabolic Factors Controlling Duration of Drug Action (Proc. of the 1. int. pharmacol. Meet. Vol. 6), p. 13-29. New York: MacMillan Co. 1962.

[E 52,874/62

Gillette, J. R.: Metabolism of drugs and other foreign compounds by enzymatic mechanisms. Fortschr. Arzneimittel-Forsch. 6, 11-73 (1963).

[G51,908/63

Gillette, J. R.: Factors that affect the stimulation of the microsomal drug enzymes induced by foreign compounds. In: Weber; Advances in Enzyme Regulation, Vol. 1, p. 215-223. New York: MacMillan Co. 1963. [G66,248/63 Gillette, J. R.: Drug toxicity as a result of interference with physiological control mechanisms. Ann. N.Y. Acad. Sci. 123, 42-54 (1965).

$[\mathrm{G} 66,246 / 65$

Gillette, J. R.: Biochemistry of drug oxidation and reduction by enzymes in hepatic endoplasmic reticulum. In: Garattini, S., Shore, P. A.; Advances in Pharmacology, p. 219-261. New York, London: Academic Press 1966.

[E 7,538/66

Gillette, J. R.: Individually different responses to drugs according to age, sex and functional or pathological state. In: Wolstenholme,
Porter; Ciba Foundation Symposium on Drug Responses in Man, p. 24-49. London: J. and A. Churchill Ltd. 1967.

[G67,333/67

Gillette, J. R.: Theoretical aspects of drug interaction. In: Siegler, P. E., Moyer, J. H.; Animal and Clinical Pharmacologic Techniques in Drug Evaluation, 2, p. 48-66. Chicago: Year Book Medical Publ. Inc. 1967.

[G78,390/67

Gillette, J. R.: Effect of various inducers on electron transport system associated with drug metabolism by liver microsomes. Metabolism 20, 215-227 (1971). [H34,126/71 Gillette, J. R., Conney, A. H., Cosmides, G. J., Estabrook, R. W., Fouts, J. R., Mannering, G. J.: Microsomes and drug oxidations (Symp. on Microsomes and Drug Oxidations, Bethesda, Md. 1968). New York, London: Academic Press Inc. 1969, p. 547. [E 8,216/69 Gillissen, G., Busanny-Caspari, W.: Utber den Einfluß der Hypophysektomie auf die experimentelle Tuberkulose. Z. Hyg. Infekt.Kr. 137, 516-517 (1953). [C6,858/53 Gillman, J., Gilbert, C.: Periarteritis and other forms of necrotising angeitis produced by vitamin $D$ in thyroximised rats with an assessment of the aetiology of those vascular lesions. Brit. J. exp. Path. 37, 584 -596 (1956).

$[\mathrm{C} 31,076 / 56$

Ginoulhiac, E.: Attività comparativa del prednisolone, del dexametasone e di altri derivati fluorurati del prednisolone sulla triptofano-perossidasi-ossidasi. Acta vitamin (Milano) 13, 149-154 (1959). [G67,780/59 Giordano, P. L., Invernizzi, G.: Tierexperimentelle Untersuchungen über die Wirkung niedriger Röntgendosen auf das Zentralnervensystem und Strahlenschutzversuche mit Arzneimitteln. Arzneimittel-Forsch. 18, 1417 bis 1420 (1968).

$[\mathrm{H} 5,873 / 68$

Giotti, A., Donatelli, L.: Influenza dello stato gravidico sulla narcosi barbiturica. Boll. Soc. ital. Biol. sper. 24, 711-712 (1948).

[B39,580/48

Girard, G.: Cortisone et pasteurella pestis (souches de virulence affaiblie) chez la souris blanche. Gaz. Hôp. (Paris) 128, 863 (1956).

$[\mathrm{C} 22,665 / 56$

Girkin, G., Kampschmidt, R. F.: Effect of thiouracil on liver enlargement in tumorbearing rats. Amer. J. Physiol. 200, 61-63 (1961).

$[\mathrm{C} 99,934 / 61$

Girolami, M.: Treatment of ascitic atrophic cirrhosis of the liver with high dosages of testosterone propionate. J. Amer. Geriat. Soc. 6, 306-323 (1958).

$[\mathrm{C} 55,043 / 58$ 
Giroud, P., Capponi, M., Dumas, N.: De la maladie inapparente à la maladie mortelle chez le rat blanc infecté par Toxoplasma gondi et traité aux stéroïdes synthétiques. Bull. Soc. Path. exot. 55, 335-339 (1962). [D68,563/62 Gish, C. D., Chura, N. J.: Toxicity of DDT to Japanese quail as influenced by body weight, breeding condition, and sex. Toxicol. appl. Pharmacol. 17, 740-751 (1970). [G80,046/70 Gispen, W. H., Greidanus, T. B. van W., Wied, D. de: Effects of hypophysectomy and $\mathrm{ACTH}_{1-10}$ on responsiveness to electric shock in rats. Physiol. and Behav. 5, 143-146 (1970).

$[\mathrm{G} 77,128 / 70$

Giuliani, L.: La rispota prostatica a variazioni dell'equilibrio ormonico sessuale nel quadro di un danno epatico irreversibile. Folia endocr. (Roma) 8, 933-952 (1955).

$[\mathrm{C} 15,153 / 55$

Giunta, F., Rath, J.: Effect of environmental illumination in prevention of hyperbilirubinemia of prematurity. Pediatrics 44, 162-167 (1969).

$[\mathrm{H} 35,532 / 69$

Giuseppe, 0.: Edema polmonare sperimentale adrenalinico ed estrogeni. Ormonologia 14, 219-236 (1954).

$[\mathrm{C} 27,530 / 54$

Glaser, R. J., Berry, J. W., Loeb, L. H., Wood, W. B., Jr:: The effect of cortisone on acute bacterial infections. 3rd Meet. Amer. Soc. clin. Invest. p. 19 (1951).

[B57,933/51

Glaser, R. J., Berry, J. W., Loeb, L. H., Wood, W. B., Jr.: The effect of cortisone in streptococcal lymphadenitis and pneumonia. J. Lab. clin. Med. 38, 363-373 (1951). [B65,298/51

Glaser, R. J., Berry, J. W., Loeb, L. H., Wood, W. B., Jr., Daughaday, W. H.: Effect of ACTH and cortisone in experimental streptococc 1 and pneumococcal infections. J. Lab. clin. Med. 36, 826 (1950).

[B58,299/50

Glaubach, S., Pick, E. P.: Ưber die Beeinflussung der Temperaturregulierung durch Thyroxin. I. Mitteilg. Naunyn-Schmiedebergs Arch. Pharmak. 151, 341-370 (1930). $\quad[11,431 / 30$

Glaubach, S., Pick, E. P.: Utber die Beeinflussung der Temperaturregulierung durch Thyroxin. II. Mitteilg. Kokain, Perkain und Novokainwirkung bei thyroxinvorbehandelten Tieren. Naunyn-Schmiedebergs Arch. Pharmak. 162, 537-550 (1931).

$[6,241 / 31$

Glaubach, S., Pick, E. P.: Über den Einfluß der Schilddrüse auf die Arzneiempfindlichkeit. Schweiz. med. Wschr. 64, 1115 (1934).

$[30,481 / 34$

Glees, P.: Experimentelle Markscheidendegeneration durch Tri-ortho-kresylphosphat und ihre
Verhütung durch Cortisonacetat. Dtsch. med. Wschr. 86, 1175-1178 (1961). [D7,966/61 Glees, P.: Central nerve fibre degeneration caused by tri-ortho-cresyl phosphate and its arrest by the action of cortisone acetate. Germ. med. Mth. 6, 245-247 (1961). [D14,872/61 Glenn, E. M., Lyster, S. C., Bowman, B. J., Richardson, S. L.: Potentiation of biological activities of steroids by carcinogenic hydrocarbons. Endocrinology 64, 419-430 (1959).

$[\mathrm{C} 64,744 / 59$

Glenn, E. M., Richardson, S. L., Bowman, B. J., Lyster, S. C.: Steroids and experimental mammary cancer. In: Pincus, G.; Biological Activities of Steroids in Relation to Cancer, p. 257-305. New York, N. Y.: Academic Press Inc. 1960.

[G70,204/60

Glenn, T. M., Lefer, A. M.: Anti-toxic action of methylprednisolone in hemorrhagic shock. Europ. J. Pharmacol. 13, 230-238 (1971).

[H34,576/71

Glickman, I., Selye, H., Smulow, J. B.: Systemic factors that influence the manifestations of osteolathyrism in the periodontium. $J$. dent. Res. 42, 835-841 (1963). [E 24,104/63

Glock, G. E.: Thiourea and the suprarenal cortex. Nature (Lond.) 156, 508 (1945).

$\mathrm{B} 23,056 / 45$

Glogner, P., Ermert A.: Untersuchung zum Metabolismus von Phenacetin. Arzneimittel-Forsch. 20, 636-637 (1970).

$[\mathrm{H} 27,073 / 70$

Glover, E. L., Reuber, M. D.: Chronic thyroiditis in Buffalo rats with carbon tetrachlorideinduced cirrhosis. Endocrinology 80, 361-364 (1967).

$[\mathrm{F} 77,043 / 67$

Glover, E. L., Reuber, M. D., Grollman, S.: Influence of age and sex on thyroiditis in rats injected subcutaneously with 3-methylcholanthrene. Path. et Microbiol. (Basel) 32, 314-320 (1968).

$[\mathrm{H} 12,898 / 68$

Gluck, T.: Utber die Bedeutung physiologischchirurgischer Experimente an der Leber. Langenbecks Arch. klin. Chir. 29, 139-145 (1883).

$[\mathrm{A} 5,289 / 1883$

Glucksmann, A., Cherry, C. P.: The effect of oestrogens, testosterone and progesterone on the induction of cervico-vaginal tumours in intact and castrate rats. Brit. J. Cancer 22, 545-562 (1968).

$[\mathrm{H} 19,200 / 68$

Glucksmann, A., Cherry, c. P.: The effect of increased numbers of carcinogenic treatments on the induction of cervico-vaginal and vulval tumours in intact and castrate rats. Brit. $J$. Cancer 24, 333-351 (1970).

$[\mathrm{G} 77,810 / 70$ 
Godfraind, T., Godiraind-De Becker, A.: Action des glucosides cardiotoniques sur l'iléon de cobaye et sa modification par la désoxycorticostérone. Arch. int. pharmacodyn. 130/3-4, 435-436 (1961).

[D45,080/61

Goedbloed, J. F., Vos, 0.: Influences on the incidence of secondary disease in radiation chimeras: thymectomy and tolerance. Transplantation (Baltimore) 3, 603-609 (1965).

$[\mathrm{G} 33,427 / 65$

Gogolák, G., Liebeswar, G., Stumpf, C.: Durch Nicotin und Pentetrazol ausgelöste EEG-Veränderungen an normalen und hypothyreotischen Kaninchen. Naunyn-Schmiedebergs Arch. Pharmak. 258, 383-390 (1967).

[G51,384/67

Goldberg, L., Störtebecker, T. P.: Antinarcotic effect of estrone on alcohol intoxication. Acta physiol. scand. 5, 289-296 (1943). [B31,834/43

Golden, J. B., Sevringhaus, E. L.: Inactivation of estrogenic hormone of the ovary by the liver. Proc. Soc. exp. Biol. (N.Y.) 39, 361-362 (1938).

$[\mathrm{A} 37,808 / 38$

Goldenthal, E. I.: A compilation of LD50 values in newborn and adult animals. Toxicol. appl. Pharmacol. 18, 185-207 (1971).

[G 81,411/71

Goldenthal, E. I., D'Aguanno, W., Lynch, J. F.: Hormonal modification of the sex differences following monocrotaline administration. Toxicol. appl. Pharmacol. 6, 434-441 (1964).

[G18,384/64

Goldfischer, S., Arias, I. M., Essner, E., Novikoff, A. B.: Cytochemical and electron microscopic studies of rat liver with reduced capacity to transport conjugated bilirubin. $J$. exp. Med. 115, 467-474 (1962). [D20,605/62

Goldhaber, P.: Bone-resorption factors, cofactors, and giant vacuole osteoclasts in tissue culture. In: Gaillard, Talmage, Budy; The Parathyroid Glands: Ultrastructure, Secretion, and Function, p. 153-169. Chicago: The University of Chicago Press 1965. [E 5,596/65 Goldin, A., Greenspan, E. M., Goldberg, B., Schoenbach, E. B.: Studies on the mechanism of action of chemotherapeutic agents in cancer. I. A sex difference in toxicity to the folic acid analogue, 4-amino-pteroylglutamic acid. Cancer (Philad.) 3, 849-855 (1950). [D76,907/50

Goldman, A. S.: Experimental congenital adrenocortical hyperplasia; persistent postnatal deficiency in activity of $3 \beta$-hydroxysteroid dehydrogenase produced in utero. $J$. clin. Endocr. 27, 1041-1049 (1967).

$[\mathrm{F} 85,342 / 67$
Goldman, A. S.: Stoichiometric inhibition of various $3 \beta$-hydroxysteroid dehydrogenases by a substrate analogue. J. clin. Endocr. 27, 325-332 (1967).

[F 78,224/67

Goldman, A. S.: Maternal and fetal effects of two inhibitors of $3 \beta$-hydroxysteroid dehydrogenase and $\Delta^{5-4}, 3$-ketosteroid isomerase in the rat. Endocrinology 85, 325-329 (1969).

[H15,818/69

Goldman, A. S.: Experimental congenital lipoid adrenal hyperplasia: prevention of anatomic defects produced by aminoglutethimide. Endocrinology 87, 889-893 (1970). [ [H31,449/70

Goldman, A. S., Bongiovanni, A. M., Yakovac, W. C.: Production of congenital adrenal cortical hyperplasia, hypospadias, and clitoral hypertrophy (adrenogenital syndrome) in rats by inactivation of $3 \beta$-hydroxysteroid dehydrogenase. Proc. Soc. exp. Biol. (N.Y.) 121, 757-766 (1966).

$[\mathrm{F} 64,070 / 66$

Goldman, A. S., Bongiovanni, A. M., Yakovac, W. C.: Experimental adrenal cortical hyperplasia produced by persistent inhibition of fetal $3 \beta$-hydroxysteroid dehydrogenase ( $3 \beta$ enzyme). (Abstr.). Excerpta med. (Amst.), Int. Congr. Ser. No. 111, p. 177. (1966). 2nd Int. Congr. on hormonal steroids, Milan, Italy.

[G73,456/66

Goldman, A. S., Neumann, F.: Differentiation of the mammary gland in experimental congenital adrenal hyperplasia due to inhibition of $\Delta^{5}, 3 \beta$-hydroxysteroid dehydrogenase in rats. Proc. Soc. exp. Biol. (N.Y.) 132, 237-241 (1969).

$[\mathrm{H} 18,122 / 69$

Goldman, A. S., Yakovac, W. C.: The enhancement of salicylate teratogenicity by maternal immobilization in the rat. J. Pharmacol. exp. Ther. 142, 351-357 (1963). [ [E35,710/63

Goldsmith, E. D., Gordon, A. S., Charipper, H. A.: Estrogens, thiourea, thiouracil, and the tolerance of rats to simulated high altitudes (low atmospheric pressures). Endocrinology 36, 364-369 (1945).

[B333/45

Goldstein, A., Aronow, L., Kalman, S. M.: Principles of Drug Action. The Basis of Pharmacology, p. 206-279. New York, Evanston, London: Harper and Row Publ. 1968. [E165/68 Goldstein, L., Stella, E. J., Knox, W. E.: The effect of hydrocortisone on tyrosine- $\alpha$-ketoglutarate transaminase and tryptophan pyrrolase activities in the isolated, perfused rat liver. J. biol. Chem. 237, 1723-1726 (1962).

[D70,931/62

Gonzalez, C. A., de Anda, L. B., Roel, R. G., Pisanty, 0. J., Rodriguez, M.: Shock bacteré- 
mico en gineco-obstetricia. Ginec. Obstet. Méx. 22, 1153-1163 (1967). $[\mathrm{F} 88,028 / 67$

González-Angulo, A., Aznar-Ramos, R., Márquez-Monter, H., Bierzwinsky, G., MartínezManautou, J.: The ultrastructure of liver cells in women under steroid therapy. I. Normal pregnancy and trophoblastic growths. Acta endocr. (Kbh.) 65, 193-206 (1970).

$[\mathrm{H} 30,301 / 70$

Gonzalez, R.: Influencia de la hipófisis sobre la hipertrofía renal compensadora. Rev. Soc. argent. Biol. 14, 173-183 (1938). [79,025/38 Gonzalez, R.: Action de l'hypophyse sur l'hypertrophie rénale compensatrice chez les batraciens. C. R. Soc. Biol. (Paris) 129, 1270-1271 (1938).

[A34,057/38

Good, E. E., Ware, G. W.: Effects of insecticides on reproduction in the laboratory mouse. IV. Endrin and dieldrin. Toxicol. appl. Pharmacol. 14, 201-203 (1969).

$[\mathrm{G} 76,670 / 69$

Goodall, C. M.: Effect of cortisone on hepatoma formation in rats. A. R. Brit. Emp. Cancer Campgn. 40, 548-549 (1962). [ [G77,088/62

Goodall, C. M.: Hepatic carcinogenesis in thyroidectomized rats: apparent blockade at the stage of initiation. Cancer Res. 26, 1880-1883 (1966).

$[$ F 71,302/66

Goodsell, E. B.: Ethanol intoxication in adrenocorticosteroid-treated mice. Fed. Proc. 20, 170 (1961).

[D3,916/61

Gorby, C. K., Leonard, C. A., Ambrus, J. L., Harrison, J. W. E.: The effects of cortisone and desoxycorticosterone on the toxicity of barbiturates. J. Amer. Pharm. Ass. 42, 213-214 (1953).

[B84,489/53

Gordeyeva, K. V.: The effect of insulin and glucose on the glucogen content of the liver in X-ray sickness. (Russian text.) Vop. med. Khim. 6/4, 408-411 (1960). [C97,407/60

Gordon, A. S., Goldsmith, E. D., Charipper, H. A.: Effects of para aminobenzoic acid and thiouracil on thyroid function and resistance to low pressures. Endrocrinology 37, 223-229 (1945).

[B761/45

Gordon, D., Kobernick, S. D., MeMillan, G. C., Duff, G. L.: The effect of cortisone on the serum lipids and on the development of experimental cholesterol atherosclerosis in the rabbit. J. exp. Med. 99, 371-386 (1954). [B95,119/54

Gordon, G. G., Southren, A. L., Tochimoto, S., Olivo, J., Altman, K., Rand, J., Lemberger, L.: Effect of medroxyprogesterone acetate (Provera) on the metabolism and biological activity of testosterone. J. clin. Endocr. 30, 449-456 (1970).

$[\mathrm{H} 24,106 / 70$

Gordon, P., Linton, M. A.: Beneficial effect of serotonin and compound $\mathrm{F}$ on $\mathrm{E}$. coli endotoxin mortality in mice. (Abstr.) Fed. Proc. 16, 301 (1957).

$[\mathrm{C} 33,200 / 57$

Gordon, P., Lipton, M. A.: Hormonal modification of endotoxin mortality in mice. Proc. Soc. exp. Biol. (N.Y.) 105, 162-164 (1960).

$[\mathrm{C} 94,649 / 60$

Goss, J. E., Dickhaus, D. W.: Increased bishydroxycoumarin requirements in patients receiving phenobarbital. New Engl. J. Med. 273, $1094-1095$ (1965). [F 53,987/65

Goswami, M. N. D., Sripati, C. E., Khouvine, Y.: Effet de la 8-azaguanine sur l'adaptation de la tyrosine aminotransférase (EC 2.6.1.5) hépatique de rats adultes surrénalectomisés et traités par la L-tyrosine. C. R. Acad. Sci. (Paris) 266, 724-727 (1968). [G55,570/68

Goth, A., Nash, W. L., Nagler, M., Holman, J.: Inhibition of histamine release in experimental diabetes. Amer. J. Physiol. 191, 25-28 (1957).

$[\mathrm{C} 43,836 / 57$

Göthe, C. J.: Effect of cortisol on lymphatic lung clearance and on experimental silicosis. A study in rats. Acta endocr. (Kbh.) 63, 313-324 (1970).

$[\mathrm{H} 20,084 / 70$

Göthe, C. J.: Effect of different doses of prednisolone and adrenocorticotrophic hormone (ACTH) on lymphatic lung clearance and on experimental silicosis. A study in rats. Acta endocr. (Kbh.) 63, 325-337 (1970).

$[\mathrm{H} 20,085 / 70$

Govier, W. C.: Reticuloendothelial cells as the site of sulfanilamide acetylation in the rabbit. J. Pharmacol. exp. Ther. 150, 305-308 (1965).

$[\mathrm{F} 57,820 / 65$

Govier, W. C., Lovenberg, W.: Induction of tyrosine aminotransferase by phentolamine. Biochem. Pharmacol. 18, 2667-2672 (1969).

[G 70,841/69

Grab, W.: Die funktionelle Bedeutung der Bauelemente der Schilddrüse. Naunyn-Schmiedebergs Arch. Pharmak. 172, 586-629 (1933).

$[44,536 / 33$

Grad, B., Leblond, C. P.: Role of the liver in the thyroxine metabolism of the albino rats. Proc. Canad. Physiol. Soc. 12th Ann. Meet. Laval Univ. Québec, 1948, p. 320-321.

$[\mathrm{B} 23,328 / 48$

Grad, B., Leblond, C. P.: Effect of thyroxine on oxygen consumption and heart rate follow- 
ing bile duct ligation and partial hepatectomy. Amer. J. Physiol. 162, 17-23 (1950).

$$
\text { [B 49,686/50 }
$$

Grafov, A. A.: The effect of ACTH on the clinical course of acute radiation sickness in hypophysectomized rats. (Russian text.) Probl. Endokr. Gormonoter. 8/2, 57-64 (1962).

[D20,890/62

Graham, A. B., Werder, A. A., Syverton, J. T., Friedman, J.: Synergistic effect of roentgen radiation and cortisone upon pathogenicity of Coxsackie virus. Fed. Proc. 11, 470 (1952).

$[\mathrm{B} 68,455 / 52$

Graham, J. B., Graham, R. M.: Pharmacological modification of resistance to radiation A preliminary report. Proc. nat. Acad. Sci. (Wash.) 35, 102-106 (1949). [A49,307/49 Graham, J. B., Graham, R. M.: The modification of resistance to ionizing radiation by humoral agents. Cancer (Philad.) 3, 709-717 (1950).

$[\mathrm{B} 58,164 / 50$

Graham, J. B., Graham, R. M., Graffeo, A. J.: The influence of adrenal cortical hormones on sensitivity of mice to ionizing radiations. Endocrinology 46, 434-440 (1950).

$[\mathrm{B} 48,335 / 50$

Graham, J. S.: Adrenal cortex and blood pressure response to carbon arc irradiation. Amer. J. Physiol. 139, 604-611 (1943).

[A61,343/43

Graham, W. D., Carmichael, E. J., Allmark, M. G.: The in vivo potentiation of barbiturates by tetraethylthiuram disulphide. J. Pharm. Pharmacol. 3, 497-500 (1951). [G77,527/51

Gram, T. E., Guarino, A. M., Greene, F. E., Gigon, P. L., Gillette, J. R.: Effect of partial hepatectomy on the responsiveness of microsomal enzymes and cytochrome P-450 to phenobarbital or 3-methylcholanthrene. Biochem. Pharmacol. 17, 1769-1778 (1968). [G62,231/68

Gram, T. E., Guarino, A. M., Schroeder, D. H., Gillette, J. R.: Changes in certain kinetic properties of hepatic microsomal aniline hydroxylase and ethylmorphine demethylase associated with postnatal development and maturation in male rats. Biochem. $J .113,681-685$ (1969).

$[\mathrm{G} 68,711 / 69$

Gran, F. C.: Structure and function of the endoplasmic reticulum in animal cells. FE BS Symp. Oslo (1967), 14, pp. 100 (1968). [G80,994/68

Grandpierre, R., Robert, A. M.: Inhibition de l'action oestrogénique par des extraits de foie. C. R. Soc. Biol. (Paris) 163, 1731-1733 (1969).

$[\mathrm{H} 22,252 / 69$
Grangaud, R., Conquy, T.: Vitamine A et progestérone. C. R. Soc. Biol. (Paris) 152, 1230-1234 (1958).

[G71,675/58

Grangaud, R., Conquy, T.: Effets de la progestérone administrée en injection à la femelle du rat blanc carencée en vitamine A. $C$. $R$. Acad. Sci. (Paris) 246, 3274-3277 (1958). $\mathrm{C} 71,751 / 58$

Grangaud, R., Conquy, T., Nicol, M.: Progestérone et accroissement pondéral chez la jeune ratte albinos carencée en vitamine A. C. $R$. Soc. Biol. (Paris) 153, 1327-1330 (1959).

$[\mathrm{C} 97,508 / 59$

Grangaud, R., Conquy, T., Nicol, M.: Action de la progestérone chez le rat mâle carencé en vitamine A. C. R. Soc. Biol. (Paris) 154, 115-118 (1960).

$[\mathrm{C} 88,406 / 60$

Grangaud, R., Conquy, T., Nicol, M.: Vitamine A et hormones stéroïdes. Arch. Sci. physiol. 14, 131-142 (1960).

$[\mathrm{C} 89,715 / 60$

Granitsas, A. N., Leathem, J. H.: Response of the rat kidney to steroids. Bull. Nat. Inst. Sci. India 19, 148-151 (1962). [D25,514/62 Granner, D. K., Hayashi, S. I., Thompson, E. B., Tomkins, G. M.: Stimulation of tyrosine aminotransferase synthesis by dexamethasone phosphate in cell culture. J. molec. Biol. 35, 291-301 (1968).

[H11,721/68

Grant, G., Roe, F. J. C., Pike, M. C.: Effect of neonatal thymectomy on the induction of papillomata and carcinomata by 3,4-benzopyrene in mice. Nature (Lond.) 210, 603-604 (1966).

$[\mathrm{F} 66,117 / 66$

Grassi, B., Cagianelli, M. A., Spremolla, G.: Rene e intossicazione sperimentale da tetracloruro di carbonio. Rilievi istologici in corso di trattamento prednisolonico e steroideo in ratti albini. Minerva nefrol. 6, 81-94 (1959).

[E58,693/59

Grassi, B., Spremolla, G.: Il fegato nella deplezione potassica. (Ricerche sperimentali in ratti albini.) Rass. Fisiopat. clin. ter. 36, 379-391 (1964).

[F 28,126/64

Graubard, M., Pincus, G.: The oxidation of estrogens by phenolases. Proc. nat. Acad. Sci. (Wash.) 149-152 (1941).

$[80,931 / 41$

Graul, E. H., Rüther, W.: The question of the efficiency of radiation-protection substances after exposure to fast neutrons. Proc. Int. Conf. Radiation Biology, Kyoto, p. 97-105 (1967). $[\mathrm{G} 66,718 / 67$

Gray, J. L., Moulden, E. J., Tew, J. T., Jensen, H.: Attempts to prevent or reduce radiation injury by pharmacological means. Fed. Proc. 11, 221 (1952).

$[\mathrm{B} 68,316 / 52$ 
Gray, J. L., Moulden, E. J., Tew, J. T., Jensen, H.: Protective effect of pitressin and of epinephrine against total body $\mathrm{x}$-irradiation. Proc. Soc. exp. Biol. (N.Y.), 79, 384-387 (1952).

$[\mathrm{B} 69,100 / 52$

Gray, J. L., Tew, J. T., Jensen, H.: Protective effect of serotonin and of p-aminopropiophenone against lethal doses of X-radiation. Proc. Soc. exp. Biol. (N.Y.) 80, 604-607 (1952).

[B92,332/52

Grayhack, J. T., Scott, W. W.: Observation on the in vivo inactivation of testosterone propionate by the liver of the white rat. Endocrinology 48, 453-461 (1951).

[B58,923/51 Grazia, A. di, Sardo, M.: Insulina e colpo di calore. Biochim. Terap. sper. 21, 176-184 (1934).

$[27,853 / 34$

Greaves, J. D., Schmidt, C. L. A.: Studies on the vitamin A requirements of the rat. Amer. J. Physiol. 116, 456-467 (1936). [A 48,725/36 Green, A. R., Curzon, G.: Decrease of 5-hydroxytryptamine in the brain provoked by hydrocortisone and its prevention by allopurinol. Nature (Lond.) 220, 1095-1097 (1968).

$[\mathrm{H} 5,891 / 68$

Green, D. M.: Mechanisms of desoxycorticosterone action: effects of liver passage. Endocrinology 43, 325-328 (1948).

$[\mathrm{B} 28,239 / 48$

Greenberg, J., Nadel, E. M., Coatney, G. R.: The influence of strain, sex and age of mice on infection with Plasmodium berghei. $J$. infect. Dis. 93, 96-100 (1953).

[G70,739/53

Greenberg, L. A.: Acetoin not a product of the metabolism of alcohol.Quart. J. Stud. Alcohol 3, 347-350 (1942).

[A 48,342/42

Greenberg, S. R.: Glomerular changes in chronic alloxan diabetes. Arch. Path. 73, 263-273 (1962).

[D 21,811/62

Greenberger, N. J., MacDermett, R. P., Martin, J. F., Dutta, S.: Intestinal absorption of six tritium-labeled digitalis glycosides in rats and guinea pigs. J. Pharmacol. exp. Ther. 167, 265 to 273 (1969).

$[\mathrm{H} 13,503 / 69$

Greene, A. E., Ambrus, J. L., Gershenfeld, L.: Effect of cortisone and desoxycorticosterone on infection with tetanus spores and upon the toxicity of tetanus toxin. Antibiot. and Chemother. 3, 1121-1124 (1953).

$[\mathrm{B} 94,257 / 53$

Greengard, 0., Feigelson, P.: Immunochemical evidence of increased liver tryptophan pyrrolase amounts following induction in vivo. Biochem. J. 84, 111P (1962). $\quad[\mathrm{G} 67,329 / 62$ Greengard, 0., Gordon, M.: The cofactormediated regulation of apoenzyme levels in animal tissues. I. The pyridoxine-induced rise of rat liver tyrosine transaminase level in vivo. J. Biol. Chem. 238, 3708-3710 (1963).

[G15,572/63

Greengard, 0., Smith, M. A., Aes, G.: Relation of cortisone and synthesis of ribonucleic acid to induced and developmental enzyme formation. J. biol. Chem. 238, 1548-1551 (1963).

$[\mathrm{D} 63,145 / 63$

Greengard, 0., Weber, G., Singhal, R. L.: Glycogen deposition in the liver induced by cortisone; dependence on enzyme synthesis. Science 141, 160-161 (1963). [E20,258/63 Greengard, P., Kalinsky, H., Manning, T. J., Zak, S. B.: Prevention and remission by adrenocortical steroids of nicotinamide deficiency disease. II. A study of the mechanism. J. biol. Chem. 243, 4216-4221 (1968).

$[\mathrm{G} 63,690 / 68$

Greengard, P., Quinn, G. P., Landrau, M. A., Hormonal effects on DPN concentration in rat liver. Biochim. biophys. Acta (Amst.) 47, 614-616 (1961).

[D 12,966/61

Greengard, P., Sigg, E. B., Fratta, I., Zak, S. B.: Prevention and remission by adrenocortical steroids of nicotinamide deficiency disorders and of 6-aminonicotinamide toxicity in rats and dogs. J. Pharmacol. exp. Ther. 154, 624-631 (1966).

$[\mathrm{F} 74,421 / 66$

Greenman, D. L., Wicks, W. D., Kenney, F. T.: Stimulation of ribonucleic acid synthesis by steroid hormones. II. High molecular weight components. J. biol. Chem. 240, 4420-4426 (1965).

$[\mathrm{G} 35,063 / 65$

Gregerman, R. I.: Estimation of thyroxine secretion rate in the rat by the radioactive thyroxine turnover technique: Influence of age, sex and exposure to cold. Endocrinology 72, 382-392 (1963).

[D57,876/63

Gregoriadis, G., Sourkes, T. L.: Regulation of hepatic copper in the rat by the adrenal gland. Canad. J. Biochem. 48, 160-163 (1970).

$[\mathrm{G} 72,808 / 70$

Gregorio, G. de, Armellini, C.: Proprietà cardiotrofiche di alcuni ormoni e principi enzimatici. Azione protettiva sulla cardiopatia sperimentale emetinica. Acta. med. ital. Med. trop. 19, 122-132 (1964).

$[\mathrm{G} 64,277 / 64$

Greig, A.: Massive doses of vitamin D. Vet. Rec. 75, 981 (1963).

$[\mathrm{G} 68,415 / 63$

Greig, M. E., Gibbons, A. J.: An antidote to cycloheximide (actidione) poisoning. Toxicol. appl. Pharmacol. 1, 598-601 (1959).

$[\mathrm{C} 94,626 / 59$ 
Greig, M. E., Gibbons, A. J., Elliott, G. A.: A comparison of the effects of melengestrol acetate and hydrocortisone acetate on experimental allergic encephalomyelitis in rats. J. Pharmacol. exp. Ther. 173, 85-93 (1970).

$[\mathrm{H} 24,654 / 70$

Greig, W. R., Crooks, J., Macgregor, A. G.o, McIntosh, J. A. R.: The radioprotective effect of methylthiouracil on the thyroid gland of the rat. Brit. J. Radiol. 38, 72-74 (1965).

$[\mathrm{E} 60,304 / 65$

Greim, H.: Toxizität und therapeutische Anwendbarkeit des DDT und seiner Metaboliten. Ärztl. Forsch. 24, 197-201 (1970).

$[\mathrm{G} 76,366 / 70$

Greim, H.: Therapeutische Möglichkeiten durch die Induzierbarkeit arzneimittelabbauender Enzyme. Dtsch. med. Wchschr. 95, 2196-2199 (1970).

$[\mathrm{H} 32,018 / 70$

Greisman, S. E., Woodward, C. L.: Mechanisms of endotoxin tolerance. VII. The role of the liver. J. Immunol. 105, 1468-1476 (1970).

$[\mathrm{G} 80,339 / 70$

Grella, P.: Ipofunzione corticosurrenalica da fluossimesterone. Attual. Ostet. Ginec. 9, 231-239 (1963).

[E21,538/63

Gresham, P. A., Pover, W. F. R.: Neuroendocrine reactions and the radiation-induced variations in rat intestinal alkaline ribonuclease levels. Radiat. Res. 34, 256-264 (1968).

$[\mathrm{G} 58,354 / 68$

Grether, I., Naugler, W. E., Kuzell, W. C.: The effect of phenylbutazone (Butazolidin) and cortisone acetate on gold toxicity. (Abstr.) Stanf. med. Bull. 10, 322 (1952). [C12,471/52

Greuel, H., Schäfer, E. L.: Die Bedeutung einer Vor-Behandlung mit ACTH, Cortison bzw. Doca für den Ablauf der experimentellen Meerschweinchentuberkulose. Z. Tuberk. 108, 321-326 (1956).

$[\mathrm{E} 54,859 / 56$

Grewe, H. E.: Experimentelle Untersuchungen der geschlechtsverschiedenen Wirksamkeit von Barbitursäurederivaten zur Narkose. Z. ges. exp. Med. 121, 497-502 (1953). [D35,140/53

Griffin, A. C., Richardson, H. L., Robertson, C. H., O'Neal, M. A., Spain, J. D.: The role of hormones in liver carcinogenesis. J. nat. Cancer Inst. 15, Sup., 1623-1628 (1955).

$[\mathrm{C} 14,406 / 55$

Griffin, A. C., Rinfret, A. P., Corsigilia, V. F.: The inhibition of liver carcinogenesis with 3methyl-4-dimethylaminoazobenzene in hypophysectomized rats. Cancer Res. 13, 77-79 (1953).

$[\mathrm{B} 77,163 / 53$
Griffin, M. J., Cox, R. P.: Studies on the mechanism of hormone induction of alkaline phosphatase in human cell cultures. II. Rate of enzyme synthesis and properties of base level and induced enzymes. Proc. nat. Acad. Sci. (Wash.) 56, 946-953 (1966). [ [F 86,851/66 Griffith, J. Q., Jr., Comroe, B. I.: Reduced tolerance to ergotamine tartrate in hyperthyroidism. An experimental study. J. Pharmacol. exp. Ther. 69, 34-36 (1940).

$[\mathrm{A33}, 738 / 40$

Griffith, W. H.: Choline metabolism. IV. The ralation of the age, weight and sex of young rats to the occurrence of hemorrhagic degeneration on a low choline diet. J. Nutr. 19, 437-448 (1940).

$[\mathrm{A33}, 347 / 40$

Grinnell, E. H., Johnson, J. R., Rhone, J. R., Tillotson, A., Noffsinger, J., Huffman, M. N.: Oestrogen protection against acute digitalis toxicity in dogs. Nature (Lond.) 190, 1117 to 1118 (1961).

[D 10,545/61

Grinnell, E. H., Smith, P. W.: Effect of estrogens on myocardial sensitivity to toxic effects of digoxin. Proc. Soc. exp. Biol. (N.Y.) 94, $524-526$ (1957).

$[\mathrm{C} 31,428 / 57$

Griswold, D. P., Jr., Green, C. H.: Observations on the hormone sensitivity of 7,12-dimethylbenz(a)anthracene-induced mammary tumors in the Sprague-Dawley rat. Cancer Res. 30, 819-826 (1970).

$[\mathrm{H} 26,709 / 70$

Grob, H. S., Gordon, A. S., Kupperman, H. S.: Estrogen-parathyroid extract interaction in the albino rat. In: The Endocrine Society, Program of 45th Meeting, p. 55 (1963).

[E $20,745 / 63$

Grognot, P., Senelar, R.: Etudes expérimentales sur les réactions histologiques précoses du poumon après inhalation d'oxygène. Rev. méd. Nancy 82, 925-931 (1957). [C41,294/57 Groppetti, A., Costa, E.: Factors affecting the rate of disappearance of amphetamine in rats. Int. J. Neuropharmacol. 8, 209-215 (1969).

[H31,959/69

Gross, A.: L'épine irritative broncho-pulmonaire dans l'asthme (étude expérimentale). Gaz. Hôp. (Paris) 127, 953-956 (1955).

$[\mathrm{C} 30,649 / 55$

Grossman, A., Boctor, A. M., Lane, B.: Dependence of pancreatic integrity on adrenal and ovarian secretions. Endocrinology 85, 956-959 (1969).

$[\mathrm{H} 18,545 / 69$

Grossman, A., Mavrides, C.: Studies on the regulation of tyrosine aminotransferase in rats. J. biol. Chem. 242, 1398-1405 (1967).

[G46,206/67 
Grossman, M. S., Penrod, K. E.: The thyroid and high oxygen poisoning in rats. Amer. $J$. Physiol. 156, 182-184 (1949). [B36,303/49

Groza, P., Buzoianu, V., Constantineseu, F., Ionescu, S.: Actiunea aldosteronului asupra ulcerului experimental atofanic. Stud. Cercet. Fiziol. 13, 391-395 (1968). [H6,695/68

Gruber, C. M., Crawiord, W. M., Greene, W. W., Drayer, C. S.: The effect of sodium phenobarbital and the antagonism of morphine to phenobarbital and to pituitary extract in intact intestine in non-anesthetized dogs. J. Pharmacol. exp. Ther. 42, 27-34 (1931). $\quad[2,199 / 31$

Gruber, C. M., Jr., Lashichenko, Z., Lee, K. S.: The effect of orally administered antabuse on the sleeping time of mice, rats, and rabbits given barbiturates, ether, chloroform, urethane, chloral hydrate, alcohol, or acetaldehyde by injection. Arch. int. Pharmacodyn. 97, $79-97$ (1954).

[D $41,363 / 54$

Grunberg, E., Titsworth, E.: The effect of cortisone on infection of white mice with Histoplasma capsulatum. Amer. Rev. resp. Dis. 87, 911-913 (1963).

[D 67,985/63

Grunert, R. R., Phillips, P. H.: Sodium and its relation to alloxan diabetes and glutathione. J. biol. Chem. 181, 821-827 (1949).

[B 48,993/49

Grunt, J. A., Higgins, J. T., Jr., Hammond, C. B.: Effects of ethionine on neonatally castrated male rats. J. Nutr. 70, 459-462 (1960).

$[\mathrm{C} 84,696 / 60$

Grushina, A. A., Sorkina, J. A., Presnova, Z. F.: Effect of desoxycorticosterone on antitumor activity of thiophosphamide in intact and adrenalectomized rats with sarcoma 45 . (Russian text.) Vop. Onkol. 15/2, 61-65 (1969).

[H31,216/69

Gualandi, G., Lusiani, G. B., Pederzini, A.: Castrazione e ateromasia sperimentale nel ratto albino. 52e Congr. Soc. ital. Med. intern. Roma, Ott., p. 6 (1951).

$[\mathrm{C} 7,736 / 51$

Guarino, A. M., Gram, T. E., Schroeder, D. H., Call, J. B., Gillette, J. R.: Alterations in kinetic constants for hepatic microsomal aniline hydroxylase and ethylmorphine $\mathrm{N}$-demethylase associated with pregnancy in rats. $J$. Pharmacol. exp. Ther. 168, 224-228 (1969). [H15,843/69

Guérois, M. F. M., De Oliveira, H. L., Da Silva, A. C.: Ação agravante da cortisone na lesão hepática produzida pelo tetracloreto de carbone. Rev. Hosp. Clin. 11, 101-106 (1957).
Guerra, L., Siccardi, A.: Il ricambio delle catecolamine nel fegato sottoposto a mutilazioni chirurgiche. Arch. De Vecchi Anat. pat. 37, 789 -798 (1962).

[D 69,656/62

Guerrero, S., Gallardo, A., Munoz, C.: Influencia de las gonadas sobre la diferencia sexual en la resistencia a los efectos tóxicos de la cocaina en ratas. Arch. Biol. Med. exp. (Santiago) 2, $51-54$ (1965).

[F 70,995/65

Guillermand, J., Duché, G., Falcoz, J.: L'apport de l'hormone somatotrope hypophysaire dans le traitement de la tuberculose pulmonaire. Rev. Tuberc. (Paris) 19, 1386-1391 (1955).

$[\mathrm{C} 15,540 / 55$

Gunn, S. A., Gould, T. C., Anderson, W. A. D.: Protective effect of estrogen against vascular damage to the testis caused by cadmium. Proc. Soc. exp. Biol. (N.Y.) 119, 901-905 (1965).

[F 46,162/65

Günther, G., Hübner, K., Schneider, E.: Die quantitative Bedeutung der Mitosen beim kompensatorischen Wachstum der Leber und der Nebennierenrinde. Beitr. pathol. Anat. 139, 261-274 (1969).

[H18,480/69

Gupta, D. das, Giroud, C. J. P.: Effect of an aldosterone antagonist on the fluid retention of aminonucleoside nephrosis. Endocrinology, 65, 500-503 (1959).

[C73,800/59

Guttman, P. H.: Effect of thymectomy and splenectomy on the course of $\mathrm{X}$-ray induced progressive intercapillary glomerulosclerosis in the mouse kidney. Int. Arch. Allergy 31, 163-173 (1967).

[G45,255/67

Guze, L. B., Beeson, P. B.: The effect of cortisone on experimental hydronephrosis following ureteral ligation. J. Urol. (Baltimore) 78, 337-342 (1957).

[C43,020/57

Gwee, M. C. E., Lim, H. S.: An interaction between hydrocortisone and hemicholiniums in mice. J. Pharm. Pharmacol. 23, 63-64 (1971).

[G81,043/71

Gyermek, L., Pataky, G.: Die Wirkung des Histamins auf den Stoffwechsel. Acta. physiol. Hung. 2, 179-188 (1950).

[B 65,706/50

György, P.: Inactivation of estrone by liver. Assay method in vivo for dietary hepatic injury in rats. Proc. Soc. exp. Biol. (N.Y.) 60, 344-349 (1945).

[E $86,573 / 45$

György, P., Goldblatt, H.: Thiouracil in the prevention of experimental dietary cirrhosis of liver. Science 102, $451-452$ (1945).

[G71,898/45

György, P., Rose, C. S.: The lipotropic effect of estrogenic hormones in inbred rats. Proc. Soc. exp. Biol. (N.Y.) 71, 552-555 (1949).

$[\mathrm{A} 48,519 / 49$ 
György, P., Rose, C. S., Goldblatt, H.: Prevention of experimental dietary hepatic cirrhosis by goitrogenic substances. Proc. Soc. exp. Biol. (N.Y.) 67, 67-70 (1948). [G71,701/48 György, P., Rose, C. S., Shipley, R. A.: Activity of estrone as a lipotropic factor. Arch. Biochem. 12, 125-133 (1947).

[A47,909/47

György, P., Rose, C. S., Shipley, R. A.: The effect of steroid hormones on the fatty liver induced in rats by dietary means. Arch. Biochem. 21, 108-118 (1949). [D77,819/49

György, P., Seifter, J., Tomarelli, R. M., Goldblatt, H.: Influence of dietary factors and sex on the toxicity of carbon tatrachloride in rats. J. exp. Med. 83, 449-462 (1946). [E 86,574/46

Haam, E. von, Rosenfeld, I.: The effect of the various sex hormones upon experimental pneumococcus infections in mice. J. infect. Dis. 70, 243-247 (1942).

[A 44,924/42

Haas, J.: Die Corticosteroidtherapie nach Intoxikation mit Schlangengiften, sowie eigene Beobachtungen bei der Behandlung eines Bisses von Bothrops nasutus. Z. Tropenmed. Parasit. 17, 26-35 (1966). [G38,758/66

Haber, M. H., Jennings, R. B.: Sex differences in renal toxicity of mercury in the rat. Nature (Lond.) 201, 1235-1236 (1964). [G10,684/64

Hagan, E. C., Woodard, G.: Toxicological properties of hexaethyl tetraphosphate (Abstr.). Fed. Proc. 6, 335 (1947). [A48,819/47

Hagen, A. A., Troop, R. C.: Influence of age, sex and adrenocortical status on hepatic reduction of cortisone in vitro. Endocrinology 67, 194-203 (1960).

[G77,512/60

Hager, C. B., Kenney, F. T.: Regulation of tyrosine- $\alpha$-ketoglutarate transaminase in rat liver. VII. Hormonal effects on synthesis in the isolated, perfused liver. J. biol. Chem. 243, 3296-3300 (1968).

[G58,950/68

Hagino, N., Ramaley, J. A., Gorski, R. A.: Inhibition of estrogen-induced precocious ovulation by pentobarbital in the rat. Endocrinology 79, 451-454 (1966).

$[\mathrm{F} 69,360 / 66$

Hahn, P., Koldovský, O.: Development of metabolic processes and their adaptations during postnatal life. In: Bajusz; Physiology and Pathology of Adaptation Mechanisms: Neural-Neuroendocrine-Humoral, p. 48-73. Oxford, London, Edingburgh: Pergamon Press 1969.

$[\mathrm{E} 8,164 / 69$

Hahn, T. J., Birge, S. J., Scharp, S. C., Avioli, L. V.: Vitamin D metabolism and phenobarbital therapy. (Abstr.) Clin. Res. 19, 50 (1971).

[H34,347/71
Hajdu, A., Chappel, C. I., Rona, G.: The influence of estrogens on scorbutic bone lesions in guinea-pigs. Experientia (Basel) 21, 466 (1965).

[G32,889/65

Hakstian, R. W., Hampson, L. G., Gurd, F. N.: Pharmacological agents in experimental hemorrhagic shock. A controlled comparison of treatment with hydralazine, hydrocortisone, and levarterenol (l-Norepinephrine). Arch. Surg. 83, 335-347 (1961). [D 10,396/61

Halac, E., Jr., Sicignano, C.: Re-evaluation of the influence of sex, age, pregnancy, and phenobarbital on the activity of UDP-glucuronyl transferase in rat liver. J. Lab. clin. Med. 73, 677-685 (1969).

[G77,576/69

Halberg, F., Spink, W. W., Bittner, J. J.: Protection by aldosterone and 11,17-oxycorticoids against effects of Brucella somatic antigen in adrenalectomized mice. Endocrinology 59, 380-383 (1956).

$[\mathrm{G} 68,353 / 56$

Haldane, J. S.: Respiration. New Haven: Yale University Press 1922.

$[\mathrm{E} 715 / 22$

Hale, H. B.: Cross-adaptation. Environm. Res. 2, 423-434 (1969).

$[\mathrm{G} 72,522 / 69$

Hale, H. B., Mefferd, R. B., Jr.: Effects of adrenocorticotropin on temperature- and pressure-dependent metabolic functions. Amer. $J$. Physiol. 197, 1291-1296 (1959). [C79,669/59

Haley, T. J., Flesher, A. M., Komesu, N.: Muscle fatigue in $\mathrm{X}$-irradiated rats (Abstr.). Fed. Proc. 17, 374 (1958). [ [C51,851/58

Haley, T. J., Mann, S., Dowdy, A. H.: A comparison of the response of normal and hypothyroid mice to acute whole body roentgen radiation. Science 112, 333-334 (1950).

[B49,990/50

Haley, T. J., Mann, S., Dowdy, A. H.: The effect of reontgen ray irradiation on normal, hypothyroid and hyperthyroid rats. Endocrinology 48, 365-369 (1951). [B [B58,913/51

Haley, T. J., Mann, S., Dowdy, A. H.: The inability of thiourea to modify roentgen ray irradiation mortality in rats. Science 114, 153-154 (1951).

$[\mathrm{B} 60,616 / 51$

Haley, T. J., Mann, S., Dowdy, A. H.: The effect of roentgen ray irradiation on rats premedicated with thyroxin and thiouracil derivatives. J. Amer. pharm. Ass. sci. Ed. 41, $39-41$ (1952).

$[\mathrm{G} 71,834 / 52$

Halmagyi, D. F. J., Starzecki, B., Horner, G. J.: Mechanism and pharmacology of endotoxin shock in sheep. J. appl. Physiol. 18, 544-552 (1963).

$[\mathrm{D} 68,121 / 63$ 
Halmagyi, D. F. J., Starzecki, B., Horner, G. J.: Mechanism and pharmacology of shock due to rattlesnake venom in sheep. J. appl. Physiol. 20, 709-718 (1965).

[G31,584/65

Halpern, B. N., Drudi-Baraceo, C., Bessirard, D.: Exaltation de la toxicité de l'amphétamine par la DL-thyroxine. C. R. Soc. Biol. (Paris) 157, 1879-1882 (1963).

$[\mathrm{G} 11,305 / 63$

Halpern, B. N., Drudi-Baraceo, C., Bessirard, D.: Aggravation par la thyroxine des réactions émotionelles induites par des amines sympathomimétiques et objectivées par la 'toxicité de groupe'. C. R. Acad. Sci. (Paris) 257, 1641-1643 (1963).

[G63,588/63

Halpern, B. N., Drudi-Baraceo, C., Bessirard, D.: Exaltation de la toxicité absolue de certaines amines sympathomimétiques par la thyroxine. C. R. Acad. Sci (Paris) 257, 1559-1562 (1963).

$[\mathrm{G} 67,689 / 63$

Halpern, B. N., Drudi-Baraceo, C., Bessirard, D.: Exaltation of toxicity of sympathomimetic amines by thyroxine. Nature (Lond.) 204, 387-388 (1964).

[F 24,137/64

Halpern, B. N., Drudi-Baraceo, C., Bessirard, D.: Potentialisation de la toxicité absolue et de la toxicité de groupe de la L-éphédrine par la thyroxine. C. R. Soc. Biol. (Paris) 158, 1284-1289 (1964).

[F 27,643/64

Hamburgh, M., Lynn, E.: The influence of temperature on skeletal maturation of hypothyroid rats. Anat. Rec. 150, 163-171 (1964).

[G21,782/64

Hamburgh, M., Vicari, E.: Physiological mechanisms underlying susceptibility to audiogenic seizures in mice. Anat. Rec. 132, 450 (1958).

$[\mathrm{C} 71,704 / 58$

Hamburgh, M., Vicari, E.: A study of some physiological mechanisms underlying susceptibility to audiogenic seizures in mice. $J$. Neuropath. exp. Neurol. 19, 461-472 (1960).

[D11,010/60

Hamilton, K. F., Sacher, G. A., Grahn, D.: A sex difference in mouse survival under daily gamma irradiation and its modification by gonadectomy. Radiat. Res. 18, 12-16 (1963).

[D $64,060 / 63$

Hammer, W., Sjöqvist, F.: Plasma levels of monomethylated tricyclic antidepressants during treatment with imipramine-like compounds. Life Sci. 6, 1895-1903 (1967). [G79,581/67

Hámori, A., Nemes, T., Hal, T.: Effect of prednisolone on the development of cinchophen ulcer in the dog. Acta med. Acad. Sci. hung. 25, 315-321 (1968).

$[\mathrm{G} 65,054 / 68$
Hámori, A., Nemes, T., Illyés, T.: Effect of desoxycorticosterone acetate and cortisone on the development of cinchophen ulcer in the dog. Acta med. Acad. Sci. hung. 26, 391-395 (1969).

$[\mathrm{G} 72,363 / 69$

Hamprecht, B.: Regulation der CholesterolSynthese. Naturwissenschaften 56, 398-405 (1969).

$[\mathrm{G} 69,560 / 69$

Hamre, C. J., Yaeger, V. L.: Influence of cortisone acetate on formation of exostoses by rats fed Lathyrus odoratus. Anat. Rec. 124, 405 to 406 (1956).

$[\mathrm{D} 76,147 / 56$

Hänninen, 0., Hartiala, K.: The induction of liver tyrosine 2-oxoglutarate transaminase in rats by immobilization. Acta endocr. (Kbh.) 54, 85-90 (1967).

[F76,119/67

Hannon, J. P., Larson, A. M.: The site and mechanism of norepinephrine-calorigenesis in the cold acclimatised rat. Fed. Proc. 20, 209 (1961).

$[\mathrm{D} 4,112 / 61$

Hanssler, H.: Über den Einfluß der Nebennierenrinde auf das Knochenwachstum Vitamin D-frei ernährter Ratten. Klin. Wschr. 34, 646-647 (1956).

$[\mathrm{C} 18,293 / 56$

Hanssler, H.: Experimentelle Untersuchungen über die Rachitisbeeinflussung durch Nebennierenrinden-Hormone. Z. ges. exp. Med. 128, $76-86$ (1956).

$[\mathrm{C} 45,007 / 56$

Hanzlik, P. J.: A study of the toxicity of the salicylates based on clinical statistics. J. Amer. med. Ass. 60, 957 (1913).

$[\mathrm{A} 49,483 / 13$

Hanzlik, P. J., Karsner, H. T.: A comparison of the prophylactic effects of atropine and epinephrine in anaphylactic shock and anaphylactoid phenomena from various colloids and arsphenamine. J. Pharmacol. exp. Ther. XIV, $425-447$ (1920).

$[10,286 / 20$

Haque, M. E., Lillie, R. J., Shaffner, C. S., Briggs, G. M.: Effects of vitamin deficiencies in New Hampshire chicks injected with high doses of thyroxine. Endocrinology 42, 273-278 (1948).

$[B 19,204 / 48$

Harada, T., Okuda, H., Fujii, S.: Effect of citrate on acyl-CoA synthetase of rat liver. $J$. Biochem. (Tokyo) 65, 497-501 (1969).

$[\mathrm{H} 15,156 / 69$

Harbison, R. D., Becker, B. A.: Barbiturate mortality in hypothyroid and hyperthyroid rats. J. pharm. Sci. 58, 183-185 (1969).

[H10,917/69

Harding, H. R., Potts, G. 0.: The anticatabolic activity of anabolic steroids based on the suppression of cortisone acetate (EAc) induc- 
tion of liver tryptophan pyrrolase (TPO). Excerpta med. (Amst.) No. 99, E155 (1965).

[F 55,311/65

Harding, H. R., Rosen, F., Nichol, C. A.: Inhibition of hepatic alanine transaminase activity in response to treatment with 11-desoxycorticosterone. Proc. Soc. exp. Biol. (N.Y.) 108, 96-99 (1961).

[D 14,355/61

Hardinge, M., Peterson, D. I.: The effects of exercise and limitation of movement on amphetamine toxicity. J. Pharmacol. exp. Ther. 141, 260-265 (1963).

$[\mathrm{E} 26,072 / 63$

Hargreaves, T., Holton, J. B.: Jaundice of the newborn due to novobiocin. Lancet 1962 I, 839.

[H30,986/62

Hargreaves, T., Lathe, G. H.: Inhibitory aspects of bile secretion. Nature (Lond.) 200, 1172-1176 (1963).

[G81,289/63

Hári, P.: Beiträge zur Physiologie der Schilddrüse. Eine kritische Studie. Pflügers Arch. ges. Physiol. 176, 123-167 (1919). [51,049/19 Hári, P.: Entgegnung auf G. Mansfelds Abwehr, p. 32. Esztergom, Ungarn: Gustav Buzarovits 1921 .

$[40,209 / 21$

Harke, H. P., Frahm, B., Schultz, C., Dontenwill, W.: Abbau von Nikotin bei Hamster und Ratte. Biochem. Pharmacol. 19, 495-498 (1970).

$[\mathrm{G} 73,847 / 70$

Harkness, R. D.: Changes in the liver of the rat after partial hepatectomy. J. Physiol. (Lond.) 117, 267-277 (1952).

$[\mathrm{E} 80,279 / 52$

Harkness, R. D.: Regeneration of liver. Brit. med. Bull. 13, 87-93 (1957). [E57,419/57

Harman, D.: Atherosclerosis: effect of antiinflammatory steroids prednisone and dexamethasone. Circulation 32, Sup. 2, II-16 (1965).

[F 59,112/65

Harris, C.: The role of the adrenal in toxicity in rats caused by dimethylbenzanthracene. Cancer Res. 28, 764-768 (1968). [F98,166/68

Harrison, H. C., Harrison, H. E., Park, E. A.: Vit. D and citrate metabolism. Inhibition of Vit. D effect by cortisol. Proc. Soc. exp. Biol. (N.Y.) 96, 768-773 (1957). [C45,829/57

Hart, L. G., Adamson, R. H.: Effect of microsomal enzyme modifiers on toxicity and therapeutic activity of cyclophosphamide in mice. Arch. int. Pharmacodyn. 180, 391-401 (1969).

$[\mathrm{G} 69,481 / 69$

Hart, L. G., Adamson, R. H., Dixon, R. L., Fouts, J. R.: Stimulation of hepatic microsomal drug metabolism in the newborn and fetal rabbit. J. Pharmacol. exp. Ther. 137, 103-106 (1962).

[D27,689/62
Hart, L. G., Fouts, J. R.: Studies of the possible mechanisms by which chlordane stimulates hepatic microsomal drug metabolism in the rat. Biochem. Pharmacol. 14, 263-272 (1965).

[G27,102/65

Hart, L. G., Shultice, R. W., Fouts, J. R.: Stimulatory effects of chlordane on hepatic microsomal drug metabolism in the rat. Toxicol. appl. Pharmacol. 5, 371-386 (1963).

[G69,761/63

Hartshorn, E. A.: Drug interaction. 2. How drugs interact. Drug Intelligence 2, 58-65 (1968).

[G78,178/68

Hartshorn, E. A.: Drug interaction. I. General considerations. Drug Intelligence 2, 4-7 (1968).

$[\mathrm{G} 81,056 / 68$

Hartshorn, E. A.: Drug interaction. Drug Intelligence 2, 174-180 (1968).

[G81,057/68

Hartshorn, E. A.: Drug interactions. III. Classes of drugs and their interactions. Anti-infective agents. Part two. Drug Intelligence 3, 131 to 137 (1969).

[G81,055/69

Hartveit, F., Andersen, K.: Reticuloendothelial activity related to age and sex in mice. Acta path. microbiol. scand. 76, 161-163 (1969).

$[\mathrm{G} 67,345 / 69$

Hasegawa, A. T., Landahl, H. D.: Studies on spleen oxygen tension and radioprotection in mice with hypoxia, serotonin, and p-aminopropiophenone. Radiat. Res. 31, 389-399 (1967).

$[\mathrm{G} 48,428 / 67$

Hass, G. M., Henson, D. E., Scott, R. A., MeClain, E. C., Hemmens, A.: Influence of cirrhosis on production of atheroarteriosclerosis and thromboarteritis with vitamin $\mathrm{D}$ and dietary cholesterol. Amer. J. Path. 57, 405 to 429 (1969).

[H $19,697 / 69$

Hasselblatt, A., Bastian, G.: Vergleichende Untersuchungen über die krampferregende Wirkung von Insulin und $\mathrm{N}_{1}$-(4-Methyl-benzolsulfonyl)- $\mathrm{N}_{2}$-butylharnstoff an der Maus unter normalen und nach einer Behandlung mit Thyroxin veränderten Stoffwechselverhältnissen. Arzneimittel-Forsch. 8, 590-594 (1958).

$[\mathrm{C} 59,171 / 58$

Hasselblatt, A., Hukuhara, T.: Beeinflussung der Elimination von Bromsulphalein (Leberfunktionstest) durch Tolbutamid. NaunynSchmiedebergs Arch. Pharmak. 243, 307-308 (1962).

$[\mathrm{G} 77,523 / 62$

Hässler, A., Bräunlich, H., Ankermann, H.: Die Bedeutung der Aufzuchtbedingungen für die Wirkungsdauer von Hexobarbital und 
deren individuelle Variation bei Ratten. Acta biol. med. Germanica 23, 831-842 (1969).

$[\mathrm{H} 23,853 / 69$

Hay, E. C.: Hepato- and nephrotoxic effect of glycine. Fed. Proc. 6, 26 (1947). [93,491/47 Hayaishi, 0.: Enzymic hydroxylation. Ann. Rev. Biochem. 38, 21-44 (1969). [H13,776/69

Hayakawa, T., Kanai, N., Yamada, R., Kuroda, R., Higashi, H., Mogami, H., Jinnai, D.: Effect of steroid hormone on activation of endoxan (cyclophosphamide). Biochem. Pharmacol. 18, 129-135 (1969).

[G64,146/69

Hayasaka, H., Howard, J. M.: Mechanism of action of D-aldosterone in endotoxin shock. Surgery 54, 761-763 (1963). [E31,136/63

Hayasaka, H., Howard, J. M.: Studies on the mechanism of action of aldosterone in endotoxic shock. Surg. Forum 14, 23-24 (1963).

[G10,112/63

Hayasaka, H., 0'Malley, J. F., Howard, J. M.: Antitoxic effect of aldosterone on cats in endotoxic shock. Further studies. Arch. Surg. 87, 861-865 (1963).

[E31,522/63

Hayasaki, N., Tsukada, K.: Increased activity of deoxyribonuclease inhibitor in rat serum after partial hepatectomy. Biochim. biophys. Acta (Amst.) 204, 255-256 (1970).

[G73,554/70

Hayashida, T.: Effect of pituitary adrenocorticotropic and growth hormones on the resistance of rats infected with Pasteurella pestis. J. exp. Med. 106, 127-143 (1957).

$[\mathrm{C} 37,366 / 57$

Hayashida, T., Li, C. H.: The influence of adrenocorticotropic and growth hormones on antibody formation. J. exp. Med. 105, 93-98 (1957).

$[\mathrm{C} 29,987 / 57$

Haydu, G. G., Wolfson, A. H.: Effect of temperature extremes and cortisone on toxicity of diphosphopyridine nucleotide in mice. Proc. Soc. exp. Biol. (N.Y.) 102, 325-327 (1959).

$[\mathrm{C} 77,942 / 59$

Hayes, W. J., Jr.: The pharmacology and toxicology of DDT. In: Müller; The Insecticide $D D T$ and its Significance. Basel: Birkhäuser vol. 2,59 .

[E 53,090/59

Hayes, W. J., Jr., Dale, W. E., Pirkle, C. I.: Evidence of safety of long-term, high, oral doses of DDT for men. A.M. A. Arch. environm. Hlth. 22, 119-135 (1971).

[G80,268/71

Heaney, R. P., Whedon, G. D.: Impairment of hepatic bromsulphalein clearance by two 17 substituted testosterones. J. Lab. Clin. Med. 52, 169-175 (1958).

$[\mathrm{C} 56,394 / 58$
Heather, A. J.: Treatment of osteoporosis with an anabolic compound and L-lysine. Delaware med. J. 35, 245-249 (1963).

$[\mathrm{G} 67,332 / 63$

Heboyan, M., Messeri, E.: Variazioni immunitarie in ratti tenuti a dieta normale e a dieta di Handler, vaccinati con salmonella typhi e trattati con 4-idrossi-19 nortestosterone-17 ciclopentil propionato. Rass. ital. Gastroent. 8, $590-598$ (1962).

[G69,057/62

Hedwall, P., Heeg, E.: Die Beeinflussung einer Staphylokokken-Infektion der Rattenniere durch Analgetica. Arzneimittel-Forsch. 11, 909-912 (1961). [D 14,804/61

Heikel, T. A. J.: Effect of steroid drugs on biliary secretion: intrahepatic cholestasis. Biochem. J. 103, 63 P-64P (1967). [G81,287/67

Heikel, T. A. J., Lathe, G. H.: The effect of oral contraceptive steroids on bile secretion and bilirubin Tm in rats. Brit. J. Pharmacol. 38, 593-601 (1970).

[G73,162/70

Heim, W. G., Ellenson, S. R.: Adrenal cortical control of the appearance of rat slow alpha $a_{2}$. globulin. Nature (Lond.) 213, 1260-1261 (1967).

$[\mathrm{F} 77,887 / 67$

Heim, W. G., Kerrigan, J. M.: Appearance of slow $\alpha_{2}$-globulin after interference with the liver. Nature (Lond.) 199, 1100-1101 (1963).

$[\mathrm{G} 68,369 / 63$

Heiman, R., Heuson, J. C., Coune, A.: Tumors developing in oophorectomized Sprague-Dawley rats after a single gastric instillation of 7,12dimethylbenz(a)anthracene. Cancer Res. 28, 309-313 (1968).

[F 95,958/68

Heimburg, A. von, Schmidt, L.: Experimenteller Beitrag zur Klärung der verschiedenen Widerstandskraft männlicher und weiblicher Ratten gegen die chronische Quecksilber-Vergiftung. Arzneimittel-Forsch. 9, 321-324 (1959).

$[\mathrm{C} 69,587 / 59$

Heinonem, J., Takki, S., Jarho, L.: Plasma lidocaine levels in patients treated with potential inducers of microsomal enzymes. Acta anaesth. scand. 14, 89-95 (1970). [G80,898/70

Heinrichs, W. L., Colas, A.: The selective stimulation, inhibition and physicochemical alteration of the 7- and 16a-hydroxylases of $3 \beta$-hydroxyandrost-5-en-17-one and drugmetabolizing enzymes in hepatic microsomal fractions. Biochemistry 7, 2273-2280 (1968).

$[\mathrm{H} 11,717 / 68$

Heinrichs, W. L., Feder, H. H., Colas, A.: The steroid $16 a$-hydroxylase system in mammalian liver. Steroids 7, 91-98 (1966). [F 72,860/66 
Helfenstein, J. E., Young, S.: Effect of 2methyl-1,2-bis-(3-pyridyl)-1-propanone (metyrapone) on the production of mammary tumours induced in rats by oral feeding with dimethylbenzanthracene. Nature (Lond.) 200, 1113-1114 (1963).

[G76,331/63

Heller, B., Saavedra, J. M., Fischer, E.: Influence of adrenergic blocking agents upon morphine and catecholamine analgesic effect. Experientia (Basel) 24, 804-805 (1968).

$[\mathrm{H} 2,707 / 68$

Heller, B., Saavedra, J. M., Lumbreras, N. de L. A.: Les relations entre mécanismes adrénergiques et effets analgésiques. C. R. Soc. Biol. (Paris) 162, 2025-2026 (1968). [H 13,896/68 Heller, C. G.: Metabolism of the estrogens. The effect of liver and uterus upon estrone, estradiol and estriol. Endocrinology 26, 619-630 (1940).

$[\mathrm{A} 32,137 / 40$

Heller, J. H., Meier, R. M., Zucker, R., Mast, G. W.: The effect of natural and synthetic estrogens on reticuloendothelial system function. Endocrinology 61, 235-241 (1957).

$[\mathrm{C} 40,073 / 57$

Hellman, L., Weitzman, E. D., Roffwarg, H., Fukushima, D. K., Yoshida, K., Zumoff, B., Gallagher, T. F.: Effect of o,p'-DDD on cortisol secretory pattern in Cushing's syndrome. $J$. clin. Endocr. 31, 227-230 (1970). [H28,347/70 Hellman, L., Zumoif, B., Fishman, J., Gallagher, T. F.: Estradiol metabolism in total extrahepatic biliary obstruction. J. clin. Endocr. 30, 161-165 (1970). [H21,323/70 Hemingway, J. T., Cater, D. B.: Effects of pituitary hormones and cortisone upon liver regeneration in the hypophysectomized rat. Nature (Lond.) 181, 1065-1066 (1958).

$[\mathrm{C} 56,780 / 58$

Hempel, R.: Der Einfluß eines Antiandrogens auf die Schlafdauer männlicher und weiblicher Mäuse und Ratten nach Hexobarbitalgabe. Naunyn-Schmiedebergs Arch. Pharmak. 257, 27 (1967).

[F 84,763/67

Hempel, R.: Zur hormonellen Beeinflussung des Hexobarbitalschlafes der Ratte. NaunynSchmiedebergs Arch. Pharmak. 259, 413-418 (1968).

[G57,828/68

Henane, R.: Effet d'inhibiteur de l'aldostérone sur l'épuisement musculaire en ambiance chaude. C. R. Soc. Biol. (Paris) 159, 878-881 (1965).

[F 52,022/65

Henane, R., Laurent, F.: Nouvelles observations sur l'inhibition de l'aldostérone, lors de l'acclimatement à la chaleur, chez le rat blanc. C. R. Soc. Biol. (Paris) 160, $733-736$ (1966). [F71,731/66
Henderson, P. T., Kersten, K. J.: Metabolism of drugs during rat liver regeneration. Biochem. Pharmacol. 19, 2343-2351 (1970).

$[\mathrm{G} 77,181 / 70$

Henneman, D.: Estradiol inhibition of lathyritic effect of nitriles on skin and bone collagen (Abstr.). Program 51st Meet. Endocr. Soc., New York, N.Y., p. 106 (1969). [H12,251/69 Henriques, 0. B., Henriques, S. B., DeGrandpré, R., Selye, H.: Influence of amino-acids on adrenal enlargement, nephrosclerosis and hypertension by anterior pituitary preparations. Proc. Soc. exp. Biol. (N.Y.) 69, 591-593 (1948).

[B24,140/48

Henry, B., Fahlberg, W. J.: The potentiating effect of hydrocortisone acetate and tetracycline on monilial infection in mice. Antibiot. and Chemother. 10, 114-120 (1960).

$[\mathrm{C} 81,623 / 60$

Henschler, D., Jacob, K. 0.: Prednisolon zur Therapie von Reizgaslungenödemen. Klin. Wschr. 36, 684 (1958). [C56,126/58

Henschler, D., Reich, E.: Zum Mechanismus der ödemhemmenden Wirkung von Prednisolon bei toxischen Lungenödemen. Klin. Wschr. 37, 716-717 (1959).

$[\mathrm{C} 71,216 / 59$

Hepler, 0. E., Simonds, J. P.: Mechanism of shock. Effects of intravenous injection of salt solution in collapse induced by mechanical impounding of blood in the splanchnic region in normal and in hyperthyroid dogs. Arch. Path. 25, 149-159 (1938).

[A 15,174/38

Herbert, I. V., Becker, E. R.: Effect of cortisone and $\mathrm{X}$-irradiation on the course of Trypanosoma lewisi infection in the rat. J. Parasit. 47, 304-308 (1961).

$[\mathrm{G} 63,454 / 61$

Herbeuval, R., Debry, G., Cuny, G.: Action de l'acétate de testostérone sur la septicémie à staphylocoque doré du lapin. Ann. Endocr. (Paris) 19, 408-411 (1958). [C55,674/58

Herbeuval, R., Debry, G., Cuny, G.: Influence de l'extrait somatotrope sur la septicémie à staphylocoque doré du lapin. Ann. Endocr. (Paris) 19, 412-417 (1958). [C55,675/58

Herbeuval, R., Debry, G., Cuny, G.: Influence de la cortisone et de la désoxycorticostérone sur la septicémie à staphylocoque doré du lapin. Ann. Endocr. (Paris) 19, 418-427 (1958).

$[\mathrm{C} 55,676 / 58$

Herken, H., Maibauer, D., Neubert, D.: Der Einfluß von Äthionin und anderen Lebergiften auf Fermentsysteme der Lebermikrosomen. Naunyn-Schmiedebergs Arch. Pharmak. 233, 139-150 (1958). 
Herken, H., Senft, G., Schwarz, W., Merker, H.: Glomerular structure and function after glucocorticoid action in nephrosis induced by aminonucleoside. Arch. Exp. Path. Pharmak. 245/2, 289-304 (1963).

$[\mathrm{G} 15,041 / 63$

Herlant, M.: Influence du thiouracyl sur l'hypertrophie compensatrice du rein. Bull. Acad. Roy. Belg. Cl. Sci. 33, 567-576 (1947).

[B30,957/47

Herlant, M.: Actions comparées de la thyroxine sur le rein normal et sur le rein en hypertrophie compensatrice. Bull. Acad. Roy. Belg. Cl. Sci., Séance 10 Jan., 85-96 (1948). [B30,956/48

Hermann, H., Portes, F., Jourdan, F.: Syncopes adrenalino-mono-, di-, et tetrachloromethaniques. C. R. Soc. Biol. (Paris) 107, 1541-1542 (1931).

$[10,215 / 31$

Hermann, H., Vial, J.: Nouvelles syncopes cardiaques par association toxique de l'adrénaline et de divers produits organiques volatils. C. R. Soc. Biol. (Paris) 119, 1316-1317 (1935).

$[32,885 / 35$

Herrick, E. H., Mead, E. R., Egerton, B. W., Hughes, J. S.: Some effects of cortisone on vitamin C-deficient guinea pigs. Endocrinology 50, 259-263 (1952).

[B 69,259/52

Herrmann, M.: Einfluß von Testosteron auf die Wiederaufnahme der Nebennierenrindenfunktion nach langfristiger Cortisonvorbehandlung beim Meerschweinchen. Ztschr. Mikrosp.-anat. Forschy. 68, 393-401 (1962).

[D34,026/62

Herrmann, M., Winkler, G.: Abkürzungen der Restitutionsphase der Nebennierenrinde beim Meerschweinchen nach langfristiger Vorbehandlung mit Cortison durch gleichzeitige Zufuhr von Methandrostenolon. Arzneimittel-Forsch. 12, 82-85 (1962).

[D 20,550/62

Herrmann, M., Winkler, G.: Utber den Einfluß von Oestradiol auf die Restitutionsphase der Nebennierenrinde nach langfristiger Cortisonvorbehandlung. Acta endocr. (Kbh.) 40, 410 to 420 (1962).

[D 27,922/62

Hershey, S. G., Mazzia, V. D. B., Gyure, L., Singer, K.: Influence of a synthetic analogue of vasopressin on survival after hemorrhagic shock in rats. Proc. Soc. exp. Biol. (N.Y.) 115, 325-328 (1964).

$[\mathrm{F} 2,455 / 64$

Hertogh, R. de, Ekka, E., Vanderheyden, I., Hoet, J. J.: Metabolic clearance rates and the interconversion factors of estrone and estradiol$17 \beta$ in the immature and adult female rat. Endocrinology 87, 874-880 (1970).

$[\mathrm{H} 31,447 / 70$

Hertz, R.: Interference with estrogen-induced tissue growth in the chick genital tract by a folic acid antagonist. Science 107, 300 (1948).

$[\mathrm{B} 18,379 / 48$

Hervé, A.: Semi-carbazone de l'adrénochrome et rayons X. Arch. int. Pharmacodyn. 85, 242-244 (1951).

$[\mathrm{B} 61,654 / 51$

Hervé, A.: Action radioprotectrice de l'ocytocine chez la souris. Arch. int. Physiol. 62, 136-137 (1954).

[D78,167/54

Hervé, A., Lecomte, J.: Action de la semicarbazone de l'adrénochrome sur les pétéchies provoquées par le rayonnement X. Arch. int. Pharmacodyn. 79, 109-112 (1949).

$[\mathrm{B} 46,855 / 49$

Hess, K.: Beitrag zur Lehre von den traumatischen Leberrupturen. Virchows Arch. pathol. Anat. 121, 154-175 (1890). [E 74,646/1890

Heuser, G.: Hormones and the nervous system. Experimental anesthesia and convulsions with steroids. Thesis, University of Montreal (1957).

$[\mathrm{C} 33,938 / 57$

Heuser, G.: Experimental anesthesia and convulsions with steroids. Rev. canad. Biol. 17, 229 (1958).

$[\mathrm{C} 54,451 / 58$

Heuson, J. C.: Nouvelle influence hormonale dans le cancer mammaire. Rôle de l'insuline in vitro et in vivo. C. R. Soc. franç. Gynéc. 40, 85-93 (1970).

$[\mathrm{G} 78,138 / 70$

Hewett, C. L., Savage, D. S., Lewis, J. J., Sugrue, M. F.: Anticonvulsant and interneuronal blocking activity in some synthetic amino-steroids. (Letter to the editor.) J. Pharm. Pharmacol. 16, 765-767 (1964). [D19,834/64 Hewitt, H. B.: Renal necrosis in mice after accidental exposure to chloroform. Brit. J. exp. Path. 37, 32-39 (1956).

$[\mathrm{C} 41,385 / 56$

Hewitt, H. B.: A sensitive method for the assay of androgens based on their power to alter the reactions of the mouse kidney to chloroform. J. Endocr. 14, $394-399$ (1957). [C28,739/57

Heymann, G., Jandl, G.: Experimentelle Untersuchungen zur Wertbemessung von TyphusImpfstoffen. I. Mitteilg. Die Schutzwirkung von humoralen Antikörpern verschiedener Spezifität bei der weißen Maus. Z. Immun.Forsch. 119, 279-294 (1960). $\quad[\mathrm{C} 94,285 / 60$

Hiestand, W. A., Stemler, F. W., Wiebers, J. E., Rockhold, W. T.: Alcohol toxicity as related to (alloxan) diabetes, insulin, epinephrine and glucose in mice. Fed. Proc. 12, 67 (1953).

$[\mathrm{B} 78,576 / 53$

Hietbrink, B. E., DuBois, K. P.: Influence of $\mathrm{X}$-radiation on development of enzymes responsible for desulfuration of an organic phosphorothioate and reduction of p-nitrobenzoic 
acid in the livers of male rats. Radiat. Res. $\mathbf{2 2}$, 598-605 (1964).

[G26,464/64

Hietbrink, B. E., DuBois, K. P.: Influence of partial-body X-irradiation on development of phosphorothioate oxidase in the livers of male rats. Radiat. Res. 27, 669-675 (1966).

$[\mathrm{F} 65,296 / 66$

Higginbotham, R. D.: Influence of adrenalectomy and cortisol on resistance of mice to histamine, serotonin, anaphylactic and endotoxin shocks. J. Allergy 33, 35-44 (1962).

[D21,395/62

Higginbotham, R. D., Dougherty, T. F.: Potentiation of polymyxin B toxicity by ACTH. Proc. Soc. exp. Biol. (N.Y.) 96, 466-470 (1957).

[C44,529/57

Higgins, G. M.: Experimental pathology of the liver. XII. Effects of feeding desiccated thyroid gland on restoration of the liver. Arch. Path. 16, 226-231 (1933).

$[9,809 / 33$

Higgins, G. M., Anderson, R. M.: Experimental pathology of the liver. I. Restoration of the liver of the white rat following partial surgical removal. Arch. Path. 12, 186-202 (1931).

$[597 / 31$

Higgins, G. M., Woods, K. A.: The influence of the adrenal gland on some of the changes induced in the animal organisms by the folic acid analogue, aminoteropterin. Proc. Mayo Clin. 24, 533-537 (1949).

$[\mathrm{B} 40,212 / 49$

Highman, B., Altland, P. D., Hanks, A. R., Rantanen, N. W.: Bacterial endocarditis. Effect of dimethyl sulfoxide in X-irradiated and non-irradiated rats. Arch. Path. 88, 645-652 (1969).

[H 19,382/69

Hildebrandt, A. G., Leibman, K. C., Estabrook, R. W.: Metyrapone interaction with hepatic microsomal cytochrome $\mathbf{P}-\mathbf{4 5 0}$ from rats treated with phenobarbital. Biochem. biophys. Res. Commun. 37, 477-485 (1969). [G69,992/69

Hilf, R., Goldenberg, H., Bell, C.: Effect of actidione (cycloheximide) on estrogen-induced biochemical changes in R 3230 AC mammary tumors, uteri, and mammary glands. Cancer Res. 27, 1485-1493 (1967). [F 88,514/67

Hines, J. R., Roncoroni, M.: Acute hepatic ischemia in dogs. Surg. Gynec. Obstet. 102, 689-694 (1956).

[G 72,976/56

Hines, J. R., Roncoroni, M.: Acute hepatic ischemia in ACTH treated dogs. Surg. Gynec. Obstet. 105, 39-48 (1957).

$[\mathrm{C} 40,870 / 57$

Hines, W. J. W.: The effect of two synthetic steroids on the ultrastructure of the liver of Rattus norvegicus L. J. Pharm. Pharmacol. 21, 509-513 (1969).

$[\mathrm{G} 68,829 / 69$
Hinshaw, L. B., Solomon, L. A., Reins, D. A., Freeny, P. C.: Peripheral and pulmonary vascular actions of the steroid methylprednisolone in endotoxin shock (Abstr.). Fed. Proc. 25, 634 (1966).

$[\mathrm{F} 65,403 / 66$

Hinton, W. E., Evers, C. G., Brunson, J. G.: The influence of adrenal medullary hormones on nephrotoxic nephritis in rabbits. Lab. Invest. 13, 1374-1380 (1964).

$[\mathrm{G} 21,390 / 64$

Hirano, T., Ruebner, B. H.: Studies on the mechanism of destruction of lymphoid tissue in murine hepatitis virus $\left(\mathrm{MHV}_{3}\right)$ infection. I. Selective prevention of lymphoid necrosis by cortisone and puromycin. Lab. Invest. 15, 270—282 (1966).

[G38,763/66

Hirokawa, T.: Studies on the poisoning by benzol and its homologues. IV. Experimental studies on the sexual differences of blood picture. Jap. J. med. Sci. Biol. 8, 275-281 (1955).

$[\mathrm{G} 71,106 / 55$

Hirschfelder, A. D., Maxwell, H. C.: Effect of insulin in experimental intoxication with alcohol and acetone. Amer. J. Physiol. 70, $520-523$ (1924).

$[26,930 / 24$

Hirschlerowa, Z.: Rola gruczołu tarczykowego przy toskoplasmozie. Wiad. Parazyt. 2, Sup., 63-64 (1956).

$[\mathrm{C} 35,235 / 56$

Hirvonen, J. I., Karlsson, L. K. J., Ojala, K.: Zum Einfluß von Äthanol auf die Zona glomerulosa und Zona fasciculata der Rattennebennierenrinde bei gleichzeitiger Belastung mit Insulin und hypertonischer Kochsalzlösung. Dtsch. Ztschr. gesamt. gerichtl. Med. 62, 232-238 (1968).

[G59,966/68

Hitachi, M.: Some observations on the effect of nicotinamide on the adrenal cortex in methylcholanthrene-treated mice. J. Fac. Sci. Univ. Tokyo, Sect. IV, 10, 459-465 (1965).

$[\mathrm{F} 67,866 / 65$

Hjort, A. M., deBeer, E. J., Fassett, D. W.: The hypnotic effect of repeated injections of unsymmetrical ethyl-0-ethylphenylurea in albino rats and the influence of sex thereon. $J$. Pharmacol. exp. Ther. 68, 62-68 (1940).

$[\mathrm{A} 32,832 / 40$

Hoak, J. C., Connor, W. E., Stone, D. B.: Hypophysectomy and blood lipids in aminonucleoside nephrosis (Abstr.). Clin. Res. 13, 308 (1965).

$[\mathrm{F} 61,136 / 65$

Hoch, F. L.: Biochemical actions of thyroid hormones. Physiol. Rev. 42, 605-673 (1962).

[D25,881/62

Hoch-Ligeti, C.: Effect of cortisone administration on induced and transplanted hepa- 
tomas. J. nat. Cancer Inst. 15, 1633-1636 (1955).

$[\mathrm{C} 14,407 / 55$

Hochwald, A.: Anaphylaktischer Shock und Vitamin C. II. Mitteilg. Z. ges. exp. Med. 98, 578-582 (1936).

$[36,114 / 36$

Hoene, R., Coutu, L., Horava, A., Procopio, J., Robert, A., Salgado, E.: Influence of ACTH on anaphylactic shock in guinea pigs. J. Allergy 23, 343-351 (1952).

[B68,152/52

Hoene, R., Rindani, T. H., Michon, J.: Study on the influence of somatotropic hormone upon the effect of $\mathrm{X}$-irradiation on antibody formation. Rev. canad. Biol. 13, 11-17 (1954).

$[\mathrm{B} 92,374 / 54$

Holck, H. G. O.: Influence of preliminary administration of insulin or of epinephrine hydrochloride upon fatal dose of Sodium Evipal in albino mice. J. Amer. pharm. Ass., sci. Ed. 37, 86-87 (1948).

$[\mathrm{B} 42,745 / 48$

Holck, H. G. 0.: Studies on sex variation to picrotoxin in the albino rat. J. Amer. pharm. Ass., sci. Ed. 38, 604-610 (1949). [D28,543/49 Holck, H. G. O., Cannon, P. R.: On the cause of the delayed death in the rat by isopropyl betabromallyl barbituric acid (nostal) and some related barbiturates. J. Pharmacol. exp. Ther. 57, 289-309 (1936).

$[\mathrm{A} 55,846 / 36$

Holek, H. G. O., Fink, L. D.: Influence of sex life upon resistance to nostal and pentobarbital. J. Amer. Pharmac. Ass. 29, 475-480 (1940).

[A35,663/40

Holck, H. G. O., Hillyard, I. W., Malone, M. H.: The influence of experimental hypo-and hyperthyroidism on the effects of Nostal, thiopental sodium, and hexobarbital sodium in the adult albino rat. J. Amer. pharm. Ass., sci. Ed. 43, 276-282 (1954).

$[\mathrm{B} 95,270 / 54$

Holck, H. G. O., Kanân, M. A.: Intravenous lethal doses of amytal in the dog and rabbit and a table of animal dosages compiled from the literature. J. Lab. clin. Med. 19, 1191-1205 (1934).

[A43,097/34

Holek, H. G. O., Kanân, M. A.: Sex difference in white rat in tolerance to certain barbiturates. Proc. Soc. exp. Biol. Med. 32, 700-701 (1935).

$[31,302 / 35$

Holck, H. G. O., Kanân, M. A., Mills, L. M., Smith, E. L.: Effects of castration and of male hormone administration upon the responses of the rat to certain barbiturates. 49th Ann. Meet. Proc. Amer. Physiol. Soc., Memphis. Tenn., p. 82 (1937).

$[68,297 / 37$

Holck, H. G. O., Kanân, M. A., Mills, L. M., Smith, E. L.: Studies upon the sex-differences in rats in tolerance to certain barbiturates and to nicotine. J. Pharmacol. exp. Ther. 60, 1-24 (1937).

$[\mathrm{A} 8,011 / 37$

Holck, H. G. O., Kimura, K. K.: Influence of sex upon resistance to ouabain in the rat. Fed. Proc. 3, 75 (1944).

$[84,604 / 44$

Holek, H. G. O., Kimura, K. K.: Studies on sex difference in resistance to ouabain in the albino rat. J. Amer. pharm. Ass., sci. Ed. 40, 327-332 (1951).

[D $99,625 / 51$

Holck, H. G. O., Mathieson, D. R.: Resistance to slowly increasing doses of sodium pentobarbital in the white rat: Duration of higher tolerance after parturition and effects of age, sex, castration and administration of testosterone propionate. Proc. Amer. physiol. Soc. p. 144 (1941).

$[80,435 / 41$

Holck, H. G. O., Mathieson, D. R.: Effects of age, sex, castration and interval of time after parturition upon the ability of the albino rat to build up tolerance to and to detoxify pentobarbital sodium. J. Amer. pharm. Ass., sci. Ed. 33, 174-176 (1944).

[B644/44

Holck, H. G. O., Mathieson, D. R., Smith, E. L., Fink, L. D.: Effects of testosterone acetate and propionate and of estradiol dipropionate upon the resistance of the rat to evipal sodium, nostal, pernostan and pentobarbital sodium. J. Amer. pharm. Ass. Sect. Ed. 31, 116-123 (1942).

$[\mathrm{A} 55,755 / 42$

Holek, H. G. O., Wecks, J. R., Mathieson, D. R., Duis, B.: Effects of age and sex upon the margin of safety of "delvinal" sodium vinbarbital and of calcium 5-ethyl 5-(2-butyl) N-methyl barbituric acid in the albino rat. J. Amer. Pharm. Ass. 32, 180-182 (1943). [84,766/43

Hollander, W., Wilkins, R. W.: The pharmacology and clinical use of rauwolfia, hydralazine; thiazides, and aldosterone antagonists in arterial hypertension. Progr. cardiovasc. Dis. 8, 291-318 (1966).

$[\mathrm{G} 37,370 / 66$

Holman, R. L., Jones, C. K.: Protective influence of pregnancy on experimental collagen disease lesions. Arch. Path. 56, 231-237 (1953).

[B93,771/53

Holmes, W. L., Bentz, J. D.: Inhibition of cholesterol biosynthesis in vitro by $\beta$-diethylaminoethyl diphenylpropylacetate hydrochloride (SKF 525-A). J. biol. Chem. 235, 3118 to 3122 (1960).

$[\mathrm{G} 74,656 / 60$

Holten, C. H., Larsen, V.: The potentiating effect of benactyzine derivatives and some other compounds on evipal anaesthesia in mice. Acta pharmacol. (Kbh.) 12, 346-363 (1956).

$[\mathrm{G} 74,395 / 56$ 
Holtman, D. F.: The effect of thiouracil and thyroactive substances on mouse susceptibility to poliomyelitis virus. Science 104, 50-51 (1946).

[B1,287/46

Holton, J. B., Lathe, G. H.: Inhibitors of bilirubin conjugation in new-born infant serum and male urine. Clin. Sci. 25, 499-509 (1963).

$[\mathrm{E} 35,112 / 63$

Holtz, P., Balzer, H., Westermann, E.: Beeinflussung der Narkosedauer durch Hemmung der Cholinesterase des Gehirns. NaunynSchmiedebergs Arch. Pharmak. 233, 438-467 (1958).

$[\mathrm{C} 76,300 / 58$

Holtz, P., Balzer, H., Westermann, E., Wezler, E.: Beeinflussung der Evipannarkose durch Reserpin, Iproniazid und biogene Amine. Naunyn-Schmiedebergs Arch. Pharmak., 231, 333-348 (1957).

[D98,342/57

Holzmann, H., Korting, G. W., Morsches, B.: Bestimmung der Myokinase und der KreatinPhosphokinase im Serum bei experimentellem Lathyrismus, bei Dermatomyositis und bei progressiver Sklerodermie. Arch. klin. exp. Dermat. 223, 319-327 (1965). [F56,165/65

Holzmann, H., Korting, G. W., Morsches, B.: Bestimmung von Sorbit-Dehydrogenase und Creatin-Phosphokinase im Serum von lathyritischen und mit Prednison behandelten lathyritischen Ratten. Naturwissenschaften, 52, p. 499 (1965).

$[\mathrm{G} 33,879 / 65$

Homburger, E., Etsten, B., Himwich, H. E.: Some factors affecting the susceptibility of rats to various barbiturates. The effect of age and sex. J. Lab. clin. Med. 32, 540-547 (1947).

$[\mathrm{E} 61,371 / 47$

Homburger, F., Kasdon, S. C., Fishman, W. H.: Methylandrostenediol, a non-virilizing steroid hormone with testosterone-like effects. 42nd Meet. Amer. Soc. clin. Invest., p. 33, May (1950).

$[\mathrm{B} 47,878 / 50$

Homburger, F., Kelley, T., Jr., Baker, T. R., Russfield, A. B.: Sex effect on hepatic pathology from deficient diet and safrole in rats. Arch. Path. 73, 118-125 (1962). [E94,913/62 Homburger, F., Pettengill, 0.: The protein anabolic and other effects of testosterone propionate in mice: effects of nutrition and interrelationship of biologic activities of the hormone. Endocrinology 57, 296-301 (1955).

$[\mathrm{C8}, 310 / 55$

Honjo, I., Kozaka, S.: Extensive resection of the liver in two stages. Rev. int. Hépat. 15, 309-319 (1965).

$[\mathrm{E} 51,472 / 65$

Hook, J. B., Williamson, H. E.: Addition of the natruretic action of SKF 525-A to the action of certain other natruretic agents. J. Pharmacol. exp. Ther. 146, 265-269 (1964).

[F 24,917/64

Hoosier, G. L. van, Jr., Gist, C., Trentin, J. J.: Facilitation, by thymectomy, of tumor formation by weakly oncogenic adenoviruses. Proc. Amer. Ass. Cancer Res. 8, 70 (1967).

$[\mathrm{F} 78,860 / 67$

Hoosier, G. L. van, Jr., Kirschstein, R. L., Abinanti, F. R., Hottle, G. A., Baron, S.: The safety test for poliomyelitis vaccine. I. An evaluation of variable factors in the monkey and cell culture systems. Amer. J. Hyg. 74, 209-219 (1961).

[D 12,216/61

Horák, J., Hûlek, P., Simek, J.: Changes of the blood volume, plasma volume and blood cell mass after partial hepatectomy. Sborn. véd. Praci lék. Fak. Hradci Králové 11, 773-774 (1968).

[G71,097/68

Horava, A., Selye, H.: Sur les effects de l'administration de l'hydrocortisone et de l'hormone somatotrope. Ann. Endocr. (Paris) 14, 772-778 (1953).

$[\mathrm{B} 70,249 / 53$

Hori, S., Masumura, S., Ono, K.: Effect of aldosterone on angiotensin-induced glycosuria. Mie med.J. 19, 61-66 (1969).

$[\mathrm{G} 72,331 / 69$

Horinaga, T.: Utber den sexuellen Empfindlichkeitsunterschied gegen Narkotika. Hukuoka Acta Med. 34, 2-3 (1941).

$[\mathrm{A} 36,414 / 41$

Horton, H. R., Franz, J. M.: Effect of ethionine on the cortisone-evoked stimulation of tryptophan peroxidase-oxidase activity. Endocrino$\log y$ 64, 258-261 (1959).

$[\mathrm{C} 63,790 / 59$

Horváth, E., Kováes, K., Blascheck, J. A., Somogyi, A.: Ultrastructural changes induced in the liver of rats by various steroid compounds. Virchows Arch. Abt. B Zellpath. 29, 756 (1970).

$[\mathrm{G} 70,490 / 70$

Horváth, E., Kováes, K., Tuchweber, B., Blascheck, J. A., Gardell, C., Somogyi, A.: Effects of various steroids on the ultrastructure of the liver (Abstr.). Fed. Proc. 29, 756 (1970).

[G70,408/70

Horváth, E., Somogyi, A., Kováes, K.: Einfluß von Spironolacton auf das Regenerationsvermögen der Leber bei Ratten. Klin. Wschr. 48, 385-387 (1970).

$[\mathrm{G} 70,405 / 70$

Horváth, E., Somogyi, A., Kováes, K.: Effect of estradiol on 7,12-dimethylbenz(a)anthracene-induced adrenocortical necrosis. A histochemical study. Arch. Geschwulstforsch. (in press).

[G70,443/

Horváth, F., Horváth, J.: Untersuchungen zur Verminderung von Strahlenschädigungen der 
Ossifikationszonen bei in Entwicklung begriffenen Kaninchen durch Verabreichung von Durabolin, Vitamin $D_{2}$ und Eierschalenpulver. Strahlentherapie 135/1, 38-47 (1968).

$[\mathrm{G} 55,076 / 68$

Hoshino, J., Kröger, H.: Properties of L-serine dehydratase purified from rat liver after induction by fasting or feeding casein hydrolysate. Hoppe-Seylers Z. physiol. Chem. 350, 595-602 (1969).

$[\mathrm{H} 13,867 / 69$

Hotchin, J., Sikora, E.: Protection against the lethal effect of lymphocytic choriomeningitis virus in mice by neonatal thymectomy. Nature (Lond.) 202, 214-215 (1964). [F 8,620/64 Hotterbeex, P., Darcis, L.: Action du phénylpropionate de testostérone sur la sensibilité de la muqueuse rectale de la rate à une irradiation locale. Ann. Endocr. (Paris) 20, 366-370 (1959).

$[\mathrm{C} 75,318 / 59$

Houchin, 0. B., Smith, P. W.: Cardiac insufficiency in the vitamin $\mathrm{E}$ deficient rabbit. Amer. J. Physiol. 141, 242-248 (1944). [B6,967/44

Houck, J. C., Jacob, R. A.: Connective tissue. VIII. Factors inhibiting the dermal chemical response to cortisol. Proc. Soc. exp. Biol. (N. Y.) 113, 692-698 (1963). [E 21,446/63

Houssay, B. A.: Action of sulphur compounds on carbohydrate metabolism and on diabetes. Amer. J. med. Sci. 219, 353-367 (1950).

[B $60,812 / 50$

Houssay, B. A., Busso, R. R.: Sensibilité des animaux éthyroïdés vis-à-vis de l'insuline. $C$. R. Soc. Biol. (Paris) 91, 1037-1038 (1924).

$[20,601 / 24$

Houssay, B. A., Cisneros, A. D.: Le choc anaphylactique et peptonique chez les chiens éthyroïdés. C. R. Soc. Biol. (Paris) 93, 886 a 887 (1925).

$[26,936 / 25$

Houssay, B. A., Houssay, A. B., Cardeza, A. F.: Acción de la radioyodotiroidectomia sobre la diabetes aloxánica del perro. Rev. Soc. argent. Biol. 31, 213-222 (1955).

$[\mathrm{C} 15,702 / 55$

Houssay, B. A., Rietti, C. T.: Hipófisis y tiroides. VIII. Extracto de lóbulo anterior de hipófisis y sensibilidad a la anoxemia. Rev. Soc. argent. Biol. 8, 53-57 (1932).

$[3,187 / 32$

Houssay, B. A., Rietti, C. T.: Hypophyse et thyroïde. Extrait de lobe antérieur d'hypophyse et sensibilité à l'anoxémie. $C$. $R$. Soc. Biol. (Paris) 110, 144-145 (1932). [3,283/32 Houssay, B. A., Rietti, C. T.: Hipófisis y tiroides. X. Nuevos experimentos sobre extracto de lóbulo anterior de hipófisis y resistencia a la anoxemia. Rev. Soc. argent. Biol. 8, 249-253 (1932).

$[5,793 / 32$
Houssay, B. A., Sara, J.: Tiroides y sensibilidad al aloxano. Rev. Soc. argent. Biol. 21, 81-85 (1945).

[B727/45

Houssay, B. A., Sordelli, A.: Sensibilité des animaux éthyroïdés envers les toxines et le bacille diphtérique. Formation d'anticorps chez les animaux éthyroïdés. C. R. Soc. Biol. (Paris) $85,677,679,1220$ (1921).

$[\mathrm{A} 48,113 / 21$

Houssay, B. A., Sordelli, A.: Thyroïde et anaphylaxie. C. R. Soc. Biol. (Paris) 87, 354-356 (1923).

$[13,430 / 23$

Howard, R. G., Maeir, D. M., Zaiman, H.: Experimental trichinous myocarditis: effect of cortisone. Fed. Proc. 21, 134 (1962).

[D22,789/62

Hoyrup, E., Vinten-Johansen, E.: Acut phenemal-og difhydanforgiftning. (Acute phenobarbital and diphenylhydantoin poisoning.) Nord. Med. 47, 283-285 (1952). [B84,197/52 Hrůza, Z.: Sex differences in the circulatory reaction of rats traumatized in the NobleCollip drum. Physiol. bohemoslov. 8, 300-306 (1958).

$[\mathrm{C} 74,576 / 58$

Hrůza, Z.: Sexual differences in resistance to trauma in the Noble-Collip drum and during adaptation to trauma and the effect of castration. Physiol. bohemoslov. 10, 173-180 (1961).

[D5,993/61

Hrůza, Z., Poupa, 0.: Studies on the adaptation of metabolism. V. A method of experimental traumatization in the Noble-Collip drum. Physiol. bohemoslov. 6, 179-187 (1957).

$[\mathrm{C} 44,659 / 57$

Hrůza, Z., Stetson, C. A., Jr.: Protective effect of depot catecholamines in traumatic and endotoxin shock (Abstr.). Fed. Proc. 27, 447 (1968).

[H $455 / 68$

Hrůza, Z., Zweifach, B. W.: Catecholamines and dibenzyline in trauma and adaptation to trauma. J. Trauma 10, 412-419 (1970).

$[\mathrm{G} 77,195 / 70$

Hsia, D. Y. Y., Dowben, R. M., Shaw, R., Grossman, A.: Inhibition of glucuronosyl transferase by progestational agents from serum of pregnant women. Nature 187, 693-694 (1960).

$[\mathrm{C} 90,465 / 60$

Hsieh, A. C. L.: The role of the thyroid in rats exposed to cold. J. Physiol. (Lond.) 161, 175-188 (1962).

[D20,969/62

Hsieh, A. C. L.: Thyroid hormone requirement in rats exposed to cold. Gunma Symp. Endocr. 3, 239-248 (1966).

$[\mathrm{F} 71,817 / 66$

Hsu, H. S.: Cellular basis of cortisone-induced host susceptibility to tuberculosis. Amer. Rev. resp. Dis. 100, 677-684 (1969). [G70,576/69 
Hucker, H. B., Zacchei, A. G., Cox, S. V., Brodie, D. A., Cantwell, N. H. R.: Studies on the absorption, distribution and excretion of indomethacin in various species. J. Pharmacol. exp. Ther. 153, 237-249 (1966).

$[\mathrm{G} 67,791 / 66$

Huebener, H. J., Amelung, D.: Enzymatische Umwandlungen von Steroiden. II. Mittlg. Geschlechtsunterschiede der enzymatischen Leberleistungen. Hoppe-Seylers Z. physiol. Chem. 293, 137-141 (1953). [B91,352/53

Hueper, W. C.: Experimental studies in cardiovascular pathology. VII. Chronic nicotine poisoning in rats and in dogs. Arch. Path. 35, 846-856 (1943).

$[91,722 / 43$

Huggins, C., Briziarelli, G., Sutton, H., Jr.: Rapid induction of mammary carcinoma in the rat and the influence of hormones on the tumors. J. exp. Med. 109, 25-42 (1959).

$[\mathrm{C} 62,178 / 59$

Huggins, C., Fukunishi, R.: Cancer in the rat after single exposures to irradiation or hydrocarbons. Age and strain factors. Hormone dependence of the mammary cancers. Radiat. Res. 20, 493-503 (1963).

[E35,442/63

Huggins, C., Fukunishi, R.: Induced protection of adrenal cortex against 7,12-dimethylbenz(a)anthracene. Influence of ethionine. Induction of menadione reductase. Incorporation of thymidine- $\mathrm{H}^{3}$. J. exp. Med. 119, 923-942 (1964).

[G14,366/64

Huggins, C., Fukunishi, R.: Molecular structure of aromatics related to their ability to induce adrenal protection. Arzneimittel-Forsch. 14, 834-836 (1964).

[F 18,350/64

Huggins, C., Grand, L. C., Brillantes, F. P.: Mammary cancer induced by a single feeding of polynuclear hydrocarbons and its suppression. Nature (Lond.) 189, 204-207 (1961).

[C99,772/61

Huggins, C., Morii, S.: Selective adrenal necrosis and apoplexy induced by 7,12-dimethylbenz(a)anthracene. J. exp. Med. 114, 741-760 (1961).

[D 13,007/61

Huggins, C., Yang, N. C.: Induction and extinction of mammary cancer. Science 137, 257-262 (1962).

[D 27,549/62

Huggins, C. B., Grand, L.: Neoplasms evoked in male Sprague-Dawley rat by pulse doses of 7,12-dimethylbenz(a)anthracene. Cancer Res. 26, 2255-2258 (1966).

$[\mathrm{F} 74,177 / 66$

Huggins, C. B., Sugiyama, T.: Production and prevention of two distinctive kinds of destruction of adrenal cortex. Nature (Lond.) 206, 1310-1314 (1965).

$[\mathrm{F} 44,582 / 65$
Hughes, P. E.: Mitotic responses to partial hepatectomy in preneoplastic rat liver. Chem.Biol. Interaction 1, 315-320 (1970).

$[\mathrm{G} 74,311 / 70$

Huizenga, K. A., Brofman, B. L., Wiggers, C. J.: Ineffectiveness of adreno-cortical preparations in standardized hemorrhagic shock. Proc. Soc. exp. Biol. (N.Y.) 52, 77 (1943). [A54,816/43

Huizenga, K. A., Brofman, B. L., Wiggers, C. J.: The ineffectiveness of adrenal cortex extracts in standardized hemorrhagic shock. J. Pharmacol. exp. Ther. 78, 139-153 (1943).

$[\mathrm{A} 59,447 / 43$

Hulka, J. F., Mohr, K.: Interference of cortisone-induced homograft survival by progestins. Amer. J. Obstet. Gynec. 97, 407-410 (1967).

$[\mathrm{G} 44,272 / 67$

Hulth, A., Westerborn, 0.: Effect of cortisone on the epiphysial cartilage. A histologic and autoradiographic study. Virchows Arch. pathol. Anat. 336, 209-219 (1963). [D 56,601/63

Hunt, C. E., Carlton, W. W.: Neural-lathyrism in white Pekin duck. Fed. Proc. 23, 128 (1964).

$[\mathrm{F} 3,186 / 64$

Hunt, R.: The influence of thyroid feeding upon poisoning by acetonitrile. J. biol. Chem. 1, 1-12 (1905).

$[60,064 / 05$

Hunt, R.: The relation of iodin to the thyroid gland. J. Amer. med. Ass. 49, 1323-1329 (1907).

$[49,716 / 07$

Hunt, R.: The probable demonstration of thyroid secretion in the blood in exophthalmic goiter. J. Amer. med. Ass. 49, 240-241 (1907).

$[49,717 / 07$

Hunt, R.: The effects of a restricted diet and of various diets upon the resistance of animals to certain poisons. Hyg. Lab., Bull. No. 69, pp. 93 (1910).

$[50,349 / 10$

Hunt, R.: Experiments on the relation of the thyroid to diet. J. Amer. med. Ass. 57, 1032 to 1033 (1911).

$[49,718 / 11$

Hunt, R.: The acetonitril test for thyroid and of some alterations of metabolism. Amer. $J$. Physiol. 68, 257-299 (1923).

$[13,889 / 23$

Hunt, R., Seidell, A.: Studies on thyroid. I. The relation of iodine to the physiological activity of thyroid preparations. Hyg. Lab. Bull. 47, 1-115 (1909).

$[50,346 / 09$

Hunt, R., Seidell, A.: Thyreotropic iodine compounds. J. Pharmacol. exp. Ther. 2, 15-47 (1910).

$[46,617 / 10$

Hunter, J., Maxwell, J. D., Carrella, M., Stewart, D. A., Williams, R.: Urinary D-glucaric-acid excretion as a test for hepatic enzyme induction in man. Lancet $1971 \mathrm{I}, 572-575$. [H36,993/71 
Hurd, E. L., Bass, F. K., DeGraif, A. C., Kupperman, H. S.: The effect of cortisone upon the fatty liver and kidney changes of choline-deficient rats. J. clin. Endocr. 13, 839-840 (1953).

[B83,869/53

Hurst, E. W.: Sexual differences in the toxicity and therapeutic action of chemical substances. In: Walpole and Spinks; $A$ Symposium on the Evaluation of Drug Toxicity, p. 12-25. London: J. \& A. Churchill Ltd. 1958.

[D33,743/58

Hurst, E. W., Melvin, P. A., Thorp, J. M.: The influence of sex on equine encephalomyelitis in the mouse and on its treatment with mepacrine. J. comp. Path. 70, 346-360 (1960).

$[\mathrm{C} 94,088 / 60$

Hurst, E. W., Melvin, P. A., Thorp, J. M.: The influence of cortisone, ACTH, thyroxine and thiouracil on equine encephalomyelitis in the mouse and on its treatment with mepacrine. J. comp. Path. 70, 361-373 (1960).

$[\mathrm{C} 94,089 / 60$

Hussar, D. A.: Therapeutic incompatibilities: drug interactions. Hosp. Pharm. (Philad.) 3, 14-24, 32 (1968).

[G81,059/68

Hussar, D. A.: Mechanisms of drug interactions. J. Amer. pharm. Ass. 9, 208-209, 213 (1969).

$[\mathrm{G} 81,053 / 69$

Hutchinson, A. H.: Amelioration of experimental hypertension. Trans. roy. Soc. Can., Sect. $V$ 42, 25-35 (1948).

[B29,416/48

Hutchinson, L. A., Andrews, G. A., Kniseley, R. M.: Influence of cortisone on toxicity of nitrogen mustard in rats. Proc. Soc. exp. Biol. (N.Y.) 83, 376-377 (1953).

[B84,257/53

Hutter, A. M., Jr., Kayhoe, D. E.: Adrenal cortical carcinoma. Results of treatment with o,p'DDD in 138 patients. Amer. J. Med. 41, 581-592 (1966).

[F 74,271/66

Hutterer, F., Bacehin, P. G., Raisfeld, I. H., Schenkman, J. B., Schaffner, F., Popper, H.: Alteration of microsomal biotransformation in the liver in cholestasis. Proc. Soc. exp. Biol. (N.Y.) 133, 702-706 (1970). [G75,925/70

Hutterer, F., Klion, F. M., Wengraf, A., Schaffner, F., Popper, H.: Hepatocellular adaptation and injury. Structural and biochemical changes following dieldrin and methyl butter yellow. Lab. Invest. 20, 455-464 (1969).

$[\mathrm{G} 66,323 / 69$

Hutterer, F., Rubin, E., Gall, E., Popper, H.: Cortisone effect in stages of hepatic injury. A cytochemical, autoradiographic, and histologic study. Exp. molec. Path. 1, 85-95 (1962).

$[\mathrm{E} 54,152 / 62$
Hutterer, F., Rubin, E., Singer, E. J., Popper, H.: Quantitative relation of cell proliferation and fibrogenesis in the liver. Cancer Res. 21, 205-215 (1961).

[D 902/61

Huttunen, J. K., Miettinen, T. A.: Glucuronidation in rats of different ages and strains. Acta physiol. scand. 63, 133-140 (1965).

[G 27,972/65

Hyde, P. M., Elliott, W. H., Doisy, E. A., Jr., Doisy, E. A.: Synthesis and metabolic studies of 17a-methyl-C14- $\Delta^{5}$-androstene-3 $\beta, 17 \beta$-diol. J. biol. Chem. 207, 287-294 (1954).

[D99,140/54

Hyde, P. M., Williams, R. H.: Absorption and metabolism of hydrocortisone-4-C'14. J. biol. Chem. 227, 1063-1081 (1957). [C40,540/57

Hyde, T. A.: The effect of nephrectomy and renal ischaemia on liver regeneration. J. Path. Bact. 96, 131-136 (1968). [H 15,523/68

Hyde, T. A., Davis, J. C.: The effects of cortisol and chlorazanil on the mitotic rate in mouse liver and skin. Europ. J. Cancer 2, 227-230 (1966).

$[\mathrm{F} 82,461 / 66$

Hyman, G. A., Ragan, C., Turner, J. C.: Effect of cortisone and adrenocorticotropic hormone (ACTH) on experimental scurvy in the guinea pig. Proc. Soc. exp. Biol. (N.Y.) 75, $470-475$ (1950).

$[\mathrm{B} 53,374 / 50$

Hyman, G. A., Ragan, C., Turner, J. C.: The effect of cortisone and ACTH on experimental scurvy in the guinea pig. Trans. N.Y. Acad. Sci. 13, 167-168 (1951).

$[\mathrm{B} 57,989 / 51$

Ichii, S., Yago, N.: Hormonal regulation of aminopyrine $\mathrm{N}$-demethylase system in rat liver. J. Biochem. (Tokyo) 65, 597-601 (1969).

$[\mathrm{H} 15,158 / 69$

Igić, R., Jeličić, J., Nikulin, E., Stern, P.: Myotropischer Effekt des Metenolazetat auf die experimentelle Muskeldystrophie der Ratte. Endokrinologie 54, 103-106 (1969).

$[\mathrm{H} 13,355 / 69$

Ilavsky, J., Foley, E. J.: Studies on the effect of cortisone with chemotherapeutic agents on tuberculous peritonitis in mice. Antibiot. and Chemother. 4, 1068-1074 (1954). [C7,577/54 Imamura, T.: Studies upon the relation between hormones and bacterial toxins, especially on the influence of follicle liquid of the ovarium on tetanus toxin in relation to the uterine hormone. Acta med. Keijo 12, 249-285 (1929).

$[14,567 / 29$

Infante, R., Turchetto, E., Rabbi, A.: Influenza della tiroxina sulla attività lipotropa della vitamina $\mathrm{B}_{12}$. Boll. Soc. ital. Biol. sper. 31, 157-159 (1955).

$[\mathrm{C} 17,520 / 55$ 
Ingbar, S. H., Freinkel, N.: Intrinsic factors affecting radiation mortality in the mouse (Abstr.). Fed. Proc. 11, 77 (1952). [B68,221/52 Ingle, D. J.: The survival of non-adrenalectomized rats in shock with and without adrenal cortical hormone treatment. Amer. J. Physiol. 139, 460-463 (1943).

$[\mathrm{A} 59,854 / 43$

Ingle, D. J.: The effect of adrenal cortical extract on the resistance of non-adrenalectomized rats to peptone shock. Amer. J. Physiol. 142, 191-194 (1944).

$[85,588 / 44$

Ingle, D. J.: The resistance of non-adrenalectomized rats to diphtheria toxin with and without adrenal cortical hormone treatment. Exp. Med. Surg. 5, 375-378 (1947).

$[\mathrm{B} 42,751 / 47$

Ingle, D. J.: The technique of evisceration in the rat. Exp. Med. Surg. 7, 34-36 (1949).

[B39,012/49

Ingle, D. J., Baker, B. L.: Histology and regenerative capacity of liver following multiple partial hepatectomies. Proc. Soc. exp. Biol. (N.Y.) 95, 813-815 (1957). [C40,980/57 Ingle, D. J., Kuizenga, M. H.: The survival of non-adrenalectomized rats in burn shock with and without adrenal cortical hormone treatment. Amer. J. Physiol. 145, 203-205 (1945).

$[96,155 / 45$

Ingle, D. J., Nezamis, J. E.: Effect of insulin and glucose upon survival time of eviscerated rats. Proc. Soc. exp. Biol. (N.Y.) 69, 441-442 (1948).

$[\mathrm{B} 28,601 / 48$

Ingle, D. J., Nezamis, J. E.: Infection as a factor causing death in the eviscerate rat. Proc. Soc. exp. Biol. (N.Y.) 71, 438-439 (1949).

[B37,742/49

Ingle, D. J., Nezamis, J. E.: Effect of antibiotics upon survival of the eviscerate rat. Amer. J. Physiol. 166, 349-353 (1951).

$[\mathrm{B} 65,286 / 51$

Ingle, D. J., Nezamis, J. E., Kuizenga, M. H.: The effects of epinephrine and of adrenal cortex extract upon the survival of eviscerated rats. Exp. Med. Surg. 5, 379-382 (1947).

$[\mathrm{B} 42,752 / 47$

Ingle, D. J., Nezamis, J. E., Prestrud, M. C.: The effect of diethylstilbestrol upon alloxan diabetes in the male rat. Endocrinology 41, 207-212 (1947).

$[\mathrm{B} 3,163 / 47$

Ingle, D. J., Prestrud, M. C., Nezamis, J. E., Kuizenga, M. H.: Effect of adrenal cortex extract upon the tolerance of the eviscerated rat for intravenously administered glucose. Amer. J. Physiol. 150, 423-427 (1947).

$[\mathrm{B} 2,737 / 47$
Inscoe, J. K., Axelrod, J.: Some factors affecting glucuronide formation "in vitro". $J$. Pharmacol. exp. Ther. 129, 128-131 (1960).

[D 1,700/60

Inscoe, J. K., Daly, J., Axelrod, J.: Factors affecting the enzymatic formation of 0-methylated dihydroxy derivatives. Biochem. Pharmacol. 14, 1257-1263 (1965). [F 70,325/65

Ippolito, A., Pagliari, M., Manno, G., De Santis, R.: La prevenzione dell'ulcera gastro-duodenale da cortisonici mediante trattamento associato con idrossido di alluminio ed anabolizzanti. Rass. Fisiopat. clin. ter. 34, 486-494 (1962).

[D 57,498/62

Isacson, S., Nilsson, I. M.: Effect of treatment with combined phenformin and ethyloestrenol on the coagulation and fibrinolytic systems. Scand. J. Haemat. 7, 404-408 (1970).

[G 80,478/70

Ishikawa, E., Ninagawa, T., Suda, M.: Hormonal and dietary control of serine dehydratase in rat liver. $J$. Biochem. (Tokyo) 57, 506-513 (1965).

[F41,763/65

Ishimura, Y., Ullrich, V., Peterson, J. A.: Oxygenated cytochrome $\mathrm{P}-450$ and its possible role in enzymic hydroxylation. Biochem. biophys. Res. Commun. 42, 140-146 (1971).

$[\mathrm{G} 81,262 / 71$

Ishizaki, A., Tanabe, S., Matsuda, S., Sakamoto, M.: Experimental study on the chronic cadmium poisoning in relation to calcium deficiency. (Japanese text.) Jap. J. Hyg. 20, 398-404 (1966).

[F94,533/66

Israel, S. L., Meranze, D. R., Johnston, C. G.: The inactivation of estrogen by the liver. Observations on the fate of estrogen in heartlung and heart-lung-liver perfusion systems. Amer. J. med. Sci. 194, 835-843 (1937).

$[\mathrm{A} 16,424 / 37$

Issekutz, B. von, Issekutz, B. von, Jr.: Wirkungsort des Thyroxins. Naunyn-Schmiedebergs Arch. Pharmak. 177, 442-449 (1935).

$[45,261 / 35$

Ito, T.: Study on the sex difference in benzene inhalation. (Japanese text.) Showa med. J. 22/7, 25-29 (1962).

$[\mathrm{E} 44,788 / 62$

Ito, T., Hoshino, T., Sawauchi, K.: Effect of gonadectomy and adrenalectomy on development of urethan-induced thymic lymphoma in mice. Gann 57, 201-204 (1966). [G42,670/66 IUPAC Commission on the Nomenclature of 0rganic Chemistry (CNOC) and IUPAC-IUB Commission of Biochemical Nomenclature (CBN): The nomenclature of steroids. Revised tentative rules. European J. Biochem. 10, 1-19 (1969).

[G82,068/69 
Izzo, R. A., Cicardo, V. H.: Influencia de la tiroides sobre la tuberculosis experimental. Publ. Cent. Invest. tisiol. (B. Aires) 11, 237-247 (1947).

[B23,261/47

Izzo, R. A., Cicardo, V. H.: Effect of thyroid on experimental tuberculosis. Amer. Rev. Tuberc. 56, 52-58 (1947).

[B $67,482 / 47$

Jabbari, M., Leevy, C. M.: Protein anabolism and fatty liver of the alcoholic. Medicine (Baltimore) 46, 131-139 (1967). [G45,526/67

Jackson, E. B., Smadel, J. E.: The effects of cortisone and ACTH on toxins of Rickettsiae and Salmonella typhosa. J. Immunol. 66, $621-625$ (1951).

[B 77,408/51

Jackson, E. B., Smadel, J. E.: Cortisone and ACTH on toxins of Rickettsiae and Salmonella typhosa (Abstr.). Bact. Proc. 92-93 (1951).

$[\mathrm{E} 52,720 / 51$

Jackson, G. J.: The effect of cortisone on Plasmodium berghei infections in the white rat. $J$. infect. Dis. 97, 152-159 (1955). [C11,604/55

Jacob, D., Morris, J. M.: The estrogenic activity of postcoital antifertility compounds. Fertil. and Steril. 20, 211-222 (1969). [G73,856/69

Jacob, M., Forbes, R. M.: A study of the relative potency of L- and D-thyroxine in preventing kidney calcification associated with magnesium deficiency. $J$. Nutr. 99, 152-156 (1969).

[G69,934/69

Jacob, S. T., Sajdel, E. M., Munro, H. N.: Regulation of nucleolar RNA metabolism by hydrocortisone. Europ. J. Biochem. 7, 449-453 (1969).

$[\mathrm{G} 64,812 / 69$

Jacobsen, J., Broderseen, R., Trolle, D.: Patterns of bilirubin conjugation in the newborn. Scand. J. clin. Lab. Invest. 20, 249-251 (1967).

[H30,765/67

Jaffe, J. J.: Diurnal mitotic periodicity in regenerating rat liver. Anat. Rec. 120, 935-954 (1954).

$[\mathrm{G} 77,570 / 54$

Jahkola, M., Atanasiu, P., Duplan, J. F.: Evolution de la maladie due à un virus cytomégalique chez des radiochimères thymiprivés isogéniques. Ann. Inst. Pasteur 112, 781-797 (1967).

[G47,813/67

Jandásek, L.: Einfluß des Thyroxins auf die experimentelle Zeckenenzephalitis der infantilen Ratte. Z. Immun.-Forsch. 119, 365-369 (1960).

$[\mathrm{C} 88,870 / 60$

Jandásek, L.: Einfluß des Thyroxins auf die experimentelle Zeckenenzephalitis der Maus. Scr. med. Fac. Med. Brün. 33, 35-40 (1960).

$[\mathrm{C} 92,117 / 60$
Janes, R. G., Brady, J.: Thiamine deficiency in normal rats and in rats made diabetic with alloxan. Amer. J. Physiol. 153, 417-424 (1948).

[B23,359/48

Janes, R. G., Brady, J. M.: Thiamine deficiency in adult normal and diabetic rats as studied under paired-feeding conditions (Abstr.). Fed. Proc. 6, 136 (1947).

$[98,541 / 47$

Jannuzzi, C., Bassetti, D., Frigerio, G.: Ricerche cliniche controllate sull'effetto di steroidi anabolizzanti nell'epatite virale. Minerva med. 61, 1902-1911 (1970).

$[\mathrm{H} 27,335 / 70$

Jannuzzi, C., Bassi, A.: Ormoni steroidei ed anticorpopoiesi. Nota III. Potenziamento della vaccinazione antidifterica nel bambino da parte di ormoni 'anabolizzanti'. Boll. Ist. sieroter. milan. 41, 221-226 (1962).

$[\mathrm{G} 68,895 / 62$

Janofi, A.: Alterations in lysosomes (intracellular enzymes) during shock; effects of preconditioning (tolerance) and protective drugs. In: Hershey; Shock 2, p. 251-269. Boston, Mass.: Little, Brown \& Co. 1964.

[G68,991/64

Janoff, A., Kaley, G.: Studies on lysosomes in tolerance, shock, and local injury induced by endotoxin. In: Landy and Braun; Bacterial Endotoxin, p. 631-647. New Brunswick, N.J.: Institute of Microbiology, Rutgers, The State University, 1964.

$[\mathrm{E} 8,484 / 64$

Janoff, A., Weissmann, G., Zweifach, B. W., Thomas, L.: Pathogenesis of experimental shock. IV. Studies on lysosomes in normal and tolerant animals subjected to lethal trauma and endotoxemia. $J$. exp. Med. 116, 451-466 (1962).

[D35,553/62

Janoski, A. H., Shaver, J. C., Christy, N. P., Rosner, W.: On the pharmacologic actions of 21-carbon hormonal steroids ('glucocorticoids') of the adrenal cortex in mammals. In: Eichler, Farah et al.; Handbuch der Experimentellen Pharmakologie, 14/3, p. 256. Berlin, Heidelberg, New York: Springer-Verlag 1968.

[E 7,896/68

Januschke, H.: Adrenalin ein Antidot gegen Strychnin? Wien. klin. Wschr. 23, 284-286 (1910).

$[50,228 / 10$

Japundžié, M. M.: The goitrogenic effect of phenobarbital-Na on the rat thyroid. Acta anat. (Basel) 74, 88-96 (1969). [G74,862/69

Jaques, L. B.: Effects of hormones and drugs on hemostasis (Proc. 3. Int. Pharmacol. Meet. July 24-30, 1966.) In: Drugs in Relation to Blood Coagulation, Haemostasis and Throm- 
bosis, p. 25-55. Oxford \& New York: Pergamon Press 1968.

[G 70,979/68

Jaques, R.: The protection afforded by a benzyl glucofuranoside and hydrocortisone against lethal wasp venom shock in the guinea-pig. Pharmacology (Basel) 2, 21-26 (1969).

$[\mathrm{H} 13,146 / 69$

Jarcho, L. W., Eyzaguirre, C., Lilienthal, J. L., Jr.: Sex difference in the response of rats to sodium pentobarbital. Proc. Soc. exp. Biol. (N.Y.) 74, 332-333 (1950). [B59,706/50

Jasmin, G.: Production expérimentale chez le rat de lésions ressemblant à l'éclampsie. Rev. Canad. Biol. 12, 89 (1953).

[B80,596/53

Jasmin, G.: Action of hormones on the progression of magnesium deficiency syndrome in rats. In: Jasmin, G., Endocrine Aspects of Disease Processes, p. 356-381. St. Louis, Missouri: Warren H. Green Inc. 1968.

[E7,631/68

Jasmin, G., Bajusz, E., Mongeau, A.: Influence du sexe et de la castration sur la production de tumeurs musculaires chez le rat par le sulfure de nickel. Rev. canad. Biol. 22, 113-114 (1963).

$[\mathrm{D} 68,263 / 63$

Jasmin, G., Bois, P.: Myotoxic action of dimethyl-phenylenediamine. Proc. Canad. Fed. biol. Soc. 2nd. Ann. Meet. Toronto, p. 32 (1959).

[G73,640/59

Jasmin, G., Bois, P.: Effect of various agents on the development of kidney infarcts in rats treated with serotonin. Lab. Invest. 9, 503-515 (1960).

$[\mathrm{C} 92,099 / 60$

Jasmin, G., Bois, P.: Experimental muscular dystrophy induced in rats by dimethyl-pphenylenediamine. Fed. Proc. 19, 254 (1960).

[G83,058/60

Jasmin, G., Bois, P., Mongeau, A.: Effect of cortisol and norethandrolone on inflammation and tumor growth. Experientia (Basel) 16, 212 to 213 (1960).

$[\mathrm{C} 89,132 / 60$

Jasmin, G., Riopelle, J. L.: Nephroblastomas induced in ovariectomized rats by dimethylbenzanthracene. Cancer Res. 30, 321-326 (1970).

$[\mathrm{H} 23,587 / 70$

Jay, G. E., Jr.: Variation in response of various mouse strains to hexobarbital (Evipal). Proc. Soc. exp. Biol. (N.Y.) 90, 378-380 (1955).

[G71,140/55

Jayle, M. F., Pasqualini, J. R.: Implication of conjugation of endogenous compounds-Steroids and thyroxine. In: Dutton, G. J.; Glucuronic Acid. Free and Combined Chemistry, Biochemistry, Pharmacology and Medicine, p. 507-543. New York, London: Academic Press Inc. 1966.

$[\mathrm{G} 67,284 / 66$

Jean, C.: Développement somatique embryonnaire et post-natal après traitement oestrogénique prénatal. C. R. Soc. Biol. (Paris) 164, 784 à 791 (1970).

[H33,486/70

Jean, C., Jean, C.: Influence des oestrogènes injectés à la mère gravide sur la mortalité du foetus et du nouveau-né. C.R. Soc. Biol. (Paris) 164, 779-783 (1970). $\quad[\mathrm{H33}, 485 / 70$

Jeffries, C. D.: Liver carbohydrate levels in mice treated with endotoxin, cortisone, and elipten. Proc. Soc. exp. Biol. (N.Y.) 132, $540-542$ (1969).

[H19,361/69

Jelínek, J., Křeček, J.: The effect of age and pinealectomy on the hypertension produced by adrenal regeneration. Experientia (Basel) 24, 912-913 (1968).

$[\mathrm{H} 2,778 / 68$

Jelínek, J., Mikulášková, J., Pele, B.: The action of some steroid compounds on $\mathrm{HgCl}_{2}$ nephrosis in mouse and rat kidney. Acta biol. med. Germanica 13, 204-208 (1964).

[F 20,543/64

Jelínek, J., Mikulášková, J., Veselá, H., Jelínek, V., Pele, B.: The effect of some steroid compounds on compensatory hypertrophy and regenerative processes. Biochem. Pharmacol. 12, 219 (1963).

[E32,261/63

Jelínek, J. M.: The effect of some androgenic steroids on anesthesia. Acta biol.med. Germanica 20, 495-501 (1968).

$[\mathrm{H} 1,518 / 68$

Jelínek, V., Zikmund, E.: Variations sexuelles de l'action vasculaire de l'acide nicotinique. C. R. Soc. Biol. (Paris) 142, 1044-1047 (1949).

$[\mathrm{B} 52,661 / 49$

Jelliffe, R. W., Blankenhorn, D. H.: Effect of phenobarbital on digitoxin metabolism. Clin. Res. 14, 160 (1966).

$[\mathrm{E} 65,188 / 66$

Jellinck, P. H., Cox, J.: Effect of spermine on the kinetics of estradiol hydroxylation by rat liver microsomes. Experientia (Basel) 26, 1066 (1970).

$[\mathrm{H} 32,603 / 70$

Jellinck, P. H., Garland, M., McRitchie, D.: Effect of metopirone and 3-(1,2,3,4-tetrahydro1-oxo-2-naphthyl)-pyridine on the metabolism of corticosteroids and DMBA in relation to adrenal necrosis. Experientia (Basel) 24, 124 to 125 (1968).

$[\mathrm{F} 96,053 / 68$

Jellinck, P. H., Lucieer, I.: Sex differences in the metabolism of oestrogens by rat liver microsomes. J. Endocr. 32, 91-98 (1965).

$[\mathrm{F} 37,592 / 65$

Jenkins, V. K., Upton, A. C., Odell, T. T., Jr.: Effect of estradiol on splenic repopulation by 
endogenous and exogenous hemopoietic cells in irradiated mice. J. cell. Physiol. 73, 149-157 (1969).

[H 27,688/69

Jensen, D., Chaikoff, I. L., Tarver, H.: The ethionine-induced fatty liver: dosage, prevention, and structural specificity. J. biol. Chem. 192, 395-403 (1951).

[D83,567/51

Jensen, H., Grattan, J. F.: The identity of the glycotropic (antiinsulin) substance of the anterior pituitary gland. Amer. J. Physiol. 128, 270-275 (1940).

$[77,887 / 40$

Jeremy, R., Towson, J.: Interaction between aspirin and indomethacin in the treatment of rheumatoid arthritis. Med. J. Austral. 2, 127-129 (1970).

$[\mathrm{G} 77,324 / 70$

Jöchle, W., Langecker, H.: Biologische Wirkungen des 1-Methyl- $\Delta^{\prime}$-androsten-17 $\beta$-ol-3-on-17acetats und -17-önanthats (Methenolon-acetat und Methenolon-önanthat): Wachstumsstimulierung, Zusammensetzung des Tierkörpers und Fermenthaushalt. Arzneimittel-Forsch. 12, 218 bis 223 (1962).

[D 22,258/62

Johnson, A. D., Gomes, W. R., Demark, N. L. van: Early actions of cadmium in the rat and domestic fowl testis. I. Testis and body temperature changes caused by cadmium and zinc. J. Reprod. Fertil. 21, 383-393 (1970).

[H $23,801 / 70$

Johnson, A. E., Eckman, M., Lowenstein, B. E.: Effect of adrenal cortical extract on the altitude tolerance of normal and of adrenalectomized rats. War Med. (Chic.) 4, 318-323 (1943).

$[96,626 / 43$

Johnson, A. R., Hewgill, F. R.: The effect of the antioxidants, butylated hydroxy anisole, butylated hydroxy toluene and propyl gallate on growth, liver and serum lipids and serum sodium levels of the rat. Austral. J. exp. Biol. med. Sci. 39, 353-360 (1961). [E51,900/61

Johnson, H. A.: Liver regeneration and the "critical mass" hypothesis. Amer. J. Path. 57, 1-15 (1969).

$[\mathrm{H} 18,571 / 69$

Johnson, S., Siebert, W. J.: Experimental myocarditis. Amer. Heart J. 3, 279-286 (1928).

$[\mathrm{C} 91,021 / 28$

Johnson, S., Siebert, W. J.: Experimental myocarditic lesions in the rabbit. Their effect on myocardial abscess from intravenous injection of staphylococci. Arch. Path. 6, $54-66$ (1928).

$[\mathrm{C} 91,037 / 28$

Johnston, A. D., Follis, R. H., Jr.: Bone destruction associated with aminonucleoside administration. $J$. Bone Jt Surg. 43-A, 865 to 875 (1961).

[D12,799/61
Johnston, L. C., Grieble, H. G.: Treatment of arterial hypertensive disease with diuretics. V. Spironolactone, and aldosterone antagonist. Arch. intern. Med. 119, 225-231 (1967).

[F 94,590/67

Jondorf, W. R., Maickel, R. P., Brodie, B. B.: Inability of newborn mice and guinea pigs to metabolize drugs. Biochem. Pharmacol. 1, 352-354 (1958).

$[\mathrm{E} 90,586 / 58$

Jones, A. L., Armstrong, D. T.: Increased cholesterol biosynthesis following phenobarbital induced hypertrophy of agranular endoplasmic reticulum in liver. Proc. Soc. exp. Biol. (N.Y.) 119, 1136-1139 (1965).

[F 51,262/65

Jones, B.: Glucuronyl transferase inhibition by steroids. J. Pediat. 64, 815-821 (1964).

$[\mathrm{G} 19,777 / 64$

Jones, B. J., Roberts, D. J.: The effects of intracerebroventricularly administered noradnamine and other sympathomimetic amines upon leptazol convulsions in mice. Brit. J. Pharmacol. 34, 27-31 (1968).

$[\mathrm{G} 60,654 / 68$

Jones, J. H.: Further observations on the possible interrelationship between the physiological actions of the parathyroid glands and vitamin D. J. biol. Chem. 111, 155-161 (1935).

$[33,139 / 35$

Jones, R. K., Shapiro, A. P.: Increased susceptibility to pyelonephritis during acute hypertension by angiotensin II and norepinephrine. J. clin. Invest. 42, 179-186 (1963).

[D55,793/63

Jones, W. A., Cohen, R. B.: The effect of estrogen on the liver in murine viral hepatitis. Amer. J. Path. 42, 237-249 (1963).

$[\mathrm{D} 55,380 / 63$

Jori, A., Bianchetti, A., Prestini, P. E.: Effect of contraceptive agents on drug metabolism. Europ. J. Pharmacol. 7, 196-200 (1969).

$[\mathrm{H} 17,070 / 69$

Jori, A., Bianchetti, A., Prestini, P. E.: Relations between barbiturate brain levels and sleeping time in various experimental conditions. Biochem. Pharmacol. 19, 2687-2694 (1970).

$[\mathrm{G} 81,674 / 70$

Jori, A., Pugliatti, C.: An interaction between the antidepressant drugs desipramine and modaline sulphate. J. Pharm. Pharmacol. 19, 853-855 (1967).

$[\mathrm{G} 70,112 / 67$

Joshi, U. M., Rao, S. S.: Potentiation by a progestational agent of liver damage induced by a hepatotoxic agent. Indian J. exp. Biol. 7, 79-81 (1969). 
Jost, J. P., Khairallah, E. A., Pitot, H. C.: Studies on the induction and the repression of enzymes in rat liver. J. Biol. Chem. 243, 3057-3066 (1968).

$[\mathrm{H} 11,724 / 68$

Jouppila, P., Suonio, S.: The effect of phenobarbital given to toxaemic and normal parturients on the serum bilirubin concentration of newborn infants. Ann. clin. Res. 2, 209-213 (1970).

$[\mathrm{G} 78,916 / 70$

Juchau, M. R., Cran, R. L., Plaa, G. L., Fouts, J. R.: The induction of benzpyrene hydroxylase in the isolated perfused rat liver. Biochem. Pharmacol. 14, 473-482 (1965). [E 50,728/65

Juchau, M. R., Fouts, J. R.: Effects of norethynodrel and progesterone on hepatic microsomal drug-metabolizing enzyme systems. Biochem. Pharmacol. 15, 891-898 (1966). [G40,275/66

Jude, A., Laborit, H., Leroux, R.: Action de l'hormone somatotrope sur la toxi-infection typhoïdique expérimentale de la souris blanche. Rev. Immunol. 19, 58-63 (1955). [C16,220/55

Julius, H. W.: The action of the gonadotropic extract of urine, Pregnyl on tar carcinoma. Acta brev. neerl. Physiol. 4, 74 (1934).

$[29,127 / 34$

Jull, J. W.: The effect of infection, hormonal environment, and genetic constitution on mammary tumor induction in rats by 7,12dimethylbenz(a)anthracene. Cancer Res. 26, 2368-2373 (1966).

[F 74,180/66

Jull, J. W., Streeter, D. J., Sutherland, L.: The mechanism of induction of ovarian tumors in the mouse by 7,12-dimethylbenz-(a)anthracene. I. Effect of steroid hormones and carcinogen concentration in vivo. $J$. nat. Cancer Inst. 37, 409-420 (1966).

[G41,663/66

Kabelik, J.: L'action antianaphylactique du sérum au thiosulfate. C. R. Soc. Biol. (Paris) 110, 397-400 (1932).

$[9,032 / 32$

Kádas, L., Zsámbéky, P.: The hormonal therapy of mercury bichloride poisoning. Acta med. Acad. Sci. hung. 9, 363-379 (1956).

$[\mathrm{C} 26,265 / 56$

Kádas, L., Zsámbéky, P.: Neue experimentelle Angaben zur Hormontherapie der Sublimatvergiftung. Endokrinologie 35, 127-137 (1957).

$[\mathrm{C} 49,522 / 57$

Kadzielawa, K., Widy-Tyszkiewicz, E.: Shortening of hexobarbital sleeping time after p-chlorophenylalanine. Arch. int. Pharmacodyn. 180, 368-372 (1969).

[H 18,469/69

Kaeser, H. E., Wüthrich, R.: Versuch zur Beeinflussung einer experimentellen Myopa- thie mit einer anabolen Substanz. Med. Pharmacol. exp. (Basel) 16, 365-370 (1967).

$[\mathrm{F} 80,357 / 67$

Kagawa, C. M.: Anti-Aldosterones. In: Dorfman; Methods in Hormone Research 3, 351 to 414. New York, London: Academic Press 1964.

$[\mathrm{E} 4,593 / 64$

Kagawa, C. M.: Action of antialdosterone compounds in the laboratory. In: Martini et al.; Hormonal Steroids 1, 445-456. New York, London: Academic Press 1964. [E4,772/64

Kagawa, C. M., Sturtevant, F. M., van Arman, C. G.: Pharmacology of a new steroid that blocks salt activity of aldosterone and desoxycorticosterone. J. Pharmacol. exp. Ther. 126, 123-130 (1959).

[D 88,974/59

Kahl, G. F.: Zur Wirkung von Metyrapon auf Elektronentransportvorgänge in der Leberzelle. Naunyn-Schmiedebergs Arch. Pharmak. 264, 251-252 (1969).

$[\mathrm{G} 69,105 / 69$

Kahlson, G.: A place for histamine in normal physiology. Lancet 1960I, 67-71.

$[\mathrm{G} 52,949 / 60$

Kaczak, M., Gutowska-Grzegorezyk, G., Madyk, E.: The effect of chronic administration of acetylsalicylic acid on the rabbit's liver. Pol. med.J. 9, 128-134 (1970). [G75,716/70

Kalnins, V., Ledina, H.: Die Wirkung des Epithelkörperchenhormons auf Zähne und Knochen normaler und skorbutischer Meerschweinchen. Upsala Läk.-Fören. Förh. 52, 235-276 (1947).

[B 19,372/47

Kalow, W.: Pharmacogenetics. Heredity and the response to drugs. Philadelphia, London: W. B. Saunders Co., pp. 231 (1962).

$[\mathrm{E} 695 / 62$

Kalser, S. C., Kunig, R.: Effect of varying periods of cold exposure on the action and metabolism of hexobarbital. Biochem. Pharmacol. 18, 405-412 (1969). [G65,211/69

Kalter, H.: The effect of cortisone on the food consumption of pregnant mice. Canad. J. Biochem. 33, 767-772 (1955). $\quad[\mathrm{C} 8,008 / 55$

Kalter, S. S., Stuart, D. C., Jr., Tepperman, J.: Alterations in rate of influenza virus proliferation produced by growth hormone and testosterone. Proc. Soc. exp. Biol. (N.Y.) 74, 605-607 (1950).

$[\mathrm{B} 49,656 / 50$

Kaltiala, E. H.: Drug metabolism by liver microsomes after partial hepatectomy. Ann. Med. exp. Fenn. 48, 184-187 (1970). [G79,608/70 Kalyanpur, S. G., Naik, S. R., Pahujani, S., Sheth, U. K.: Anti-convulsant action of anabolic steroids. Biochem. Pharmacol. 18, 957-959 (1969).

[G66,147/69 
Kalyanpur, S. G., Naik, S. R., Sheth, U. K.: Study of some factors affecting pentobarbital sleeping time. Arch. int. Pharmacodyn. 173, 1-10 (1968).

[F 99,270/68

Kamikubo, A.: The influence of alloxan on the distribution of zinc in animals bearing malignant tumours. (Japanese text.) Advanc. Obst. \& Gynaec. 11, 182 (1959). [D7,362/59

Kampioni, B.: The effect of ACTH on the pleura of a tuberculous guinea pig. Pol. med. J. 3, 1074-1077 (1964).

[G33,098/64

Kandror, V. I.: The role of the hypophysialadrenal system in the development of symptoms originating from radiation pathology (Literature survey). (Russian text.) Probl. Endokr. Gormonoter. 9, 109-117 (1963).

$[\mathrm{E} 27,416 / 63$

Kaneko, A., Sakamoto, S., Morita, M., Onoé, T.: Morphological and biochemical changes in rat liver during the early stages of ethyl chlorophenoxyisobutyrate administration. Tohoku J. exp. Med. 99, 81-101 (1969).

[H 19,398/69

Kaplan, H. S., Nagareda, C. S., Brown, M. B.: V. The role of hormones in blood and bloodforming organs. Endocrine factors and radiation-induced lymphoid tumors in mice. In: Recent Progress in Hormone Research 10, p. 293-338. New York: Academic Press Inc. 1954.

[B98,601/54

Kappas, A.: Estrogens and the liver. Gastroenterology 52, 113-116 (1967). [G43,772/67

Kappas, A.: Studies in endocrine pharmacology. Biologic actions of some natural steroids on the liver. New Engl. J. Med. 278, 378-384 (1968).

[F 94,299/68

Kar, A. B., De, N. N.: Experimental heat stress and the adrenal hormones. Bull. nat. Inst. Sci. India, No. 10B, 41-43 (1955).

[C72,791/55

Kar, A. B., Karkun, J. N., De, N. N.: The effect of 19-nortestosterone on the adrenal cortex of the rat. Acta endocr. (Kbh.) 25, 238-248 (1957).

[G79,565/57

Kar, A. B., Roy, A. C., Chakravarty, R. N.: The effect of testosterone propionate on glycogen content and histopathology of the liver of experimental hypothyroid rats. Indian J. med. Res. 43, 217-222 (1955). [C17,531/55

Karásek, F.: Teoretické předpoklady chininové léčby srdce při thyreotoxikose. (Bases théoriques de la médication quinique de coeur au cours de l'hyperthyroidisme.) Cas. lék. čes. 76, 105-146 (1937).

[B52,652/37
Karim, M. F., Taylor, W.: Steroid metabolism in the cat. Biliary and urinary excretion of metabolites of $\left[4^{-14} \mathrm{C}\right]$ oestradiol. Biochem. $\mathrm{J}$. 117, 267-270 (1970).

$[\mathrm{G} 74,179 / 70$

Karlson, P., Sekeris, C. E.: Biochemical mechanisms of hormone action. Acta endocr. (Kbh.) 53, 505-518 (1966).

[F 73,338/66

Karnofsky, D. A., Hamre, P. J., Hysom, G.: Toxicity of progesterone in the newborn mouse. Proc. Soc. exp. Biol. (N.Y.) 79, 641-643 (1952).

[B 69,772/52

Kass, E. H.: Effect of corticosteroids and of hormones of pregnancy on the lethal action of bacterial endotoxin. Ann. N.Y. Acad. Sci. 88, 107-115 (1960).

[D35,079/60

Kass, E. H., Finland, M.: Effect of ACTH on induced fever. New Engl. J. Med. 243, $693-695$ (1950).

[B 54,130/50

Kass, E. H., Finland, M.: The role of adrenal steroids in infection and immunity. New Engl. J. Med. 244, $464-470$ (1951). [B59,076/51

Kass, E. H., Finland, M.: Adrenocortical hormones in infection and immunity. Ann. Rev. Microbiol. 7, 361-388 (1953).

$[\mathrm{C} 80,582 / 53$

Kass, E. H., Finland, M.: Adrenocortical hormones and the management of infection. Ann. Rev. Med. 8, 1-18 (1957). [E56,566/57

Kass, E. H., Finland, M.: Corticosteroids and infections. Advanc. intern. Med. 9, 45-80 (1958).

[D 87,314/58

Kass, E. H., Ingbar, S. H., Lundgren, M. M., Finland, M.: The effect of ACTH and cortisone on pneumococcal and influenza viral infections in the white mouse. J. Lab. clin. Med. 37, 780 -788 (1951).

[B69,981/51

Kass, E. H., Lundgren, M. M., Finland, M.: The effect of adrenal steroids, corticotropin and growth hormone on resistance to experimental infections. $J$. exp. Med. 99, 89-104 (1954).

[B95,353/54

Katabuchi, H.: On the production of typhoid antitoxic substance and its relation with hormones. Acta med. Keijo 12, 105-146 (1929). $[44,803 / 29$

Katine, F., Hurd, E. L., Kupperman, H. S., DeGraff, A. C.: Prevention of fatty liver changes by cortisone in choline deficient rats (Abstr.). J. Pharmacol. exp. Ther. 106, 399 to 400 (1952).

[B80,347/52

Kato, R.: An antagonism between 3-4 dioxyphenylalanine (DOPA) and 5-hydroxytryptophan (5-HTP). Experientia (Basel) 15, $424-425$ (1959).

$[\mathrm{C} 78,047 / 59$ 
Kato, R.: Un pretrattamento, eseguito 48 ore prima, con svariate sostanze può diminuire gli effetti farmacologici del nembutal. Atti Soc. lombarda Sci. med.-biol. 14, 777-780 (1959).

$[\mathrm{E} 60,785 / 59$

Kato, R.: Reduced sensitivity to some drugs $48 \mathrm{~h}$ after chlorpromazine treatment. Experientia (Basel) 16, 427-428 (1960).

[E 87,340/60

Kato, R.: Modifications of the toxicity of strychnine and octomethylpyrophosphoramide (OMPA) induced by pretreatment with phenaglycodol and thiopental. Arzneimittel-Forsch. 11/8, 797-798 (1961).

[D 46,405/61

Kato, R.: Possible role of P-450 in the oxidation of drugs in liver microsomes. J. Biochem. (Tokyo) 59, 574-583 (1966). [G74,104/66

Kato, R.: Effects of starvation and refeeding on the oxidation of drugs by liver microsomes. Biochem. Pharmacol. 16, 871-881 (1967).

[G66,471/67

Kato, R., Chiesara, E.: Diversa capacità di metabolizzazione della stricnica in rapporto al sesso. Atti Accad. med. lombarda 15, 397-401 (1960).

$[\mathrm{G} 68,581 / 60$

Kato, R., Chiesara, E., Frontino, G.: Induction of hepatic carisoprodol-metabolizing enzyme by pretreatment with some neuropsychotropic drugs in rats. Jap. J. Pharmacol. 11, 31-36 (1961).

[G74,632/61

Kato, R., Chiesara, E., Frontino, G.: Induced increase of meprobamate metabolism in rats pretreated with phenobarbital or phenaglycodol in relation to age. Experientia (Basel) 17, 520-521 (1961).

$[\mathrm{H} 27,665 / 61$

Kato, R., Chiesara, E., Frontino, G.: Influence of sex difference on the pharmacological action and metabolism of some drugs. Biochem. Pharmacol. 11, 221-227 (1962). [G64,325/62

Kato, R., Chiesara, E., Vassanelli, P.: Metabolic differences of carisoprodol in the rat in relation to sex. Med. exp. (Basel) 4, 387-392 (1961).

[G66,023/61

Kato, R., Chiesara, E., Vassanelli, P.: Increased activity of microsomal strychnine-metabolizing enzyme induction by phenobarbital and other drugs. Biochem. Pharmacol. 11, 913-922 (1962).

[G74,030/62

Kato, R., Chiesara, E., Vassanelli, P.: Stimulating effect of some inhibitors of the drug metabolisms (SKF 525 A, Lilly 18947, Lilly 32391 and MG 3062) on excretion of ascorbic acid and drug metabolisms. Med. exp. (Basel) 6, 254-260 (1962).

[D27,768/62
Kato, R., Chiesara, E., Vassanelli, P.: Metabolic differences of strychnine in the rat in relation to sex. Jap. J. Pharmacol. 12, 26-33 (1962).

[D38,983/62

Kato, R., Chiesara, E., Vassanelli, P.: Further studies on the inhibition and stimulation of microsomal drug-metabolizing enzymes of rat liver by various compounds. Biochem. Pharmacol. 13, 69-83 (1964). [E 47,494/64

Kato, R., Gillette, J.: Differences in the effects of starvation and sucrose feeding on TPNHdependent enzymes in liver microsomes of rats. Fed. Proc. 28,538 (1964). $\quad$ [F 5,638/64

Kato, R., Gillette, J. R.: Effect of starvation on NADPH-dependent enzymes in liver microsomes of male and female rats. $J$. Pharmacol. exp. Ther. 150, 279-284 (1965).

[F 57,816/65

Kato, R., Gillette, J. R.: Sex differences in the effects of abnormal physiological states on the metabolism of drugs by rat liver microsomes. J. Pharmacol. exp. Ther. 150, 285-291 (1965).

$[\mathrm{F} 57,817 / 65$

Kato, R., Onoda, K.: Effect of morphine administration on the activities of microsomal drug-metabolizing enzyme systems in liver of different species. Jap. J. Pharmacol. 16, 217 to 219 (1966).

[G68,411/66

Kato, R., Onoda, K.: Studies on the regulation of the activity of drug oxidation in rat liver microsomes by androgen and estrogen. Biochem. Pharmacol. 19, 1649-1660 (1970).

$[\mathrm{G} 75,544 / 70$

Kato, R., Onoda, K. I., Omori, Y.: Mechanism of thyroxine-induced increase in steroid $\Delta^{4}$. reductase activity in male rats. Endocr. jap. 17, 215-219 (1970).

$[\mathrm{H} 31,735 / 70$

Kato, R., Takahashi, A.: Thyroid hormone and activities of drug-metabolizing enzymes and electron transport systems of rat liver microsomes. Molec. Pharmacol. 4, 109-120 (1968).

[G55,715/68

Kato, R., Takahashi, A.: Effect of phenobarbital on the activities of drug-metabolizing enzymes and electron transport system of liver microsomes in alloxan diabetes and thyroxine treated rats. Jap. J. Pharmac. 19, 45-52 (1969).

[H 11,853/69

Kato, R., Takahashi, A.: Decreased hydroxylation of steroid hormones by liver microsomes from rats bearing walker carcinosarcoma 256 . Cancer Res. 30, 2346-2352 (1970). [H30,605/70

Kato, R., Takahashi, A., Ohshima, T., Hosoya, E.: Effect of morphine administration on the 
hydroxylation of steroid hormones by rat liver microsomes. J. Pharmacol. exp. Ther. 174, 211 to $220(1970)$.

$[\mathrm{H} 27,934 / 70$

Kato, R., Takahashi, A., Omori, Y.: Effect of androgen and estrogen on the hydroxylation of steroid hormones by rat liver microsomes. Endocr. jap. 16, 653-663 (1969). [H25,499/69

Kato, R., Takahashi, A., Omori, Y.: The mechanism of sex differences in the anesthetic action of progesterone in rats. Europ. J. Pharmacol. 13, $141-149$ (1971).

[H34,571/71

Kato, R., Takahashi, A., Onoda, K. I., Omori, Y.: Effect of adrenalectomy on the substrate interaction with cytochrome P-450 in the hydroxylation of steroid hormones by liver microsomes. Endocr. jap. 17, 207-213 (1970).

[H31,734/70

Kato, R., Takanaka, A.: Effect of starvation on the in vivo metabolism and effect of drugs in female and male rats. Jap. J. Pharmacol. 17, 208-217 (1967).

[F 88,660/67

Kato, R., Takanaka, A., Omori, Y.: Factors affecting toxicity and metabolisms of OMPA (octamethylpyrophosphoramide) in rats. Jap. J. Pharmacol. 17, 509-518 (1967).

[H34,342/67

Kato, R., Takanaka, A., Onoda, K.: Species and sex differences in aminopyrine $\mathrm{N}$-demethylating activity of liver microsomes under unphysiological conditions. Jap. J. Pharmacol. 18, 516-517 (1968).

[G80,897/68

Kato, R., Takanaka, A., Onoda, K.: Individual difference in the effect of drugs in relation to the tissue concentration of drugs. Jap. J. Pharmacol. 19, 260—267 (1969). [H15,635/69

Kato, R., Takanaka, A., Shoji, H.: Inhibition of drug-metabolizing enzymes of liver microsomes by hydrazine derivatives in relation to their lipid solubility. Jap. J. Pharmacol. 19, 315-322 (1969).

[H 15,638/69

Kato, R., Takanaka, A., Takahashi, A., Onoda, K.: Species differences in the alteration of drug-metabolizing activities of liver microsomes by thyroxine treatment. Jap. J. Pharmacol. 19, 5-18 (1969).

[H 11,851/69

Kato, R., Takayanaghi, M.: Differences among the action of phenobarbital, methylcholanthrene and male sex hormone on microsomal drug-metabolizing enzyme systems of rat liver. Jap. J. Pharmacol. 16, 380-390 (1966).

[F 76,403/66

Kato, R., Takayanagi, M., Oshima, T.: Differences in the oxidative metabolism of drugs by liver microsomes. Jap. J. Pharmacol. 19, 53-62 (1969).

$[\mathrm{H} 11,854 / 69$
Kato, R., Vassanelli, P.: Induction of increased meprobamate metabolism in rats pretreated with some neurotropic drugs. Biochem. Pharmacol. 11, 779-794 (1962). [D40,237/62

Kato, R., Vassanelli, P., Frontino, G., Chiesara, E.: Variation in the activity of liver microsomal drug-metabolizing enzymes in rats in relation to the age. Biochem. Pharmacol. 13, 1037-1051 (1964).

[G17,077/64

Kato, Y.: Factors elevating liver tyrosine: 2-oxoglutarate aminotransferase activity in tumor-bearing mice. Nagoya J. med. Sci. 30, 211-223 (1967).

[G54,276/67

Kaufmann, G.: Tetrachlorkohlenstoff-Zirrhose und Restauration der Leber. Beitr. pathol. Anat. 113, 253-270 (1953). [E60,536/53

Kawashima, S., Ueda, T.: Protective effect of ethylcarbamate on the sensitized rats to hypoxia by insulin. (Japanese text.) $J$. Nara med. Ass. 17, 219-223 (1966). $\quad$ [F68,970/66

Kay, J. H., Balla, G. A., Lamb, W.: Effect of certain antihistaminic and steroid compounds on appendical peritonitis. Proc. Soc. exp. Biol. (N.Y.) 76, 496-497 (1951).

[B $60,579 / 51$

Kedrova, E. M., Krekhova, M. A.: Absence of summation of protective effect of cysteine and ACTH in irradiation of rats by X-ray. (Russian text.) Med. Radiol. (Mosk.) 4/1, 60-63 (1959).

$[\mathrm{G} 71,665 / 59$

Keil, A. M.: Effects of oxytocin on the response to suxamethonium in rabbits, sheep and pigs. Brit. J. Anaesth. 34, 306-308 (1692).

[D 27,254/62

Kellaway, P. E., Hoff, H. E., Leblond, C. P.: The response to thyroxine after subtotal hepatectomy. Endocrinology 36, 272-279 (1945).

[B 14,515/45

Kelly, A. R., Shideman, F. E.: Liver as the major organ involved in the detoxication of thiopental by the dog (Abstr.). Fed. Proc. 8, 306 (1949).

[A 49,706/49

Kelly, L. S., Brown, B. A., Dobson, E. L.: Cell division and phagocytic activity in liver reticulo-endothelial cells. Proc. Soc. exp. Biol. (N.Y.) 110, 555-559 (1962). [D32,495/62

Kemény, T., Filipp, G., Csalay, L., Kelenhegyi, M.: Gonadok, thymus és anaphylaxia. Kiserl. Orvostad. 3, 145-147 (1951). [B66,729/51

Keminger, K.: Thyreotoxische Krisen in der Chirurgie. Klin. Med. (Wien) 21, 1-34 (1966).

[G42,501/66

Kemmer, C., Müller, M.: Morphologische und histochemische Leberveränderungen weib- 
licher Mäuse nach Oestrastilben D-Applikation. Frankfurt. Z. Path. 77, 235-244 (1967).

[F 89,190/67

Kennedy, B. J., Pare, J. A. P., Pump, K. K., Beck, J. C., Johnson, L. G., Epstein, N. B., Venning, E. H., Browne, J. S. L.: Effect of adrenocorticotropic hormone (ACTH) on beryllium granulomatosis and silicosis. Amer. $J$. Med. 10, 134-155 (1951). [B59,278/51 Kennedy, W. P.: Sodium salt of C-C-cyclohexenylmethyl-N-methyl barbituric acid (Evipan) anaesthesia in laboratory animals. $J$. Pharmacol. exp. Ther. 50, 347-353 (1934).

[A43,060/34

Kenney, F. T.: On the nature of adrenocorticoid-induced increase in tyrosine- $a$-ketoglutarate transaminase activity of rat liver. Biochem. biophys. Res. Commun. 2, 333-335 (1960).

$[\mathrm{D} 98,193 / 60$

Kenney, F. T.: Induction of tyrosine- $\alpha$-ketoglutarate transaminase in rat liver. III. Immunochemical analysis. J. biol. Chem. 287, 1610-1614 (1962).

[E 89,716/62

Kenney, F. T.: Induction of tyrosine- $\alpha$-ketoglutarate transaminase in rat liver. IV. Evidence for an increase in the rate of enzyme synthesis. J. biol. Chem. 237, 3495-3498 (1962).

$[\mathrm{E} 98,787 / 62$

Kenney, F. T.: Regulation of tyrosine- $\alpha$-ketoglutarate transaminase in rat liver. V. Repression in growth hormone-treated rats. $J$. biol. Chem. 242, 4367-4371 (1967).

[G50,810/67

Kenney, F. T., Albritton, W. L.: Repression of enzyme synthesis at the translational level and its hormonal control. Proc. nat. Acad. Sci. (Wash.) 54, 1693-1698 (1965). [G64,557/65

Kenney, F. T., Flora, R. M.: Induction of tyrosine- $\alpha$-ketoglutarate transaminase in rat liver. I. Hormonal nature. J. Biol. Chem. 236, 2699-2702 (1961).

[D12,237/61

Kenney, F. T., Holten, D., Hager, C. B.: Hormonal regulation of enzyme synthesis. Gunna Symp. Endocr. 5, 31-41 (1968).

$[\mathrm{H} 4,503 / 68$

Kenney, F. T., Kull, F. J.: Hydrocortisonestimulated synthesis of nuclear RNA in enzyme induction. Proc. nat. Acad. Sci. (Wash.) 50, 493-499 (1963).

$[\mathrm{G} 22,373 / 63$

Képinow, L.: Anaphylaxie chez les animaux éthyroïdés nourris avec de la thyroïde. $C$. $R$. Soc. Biol. (Paris) 87, 409-411 (1922).

$[13,298 / 22$

Képinow, L.: Glande thyroïde et anaphylaxie. Influence de la glande thyroîde sur le choc anaphylactique lors de son administration per os peu de temps avant l'injection déchaînante. C. R. Soc. Biol. (Paris) 88, 846-847 (1923).

$[13,941 / 23$

Képinow, L., Lanzenberg, A.: Glande thyroïde et anaphylaxie. C. R. Soc. Biol. (Paris) 86, 906-908 (1922).

$[13,258 / 22$

Képinow, L., Metalnikow, S.: Glande thyroïde et sensibilité des animaux tuberculeux envers la tuberculine. C. R. Soc. Biol. (Paris) 87, 210 à 212 (1922).

$[40,285 / 22$

Kepl, M., Caldwell, G., Ochsner, A.: Use of adrenal cortical hormone in Cl. welchii infections in guinea pigs. Proc. Soc. exp. Biol. (N.Y.) 52, 25-26 (1943). [A56,633/43

Keplinger, M. L., Lanier, G. E., Deichmann, W. B.: Effects of environmental temperature on the acute toxicity of a number of compounds in rats. Toxicol. app. Pharmacol. 1, 156-161 (1959).

$[\mathrm{G} 70,208 / 59$

Kepp, R., HoImann, D.: Utber den Einfluß der weiblichen Keimdrüsen auf die allgemeine und lokale Strahlenempfindlichkeit. Strahlentherapie 108, 34-42 (1959). [ [C65,530/59

Kerman, E. F.: Experimental catalepsy in the rat produced by a steroid hormone: Desoxycorticosterone acetate, and the antagonistic effect of pentamethylenetetrazol (Metrazol). Dis. nerv. Syst. 8, 313-317 (1947).

$[\mathrm{A43}, 330 / 47$

Kersten, H., Staudinger, H.: Der Einfluß von Butazolidin auf die Cortisoninaktivierung in Leberhomogenaten. Klin. Wschr. 34, 523-525 (1956).

$[\mathrm{G} 67,796 / 56$

Kessler, F. J., Krüskemper, H. L., Noell, G.: Tierexperimentelle Vergleichsuntersuchungen zur Wirkung von D-Thyroxin und D-Trijodthyronin bei alimentär gestörtem Lipidstoffwechsel. Arzneimittel-Forsch. 17, 1190 bis 1195 (1967).

[F 89,469/67

Ketkar, M. B., Sirsat, S. M.: Mast cells in experimental skin carcinogenesis in relation to hormonal stress. Indian J. med. Sci. 19, 477 to 484 (1965).

[G32,601/65

Khandekar, J. D.: Catatoxic steroids. $J$. Indian med. Ass. 56, 59 (1971). [ [G70,492/71

Khandekar, J. D., Garg, B. D., Dardachti, D., Tuchweber, B., Kovacs, K.: Effect of cycloheximide on the ultrastructural changes produced by spironolactone and pregnenolone$16 \alpha$-carbonitrile in the rat liver. Beitr. Pathol. (in press).

[G 79,026

Khandekar, J. D., Garg, B. D., Kovaes, K.: Effect of N-y-phenylpropyl-N-benzyloxy acet- 
amide (W-1372) on the liver ultrastructure in rats. A. M. A. Arch. Path. (in press)

[G79,016

Khandekar, J. D., Garg, B. D., Tuchweber, B., Kovaes, K.: Influence of cycloheximide on the ultrastructural changes in rat hepatocytes caused by spironolactone (SNL) and pregnenolone$16 \alpha$-carbonitrile (PCN). (Abstr.) 5th Ann. Meet. Europ. Soc. clin. Invest., Scheveningen, Netherlands, April 22-24, p. 48 (1971). [G79,014/71 Khogali, A.: Quantitative studies on the suppression of the skeletal lesions of $\beta$-aminopropionitrile by L- and D-triiodothyronine. J. Physiol. 158, 29P-30P(1961). [D 10,840/61

Khogali, A.: Bone strength and calcium retention of rats in hypervitaminosis-A. Quart. J. exp. Physiol. 51, 120-129 (1966).

[F 73,238/66

Khoobyarian, N., Walker, D. L.: Effect of cortisone on mouse resistance to intravenous toxicity of influenza virus. Proc. Soc. exp. Biol. (N.Y.) 94, 295-298 (1957).

[C30,210/57

Khrabrova, 0. P.: Specific features in the reaction to shockogenic stimulus following aminazine administration. (Russian text.) Byull. eksp. Biol. Med. 51/2, 23-27 (1961).

[D 49,985/61

Khrabrova, 0. P.: On the application of ACTH and cortisone in experimental shock. (Russian text.) Probl. Endokr. Gormonoter. 8, 16-18 (1962).

[D33,557/62

Kilbourne, E. D.: Paradoxical effects of cortisone on influenza $B$ virus infection of the chick embryo (Abstr.). Amer. Soc. clin. Invest. 34 (1952).

[B69,376/52

Kilbourne, E. D., Horsfall, F. L., Jr.: Increased virus in eggs injected with cortisone. Proc. Soc. exp. Biol. (N.Y.) 76, 116-118 (1951).

[B55,005/51

Kilbourne, E. D., Horsfall, F. L., Jr.: Lethal infection with Coxsackie virus of adult mice given cortisone. Proc. Soc. exp. Biol. (N.Y.) 77, 135-138 (1951).

$[\mathrm{B} 65,487 / 51$

Kim, U., Furth, J.: Relation of mammary tumors to mammotropes. II. Hormone responsiveness of 3-methylcholanthrene induced mammary carcinomas. Proc. Soc. exp. Biol. (N.Y.) 103, 643-645 (1960).

[H31,205/60

Kimbrough, R. D., Gaines, T. B., Linder, R. E.: The ultrastructure of livers of rats fed DDT and dieldrin. A. M. A. Arch. environm. Hlth. 22, 460-467 (1971).

[G81,969/71
Kimeldorí, D. J., Jones, D. C., Fishler, M. C.: The effect of exercise upon the lethality of roentgen rays for rats. Science 112, 175-176 (1950).

[B $49,240 / 50$

Kimura, A.: An electron microscopic study on regenerating rat liver after partial hepatectomy. I. Ultrastructural alterations of hepatocytes in early post-operative stage. (Japanese text.) Sapporo med. J. 35, 265-288 (1969).

[G75,331/69

Kind, L. S.: Inhibition of histamine death in pertussis-inoculated mice by cortisone and neoantergan. J. Allergy 24, 52-59 (1953).

[B81,943/53

Kind, L. S.: The altered reactivity of mice after inoculation with Bordetella pertussis vaccine. Bact. Rev. 22, 173-182 (1958).

[E67,787/58

King, J. E.: Sex differences in the response of rats to pentobarbital sodium. IV. Pentobarbital levels in pregnant and nonpregnant rats. Amer. J. Obstet. Gynec. 89, 1019-1025 (1964).

[G78,963/64

King, J. E., Becker, R. F.: The influence of sex on response of rat to pentobarbital. Anat. Rec. 136, 223 (1960).

[E38,612/60

King, J. E., Becker, R. F.: Differential response of pregnant rats to pentobarbital. Anat. Rec. 139, 245 (1961).

[D5,106/61

King, J. E., Becker, R. F.: Sex differences in the response of rats to pentobarbital sodium. I. Males, nonpregnant females, and pregnant females. Amer. J. Obstet. Gynec. 86, 856-864 (1963).

[G78,964/63

King, T. M., Burgard, J. K.: Drug interaction. Amer. J. Obstet. Gynec. 98, 128-134 (1967).

[G46,498/67

King, T. M., Fahim, M. S., Bolt, D. J.: Androgen response in phenobarbital-treated orchiectomized rats. Amer. J. Obstet. Gynec. 101, 850 to 852 (1968).

[H16,446/68

Kinoshita, F. K., Du Bois, K. P.: Induction of hepatic microsomal enzymes by Herban, Diuron, and other substituted urea herbicides. Toxicol. appl. Pharmacol. 17, 406-417 (1970).

[G78,681/70

Kinoshita, F. K., Frawley, J. P., Du Bois, K. P.: Quantitative measurement of induction of hepatic microsomal enzymes by various dietary levels of DDT and toxaphene in rats. Toxicol. appl. Pharmacol. 9, 505-513 (1966).

[G71,863/66

Kinsell, L. W., Zillesson, F. 0., Smith, A. M., Palmer, J.: Protective action of cardiac gly- 
cosides and adrenal cortical hormone against thyroxin. Endocrinology 20, 221-226 (1942).

$[\mathrm{A} 37,369 / 42$

Kinsey, V. E.: Use of sodium pentobarbital for repeated anesthesia in the white rat. J. Amer. Pharm. Ass. 29, 387-390 (1940). [A 39,742/40 Kirby, A. H. M.: The combined action of 2-acetylaminofluorene and sex hormones in the Wistar rat. Brit. J. Cancer 1, 68-79 (1947).

[B30,101/47

Kirschbaum, A., Shapiro, J. R., Mixer, H. W.: Synergistic action of leukemogenic agents. Cancer Res. 13, 262-268 (1953). [H27,666/53 Kirsteins, A.: Survival of cortisone- and corticotropin-treated rats during exposure to cold. Surgery 40, 337-348 (1956).

[C41,958/56

Klaassen, C. D.: Plasma disappearance and biliary excretion of sulfobromophthalein and phenol-3,6-dibromphthalein disulfonate after microsomal enzyme induction. Biochem. Pharmacol. 19, 1241-1249 (1970). [G75,506/70

Klaassen, C. D., Plaa, G. L.: Studies on the mechanism of phenobarbital-enhanced sulfobromophthalein disappearance. J. Pharmacol. exp. Ther. 161, 361-366 (1968). [F99,395/68 Klain, G. J., Hannon, J. P.: Gluconeogenesis in cold-exposed rats. Fed. Proc. 28, 965-968 (1969).

[H 13,174/69

Klärner, P., Klärner, R.: Die Beeinflussung induzierter Lungentumoren durch Hitze, Alloxan-Diabetes, Thyroxin und andere Agentien. Z. Krebsforsch. 62, 297-301 (1958).

$[\mathrm{C} 45,812 / 58$

Klatskin, G.: Toxic and drug-induced hepatitis. In: Schiff, L.; Diseases of the Liver, 3rd ed., p. 498-601. Philadelphia, Toronto: J. B. Lippincott Company 1969. [G65,221/69

Klein, M.: Development of hepatomas in inbred albino mice following treatment with 20 -methylcholanthrene. Cancer Res. 19, 1109-1113 (1959).

$[\mathrm{G} 76,354 / 59$

Kleinbaum, H.: Vitamin $\mathrm{D}_{2}$-Intoxikation im Kindesalter. Dtsch. Gesundh.-Wesen 17, 35-37 (1962).

[E23,570/62

Kleiner, G. J., Kresch, L., Arias, I. M.: Studies of hepatic excretory function. II. The effect of norethynodrel and mestranol on bromsulfalein sodium metabolism in women of childbearing age. New Engl. J. Med. 273, 420-423 (1965).

$[\mathrm{F} 47,209 / 65$

Kleinsorg, H., Loeser, A.: Schilddrüse und kompensatorische Hypertrophie der Niere bei Nephrektomie. Arch. int. Pharmacodyn. 79, 83-96 (1949).

$[\mathrm{B} 41,137 / 49$
Klevay, L. M.: Dieldrin excretion by the isolated perfused rat liver: a sexual difference. Toxicol. appl. Pharmacol. 17, 813-815 (1970).

[G80,049/79

Kligman, A. M., Baldridge, G. D., Rebell, G., Pillsbury, D. M.: The effect of cortisone on the pathologic responses of guinea pigs infected cutaneously with fungi, viruses, and bacteria. J. Lab. clin. Med. 37, 615-620 (1951).

[G64,164/51

Kline, E. M., Inkley, S. R., Pritchard, W. H.: Five cases from the fluorescent lamp industry. Treatment of chronic beryllium poisoning with ACTH and cortisone. Arch. industr. Hyg. 3, 549-564 (1951).

$[\mathrm{B} 65,488 / 51$

Kline, R. F., Britton, S. W.: Age and sex differences in resistance to anoxia (Abstr.). Fed. Proc. 4, 41 (1945).

$[85,856 / 45$

Klinenberg, J. R., Miller, F.: Effect of corticosteroids on blood salicylate concentration. $J$. Amer. med. Ass. 194, 601-604 (1965).

[F 54,504/65

Klinger, R.: Utber den angeblichen Antagonismus von Schilddrüse und Milz. Biochem. $Z$. 92, 376-384 (1918).

$[51,094 / 18$

Klinger, W.: Untersuchungen zum Mechanismus der Enzyminduktion bei Ratten und Mäusen. VII. Der Einfluß der Schilddrüse auf die Askorbinsäure-Normausscheidung und ihre Steigerung sowie auf die Hexobarbitalschlafzeit und ihre Verkürzung durch Barbital. Acta biol. med. germ. 16, 404-414 (1966).

$[\mathrm{F} 66,416 / 66$

Klinger, W.: Toxizität, narkotische Wirkung, Aufwachkonzentration im Blut, Elimination aus dem Blut und Biotransformation von Hexobarbital bei Ratten unterschiedlichen Alters nach Induktion mit Barbital und nach $\mathrm{CCl}_{4}$-Schädigung. Arch. int. Pharmacodyn. 184, 5-18 (1970).

$[\mathrm{H} 25,517 / 70$

Klinger, W., Elger, J., Franke, H., Reinicke, C., Traeger, A., Volkmann, H., Wahrenberg, I., Ankermann, H.: Untersuchungen zum Mechanismus der Enzyminduktion. XV. Induktionsmuster und submikroskopische Veränderungen in der Leber nach Applikation von Phenylbutazon bei unterschiedlich alten Ratten. Acta biol. med. germ. 24, 463-482 (1970).

[H28,896/70

Klinger, W., Koch, M., Kramer, B.: Untersuchungen zum Mechanismus der Enzyminduktion bei Ratten und Mäusen. V. Der Einfluß der Keimdrüsen auf die L-Askorbinsäure-Normausscheidung und ihre Steigerung sowie auf die Hexobarbitalschlafzeit und ihre 
Verkürzung durch Barbital. Acta biol. med. germ. 15, 700-706 (1965). [F62,929/65

Klinger, W., Zwacka, G.o, Ankermann, H.: Untersuchungen zum Mechanismus der Enzyminduktion. XIII. Die Übertragung eines zytoplasmatischen Hemmfaktors der Entwicklung mikrosomaler Leberenzyme aus der Leber von Rattenfoeten auf infantile Ratten. Acta biol. med. germ. 20, 137-145 (1968). [H30,598/68

Klinkmann, H., Hübel, A.: Testosteron-Behandlung bei schwerer intravenöser SublimatIntoxikation. Münch. med. Wschr. 106, 1466 bis 1468 (1964).

[F 19,820/64

Klotz, H. P.: Le rôle du terrain préalable dans l'accoutumance à l'alcool. C. R. Soc. Biol. (Paris) 124, $23-25$ (1937). [A96,052/37

Klug, W.: Klinische Erfahrungen mit dem anabol wirkenden Testosteronderivat Nerobol. Dtsch. Gesundh.-Wesen 19, 1360-1363 (1964).

$[\mathrm{G} 19,783 / 64$

Knaab, I.: Reid Hunt-Reaktion und Leberglykogen. Naunyn-Schmiedebergs Arch. Pharmak. 171, 65-72 (1933).

$[14,828 / 33$

Knigge, K. M.: Neuroendocrine mechanisms influencing ACTH and TSH secretion and their role in cold acclimation. Fed. Proc. 19, Sup. 5, 45-50 (1960).

$[\mathrm{C} 97,819 / 60$

Knox, A. W.: Influence of pregnancy in mice on the course of infection with murine poliomyelitis virus. Proc. Soc. exp. Biol. (N.Y.) 73, 520-523 (1950).

[B47,631/50

Knox, W. E.: Two mechanisms which increase in vivo the liver tryptophan peroxidase activity: specific enzyme adaptation and stimulation of the pituitary-adrenal system. Brit. J. exp. Path. 32, 462-469 (1951). [B 71,418/51

Knox, W. E.: Adaptive enzymes in the regulation of animal metabolism. In: Prosser; Physiological Adaptation, p. 107-125. Washington, D.C.: Amer. Physiol. Soc. 1958.

$[\mathrm{G} 67,799 / 58$

Knox, W. E.: Adaptive enzymes in animals. In: Mongar and de Reuck; Ciba Found. Symp. for Symp. on Drug Action on Enzymes and Drug Action, p. 275, London: J. \& A. Churchill Ltd. 1962.

[G51,969/62 Knox, W. E.: The adaptive control of tryptophan and tyrosine metabolism in animals. Trans. N.Y. Acad. Sci. 25, 503-512 (1963).

[D 66,995/63

Knox, W. E.: Substrate-type induction of tyrosine transaminase, illustrating a general adaptive mechanism in animals. In: Weber; Advances in Enzyme Regulation 2, p. 311-318. New York: MacMillan Co. 1964. [G65,171/64
Knox, W. E., Auerbach, V. H.: The hormonal control of tryptophan peroxidase in the rat. J. biol. Chem. 214, 307-313 (1955).

$[\mathrm{E} 76,825 / 55$

Knox, W. E., Auerbach, V. H., Lin, E. C. C.: Enzymatic and metabolic adaptations in animals. Physiol. Rev. 36, 164-254 (1956).

$[\mathrm{E} 83,471 / 56$

Kobayashi, K.: Experimental analysis of skin cancer production in mice thymectomized at adult age. J. Fac. Sci. Tokyo., Sect. 4, 11, 537-540 (1969).

$[\mathrm{H} 27,113 / 69$

Kobayashi, K.: Effect of thymus extract injection and thymus cell transfusion on papilloma production due to DMBA, in mice thymectomized as adults. J. Fac. Sci. Tokyo., Sect. 4, 11, 541-544 (1969). [H27,114/69 Kobayashi, S., Nakamura, W., Eto, H.: Protective effect of 5-hydroxytryptophan against lethal doses of $\mathrm{X}$-radiation in mice. Int. J. Radiat. Res. 11, 505-508 (1966).

$[\mathrm{G} 73,566 / 66$

Kobayashi, T., Danjo, H., Hata, K.: Fine structural changes in the liver cells of Gilbert's and Dubin-Johnson's syndrome induced by phenobarbital. (Japanese text.) Jap. J. clin. Elect. Micr. 2, 418-419 (1970).

$[\mathrm{H} 28,794 / 70$

Kobrin, S., Seifter, J.: $\omega$-Amino acids and various biogenic amines as antagonists to pentylenetetrazol. J. Pharmacol. exp. Ther. 154, 646-651 (1966). [F74,422/66

Koch, P., Guy, R., Venne, L.: Influence du Somatron, de l'Acton et du Duracton sur l'évolution du trauma thermique chez le rat. Un. méd. Can. 86, 515-518 (1957).

$[\mathrm{C} 33,922 / 57$

Koch, R.: Untersuchungen über einen biologischen Strahlenschutz. 80. Mitteilg. Úber quantitative Beziehungen des chemischen Strahlenschutzes zu seinem Wirkungsmechanismus. Strahlentherapie 134, 102-109 (1967).

$[\mathrm{G} 51,862 / 67$

Kochmann, M.: Standardisierung des Parathyreoideahormons und seine antagonistische Wirkung gegenüber dem Oxalation. Dtsch. med. Wschr. 60, 406 (1934). $\quad[55,946 / 34$ Kochmann, M.: Zur Wertbestimmung des Parathyreoideahormons mittels Natriumfluorid. Dtsch. med. Wschr. 60, 1062-1063 (1934). $[55,947 / 34$

Koch-Weser, J.: Potentiation by glucagon of the hypoprothrombinemic action of warfarin. Ann. intern. Med. 72, 331-335 (1970).

$[\mathrm{G} 73,494 / 70$ 
Kocsár, L. T., Bertók, L., Várterész, V.: Effect of bile acids on the intestinal absorption of endotoxin in rats. $J$. Bact. 100, 220-223 (1969).

[G69,983/69

Kodama, M., Moore, G. E.: The role of the thymus in polyoma virus infection. $J$. nat. Cancer Inst. 30, 225-238 (1963). [D56,877/63

Kodicek, E.: Discussion. In: Wolstenholme \& O'Connor; Bone Structure and Metabolism, p. 201-205. London: J. and A. Churchill Ltd. 1956.

$[\mathrm{C} 32,412 / 56$

Kodoma, Y., Bock, F. G.: Benzo( $\alpha$ pyrene-metabolizing enzyme activity of livers of various strains of mice. Cancer Res. 30, 1846-1849 (1970).

$[\mathrm{H} 28,307 / 70$

Kodousková, V., Kod̆ousek, R., Dušek, J.: Calcification of the Islets of Langerhans and renal corticol tubular epithelium in alloxan treated calciphylactic rats. Experientia ( $B a$ sel) 19, 314 (1963).

[D69,797/63

Koerner, D. R.: Assay and substrate specificity of liver $11 \beta$-hydroxysteroid dehydrogenase. Biochim. biophys. Acta (Amst.) 176, 377-382 (1969).

$[\mathrm{G} 65,718 / 69$

Koff, R. S., Carter, E. A., Lui, S., Isselbacher, K. J.: Prevention of the ethanol-induced fatty liver in the rat by phenobarbital. Gastroenterology 59, 50-61 (1970).

$[\mathrm{G} 76,179 / 70$

Kohn, H. I., Corbascio, A. N., Gultman, P. H.: Estradiol treatment and the $\mathrm{X}$-ray-induced acceleration of the age-specific mortality rate. J. nat. Cancer Inst. 29, 853-862 (1962).

$[\mathrm{D} 42,858 / 62$

Kohn, H. I., Corbascio, A. N., Gultman, P. H., Ludwig, F. C.: Effect of X-ray dose and estradiol treatment on the chronic mortality rate of adult female mice. Radiation Res. 14, 479 (1961).

[D9,831/61

Kohn, H. I., Kallman, R. F.: The influence of strain on acute $\mathrm{X}$-ray lethality in the mouse. 1. $\mathrm{LD}_{50}$ and death rate studies. Radiat. Res. 5, 309-317 (1956).

$[\mathrm{C} 25,371 / 56$

Kohn, R. R., Rivera-Velez, J. M.: Function of collagen: blood pressure in lathyritic rats. Nature (Lond.) 207, 537 (1965). [F 73,678/65

Köhnlein, H. E., Rehn, J.: Der Einfluß von Androgenen auf die ischaemisierte Rattenniere. Arzneimittel-Forsch. 12, 1112-1116 (1962).

[D44,607/62

Köhnlein, H. E., Rehn, J., Berneker, G. C.: Der Einfluß des Wachstumshormons auf die ischaemisierte Rattenniere. ArzneimittelForsch. 12, 957-963 (1962). [D38,961/62
Koike, K., Otaka, T., Okui, S.: Repressive effect of cortisone administration on protein synthesis of mouse liver in vitro. J. Biochem. (Tokyo) 63, 709-715 (1968). [H 15,766/68

Koivisto, M., Ojala, A., Järvinen, P. A.: The effect of neonatal bilirubin levels of oestrogen given to the mother before delivery. Ann. clin. Res. 2, 204-208 (1970). [G78,915/70

Kolb, K. H., Kimbel, K. H., Schulze, P. E.: Der Einfluß verschiedener anabol wirksamer Steroide auf die Farbstoffausscheidung in die Rattengalle. Arzneimittel-Forsch. 12, 228-230 (1962).

[D22,260/62

Koller, M.: Sulla dipendenza dal sesso dell'attività di steroidi ad azione anestetica. Boll. Soc. ital. Biol. sper. 32, 78-80 (1956). [C19,288/56

Komiya, A.: Effect of adrenocortical hormones on the concentration of barbital in mouse brain. Gunma J. med. Sci. 4, 87 (1955).

$[\mathrm{C} 7,045 / 55$

Komiya, A.: Effects of the administration of adrenocortical hormones and ACTH on the barbital anesthesia. Gunma J. med. Sci. 4, 175 (1955).

$[\mathrm{C} 8,533 / 55$

Komiya, A., Machida, J., Kosuge, M., Fukushima, K.: The effect of the administration of cortisone acetate on barbital anesthesia in male rabbits. Gunma J. med. Sci. 5, 71 (1956).

[D26,331/56

Komiya, A., Shibata, K.: Effect of adrenalectomy and replacement with adrenocortical steroids on barbital anesthesia in mice. $J$. Pharmacol. exp. Ther. 116, 98-106 (1956).

$[\mathrm{C} 13,129 / 56$

Komiya, A., Shibata, K.: Effect of adrenocortical steroids and ACTH administration on barbital anesthesia in normal mice. $J$. Pharmacol. exp. Ther. 117, 68-74 (1956).

$[\mathrm{C} 16,708 / 56$

Komiya, A., Shibata, K., Kosuge, M.: Effects of epinephrine and norepinephrine on barbiturates anesthesia in mice. Endocr. jap. 2, 221-228 (1956).

$[\mathrm{C} 21,326 / 56$

König, M. P.: Androgentherapie und Antiandrogene. Schweiz. med. Wschr. 99, 744-747 (1969).

[G66,684/69

Konishi, G.: Change in $\Delta^{4}$-steroid hydrogenase activity in rat liver after tumor implantation. Bull. Tokyo med. dent. Univ. 16, 37-46 (1969).

$[\mathrm{H} 14,720 / 69$

Korenchersky, V.: I. The influence of removal of sexual glands on the skeleton of animals kept on normal or rickets-producing diets. II. Spontaneous rickets in rats. J. Path. Bact. 26, 207-223 (1923).

$[14,032 / 23$ 
Korenchevsky, V.: Treatment of senescent male rats with cortisone acetate alone or together with sex and thyroid hormones. J. Geront. 11, 261-267 (1956). [C18,714/56

Korenchersky, V., Dennison, M., KohnSpeyer, A.: Simultaneous administration of testicular hormone with antuitrin and prolan or with desiccated thyroid. Biochem. J. 27, 1513-1516 (1933).

$[16,451 / 33$

Korényi, Z., Hajdu, I.: Die Rolle der Nebenniere im physiologischen Mechanismus des Trainings. Arbeitsphysiol. 12, 31-43 (1942).

[A 56,945/42

Korpássy, B., Kováes, K., Sztanojevits, A.: Influence of sex and dietary casein content upon lethal and liver injurious effect of tannic acid. Ineffectiveness of certain so-called liver protecting substances. Acta physiol. Acad. Sci. hung. 3, 233-241 (1952).

[B 74,333/52

Korteweg, R., Thomas, F.: Tumor induction and tumor growth in hypophysectomized mice. Amer. J. Cancer 37, 36-44 (1939).

[A 33,075/39

Korting, G. W., Holzmann, H., Morsches, B.: Enzymatic determination in serum of lathyritic and prednisone-treated lathyritic rats. Nature (Lond.) 209, 1130 (1966). [F 63,363/66

Kory, R. C., Bradley, M. H., Watson, R. N., Callahan, R., Peters, B. J.: A six-month evaluation of an anabolic drug, norethandrolone in underweight persons. II. Bromsulphalein (BSP) retention and liver function. Amer. $J$. Med. 26, 243-248 (1959).

[C75,742/59

Kosdoba, A. S.: Zur Frage nach den pathologisch-anatomischen Begründungen Zusammenhanges einiger chirurgischer Erkrankungen des Blutgefäßsystems mit Nikotinismus. Mitt. Grenzgeb. Med. Chir. 41, 687-699 (1929-30).

[A39,432/29-30

Koss, L. G., Lavin, P.: Effects of a single dose of cyclophosphamide on various organs in the rat. II. Response of urinary bladder epithelium according to strain and sex. J. nat. Cancer Inst. 44, 1195-1200 (1970).

[G75,309/70

Kostowski, W., Nowacka, M.: Influence of some adrenal steroids on hexobarbital and hydroxydione anaesthesia. Arch. int. Pharmacodyn. 184, 362-365 (1970). [H26,526/70

Kostrubiak, W., Howard, J. M.: Studies of the effect of aldosterone in the experimental toxemia with the alpha-toxin of Clostridium welchii. J. Trauma 4, $814-818$ (1964).

[G57,804/64
Kostrubiak, W., Howard, J. M.: The protective effect of aldosterone against the toxin of clostridium tetani. Surg. Gynec. Obstet. 121, $59-62$ (1965).

[F 43,646/65

Kotin, P., Edmondson, H. A., Falk, H. L.: The inhibiting effect of estrogens on the development of cirrhosis and hepatocellular carcinoma in rats on a choline deficient diet. Amer. $J$. Path. 32, 633-634 (1956). $\quad$ [C16,597/56

Kottke, F. J., Taylor, c. B., Kubicek, W. G., Erickson, D. M., Evans, G. T.: Adrenal cortex and altitude tolerance. Amer. J. Physiol. 153, 16-20 (1948).

[B25,989/48

Kottra, J., Kappas, A.: Steroid effects on hepatic function: recent observations. Ann. Rev. Med. 18, 325-332 (1967). [F 79,911/67

Kottra, L. L., Kappas, A.: Estrogen pharmacology. III. Effect of estradiol on plasma disappearance rate of sulfobromophthalein in man. Arch. intern. Med. 117, 373-376 (1966).

[G37,574/66

Koudstaal, J., Hardonk, M. J.: Histochemical demonstration of enzymes related to NADPHdependent hydroxylating systems in rat liver after phenobarbital treatment. Histochemie $\mathbf{2 0}$, 68-77 (1969).

[G69,482/69

Koudstaal, J., Hardonk, M. J.: Histochemical demonstration of enzymes in rat liver during post-natal development. Enzymes related to NADPH-dependent hydroxylating systems and to sex-difference. Histochemie 23, 71-81 (1970).

$[\mathrm{G} 78,115 / 70$

Kovách, A. G. B., Takács, L., Mohǎesi, A., Kaldor, V., Kalmar, Z.: Effect of metabolismincreasing or -decreasing substances on the susceptibility of rats to shock. Acta physiol. Acad. Sci. hung. 11, 181-188 (1957).

[C50,699/57

Kovács, I. B., Görög, P.: Bronchoconstrictor effect of endotoxin in guinea-pig; the protective effect of antihistamine and antiinflammatory compounds. Europ. J. Pharmacol. 4, 91-95 (1968).

[H 2,570/68

Kováes, K.: Effect of androgenisation on the development of mammary tumours in rats induced by the oral administration of 9,10-dimethyl-1,2-benzanthracene. Brit. J. Cancer 19, 531-537 (1965).

[G34,582/65

Kovács, K.: Effect of spironolactone on the liver and of 7,12-dimethylbenz( $\alpha$ )anthracene on the adrenal cortex. An electronmicroscopic study. Workshop on DMBA Activity, Laval Univ. Quebec City, p. 57-62 (1969).

$[\mathrm{G} 70,404 / 69$ 
Kováes, K., Blascheck, J. A., Gardell, C.: Spironolactone-induced proliferation of smoothsurfaced endoplasmic reticulum in the liver of rats. Z. ges. exp. Med. 152, 104-110 (1970). $[\mathrm{G} 60,045 / 70$

Kovács, K., Blascheck, J. A., Garg, B. D., Somogyi, A.: Effect of cyproterone acetate on the liver ultrastructure in rats. Horm. metab. Res. 3, 44-47 (1971).

$[\mathrm{G} 70,476 / 71$

Kováes, K., Garg, B. D., Khandekar, J. D.: Hepatic injury caused by $\mathrm{N}$-y-phenylpropyl-Nbenzyloxy acetamide (W-1372). A light and electron microscopic study. J. Pharm. Sci. (in press).

$[\mathrm{G} 79,003$

Kováes, K., Khandekar, J., Dardachti, D., Garg, B. D., Tuchweber, B.: Ultrastructural changes in rat liver cells after intramuscular implantation of a Walker tumor. Experientia (Basel) (in press).

[G46,737

Kováes, K., Khandekar, J. D., Dardachti, D., Garg, B. D., Tuchweber, B.: Alteraciones ultraestructurales producidas por la pregnenolona$16 \alpha$-carbonitrilada en hepatocitos de ratas portadoras de un tumor Walker. Rev. argent Med. intern. (in press).

[G 79,033

Kovács, K., Somogyi, A.: Prevention by spironolactone of 7,12-dimethylbenz $(\alpha)$ anthraceneinduced adrenal necrosis. Proc. Soc. exp. Biol. (N.Y.) 131, 1350-1352 (1969). [G60,025/69 Kováes, K., Somogyi, A.: Abolition by Dlethionine of the protective effect of spironolactone on 7,12-dimethylbenz ( $\alpha$ )anthraceneinduced adrenal necrosis in rats. Biochim. Biol. sper. 8, 227-230 (1969). [ [G60,060/69 Kováes, K., Somogyi, A.: Suppression by spironolactone of 7,12-dimethylbenz $(\alpha)$ anthraceneinduced mammary tumors. Europ. J. Cancer 6, 195-201 (1970).

$[\mathrm{G} 60,089 / 70$

Kováes, K., Szijj, I.: Effect of alloxan diabetes and insulin administration on the incidence of pituitary necrosis caused by hexadimethrine bromide in rats. Experientia (Basel) 24, 257-258 (1968).

[F 96,892/68

Kowalewski, K.: Uptake of radiosulphur in growing bones of cockerels treated with cortisone and 17-ethyl-19-nortestosterone. Proc. Soc. exp. Biol. (N.Y.) 97, 432-434 (1958).

$[\mathrm{C} 48,527 / 58$

Kowalewski, K.: Comparison of the effects of cortisone and certain anabolic-androgenic steroids on the uptake of radiosulfur in a healing fractured bone. Endocrinology 62, 493-497 (1958).

$[\mathrm{C} 50,864 / 58$

Kowalewski, K.: Uptake of radiosulfate in growing bones of cockerels treated with cortisone and certain anabolic-androgenic steroids. Endocrinology 63, 759-764 (1958).

$[\mathrm{C} 61,936 / 58$

Kowalewski, K.: Effect of certain androgenic steroids and cortisone on gastric ulcerogenesis in fasting rats. Proc. Soc. exp. Biol. (N.Y.) 101, 147-150 (1959).

$[\mathrm{C} 68,938 / 59$

Kowalewski, K.: Effect of steroids on bone formation. In: Gross; Protein Metabolism (An Inter. Symp.), p. 238-262. Berlin, Göttingen, Heidelberg: Springer Verlag 1962.

$[\mathrm{G} 41,978 / 62$

Kowalewski, K., Bain, G. 0.: Prevention of post-histaminic gastric ulcers in guinea pigs by posterior pituitary extract. Acta gastro-ent. belg. 17, 539-551 (1954). [C3,897/54

Kowalewski, K., Couves, C. M., Lang, A.: Protective action of 17-ethyl-19-nortestosterone against the inhibition of bone repair in the lathyrus-fed rat. Acta endocr. (Kbh.) 30, 268-272 (1959).

$[\mathrm{C} 63,273 / 59$

Kowalewski, K., Emery, M. A.: Effect of a lathyrus factor and of an anabolic steroid on healing of fractures in rats studied by ${ }^{35} \mathrm{~S}$ uptake method. Acta endocr. (Kbh.) 34, 317-322 (1960). [C86,516/60

Kowalewski, K., Gort, J.: An anabolic androgen as a stimulant of bone healing in rats treated with cortisone. Acta endocr. (Kbh.) 30, 273 to 276 (1959).

$[\mathrm{C} 63,274 / 59$

Kozlowski, H., Hrabowska, M.: Utber den Einfluß anaboler Steroide auf die Entwicklung der experimentellen Amyloidose bei Mäusen. Zbl. allg. Path. path. Anat. 112, 184-193 (1969).

$[\mathrm{H} 14,243 / 69$

Kozuka, S.: Inhibiting effect of reserpine and female sensitivity in hepatic tumor induction with 2,7-diacetamidofluorene in SMA/Ms strain mice. Cancer Res. 30, 1384-1386 (1970).

$[\mathrm{H} 27,469 / 70$

Kracht, J., Meissner, G.: Wachstumshormon und Cortison bei experimenteller Tuberkulose mit unterschiedlicher Keimvirulenz. Frankfurt. Z. Path. 67, 391-405 (1956).

$[\mathrm{C} 21,867 / 56$

Krahe, M., Heinen, G.: Ưber den proteinanabolen Effekt von Methandrostenolon auf das Yoshida-Sarkom und das Walker-256-Carcinosarkom. Klin. Wschr. 40, 913-916 (1962).

[D35,677/62

Krahe, M., Künkel, H.-A.: Die Strahlenempfindlichkeit der Ratten bei erhöhtem Grundumsatz. Strahlentherapie 106, 260-262 (1958).

$[\mathrm{C} 77,236 / 58$ 
Kramer, M., Arrigoni-Martelli, E.: Die Verstärkung des narkotischen Effekts und die Abbauhemmung von Hexobarbital durch Malonsäurederivate. Naunyn-Schmiedebergs Arch. Pharmak. 237, 264-275 (1959).

[G74,673/59

Kratter, V., Martelli, 0. F.: Ricerche sperimentali sul comportamento di conigli stimizzati in rapporto alle infezioni provocate. Sperimentale 99, 453-470 (1949).

[B60,263/49

Krawezak, J. J., Brodie, B. B.: Effect of adrenalectomy and complete blockade of adrenergic function on mortality from histamine, endotoxin, formation and tourniquet stress in rats. Pharmacology (Basel) 3, 65-75 (1970).

[H 25,296/70

Kreek, M. J., Peterson, R. E., Sleisenger, M. H., Jefiries, G. H.: Influence of ethinyl estradiolinduced cholestasis on bile flow and biliary excretion of estradiol and bromsulfophthalein by the rat. (Abstr.) J. clin. Invest. 46, 1080 (1967).

[F 83,145/67

Kreek, M. J., Sleisenger, M. H.: Reduction of serum-unconjugated-bilirubin with phenobarbitone in adult congenital non-haemolytic unconjugated hyperbilirubinaemia. Lancet 1968II, 73-78.

[G71,811/68

Kreek, M. J., Sleisenger, M. H.: Estrogen induced cholestasis due to endogenous and exogenous hormones. Scand. J. Gastroent., Sup. 7, 123-131 (1970).

[G77,590/70

Kreek, M. J., Sleisenger, M. H., Jefiries, G. H.: Recurrent cholestatic jaundice of pregnancy with demonstrated estrogen sensitivity. Amer. J. Med. 43, 795-803 (1967).

[G51,605/67

Kreek, M. J., Weser, E., Sleisenger, M. H., JefIries, G. H.: Idiopathic cholestasis of pregnancy. The response to challenge with the synthetic estrogen, ethinyl estradiol. New Engl. J. Med. 277, 1391-1395 (1967).

[F 92,343/67

Krems, A. D., Martin, A. W., Dille, J. M.: Experimental study of tolerance to sulfanilamide in the albino rat. $J$. Pharmacol. exp. Ther. 71, 215-221 (1941).

[A46,116/41

Kritchevsky, D., Tepper, S. A., Staple, E., Whitehouse, M. W.: Influence of sex and sex hormones on the oxidation of cholesterol-26$\mathrm{C}^{14}$ by rat liver mitochondria. J. Lipid Res. 4, 188-192 (1963).

[G 16,024/63

Krizek, T. J., Davis, J. H.: The effect of diabetes on experimental infection. Surg. Forum 15, 60-61 (1964). [F 14,734/64 Křǐ̌enecký, J.: Ưber den Einfluß der Hyperthyreoidisation und der Hyperthymisation auf das Gewicht der ausgewachsenen Vögel. Ein fünfter Beitrag zum Studium der entwicklungsmechanisch-antagonistischen Wirkung der Thymus und der Thyreoidea. Z. vergl. Physiol. 8, 16-36 (1928). [4,176/28

KY̌íženecký, J.: Recherches sur l'antagonisme du thymus et du corps thyroide au point de vue de leur influence sur le poids du corps. C. R. Soc. Biol. (Paris) 98, 1031-1033 (1928).

$[23,688 / 28$

Kříženecký, J.: Nouvelles recherches sur l'antagonisme du thymus et du corps thyroïde. $C$. $R$. Soc. Biol. (Paris) 106, 325-327 (1930).

$[277 / 30$

Křix̌enecký, J., Podhradský, J.: Zur Frage der entwicklungsmechanisch-antagonistischen Wirkung der Thymus und der Thyreoidea. (Versuche an Kaulquappen.) Wilhelm Roux' Arch. Entwickl. Mechanik. Organis. 108, 68-86 (1926).

$[4,186 / 26$

Kröger, H., Kotulla, W., Hoshino, J.: Zur Rolle des Substrats bei der Cortison-Induktion von Enzymen in der Leber. Z. Naturforsch. 24b, 229-233 (1969).

[G66,240/69

Kroneberg, G.: Ủber den Einfluß des Thyroxins auf die Wirkungen von Adrenalin und Arterenol. Naunyn-Schmiedebergs Arch. Pharmak. 216, 240-249 (1952).

[B 87,448/52

Kroneberg, G., Hüter, F.: Der Einfluß von Thyroxin auf die Toxicität des Adrenalins und Arterenols. Klin. Wschr. 29, 649 (1951).

[B $69,838 / 51$

Kroneberg, G., Pötzseh, E.: Ưber die Toxizität des Flexner-Endotoxins und den Endotoxinkollaps an thyroxinbehandelten Mäusen. Naunyn-Schmiedebergs Arch. Pharmak. 216, 233 bis 239 (1952).

[E54,858/52

Krupa, P. L., Hamburgh, M., Zaiman, H.: Effect of hypothyroidism on resistance of mice to infection with Trichinella spiralis. J. Parasit. 53, 126-129 (1967).

[G45,694/67

Krus, D. M., Wapner, S., Bergen, J., Freeman, H.: The influence of progesterone on behavioral changes induced by lysergic acid diethylamide (LSD-25) in normal males. Psychopharmacologia (Berlin) 2, 177-184 (1961).

[G78,688/61

Krüskemper, H. L.: Anabolic Steroids, pp. 236. New York, London: Academic Press, Inc. 1968. (Originally published in the German Language. Stuttgart: George Thieme Verlag 1963.)

[E933/68

Krüskemper, H. L., Noell, G.: Liver toxicity of a new anabolic agent: methyltrienolone (17 $\alpha$ - methyl-4,9,11-estratriene-17 $\beta$-ol-3-one). Steroids 8, 13-24 (1966).

[G48,300/66 
Kubota, D. C., Bernstein, A.: Adrenocorticotropic hormone (ACTH) in the treatment of barbiturate poisoning. Illinois med. J. 111, $80-83$ (1957).

$[\mathrm{C} 52,401 / 57$

Kucharik, J., Telbisz, A.: Die Rolle der Nebenniere in der Pathologie und Behandlung der Senfgasvergiftungen. Schweiz. med. Wschr. 75, 996-997 (1945).

$[96,165 / 45$

Küchmeister, H., Schuhmacher, H. H., Herrning, G., Pentz, U. von: Die Wirkung des ACTHs auf die Reaktionsweise der Leber nach Allylformiatvergiftung. $Z$. ges. exp. Med. 120, 215-220 (1953).

[B84,244/53

Kuck, N. A.: The effect of triamcinolone, prednisolone, and hydrocortisone on dosage requirements of tetracycline for control of a streptococcus infection in mice. In: Welch and Marti-Ibanez; Antibiotics Annual 1958-1959, p. 234 -238. New York: Medical Encyclopedia Inc. 1959.

$[\mathrm{C} 69,754 / 59$

Kudo, M., Mutai, S., Uraguchi, K.: The effects of cortisone, cortate, parotin and adrenalectomy on Japanese encephalitis virus infection in mice. Yokohama med. Bull. 5, 337-344 (1954).

$[\mathrm{C} 11,417 / 54$

Kuhlmann, K., Oduah, M., Coper, H.: Über die Wirkung von Barbituraten bei Ratten verschiedenen Alters. Naunyn-Schmiedebergs Arch. Pharmak. 265, 310-320 (1970). [G74,362/70

Kühn, H. A., Creutzfeldt, W., Discher, R., Röttger, P.: Untersuchungen über die therapeutische Beeinflußbarkeit experimenteller Lebercirrhosen bei der Ratte. I. Beobachtungen an gesunden Ratten nach alleiniger und kombinierter Gabe von Glucocorticoiden, Androgenen, Leberextrakten, Lipocaic, Antibiotica und Sulfonamidderivaten. $Z$. ges. exp. Med. 136, 162-168 (1962).

[D 64,992/62

Kuhn, L. A., Page, L. B., Turner, J. K., Frieden, J.: Effect of cold exposure on resistance to hemorrhage in dogs. Amer. J. Physiol. 196, 715-718 (1959).

$[\mathrm{C} 67,681 / 59$

Kuipers, F., Ely, R. S., Kelley, V. C.: Metabolism of steroids: the removal of exogenous 17-hydroxycorticosterone from the peripheral circulation in dogs. Endocrinology 62, 64-74 (1958).

$[\mathrm{C} 48,349 / 58$

Kulagin, V. K.: The use of certain hormones of hypophysis and adrenals for shock prophylaxis and therapy in prolonged crush syndrome. (Russian text.) Byul. eksper. biol. $i$ med. 49, 35-39 (1960).

[D236/60

Kulesár, A., Földes, I., Kulesár-Gergely, J.: Importance of mucopolysaccharides in the development of the protective hepatotropic effect of hypothyrosis. Tohoku J. exp. Med. 97, 373-384 (1969).

$[\mathrm{H} 14,649 / 69$

Kulcsár, A., Kulcsár-Gergely, J.: Ưber Leberschutz durch Kastration bei experimenteller Leberläsion. Naturwissenschaften 47,183 (1960).

$[\mathrm{C} 94,710 / 60$

Kulesár, A., Kulesár-Gergely, J.: The influence of hormonal disturbances on the survival of liver-damaged animals. Tohoku J. exp. Med. 89, 315-320 (1966).

$[\mathrm{F} 74,930 / 66$

Kulesár, A., Kulesár-Gergely, J., Dan, S., Sari, B.: Functional adaptation of the liver in thyroidal disturbances. Rev. int. Hepat. 19, 359 to 364 (1969).

$[\mathrm{G} 72,002 / 69$

Kulesár, A., Kulcsár-Gergely, J., Daroczy, A.: Influence of thyroid function on experimental liver injuries. Tohoku J. exp. Med. 101, 251 to 256 (1970).

$[\mathrm{H} 24,478 / 70$

Kulcsár-Gergely, J., Kulesár, A.: Toxic actions of oestrogens on the liver. J. Pharm. Pharmacol. 12, 312-316 (1960).

$[\mathrm{C} 99,083 / 60$

Kulesár-Gergely, J., Kulesár, A.: Leberfunktion während der Hypothyreose. Naturwissenschaften 49, 610 (1962).

$[\mathrm{G} 71,532 / 62$

Kulesár-Gergely, J., Kulesár, A.: Utber die Leberschutzwirkung der Hypothyreose. Naturwissenschaften 50, 693 (1963). [E33,917/63 Kulesár-Gergely, J., Kulesár, A.: Ưber die hepatoendokrinen Zusammenhänge des Eierstockes und der Schilddrüse. Naturwissenschaften 51, 43 (1964).

[G1,372/64

Kulesár-Gergely, J., Kulesár, A., Dévényi, I.: The protective effect of thyroidectomy and ovariectomy on experimental liver lesion. Tohoku J. exp. Med. 84, 256-258 (1964).

$[\mathrm{F} 32,037 / 64$

Kumagai, A., Otomo, M., Yano, S., Takeuchi, N., Nishino, K., Ueda, H., Ko, S., Kitamura, M.: Inhibitors of the corticoid metabolism in vitro. Endocr. jap. 5, 122-126 (1958). [C57,345/58

Kumagai, A., Otomo, M., Yano, S., Takeuchi, N., Nishino, K., Ueda, H., Ko, S., Kitamura, M.: Inhibition of cortisol metabolism in the liver by other steroids. Endocr. jap. 6, 86-92 (1959).

$[\mathrm{C} 73,732 / 59$

Kunde, M. M., Williams, L. A.: Experimental cretinism. II. The influence of the thyroid gland on the production and control of experimental rickets. Amer. J. Physiol. 83, 245-249 (1927).

$[18,960 / 27$

Kuntzman, R.: Drugs and enzyme induction. Ann. Rev. Pharmacol. 9, 21-36 (1969).

[G64,989/69

Kuntzman, R., Jacobson, M.: Effect of drugs on the metabolism of progesterone by liver 
microsomal enzymes from various animal species. Fed. Proc. 24, 152 (1965). [F 35,869/65

Kuntzman, R., Jacobson, M., Conney, A. H.: Effect of phenylbutazone on cortisol metabolism in man (Abstr.). Pharmacologist 8, 195 (1966).

[G67,761/66

Kuntzman, R., Jacobson, M., Levin, W., Conney, A. H.: Stimulatory effect of n-phenylbarbital (phetharbital) on cortisol hydroxylation in man. Biochem. Pharmacol. 17, 565-571 (1968).

[G57,741/68

Kuntzman, R., Jacobson, M., Schneidman, K., Conney, A. H.: Similarities between oxidative drug-metabolizing enzymes and steroid hydroxylases in liver microsomes. $J$. Pharmacol. exp. Ther. 146, 280-285 (1964). [F 27,893/64

Kuntzman, R., Kluteh, A., Tsai, I., Burns, J. J.: Physiological distribution and metabolic inactivation of chlorcyclizine and cyclizine. $J$. Pharmacol. exp. Ther. 149, 29-35 (1965).

$[\mathrm{F} 45,464 / 65$

Kuntzman, R., Lawrence, D., Conney, A. H.: Michaelis constants for the hydroxylation of steroid hormones and drugs by rat liver microsomes. Molec. Pharmacol. 1, 163-167 (1965).

$[\mathrm{E} 55,528 / 65$

Kuntzman, R., Levin, W., Jacobson, M., Conney, A. H.: Studies on microsomal hydroxylation and the demonstration of a new carbon monoxide binding pigment in liver microsomes. Live Sci. 7, 215-224 (1968).

$[\mathrm{G} 71,857 / 68$

Kuntzman, R., Mark, L. C., Brand, L., Jacobson, M., Levin, W., Conney, A. H.: Metabolism of drugs and carcinogens by human liver enzymes. J. Pharmacol. exp. Ther. 152, 151 to 156 (1966).

[H30,992/66

Kuntzman, R., Sansur, M., Conney, A. H.: Effect of drugs and insecticides on the anesthetic action of steroids. Endocrinology 77,952 to 954 (1965).

[F 55,537/65

Kuntzman, R., Welch, R., Conney, A. H.: Factors influencing steroid hydroxylases in liver microsomes. In: Weber; Advances in Enzyme Regulation 4, p. 149-160. Oxford, London, Edinburgh: Pergamon Press 1966.

$[\mathrm{G} 66,245 / 66$

Künzel, B., Müller-Oerlinghausen, B.: Wirkung von Testosteron und einem Anti-Androgen (Cyproteronacetat) auf die Glucuronidbildung in der Rattenleber. Naunyn-Schmiedebergs Arch. Pharmak. 262, 112-123 (1969).

$[\mathrm{G} 64,178 / 69$
Kupfer, D., Peets, L.: The effect of o,p'DDD on cortisol and hexobarbital metabolism. Biochem. Pharmacol. 15, 573-581 (1966). [G40,053/66

Kupfer, D., Peets, L.: Potentiation of cortisol induction of hepatic tyrosine transaminase by $\beta$-diethylaminoethyl diphenylpropylacetate. Nature (Lond.) 215, 637-638 (1967).

[F 85,854/67

Kupferberg, H. J., Way, E. L.: Pharmacologic basis for the increased sensitivity of the newborn rat to morphine. J. Pharmacol. exp. Ther. 141, 105-112 (1963).

[E21,867/63

Kupperman, H. S., de Graff, A. C.: Effect of hypoadrenalcorticoidism and excessive doses of desoxycorticosterone acetate and thyroid upon response of rat to cardiac glycosides. $F e d$. Proc. 9, 293 (1950).

$[\mathrm{B} 47,267 / 50$

Kusama, J.: Studies on carbohydrate metabolism of Graves' disease. Part 3. On glycogen of thyroid-fed rats. (Japanese text.) Shinshu med. J. 6, 395-398 (1957).

$[\mathrm{C} 58,473 / 57$

Kutner, F. R., Schwartz, S. I., Adams, J. T.: The effect of adrenergic blockade on lymph flow in endotoxin shock. Ann. Surg. 165, 518-527 (1967).

$[\mathrm{G} 46,379 / 67$

Laatikainen, T.: Excretion of neutral steroid hormones in human bile. Ann. clin. Res. 2, Sup. 5, 7-28 (1970).

$[\mathrm{G} 78,706 / 70$

Labbé, H., Théodoreseo, B.: Recherches sur l'antagonisme physiologique de la caféine et de l'insuline. Ann. Méd. 16, 211-217 (1924).

$[17,831 / 24$

Laborit, H., Broussolle, B., Perrimond-Trouchet, R.: Essais pharmacologiques concernant le mécanisme des convulsions dues a l'oxygène pur en pression chez la souris. J. Physiol. (Paris) 49, 953-962 (1957). [C48,371/57 Laborit, H., Broussolle, B., Perrimond-Trouchet, R.: Action protectrice de la 5-hydroxytryptamine contre les accidents convulsifs de l'oxygène sous pression chez la souris. $C . R$. Soc. Biol. (Paris) 151, 930-933 (1958).

$[\mathrm{C} 52,731 / 58$

Laborit, H., Niaussat, P., Broussolle, B., Jouanu, J. M.: Exposé de résultats expérimentaux concernant certaines propriétés originales de la sérotonine. Med. exp. (Basel) 1, 27-33 (1959).

$[\mathrm{C} 77,964 / 59$

Labrie, F., Korner, A.: Growth hormone inhibition of hydrocortisone induction of tyrosine transaminase and tryptophan pyrrolase and its reversal by amino acids. $J$. biol. Chem. 243, 1120-1122 (1968). [G56,018/68

Lacassagne, A., Chamorro, A., Hurst, L., Giao, N. B.: Effet de l'éphysectomie sur l'hépatocan- 
cérogenèse chimique, chez le rat. C. R. Acad. Sci. (Paris) 269, 1043-1046 (1969).

[G74,931/69

Lacassagne, A., Hurst, L.: The effect of desoxycorticosterone and of hydrocortisone on the development of cancer in the rat liver under the influence of p-dimethylaminoazobenzene (DAB). C. R. Acad. Sci. (Paris) 257, 1576-1580 (1963).

$[\mathrm{G} 12,688 / 63$

Lacassagne, A., Hurst, L.: Influence de sulfamides hypo- ou hyperglycémiants sur la cancérisation du foie du rat par le 2-acétylaminofluorène. Bull. Cancer 56, 397-410 (1969).

$[\mathrm{G} 78,530 / 69$

Lacassagne, A., Jayle, M. F., Hurst, L.: Action des stéroïdes en C 21 sur la cancérisation du foie du rat par le paradiméthyl-aminoazobenzène (DAB). C. R. Acad. Sci. (Paris) 268, 740 -743 (1969).

[G74,932/69

Lacassagne, A., Jayle, M. F., Hurst, L., Pasqualini, J. R.: Influence de differents corticostéroïdes sur la cancérisation du foie du rat par le p-diméthylaminoazobenzène (DAB). C. R. Acad. Sci. (Paris) 262, 2117-2119 (1966).

$[\mathrm{G} 39,677 / 66$

Lacassagne, A., Nyka, W.: Influence de la privation d'hypophyse sur le développement des tumeurs chez le lapin. C. R. Soc. Biol. (Paris) 121, 822-824 (1936).

$[59,016 / 36$

Lacassagne, A., Tuchmann-Duplessis, H.: Atténuation de la radiosensibilité du rat et du cobaye par l'hormone de croissance antéhypophysaire. C. R. Acad. Sci. (Paris) 236, 440 a 443 (1953).

[E53,832/53

Lack, C. H.: Increased vascular permeability, chondrolysis and cortisone. Proc. Roy. Soc. Med. 55, 5-8 (1962).

[D54,382/62

Laddu, A. R., Sanyal, R. K.: Effects of newer glucocorticoids on anaphylactic shock in the rat and the mouse. Int. Arch. Allergy 33, 593-597 (1968).

[G60,298/68

Ladner, H. A., Wollschläger, G., Schneider, J. Zur Strahlenschutzwirksamkeit von Serotonin bei Ratten. Naturwissenschaften 52, 393 (1965).

[G31,673/65

LaDu, B. N., Trousof, N., Brodie, B. B.: Enzymatic dealkylation of aminopyrine and other alkylamines in vitro. Fed. Proc. 12, 339 (1953).

[G74,654/53

Lage, G. L., Spratt, J. L.: Antagonism of intravenous digitoxigenin lethality by reserpine pretreatment in the mouse. Proc. Soc. exp. Biol. (N.Y.) 125, 580-583 (1967).

$[\mathrm{F} 86,237 / 67$
Lagôa, F. R.: Infecções experimentais pelo virus da influenza e corticoesteróides. Brasilméd. 76, 187-192 (1962). [D 58,191/62 Lagrange, E.: L'action des ultrasons sur la bilharziose expérimentale de la souris. $C$. $R$. Soc. Biol. (Paris) 156, 1725-1727 (1962). [D57,434/62

Lagrange, E.: A la recherche de stéroïdes de synthèse à action antibilharzienne. C. R. Soc. Biol. (Paris) 157, 425-427 (1963).

[D $69,093 / 63$

Lal, H., Puri, S. K., Fuller, G. C.: Impairment of hepatic drug metabolism by carbon tetrachloride inhalation. Toxicol. appl. Pharmacol. 16, 35-39 (1970).

$[\mathrm{G} 77,285 / 70$

Lalich, J. L., Turner, H.: Dilatation of colon induced in rats by $\beta$-aminopropionitrile feeding. Exp. Molecul. Path. 6, 1-10 (1967).

[G44,676/67

Lamanna, C., Jensen, W. I., Bross, I. D. J.: Body weight as a factor in the response of mice to botulinal toxins. Amer. J. Hyg. 62, 21-28 (1955).

$[\mathrm{G} 60,750 / 55$

Lamarche, M., Pluche, B.: Etude de l'action de l'acide triiodothyroacétique sur la résistance à l'anoxie aiguë. C. R. Soc. Biol. (Paris) 160, 367-368 (1966).

$[\mathrm{F} 68,410 / 66$

Lamson, P. D., Greig, M. E., Hobdy, C. J.: Modification of barbiturate anesthesia by glucose, intermediary metabolites and certain other substances. J. Pharmacol. exp. Ther. 103, $460-470$ (1951).

$[\mathrm{C} 14,547 / 51$

Lamson, P. D., Greig, M. E., Williams, L.: Potentiation by epinephrine of the anesthetic effect in chloral and barbiturate anesthesia. J. Pharmacol. exp. Ther. 106, 219-225 (1952).

[B 89,712/52

Lancker, J. L. van: Control of DNA synthesis in regenerating liver. Fed. Proc. 29, 1439-1442 (1970).

$[\mathrm{H} 28,381 / 70$

Lane, E. A., Mavrides, C.: Hormonal-dietary interactions in the regulation of tyrosine aminotransferase. Proc. Canad. Fed. biol. Soc. Edmonton, Alta 12, 78 (1969). [H12,953/69

Lane, M., Liebelt, A., Calvert, J., Liebelt, R. A.: Effect of partial hepatectomy on tumor incidence in BALB/c mice treated with urethan. Cancer Res. 30, 1812-1816 (1970).

[H 28,306/70

Lang, D. J.: Polyoma virus infection in neonatally thymectomized hamster. Arch. ges. Virusforsch. 22, 159-170 (1968). [G55,002/68

Lange, G.: Verschiedene Induktion der mikrosomalen $\mathrm{N}$ - und $\mathrm{p}$-Hydroxylierung von Anilin 
und N-Äthylanilin bei Kaninchen. NaunynSchmiedebergs Arch. Pharmak. 257, 230-256 (1967).

$[\mathrm{G} 78,593 / 67$ Lange, K., Gold, M. M. A., Weiner, D., Kramer, M.: Factors influencing resistance to cold environments. Bull. U. S. Army med. Dep. 8, 849-859 (1948).

[B23,962/48

Langendorff, H.: Grundlagen und Möglichkeiten eines biologisch-chemischen Strahlenschutzes bei äußerer Strahleneinwirkung. Arzneimittel-Forsch. 15, 463-472 (1965).

$[\mathrm{F} 42,481 / 65$

Langendorif, H., Catsch, A., Koch, R.: Untersuchungen über einen biologischen Strahlenschutz. XIX Mitteilg. Weitere Untersuchungen über die Strahlenempfindlichkeit und den Cysteaminschutz bei gonadektomierten männlichen Mäusen. Strahlentherapie 102, 291-297 (1957).

$[\mathrm{C} 36,885 / 57$

Langendorfi, H., Koch, R.: Untersuchungen über einen biologischen Strahlenschutz. VI. Mitteilg. Ưber die Absterbeordnung röntgenbestrahlter Mäuse, die Unterschiede des Geschlechtes und den Einfluß der Keimdrüsen auf die Strahlenempfindlichkeit. Strahlentherapie 94, 250-257 (1954). [B98,043/54 Langendorif, H., Koch, R.: Untersuchungen über einen biologischen Strahlenschutz. XVIII. Mitteilg. Die Wirkung zentralerregender Pharmaka auf das bestrahlte Tier. Strahlentherapie 102, 58-64 (1957).

$[\mathrm{C} 36,881 / 57$

Langendorfi, H., Koch, R., Beisinghoff, G.: The influence of chemical protective agents on the radioiron utilization of irradiated animals. Int. J. appl. Radiat. 16, 521-522 (1965).

[G34,793/65

Langendorif, H., Langendorfi, M.: Untersuchungen über einen biologischen Strahlenschutz. 68. Mitteilg. Strahlenempfindlichkeit und Schutzwirkung des Serotonins bei Mäusen verschiedener Altersstufen. Strahlentherapie 129, $425-431$ (1966).

[G38,396/66

Langendorif, H., Langendorif, M.: Untersuchungen über einen biologischen Strahlenschutz. 72. Mitteilg. Die Wirksamkeit verschiedener Strahlenschutzsubstanzen bei fraktionierter Röntgenbestrahlung von Mäusen. Strahlentherapie 131, 37-50 (1966).

[G42,801/66

Langendorff, H., Melching, H. J., Ladner, H. A.: Untersuchungen über einen biologischen Strahlenschutz. XXX. Mitteilg. über die Strahlenschutzwirkung des 5-Hydroxytryptamin im Tierversuch. Strahlentherapie 108, $251-256$ (1959).

$[\mathrm{C} 69,396 / 59$
Langendorif, H., Melching, H. J., Messerschmidt, 0., Streffer, C.: Untersuchungen über Kombinationsschäden. 3. Mitteilg. Zur Wirksamkeit von Strahlenschutzsubstanzen bei einer Kombination von Strahlenbelastung und Hautwunde. Strahlentherapie 128, 264-272 (1965).

[G38,385/65

Langendorfi, H., Messerschmidt, 0.: Strahlenbelastung und Wunde (tierexperimenteller Beitrag zur Frage der Kombinationsschäden). Nippon Acta Ragior. 3, 289-297 (1966).

$[\mathrm{G} 45,424 / 66$

Lannigan, R.: The production of chronic renal disease in rats by a single intravenous injection of aminonucleoside of pyromycin and the effect of low dosage continuous hydrocortisone. Brit. J. exp. Path. 44, 326-333 (1963).

[D 69,709/63

Lansing, A. M., Stevenson, J. A. F., Gowdey, C. W.: The effect of noradrenaline on the survival of rats subjected to hemorrhagic shock. Canad. J. Biochem. 35, 93-101 (1957).

$[\mathrm{C} 30,227 / 57$

Lanzenberg, A., Képinow, L.: Glande thyroide et anaphylaxie. C. R. Soc. Biol. (Paris) 86, 204-205 (1922).

$[13,117 / 22$

Lanzetta, A.: Tiroxina, 2-4 DPN e narcosi da barbiturici. Boll. Soc. ital. Biol. sper. 34, 1955-1956 (1958).

$[\mathrm{C} 68,990 / 58$

Larizza, P., Ventura, S.: Hanno anche gli estrogeni un'azione antisteatogena? Rif. med. 63, $457-463$ (1949).

$[\mathrm{B} 38,397 / 49$

Laroche, M. J., Brodie, B. B.: Lack of relationship between inhibition of monoamine oxidase and potentiation of hexobarbital hypnosis. $J$. Pharmacol. exp. Ther. 130, 134-137 (1960).

$[\mathrm{H} 21,467 / 60$

Laron, Z., Boss, J. H.: Failure of 19-nor-androstenolone phenylpropionate (durabolin) to prevent the alterations produced by cortisone on the growing bone in rats. Endocrinology 69 , 608-612 (1961).

[D10,620/61

Laron, Z., Canlas, B. D., Jr., Crawford, J. D.: The action of cortisone on the teeth of rachitic rats. Arch. Path. 61, 177-180 (1956).

$[\mathrm{C} 12,833 / 56$

Laron, Z., Canlas, B. D., Jr., Crawford, J. D.: The interaction of cortisone and vitamin $\mathrm{D}$ on bones of rachitic rats. Arch. Path. 65, 403-406 (1958).

$[\mathrm{C} 50,634 / 58$

Laron, Z., Laufer, A.: Effect of cortisone on the development of nephrocalcinosis and ectopic bone in the ischemic rat kidney. Endocrinology 70, 437-441 (1962). [D20,687/62 
Laron, Z., Muhlethaler, J. P., Klein, R.: The interrelationship between cortisone and parathyroid extract in rats. Arch. Path. 65, 125 to 130 (1958).

$[\mathrm{C} 47,872 / 58$

Larsh, J. E., Jr.: The effect of thyroid and thiouracil on the natural resistance of mice to infection with Hymenolepsis. (Abstr.) J. Parasit. 33, Sup. 24-25 (1947).

[A47,571/47

Larson, R. E., Plaa, G. L.: A correlation of the effects of cervical cordotomy, hypothermia, and catecholamines on carbon tetrachlorideinduced hepatic necrosis. J. Pharmacol. exp. Ther. 147, 103-111 (1965). [F29,496/65

Larsson-Cohn, U.: The 2 hour sulfobromophthalein retention test and the transaminase activity during oral contraceptive therapy. Amer. J. Obstet. Gynec. 98, 188-193 (1967).

[G46,952/67

Larsson-Cohn, U.: The serum alanine aminotransferase activity and the two-hour sulphobromophthalein retention test during daily low-dose gestagen oral-contraceptive treatment. Acta Soc. Med. upsalien. 74, 283-288 (1969).

[G74,875/69

Laszt, L., Verzár, F.: Hemmung des Wachstums durch Jodessigsäure und antagonistische Beeinflussung durch Vitamin $B_{2}$ sowie Nebennierenrinden-Hormon. Pflügers Arch. ges. Physiol. 236, 693-704 (1935). $\quad[34,843 / 35$

Lathe, G. H., Walker, M.: Inhibition of bilirubin conjugation in rat liver slices by human pregnancy and neonatal serum and steroids. Quart. J. exp. Physiol. 43, 257-265 (1958).

$[\mathrm{C} 55,335 / 58$

Lathe, G. H., Walker, M.: The synthesis of bilirubin glucuronide in animal and human liver. Biochem. J. 70, 705-712 (1958).

$[\mathrm{G} 78,969 / 58$

Latvalahti, J.: Experimental studies on the influences of certain hormones on the development of amyloidosis. Thesis, University of Helsinki (1953).

[B88,191/53

Lauber, H. J.: Hormonwirkung bei akuten Infektionen. Bruns Beitr. Klin. Chir. 154, 613-634 (1932).

$[9,102 / 32$

Laufer, A., Tal, C., Kolander, N.: Experimental amyloidosis and the effect of cortisone treatment. Path. Microbiol. 31, 85-92 (1968).

$[\mathrm{H} 13,434 / 68$

Laufman, H., Freed, S. C.: Observations on the transudate in intestinal strangulation. I. The effect of adrenal cortical extract on its toxicity. Surg. Gynec. Obstet. 77, 605-609 (1943).

$[88,861 / 43$
Laug, E. P., Nelson, A. A., Fitzhugh, 0. G., Kunze, F. M.: Liver cell alteration and DDT storage in the fat of the rat induced by dietary levels of 1 to 50 p.p.m. DDT. J. Pharmacol. exp. Ther. 98, 268-273 (1950). [A 94,356/50

Lauria, P., Sharma, V. N.: Effects of three recently synthesized indole derivatives on central nervous system. Indian J. med. Res. 54, 374-382 (1966).

$[\mathrm{F} 67,259 / 66$

Lavelle, G. C., Starr, T. J.: Relationship of phagocytic activity to pathogenicity of mouse hepatitis virus as affected by triolein and cortisone. Brit. J. exp. Path. 50, 475-480 (1969).

$[\mathrm{H} 18,566 / 69$

Leathem, J. H.: The influence of antithyroid drugs and testosterone propionate on the organ weights of rats. Exp. Med. Surg. 6, $428-433$ (1948).

[B38,768/48

Leathem, J. H.: Influence of sex on 2-acetylaminofluorene-induced liver tumors in rats and mice (Abstr.). Cancer Res. 11, 266 (1951).

$[\mathrm{G} 74,736 / 51$

Leathem, J. H., Oddis, L.: Hyperthyroidism and hepatic tumor induction. (Abstr.) Proc. Amer. Ass. Cancer Res. 3, 243 (1961). [D2,742/61

Leber, H. W., Rawer, P., Schütterle, G.: Beeinflussung mikrosomaler Enzyme der Rattenleber durch Spironolacton, Etacrynsäure und Furosemid. Klin. Wschr. 49, 116-118 (1971).

$[\mathrm{H} 35,676 / 71$

Leblanc, J., Pouliot, M.: Direct evidence for a role of noradrenaline in cold adaptation. Fed. Proc. 23, 368 (1964).

[F4,622/64

Leblond, C. P.: Detoxification of pregnanediol in the liver (Abstr.). Fed. Proc. 1, 49 (1942).

$[82,066 / 42$

Leblond, C. P.: Detoxification of progesterone derivatives in the liver. Amer. J. med. Sci. 204, 566 - 570 (1942).

$[\mathrm{A} 55,928 / 42$

Lecannelier, S., Quevedo, M.: Analgesic effect of salicylic and pyrazolon derivatives associated with morphine. Arch. Biol. Med. exp. (Santiago) 4, 150-153 (1967). [H8,759/67 Lecomte, J.: Sur les facteurs surrénaliens qui conditionnent la résistance du rat intoxiqué par l'histamine. $1^{\mathrm{e}}$ partie: l'histamine exogène. Arch. int. Physiol. 69, 563-581 (1961).

[D12,212/61

Lecomte, J., Sodovez, J. C.: Sur les facteurs surrénaliens qui conditionnent la résistance du rat intoxiqué par l'histamine. II ${ }^{\mathrm{e}}$ partie: L'histamine endogène. Arch. int. Physiol. Biochim. 70, 16-26 (1962). [D20,641/62 Lecoq, R.: Action comparée des effets de l'hormone adrénocorticotrope (A.C.T.H.) et de la 
cortisone avec quelques facteurs enzymatiques sur l'intoxication alcoolique expérimentale. $C$. R. Soc. Biol. (Paris) 145, 1600-1603 (1951).

[B 79,754/51

Lecoq, R., Chauchard, P., Mazoué, H.: Vitamines, sécrétions endocrines et métabolisme de l'alcool. Déductions sur le rôle de ces substances dans l'intoxication et la désintoxication des alcooliques. Int. Z. Vitamin-Forsch. 23, 141 a 163 (1951).

$[\mathrm{B} 66,406 / 51$

Leduc, E. H.: Regeneration of the liver. In: Rouiller, C.; The Liver. Morphology, Biochemistry, Physiology 2, p. 63-89. New York, London: Academic Press Inc. 1964. [G 79,104/64

Lee, N. D., Baltz, B. E.: Tryptophan pyrrolase induction and the influence of adrenocorticoids. Endocrinology 70, 84-87 (1962).

[D $16,649 / 62$

Lee, Y. C.: Experimental studies on the relation between nicotine and sexual hormone. I. $J$. Severance Un. Med. Coll. 2, 80 (1935).

$[32,854 / 35$

Lees, M. H., Ruthven, C. R. J.: The effect of triiodothyronine in neonatal hyperbilirubinaemia. Lancet 1959 II, 371-373. [C74,543/59

Leevy, C. M., Paumgartner, G.: Jaundice in Alcoholism. Int. Symp. on Jaundice, Friesburg, p. 205-210 (1968).

$[\mathrm{G} 72,234 / 68$

Lefer, A. M., Martin, J.: Mechanism of the protective effect of corticosteroids in hemorrhagic shock. Amer. J. Physiol. 216, 314-320 (1969).

$[\mathrm{H} 7,806 / 69$

Leiort, P., Déziel, C., Côté, G., Tuchweber, B., Gabbiani, G.: Action de la thyroxine et de la thyrocalcitonine (TCT) chez l'animal nephrectomisé. Ann. ACF AS 35e Congr. 3 et 4 Nov. $\left(196{ }^{\prime}\right.$, ,

[G46,725/67

Leger, J., Leith, W., Rose, B.: Effect of adrenocorticotrophic hormone on anaphylaxis in the guinea pig. Proc. Soc. exp. Biol. (N.Y.) 69, $465-467$ (1948).

$[\mathrm{A} 48,766 / 48$

Lehmann, P., Thierree, R. A., Metzger, Mlle: Sur des nouvelles techniques de radio-protection de l'organisme. Action favorable de la cortisone. J. Radiol. Electrol. 37, 480-483 (1956).

$[\mathrm{C} 46,970 / 56$

Lehmann, W. D., Breuer, H.: Einfluß der Schilddrüse auf den Stoffwechsel von Östron in der Leber. In: Kracht, J.; Nebenschilddrüse und endokrine Regulationen des Calciumstoffwechsels Spontan-Hypoglykämie Glucagon, p. 286-288. Berlin, Heidelberg, New York: Springer-Verlag 1968.

$[\mathrm{E} 8,112 / 68$
Lehmann, W. D., Breuer, H.: Wirkung des Funktionszustandes der Schilddrüse auf den Stoffwechsel der Östrogene in der MikrosomenFraktion der Rattenleber. Acta endocr. (Kbh.) 61, 461-476 (1969).

$[\mathrm{H} 15,110 / 69$

Lehmann, W. D., Schütz, M.: Oestronstoffwechsel in der Mikrosomenfraktion der Leber von menschlichen Feten und von einem erwachsenen Mann. Arch. Gynäk. 207, 539-549 (1969).

$[\mathrm{H} 14,215 / 69$

Lehr, D.: Causative relationships of parathyroid hormone to renogenic and reniprival cardiovascular disease. Ann. N.Y. Acad. Sci. 72, 901-969 (1959).

$[\mathrm{C} 84,326 / 59$

Lehr, D., Krukowski, M.: Protection by pregnancy against the sequalae of acute hyperparathyroidism. Naunyn-Schmiedebergs Arch. Pharmak. 242, 143-167 (1961). [D22,446/61

Lehr, D., Krukowski, M.: Prevention of myocardial necrosis by advanced pregnancy. $J$. Amer. med. Ass. 178, 823-826 (1961).

[D81,044/61

Lehr, D., Krukowski, M.: About the mechanism of protection by advanced pregnancy against experimental myocardial necrosis. Rev. Canad. Biol. 22, 281-295 (1963). [E21,312/63

Lehr, D., Martin, C.: Prevention of cardiovascular and smooth muscle necrosis in the albino rat by parathyroidectomy. $J$. Pharmacol. exp. Ther. 116, 38 (1956).

$[\mathrm{C} 13,119 / 56$

Lehr, D., Martin, C. R.: Prevention of severe cardiovascular and smooth muscle necrosis in the rat by thyro-parathyroidectomy. Endocrinology 59, 273-288 (1956). [C23,011/56

Leibman, K. C.: Effects of metyrapone on liver microsomal drug oxidations. Molec. Pharmacol. 5, 1-9 (1969).

$[\mathrm{G} 66,210 / 69$

Lemonde, P.: Etude sur les facteurs hormonaux dans les infections. These, Université de Montréal (1954).

$[\mathrm{C} 310 / 54$

Lemonde, P.: S.T.H. and tuberculosis. Brit. med. J. 1955 I, 537 . [C6,400/55

Lemonde, P., Jasmin, G., Mongeau, A.: Action de la noréthandrolone sur la tuberculose expérimentale chez le rat. $A C F A S, 28$. Congr., p. 28 (1960). $[\mathrm{C} 95,984 / 60$

Lemonde, P., Panisset, M., Dobija, M., Selye, H.: Protection by somatotropic hormone (STH) against experimental tuberculosis. $J$. clin. Endocr. 12, 973-974 (1952). [ [B69,349/52 Lemonde, P., Panisset, M., Dobija, M., Selye, H.: Influence de la somatotrophine sur la tuberculose expérimentale chez le rat et la souris. Ann. Endocr. (Paris) 13, 897-904 (1952).

$[\mathrm{B} 70,248 / 52$ 
Lemonde, P., Panisset, M., Selye, H.: Somatotrophic hormone in tuberculosis. Amer. Rev. Tuberc. 71, 319-321 (1955).

$[\mathrm{C} 526 / 55$

Lennon, H. D.: Effect of several anabolic steroids on sulfobromophthalein (BSP) retention in rabbits. Steroids 5, 361-373 (1965).

$[\mathrm{F} 69,077 / 65$

Lennon, H. D.: Relative effects of 17-alkylated anabolic steroids on sulfobromophthalein (BSP) retention in rabbits. J. Pharmacol. exp. Ther. 151, 143-150 (1966). [F63,769/66

Léonard, A., Maisin, J. R.: Effets de la $\beta$-aminoéthylisothiourée (AET) sur les mutations induites chez la souris par les rayons X. II. Diminution du taux de létalité dominante induite chez les spermatozoïdes irradiés avec des fortes doses de rayons X. C. R. Soc. Biol. (Paris) 157, 913-915 (1963).

$[\mathrm{E} 26,654 / 63$

Léonard, A., Maisin, J. R., Mattelin, G.: Effect of a mixture of chemical protectors against $\mathrm{X}$-irradiation induced testis injury in mice. Strahlentherapie 138, 614-618 (1969).

$$
\text { [G71,644/69 }
$$

Leonard, C. A., Gorby, C. K., Ambrus, J. L., Harrisson, J. W. E.: A note on the effect of cortisone and desoxycorticosterone on metrazol convulsions in mice. J. Amer. pharm. Ass. sci. $E d .42,444-445$ (1953).

$[\mathrm{B} 86,814 / 53$

Leone, G., Rinaldi, L.: Effetti della talidomide sull'ossificazione endomidollare del piccione (Columba livia Gm.) adulto. R. C. Cl. Sci. fis. nat e nat. Ser. VIII 38, 578-581 (1965).

[G44,123/65

LePage, G. A., Kaneko, T.: Effective means of reducing toxicity without concomitant sacrifice of efficacy of carcinostatic therapy. Cancer Res. 29, 2314-2318 (1969).

$[\mathrm{H} 22,380 / 69$

Lepri, G., Fornaro, L.: Considerazioni sull' azione dell'A.C.T.H. et del cortisone nella tubercolosi oculare sperimentale. Boll. Oculist. 33, 725-736 (1954).

[D91,865/54

Lerner, L. J., Holthaus, F. J., Jr., Thompson, C. R.: A non-steroidal estrogen antagonist 1-(p-2-diethylaminoethoxyphenyl) -1-phenyl-2p-methoxyphenyl ethanol. Endocrinology 63, 295-318 (1958).

$[\mathrm{C} 57,905 / 58$

Lesca, S., Mosea, L.: Possibili rapporti tra rigenerazione epatica funzionalitá tiroidea. Atti Soc. Ital. Pat. 1, 223-226 (1949). [B48,329/49 Letov, V. N.: The effect of noradrenaline on radiation injury of proliferative pilary follicles. (Russian text.) Vop. Onkol. 14, 63-66 (1968).

[H $19,253 / 68$
Lettré, H., Landschütz, C., Nobel, J.: Ưber Synergisten von Mitosegiften. 10. Nebennierenrindenhormone und Colchicin. Klin. Wschr. 29, 555 (1951).

$[\mathrm{B} 63,159 / 51$

Leung, P. M.-B., Rogers, O. R., Harper, A. E.: Effect of cortisol on growth, food intake, dietary preference and plasma amino acid pattern of rats fed amino acid imbalanced diets. J. Nutr. 96, 139-151 (1968). [ [G60,800/68 Levaditi, C., Haber, P.: Influence de certaines glandes endocrines sur la réceptivité des $\mathrm{Si}$ miens à l'égard du virus poliomyélitique et sur leur immunité acquise. C. R. Soc. Biol. (Paris) 119, 16-17 (1935).

$[33,069 / 35$

Levens, P., Swann, H. G.: Obesity in the rat. Proc. Amer. physiol. Soc. p. 173 (1941).

$$
[80,483 / 41
$$

Levey, R. H., Trainin, N., Law, L. W., Black, P. H., Rowe, W. P.: Lymphocytic choriomeningitis infection in neonatally thymectomized mice bearing diffusion chambers containing thymus. Science 142, 483-485 (1963).

[E 30,471/63

Levi, A. J., Sherlock, S., Walker, D.: Phenylbutazone and isoniazid metabolism in patients with liver disease in relation to previous drug therapy. Lancet 1968 I, 1275 . [F99,523/68

Levin, G. E., MeMullin, G. P., Mobarak, A. N.: Controlled trial of phenobarbitone in neonatal jaundice. Arch. Dis. Childh. 45, 93-96 (1970).

$[\mathrm{G} 73,664 / 70$

Levin, L.: Physical stress and liver fat content of the fasted mouse (Abstr.). Fed. Proc. 8, 218-219 (1949).

$[\mathrm{B} 32,877 / 49$

Levin, L.: The possible involvement of the adrenal cortex and thyroid in mobilization of fat to the liver. Ass. Study Int. Secr. 31st Meet. Atlantic City, N.J., June 3 and 4, p. 16 (1949).

[B35,913/49

Levin, S. S., Cooper, D. Y., Vars, H. M., Parkins, W. M.: Adrenal corticoids in ischemic shock induced by temporary occlusion of the thoracic aorta in dogs. Fed. Proc. 19, 102 (1960).

$[\mathrm{C} 82,785 / 60$

Levin, W., Conney, A. H.: Effect of phenobarbital on the uterine response to estradiol-17B (Abstr.). Fred. Proc. 25, 251 (1966).

$[\mathrm{F} 64,557 / 66$

Levin, W., Welch, R. M., Conney, A. H.: Effect of chronic phenobarbital treatment on the liver microsomal metabolism and uterotropic action of 17 $\beta$-estradiol. Endocrinology 80, $135-140$ (1967).

$[\mathrm{F} 75,365 / 67$ 
Levin, W., Welch, R. M., Conney, A. H.: Effect of phenobarbital and other drugs on the metabolism and uterotropic action of estradiol-17 $\beta$ and estrone. J. Pharmacol. exp. Ther. 159, 362-371 (1968).

[F 94,711/68

Levin, W., Welch, R. M., Conney, A. H.: Decreased uterotropic potency of oral contraceptives in rats pretreated with phenobarbital. Endocrinology 83, 149-156 (1968). [H 894/68

Levin, W., Welch, R. M., Conney, A. H.: Inhibitory effects of phenobarbital or chlordane pretreatment on the androgen-induced increase in seminal vesicle weight in the rat. Steroids 13, 155-161 (1969).

$[\mathrm{G} 64,184 / 69$

Levin, W., Welch, R. M., Conney, A. H.: Effect of carbon tetrachloride and other inhibitors of drug metabolism on the metabolism and action of estradiol-17 $\beta$ and estrone in the rat. $J$. Pharmacol. exp. Ther. 173, 247-255 (1970).

$[\mathrm{H} 26,593 / 70$

Levine, W. G.: Effect of SKF 525-A on biliary function. Influence of body temperature. Life Sci. 9, 437-442 (1970).

$[\mathrm{G} 75,350 / 70$

Levine, W. G.: The role of microsomal drugmetabolizing enzymes in the biliary excretion of 3,4-benzpyrene in the rat. J. Pharmacol. exp. Ther. 175, 301-310 (1970). [H31,806/70

Levine, W. G., Millburn, P., Smith, R. L., Williams, R. T.: The role of the hepatic endoplasmic reticulum in the biliary excretion of foreign compounds by the rat. The effect of phenobarbitone and SKF 525-A (diethylaminoethyl diphenylpropylacetate). Biochem. Pharmacol. 19, 235-244 (1970).

$[\mathrm{G} 73,357 / 70$

Levitan, I. B., Webb, T. E.: Modification by 8-azaguanine of the effects of hydrocortisone on the induction and inactivation of tyrosine transaminase of rat liver. J. biol. Chem. 244, 341-347 (1969).

$[\mathrm{G} 64,051 / 69$

Levitan, I. B., Webb, T. E.: Posttranscriptional control in the steroid-mediated induction of hepatic tyrosine transaminase. Science $\mathbf{1 6 7}$, 283-285 (1970).

$[\mathrm{H} 20,594 / 70$

Levitin, H., Kendrick, M. I., Kass, E. H.: Effect of route of administration on protective action of corticosterone and cortisol against endotoxin. Proc. Soc. exp. Biol. (N.Y.) 93, 306 to 309 (1956).

$[\mathrm{C} 26,683 / 56$

Levy, E. Z., North, W. C., Wells, J. A.: Modification of traumatic shock by adrenergic blocking agents. J. Pharmacol. exp. Ther. 112, 151-157 (1954).

$[\mathrm{C} 10,848 / 54$

Levy, R. P., Moir, T. W., Miller, M.: BAL and testosterone propionate in the treatment of mercuric chloride poisoning. Proc. Soc. exp. Biol. (N.Y.) 73, 498-500 (1950). [B47,634/50

Lewis, D. A., Symons, A. M., Ancill, R. J.: The stabilization-lysis action of anti-inflammatory steroids on lysosomes. J. Pharm. Pharmacol. 22, 902-908 (1970).

[G 80,342/70

Lewis, J. J., Martin-Smith, M., Muir, T. C., Ross, H. H.: Steroidal monoquaternary ammonium salts with non-depolarizing neuromuscular blocking activity. J. Pharm. Pharmacol. 19, 502-508 (1967).

[F 95,691/67

Lewis, J. T.: Sensibilité des rats privés de surrénales envers les toxiques. C. R. Soc. Biol. (Paris) 84, 163-164 (1921).

$[12,272 / 21$

Lewis, J. T.: Sensibility to intoxication in albino rats after double adrenalectomy. Amer. J. Physiol. 64, 506-511 (1923). [61,803/23

Leybold, K., Staudinger, H.: Geschlechtsunterschiede im Steroidstoffwechsel von Rattenlebermikrosomen. Biochem. Z. 331, 389-398 (1959).

$[\mathrm{C} 77,908 / 59$

Leybold, K., Staudinger, H.: Geschlechtsunterschied im Steroidstoffwechsel von Rattenlebercytoplasma. Med. exp. 2, 46-53 (1960).

$[\mathrm{C} 88,830 / 60$

Leybold, K., Staudinger, H.: Wirkung von Pharmaka auf den Steroidstoffwechsel von Rattenlebermikrosomen. Klin. Wschr. 39, 952-953 (1961).

[D 11,904/61

Li, B. N., Sos, J.: The effect of thyroidectomy on the increase in blood pressure caused by $\mathrm{p} \mathrm{N}$ oxyphenyl glycine. (Abstr.) Kisérl. Orvostud. 20, 588-590 (1968).

[H30,786/68

Li, C. H., Evans, H. M.: I. Hormones in growth and metabolism. The biochemistry of pituitary growth hormone. In: Pincus, G.; Recent Progress in Hormone Research. Proc. Laur. Horm. Conf., p. 3. New York: Acad. Press. Inc. Publ. 1948.

$[\mathrm{B} 29,320 / 48$

Li, C. H., Ingle, D. J., Evans, H. M., Prestruda, M. C., Nezamis, J. E.: Effect of adrenocorticotrophic hormone upon liver fat and urinary phosphorus in normal force-fed rat. Proc. Soc. exp. Biol. (N.Y.) 70, 753-756 (1949).

[B34,773/49

Li, C. P., Prescott, B., Chi, L. L., Martino, E. C.: Antiviral and antibacterial activity of thymus extracts. Proc. Soc. exp. Biol. (N.Y.) 114, 504-509 (1963).

$[\mathrm{E} 33,523 / 63$

Liashenko, V. A.: The influence exerted by cortisone on the therapeutic effect of levomycetin employed in treatment of acute experimental infections. (Russian text.) Antibiotiki 5, 41-44 (1960).
$[\mathrm{D} 51,368 / 60$ 
Liashenko, V. A.: Effect of cortisone on the therapeutic action of levomycetin at different stages of experimental infection in connection with the hormone's action on phagocytosis. (Russian text.) Antibiotiki 6, 504-507 (1961).

[D 50,402/61

Liddle, G. W.: Specific and non-specific inhibition of mineralocorticoid activity. Metabolism 10, 1021-1030 (1961). [D 14,432/61

Lieberman, J.: Papain-induced emphysema in hamsters and the role of progesterone and stilbesterol in prevention. (Abstr.) Clin. Res. 19, 192 (1971).

$[\mathrm{H34}, 495 / 71$

Lieberman, M., Pollikoff, R., Pascale, A. M.: Effect of concomitant treatment by cortisone and $\mathrm{N}$-ethylisatin $\beta$-thiosemicarbazone on neurovaccinia virus infected mice. Proc. Soc. exp. Biol. (N.Y.) 122, 484-489 (1966).

[F 67,288/66

Lieberman, M. W.: Early developmental stress and later behavior. Science 141, 824-825 (1963).

$[\mathrm{E} 24,883 / 63$

Lien, W. M., MeCormick, J. R., Davies, M. W., Egdahl, R. H.: Corticosteroid clearance by the gastrointestinal tract in dogs and monkeys. Endocrinology 87, 206-208 (1970).

[H25,091/70

Liling, M., Gaunt, R.: Acquired resistance to water intoxication. Amer. J. Physiol. 144, 571-577 (1945).

$[89,147 / 45$

Lillehei, R. C., Dietzman, R. H., Movsas, S., Bloch, J. H.: Treatment of septic shock. In: Kuhn and Abramson; Modern Treatment, p. 321-346. New York: Hoeber Medical Division, Harper \& Row 1967.

[G45,335/67

Lillehei, R. C., Longerbeam, J. K., Bloch, J. H.: Physiology and therapy of bacteremic shock. Experimental and clinical observations. Amer. J. Cardiol. 12, 599-613 (1963). [E31,273/63

Lillehei, R. C., Longerbeam, J. K., Bloch, J. H., Manax, W. G.: The modern treatment of shock based on physiologic principles. Clin. Pharmacol. Ther. 5, 63-101 (1964).

$[\mathrm{E} 37,842 / 64$

Lillehei, R. C., MacLean, L. D.: The intestinal factor in irreversible endotoxin shock. Ann. Surg. 148, 513-525 (1958). [D59,725/58

Lillehei, R. C., MacLean, L. D.: Physiological approach to successful treatment of endotoxin shock in the experimental animal. Arch. Surg. 78, 464-471 (1959).

[D 84,873/59

Lim, H. S., Davenport, H. T., Robson, J. G.: The response of infants and children to muscle relaxants. Anesthesiology 25, 161-168 (1964).

[G78,962/64
Limperos, G.: Effects of varying oxygen tension on mortality of x-rayed mice. J. Franklin Inst. 249, 513-514 (1950).

[E 50,944/50

Limperos, G., Mosher, W. A.: Protection of mice against $\mathrm{X}$-radiation by thiourea. Science 112, 86-87 (1950).

$[\mathrm{B} 49,737 / 50$

Lin, C. D., Hoshino, K.: Testosterone dependency of the lethal factor in mouse submandibular gland isografts. Canad. J. Physiol. Pharmacol. 47, 335-338 (1969).

[H9,995/69

Lin, E. C. C., Knox, W. E.: Adaptation of the rat liver tyrosine- $\alpha$-ketoglutarate transaminase. Biochim. biophys. Acta (Amst.) 26, 85-88 (1957).

$[\mathrm{E} 63,521 / 57$

Lin, E. C. C., Knox, W. E.: Specificity of the adaptive response of tyrosine- $\alpha$-ketoglutarate transaminase in the rat. $J$. biol. Chem. 233, 1186-1189 (1958).

$[\mathrm{C} 73,824 / 58$

Lin, E. C. C., Rivlin, R. S., Knox, W. E.: Effect of body weight and sex on activity of enzymes involved in amino acid metabolism. J. Physiol. 196, 303-306 (1959).

$[\mathrm{C} 96,929 / 59$

Lindegren, C. C.: The receptor-hypothesis of induction of gene-controlled adaptive enzymes. J. theor. Biol. 5, 192-210 (1963). [G66,494/63 Lindegren, C. C.: The receptor hypothesis of gene action. In: Bajusz, E.; Physiology and Pathology of Adaption Mechanisms: NeuralNeuroendocrine-Humoral, p. 452-461. Oxford, London, Edinburgh: Pergamon Press 1969.

$[\mathrm{E} 8,182 / 69$

Lindner, A., Stoklaska, E.: Über den Einfluß des Cortisons auf die Digitoxinwirkung. Wien. klin. Wschr. 68, 516-519 (1956). [C35,550/56 Linet, 0.: Interactions between androgenicanabolic steroids and glucocorticoids. Fortschr. Arzneimittel-Forsch., 14, 139-195 (1970).

[G79,963/70

Linet, O., Hava, M., Jakubovic, A., Mikulaskova, J.: On the pharmacology of 1,2 $\alpha$-oxydoandrostan-3,17-dione (OAD). Arch. int. Pharmacodyn. 158, 222-233 (1965). [F 58,620/65

Linet, 0., Mikulašková, J.: On the problem of gastric ulcer formation by glucocorticoids in rats and the effect of androgenic-anabolic steroid on them. Endokrinologie 51, 224-233 (1967).

$[\mathrm{F} 86,027 / 67$

Lippman, R. W., Marti, H. U., Jacobs, E. E.: Sex differences in pathogenesis of nephrotoxic globulin (NTG) nephritis. Fed. Proc. 11, 96 (1952).

$[\mathrm{B} 68,238 / 52$

Lissák, K.: Beiträge zur Frage der Beziehung zwischen Tetanie und Tetanus. NaunynSchmiedebergs Arch. Pharmak. 176, 425-428 (1934). 
Little, K.: Interaction between catabolic and anabolic steroids. Curr. ther. Res. 12, 658-676 (1970).

[G78,533/70

Litwack, G., Nemeth, A. M.: Development of liver tyrosine aminotransferase activity in the rabbit, guinea pig, and chicken. Arch. Biochem. 109, 316-320 (1965).

[G26,050/65

Llanos, J. M. E., Saffe, I. E.: Acción promotora de la regeneración posthepatectomía sobre los hepatomas espontáneos de $\mathrm{C3H} / \mathrm{mza}$ machos. Rev. Soc. argent. Biol. 37, 240-249 (1961).

[G71,663/61

Llaurado, J. G., Trunnell, J.B., Claus, J. L.: Some effects of simultaneous administration of norethandrolone and cortisone in the rat. Acta endocr. (Kbh.) 32, 536-544 (1959).

[G79,936/59

Locatelli, P.: Alterazioni delle cellule epatiche in seguito ad avvelenamento da tossina difterica. Influenza della tiroidectomia. Boll. Soc. med.-chir. Pavia 48, 405-410 (1934).

$[28,678 / 34$

Lockwood, J. E., Hartman, F. A.: Relation of the adrenal cortex to vitamins $A, B_{1}$ and $C$. Endocrinology 17, 501 (1933).

$[15,573 / 33$

Loewe, L., Lenke, S. E.: The use of estrogenic hormone in experimental peripheral gangrene. J. Pharmacol. exp. Ther. 63, 93-98 (1938).

[A43,451/38

Loewit, K.: Utber den Einfluß anaboler Hormone auf die Folgen einer Strahlenschädigung bei der weißen Maus. Strahlentherapie 125, 281-298 (1964).

[G23,765/64

Logaras, G., Drummond, J. C.: Vitamin A and the thyroid. Biochem. J. 32, 964-968 (1938).

[A 16,392/38

Loggie, J. M. H., Privitera, P. J., Sugarman, S., Gafiney, T. E.: Effects of hydrocortisone on survival in neonatal beagles given endotoxin. Proc. Soc. exp. Biol. (N.Y.) 128, 326-329 (1968).

[F99,839/68

Long, D. A.: The influence of the thyroid gland upon immune responses of different species to bacterial infection. In: Wolstenholme and Millar; Ciba Foundation Colloquia on Endocrinology, Vol. 10, 287-297. London: J. \& A. Churchill Ltd. 1957.

$[\mathrm{C} 32,348 / 57$

Long, D. A., Miles, A. A.: Opposite actions of thyroid and adrenal hormones in allergic hypersensitivity. Lancet 1950 I, $492-495$.

[D41,973/50

Long, D. A., Miles, A. A., Perry, W. L. M.: Influence of thyroxine on the desensitizing action of A.C.T.H. and of cortisone in B.C.G.infected guinea-pigs. Lancet 1951 I, 1392-1394.

[B60,189/51

Long, D. A., Miles, A. A., Perry, W. L. M.: Action of ascorbic acid on tuberculin-sensitivity in guinea-pigs and its modification by dietary and hormonal factors. Lancet 1951 I, 1085-1088.

[D 85,907/51

Long, D. A., Miles, A. A., Perry, W. L. M.: The action of dehydroascorbic acid and alloxan on tuberculin-sensitivity in guinea pigs. Lancet 1951 II, 902-904. [B 63,843/51

Long, D. A., Shewell, J.: The influence of the thyroid gland on sensitivity to tuberculin in guinea-pigs. Brit. J. exp. Path. 35, 503-506 (1954).

[G71,833/54

Long, D. A., Shewell, J.: The influence of the thyroid gland on the production of antitoxin in the guinea-pig. Brit. J. exp. Path. 36, $351-356$ (1955).

[G71,832/55

Long, P. L., Rose, M. E.: Extended schizogony of Eimeria mivati in betamethasone-treated chickens. Parasitology 60, 147-155 (1970).

$[\mathrm{G} 72,642 / 70$

Longenecker, H. E., Fricke, H. H., King, C. G.: The effect of organic compounds upon vitamin C synthesis in the rat. $J$. biol. Chem. 135, $497-510$ (1940).

[A47,520/40

Longerbeam, J. K., Lillehei, R. C.: The effects of various pharmacological agents on the canine intestinal hemodynamics during endotoxin shock (Abstr.). Fed. Proc. 20, 116 (1961).

[D3,868/61

Longley, L. P.: Effect of treatment with testosterone propionate on mercuric chloride poisoning in rats. J. Pharmacol. exp. Ther. 74, 61-64 (1942).

[A37,552/42

Loosli, C. G., Hull, R. B., Berlin, B. S., Alexander, E. R.: The influence of ACTH on the course of experimental influenza virus type A infections. J. Lab. Clin. Med. 37, 464-476 (1950).

[B58,316/50

Lopez-Lomba, J.: Prolongation de la survie dans le scorbut chez les cobayes thymectomisés. C. R. Soc. Biol. (Paris) 89, 370-371 (1923).

$[17,165 / 23$

Loschiavo, F.: Potere battericida del sangue in convalescenti d'ileo-tifo sottoposti alla vaccinazione antitifica e trattati con 4-idrossi19-nortestosterone-17-ciclopentilpropionato. $G$. Mal. infett. 17, 59-65 (1965). [G28,338/65 Lostroh, A. J.: Relationship of steroid and pituitary hormones to myocardial calcification in the mouse. Proc. Soc. exp. Biol. (N.Y.) 98, $84-88$ (1958). 
Louria, D. B., Fallon, N., Browne, H. G.: The influence of cortisone on experimental fungus infections in mice. J. clin. Invest. 39, 1435 to 1449 (1960).

$[\mathrm{C} 91,764 / 60$

Lowenstein, B. E., Zwemer, R. L.: Resistance of rats to potassium poisoning after administration of thyroid or of desoxycorticosterone acetate. Endocrinology 33, 361-365 (1943).

[A74,481/43

Lowenthal, J., Fisher, L. M.: The effect of thyroid function on the prothrombin time response to Warfarin in rats. Experientia (Basel) 8, 253-254 (1957). [C40,044/57

Lu, A. Y., Junk, K. W., Coon, M. J.: Resolution of the cytochrome P-450 containing $\omega$-hydroxylation system of liver microsomes into three components. J. biol. Chem. 244, 3714-3721 (1969).

$[\mathrm{G} 67,623 / 69$

Lu, A. Y. H., Coon, M. J.: Role of hemoprotein $\mathrm{P}-450$ in fatty acid $\omega$-hydroxylation in a soluble enzyme system from liver microsomes. J. biol. Chem. 243, 1331-1332 (1968).

[G 71,879/68

Lu, A. Y. H., Strobel, H. W., Coon, M. J.: Hydroxylation of benzphetamine and other drugs by a solubilized form of cytochrome P-450 from liver microsomes: lipid requirement for drug demethylation. Biochem. biophys. Res. Commun. 36, 545-551 (1969). $\quad$ [G68,802/69

Lübke, A.: Leberveränderungen thyreotoxischer Mäuse nach Úberwärmung und akutem Hitzekollaps. Zbl. allg. Path. path. Anat. 94, 365-372 (1956).

$[\mathrm{C} 12,952 / 56$

Lucey, J. F.: Nursery illumination as a factor in neonatal hyperbilirubinemia. Pediatrics 44, 155-157 (1969).

[H35,539/69

Lucherini, T., Schiavetti, L., Marino, T., Lucchesi, M.: Influenza del cortisone E della somatotropina (STS) sulla infezione tubercolare sperimentale della cavia. Policlinico Sez. med. 60, 358-369 (1953). [B [B9,088/53

Ludewig, S.: The effect of partial hepatectomy on the liver lipids. Proc. Amer. Soc. biol. Chem. Toronto, Can., 33. Meet. LX11. (1939).

$[74,865 / 39$

Lüders, D.: Bilirubin distribution studies in Gunn rats following the injection of sodium dehydrocholate. Biol. Neonat. (Basel) 15, 329-341 (1970).

[G81,789/70

Lüders, D.: Das Für und Wider der Luminalbehandlung von Hyperbilirubinämien. Monatschr. Kinderheilk. 118, 94-102 (1970).

[H24,062/70

Lüders, D.: Einfluss von Phenobarbital auf den Bilirubinstoffwechsel bei Gunnratten. Versuche mit inaktivem und ${ }^{14} \mathrm{C}$-markiertem Bilirubin. Ztschr. Kinderheilk. 109, 149-168 (1970).

$[\mathrm{H} 34,593 / 70$

Luhby, A. L., Davis, P., Murphy, M., Gordon, M., Brin, M., Spiegel, H.: Pyridoxine and oral contraceptives. Lancet 1970 II, 1083.

$[\mathrm{H} 32,376 / 70$

Lum, B. K. B.: Protection against potassium intoxication by nicotine and by epinephrine (Abstr.). Fed. Proc. 29, 476 (1970).

$[\mathrm{H} 22,940 / 70$

Lumper, L., Zahn, H.: Chemie und Biochemie des Disulfidaustausches. Advanc. Enzymol. 27, 199-237 (1965).

$[\mathrm{G} 72,128 / 65$

Lund, C. C., Benediet, E. B.: The influence of the thyroid gland on the action of morphine. New Engl.J. Med. 201, 345-353 (1929).

[A 14,206/29

Lund, H.: Corticosteroid osteoporosis and treatment with anabolic hormone. Acta med. scand. 174, 735-738 (1963). [E38,261/63

Lungu, M., Petreseu, A., Tonescu, T.: Antiinfluenza vaccination in mice with experimental hyper- and hypothyroidism. Rev. roum. Endocr. 3, 127-132 (1967).

$[\mathrm{F} 84,406 / 67$

Luongo, M. A., Reid, D. H., Weiss, W. W.: The effect of ACTH in trichinosis; a clinical and experimental study. New Engl. J. Med. 245, 757-760 (1951).

$[\mathrm{B} 69,505 / 51$

Lupulescou, A.: Les effets des hormones oestrogènes, de la noradrénaline et de l'hormone corticotrope (ACTH) sur le myocarde de cobaye. Folia endocr. (Roma) 16, 91-104 (1963).

$[\mathrm{E} 21,838 / 63$

Lupulescu, A., Potorac, E., Vasilescu, T., Pop, A., Merculiev, E., Oprisan, R., Oprisan, A.: Effects of the anabolic steroid (4-chlorotestosterone) on antibody production in hyper- and hypothyroid rabbits. Path. et Microbiol. (Basel) 29, 800-810 (1966).

$[\mathrm{F} 77,999 / 66$

Lurie, M. B.: On the role of hormones in experimental tuberculosis. Advanc. Tuberc. Res. 6, 18-48 (1955).

$[\mathrm{C} 14,768 / 55$

Lurie, M. B., Abramson, S., Allison, M. J.: Constitutional factors in resistance to infection. I. The effect of estrogen and chorionic gonadotropin on the course of tuberculosis in highly inbred rabbits. Amer. Rev. Tuberc. 59, 168-185 (1949).

$[$ B31,931/49

Lurie, M. B., Abramson, S., Heppleston, A. G., Allison, M. J.: Constitutional factors in resistance to infection. III. On the mode of action of estrogen and gonadotropin on the 
progress of tuberculosis. Amer. Rev. Tuberc. 59, 198-218 (1949).

[B31,933/49

Lurie, M. B., Abramson, S., Heppleston, A. G., Dannenberg, A. M., Jr.: Immunological and hormonal studies on the nature of genetic resistance to tuberculosis (Abstr.). Fed. Proc. 11, 475 (1952).

[B68,457/52

Lurie, M. B., Harris, T. N., Abramson, S., Allison, J. M.: Constitutional factors in resistance to infection. II. The effect of estrogen on tuberculin skin sensitivity and on the allergy of the internal tissues. Amer. Rev. Tuberc. 59, 186-197 (1949). [B31,932/49

Lurie, M. B., Ninos, G. S.: Effect of triiodothyronine and propyl thiouracil on native resistance to tuberculosis. Fed. Proc. 15, 601 (1956).

$[\mathrm{C} 14,387 / 56$

Lurie, M. B., Zappasodi, P., Blaker, R. G., Levy, R. S.: On the role of the thyroid in native resistance to tuberculosis. II. The effect of hypothyroidism. The mode of action of thyroid hormones. Amer. Rev. Tuberc. 79, 180-203 (1959).

[C64,295/59

Lurie, M. B., Zappasodi, P., Dannenberg, A. M., Jr., Swartz, I. B.: Constitutional factors in resistance to infection: The effect of cortisone on the pathogenesis of tuberculosis. Science 113, $234-237$ (1951).

[B 55,625/51

Lurie, M. B., Zappasodi, P., Levy, R. S., Blaker, R. G.: Role of thyroid in native resistance to tuberculosis (Abstr.). Fed. Proc. 17, 447 (1958).

$[\mathrm{C} 52,055 / 58$

Lurie, M. B., Zappasodi, P., Levy, R. S., Blaker, R. G.: On the role of the thyroid in native resistance to tuberculosis. I. The effect of hyperthyroidism. Amer. Rev. Tuberc. 79, 152-179 (1959).

[C65,610/59

Lurie, M. B., Zappasodi, P., Levy, R. S., Twisdom, J. M., Ninos, G. S.: On the effect of levo-triiodothyronine and propylthiouracil on native resistance to tuberculosis (Abstr.). J. clin. Endocr. 16, 979 (1956). $\quad$ [C14,963/56

Luther, I. G., Heistad, G. T., Sparber, S. B.: Effect of ovariectomy and of estrogen administration upon gastric ulceration induced by cold-restraint. Psychosom. Med. 31, 389-392 (1969).

[G70,681/69

Lutzmann, L., Sehmidt, C. G.: Anabole Steroide und zytostatische Therapie. Med. Welt (Stuttg.) Nr. 47, 2644-2646 (1965).

[F 57,784/65

Macco, G. di: Azione della tirossina nell'ipertermia passiva. Boll. Soc. ital. Biol. sper. 10, 904-905 (1935).

$[34,121 / 35$
MacDonald, R. A., Guiney, T., Tank, R.: Regeneration of the liver in Tirturus viridescens. Proc. Soc. exp. Biol. (N.Y.) 111, 277-280 (1962).

[D41,743/62

MacGillivray, M. H., Crawford, J. D., Robey, J. S.: Congenital hypothyroidism and prolonged neonatal hyperbilirubinemia. Pediatrics 40, 283-286 (1967).

[G48,968/67

Machinist, J. M., Dehner, E. W., Ziegler, D. M.: Microsomal oxidases. III. Comparison of species and organ distribution of dialkylarylamine $\mathrm{N}$-oxide dealkylase and dialkylarylamine $\mathrm{N}$ oxidase. Arch. Biochem. 125, 858-864 (1968).

[H 15,503/68

Mack, L., Smith, E. A.: Methylene blue in illuminating gas poisoning. Proc. Soc. exp. Biol. (N.Y.) 31, 1031-1032 (1934).

$[45,162 / 34$

MacKay, E. M., Carne, H. 0.: Influence of adrenalectomy and choline on the fat content of regenerating liver during fasting. Proc. Soc. exp. Biol. (N.Y.) 38, 131-133 (1938).

[A 14,767/38

MacKay, E. M., MacKay, L. L.: The relation of natural morphine tolerance to age and sex and the weight of the adrenal glands. Arch. int. Pharmac. therap. 52, 363-367 (1936).

$[56,167 / 36$

MacKenzie, J. B., MacKenzie, C. G.: Production of pulmonary edema by thiourea in the rat, and its relation to age. Proc. Soc. exp. Biol. (N.Y.) 54, 34-37 (1943).

[A49,024/43

Maddaloni, F.: Ormone cortico-surrenale ed ipertermia passiva. Ricerche sperimentali. Arch. ital. Med. sper. 2, 1 (1938). [A 18,244/38

Maddock, W. O., Rankin, V. M., Youmans, W. B.: Prevention of the anti-curare action of epinephrine by dibenamine. Proc. Soc. exp. Biol. (N.Y.) 67, 151-153 (1948).

[B18,670/48

Maekawa, K., Hosoyama, Y.: Protective effects of steroidal hormones on rat testis against injurious actions of cadmium. (Japanese text). Zool. Mag. 74, 17-23 (1965).

$[\mathrm{G} 79,815 / 65$

Maekawa, K., Tsunenari, Y.: Mechanism involved in selective injurious effect of cadmium on the testis. Gunma Symp. Endocr. 4, 161169 (1967).

[H1,627/67

Maekawa, K., Tsunenari, Y., Yoshitoshi, K.: Estrogen and destructive effect of cadmium on testicular tissue. (Japanese text). Zool. Mag. 76, 84-90 (1967).

[G79,814/67 
Magalhães, M. M., Magalhães, M. C.: Ultrastructural alterations produced in rat liver by metopiron. J. Ultrastruct. Res. 32, 32-42 (1970).

[G76,648/70

Magara, M.: Sur l'action défensive de l'hormone sexuelle contre l'infection. $C$. $R$. Soc. Biol. (Paris) 121, 1193-1194 (1936).

$[35,283 / 36$

Maibauer, D., Neubert, D., Rottka, H.: Pharmakologische Untersuchungen bei der experimentellen Leberverfettung. Naunyn-Schmiedebergs Arch. Pharmak. 234, 474-489 (1958).

[G74,663/58

Maickel, R. P., Brodie, B. B.: Increase in rat liver tryptophan peroxidase as a response to pituitary-adrenal stimulation by various centrally acting drugs. Fed. Proc. 19, 267 (1960).

$[\mathrm{C} 83,071 / 60$

Maickel, R. P., Bush, M. T., Jondorí, W. R., Miller, F. P., Gillette, J. R.: Factors influencing the metabolism and distribution of corticosterone-1,2- ${ }^{3} \mathrm{H}$ in the rat. Molec. Pharmacol. 2, 491-495 (1966).

[G41,515/66

Mairesse, M., Darcis, L.: Influence de la castration et de la testostérone sur la radiosensibilité de la muqueuse jugale de la Lapine. C. R. Soc. Biol. (Paris) 156, 407-409 (1962).

[D27,579/62

Maisin, J., Desmedt, P., Jacqmin, L.: Influence de la castration sur l'éclosion et l'évolution du cancer du goudron chez la souris blanche. C. R. Soc. Biol. (Paris) 94, 769-770 (1926).

$[25,708 / 26$

Maisin, J., Pourbaix, Y., Rijekaert, G.: Influence $d u$ propionate de testostérone sur l'évolution du cancer au benzopyrène chez la souris. C. R. Soc. Biol. (Paris) 130, 109-112 (1939).

$[\mathrm{A} 30,500 / 39$

Maisin, J. R., Doherty, D. G.: Chemical protection of mammalian tissues. Fed. Proc. 19, 564-572 (1960).

[C91,781/60

Maisin, J. R., Léonard, A., Lambiet, M., Mattelin, Go: Action de la 2- $\beta$-aminoéthylisothiourée (AET) et de la 5-hydroxytryptamine (sérotonine) sur l'intestin grêle et le système hématopoiétique des souris irradiées. $C . R$. Soc. Biol. (Paris) 157, 1525-1529 (1963).

$[\mathrm{E} 36,751 / 63$

Maisin, J. R., Mattelin, G.: Reduction in radiation lethality by mixtures of chemical protectors. Nature (Lond.) 214, 207-208 (1967).

[F 78,796/67

Maisin, J. R., Mattelin, G.: Radioprotecteurs et radiothérapie des cancers. Bull. Cancer 54, 149-158 (1967).

$[\mathrm{H} 719 / 67$
Maisin, J. R., Mattelin, G., Fridman-Manduzio, A., Parren, J. van der: Reduction of short- and long-term radiation lethality by mixtures of chemical protectors. Radiat. Res. 35, 26-44 (1968).

$[\mathrm{G} 59,894 / 68$

Mäkinen, E., Näätänen, E., Similä, S.: The role of androgens in inducing experimental electrolyte-steroid-cardiopathy. Ann. Med. exp. Fenn. 40, 401-408 (1963).

$[\mathrm{E} 20,847 / 63$

Makino, Y.: Effects of hepatic periarterial neurectomy upon hepatic blood flow and regeneration of the liver after partial hepatectomy in the dog. Arch. jap. Chir. 37, 485-502 (1968).

[H 19,101/68

Malhotra, 0. P., Reber, E. F.: Effects of hormones and strain of rat on the incidence of the hemorrhagic syndrome in male rats fed irradiated beef. Fed. Proc. 19, 421 (1960).

$[\mathrm{C} 83,177 / 60$

Malhotra, 0. P., Reber, E. F.: Methionine and testosterone effect on occurrence of hemorrhagic diathesis in rats. Amer.J. Physiol. 205, 1089-1092 (1963).

[E36,906/63

Malik, Z: Pokusy s experimentálnou vnímavostou kurčiat voči mikróbu erysipelothrix rhusiopathiae. Vet. Cas. 11, 89-94 (1962).

[D34,701/62

Malkiel, S.: The influence of ACTH and cortisone on histamine and anaphylactic shock in the guinea pig. J. Immunol. 66, 379-384 (1951).

$[\mathrm{G} 71,451 / 51$

Malkiel, S., Hargis, B. J.: Histamine sensitivity and anaphylaxis in the pertussis-vaccinated rat. Proc. Soc. exp. Biol. (N.Y.) 81, 689-691 (1952).

$[\mathrm{D} 27,396 / 52$

Mallov, S.: Effect of sex hormones on ethanol induced fatty infiltration of liver in rats. Proc. Soc. exp. Biol. (N.Y.) 97, 226-229 (1958).

$[\mathrm{C} 47,222 / 58$

Maloney, A. H., Fitch, R. H., Tatum, A. L.: Picrotoxin as an antidote in acute poisoning by the shorter acting barbiturates. J. Pharm. exp. Ther. 41, 465-482 (1931).

$[61,235 / 31$

Maloney, A. H., Froix, C., Booker, W. M.: Further studies on effect of pentobarbital sodium on adrenalectomized rats. Fed. Proc. 11, 398 (1952).

$[\mathrm{E} 48,771 / 52$

Mancini, R. T., Gautieri, R. F., Mann, D. E., Jr.: Effect of cortisone on the minimal carcinogenic dose $_{50}$ of methylcholanthrene in albino mice. J. pharm. Sci. 53, 385-388 (1964).

$[\mathrm{D} 18,183 / 64$

Mandel, L., Wintzerith, M., Mandel, P.: Action du propylthiouracile sur l'évolution biochimique de l'hypertrophie rénale compensa- 
trice. C. R. Soc. Biol. (Paris) 154, 2125-2128 (1960).

[D6,027/60

Mangum, J. H., Klingler, M. D., North, J. A.: The purification of a soluble cytochrome from pig kidney with spectral properties similar to those of microsomal cytochrome $b_{5}$. Biochem. biophys. Res. Commun. 40, 1520-1525 (1970).

$[\mathrm{G} 81,296 / 70$

Man'ko, Y. K.: Toxicity of dopan, chlorambucil and endoxan by reduced serotonin. Fed. Proc. 25, T1073-T1075 (1966). [F 74,715/66

Man'ko, Y. K.: Decrease of dopan, chlorambucil and endoxan toxic effect on animals by means of treatment with serotonin. (Russian text.) Vop. Onkol. 12/1, 52-56 (1966).

$[\mathrm{F} 82,459 / 66$

Mann, F. D., Fishback, F. C., Gay, J. G., Green, G. F.: Experimental pathology of the liver. Arch. Pathol. 12, 787 (1931). [712/31

Mannering, G. J.: Significance of stimulation and inhibition of drug metabolism in pharmacological testing. In: Burger, A.; Selected Pharmacological Testing Methods 3, p. 51-119. New York: Marcel Dekker Inc. 1968.

$[\mathrm{G} 71,818 / 68$

Mannering, G. J.: Significance of stimulation and inhibition of drug metabolism in pharmacologic testing. In: Tedeschi and Tedeschi; Importance of Fundamental Principles in Drug Evaluation, p. 105-127. New York: Raven Press 1968.

[G75,980/68

Mannering, G. J.: Stimulation and inhibition of drug metabolism. In: Cerletti, A. and Bové F. J.; The Present Status of Psychotropic Drugs, p. 107-110. Excerpta med. Found. 1969.

$[\mathrm{G} 75,979 / 69$

Mannering, G. J.: Properties of cytochrome P-450 as affected by environmental factors: qualitative changes due to administration of polycyclic hydrocarbons. Metabolism 20, 228245 (1971).

$[\mathrm{H} 34,127 / 71$

Mannering, G. J.: Microsomal enzyme systems which catalyze drug metabolism. In: LaDu et al.; Fundamentals of Drug Metabolism and Disposition. Baltimore, Md.: Williams and Wilkins (in press).

[G74,558

Mannering, G. J.: Inhibition of drug metabolism. In: Brodie and Gillette; Handbook of Experimental Pharmacology. Berlin, Heidelberg, New York: Springer-Verlag (in press).

$[\mathrm{G} 74,572$

Mannering, G. J.: Drug interactions. In: Epstein and Lederberg; Chronic Non-Psychiatric Hazards of Abuse. U. S. Government Printing Office (in press).

$[\mathrm{G} 74,881$
Mannering, G. J.: Role of substrate binding to P-450 hemoproteins in drug metabolism. In: Michich; Drugs and Cell Regulation. New York: Academic Press (in press).

[G78,898

Mansfeld, G.: Beiträge zur Physiologie der Schilddrüse. IX. Mitteilg. (Zur Abwehr). Pfügers Arch. gesamt. Physiol. 181, 249-270 (1920).

$[11,881 / 20$

Mansfeld, G., Müller, F.: Beiträge zur Physiologie der Schilddrüse. I. Mitteilg. Die Ursache der gesteigerten Stickstoffausscheidung infolge Sauerstoffmangels. Pfügers Arch. gesamt. Physiol. 143, 157-174 (1911). $\quad[35,416 / 11$

Manso, C., Friend, C., Wroblewsky, F.: The influence of 17-hydrocorticosterone on viral hepatitis of mice. J. Lab. clin. Med. 53, $729-736$ (1959).

$[\mathrm{C} 68,152 / 59$

Manston, R.: Calcium and phosphorus metabolism in cows after simultaneous injection of vitamin $\mathrm{D}_{3}$ with vitamin $\mathrm{A}$ or thyroxine. Brit. vet. J. 125, 177-182 (1969). [G69,733/69

Mantegazza, P., Naimzada, K. M., Riva, M.: Activity of amphetamine in hypothyroid rats. Europ. J. Pharmacol. 5, 10-16 (1968).

$[\mathrm{H} 7,676 / 68$

Mantegazza, P., Riva, M.: Attività della amfetamina in animali ipotiroidei. Atti Acad. med. lombarda 20, 10-15 (1965).

$[\mathrm{F} 47,703 / 65$

Mantegazzini, P.: Alcune osservazioni circa l'azione di forti dosi di $5 \mathrm{HT}$ sul sistema nervoso centrale. Boll. Soc. ital. Biol. sper. 32, 839-841 (1956).

$[\mathrm{C} 33,637 / 56$

Manunta, G.: Azione del benzoato di estradiolo sulla sopravvivenza dei ratti maschi tiroparatiroidectomizzati. $R$. C. Accad. naz. Lincei, Cl. Sci. fis. mat. nat. Ser. VIII, 12, 104-107 (1952).

$[\mathrm{B} 73,160 / 52$

Maral, R.: Etude comparée de l'action du 4.560 R.P. (chloropromazine) et de la cortisone sur certaines toxines. Atti $6 e$ Congr. int. Microbiol. Roma 1, 615-618 (1953).

$[\mathrm{C} 17,604 / 53$

Maral, R., Cosar, C.: Etude de l'action de la chlorpromazine, de la prométhazine et de la cortisone vis-à-vis de diverses infections expérimentales. Arch. int. Pharmacodyn. 102, 1-16 (1955).

$[\mathrm{C} 14,760 / 55$

Marañón, G.o, Aznar, C.: Sobre la acción protectora de diferentes extractos de órganos contra la estricnina. Bol. Soc. esp. Biol. 302-305 (1915). [46,926/15

Marbé, S.: Les opsonines dans les états thyroïdiens. I. Les opsonines des animaux hyperthyroïdés. C. R. Soc. Biol. (Paris) 64, 1058 a 1060 (1908).
$[\mathrm{A4}, 623 / 08$ 
Marbé, S.: Les opsonines dans les états thyroïdiens. II. Les opsonines des animaux éthyroïdés. C. R. Soc. Biol. (Paris) 64, 1113-1115 (1908).

$[\mathrm{A4}, 624 / 08$

Marbé, S.: Les opsonines dans les états thyroïdiens. III. Les opsonines et la phagocytes chez les myxoedémateux. C. R. Soc. Biol. (Paris) 65, 612-614 (1908).

$[\mathrm{A} 4,625 / 08$

Marbé, S.: Les opsonines et la phagocytose dans les états thyroïdiens. IV. Action directe, in vitro, du corps thyroïde. C. R. Soc. Biol. (Paris) 66, 432-433 (1909). [A4,626/09

Marbé, S.: Les opsonines et la phagocytose dans les états thyroïdiens. V. La phagocytose chez les animaux hyperthyroïdes et éthyroïdés. L'indice phagocytaire. $C$. R. Soc. Biol. (Paris) 66, 1073-1075 (1909). [A4,627/09

Marbé, S.: Les opsonines et la phagocytose dans les états thyroïdiens. VI. Le nombre des leucocytes et la formule leucocytaire chez les animaux hyperthyroïdés et chez les éthyroïdés. Rapport entre la formule leucocytaire et la phagocytose. C. R. Soc. Biol. (Paris) 67, 44-46 (1909).

[A23,010/09

Marbé, S.: Les opsonines et la phagocytose dans les états thyroïdiens. VII. La phagocytose non microbienne dans les états thyroïdiens. Sur la chimiotaxie. C. R. Soc. Biol. (Paris) 67, 111-113 (1909).

[A23,011/09

Marbé, S.: Les opsonines et la phagocytose dans les états thyroïdiens. VIII. Aspect et réaction du sérum et des leucocytes des animaux hyperthyroïdés et éthyroïdés. Rapport entre la réaction du sérum et l'indice opsonique. C. R. Soc. Biol. (Paris) 67, 293-295 (1909).

[A23,012/09

Marbé, S.: Les opsonines et la phagocytose dans les états thyroïdiens. IX. L'indice phagoopsonique, la formule leucocytaire et la réaction $d u$ sérum dans la maladie de Basedow. Sur la pathogénie de la maladie de Basedow. C. R. Soc. Biol. (Paris) 67, 362-364 (1909).

[A 23,013/09

Marbé, S.: Les opsonines et la phagocytose dans les états thyroïdiens. XII. L'influence de la thyratoxine sur le pouvoir opsonique normal des animaux. C. R. Soc. Biol. (Paris) 69, 355-357 (1910).

$[\mathrm{A} 23,016 / 10$

Marbé, S.: Hypersensibilisation générale thyroïdienne. III. La recherche des leucocytes dans le liquide péritonéal, et la formule leucocytaire des cobayes hyperthyroïdés et infectés avec le bacille d'Eberth. $C$. $R$. Soc. Biol. (Paris) 68, 468-470 (1910).

$[\mathrm{A} 23,018 / 10$
Marbé, S.: Hypersensibilisation générale thyroïdienne. I. Sur la diminution de la résistance des cobayes hyperthyroïdés vis-à-vis de l'infection éberthienne expérimentale. $C . R$. Soc. Biol. (Paris) 68, 351-353 (1910).

$[34,320 / 10$

Marbé, S.: Hypersensibilisation générale thyroïdienne. II. Sur la diminution de la résistance des cobayes pesteux et hyperthyroïdés, ainsi que de ceux soumis même au traitement spécifique. $C . \quad R$. Soc. Biol. (Paris) 68, 412-414 (1910). [34,321/10

Marbé, S.: Les opsonines et la phagocytose dans les états thyroïdiens. XIII. Les inhibines phagocytaires d'origine thyroïdienne. $C$. $R$. Soc. Biol. (Paris) 69, 387-389 (1910).

$[34,561 / 10$

Marbé, S.: Hypersensibilisation générale thyroïdienne. VI. Sur la diminution de la résistance des cobayes hyperthyroïdés vis-à-vis de l'intoxication diphtérique, but de ces expériences. C. R. Soc. Biol. (Paris) 71, 357-358 (1911).

$[35,374 / 11$

Marbé, S.: L'hypersensibilisation générale thyroïdienne. VII. Exaltation et atténuation du bacille typhus muyium dans les milieux de culture thyroïdés. C. R. Soc. Biol. (Paris) 72, 710-712 (1912).

[A23,015/12

Mare, V., Morselli, P. L.: Metabolism of exogenous cortisol in the rat in various experimental conditions. J. Pharm. Pharmacol. 21, 864-866 (1969).

$[\mathrm{G} 71,617 / 69$

March, C. H., Elliott, H. W.: Distribution and excretion of radioactivity after administration of morphine-N-methyl $\mathrm{C}^{14}$ to rats. Proc. Soc. exp. Biol. (N.Y.) 86, 494-497 (1954).

$[\mathrm{G} 77,519 / 54$

March, C. H., Gordan, G. S., Way, E. L.: The effect of castration and of testosterone on the action and distribution of dl-methadone in the rat. Arch. int. Pharmacodyn. 83, 270-276 (1950).

[B 58,376/50

Marchal, C., Benichoux, R.: Histoire de la régénération hépatique expérimentale. Lyon chir. 58, 47-55 (1962).

[D 37,572/62

Marchant, J.: The influence of sex and castration on the induction of skin tumours in mice by methyl cholanthrene. Brit. J. Cancer 13, 106-114 (1959).

$[\mathrm{C} 69,830 / 59$

Marchi, G. de: Ricerche sull'azione della vitamina $\mathrm{C}$ e dell'estratto corticosurrenale nell'intossicazione difterica sperimentale, con particolare riguardo alle lesioni cardiache. Accad. med. 53, 254-262 (1938). [A 30,837/38 
Marie, A.: Glandes surrénales et toxi-infections. (Troisième note.) C. R. Soc. Biol. (Paris) 74, 221-223 (1913). $\quad[37,085 / 13$ Marie, A.: Glandes surrénales et toxi-infections. Ann. Inst. Pasteur 32, 97-110 (1918).

$[32,348 / 18$

Marie, A.: Du mode d'action de l'adrénaline vis-à-vis des toxines solubles. C. R. Soc. Biol. (Paris) 82, 581-583 (1919).

$[37,087 / 19$ Marino, A., Bianchi, A., Giaquinto, S., Casola, L.: Induzione e trattamento della cardiopatia sperimentale da stress psicologico e pitressina. Arch. int. Pharmacodyn. 141, 377-395 (1963).

[D 58,761/63

Markova, I. V.: Age sensitivity to barbiturates and its dependence on the development of the hypophyseal adrenal system. (Russian text.) Byull. eksp. Biol. Med. 50, 87-91 (1960).

[D $49,769 / 60$

Markova, I. V.: Underdevelopment of the hypophyseo-adrenal system in the newborn animals as a cause of reduced morphine resistance. (Russian text.) Probl. Endokr. Gormonoter. 8, 3-8 (1962). [D47,081/62

Marmo, E., Miele, E.: Effetti di associazioni fra steroidi anabolizzanti e thiotepa su diverse neoplasie sperimentali. Boll. Soc. ital. Biol. sper. 37, 1474-1477 (1961). [ [D27,478/61

Marmorston-Gottesman, J., Perla, D.: Immunological studies in relation to the suprarenal gland. III. The effect of injections of epinephrine on the hemolysin formation in normal rats. J. exp. Med. 48, 225-233 (1928).

$[23,446 / 28$

Maros, T., Hadnagy, C., Seress-Sturm, L., Csiky, M., Kováes, I.: Die Wirkung von Vitamin $\mathrm{B}_{12}$ und von Cortison auf die Regeneration der Rattenleber. Int.Z. Vitamin-Forsch. 31, 303-307 (1961).

[D 12,784/61

Marquardt, G. H., Fisher, C. I., Levy, P., Dowben, R. M.: Effect of anabolic steroids on liver function tests and creatine excretion. J. Amer. med. Ass. 175, 851-853 (1961). [D 82,860/61

Marshall, R. T., Freeman, S.: Effect of 'thyroidectomy' on nephrectomized dogs and rats. Fed. Proc. 11, 101 (1952). [B68,239/52

Marshall, R. T., Freeman, S.: The effect of hypothyroidism on the development of experimental uremia. Endocrinology 55, 205-211 (1954).

[B96,575/54

Marsilii, G., Simone, M. de: Su alcuni aspetti submicroscopici del fegato rigenerante. Boll. Soc. ital. Biol. sper. 38, 1034-1036 (1962).

$[\mathrm{G} 1,552 / 62$
Martin, J. M.: Necrosis hepática por aloxano y cloroformo. Factores agravantes y protectores. Rev. Soc. argent. Biol. 29, 103-107 (1953).

$[\mathrm{B} 88,524 / 53$

Martin, L. G., Bullard, R. W.: Thyroxineenhanced susceptibility of mice to Klebsiella pneumoniae. Proc. Soc. exp. Biol. (N.Y.) 131, 824-827 (1969).

$[\mathrm{H} 15,263 / 69$

Martin, S. J., Herrlich, H. C., Clark, B. B.: The effect of various tissues on the detoxification of evipal in the dog. Anesthesiology 1, 153-157 (1940).

$[\mathrm{A} 48,575 / 40$

Martinengo, L., Beghelli, G.: Dijodotirosina e ipertermia passiva. Folia Ther. 17, 35-50 (1939).

$[\mathrm{B} 3,426 / 39$

Martinez, C.: Tiroids y sensibilidad al aloxano endovanoso. Rev. Soc. argent. Biol. 21, 254-258 (1945). [B 15,837/45

Martinez, C.: Acción del tiouracilo sobre la diabetes aloxánica y pancreática en la rata. Rev. Soc. argent. Biol. 22, 135-146 (1946).

$[\mathrm{B} 2,342 / 46$

Martinez, C.: The SH groups in experimental diabetes. Acta physiol. lat.-amer. 2, 135-162 (1951).

[B $61,239 / 51$

Martinez-Manautou, J., Aznar-Ramos, R., Bautista-0'Farrill, J., Gonzáles-Angulo, A.: The ultrastructure of liver cells in women under steroid therapy. II. Contraceptive therapy. Acta endocr. (Kbh.) 65, 207-221 (1970).

[H30,302/70

Maruyama, M., Fujita, T., Ohata, M.: Purification and properties of a microsomal endopeptidase from rat kidney preferentially hydrolyzing parathyroid hormone. Arch. Biochem. 138, 245-253 (1970). [G74,893/70

Marver, H. S., Sehmid, R., Sehützel, H.: Heme and methemoglobin: naturally occurring repressors of microsomal cytochrome. Biochem. biophys. Res. Commun. 33, 969-974 (1968).

$[\mathrm{G} 76,839 / 68$

Maśliński, C.: The effect of thyroid gland on the course of experimental tuberculosis. Bull. Acad. pol. Sci. 4, 273-278 (1956). [C50,519/56

Maśliński, C.: The course of tuberculous infection on the ground of the existing hyperfunction or hypofunction of the thyroid gland. Bull. Acad. pol. Sci. 4, 279-282 (1956).

[C50,520/56

Maśliński, C.: Tarczyca a gruźlica doświadczalna. (Thyroid gland and experimental tuberculosis) Rozpr. Wydz. Nauk Med. 2/1, 137-192 (1957).

$[\mathrm{C} 48,845 / 57$ 
Mason, H. S., North, J. C., Vanneste, M.: Microsomal mixed-function oxidations: the metabolism of xenobiotics. Fed. Proc. 24, 1172-1180 (1965).

[F 51,528/65

Mason, R. C., Johnson, D. H., Robinson, H. J.: Comparative effects of corticosterone and cortisone on experimental corynebacterium infection of mice. Fed. Proc. 15, 456 (1956).

$[\mathrm{C} 14,288 / 56$

Massalski, W., Kulejewska, M.: Działanie ACTH w doświadczalnym tezcu. (Influence of ACTH in experimental tetanus.) Pol. Tyg. lék. 12, 252-254 (1957).

$[\mathrm{C} 52,338 / 57$

Massei, G., Villani, C., Caturegli, G.: Effetti del propionato di testosterone a forti dosi nella epatopatia sperimentale da $\mathrm{CCl}_{4}$. Arch. Sci. med. 108, 811-852 (1959).

[D2,594/59

Masson, G.: Influence des traits hypophysaires sur la résistance à l'anesthésie. Rev. canad. Biol. 4, 121-124 (1945).

[B275/45

Masson, G.: Effects of proteins on the resistance to anesthesia produced by barbiturates. Fed. Proc. 5, 72 (1946).

$[\mathrm{A} 95,888 / 46$

Masson, G.: Influence de préparations hypophysaires sur la résistance à l'anesthésie produite par les barbiturates. Rev. canad. Biol. 5, 400-406 (1946).

[B 1,217/46

Masson, G.: Non-spécificité de l'action de préparations hypophysaires sur la résistance au nembutal. Rev.canad. Biol. 6, 26-35 (1947).

$[94,205 / 47$

Masson, G.: Action de la thyroxine sur l'effet testoìde de la testostérone. Rev. canad. Biol. 6, 355-358 (1947).

$[96,171 / 47$

Masson, G.: Inhibition de l'action hépatotoxique du tétrachlorure de carbone. Rev. canad. Biol. 6, 362-366 (1947).

$[96,335 / 47$

Masson, G., Beland, E.: Studies on the detoxification of barbiturates. Fed. Proc. 3,32 (1944).

$[\mathrm{A} 72,286 / 44$

Masson, G., Corcoran, A. C., Page, I. H.: Dietary and hormonal influences in experimental uremia. J. Lab. clin. Med. 34, 925-931 (1949).

$[\mathrm{B} 40,204 / 49$

Masson, G., Hoffman, M. M.: Studies on the role of the liver in the metabolism of progesterone. Endocrinology 37, 111-116 (1945).

[B513/45

Masson, G. M. C., Beland, E.: Influence of the liver and the kidney on the duration of anesthesia produced by barbiturates. Anesthesiology 6, 483-491 (1945).

[B344/45

Masson, G. M. C., Page, I. H., Coreoran, A. C.: Vascular reactivity of rats and dogs treated with desoxycorticosterone acetate. Proc. Soc. Exp. Biol. (N.Y) 73, 434-436 (1950).

$[\mathrm{B} 47,635 / 50$

Masson, M. C., Corcoran, A. C., Page, H.: Experimental vascular diseases due to desoxycorticosterone acetate and anterior pituitary extract. 1. Comparison of functional changes. J. Lab. clin. Med. 34, 1416-1426 (1949).

$[\mathrm{B} 48,694 / 49$

Matsumura, F., Wang, C. M.: Reduction of dieldrin storage in rat liver: factors affecting in situ. Bull. environm. Contam. Toxicol. 3, 203-210 (1968).

[G74,472/68

Matthews, S. A., Austin, W. C.: The effect of the blood calcium level on the tolerance to magnesium. Some observations on hypercalcemia induced by the parathyroid hormone. Amer. J. Physiol. 79, 708-718 (1927).

$[21,067 / 27$

Matthies, H., Schmidt, J.: Die Beeinflussung der Hexobarbitalnarkose durch intracerebrale Injektion biogener Amine nach Reserpinvorbehandlung. Naunyn-Schmiedebergs Arch. Pharmak. 241, 508-509 (1961).

[D 84,334/61

Matzen, R. N.: Effect of vitamin $\mathrm{C}$ and hydrocortisone on the pulmonary edema produced by ozone in mice. J. appl. Physiol. 11, 105-109 (1957).

$[\mathrm{C} 39,985 / 57$

Maurer, H. M.: New concepts in the management of neonatal jaundice: use of enzyme induction and phototherapy. Med. Coll. Va Quart. 6, 79-86 (1970).

$[\mathrm{H} 29,765 / 70$

Maurer, H. M., Wolff, J. A., Finster, M., Poppers, P. J., Pantuck, E., Kuntzman, R., Conney, A. H.: Reduction in concentration of total serum-bilirubin in offspring of women treated with phenobarbitone during pregnancy. Lancet 1968II, 122-124. [G71,810/68

Mayer, J., Goddard, J. W.: Effects of administration of gonadotropic hormone on vitamin A deficient rats. Proc. Soc. exp. Biol. (N.Y.) 76, 149-151 (1951).

[B55,008/51

Mayer, J., Truant, A. P.: Effects of administration of testosterone on vitamin A-deficient rats. Proc. Soc. exp. Biol. (N.Y.) 72, 436-438 (1949).

$[\mathrm{B} 43,456 / 49$

Mayer, R. L., Hays, H. W., Brousseau, D., Mathieson, D., Rennick, B., Yonkman, F. F.: Pyribenzamine (N'-pyridyl-N'-benzyl-N-dimethylethylene-diamine HCL), an antagonist of histamine. J. Lab. clin. Med. 31, 749-751 (1946).

$[\mathrm{B} 3,674 / 46$

Mayewski, R. J., Litwack, G.: ${ }^{3} \mathrm{H}$-cortisol radioactivity in hepatic smooth endoplasmic 
reticulum. Biochem. biophys. Res. Commun. 37, 729-735 (1969).

$[\mathrm{G} 70,720 / 69$

Mazel, P., Bush, M. T.: Pharmacological studies of the bloodbrain barrier. Fed. Proc. 20, 306 (1961).

[D4,194/61

Mazel, P., Bush, M. T.: Brain barbital levels and anesthesia as influenced by physostigmine and epinephrine. Biochem. Pharmacol. 18, 579-586 (1969).

[G65,299/69

MeArthur, J. N., Dawkins, P. D., Smith, M.J.H.: The binding of indomethacin, salicylate and phenobarbitone to human whole blood in vitro. J. Pharm. Pharmacol. 23, 32-36 (1971).

[G81,040/71

MeCallum, H. M.: Lathyrism in mice. Nature (Lond.) 182, 1169-1170 (1958). [C61,614/58 MeCann, S. M., Matsumura, Y., Dimick, M. K., Pencharz, R., Lepkovsky, S.: Effect of hypothalamic lesions on tryptophan peroxidase of the liver. Proc. Soc. exp. Biol. (N.Y.) 100, 586-588 (1959).

$[\mathrm{E} 93,864 / 59$

MeCarthy, J. L., Rietz, C. W., Wesson, L. K.: Inhibition of adrenal corticosteroidogenesis in the rat by cyanotrimethylandrostenolone, a synthetic androstane. Endocrinology 79, 1123 to 1129 (1966).

$[\mathrm{F} 74,065 / 66$

MeCarthy, J. S., Furner, R. L., Dyke, K. van, Stitzel, R. E.: Effect of malarial infection on host microsomal drug-metabolizing enzymes. Biochem. Pharmacol. 19, 1341-1349 (1970).

[G75,511/70

MeClure, D. J., Cleghorn, R. A.: Suppression studies in affective disorders. Canad. psychiat. Ass. J. 13, 477-488 (1968). [G76,696/68

MeCluskey, R. T., Thomas, L.: The removal of cartilage matrix in vivo by papain. Prevention of recovery with cortisone, hydrocortisone and prednisolone by a direct action on cartilage. Amer. J. Path. 35, 819-833 (1959).

$[\mathrm{C} 71,485 / 59$

MeColl, J. D., Robinson, S., Sagritalo, G. M.: Enhancement of postcoital antifertility activity of estrogens by dimenhydrinate in the rat. (Abstr.) Fed. Proc. 29, 781 (1970). [H24,915/70

MeColl, J. D., Sacra, P.: Alteration in toxicity and action of hypoglycemic agents in the rat by sex hormones. Toxicol. appl. Pharmacol. 4, 631-637 (1962).

[D34,973/62

MeCormack, C. E., Meyer, R. K.: Ovulating hormone release in gonadotropin treated immature rats. Proc. Soc. exp. Biol. (N.Y.) 110, 343-346 (1962).

[D29,101/62

MeCormack, C. E., Meyer, R. K.: Minimal age for induction of ovulation with progesterone in rats: evidence for neutral control. Endocrinology 74, 793-799 (1964). [F9,493/64 MeDonagh, J. E. R.: The active principle of the parathyroid glands, tetany and calcium metabolism. Amer. Med. (Philad.) 34, 36-49 (1928).

$[19,285 / 28$

McEuen, C. S., Selye, H., Collip, J. B.: Effect of testosterone on somatic growth. Proc. Soc. exp. Biol. (N.Y.) 36, 390-394 (1937).

$[39,157 / 37$

McFarlane, E. S., Embil, J. A., Jr.: Effect of gonadectomy on adenovirus-12 oncogenesis in Syrian hamsters. Canad. J. Microbiol. 14, 1013-1014 (1968).

[H18,880/68

MeFarland, L. Z., Lacy, P. B.: Physiologic and endocrinologic effects of the insecticide kepone in the Japanese quail. Toxicol. appl. Pharmacol.15, 441-450 (1969).

$[\mathrm{G} 68,855 / 69$

MeGill, H. C., Parrish, L. E., Holman, R. L.: Influence of alloxan diabetes of cholesterol atherosclerosis in the rabbit. Fed. Proc. 8, 361 (1949).

[B32,954/49

MeGrath, E. J.: Experimental peripheral gangrene. J. Amer. med. Ass. 105, 854-856 (1935).

$[\mathrm{A} 29,208 / 35$

MeGrath, E. J., Herrmann, L. G.: Influence of estrogens on the peripheral vasomotor mechanism. Ann. Surg. 120, 607-616 (1944).

[B500/44

MeGraw, J. Y.: La régulation de la résistance capillaire. IV. Influence de traitements vitaminiques et hormonaux sur la croissance et la résistance capillaire du cobaye. Laval méd. 27, 660-710 (1959).

$[\mathrm{C} 68,484 / 59$

MeGraw, J. Y.: La régulation de la résistance capillaire. VII. Influence de la thyroïde et des surrénales sur la croissance et la résistance capillaire. Laval méd. 28, 643-698 (1959).

$[\mathrm{C} 80,136 / 59$

MeGuire, J. S., Jr., Hollis, V. W., Jr., Tomkins, G. M.: Some characteristics of the microsomal steroid reductases $(5 \alpha)$ of rat liver. J. biol. Chem. 235, 3112-3117 (1960). [D82,559/60

McGuire, J. S., Jr., Tomkins, G. M.: The effects of thyroxin administration on the enzymic reduction of $\Delta^{4}$-3-ketosteroids. $J$. biol. Chem. 234, 791-794 (1959).

[E $90,938 / 59$

McGuire, J. S., Jr., Tomkins, G. M.: The heterogeneity of $\Delta^{4}$-3-ketosteroid reductases $(5 \alpha)$. J. biol. Chem. 235, 1634-1638 (1960).

$[\mathrm{D} 5,722 / 60$

MeGuire, J. S., Tomkins, G. M.: The multiplicity and specificity of $\triangle^{4}$-3-ketosteroid hydrogenases (5a). Arch. Biochem. 82, 475-477 (1959).

$[\mathrm{E} 91,579 / 59$ 
MeIver, A. K.: Drug incompatibilities. Pharm. $J .195,609-612$ (1965). $[\mathrm{G} 78,391 / 65$

MeIver, A. K.: Drug interactions. Pharm. $J$. 199, 205-210 (1967).

$[\mathrm{G} 77,708 / 67$

MeIver, M. A.: Increased susceptibility to chloroform poisoning produced in the albino rat by injection of crystalline thyroxin. Proc. Soc. exp. biol. (N.Y.) 45, 201-206 (1940).

[A35,431/40

MeIver, M. A., Winter, E. A.: Deleterious effects of anoxia on the liver of the hyperthyroid animal. Arch. Surg. 46, 171-185 (1943).

[B33,399/43

McKenna, J. M., Zweifach, B. W.: Reticuloendothelial system in relation to drum shock. Amer. J. Physiol. 187, 263-268 (1956).

$[\mathrm{C} 27,414 / 56$

McLean, E. K., McLean, A. E. M., Sutton, P. M.: Instant cirrhosis. An improved method for producing cirrhosis of the liver in rats by simultaneous administration of carbon tetrachloride and phenobarbitone. Brit. J.exp. Path. 50, 502-506 (1969).

[H 18,569/69

McLean, S., Marchand, C.: The effect of SKF 525-A on drug concentration in the blood. Life Sci. 9/I, 1075-1080 (1970). [G78,253/70 MeLoughlin, D. K.: The influence of dexamethasone on attempts to transmit Eimeria meleagrimitis to chickens and E. tenella to turkeys. J. Protozool. 16, 145-148 (1969). [G73,149/69 MeLuen, E. F., Fouts, J. R.: The effect of obstructive jaundice on drug metabolism in rabbits. $J$. Pharmacol. exp. Ther. 131, 7-11 (1961).

$[\mathrm{E} 99,285 / 61$

MeMullin, G. P.: Phenobarbitone and neonatal jaundice. Lancet 1968 II, 978-979.

$[\mathrm{G} 77,713 / 68$

MeMullin, G. P., Hayes, M. F., Arora, S. C.: Phenobarbitone in rhesus haemolytic disease. A controlled trial. Lancet 1970 II, 949-952.

[H31,772/70

MeQueen-Williams, M., Thompson, K. W.: The effect of ablation of the hypophysis upon the weight of the kidney of the rat. Yale J. Biol. Med. 12, 531-541 (1940).

$[\mathrm{A} 33,938 / 40$

Medina, M. A., Merritt, J. H.: Drug metabolism and pharmacologic action in mice exposed to reduced barometric pressure. Biochem. Pharmacol. 19, 2812-2816 (1970). [G81,699/70

Medlinsky, J. T., Napier, C. D., Gurney, C. W.: The use of an antiandrogen to further investigate the erythropoietic effects of androgens. J. Lab. clin. Med. 74, 85-92 (1969).

$[\mathrm{G} 67,839 / 69$
Medvedeva, G. I.: Correlations of direct and indirect calorimetry data during recovery from hypothermia in healthy rabbits and in experimental hypothyroidism. Probl. Endokr. 14/1, 105-110 (1968).

[F 96,027/68

Meer, C. van der, Bekkum, D. W. van: The mechanism of radiation protection by histamine and other biological amines. Int. $J$. Radiat. Biol. 1, 5-23 (1959). [ [G71,673/59

Mehrotra, R. M. L., Mangalik, V. S., Nayak, N. C.: An experimental study of the effect of doca on the development of ascites in $\mathrm{CCl}_{4}$ cirrhosis. Indian J. med. Res. 45, 183-190 (1957).

$[\mathrm{C} 54,806 / 57$

Mehrotra, R. M. L., Sarna, S.: Thyroid hormone and paraaminosalicylate-induced liver changes. J. Path. Bact. 82, 522-526 (1961).

[D14,287/61

Meier, H.: Experimental pharmacogenetics. Physiopathology of heredity and pharmacologic responses. New York, London: Academic Press, Inc., pp. 213 (1963).

[E690/63

Meier, R., Neipp, L.: Verstärkung der chemotherapeutischen Wirkung von Sulfonamiden durch zusätzliche Behandlung mit chemotaktisch wirkenden Polysacchariden aus Harn und Bakterien. Schweiz. med. Wschr. 86, 249 bis 251 (1956).

$[\mathrm{C} 37,215 / 56$

Meissner, R.: Úber Paraphenylendiamin. Naunyn-Schmiedebergs Arch. Pharmak. 84, 181 bis 222 (1919).

[E52,567/19

Meister, V. von: Recreation des Lebergewebes nach Abtragung ganzer Leberlappen. Experimentelle Untersuchung. Beitr. path. Anat. 15, 1-116 (1894).

[A25,263/1894

Meites, J., Feng, Y. S. L., Wilwerth, A. M.: The effects of endocrine imbalances on vitamin requirements. Amer. J. clin. Nutr. 5, 381-392 (1957).

$[\mathrm{C} 39,753 / 57$

Mejia, R. H., Rennis, M. A., Bolo, H. J.: Influence of adrenal glands on the survival time of hypovolemic shock. Acta physiol. lat.-amer. 18, 151-156 (1968). [G60,637/68

Melby, J. C., Bradley, G. M., Spink, W. W.: The influence of triiodothyronine on the lethal effect of bacterial endotoxin and infection due to Br. melitensis. Clin. Res. 6, 280 (1958).

$[\mathrm{C} 86,232 / 58$

Melby, J. C., Egdahl, R. H., Bossenmaier, I. C., Spink, W. W.: Suppression by cortisol of increased serum-transaminase induced by endotoxin. Lancet 1959I, 441-444. [C65,221/59

Melby, J. C., Spink, W. W.: Enhancement of lethal action of endotoxin in mice by triiodo- 
thyronine. Proc. Soc. exp. Biol. (N.Y.) 101, 546-547 (1959).

$[\mathrm{C} 72,440 / 59$

Melcher, G. W., Jr., Blunt, J. W., Ragan, C.: Occurrence of hepatitis in cortisone-treated rats following inoculation with human infectious hepatitis serum. Amer. Soc. clin. Invest. 44th Ann. Meet. Atlantic City, p. 40 (1952).

$[\mathrm{B} 69,381 / 52$

Melching, H. J., Langendorff, M., Ladner, H. A.: Ủber die Abhängigkeit der Strahlenschutzwirksamkeit des 5-Hydroxytryptamins von Konzentration und Zeitfaktor. Naturwissenschaften 45, 545 (1958).

$[\mathrm{C} 76,527 / 58$

Meldolesi, J.: On the significance of the hypertrophy of the smooth endoplasmic reticulum in liver cells after administration of drugs. Biochem. Pharmacol. 16, 125-129 (1967).

$[\mathrm{G} 66,053 / 67$

Meldolesi, J., Vincenzi, L., Bassan, P., Morini, M. T.: Effect of carbon tetrachloride on the synthesis of liver endoplasmic reticulum membranes. Lab. Invest. 19, 315-323 (1968).

[G69,793/68

Mellette, S. J.: Interrelationships between vitamin $\mathrm{K}$ and estrogenic hormones. Amer. $J$. clin. Nutr. 9, 109-116 (1961). [D7,939/61

Melnik, M.: Contribution à l'étude des relations entre les glandes à sécrétion interne et l'immunité. Le corps thyroïde et le bacilli de Shiga. C. R. Soc. Biol. (Paris) 92, 474-475, 944-945 (1925).

$[26,134 / 25$

Menguy, R., Masters, Y. F.: The effects of parathyroid extract on the stomach. Physiologist 7, 205 (1964).

[F 17,447/64

Menguy, R., Masters, Y. F.: Role of the liver in the glycoprotein mobilizing property of parathyroid extract (Abstr.). Clin. Res. 13, 257 (1965).

$[\mathrm{F} 61,098 / 65$

Mercier-Parot, L., Tuchmann-Duplessis, H.: Propriétés embryotoxique et tératogène d'une méthylhydrazine antitumorale: influence de la progestérone. C. R. Acad. Sci. (Paris) 270, $1153-1156$ (1970).

$[\mathrm{G} 73,572 / 70$

Merli, G. M., Gandini, A.: Richerche sperimentali sulla resistenza alla intossicazione latirogenica da n-butilamina in ratti epatectomizzati. Biochem. Biol. sper. 111, 289 (1964).

[F 32,684/64

Messina, C.: Effetti del trattemento con H.C.G. e con ergotamina in ratti integri ed ipofisectomizzati. Boll. Soc. ital. Biol. sper. 40, 439-442 (1964).

[G18,016/64

Messini, M., Coppo, M.: Ricerche sui rapporti fra ormoni e vitamine. Studio sul mecca- nismo d'azione della vitamina antirachitica nell'organismo come contributo alla conoscenza della fisiopatologia del timo. Arch. Ist. biochim. ital. 7, 195-232 (1935). $\quad[31,827 / 35$

Metzenberg, R. L., Marchall, M., Paik, W. K., Cohen, P. P.: The synthesis of carbamyl phosphate synthetase in thyroxin-treated tadpoles. J. Biol. Chem. 36, 162-165 (1961).

$[\mathrm{D} 86,024 / 61$

Metzler, A. von: Die Wirkung von Desoxycorticosteron auf den Blutdruck bei der Ratte nach vorheriger Behandlung mit 3-Methylcholanthren. Klin. Wschr. 48, 695-696 (1970).

$[\mathrm{H} 27,243 / 70$

Metzler, A. von, Hergott, J.: Über den Einfluß des Percortens auf toxische Strophanthindosen am Froschherzen in situ. Klin. Wschr. 29, 91-92 (1951).

$[\mathrm{B} 63,494 / 51$

Méwissen, D. J., Lagneau, L. E.: Le rôle du thymus sur la survie des souris après irradiation totale, avec ou sans protection chimique. Acta clin. belg. 19, 71-72 (1964). [G 14,713/64

Méwissen, D. J., Rust, J. H., Lagneau, L. E.: Le rôle du thymus dans la survie de la souris C57 BL irradiée, avec ou sans protection chimique. C. R. Soc. Biol. (Paris) 159, 240-242 (1965).

$[\mathrm{F} 45,017 / 65$

Meyer, B. J., Karel, L.: The effects of iodides, 1-thiosorbitol, and twenty-five other compounds on alphanaphthylthiourea (ANTU) toxicity in rats. $J$. Pharmacol. exp. Ther. 92, 15-31 (1948).

$[\mathrm{B} 18,102 / 48$

Meyer, B. J., Vos, A. C.: The effect of lathyrus odoratus meal, cholesterol and various hormones on the structure of the aorta and coronary arteries. S. Afr. J. med. Sci. 22, 29-36 (1957).

$[\mathrm{C} 41,429 / 57$

Meyer, D. L., Forbes, R. M.: Effects of thyroid hormone and phosphorus loading on renal calcification and mineral metabolism of the rat. J. Nutr. 93, 361-367 (1967). [G53,688/67

Meyers, F. H., Peoples, D.: The positive role of the liver in the rapid metabolism of thiopental. Anesthesiology 15, 146-149 (1954).

[G 70,570/54

Meyers, K. P.: Implantation and deciduoma formation after administration of antiestrogenic compounds. Biol. Reprod. 3, 61-66 (1970).

$[\mathrm{G} 77,432 / 70$

Mezzano, M., Peluffo, G.: Elettività cardiotropa nel sinergismo endotossina noradrenalina. Pathologica 52, 369-377 (1960).

$[\mathrm{D} 9,328 / 60$ 
Michael, M., Jr., Cummings, M. M., Bloom, W. L.: Course of experimental tuberculosis in the albino rat as influenced by cortisone. Proc. Soc. exp. Biol. (N.Y.) 75, 613-616 (1950). [B53,378/50

Michalek, L., Slaughter, D., Harshfield, R.: Morphine addiction and cortone (Abstr.). J. Pharmacol. exp. ther. 103, 354-355 (1951).

[B91,619/51

Michalovà, G.: The effect of ACTH on experimental silicosis, with special respect to neurohumoral regulation. Acta physiol. Acad. Sci. 14, 79-87 (1958).

$[\mathrm{C} 56,094 / 58$

Michel, R., Truchot, R.: Sur la concentration hépatique du cholestérol chez le rat traité par la thyroxine. C. R. Soc. Biol. (Paris) 153, 572-574 (1959).

$[\mathrm{C79}, 107 / 59$

Middleton, W. R. J., Isselbacher, K. J.: The stimulation of intestinal cholesterogenesis in the rat by phenobarbital. Proc. Soc. exp. Biol. (N.Y.) 131, 1435-1437 (1969). [H 17,133/69

Mikes, A., Todorovié, D.: Effet de la 6-aminonicotamide sur le foie du cobaye. Effet protecteur de la nicotamide et de la prednisolone. I. Intoxication aiguë. Rev. int. Hépat. 9, 759-767 (1959).

[C86,716/59

Mikuni, C., Ujiie, T., Ibayashi, J.: Electron micrographs of biligraphin in rat's hepatic tissue. (Japanese text.) Jap. J. clin. Elect. Micr, 2, 474 (1970).

[H $28,797 / 70$

Millen, J. W., Woollam, D. H. M.: Influence of cortisone on teratogenic effects of hypervitaminosis-A. Brit. med. J. 1957II, 196-197.

$[\mathrm{C} 38,328 / 57$

Miller, J. F. A. P.: Rôle du thymus dans les processus immunitaires. Ann. Inst. Pasteur 105, 1007-1016 (1963).

$[\mathrm{E} 37,260 / 63$

Miller, J. W., George, R., Elliott, H. W., Sung, C. Y., Way, E. L.: The influence of the adrenal medulla in morphine analgesia. J. Pharmacol. exp. Ther. 113, 43-50 (1955). [G73,877/55

Miller, V. L., Bearse, G. E., Russell, T. S., Csonka, E.: The effect of several hormones and sodium thiomalate on retention of mercury by two strains of chicks. Poultry Sci. 48, 613 to 620 (1969).

[G77,153/69

Miller, W. L., Jr., Baumann, C. A.: Basal metabolic rate and liver tumors due to azo dyes. Cancer Res. 11, 634-639 (1951).

[G74,552/51

Miloševie, M. P.: The action of sympathomimetic amines on intravenous anesthesia in rats. Arch. int. Pharmacodyn. 106, 437-446 (1956).

$[\mathrm{C} 39,053 / 56$
Miloševié, M. P.: Uticaj reserpina i 5-hidroksitriptamina (serotonina) na toksićnost adrenalina. [The toxicity of adrenaline as influenced by reserpine and 5-hydroxytryptamine (serotonin).] Acta med. jugosl. 11, 180-185 (1957).

$[\mathrm{C} 41,594 / 57$

Mims, C. A.: The haemorrhagic enteritis syndrome in mice. Brit. J. exp. Path. 53, 24-30 (1962).

$[\mathrm{G} 68,101 / 62$

Mincis, M.: A ação do álcool sôbre o fígado. Rev. Ass. méd. bras. 16, 157-166 (1970).

$[\mathrm{H} 30,210 / 70$

Minkowitz, S., Berkovich, S.: Hepatitis produced by Coxsackie-virus B1 in adult mice. Arch. Path. 89, 427-433 (1970). [H23,844/70

Minz, B., Domino, E. F.: Effects of epinephrine and norepinephrine on electrically induced seizures. J. Pharmacol. exp. Ther. 107, 204 to 218 (1953).

$[\mathrm{B} 81,852 / 53$

Mirand, E. A., Reinhard, M. C., Goltz, H. L.: Protective effect of adrenal steroid administration on irradiated mice. Proc. Soc. exp. Biol. (N.Y.) 81, 397-400 (1952).

$$
\text { [B 76,197/52 }
$$

Mistry, P. B., Monnot, P., Duplan, J. F.: Stimulation de la leucémogenèse AKR par des irradiations $X$ fractionnées: action inhibitrice de l'hydrocortisone. C. R. Soc. Biol. (Paris) 164, 697-700 (1970).

$[\mathrm{H} 33,481 / 70$

Mitchell, M. L., Girerd, R. J.: Effect of growth hormone and antibiotics upon nitrogen mustard treated rats. Proc. Soc. exp. Biol. (N.Y.) 83, 615-618 (1953). [B82,866/53
[

Miti, L., Memeo, S. A.: Influenza dell'aldosterone sulla rigenerazione epatica. G. Geront. 10, 281-286 (1962).

[D 27,223/62

Mitoma, C.: Response to drugs by rats showing long or short hexobarbital-induced sleep. Arch. int. Pharmacodyn. 184, 124-128 (1970).

$[\mathrm{H} 25,522 / 70$

Mitoma, C., LeValley, S. E.: Effect of newborn rats of perinatal exposure to phenobarbital. Arch. int. Pharmacodyn. 187, 155-162 (1970).

$[\mathrm{H} 31,720 / 70$

Mitoma, C., Neubauer, S. E., Badger, N. L., Sorich, T. J.: Hepatic microsomal activities in rats with long and short sleeping times after hexobarbital: a comparison. Proc. Soc. exp. Biol. (N.Y.) 125, $284-288$ (1967).

[G69,268/67

Mitoma, C., Yasuda, D., Tagg, J. S., Neubauer, S. E., Calderoni, F. J., Tanabe, M.: Effects of various chemical agents on drug metabolism and cholesterol biosynthesis. Biochem. Pharmacol. 17, 1377-1383 (1968). [G72,113/68 
Mitri, T. de, Felisati, D., Bastianini, L.: Influence of cortisone on the evolution of experimental bronchopneumonia due to Candida albicans. Pract. oto-rhino-laryng. (Basel) 25, 15-22 (1963).

[D64,042/63

Mitropoulos, K. A., Myant, N. B.: The metabolism of cholesterol in the presence of liver mitochondria from normal and thyroxine treated rats. Biochem. J. 94, 594-603 (1965).

$[\mathrm{G} 26,978 / 65$

Mitznegg, P., Säbel, M., Heim, F.: Inhibition of estrogen-induced radioprotection of placental nucleic acids and proteins by the antiestrogen clomiphene. Life Sci. 9/II, 815-820 (1970).

$[\mathrm{G} 77,075 / 70$

Miura, M.: The effects of thyroid, thyroxin and other iodine compounds upon the acetonitrile tests. $J$. Lab. clin. Med. 7, 349-356 (1922).

$[13,081 / 22$

Miyaji, T., Moszkowski, L. I., Senoo, T., Ogata, M., Oda, T., Kawai, K., Sayama, Y., Ishida, H., Matsuo, H.: Inhibition of 2-acetylaminofluorene tumors in rats with simultaneously fed 20-methylcholanthrene, 9: 10-dimethyl-1: 2-benzanthracene and chrysene, and consideration of sex difference in tumor genesis with 2-acetylaminofluorene. Gann 44, 281-283 (1953).

[D 24,881/53

Mizumoto, R., Wexler, M., Slapak, M., Kojima, Y., MeDermott, W. V., Jr.: The effect of hepatic artery inflow on regeneration, hypertrophy, and portal pressure of the liver following 50 per cent hepatectomy in the dog. Brit. J. Surg. 57, 513-517 (1970).

$[\mathrm{H} 28,787 / 70$

Mody, J. K.: Influence of testosterone in intact and mammectomised female mice. Gann 58, $291-295$ (1967).

$[\mathrm{G} 49,656 / 67$

Mody, M. R., Anjaria, P. D., Golwalla, A. F.: Intravenous hydrocortisone in the toxaemia of typhoid fever. Antiseptic 53, 866-868 (1956).

$[\mathrm{C} 45,962 / 56$

Mogabgab, W. J., Thomas, L.: The effects of cortisone on bacterial infection. J. Lab. Clin. Med. 39, 271-289 (1952).

$[\mathrm{B} 72,457 / 52$

Mohammed, A. H., Rohayem, H., Zaky, O.: The action of scorpion toxin on blood sodium and potassium. J. trop. Med. Hyg. 57, 85-87 (1954).

$[\mathrm{C} 7,579 / 54$

Moir, W. M.: The influence of age and sex on the repeated administration of sodium pentobarbital to albino rats. J. Pharmacol. exp. Ther. 59, 68-85 (1937). $[\mathrm{E} 54,544 / 37$ Mole, R. H., Philpot, J. S. L., Hodges, G. R. V.: Reduction in lethal effect of X-radiation by pretreatment with thiourea or sodium ethane dithiophosphonate. Nature (Lond.) 166, 515 (1950).

[D 96,011/50

Molimard, R., Benozio, M.: Étude de la rate au cours de la régénération hépatique après hépatectomie partielle. Path. et Biol. 18, $429-432$ (1970).

[G 75,048/70

Moll, T.: The susceptibility of weaned mice to Escherichia coli and Salmonella typhimurium endotoxins during, and subsequent to, cortisone treatment. Amer. J. vet. Res. 17, 786-788 (1956).

[D38,913/56

Moll, T.: The susceptibility of weaned mice to Escherichia coli during, and subsequent to, cortisone treatment. Amer. J. vet. Res. 17, 795-798 (1956).

$[\mathrm{D} 38,927 / 56$

Møller-Christensen, E.: Investigations on the inactivation of vasopressin in the liver. Acta Endocr. (Kbh.) 6, 153-160 (1951).

[B56,243/51

Molomut, N.: The effect of hypophysectomy on immunity and hypersensitivity in rats with a brief description of the operative technic. J. Immunol. 37, 113-131 (1939).

$[76,648 / 39$

Molteni, A., Brownie, A. C., Skelton, F. R.: Potentiation of methylandrostenediol hypertension by ACTH administration (Abstr.). Circulation, 38, Sup. 6, VI-140 (1968).

$[\mathrm{H} 4,919 / 68$

Money, W. L.: The interrelation of the thyroid and the adrenals. In: Edelmann; The Thyroid, p. 137-168. Brookhaven Symp. in Biol., Brookhaven National Laboratory 1954. $[\mathrm{C} 5,393 / 54$

Montgomery, E. H.: The role of thyroid and of diet in the acetonitrile test. Yale J. Biol. Med. 6, 101-110 (1933).

$[18,184 / 33$

Montuori, E.: Action de la cortisone sur la toxicité du salicylate de soude. C. R. Soc. Biol. (Paris) 148, 1640-1642 (1954).

$[\mathrm{G} 60,881 / 54$

Moolten, F. L., Oakman, N. J., Bucher, N. L. R.: Accelerated response of hepatic DNA synthesis to partial hepatectomy in rats pretreated with growth hormone or surgical stress. Cancer Res. 30, 2353-2357 (1970).

$[\mathrm{H} 30,606 / 70$

Moon, H. D., Simpson, M. E., Evans, H. M.: Inhibition of methylcholanthrene carcinogenesis by hypophysectomy. Science 116, 331 (1952).

$[\mathrm{B} 74,251 / 52$

Moon, R. J., Berry, L. J.: Role of tryptophan pyrrolase in endotoxin poisoning. $J$. Bact. 95, 1247-1253 (1968).
$[\mathrm{G} 57,245 / 68$ 
Moor, P. de, Hendrikx, A., Hinnekens, M.: Extra-adrenal influence of corticotropin (ACTH) on cortisol metabolism. J. clin. Endocr. 21, 106-109 (1961).

[G75,989/61

Moore, H. C.: The effect of oxytocin on the kidneys of weanling, adult non-pregnant and pregnant rats receiving progesterone and oestrogens. J. Obstet. Gynaec. Brit. Cwlth. 71, 272-276 (1964).

$[\mathrm{G} 11,771 / 64$

Moore, K. E.: Amphetamine toxicity and thyroid hormones. Fed. Proc. 24, 518 (1965).

$[\mathrm{F} 36,358 / 65$

Moore, K. E.: Amphetamine toxicity in hyperthyroid mice: effects on endogenous catecholamines. Biochem. Pharmacol. 14, 1831 to 1837 (1965).

[G36,616/65

Morcos, S. R.: The effect of the protein value of the diet on the neurological manifestations produced in rats by $\beta, \beta$-iminodipropionitrile. Brit. J. Nutr. 21, 269-274 (1967).

$[\mathrm{F} 80,855 / 67$

Moreno, 0. M., Brodie, D. A.: Effects of drugs on gastric hemorrhages produced by the administration of polymyxin B. J. Pharmacol. exp. Ther. 135, 259-264 (1962). [D20,261/62

Morgan, L. M., Binnion, P. F.: The distribution of $3 \mathrm{H}$-digoxin in normal and acutely hyperkalaemic dogs. Cardiovasc. Res. 4, 235-241 (1970).

[G76,782/70

Morii, S.: Adrenocortical damage induced by 7,12-dimethylbenz $(\alpha)$ anthracene and its implication in carcinogenesis. Acta path. jap. 15, 93-110 (1965).

[G34,628/65

Morii, S., Huggins, C.: Adrenal apoplexy induced by 7,12-dimethylbenz(a)anthracene related to corticosterone content of adrenal gland. Endocrinology 71, 972-976 (1962).

[D 45,369/62

Morii, S., Kuwahara, I.: The effect of 7,12-dimethylbenz $(\alpha)$ anthracene upon the adrenal cortex of mammals (Japanese text). J. Kansai Med. Sch. 230-234 (1963).

[G33,213/63

Moritsch, H.: Virologische Untersuchungen über den Einfluß von Penicillin und Cortison auf die experimentelle Infektion der Maus mit Psittakosisvirus. Wien. klin. Wschr. 68, 80-83 (1956).

$[\mathrm{C} 15,606 / 56$

Morris, D. M., Mokal, A.: Effect of nutrition on survival time of thyroidectomized rats bearing a transplantable leukemia. $J$. nat. Cancer Inst. 30, 847-854 (1963). [D 65,803/63 Morrison, J., Kilpatrick, N.: Low urinary oestriol excretion in pregnancy associated with oral prednisone therapy. J. Obstet. Gynaec. Brit. Cwlth. 76, 719-720 (1969). [G69,282/69
Morrow, D. H.: Anesthesia and digitalis toxicity. II. Effect of norepinephrine infusion on ouabain tolerance. Anesth. Analg. Curr. Res. 46, 319-323 (1967). [G47,272/67 Morselli, P. L., Mare, V., Garattini, S., Zaceala, M.: Metabolism of exogenous cortisol in humans. Influence of phenobarbital treatment on plasma cortisol disappearance rate. Rev. europ. Etud. clin. biol. 15, 195-198 (1970).

$[\mathrm{G} 76,129 / 70$

Morton, D. M., Chatfield, D. H.: The effects of adjuvant-induced arthritis on the liver metabolism of drugs in rats. Biochem. Pharmacol. 19, 473-481 (1970).

$[\mathrm{G} 73,681 / 70$

Mosbach, E. H., Bevans, M.: Biological studies of dihydrocholesterol. V. Effect of androgens upon the biologic disposition of dihydrocholesterol in the rabbit. Arch. Path. 75, 558-563 (1963).

$[\mathrm{D} 65,362 / 63$

Moscona, A. A., Piddington, R.: Enzyme induction by corticosteroids in embryonic cells: steroid structure and inductive effect. Science 158, 496-497 (1967). [F90,487/67

Moses, S. W., Levin, S., Chayoth, R., Steinitz, K.: Enzyme induction in a case of glycogen storage disease. Pediatrics 38, 111-121 (1966).

[G40,253/66

Moss, L. D., Dury, A.: Influences of adrenal hormones on aortic histopathology in relation to blood lipoproteins in rabbits. J. Mt Sinai Hosp. 24, 1047-1054 (1957). [C $44,068 / 57$

Motsay, G. J., Alho, A., Jaeger, T., Dietzman, R. H., Lillehei, R. C.: Effects of corticosteroids on the circulation in shock: experimental and clinical results. Fed. Proc. 29, 1861-1873 (1970).

$[\mathrm{H} 32,852 / 70$

Moudgil, L. R.: Possible protective action of antialdosterone compounds in myocardial necrosis in rats. Brit. J. Pharmacol. 35, 558-562 (1969). [G65,314/69

Mouriquand, G., Michel, P.: Accidents du type scorbutique chez des animaux à une alimentation normale, non carencée, soumis à l'action de l'extrait thyroïdien. $C$. $R$. Soc. Biol. (Paris) 84, 43-45 (1921). [12,231/21

Mowat, A. P., Arias, I. M.: Liver function and oral contraceptives. J. reprod. Med. 3, 19-29 (1969).

[G74,246/69

Mrozikiewiez, A., Strzyzewski, W.: Wplyw ACTH i niektórych hormonów kory nadnerczy na drgawki wywołane hydrazydem kwasu izonikotynowego. Przegl. lek. 22, 543-544 (1966).

$[\mathrm{G} 68,152 / 66$

Mrozikiewicz, A., Strzyzewski, W.: Effect of long-term administration of ACTH and 
adrenocortical hormones on the course of hydrazide convulsions. Arch. Immunol. Ther. exp. 15, 909-911 (1967).

$[\mathrm{H} 7,524 / 67$

Mückter, H., Frankus, E., Moré, E.: Experimental investigations with 1-(morpholinomethyl)-4-phthalimido-piperidindione-2, 6 and drostanolone propionate in dimethylbenzanthracene induced tumors of SpragueDawley rats. Cancer Res. 30, 430-438 (1970).

$[\mathrm{H} 23,589 / 70$

Mudge, G. H.: Drugs affecting renal function and electrolyte metabolism. In: Goodman, L. S.; A. Gilman; The Pharmacological Basis of Therapeutics, 3rd ed., p. 820. Toronto, Canada: Collier-Macmillan Canada Ltd. 1965.

$[\mathrm{E} 4,490 / 65$

Mueller, G. C., Rumney, G.: Formation of 6- $\beta$-hydroxy and 6-keto derivatives of estradiol-16-C14 by mouse liver microsomes. $J$. Amer. Chem. Soc. 79, 1004 (1957). [C30,708/57 Mueller, M. N., Kappas, A.: Estrogen pharmacology. I. The influence of estradiol and estriol on hepatic disposal of sulfobromophthalein (BSP) in man. J. clin. Invest. 43, 1905-1914 (1964).

[F 22,282/64

Mueller, M. N., Kappas, A.: Impairment of hepatic excretion of sulfobromophthalein (BSP) by natural estrogens. Trans. Ass. Amer. Phycns. 77, 248-258 (1964). [G81,288/64 Muftic, M., Redmann, U.: Wachstumsförderung und Wachstumshemmung von Mycoplasma gallisepticum durch Steroide. Z $\mathrm{Zl}$. Bakt., I. Abt. Orig. 206, 228-237 (1968).

$[\mathrm{G} 58,918 / 68$

Mullen, J. 0., Juchau, M. R., Fouts, J. R.: Studies of interactions of 3,4-benzpyrene, 3-methylcholanthrene, chlordane, and methyltestosterone as stimulators of hepatic microsomal enzyme systems in the rat. Biochem. Pharmacol. 15, 137-144 (1966). [G37,764/66 Müller, L.: Recherches sur le lieu et le mode d'origine des cytolysines naturelles (alexines et ambocepteurs normaux) et les moyens d'en provoquer l'hypersécrétion. Zbl. Bakt., $I$. Abt. Orig. 57, 577-656 (1911). [A47,855/11 Müller-0erlinghausen, B., Jahns, R., Künzel, B., Hasselblatt, A.: Die Wirkung von Tolbutamid auf Blutglucose und Glucuronsäurekonjugation im Lebergewebe normaler und adrenalektomierter Mäuse. Naunyn-Schmiedebergs Arch. Pharmak. 262, 17-28 (1969).

$[\mathrm{G} 64,175 / 69$

Müller-0erlinghausen, B., Schinke, G.: Wirkung eines Insulinmangels auf die Bilirubinausscheidung in der Galle, Naunyn-Schmiedebergs Arch. Pharmak. 266, 3-17 (1970).

[G79,199/70
Mullins, L. J., Adler, T. K., Fenn, W. 0.: The effect of adrenocortical extracts on the distribution of injected potassium (Abstr.). Fed. Proc. 2, 36 (1943).

$[83,885 / 43$

Munan, L. P., Einheber, A.: Greater resistance of the female to experimental burns following starvation. Science 116, 425-427 (1952).

$[\mathrm{B} 74,511 / 52$

Munan, L. P., Einheber, A.: The effect of sex on survival following standardized burn shock. Endocrinology 52, 484-485 (1953).

$[\mathrm{B} 82,207 / 53$

Muñoz, C., Guerrero, S., Paeile, C., Campos, I.: Sexual differences in the toxicity of procaine in rats. Toxicol. appl. Pharmacol. 3, 445-454 (1961).

$[\mathrm{G} 68,223 / 61$

Muñoz, J.: Hypersensitivity reactions induced in mice treated with Bordetella pertussis. In: Landy and Braun; Bacterial Endotoxins, p. 460-473. New Brunswick, N.J.: Institute of Microbiology, Rutgers, The State University 1964 .

$[\mathrm{E} 8,473 / 64$

Muñoz, J., Schuchardt, L. F.: Effect of H. pertussis on sensitivity of mice to cold stress. Proc. Soc. exp. Biol. (N.Y.) 94, 186-190 (1957).

$[\mathrm{C} 28,986 / 57$

Muñoz, J. M.: El fluor de los huesos y dientes en la fluorosis. Rev. Soc. argent. Biol. 12, 50 -56 (1936).

$[67,126 / 36$

Munson, A. E., Barnes, D., Regelson, W., Wooles, W. R.: The relationship between drug metabolism and the reticuloendothelial (RE) activity (Abstr.). Fed. Proc. 29, 411. (1970).

$[\mathrm{H} 22,843 / 70$

Murakami, H., Kowalewski, K.: Effects of cortisone and an anabolic androgen on the fractured humerus in guinea pigs: clinical and histological study over a six-week period of fracture healing. Canad. J. Surg. 9, 425-434 (1966).

$[\mathrm{G} 41,228 / 66$

Murnaghan, M. F., Mazurkiewicz, I. M.: Some pharmacological properties of 4-methyltropolone. Rev. canad. Biol. 22, 99-102 (1963).

[D $68,260 / 63$

Muro, P. de, Rowinski, P.: The role of sex in the hypertensive action of desoxycorticosterone acetate (DCA). Acta med. scand. 141, 70-76 (1951).

$[\mathrm{B} 66,413 / 51$

Murphy, S. D., Anderson, R. L., DuBois, K. P.: Potentiation of toxicity of malathion by triorthotolyl phosphate. Proc. Soc. exp. Biol. (N.Y.) 100, 483-487 (1959). [G74,671/59

Murphy, S. D., DuBois, K. P.: Quantitative measurement of inhibition of the enzymatic 
detoxification of malathion by EPN (ethyl p-nitrophenyl thionobenzenephosphonate). Proc. Soc. exp. Biol. (N.Y.) 96, 813-818 (1957).

$[\mathrm{G} 74,670 / 57$

Murphy, S. D., DuBois, K. P.: The influence of various factors on the enzymatic conversion of organic thiophosphates to anticholinesterase agents. J. Pharmacol. Exp. Ther. 124, 194-202 (1958).

[D 28,546/58

Murphy, S. D., Malley, S.: Effect of carbon tetrachloride on induction of liver enzymes by acute stress or corticosterone. Toxicol. appl. Pharmacol. 15, 117-130 (1969). [G68,408/69

Murphy, W. H., Jr., Wiens, A. L., Watson, D. W.: Impairment of innate resistance by triiodothyronine. Proc. Soc. exp. Biol. (N.Y.) 99, 213-215 (1958).

$[\mathrm{C} 60,008 / 58$

Murray, F. J.: Outbreak of unexpected reactions among epileptics taking isoniazid. Amer. Rev. resp. Dis. 86, 729-732 (1962).

$[\mathrm{G} 77,553 / 62$

Murray, R., Branham, S. E.: Effect of cortisone and ACTH on adrenals in experimental diphtheria, Shiga, and Meningococcus intoxication. Proc. Soc. exp. Biol. (N.Y.) 78, $750-753$ (1951).

[B 65,414/51

Myers, D. K., Hemphill, C. A., Townsend, C. M.: Deoxycytidylate deaminase levels in regenerating rat liver. Canad. J. Biochem. 39/6, 1043-1054 (1961).

[D 48,663/61

Myers, H. B., Ferguson, C.: Iodine poisoning counteracted by thiosulphate. Proc. Soc. exp. Biol. (N.Y.) 25, 784-785 (1928).

$[\mathrm{A} 48,023 / 28$

Nadasdi, M.: Effect of a steroid spirolactone on the cardiovascular changes produced by renal ischemia. Endocrinology 69, 246-249 (1961).

[D9,288/61

Nadel, E. M., Young, B., Hilgar, A., Mandell, A.: Effects of adrenocorticotropin and endotoxin on adrenal stimulation and resistance to infection. Amer.J. Physiol. 201, 551-553 (1961).

[D12,681/61

Nagata, K., Baba, T., Nagasawa, Y., Takagi, K., Hara, K.: Effect of cortisone on the course of Schistosoma japonicum infection in mice, particularly of the hepatic tissue. Gunma $J$. med. Sci. 5, 24-36 (1956). [D26,285/56

Naguib, M., Robson, J. M.: The effect of cortisone alone and in combination with isoniazid on experimental murine leprosy in mice. Brit. J. Pharmacol. 11, 326-329 (1956).

$[\mathrm{C} 23,199 / 56$
Naidu, N. V., Reddi, 0. S.: Effect of post-treatment with erythropoietin(s) on survival and erythropoietic recovery in irradiated mice. Nature (Lond.) 214, 1223-1224 (1967).

[F 80,336/67

Nair, V.: Modification of pharmacological activity following $\mathrm{X}$-irradiation. Radiat. Res. 30, 359-373 (1967).

$[\mathrm{G} 67,247 / 67$

Nair, V., Bau, D.: Inhibition of a hepatic microsomal enzyme system after head $X$ irradiation of rats. Proc. Soc. exp. Biol. (N.Y.) 126, 853-856 (1967).

[G67,246/67

Nair, V., Bau, D., Siegel, S.: Effects of prenatal $\mathrm{X}$-irradiation: studies on the mechanism of $\mathrm{X}$-irradiation-induced inhibition of microsomal enzyme development in rat liver. Radiat. Res. 36, 493-507 (1968).

$[\mathrm{G} 67,245 / 68$

Nair, V., Bau, D., Siegel, S.: X-irradiation effects on the ontogenic vs. drug induced increase in the activity of a hepatic microsomal enzyme system. Radiat. Res. 35, 559 (1968).

$[\mathrm{G} 67,304 / 68$

Nair, V., Brown, T., Bau, D., Siegel, S.: Evidence for hypothalamic regulation of hepatic hexobarbital oxidase in rats. Pharmacologist 11, 252 (1969).

$[\mathrm{G} 67,250 / 69$

Nair, V., Brown, T., Bau, D., Siegel, S.: Hypothalamic regulation of hepatic hexobarbital metabolizing enzyme system. Europ. J. Pharmacol. 9, 31-40 (1970).

$[\mathrm{H} 21,083 / 70$

Nair, V., DuBois, K. P.: Prenatal and early postnatal exposure to environmental toxicants. Chic. med. Sch. Quart. 27, 75-89 (1968).

$[\mathrm{G} 67,244 / 68$

Nair, V., Finer, S., Shah, D.: Interactive effects of X-irradiation and barbiturates. Proc. Soc. exp. Biol. (N.Y.) 120, 246-252 (1965).

[F 53,576/65

Nair, V., Zeitlin, E.: Impairment of the development of a liver microsomal enzyme system (hexobarbital metabolizing system) after inutero and early postnatal exposure to X-irradiation. Radiat. Res. 31, 609-610 (1967).

$[\mathrm{G} 65,099 / 67$

Nakagawa, Y., Kanda, Y.: Studies on the influence upon the susceptibility of mice to virus. III. Report. Effect of cortisone on the susceptibility of mice to virus. Kurume med.J. 2, 1-18 (1955).

$[\mathrm{C} 8,165 / 55$

Nakagawa, Y., Kanda, Y.: Studies on the influence upon the susceptibility of mice to virus. III. Report. Effect of cortisone on the susceptibility of mice to virus. Kurume med. J. 2, 92-109 (1955).

$[\mathrm{C} 9,941 / 55$ 
Nakamura, T., Nakamura, S., Sugawara, K., Katakura, Y., Takizawa, T., Isono, T.: On renal injuries in young rats on choline deficiencies. Tohoku J. exp. Med. 66, 1-6 (1957).

$$
[\mathrm{C} 41,067 / 57
$$

Nakanishi, S., Masamura, E., Tsukada, M., Akabane, J.: Effects of different types of stress on hepatic drug-metabolizing enzyme activity in the rat. Med. J. Shinshu Univ. 15, 71-76 (1970).

$[\mathrm{G} 79,299 / 70$

Nakano, K., Kishi, T., Kurita, N., Ashida, K.: Effect of dietary amino acids on amino acidcatabolizing enzymes in rat liver. $J$. Nutr. 100, 827-836 (1970).

$[\mathrm{G} 76,247 / 70$

Nash, C. B., Alley, J. H., Manley, E. S.: The suppression of ouabain toxicity by oxytocin and reserpine. Toxicol. appl. Pharmacol. 6, 163-167 (1964).

[G9,641/64

Nasio, J.: Influence of some vitamins and hormones in the prevention of experimental cinchophen peptic ulcer. Rev. Gastroent. 13, 195-204 (1946).

$[97,932 / 46$

Nasio, J.: Acción del estilbestrol en la prevención de la úlcera péptica cincofénica en perros castrados. Pren. méd. argent. 33, 1603-1605 (1946).

$[\mathrm{B} 34, \mathbf{1 0 0 / 4 6}$

Nasio, J.: Tratamiento médico de la úlcera gastroduodenal experimental, pp. 151. Buenos Aires: La Prensa Médica Argentina 1946.

$[\mathrm{B} 77,063 / 46$

Nassi, L.: Ricerche radiologiche ed emochimiche sull'effetto svolto dall'estratto liposolubile di timo nel rachitismo sperimentale. Boll. Soc. ital. Biol. sper. 38, 678-681 (1962).

[G1,107/62

Nassi, L.: Ricerche istologiche sull'effetto svolto dall'estratto liposulubile del timo nel rachitismo sperimentale. Boll. Soc. ital. Biol. sper. 38, 681-683 (1962).

$[\mathrm{G} 1,108 / 62$

Nayak, N. C., Chopra, P., Ramalingaswami, V.: The role of liver cell endoplasmic reticulum and microsomal enzymes in carbon tetrachloride toxicity: an in vivo study. Life Sci. 9/I, 1431-1439 (1970).

$[\mathrm{G} 80,728 / 70$

Neal, P. A., Oettingen, W. F. von, Dunn, R. G., Sharpless, N. E.: Toxicity and potential dangers of aerosols and residues from such aerosols containing three percent DDT. (Second report.) Publ. Hlth Res. Sup. 183, 1-32 (1945).

$[17,438 / 45$

Neal, R. A., DuBois, K. P.: Studies on the mechanism of detoxification of cholinergic phosphorothioates. J. Pharmacol. exp. Ther. 148, 185-192 (1965).

$[\mathrm{F} 40,198 / 65$
Neal, W. B., Jr., Woodward, E. R., Kark, A. E., Zubiran, J. M., Montalbetti, J. A.: Effect of ACTH, cortisone, and DOCA on survival of burned rat. Arch. Surg. 65, 774-782 (1952).

$[\mathrm{B} 80,371 / 52$

Neale, M. G., Parke, D. V.: The effect of pregnancy on the hydroxylation and reduction of drugs and cytochrome P-450 content of rat liver microsomes. Biochem. J. 113, 12P-13P (1969).

[G67,965/69

Nebert, D. W., Gelboin, H. V.: Substrate-inducible microsomal aryl-hydroxylase in mammalian cell culture. I. Assay and properties of induced enzyme. J. biol. Chem. 243, 62426249 (1968).

$[\mathrm{H} 23,691 / 68$

Nebert, D. W., Gelboin, H. V.: Substrate-inducible microsomal aryl hydroxylase in mammalian cell culture. II. Cellular responses during enzyme induction. $J$. biol. Chem. 243, 6250-6261 (1968).

$[\mathrm{H} 23,692 / 68$

Nebert, D. W., Gelboin, H. V.: Drugs and microsomal enzyme formation in vivo and in mammalian cell culture. In: Gillette, Conney et al.; Microsomes and Drug Oxidations, p. 389-429. New York, London: Academic Press 1969.

$[\mathrm{E} 8,237 / 69$

Negrete, J. M.: Influencia de la progesterona sobre la "anestesia" producida por desoxicorticosterona. Bol. Inst. Estud. Med. Biol. (Mex.) 13, 135-137 (1955).

$[\mathrm{C} 23,001 / 55$

Nelson, R. S., Lanza, F. L.: Steroid therapy in massive hepatic necrosis due to viral hepatitis. Sth. med. J. (Bgham, Ala.) 63, 1436-1439 (1970).

$[\mathrm{G} 80,151 / 70$

Németh, Š., Vigaš, M.: Endocrine glands and metabolic background of trauma resistance. I. Resistance of rats with different hormonal states traumatized in the Noble-Collip drum. Endocr. exp. 2, 39-44 (1968). [F98,055/68

Netter, K. J.: Die Hemmung der Procainhydrolyse durch die Diäthylaminoäthanolester der Diphenylpropylessigsäure (SKF 525-A) und der Diphenylessigsäure ('Trasentin'). NaunynSchmiedebergs Arch. Pharmak. 235, 498-512 (1959).

[G74,665/59

Netter, K. J.: Eine Methode zur direkten Messung der 0-Demethylierung in Lebermikrosomen und ihre Anwendung auf die Mikrosomenhemmwirkung von SKF 525-A. NaunynSchmiedebergs Arch. Pharmak. 238, 292-300 (1960).

[G74,666/60

Netter, K. J.: Drugs as inhibitors of drug metabolism. In: Brodie and Erdös; Metabolic Factors Controlling Duration of Drug Action (Proc. 
1. int. pharmacol. Meet. Vol. 6), p. 213-233. New York: The Macmillan Company 1962.

[E52,768/62

Netter, K. J., Jenner, S., Kajuschke, K.: Utber die Wirkung von Metyrapon auf den mikrosomalen Arzneimittelabbau. Naunyn-Schmiedebergs Arch. Pharmak. exp. Pathol. 259,1-16 (1967).

$[\mathrm{G} 53,255 / 67$

Netter, K. J., Kahl, G. F., Magnussen, M. P.: Kinetic experiments on the binding of metyrapone to liver microsomes. Naunyn-Schmiedebergs Arch. Pharmak. 265, 205-215 (1969).

[G71,785/69

Neubaur, J., Hollmann, S.: Die Aktivität der Glucuronyltransferase in der Leber des menschlichen Feten und Frühgeborenen. Klin. Wschr. 44, 723-724 (1966).

[H30,996/66

Neubert, D.: Enzymatische Leistungen der Lebermikrosomen bei der Äthioninvergiftung. Naunyn-Schmiedebergs Arch. Pharmak. 232, 235-237 (1957).

[G74,661/57

Neubert, D., Herken, H.: Wirkungssteigerung von Schlafmitteln durch den Phenyldiallylessigsäureester des Diäthylaminoäthanols. Naunyn-Schmiedebergs Arch. Pharmak. 225, 453-462 (1955).

[G74,660/55

Neubert, D., Hoffmeister, I.: Mitochondrienatmung und Atmungskettenphosphorylierung bei erhöhtem intramitochondralen Gehalt an Gesamtfetten. Naunyn-Schmiedebergs Arch. Pharmak. 238, 348-357 (1960). [G 74,667/60 Neubert, D., Maibauer, D.: Vergleichende Untersuchungen der oxydativen Leistungen von Mitochondrien und Mikrosomen bei experimenteller Leberschädigung. NaunynSchmiedebergs Arch. Pharmak. 235, 291-300 (1959).

[G74,664/59

Neubert, D., Schaefer, J., Stein, F.: Eigenwirkungen radioaktiven Phosphates $\left(\mathrm{P}^{32}\right)$ auf oxydative Leistungen von Mitochondrien und Mikrosomen der Rattenleber. Naunyn-Schmiedebergs Arch. Pharmak. 239, 245-255 (1960).

$[\mathrm{G} 74,787 / 60$

Neubert, D., Timmler, R.: Einfluß einiger Phenylessigsäurederivate (CFT 1201, SKF 525 A) auf den Einbau von 1-C ${ }^{14}$-dl-Alanin in Mikrosomenproteine. Naunyn-Schmiedebergs Arch. Pharmak. 238, 358-363 (1960).

[G74,668/60

Neuman, M.: Intéractions médicamenteuses. (I). Presse méd. 78, 1938-1940 (1970).

$[\mathrm{G} 80,018 / 70$

Neuman, M.: Intéractions médicamenteuses. (II). Presse méd. 78, 2023-2025 (1970).

[G80,550/70
Neumann, F., Elger, W., von Berswordt-Wallrabe, R.: Intersexualität männlicher Feten und Hemmung androgenabhängiger Funktionen bei erwachsenen Tieren durch Testosteronblocker. Dtsch. med. Wschr. 92, 360-366 (1967).

[F 78,500/67

Neumann, F., Goldman, A. S.: Prevention of mammary gland defects in experimental congenital adrenal hyperplasia due to inhibition of $3 \beta$-hydroxysteroid dehydrogenase in rats. Endocrinology 86, 1169-1171 (1970).

[H25,234/70

Neuweiler, W.: Reid Hunt'sche Reaktion und Schwangerschaft. Zbl. Gynäk. 56, 2936-2938 (1932).

$[43,582 / 32$

Neville, A. M., Engel, L. L.: Inhibition of $3 \beta$ and $3 \alpha$-hydroxysteroid dehydrogenases and of steroid $\Delta$-isomerase by anabolic steroids (Abstr.). Program 49th Ann. Meet. Endocr. Soc. Bal Harbour, Fla., p. 67 (1967). [F 83,477/67 Newberne, P. M., Williams, G.: Inhibition of aflatoxin carcinogenesis by diethylstilbestrol in male rats. Arch. environm. Hlth 19, 489-498 (1969).

[G69,601/69

Newman, A. J., Gross, S.: Hyperbilirubinemia in breast-fed infants. Pediatrics 32, 995-1001 (1963).

$[\mathrm{G} 75,237 / 63$

Nieák, A.: The influence of serotonine and amphetamine on analgesic effect of morphine after reserpine premedication in rats and mice. Med. Pharmacol. exp. (Basel) 13, 43-48 (1965).

$[\mathrm{F} 47,918 / 65$

Nichol, C. A., Rosen, F.: Induction of drugmetabolizing and cortisol-responsive enzymes. Fed. Proc. 28, 386 (1964).

$[\mathrm{F} 4,729 / 64$

Nicholas, J. S., Barron, D. H.: The use of sodium amytal in the production of anesthesia in the rat. J. Pharm. exp. Ther. 46, 125-129 (1932).

$[62,223 / 32$

Nicol, M., Grangaud, R.: Vitamine A et progestérone chez le rat traité au thiouracile. C. R. Soc. Biol. (Paris) 155, 1634-1638 (1961).

[D $20,176 / 61$

Nicol, T., Bilbey, D. L. J., Charles, L. M., Cordingley, J. L., Vernon-Roberts, B.: Oestrogen: the natural stimulant of body defence. J. Endocr. 30, 277-291 (1964). [ [F 25,320/64

Nicol, T., Brownlee, G., Druce, C., Ware, C. C.: Effect of three compounds related to diethylstilboestrol on the phagocytic activity of the reticulo-endothelial system. Nature (Lond.) 187, 1032-1033 (1960).

$[\mathrm{C} 92,079 / 60$

Nicol, T., Vernon-Roberts, B., Quantock, D. C.: Protective effect of oestrogens against the 
toxic decomposition products of tribromoethanol. Nature (Lond.) 208, 1098-1099 (1965).

[F 58,460/65

Nicol, T., Vernon-Roberts, B., Quantock, D. C.: Effect of orchidectomy and ovariectomy on survival against lethal infections in mice. Nature (Lond.) 211, 1091-1092 (1966).

$[\mathrm{F} 70,028 / 66$

Nicola, C. de: El choque peptónico en los perros sin hígado. Rev. Sco. argent. Biol. 6, 437 (1930).

$[43,101 / 30$

Nichols, J., Hennigar, G.: Studies on DDD, 2,2,-Bis (parachlorophenyl)-1,1-dichloroethane. Exp. Med. Surg. 15, 310-316 (1957).

$[\mathrm{C} 48,736 / 57$

Nicolette, J. A., Gorski, J.: Cortisol effects on the uterine response to estrogen. Endocrinology 74, 955-959 (1964).

[F 12,788/64

Nicolis, F. B., Ginoulhiac, E.: La determinazione della triptofanpirrolasi come test biologico di attività dei derivati prednisonici. Boll. Soc. ital. Biol. sper. 37, 1534 (1961).

[D27,485/61

Nicolis, F. B., Ginoulhiac, E.: Studio delle variazioni della triptofano-pirrolasi epatica indotte da differenti corticosteroidi nel ratto. Acta vitamin (Milano) 23, 19-26 (1969).

[H 14,045/69

Nienstedt, W., Hartiala, K.: Steroid metabolism by the canine intestine. I. Qualitative experiments with progesterone. Scand. J. Gastroent. 4, 483-488 (1969).

$[\mathrm{G} 69,886 / 69$

Nikki, P.: Arecoline and halothane shivering in thyroxine-treated mice. Ann. Med. exp. Fenn. 47, 191-196 (1969).

$[\mathrm{G} 71,573 / 69$

Nikki, P., Rosenberg,P.: Halothane shivering in mice after injection of catecholamines and $5 \mathrm{HT}$ into the cerebral ventricles. Ann. Med. exp. Fenn. 47, 197-202 (1969). [G71,574/69

Nimni, M. E., Geiger, E.: Non-suitability of levator ani method as an index of anabolic effect of steroids. Proc. Soc. exp. Biol. (N.Y.) 94, 606-610 (1957).

$[\mathrm{C} 31,438 / 57$

Nishikawa, T.: The effect of cortisone acetate on the oral inoculation with Candida albicans in the germ-free mice. Keio J. Med. 18, 47-57 (1969).

[G73,894/69

Nishimura, S., Nitta, K.: Utber das Knochenwachstum bei B-Avitaminose und besonders den Einfluß der Schilddrüse auf dasselbe. I. Mitteilg. Über den Einfluß der Fütterung mit kleinen Mengen von Schilddrüsensubstanz auf das Knochenwachstum der B-avitaminösen Ratten. Folia endocr. jap. 4, 83-84 (1929).

$[1,171 / 29$
Noble, G. A.: Leishmania braziliensis: physical and chemical stress in hamsters. Exp. Parasit. 29, 30-32 (1971).

$[\mathrm{G} 81,736 / 71$

Noble, R. L.: Effects of synthetic oestrogens and carcinogens when administered to rats by subcutaneous implantation of crystals or tablets. J. Endocr. 1, 216-229 (1939).

$[\mathrm{A} 30,160 / 39$

Noble, R. L.: The effect of adrenergic blocking agents on drum shock. Proc. Canad. Physiol. Soc. 19th Ann. Meet., 13th-15th Oct., p. 47. London 1955.

$[\mathrm{C} 10,541 / 55$

Noble, R. L., Collip, J. B.: Adrenal and other factors affecting experimental traumatic shock in the rat. Quart. J. exp. Physiol. 31, 201-210 (1942).

$[\mathrm{A} 56,107 / 42$

Nocke, L., Breuer, H., Lichton, J. I.: Effect of aldactone on the urinary excretion of total oestrogens, 17-hydroxycorticosteroids and 17oxosteroids in pregnant women. (Abstr.) $E x$ cerpta med. (Amst.), Int. Congr. Ser. No. 210, p. 183. (1970) 3rd Int. Congr. on Hormonal Steroids, Hamburg.

$[\mathrm{H} 29,580 / 70$

Nola, F. di, Angela, G. C., Salassa, M. R., Rapellini, M.: Intossicazione difterica sperimentale in cavie pretrattate con cortisone. Arch. Sci. med. 103, 242-248 (1957).

$[\mathrm{C} 33,308 / 57$

Nola, F. di, Salassa, M. R., Rapellini, M., Sardi, P.: Intossicazione difterica sperimentale nella cavia pretrattata con ACTH. Arch. Sci. med. 104, 554-560 (1957).

$[\mathrm{C} 43,232 / 57$

Nolan, J. P.: Protective action of oestrogen against the lethal effect of endotoxin in the rat. Nature (Lond.) 213, 201-202 (1967).

$[\mathrm{F} 75,232 / 67$

Nolan, J. P., Ali, M. V.: Time related effect of estrogen administration on the sensitivity of rats to endotoxin. Fed. Proc. 26, 628 (1967).

$[\mathrm{F} 79,610 / 67$

Nolan, J. P., Ali, M. V.: Late effect of estrogen on endotoxin response in the rat. J. Lab. clin. Med. 71, 501-510 (1968). [G55,490/68

Nolan, J. P., Ali, M. V., Bistany, T. S.: Comparison of endotoxin blockade by estrogenic substances and hydrocortisone. J. reticuloendothel. Soc. 5, 9-21 (1968). [H5,204/68

Nomura, J., Maeda, M., Nakazawa, K., Hatotani, N.: Experimental studies on cerebrohepatic relationship-effects of several conditions on enzyme activities in rat liver and brain, and on estrogen inactivation in rat liver. Folia psychiat. neurol. jap. 19, 156-166 (1965).

[G $33,405 / 65$ 
Noordhoek, J., Rümke, C. L.: Sex differences in the rate of drug metabolism in mice. Arch. int. Pharmacodyn. 182, 401 (1969). [H 21,660/69 Norman, G. F., Mittler, A.: Interrelationship of vitamin $\mathrm{D}$ and the sex hormones in calcium and phosphorus metabolism of rats. Proc. Soc. exp. Biol. (N.Y.) 67, 104-111 (1948).

[B $18,001 / 48$

Norton, P. R. E.: Some endocrinological aspects of barbiturate dependence. Brit. J. Pharmacol. 41, 317-330 (1971).

[G 80,572/71

Novelli, A., Marinari, U. M., Cottalasso, D.: Riduzione della componente fibrotica in granulomi silicotici polmonari di ratti sottoposti a parziale epatectomia. Pathologica 61, 111 a 117 (1969).

[H24,185/69

Novelli, A., Mor, M. A. D.: Behaviour of normal and regenerated liver mitochondria after small doses of carbon tetrachloride. Ital. J. Biochem. 11, 47-53 (1962).

[D36,206/62

Novelli, A., Zinnari, A.: Inibizione della produzione di fibre collagene nel granuloma da carragenina nel ratto durante la rigenerazione del fegato dopo parziale epatectomia. Pathologica 60, 115-120 (1968).

$[\mathrm{H} 8,990 / 68$

Novick, W. J., Jr., Stohler, C. M., Swagzdis, J.: The influence of steroids on drug metabolism in the mouse. J. Pharmacol. exp. Ther. 151, 139-142 (1966).

$[\mathrm{F} 63,768 / 66$

Nutter, J. E., Gemmill, C. L., Myrvik, Q. N.: The influence of 3,3',5-triodo-L-thyronine on the survival time of mice with tuberculosis and pneumococcosis. Amer. Rev. Tuberc. 79, 339 to 343 (1959).

$[\mathrm{C} 65,285 / 59$

Nuzhdin, N. I., Shapiro, N. I., Chudinovskaia, G. A., Pankova, N. V.: Action of protective substances on mammalian gonads. (Russian text). Zh. Obshchei Biol. 21/6, 430-438 (1960).

[D 5,866/60

Nyfors, A.: The influence of cortico-steroids on the allergic skin wheal reaction and the delayed-type reaction (Mantoux). Acta allerg. (Kbh.) 25, 53-62 (1970).

$[\mathrm{G} 76,097 / 70$

Nymark, M., Rasmussen, J.: Effect of certain drugs upon amitriptyline induced electrocardiographic changes. Acta pharmacol. (Kbh.) 24, 148-156 (1966).

[G42,054/66

Oehlert, W., Hämmerling, W., Büchner, F.: Der zeitliche Ablauf und das Ausmaß der Desoxyribonukleinsäure-Synthese in der regenerierenden Leber der Ratte nach Teilhepatektomie. (Autoradiographische Untersuchungen unter Verwendung von $\mathrm{H}^{3}$-Thymidin). Beitr. pathol. Anat. 126, 91-112 (1962). [D36,669/62
Oehme, C., Paal, H.: Die Reid-Hunt-Reaktion. Klinisches und Experimentelles. Ergebn. inn. Med. Kinderheilk. 44, 214-256 (1932).

$[62,442 / 32$

Oester, Y. T.: Adrenal medullary hormones and arteriosclerosis. Ann. N.Y. Acad. Sci., 72, 885-895 (1959).

$[\mathrm{C} 84,324 / 59$

0ester, Y. T., Davis, 0. F., Friedman, B.: Progesterone and alpha tocopherol in experimental epinephrine-thyroxine arterioslcerosis and in cholesterol-induced atherosclerosis. Circulation 12, 505 (1955).

$[\mathrm{C} 8,951 / 55$

Oettel, H., Franck, E.: Ưber die Beeinflussung von Leberschäden durch Desoxycorticosteronacetat. Z. ges. exp. Med. 110, 535-547 (1942).

$[\mathrm{A} 72,420 / 42$

Ogandzhanyan, E. E., Pareishvili, E. A., Batikyan, I. G.: The effect of some hormones on the hemopoiesis and survival of irradiated black mice of the $\mathrm{C}_{57 / 6}$ strain. (Russian text.) Probl. Endokr. Gormonoter. 10, 107-110 (1964).

[F 7,045/64

0'Gara, R. W., Ards, J.: Incidence of leukemia and other tumors in thymectomized irradiated mice bearing thymic transplants. J. nat. Cancer Inst. 27, 299-309 (1961).

[D12,341/61

Ogawa, H.: Studies on protective effects of corticosteroids against Habuvenom shock of rats. Gunma J. med. Sci. 14, 60-85 (1965).

[F54,550/65

Okada, H., Fuwa, H., Kato, T.: Effects of cortisone upon guinea pigs inoculated with BCG or bole bacilli. Nagoya J. med. Sci. 18, 168-176 (1955).

$[\mathrm{C} 18,328 / 55$

Okano, K., Fujita, T., Orimo, H., Yoshikawa, M.: Age and calcium metabolism in relation to cardiovascular changes induced by renal injury with sodium sulfaacetylthiazole. $J$. Amer. Geriat. Soc. 18, 458-470 (1970).

$[\mathrm{H} 25,894 / 70$

Okonogi, T., Fukai, K., Yamaguchi, K., Kato, K., Suda, A.: Studies on the haemophilus pertussis. XIV. The effects of ACTH, cortisone and adrenaline on the morbid changes on the experimental pertussis. Gunma J. med. Sci. 5, 304-309 (1956).

$[\mathrm{C} 34,465 / 56$

Olds, W. H., Jr.: The effects of thyroidectomy on the resistance of rats to morphine poisoning. Amer. J. Physiol. 26, 354-360 (1910).

$[34,544 / 10$

0'Leary, J. A., Davies, J. E., Feldman, M.: Spontaneous abortion and human pesticide residues of DDT and DDE. Amer. J. Obstet. Gynec. 108, 1291-1292 (1970). [G80,260/70 
Oliva, L., Valli, P.: Influenza degli ormoni sessuali sugli effetti delle radiazioni ionizzanti. Studio sperimentale. Attual. Ostet. Ginec. 4, 155-166 (1958).

$[\mathrm{C} 50,803 / 58$

Olivecrona, T., Fex, G.: Metabolism of plasma lipids in partially hepatectomized rats. Biochim. biophys. Acta (Amst.) 202, 259-268 (1970).

[G74,083/70

Oliveira, H. L. de, Patricio, L. D., Cintra, A. de U., Mattar, E.: $\mathrm{O}$ propionato de testosterona no tratamento da intoxicação mercurial aguda. Rev. Hosp. Clin. Fac. Med. S. Paulo 2, 15-22 (1947).

[B43,032/47

Oliver, M. F., Roberts, S. D., Hayes, D., Pantridge, J. F., Suzman, M. M., Bersohn, I.: Effect of atromid and ethyl chlorophenoxyisobutyrate on anticoagulant requirements. Lancet $1963 \mathbf{~ I , ~}$ $143-144$.

[D 54,029/63

Oliver, W. J., Kelsch, R. C.: Effect of hypophysectomy upon edema formation in aminonucleoside nephrosis. Endocrinology 75,973 to 974 (1964).

[F 25,772/64

Olivier, L., Cheever, A. W.: Comparison of the effect of cortisone and of trichinella spiralis infection on injury to rats by encephalomyocarditis virus infection. Amer. J. trop. Med. Hyg. 12/4, 675-677 (1963).

$[\mathrm{G} 15,789 / 63$

Olson, J. A. Jr., Lindberg, M., Bloch, K.: On the demethylation of lanosterol to cholesterol. $J$. biol. Chem. 226, 941-956 (1957). [G61,438/57

Omura, T., Sato, R., Cooper, D. Y., Rosenthal, 0., Estabrook, R. W.: Function of cytochrome P-450 of microsomes. Fed. Proc. 24, 1181 to 1189 (1965).

[F 51,529/65

0'Neal, M. A., Griffin, A. C.: Pituitary association with diacetylaminofluorene. (Abstr.) Proc. Amer. Ass. Cancer Res. 2, 236 (1957).

$[\mathrm{C31}, 971 / 57$

Oppenheim, E., Bruger, M.: The effect of cortisone and ACTH on experimental cholesterol atherosclerosis in rabbits. Program Proc. 6th Ann. Meet., Amer. Soc. Arterioscl. Chicago, Nov. 9-10, p. 470-471 (1952). [B74,288/52

Oppenheimer, J. H., Bernstein, G., Surks, M. I.: Increased thyroxine turnover and thyroidal function after stimulation of hepatocellular binding of thyroxine by phenobarbital. J. clin. Invest. 47, 1399-1406 (1968). [F99,583/68

Oppenheimer, J. H., Wise, H. M., Lasley, D. A.: The role of the thyroid gland in experimental traumatic shock. J. clin. Invest. 37, 380-388 (1958).

$[\mathrm{C} 50,563 / 58$
Oppenheimer, M. J., Flock, E. V.: Alkaline phosphatase levels in plasma and liver follow ing partial hepatectomy. Amer. J. Physiol$149,418-421$ (1947).

[B4,738/47

Orimo, H., Fujita, T., Yoshikawa, M., Hayano, K.: A progeria-like syndrome produced by dihydrotachysterol: its prevention by conjugated estrogens (Premarin). J. Amer. Geriat. Soc. 18, 11-23 (1970).

[H20,265/70

Orione, G.: Adrenalin e tossicosi da ganglioplegici. Ormonologia 16, 202-212 (1956).

$[\mathrm{C} 37,851 / 56$

Orlova, L. V., Klimova, S. P., Rodionov, V. M.: Radioprotective effect of ACTH. (Russian text.) Med. Radiol. 9, 19-22 (1963).

[G22,562/63

Orlova, L. V., Rodionov, V. M.: The time of histone synthesis in regenerating rat liver. Exp. Cell Res. 59, 329-333 (1970). [G73,079/70

Orrenius, S.: Further studies on the induction of the drug-hydroxylating enzyme system of liver microsomes. J. Cell Biol. 26, 725-733 (1965).

[G74,389/65

Orrenius, S., Das, M., Gnosspelius, Y.: Overall biochemical effects of drug induction on liver microsomes. In: Gillette, Conney et al.; Microsomes and Drug Oxidations, p. 251-277. New York, London: Academic Press 1969.

[E 8,231/69

Orrenius, S., Eriesson, J. L. E., Ernster, L.: Phenobarbital-induced synthesis of the microsomal drug-metabolizing enzyme system and its relationship to the proliferation of endoplasmic membranes. J. Cell Biol. 25, 627-639 (1965).

[G66,249/65

Ortega, P.: Light and electron microscopy of dichlorodiphenyltrichloroethane (DDT) poisoning in the rat liver. Lab. Invest. 15, 657 to 679 (1966).

[G76,671/66

Ortega, P.: Partial hepatectomy in rats fed dichlorodiphenyltrichloroethane (DDT). Amer. J. Path. 56, 229-249 (1969). [H15,674/69

Ortega, P., Hayes, W. J., Jr., Durham, W. F., Mattson, A. M.: Publ. Hlth. Monogr. No. 43 (1956).

[E40,218/56

Osipovich, V. V.: The effect of hormones on compensatory hypertrophy of the kidneys. (Russian text.) Byull. eksp. Biol. Med. 43/3, 37-39 (1957).

$[\mathrm{C} 58,570 / 57$

Osment, L. S.: The many effects of griseofulvin. Ala. J. med. Sci. 6, 392-398 (1969).

[G72,369/69

Osorio, J. A.: Influencia de la hormona tiroidea sobre la reactividad vascular a la acción de 
sustáncias vasoactivas en la rata. Rev. Soc. argent. Biol. 32, 29-35 (1956). [C31,059/56

Osumi, Y.: Effects of 3,5,3'-triiodothyroinine on the experimental atheromatosis caused by cholesterol feeding in rabbits. Jap. J. Pharmacol. 15, 280-294 (1965).

[G34,534/65

Ouzelatz, V. S.: Etude sur l'influence des crises hypoglycémiques dans le processus évolutif de l'ulcère gastrique. Presse méd. 65, 1118 a 1119 (1957).

$[\mathrm{C} 36,618 / 57$

Ove, P., Jenkins, M. D., Laszlo, J.: DNA replication and degradation in mammalian tissue. I. Changes in DNA polymerase and nuclease during rat liver regeneration. Biochim. biophys. Acta (Amst.) 174, 629-635 (1969).

[H $23,725 / 69$

Overbeek, G. A.: Anabole Steroide. Chemie und Pharmakologie, pp. 80. Berlin, Heidelberg, New York: Springer-Verlag 1966. [E8,318/66 Overbeek, G. A., Bonta, I. L.: Steroids that act on the nervous system. In: Martini et al.; Hormonal Steroids 1, p. 493-500. New York, London: Academic Press 1964. [E4,775/64 Overman, R. R., Bass, A. C., Davis, A. K., Golden, A.: II. The effect of lipo-adrenal extract on ionic balance in fatal simian malaria. Amer. J. clin. Path. 19, 907-917 (1949).

$[\mathrm{B} 49,805 / 49$

Owens, J. C., Neely, W. B., Owen, W. R.: Effect of sodium dextrothyroxine in patients receiving anticoagulants. New Engl. J. Med. 266, $76-99$ (1962).

[D21,725/62

Oya, J. C. de, Rio, A. del, Noya, M., Villanueva, A.: Phenobarbitone in posthepatitic unconjugated hyperbilirubinaemia. Lancet 1970 II, 521.

[H 28,966/70

Paal, H.: Schilddrüsenfunktion und die Reaktion nach Reid Hunt. Naunyn-Schmiedebergs Arch. Pharmak. 148, 232-245 (1930).

$[22,603 / 30$

Paal, H.: Zur Technik der Acetonitrilreaktion nach Reid Hunt. Klin. Wschr. 12, 1988-1989 (1933).

$[18,183 / 33$

Paeile, C., Guerrero, S., Campos, I., Muñoz, E., Novoa, L., Muñoz, C.: Estudios sobre el mecanismo de las diferencias sexuales en la sensibilidad a la procaina en ratas. Arch. Biol. Med. exp. (Santiago) 1, 152-156 (1964).

$[\mathrm{F} 52,633 / 64$

Paeile, C., Guerrero, S., Gallardo, A., Muñoz, C.: Comparación de la toxicidad de diversos anestésicos locales en ratas machos y hembras. Arch. Biol. Med. exp. 2, 48-50 (1965).

$[\mathrm{G} 75,994 / 65$
Page, I. H., Taylor, R. D.: Sensitization to the pressor action of epinephrine ("adrenalin"). A warning concerning the use of epinephrine as an antidote after the administration of tetraethyl ammonium chloride. J. Amer. med. Ass. 135, 348-349 (1947).

$[\mathrm{B} 24,841 / 47$

Painter, E. E., Brues, A. M.: The radiation syndrome. New Engl. J. Med. 240, 871-876 (1949).

$[\mathrm{B} 39,627 / 49$

Pallotta, A. J., Kelly, M. G., Rall, D. P., Ward, J. W.: Toxicology of acetoxycycloheximide as a function of sex and body weight. J. Pharmacol. exp. Ther. 136, 400-405 (1962).

$[\mathrm{D} 26,380 / 62$

Palmerio, C., Fine, J.: The nature of resistance to shock. Arch. Surg. 98, 679-684 (1969).

$[\mathrm{G} 66,810 / 69$

Paluszka, D. J., Hamilton, L. H.: Effect of heparin on the metabolic and leukocyte responses to hydrocortisone injections in rats. Physiologist 2, 92-93 (1959). [C 72,116/59

Palva, I. P., Mustala, 0. 0.: Oral contraceptives and liver damage. Brit. med. J. 1964 II, 688-689.

$[\mathrm{F} 21,067 / 64$

Pan, F., Lee, S. C., Chang, G. G., Sing-Fie, C.: Gonadal hormones in the regulation of methionine adenosyltransferase levels in rat liver. Proc. Soc. exp. Biol. (N.Y.) 129, 161-165 (1968).

$[\mathrm{H} 3,934 / 68$

Panisset, J. C., Beaulnes, A., Bois, P.: Effect of thyroxine on the sensitivity of the rat smooth muscle to 5-hydroxytryptamine. Rev. canad. Biol. 25, 155-159 (1966). [F 71,775/66

Pannella, A., Gasparrini, G.: Azione del testosterone e degli estrogeni sull'insorgenza dei tumori sperimentali da 20-metilcolantrene. Arch. Pat. Clin. med. 39, 198-218 (1963).

$[\mathrm{D} 64,636 / 63$

Parant, M.: Action de la chlorpromazine, de la cortisone et de l'ACTH vis-à-vis d'une endotoxine bactérienne injectée à la souris hypophysectomisée. Ann. Inst. Pasteur 102, 85-91 (1962).

$[\mathrm{D} 82,116 / 62$

Parientjev, I. A.: The use of hypersensitive mice for standardization of new drugs. Ann. N.Y. Acad. Sci. 111, 712-714 (1964).

[F 10,707/64

Parhon, C., Urechia, C.: L'influence de la castration sur les phénomènes de l'intoxication strychnique. C. R. Soc. Biol. (Paris) 70, 610-612 (1911).

$[\mathrm{A} 23,732 / 11$

Parhon, C., Urechia, C. I.: Recherches sur l'influence des glandes endocrines sur l'excita- 
bilité des centres nerveux. Bull. Soc. Med. ment. Belg. No. 166, 5-35 (1913).

$[62,361 / 13$

Parhon, C. I., Ballif, L.: Sur l'anaphylaxie chez les animaux éthymisés et thyréoprives. $C . R$. Soc. Biol. (Paris) 88, 544-545 (1923).

$[13,548 / 23$

Parhon, C. I., Ballif, L.: Nouvelles recherches sur l'anaphylaxie chez les animaux éthyroïdés éthymisés. C. R. Soc. Biol. (Paris) 89, 1063 a 1065 (1923).

$[17,302 / 23$

Parhon, C. I., Werner, G.: Recherches expérimentales sur la tétanie guanidinique et sur les effets des injections de guanidine, chez les animaux thyroparathyroidectomisés. La biochimie du sang à la suite des injections de guanidine. Bull. Mem. Sect. endocr. 1, 188-193 (1935).

$[34,844 / 35$

Parhon, C.-J., Parhon, C.: Note sur l'hyperthyroïdisation chez les oiseaux et sur la résistance des animaux ainsi traités aux infections spontanées. C. R. Soc. Biol. (Paris) 76, $662-663$ (1914).

$[36,340 / 14$

Parized, J.: Sterilization of the male by cadmium salts. J. Reprod. Fertil. 1, 294-309 (1960).

[D 23,927/60

Parized, J.: The peculiar toxicity of cadmium during pregnancy; an experimental 'toxaemia of pregnancy' induced by cadmium salts. $J$. Reprod. Fertil. 9, 111-112 (1965). [F31,959/65

Pařízek, J., Oštádalová, I., Beneš, I., Pitha, J.: The effect of a subcutaneous injection of cadmium salts on the ovaries of adult rats in persistent oestrus. J. Reprod. Fertil. 17, 559-562 (1968).

$[\mathrm{H} 7,672 / 68$

Parker, R. T., Snyder, M. J., Merideth, A. M.: Effect of various antibiotics and cortisone upon botulinum, tetanal and diphtherial toxins in vivo (Abstr.). Amer. J. Med. 14, 753 (1953).

$[\mathrm{D} 77,476 / 53$

Parkes, A. S.: Some factors affecting resistance to anoxia in mice. J. Endocr. 7, lxii-lxiii (1951).

$[\mathrm{B} 63,024 / 51$

Parks, H. F.: Electron microscopic investigation of the source and direction of movement of lipid granules appearing in the hepatic perisinusoidal space following partial hepatectomy. Amer. J. Anat. 124, 513-529 (1969).

[H $28,647 / 69$

Parmer, L. G.: Effect of desoxycorticosterone on the development of rats treated with thiouracil. Proc. Soc. exp. Biol. (N.Y.) 66, 574-575 (1947).

[B 17,568/47
Paroli, E.: Influenza degli estrogeni sulla tolleranza alla morfina nel ratto. Arch. ital. Sci. Farmacol. (Ser. 3/4), 309-310 (1954).

$[\mathrm{G} 14,277 / 54$

Paroli, E.: Morfina ed estrogeni. I. Riduzione della resistenza alla morfina nel ratto per opera di estrogeni. Arch. Ist. biochim. ital. 18, 35-44 (1957).

$[\mathrm{C} 62,998 / 57$

Paroli, E.: Morfina ed estrogeni. II. Influenza degli estrogeni sull'analgesia morfinica, il quadro dell'intossicazione acuta e l'escrezione urinaria della morfina nel ratto. Arch. Ist. biochim. ital. 18/2, 1-5 (1957). [C63,939/57

Paroli, E.: Morfina ed estrogeni. III. Effetto dell'estradiolo, dello stilbestrolo, dell'esestrolo sulla assuefazione del ratto alla azione analgesica della morfina. Arch. Ist. biochim. ital. 18/2, 6-8 (1957).

$[\mathrm{C} 63,938 / 57$

Paroli, E.: Effetto del D.O.C.A. sul quadro dell'avitaminosi $\mathrm{B}_{1}$ nel colombo. Boll. Soc. ital. Biol. sper. 33, 1393-1396 (1957). [C63,940/57

Paroli, E.: Indagini sull'effetto antimorfinico dell'ACTH. - II. Influenza dell'idrocortisone, del prednisolone e del desametazone sugli effetti analgesico e respiratorio della morfina. Boll. Soc. ital. Biol. sper. 40, 23-25 (1963).

[G12,543/63

Paroli, E., De Arcangelis, A.: Influenza del progesterone, del pregnandiolo, del pregnandione e del pregnenolone sull'effetto analgesico della morfina nel ratto. Arch. Ist. biochim. ital. 18/2, 8-10 (1957).

$[\mathrm{C} 63,937 / 57$

Parratt, J. R., West, G. B.: Hypersentitivity and the thyroid gland. Int. Arch. Allergy 16, 288-302 (1960).

[D 235/60

Paschkis, K. E., Cantarow, A., Stasney, S.: Pregnancy in partially hepatectomized rats. Fed. Proc. 15, 141-142 (1956). [C14,122/56 Paschkis, K. E., Cantarow, A., Stasney, J., Hobbs, J. H.: Tumor growth in partially hepatectomized rats. Cancer Res. 15, 579-582 (1955).

$[\mathrm{C} 8,982 / 55$

Pasley, J. N., Chadwick, G. G., Krueger, H.: Thyroxine antagonism of pentachlorophenol poisoning in cichlid fish. Proc. West. pharmocol. Soc. 11, 129-132 (1968).

$[\mathrm{G} 67,522 / 68$

Pasquariello, C., Mainardi, L.: Effetto di replicazione ravvicinata di un trattamento cortisonico sulla linea triptofano-acido nicotinico nell'uomo. Acta vitamin. (Milano) 24, 11-14 (1970).

$[\mathrm{H} 28,663 / 70$

Passow, H., Rothstein, A., Clarkson, T. W.: The general pharmacology of the heavy metals. Pharmacol. Rev. 13, 185-224 (1961).

$[\mathrm{G} 38,172 / 61$ 
Pataki, A.: Experimentelle Nebennierenrindennekrosen durch massive intravasale Gerinnung und ihre Beeinflussung durch ACTH. Z ges. exp. Med. 142, 75-86 (1967). [F 75,591/67 Patel, A. A., Rao, S. S.: Action of adrenaline on tetanus toxin. Indian J. med. Sci. 19, 818-820 (1965).

[G36,076/65

Patrick, R. S.: The influence of cortisone and ACTH on experimental zonal necrosis of the liver. J. Path. Bact. 70, 377-385 (1955).

$[\mathrm{C} 12,967 / 55$

Patrignani, A.: Incorporazione dell'acido $\Delta$ amino levulinico ${ }^{4-14} \mathrm{C}$ nella bilirubina biliare del ratto: modificazioni indotte dal trattamento con testosterone. Riv. Farmacol. Ter. 1, 337-345 (1970).

$[\mathrm{H} 32,792 / 70$

Patt, H. M., Smith, D. E., Tyree, E. B., Straube, R. L.: Further studies on modification of sensitivity to X-rays by cysteine. Proc. Soc. exp. Biol. (N.Y.) 73, 18-21 (1950). [B54,522/50 Patt, H. M., Straube, R. L., Tyree, E. B., Swiit, M. N., Smith, D. E.: Influence of estrogens on the acute $\mathrm{x}$-irradiation syndrome. Amer. $J$. Physiol. 159, 269-280 (1949). [B [33,570/49

Patt, H. M., Swift, M. N., Straube, R. L., Tyree, E. B., Smith, D. E.: Influence of a conditioning injection of estrogen on the hematologic and organ weight response to $\mathrm{X}$-irradiation. Fed. Proc. 8, 124 (1949).

$[\mathrm{B} 32,806 / 49$

Patt, H. M., Swift, M. N., Tyree, E. B., Straube, R. L.: X-irradiation of the hypophysectomized rat. Science 108, 475-476 (1948). [B33,711/48

Patt, H. M., Tyree, E. B., Straube, R. L., Smith, D. E.: Cysteine protection against $\mathrm{X}$ irradiation. Science 110, 213-214 (1949). [B54,521/49

Patton, C. L., Clark, D. T.: Trypanosoma lewisi infections in normal rats and in rats treated with dexamethasone. J. Protozool. 15, 31-35 (1968).

$[\mathrm{G} 73,195 / 68$

Pavlovic-Hournac, M., Andjus, R. K.: Survie en milieu froid des rats thyroïdectomisés porteurs de greffes intraoculaires de thyroïdes. C. R. Soc. Biol. (Paris) 157, 1201-1203 (1963).

$[\mathrm{E} 33,972 / 63$

Pawłowski, Z.: The hormonal homeostasis of the host and the development of the parasite. Helminthologia (Bratisl.) 9, 463-466 (1968).

$[\mathrm{G} 65,301 / 68$

Payne, J. M.: The pathogenesis of experimental brucellosis in virgin heifers with and without continuous progesterone treatment. $J$. Endocr. 20, 345-354 (1960). [C89,814/60

Payne, J. M., Belyavin, G.: The experimental infection of pregnant rats with the virus of enzootic abortion of sheep. J. Path. Bact. 80, 215-223 (1960).

$[\mathrm{C} 95,892 / 60$

Payne, R. W.: Studies on the fat-mobilizing hormone of the anterior pituitary gland (Abstr.). Fed. Proc. 125-126 (1949).

[B32,809/49

Peakall, D. B.: Pesticide-induced enzyme breakdown of steroids in birds. Nature (Lond.) 216, 505-506 (1967).

[F90,310/67

Pecori, V., Altucci, P., Cimino, R., Buonanno, G. A.: Steroidi a tipo prednisonico nelle infezioni sperimentali da virus. I. Studio comparativo delle modificazioni indotte dal prednisolone e dal triamcinolone nel quadro della epatite da virus MHV-3 del topo. G. Mal. infett. 11, 1144-1146 (1959). [C89,118/59

Pecori, V., Altucei, P., Coraggio, F., De Martino, E., Guarino, G.: L'aldosterone nelle infezioni virali sperimentali. II. Attività nell'infezione da virus vaccinico nel coniglio. $B$. D. S. Italiana 37, 711-714 (1961).

[D $12,549 / 61$

Pecori, V., Cimino, R., Buonanno, G. A., Altucci, P.: Il prednisolone e l'ormone somatotropo nell'epatite del topo da virus MHV-3. G. Mal. infett. 11, 1148-1150 (1959). [C89,121/59

Pekárek, J., Vrána, M.: The effect of hormones on histamine shock in rats sensitized with pertussis vaccine. Acta allerg. (Kbh.) 17, 387-399 (1962).

[D 52,098/62

Pelissier, N. A., Burgee, S. L., Jr.: Guide to incompatibilities. Hosp. Pharm. (Philad.) 3, 15-28, 32 (1968).

[G79,655/68

Pellanda, E. B.: Eclampsia experimental. Rev. Med. Rio Grande do Sul 11, 247-266 (1955).

$[\mathrm{C} 7,961 / 55$

Pellerin, J., D'Iorio, A., Robillard, E.: Influence des hormones sexuelles et l'hépatectomie partielle sur l'anesthésie au pentobarbital. Rev. Canad. Biol. 13, 257-263 (1954). [B98,672/54

Pelouze, P. S., Rosenberger, R. C.: The interesting behavior of tuberculous guinea-pigs under parathyroid and calcium administration. A preliminary report. Amer. J. med. Sci. 168, 546-553 (1924).

$[62,508 / 24$

Peltola, P.: The effect of thyroid powder on the lethal dose of adrenaline. Ann. Med. exp. Fenn. 28, Sup., pp. 59 (1950).

$[\mathrm{B} 57,468 / 50$

Penhos, J. C.: Effect of triamcinolone, dexamethasone and aminopterin on the growth of rats. Acta physiol. lat.-amer. 12, 329-341 (1962).

[G8,997/62

Penhos, J. C., Blaquier, J. A.: Toxicidad de la fenetildiguanida (DBI). Rev. Soc. argent. Biol. 34, 21-28 (1958).

$[\mathrm{C} 59,755 / 58$ 
Peraino, C., Lamar, C., Pitot, H. C.: Studies on the induction and repression of enzymes in rat liver. IV. Effects of cortisone and phenobarbital. J. biol. Chem. 241, 2944-2948 (1966).

[G40,083/66

Peräsalo, 0., Latvalahti, J.: Amyloid degeneration in the light of clinical and experimental studies. Acta path. microbiol. scand. 34, 208 to 217 (1954).

$[\mathrm{C} 9,661 / 54$

Perelmuter, C., Miletzkaja, S.: Interaction between thyroid gland and vitamin B. (Russian text.) Probl. zootech. exp. Endocr. 1, 283-305 (1934).

$[78,650 / 34$

Pérez, V.: Higado y drogas. Buenos Aires: Editorial Paidos, pp. 270 (1969). [E 8,836/69

Pérez, V., Gorosdisch, S., de Martire, J., Nicholson, R., di Paola, G.: Oral contraceptives: longterm use produces fine structural changes in liver mitochondria. Science 165, 805-807 (1969).

[H14,794/69

Pérez-Tamayo, R., Romero, R.: Role of the spleen in regeneration of the liver. Lab. Invest. 7, 248-257 (1958).

[D38,897/58

Perla, D., Freiman, D. G., Sandberg, M., Greenberg, S. S.: Prevention of histamine and surgical shock by cortical hormone (desoxy-corticosterone acetate and cortin) and saline. Proc. Soc. exp. Biol. (N.Y.) 43, 397-404 (1940).

$[\mathrm{A} 31,863 / 40$

Perla, D., Marmorston-Gottesman, J.: Immunological studies in relation to the suprarenal gland. IV. The effect of repeated injections of epinephrine on the hemolysin formation in suprarenalectomized rats. J. exp. Med. 50, 87-92 (1929).

$[16,042 / 29$

Perla, D., Marmorston-Gottesman, J.: Further studies on T. lewisi infection in albino rats. I. The effect of splenectomy on T. lewisi infection in albino rats and the protective action of splenic autotransplants. II. The effect of thymectomy and bilateral gonadectomy on T. lewisi infection in albino rats. J. exp. Med. 52, 601-616 (1930).

$[810 / 30$

Perla, D., Marmorston-Gottesman, J.: Injections of cortin on resistance of suprarenalectomized rats. Biological assay of extracts of suprarenal cortex. Proc. Soc. exp. Biol. (N.Y.) 28, 475-477 (1931).

$[10,865 / 31$

Perry, A. S.: Studies on microsomal cytochrome P-450 in resistant and susceptible houseflies. Life Sci. 9, 335-350 (1970).

[G74,358/70

Perry, D. J.: The effect of adrenalectomy on the development of tumours induced by 2-acetylaminofluorene. Brit. J. Cancer 15, 284-290 (1961).

$[\mathrm{D} 10,864 / 61$
Pesch, L. A., Segal, S., Topper, Y. J.: Progesterone effects on galactose metabolism in prepubertal patients with congenital galactosemia and in rats maintained on high galactose diets. J. clin. Invest. 39, 178-184 (1960).

$[\mathrm{C} 79,957 / 60$

Peterkofsky, B., Tomkins, G. M.: Effect of inhibitors of nucleic acid synthesis on steroidmediated induction of tyrosine aminotransferase in hepatoma cell cultures. $J$. molec. Biol. 30, 49-61 (1967).

$[\mathrm{G} 52,839 / 67$

Peters, J. M., Boyd, E. M.: The influence of sex and age in albino rats given a daily oral dose of caffeine at a high dose level. Canad. $J$. Physiol. Pharmacol. 45, 305-311 (1967).

$[\mathrm{F} 77,819 / 67$

Petty, W. C., Karler, R.: The influence of aging on the activity of anticonvulsant drugs. $J$. Pharmacol. exp. Ther. 150, 443-448 (1965).

[F 58,540/65

Petzold, H.: Der Einfluß von Turinabol auf die Tetrachlorkohlenstoff-Fibrose des Kaninchens. Z. ges. inn. Med. 20, 191-193 (1965).

$[\mathrm{F} 61,425 / 65$

Petzold, H., Matzkowski, H., Burckhardt, M.: Der Einfluß von Oral-Turinabol auf die 'Thioacetamidzirrhose' der Rattenleber. Dtsch. Z. Verdau.- u. Stoffwechselkr. 29, 127-132 (1969).

[H20,651/69

Petzold, H., Meincke, K.: Die Wirkung von 6-Methylprednisolon auf Gewebsenzyme der Tierleber bei chronischer Tetrachlorkohlenstoffschädigung. Dtsch. Z. Verdau.- u. Stoffwechselkr. 22, 150-157 (1962). [D39,959/62

Petzold, H., Ziegler, A.: Der Einfluß von Prednison und Turinabol auf Gewebsphosphatasen der experimentellen Fettleber der Ratte. Z. ges. inn. Med. 22, 654-657 (1967).

[F $92,832 / 67$

Peyster, F. A. de, Jobgen, E. A., Petravicius, M. A.: Humoral accelerating effect of regeneraing liver on distant tumor take and growth in rats. Surg. Forum 12, 149-150 (1961).

[G71,671/61

Pfeifer, A. K., György, L., Fodor, M.: Role of catecholamines in the central effects of amphetamine. Acta med. Acad. Sci. hung. 25, $441-450$ (1968).

$[\mathrm{G} 65,057 / 68$

Pfeifer, A. K., Pataky, I., Sátory, E., Vértes, P.: Observations on the early pharmacological effects of thyroxine. Arch. int. Pharmacodyn. 127, 44-57 (1960).

[D 12,952/60

Pfeiffer, H.: Ưber den Einfluß des Schilddrüsenverlustes auf die Wärmeregulation des Meer- 
schweinchens. Naunyn-Schmiedebergs Arch. Pharmak. 98, 253-256 (1923). $\quad[16,694 / 23$ Pflüger, E.: Die teleologische Mechanik der lebendigen Natur. Pflügers Arch. ges. Physiol. 15, 57-103 (1877).

$[\mathrm{A} 4,877 / 1877$

Phansalkar, A. G., Joglekar, G. V., Balwani, J. H.: A study of digoxin, thyroxine and reserpine interrelationship. Arch. int. Pharmacodyn. 182, $44-48$ (1969). [H20,555/69 Phillips, P. H., English, H., Hart, E. B.: The augmentation of the toxicity of fluorosis in the chick by feeding desiccated thyroid.J.Nutr.10, 399-407 (1935).

$[34,798 / 35$

Piantoni, L.: Azione del cortisone sulle infezioni sperimentali da lieviti asporigeni avirulenti e virulenti. G. Mal. infett. 7, 1-47 (1955).

$[\mathrm{C} 38,892 / 55$

Piantoni, L.: Azione del cortisone sulle infezioni sperimentali da actinomiceti avirulenti e virulenti. Biol. lat. (Milano) 8, 1095-1117 (1955).

$[\mathrm{C} 38,895 / 55$

Picha, E.: Neue Gesichtspunkte zur Anwendung anaboler Steroide in der gynäkologischen Strahlentherapie. Strahlentherapie 138, 300 bis 322 (1969).

$[\mathrm{G} 70,118 / 69$

Pichler, E.: Behandlung eines Cushing-Syndroms auf Grund einer Nebennierenrindenhyperplasie bei einem 7jährigen Mädchen mit dem Nebennierenrindenblocker opDDD. Helv. paediat. Acta 21, 447-474 (1966). [G43,794/66

Pierce, A. E., Long, P. L.: Studies on acquired immunity to coccidiosis in bursaless and thymectomized fowls. Immunology 9, 427-439 (1965).

[G36,006/65

Pieroni, R. E., Broderick, E. J., Bundeally, A., Levine, L.: A simple method for the quantitation of submicrogram amounts of bacterial endotoxin. Proc. Soc. exp. Biol. (N.Y.) 133, 790-794 (1970).

$[\mathrm{H} 31,137 / 70$

Pieroni, R. E., Levine, L.: Enhancing effect of insulin on endotoxin lethality. Experientia (Basel) 25, 507-508 (1969). $\quad[\mathrm{G} 68,105 / 69$

Pierre, R.: Influence de la sérotonine, de dérivés de la phénothiazine, de stéroïds, de tranquillisants sur l'EEG du lapin intoxiqué par la diéthylamide de l'acide lysergique. I. Action sur l'intoxication chronique par la LSD. C. R. Soc. Biol. (Paris) 151, 890-892 (1957).

$[\mathrm{C} 52,727 / 57$

Pierre, R.: Influence de la sérotonine, de dérivés de la phénothiazine, de stéroïdes, de tranquillisants sur l'EEG du lapin intoxiqué par le diéthylamide de l'acide lysergique. II. Action sur la réaction d'éveil produite par la
LSD. C. R. Soc. Biol. (Paris) 151, 1135-1137 (1957).

$[\mathrm{C} 55,459 / 57$

Pierre, R., Cahn, J.: Essais d'anesthésie prolongée par la 5-hydroxytrytamine. $C$. $R$. Soc. Biol. (Paris) 149, 1406-1407 (1955).

$[\mathrm{C} 24,570 / 55$

Pierre, R., Cahn, J., Herold, M., Georges, G.: Actions de la 21-hydroxyprégnanedione et du méthyl-androstanolone sur le système nerveux central. Presse méd. 65, 1621 (1957).

$[\mathrm{C} 46,326 / 57$

Pinchot, G. B., Close, V. P., Long, C. N. H.: Adrenal changes produced in rats by infection with B. Tularense and B. Coli. Endocrinology 45, 135-142 (1949).

$[\mathrm{B} 39,038 / 49$

Pincus, G.: The Control of Fertility. New York, London: Academic Press Inc., pp. 360 (1965).

[E689/65

Pincus, G., Martin, D. W.: Liver damage and estrogen inactivation. Endocrinology 27, 838 to 839 (1940).

[A34,939/40

Pines, I., Salazar, E., Lopez, T.: On the influence of the intravenous injections of glucocorticoids upon the electrocardiogram. An experimental study. Arch. int. Pharmacodyn. 122, 1-14 (1959).

$[\mathrm{C} 87,661 / 59$

Pinto, M. I. M.: Estudos sobre epidemiologia experimental. I.-Acção da cortisona na infestação do rato albino pelo cestodo Hymenolepis nana, Tipo "M". An. Inst. Med. trop. 17, 83-97 (1960).

$[\mathrm{D} 23,719 / 60$

Pirani, C. L., Stepto, R. C., Sutherland, K.: Effects of cortisone on normal and ascorbic acid-deficient guinea pigs. Fed. Proc. 10, 368 (1951).

$[\mathrm{B} 57,272 / 51$

Pisanty, J., Toscano, S.: Adrenal cortex performance in shock. Amer. J. Physiol. 187, 622 (1956).

$[\mathrm{C} 30,049 / 56$

Pitot, H. C.: Substrate and hormonal interactions in the regulations of enzyme levels in rat hepatomas. Advanc. Enzyme Regul. 1, 309 to 319 (1963).

$[\mathrm{G} 65,475 / 63$

Pitot, H. C., Peraino, C., Morse, P. A., Jr., Potter, V. R.: Hepatomas in tissue culture compared with adapting liver in vivo. Nat. Cancer Inst. Monogr. 13, 229-245 (1964).

[G37,125/64

Pizzi, P. T., Chemke, S. J.: Acción de la cortisona sobre la infección experimental de la rata por Trypanosoma cruzi. Biologica 21, 31-48 (1955).

$[\mathrm{C} 34,555 / 55$

Plaa, G. L.: Biliary and other routes of excretion of drugs. In: Ladu, B., Way, E. L., and Mandell, H. G.: Fundamentals of Drug Metabolism 
and Drug Disposition Baltimore: Williams and Wilkins Co. (in press).

[G73,820

Plaa, G. L., Becker, B. A.: Demonstration of bile stasis in the mouse by a direct and an indirect method. J. appl. Physiol. 20, 534-537 (1965).

[G76,082/65

Plagge, J. C., Marasso, F. J., Zimmerman, H. J.: Estrogen inhibition of nutritional fatty liver. Metabolism 7, 154-161 (1958). [C50,216/58 Plotka, C., Jequier, R., Velluz, L.: Sur un effet protecteur de l'adrénostérone dans l'athérome expérimental a l'adrénaline. C. R. Acad. Sci. (Paris) 244, $264-265$ (1957). $\quad[\mathrm{C} 51,239 / 57$

Podwyssozki, W.: Utber die Regeneration der Epithelien der Leber, der Niere, der Speichelund Meibom'schen Drüsen unter pathologischen Bedingungen. Vorläufige Mitteilung. Fortschr.Med.3(1885).

$[\mathrm{E} 77,767 / 1885$

Poe, C. F., Suchy, J. F.: Effect of vitamin $B_{1}$ on the toxicity of strychnine. Arch. int. Pharmacodyn. 86, 449-453 (1951).

[D75,977/51

Poe, C. F., Suchy, J. F., Witt, N. F.: Toxicity of strychnine for male and female rats of different ages. J. Pharmacol. exp. Ther. 58, 239-242 (1936).

$[\mathrm{A} 45,388 / 36$

Poe, R. H., Davis, T. R. A.: Cold exposure and acclimation in alloxan-diabetic rats. Amer. $J$. Physiol. 202, 1045-1048 (1962). [D27,155/62

Poe, R. H., White, J. W., Davis, T. R. A.: Alloxan-diabetic rats during acclimation to cold. Amer. J. Physiol. 205, 184-188 (1963).

$[\mathrm{E} 21,412 / 63$

Poel, W. E.: Progesterone enhancement of mammary tumor development as a model of co-carcinogenesis. Brit. J. Cancer 22, 867 to 873 (1968).

$[\mathrm{H} 23,662 / 68$

Pohl, H., Hart, J. S.: Thermoregulation and cold acclimation in a hibernator, Citellus tridecemlineatus. J. appl. Physiol. 20, 398 to 404 (1965).

$[\mathrm{F} 62,568 / 65$

Pohle, K., Bekemeier, H.: Antagonistische Beeinflussung der Rattenniere durch Oestrogene und Nebennierenrindenhormone. Endokrinologie 51, 314-318 (1967). [F91,972/67

Pokrajac, N., Osterman, J., Bilic, N.: The tolerance to massive doses of insulin in adrenalectomized and cortisol-treated rats. Diabetologia (Berlin) 3, 361-367 (1967). [G49,275/67 Poland, A., Smith, D., Kuntzman, R., Jacobson, M., Conney, A. H.: Effect of intensive occupational exposure to DDT on phenylbutazone and cortisol metabolism in human subjects. Clin. Pharmacol. Ther. 11, 724-732 (1970).

$[\mathrm{G} 78,061 / 70$
Polemann, G., Froitzheim, G.: Tierexperimentelle Untersuchungen zur Therapie der $D_{2^{-}}$ Hypervitaminose.Z. Vitamin-, Hormon- u. Fermentforsch. 5, 329-357 (1953). [B87,589/53

Polishuk, Z. W., Wassermann, M., Wassermann, D., Groner, Y., Lazarovici, S., Tomatis, L.: Effects of pregnancy on storage of organochlorine insecticides. A. M. A. Arch. environm. Hlth. 20, 215-217 (1970).

$[\mathrm{G} 72,380 / 70$

Poll, M., Seitehik, M. W., Canter, J. W., Segal, R. L., Baronofsky, I. D.: The effect of thyroidectomy on experimental ascites. Surgery 49,636 to $640(1961)$.

$[\mathrm{D} 4,775 / 61$

Polliack, A., Charuzy, I., Levij, I. S.: The effect of oestrogen on 9, 10-dimethyl-1,2-benzanthracene (DMBA)-induced cheek pouch carcinoma in castrated and non-castrated male Syrian golden hamsters. Brit. J. Cancer 23, 781-786 (1969).

$[\mathrm{G} 72,389 / 69$

Polliack, A., Charuzy, I., Levij, I. S.: The effect of testosterone on chemical carcinogenesis in the buccal pouches of castrated and intact male hamsters. Path. et Microbiol. (Basel) 35, 348 to 354 (1970).

$[\mathrm{H} 31,578 / 70$

Poloni, A.: Serotonia e schizofrenia. Rilievi sperimentali in favore dell'ipotesi di una tossicosi da 5-idrossitriptamina della schizofrenia. Cervello 31, 231-242 (1955).

$[\mathrm{D} 95,333 / 55$

Poloni, A.: Serotonina e schizofrenia. Azione della serotonia (S.) sola e associata ai barbiturici (Ba.), alla dietilamide dell'acido lisergico (LSD. 25), alla mescalina (M.) e alla bulbocapnina (B.) sul tracciato EEG. di schizofrenici, epilettici e altri ammalati di mente. Cervello $\mathbf{3 1}$, 355-382 (1955).

[D 99,472/55

Pomp, H., Schnoor, M., Netter, K. J.: Untersuchungen über die Arzneimitteldemethylierung in der fetalen Leber. Dtsch. med. Wschr. 94, 1232, 1237-1240 (1969). [H 14,237/69

Ponchon, G., Kennan, A. L., DeLuca, H. F.: "Activation" of vitamin D by the liver. J. clin. Invest. 48, 2032-2037 (1969).

[H18,243/69

Ponfick, E.: Experimentelle Beiträge zur Pathologie der Leber. Virchows Arch. pathol. Anat. 118, 209-249 (1889). [A 24,568/1889

Ponseti, I. V.: Lesions of the skeleton and of other mesodermal tissues in rats fed sweet-pea (lathyrus odoratus) seeds. J. Bone $J t$ Surg. 36-A, 1031-1058 (1954). [ [D 49,845/54 Ponseti, I. V.: Prevention of aminonitrile lesions in rats with L-triiodothyronine. Proc. Soc. exp. Biol. (N.Y.) 96, 14-17 (1957).

$[\mathrm{E} 54,643 / 57$ 
Ponseti, I. V.: Studies of the suppression of aminonitrile lesions in rats by thyroxine analogues. Endocrinology 64, 795-806 (1959).

$[\mathrm{C} 68,050 / 59$

Ponseti, I. V.: Studies on the nature of skeletal lesions produced by aminonitriles. Bull. Hosp. Dis. (N.Y.) 20, $1-8$ (1959). $\quad[C 78,321 / 59$

Ponseti I. V., Aleu, F.: Fracture healing in rats treated with aminoacetonitrile. J. Bone Surg. 40-A, 1093-1102 (1958).

$[\mathrm{C} 61,715 / 58$

Pontremoli, S., Arrigo, L.: Effetti dell'asportazione della milza sulla 'rigenerazione' del fegato dopo parziale epatectomia. Boll. Soc. ital. Biol. sper. 26, 355-357 (1950). $\quad[\mathrm{D} 63,528 / 50$ Popper, H., Stein, R., Kent, G.o, Bruce, C.: Hepatic interstitial cell reaction in experimental liver damage. Fed. Proc. 16, 369 (1957).

$[\mathrm{C} 33,264 / 57$

Porrazzi, L. C., Vecchione, R., Cali, A.: Effetti del DOCA sull'aterogenesi da colesterolo nel coniglio. Riv. Anat. pat. 33, 351-367 (1968).

[H34,157/68

Porto, A., Donato, A.: Estudos sobre a regeneracao hepatica experimental. Medico (Porto) 51, 11-25 (1969).

[H34,703/69

Poser, W., Jahns, R.: Eine vereinfachte Methode zur funktionellen Hepatektomie. Pflügers Arch. gesamt. Physiol. 297, 196 (1967).

$[\mathrm{F} 90,235 / 67$

Posner, H. S., Graves, A., King, C. T. G., Wilk, A.: Experimental alteration of the metabolism of chlorcyclizine and the incidence of cleft palate in rats. $J$. Pharmacol. exp. Ther. 155, 494-505 (1967).

$[\mathrm{H} 31,661 / 67$

Pospišil, M., Novák, L.: Effect of thyroid pretreatment on the mortality of $\mathrm{X}$-irradiated mice. Nature (Lond.) 182, 1603-1604 (1958).

$[\mathrm{C} 67,534 / 58$

Post, J., Himes, M. B., Klein, A., Hoffman, J.: Responses of the liver to injury. Effects of growth hormone upon acute carbon tetrachloride poisoning. Arch. Path. 64, 278-283 (1957).

$[\mathrm{C} 40,180 / 57$

Potop, I., Boeru, V., Biener, J.: L'influence d'un extrait lipoprotéique isolé du thymus sur le développement des tumeurs expérimentales. Rev. roum. Endocr. 2, 41-48 (1965).

$[\mathrm{F} 38,309 / 65$

Potop, I., Lupuleseo, A., Biener, J.: Modifications morphologiques et biochimiques dans le foie des rats après administration de diète cancérigène et d'extrait thymique. Acta biol. med. Germ. 8, 230-237 (1962). [E39,894/62
Potter, J. L.: On papain and flop-eared rabbits. Arthr. and Rheum. 4, 389-399 (1961).

$[\mathrm{D} 23,805 / 61$

Potvliege, P. R.: Hypervitaminosis $\mathrm{D}_{2}$ in gravid rats. Study of its influence on fetal parathyroid glands and a report of hitherto undescribed placental alterations. Arch. Path. 73, 371-382 (1962).

$[\mathrm{E} 98,323 / 62$

Powell, J., Waterhouse, J., Culley, P., Wood, B.: Effect of phenobarbitone and pre-eclamptic toxaemia on neonatal jaundice. Lancet 1969 II, 802.

[H17,195/69

Pozo, E. C. del, Negrete, J.: Effects of cortisone on muscular contraction. Fed. Proc. 11, 32 (1952).

$[\mathrm{B} 68,183 / 52$

Pradhan, S. N., Achinstein, B., Shear, M. J.: Potentiation of urethan anesthesia by epinephrine. Proc. Soc. exp. Biol. (N.Y.) 92, 146-149 (1956).

$[\mathrm{C} 13,632 / 56$

Prange, A. J., Jr., Lipton, M. A.: Enhancement of imipramine mortality in hyperthyroid mice. Nature (Lond.) 196, 588—589 (1962).

$[\mathrm{D} 42,869 / 62$

Prange, A. J., Jr., Lipton, M. A.: Effects of propylthiouracil and thyroid feeding on the response of mice to injected convulsant barbiturate. Nature (Lond.) 208, 791-792 (1965).

[F 56,756/65

Prange, A. J., Jr., Lipton, M. A., Love, G. N.: Diminution of imipramine mortality in hypothyroid mice. Nature (Lond.) 197, 1212-1213 (1963).

$[\mathrm{D} 62,707 / 63$

Prange, A. J., Jr., Lipton, M. A., Love, G. N.: Effect of altered thyroid status on desmethylimipramine mortality in mice. Nature (Lond.) 204, 1204-1205 (1964).

[F 29,162/64

Prange, A.J., Jr., Lipton, M.A., Shearin, R.B., Love, G. N.: The influence of thyroid status on the effects and metabolism of pentobarbital and thiopental. Biochem. Pharmacol. 15, 237 to 248 (1966).

$[\mathrm{G} 40,154 / 66$

Prange, A. J., Jr., Wilson, I. C., Knox, A., MeClane, T. K., Lipton, M. A.: Enhancement of imipramine by thyroid stimulating hormone: clinical and theoretical implications. Amer. $J$. Psychiat. 127, 191-199 (1970). [G76,612/70

Prange, A.J., Jr., Wilson, I.C., Lipton, M.A., Rabon, A.M., MeLae, T.K., Knox, A.E.: Use of a thyroid hormone to accelerate the action of imipramine. Psychosomatics 11, 442-444 (1970).

$[\mathrm{H} 31,796 / 70$

Prange, A. J., Jr., Wilson, I. C., Rabon, A. M., Lipton, M. A.: Enhancement of imipramine 
antidepressant activity by thyroid hormone. Amer. J. Psychiat. 126, 457-469 (1969).

[G69,595/69

Prasad, A. S., Oberleas, D., Wolf. P., Horwitz, J. P.: Effect of growth hormone on nonhypophysectomized zinc-deficient rats and zinc on hypophysectomized rats. J. Lab. clin. Med. 73, 486-494 (1969).

[G64,823/69

Prasad, M. R. N., Singh, S. P., Rajalakshmi, M.: Fertility control in male rats by continuous release of microquantities of cyproterone acetate from subcutaneous silastic capsules. Contraception 2, 165-178 (1970). [G78,450/70

Pratt, T. W.: A comparison of the action of pentobarbital (Nembutal) and sodium barbital in rabbits as related to the detoxicating power of the liver. J. Pharmacol. exp. Ther. 48, 285 (1933).

[G71,897/33

Pratt, T. W., Vanlandingham, H. W., Talley, E. E., Nelson, J. M., Johnson, E. O.: Studies of the liver function of dogs. Amer. J. Physiol. 102, 148-152 (1932).

$[\mathrm{G} 72,105 / 32$

Preisig, R., Morris, T. Q., Shaver, J.C., Christy, N.P.: Volumetric, hemodynamic, and excretory characteristics of the liver in acromegaly. $J$. clin. Invest. 45, 1379-1387 (1966). [F 70,515/66

Prellwitz, W., Bässler, K. H.: Veränderungen an Proteinen der Leber und des Blutes bei experimenteller Lebercirrhose und nach Behandlung mit Decortin und einem anabolen Steroid. Klin. Wschr. 41,1125-1139 (1963).

[E 36,762/63

Prescott, L. F.: Pharmacokinetic drug interactions. Lancet 1969 II, $1239-1243$.

[H19,333/69

Preusse, H.: Zur Frage der Alkoholentgiftung durch Thyroxin. Thesis, University of HalleWittenberg (1933).

$[26,352 / 33$

Previte, J. J., Berry, L. J.: Studies on the potentiation of endotoxin in mice by exposure to cold. J. infect. Dis. 113, 43-51 (1963).

[E 89,101/63

Prewitt, R., Musacchia, X. J.: Mechanisms of radio-protection by sympathomimetics. Physiologist 12, 330 (1969).

$[\mathrm{H} 16,155 / 69$

Preziosi, P., Scapagnini, U., Nistico, G.: Toxicite d'esters de la bétaméthasone seuls ou associés à des anabolisants chez le rat nouveauné. Arch. int. Pharmacodyn. 166, 208-213 (1967).

[F 78,520/67

Pribram, B.0.: Die Steuerungsmöglichkeit der Avertinnarkose durch Thyroxin. Zbl. Chir. 56, 3138-3142 (1929).

[A47,677/29
Priestly, B. G., Plaa, G.L.: Temporal aspects of carbon tetrachloride-induced alteration of sulfobromophthalein excretion and metabolism. Toxicol. appl. Pharmacol. 17, 786-794 (1970).

[G80,048/70

Priestley, J. T., Markowitz, J., Mann, F. C.: Studies on the physiology of the liver. XX. The detoxicating function of the liver with special reference to strychnine. Amer. J. Physiol. 96, 696-708 (1931).

$[9,158 / 31$

Prioreschi, P.: Stress e anestesia da bromuro di sodio. Atti Soc. lombarda Sci. med.-biol. 14, 215-217 (1959).

$[\mathrm{C} 68,485 / 59$

Proulx, L., D'Iorio, A., Beznak, M.: The metabolism of catecholamines in hyperthyroid and vitamin $\mathrm{B}_{12}$ deficient rats. Canad. J. Biochem. 44, 1577-1585 (1966).

[G43,289/66

Pulkkinen, M.0.: Sulphate conjugation during development, in human, rat and guinea pig. Acta physiol. scand. 66, 115-119 (1966).

[G39,295/66

Pyatnitskaya, T. M.: Hepatic changes in methylthiouracil treatment (Russian text). Probl. Endokr. Gormonoter. 2/4, 96-100 (1956).

[C43,809/56

Pyörälä, K., Kekki, M.: Decreased anticoagulant tolerance during methandrostenolone therapy. Scand. J. clin. Lab. Invest. 15, 367-374 (1963).

[E31,756/63

Pyörälä, K., Seppälä, T., Punsar, S.: Effect of corticoids, adrenocorticotrophic hormone, thyroxine and thyrotrophic hormone on aortic lesions in experimental lathyrism. Acta path. microbiol. scand. 45, 37-48 (1959).

[G67,833/59

Quadri, G.: Sulla funzione antitossica delle paratiroidi. Ricerche sperimentali. Gazz. med. ital. 51, 61-72 (1906).

$[45,920 / 06$

Quattrocchi, G., Foresti, A.: Influenza del trattamento con PTE sullo shock anafilattico e sul fenomeno di Sanarelli-Schwartzman. Boll. Soc. ital. Biol. sper. 42, 1093-1095 (1966).

[G43,535/66

Querci, V., Massari, L., Barni, I.: Sul metabolismo e l'azione tossica del parathion in ratti pretrattati con $\mathrm{CCl}_{4}$. Boll. Soc. ital. Biol. sper. 45, 404-406 (1969).

[G70,597/69

Quevauviller, A., Podevin, R.: Activité hypnotique et métabolisme du thiopental chez la souris rendue diabétique par l'alloxanne. Anesth. Analg. Réanim. 25, 45-52 (1968).

$[\mathrm{G} 57,209 / 68$

Quimby, F. H.: Effects of hormone, vitamin and liver supplements on the appetite and growth 
of the young rat during recovery from chronic starvation. Amer. J. Physiol. 166, 566-571 (1951).

[B 62,481/51 Quinn, G. P., Axelrod, J., Brodie, B. B.: Species and sex differences in metabolism and duration of action of hexobarbital (Evipal). Fed. Proc. 13, 396 (1954).

$[\mathrm{G} 67,327 / 54$

Quinn, G. P., Axelrod, J., Brodie, B. B.: Species, strain and sex differences in metabolism of hexobarbitone, amidopyrine, antipyrine and aniline. Biochem. Pharmacol. 1, 152-159 (1958).

[E 89,993/58

Qureshi, S. A., Zaman, H.: The effect of small doses of prednisolone on the incidence of subcutaneous sarcomas induced by 3-methylcholanthrene in virgin female Swiss mice. Cancer Res. 26, 1516-1519 (1966). [F 68,389/66

Raab, K. H., Webb, T. E.: Inhibition of DNA synthesis in regenerating rat liver by hydrocortisone. Experientia (Basel) 25, 1240-1242 (1969).

$[\mathrm{H} 20,502 / 69$

Rabboni, F., Milazzo, S.: Modificazioni anatomo-istologiche dei reni in seguito a tiroidectomia. Boll. Soc. ital. Biol. sper. 23, 6-8 (1947).

[B 18,975/47

Rabes, H., Tuczek, H. V.: Topik der Leberregeneration nach Teilhepatektomie bei Allylformiat-vergifteten Ratten (Demonstration). Verh. dtsch. path. Ges. 52, 449-453 (1968).

[H30,729/68

Rabes, H., Tuczek, H. V.: Quantitative autoradiographische Untersuchung zur Heterogenität der Leberzellproliferation nach partieller Hepatektomie. Virchows Arch. Abt. B Zellpathol. 6, 302-312 (1970). $\quad[\mathrm{H33}, 839 / 70$

Radomski, J. L., Fuyat, H. N., Nelson, A. A., Smith, P. K.: The toxic effects, excretion and distribution of lithium chloride. J. Pharmacol. exp. Ther. 100, 429-444 (1950). [B63,492/50

Radouco-Thomas, S., Radouco-Thomas, C., LeBreton, E.: Action de la Noradrénaline et de la Réserpine sur l'analgésie expérimentale. Naunyn-Schmiedeberg's Arch. exp. Pathol. Pharmak. 232, 279-281 (1957). [E60,201/57

Radzialowski, F. M., Bousquet, W. F.: Circadian rhythm in hepatic drug-metabolizing activity in the rat. Life Sci. 6, 2545-2548 (1967).

[G53,591/67

Radzialowski, F. M., Bousquet, W. F.: Daily rhythmic variation in hepatic drug metabolism in the rat and mouse. J. Pharmacol. exp. Ther. 163, 229-238 (1968).

$[\mathrm{H} 2,264 / 68$

Raffucci, F. L.: The effects of temporary occlusion of the afferent hepatic circulation in dogs. Surgery 33, 342-351 (1953). $\quad[B 83,148 / 53$
Raffucci, F. L., Wangensteen, 0. H.: Tolerance of dogs to occlusion of entire afferent vascular inflow to the liver. Surg. Forum 1, 191-195 (1951).

[G 33,029/51

Räihä, N. C. R., Kekomäki, M. P.: Studies on the development of ornithine-keto acid aminotransferase activity in rat liver. Biochem. $J$. 108, 521—525 (1968).

$[\mathrm{G} 68,114 / 68$

Raisield, I. H., Bacehin, P., Hutterer, F., Schaffner, F.: The effect of 3-amino-1,2,4triazole on the phenobarbital-induced formation of hepatic microsomal membranes. Molec. Pharmacol. 6, 231-239 (1970).

$[\mathrm{G} 75,045 / 70$

Raitschew, R.: Significance of hormonal factors in inducing melanoma in hamsters with DMBA. Z. Krebsforsch. 74, 115-121 (1970).

$[\mathrm{G} 76,731 / 70$

Rall, D. P.: Screening procedures and preclinical pharmacology relating to antineoplastic agents. In: Nodine and Siegler; Animal and Clinical: Pharmacologic Techniques in Drug Evaluation, p. 624-631. Chicago: Year Book Med. Publ. Inc. 1964.

$[\mathrm{G} 72,239 / 64$

Ramboer, C., Thompson, R.P.H., Williams, R.: Controlled trials of phenobarbitone therapy in neonatal jaundice. Lancet 1969 I, 966-968.

$[\mathrm{H} 12,643 / 69$

Ramos, A., Silverberg, M., Stern, L.: Pregnanediols and neonatal hyperbilirubinemia. A.M.A.J. Dis. Child. 111, 353-356 (1966).

$[\mathrm{G} 38,868 / 66$

Ramseyer, W. F., Smith, C. A. H., MeCay, C. M.: Effect of sodium fluoride administration on body changes in old rats. $J$. Geront. 12, 14-19 (1957).

$[\mathrm{C} 29,608 / 57$

Ranney, R. E., Drill, V. A.: The ability of 17ethyl-19-nortestosterone to block ethionineinduced fatty liver in rats. Endocrinology 61, 476- 477 (1957).

$[\mathrm{C} 41,986 / 57$

Rapoport, M. I., Lust, G., Beisel, W. R.: Host enzyme induction of bacterial infection. Arch. intern. Med. 121, 11-16 (1968).

[G53,334/68

Räsänen, T., Taskinen, E.: Protection of the gastric mucosa against the lesions caused by reserpine through degranulation of mucosal mast cells. Acta physiol. scand. 71, 96-104 (1967).

$[\mathrm{G} 51,026 / 67$

Ratnoff, 0. D., Mirick, G. S.: Influence of sex upon the lethal effects of an hepatotoxic alkaloid, monocrotaline. Bull. Johns Hopk. Hosp. 84, 507-525 (1949).

$[\mathrm{B} 48,154 / 49$ 
Ratschow, M., Klostermann, H. C.: Experimentelle Befunde zur Gefäßwirkung der Sexualhormone und ihre Beziehungen zur Klinik der peripheren Durchblutungsstörungen. Z. klin. Med. 135, 198-211 (1938).

[A 19,494/38

Ratsimamanga, A. R.: Fonction du cortex surrénal au cours du travail musculaire. $J$. Physiol. (Paris) 42, 81-112 (1950).

[B48,447/50

Ratsimamanga, A. R., Buu-Hoi, N. P.: Toxicité et non-saturation des molécules. IV. Action des substances polycycliques cancérigènes sur la fonction cortico-surrénales. Bull. Soc. Chim. Biol. (Paris) 29, 325-329 (1947).

[B33,923/47

Ravdin, I. S., Vars, H. M., Goldschmidt, S.: The non-specificity of suspensions of sodium zanthine in protecting the liver against injury by chloroform, and the probable cause of its action. J. clin. Invest. 18, 633-640 (1939).

[B25,566/39

Recknagel, R. 0.: Carbon tetrachloride hepatotoxicity. Pharmacol. Rev. 19, 145-208 (1967).

[F 85,043/67

Redmond, W. B.: Influence of cortisone on natural course of malaria in the pigeon. Proc. Soc. exp. Biol. (N.Y.) 79, 258-261 (1952).

[B 67,882/52

Regniers, P., Demeulenaere, L., Wieme, R. J.: Les modalités évolutives des lésions hépatiques provoquées par le tetrachlorure de carbone administré à dose cirrhogène sous l'influence de la cortisone. Acta clin. belg. 10, 88-100 (1955).

[C7,634/55

Reichard, S. M., Edelmann, A., Gordon, A. S.: Endocrine influences upon the uptake of colloidal thorium by reticulo-endothelial organs. Res. Bull. 2, $34-39$ (1956). [C32,593/56

Reid, E.: Growth hormone and adrenocortical hormones in relation to experimental tumors: a review. Cancer Res. 14, 249-266 (1954).

[B93,930/54

Reid, E.: Membrane systems. In: Roodyn, D. B.; Enzyme Cytology, p. 321-406. London, New York: Academic Press Inc. 1967.

$[\mathrm{G} 71,333 / 67$

Reif, A. E., Brown, R. R., Potter, V. R., Miller, E. C., Miller, J. A.: Effect of diet on the antimycin titer of mouse liver. J. biol. Chem. 209, 223-226 (1954).

[D 97,006/54

Reifenstein, E. C., Jr.: Control of corticoidinduced protein depletion and osteoporosis by anabolic steroid therapy. Metabolism 7, $78-89$ (1958).

$[\mathrm{C} 47,377 / 58$
Reinhard, J. F.: Prolongation of hypnosis by epinephrine and insulin. Proc. Soc. exp. Biol. (N.Y.) 58, 210-211 (1945). [B283/45

Reinmuth, 0. M., Smith, D. T.: The effect of ACTH on pneumonia induced with tuberculin in sensitized rabbits. Trans. nat. Ass. Tuberc. (Lond.) 47th Ann. Meet. 1951, p. 1-7.

[B 60,585/51

Reis, G. von: Stora doser noradrenalin vid akuta barbituratin-toxikationer. (Large doses of norepinephrine in the treatment of acute barbiturate intoxications.) Opuscula med. (Stockh.) 4, 50-52 (1959).

[C76,244/59

Reisfield, D. R., Leathem, J. H.: The closed vessel technic for testing thyroid activity in mice. Endocrinology 46, 122-124 (1950).

[B46,491/50

Reiss, M., Sideman, M. B., Plichta, E. S.: Influence of anabolic hormones on phenylalanine metabolism: II. Studies in animals. J. ment. Defic. Res. 10, 130-140 (1966).

[F 81,632/66

Remmer, H.: Der Einfluss von Steroidhormonen auf den Abbau von Evipan bei der Ratte. Naunyn-Schmiedebergs Arch. Pharmak. 232, 268-269 (1957).

[G79,941/57

Remmer, H.: Die Wirkung der Nebennierenrinde auf den Abbau von Pharmaka in den Lebermikrosomen. Naturwissenschaften 45, 522 (1958).

$[\mathrm{C} 73,857 / 58$

Remmer, H.: Die Verstärkung der Abbaugeschwindigkeit von Evipan durch Glykocorticoide. Naunyn-Schmiedebergs Arch. Pharmak. 233, $184-191$ (1958).

[D 86,728/58

Remmer, H.: Geschlechtsspezifische Unterschiede in der Entgiftung von Evipan und Thiopental bei Ratten. Naunyn-Schmiedebergs Arch. Pharmak. 233, 173-183 (1958).

[D 86,916/58

Remmer, H.: Der beschleunigte Abbau von Pharmaka in den Lebermikrosomen unter dem Einfluß von Luminal. Naunyn-Schmiedebergs Arch. Pharmak. 235, 279-290 (1959).

$[\mathrm{E} 52,112 / 59$

Remmer, H.: Die Beschleunigung des Abbaues als Ursache der Gewöhnung an Barbiturate. Naturwissenschaften 46, 580-581 (1959).

[E61,211/59

Remmer, H.: Drug tolerance. In: Mongar and de Reuck; Ciba Foundation Symposium on Enzymes and Drug Action, p. 276-300. London: J. \& A. Churchill Ltd. 1962.

$[\mathrm{G} 66,542 / 62$ 
Remmer, H.: Drugs as activators of drug enzymes. In: Brodie and Erdös; Metabolic Factors Controlling Duration of Drug Action 6, p. 235-256. New York: MacMillan Co. 1962.

[G67,788/62

Remmer, H.: Drug-induced formation of smooth endoplasmic reticulum and of drugmetabolizing enzymes. In: Some Factors Affecting Drug Toxicity, 4, p. 57-77. Amsterdam, New York, London: Excerpta Medica Foundation. Int. Congr. Ser. 81. 1964.

[G67,786/64

Remmer, H.: Gewöhnung an Hexobarbital durch beschleunigten Abbau. Arch. int. Pharmacodyn. 152, 346-359 (1964).

[F 31,499/64

Remmer, H.: The fate of drugs in the organism. Ann. Rev. Pharmacol. 5, 405-428 (1965).

[G78,385/65

Remmer, H.: Die Induktion arzneimittelabbauender Enzyme im endoplasmatischen Retikulum der Leberzelle durch Pharmaka. Dtsch. med. Wschr. 92, 2001-2008 (1967).

[F 90,864/67

Remmer, H., Alsleben, B.: Die Aktivierung der Entgiftung in den Lebermikrosomen während der Gewöhnung. Klin. Wschr. 36, 332-333 (1958).

[G67,790/58

Remmer, H., Merker, H.-J.: Enzyminduktion und Vermehrung von endoplasmatischem Reticulum in der Leberzelle während der Behandlung mit Phenobarbital (Luminal). Klin. Wschr. 41, 276-283 (1963). [D61,064/63

Remmer, H., Merker, H.-J.: Drug-induced changes in the liver endoplasmic reticulum. Association with drug-metabolizing enzymes. Science 142, 1657-1658 (1963). [E36,389/63

Remmer, H., Merker, H.-J.: Evaluation and mechanisms of drug toxicity. Part II. Metabolic aspects of the toxicity of drugs. Effect of drugs on the formation of smooth endoplasmic reticulum and drug-metabolizing enzymes. Ann. N. Y. Acad. Sci. 123, 79-97 (1965).

[G66,868/65

Remmer, H., Siegert, M.: Kumulation und Elimination von Phenobarbital. NaunynSchmiedebergs Arch. Pharmak. 243, 479-494 (1962).

[G74,636/62

Remmer, H., Siegert, M., Merker, H.-J.: Vermehrung arzneimitteloxydierender Enzyme durch Tolbutamid. Naunyn-Schmiedebergs Arch. Pharmak. 249, 71-84 (1964).

$[\mathrm{D} 19,894 / 64$
Renaud, S.: The influence of weather, climate and season on the effect of pharmacological treatment. In: Tromp; Medical Biometeorology. Weather, Climate and the Living Organism, p. 585-930. Amsterdam, London, New York: Elsevier Publ. Co. 1963.

$[\mathrm{C} 77,620 / 63$

Renaud, S., Allard, C., Latour, J. G.: The prevention by glucocorticoids of endotoxininitiated thrombosis in rat, in relation to fibrinolysis, coagulation, and lipemia. Amer. Heart J. 72, 797-805 (1966).

[F 74,449/66

Renaud, S., Latour, J. G.: Effect of prolonged glucocorticoid administration on lipemia, coagulation and thrombosis in rat. Proc. Soc. exp. Biol. (N.Y.) 128, 32-35 (1968).

[F 99,806/68

Renovanz, H. D.: Der Einfluß des Paraoxypropiophenons auf den Tuberkulose-Ablauf im Tierversuch. Ärztl. Wschr. 14, 524-529 (1959).

[C78,772/59

Repke, K.: Ưber Spaltung und Hydroxylierung von Digitoxin bei der Ratte. Naunyn-Schmiedebergs Arch. Pharmak. 237, 34-48 (1959).

$[\mathrm{D} 27,189 / 59$

Replogle, R. L., Gazzaniga, A. B., Gross, R. E.: Use of corticosteroids during cardiopulmonary bypass: possible lysosome stabilization. Circulation 33, 86-92 (1966). [ [G40,447/66

Reuber, M. D.: Accentuation of Ca edetate nephrosis by cortisone. Arch. Path. 76, 382 to 386 (1963).

[E27,340/63

Reuber, M. D.: The role of the thyroid gland in hepatic carcinogenesis. (Abstr.) Fed. Proc. 23, 336 (1964).

$[\mathrm{F} 4,431 / 64$

Reuber, M. D.: The influence of thyroid hormone and testosterone on the induction of carcinoma and cirrhosis of the liver in female -Wistar rats ingesting N-2-fluorenyldiacetamide. Fed. Proc. 24, 431 (1965). [F36,234/65

Reuber, M. D.: Thyroiditis in rats given subcutaneous injections of trypan blue. Toxicol. appl. Pharmacol. 14, 108-113 (1969).

$[\mathrm{G} 64,737 / 69$

Reuber, M. D.: Influence of age and sex on dietary-induced cirrhosis. An experimental study in the rat. Arch. environm. Hlth. 18, $792-797$ (1969).

[H $29,035 / 69$

Reuber, M. D.: Influence of age and sex on chronic thyroiditis in rats given subcutaneous injections of trypan blue. Toxicol. appl. Pharmacol. 17, 60-66 (1970).

[G77,295/70

Reuber, M. D.: Hepatic vein thrombosis. Increased incidence in rats given methylchol- 
anthrene and carbon tetrachloride. A. M. $A$ Arch. environm. Hlth. 20, 458-461 (1970).

[G73,605/70

Reuber, M. D., Glover, E. L.: Thyroiditis in rats injected subcutaneously with 3-methylcholanthrene. Proc. Soc. exp. Biol. (N.Y.) 129, 509-511 (1968).

[H5,582/68

Reuber, M. D., Grollmann, S., Glover, E. L.: Effect of 3-methyl-cholanthrene on experimentally induced cirrhosis. A study using rats of varying ages. A. M. A. Arch. Path. 89, 531 to 536 (1970).

[H26,492/70

Reyes, H., Levi, A. J., Gatmaitan, Z., Arias, I. M.: Organic anion-binding protein in rat liver: drug induction and its physiologic consequence. Proc. nat. Acad. Sci. (Wash.) 64, 168-170 (1969).

[G71,233/69

Ribble, J. C., Zalesky, M., Braude, A. I.: Distribution of $\mathrm{Cr}^{51}$-labelled endotoxin in cortisone-treated mice. Bull. Johns Hopk. Hosp. 105, 272-283 (1959).

[C92,576/59

Rice, A. J., Roberts, R. J., Plaa, G.L.: The effect of carbon tetrachloride, administered in vivo, on the hemodynamics of the isolated perfused rat liver. Toxicol. appl. Pharmacol. 11, 422-431 (1967).

[G55,767/67

Richards, R. K.: Toxicity of hypnotics as affected by temperature, thyroxin and adrenalectomy. Anesthesiology 2, 37-43 (1941).

$[79,646 / 41$

Richards, R. K., Appel, M.: The barbiturates and the liver. Anesth. Analg. Curr. Res. 20, $64-77$ (1941).

[A48,718/41

Richards, R. K., Taylor, J. D.: Some factors influencing distribution, metabolism and action of barbiturates: a review. Anesthesiology 17, $414-458(1956)$.

[H19,235/56

Richardson, H. L., Griffin, A. C., Riniret, A. P.: Adrenal histological change and liver tumor inhibition in hypophysectomized rats fed the azo dye, 3-methyl-4-methylaminoazobenzene. Cancer (Philad.) 6, 1025-1029 (1953).

$[\mathrm{C} 2,406 / 53$

Richardson, H. L., 0'Neal, M. A., Robertson, C. H., Griffin, A. C.: The role of hormones in azo-dye induction of liver cancer and the adrenal-lipoid response in hypophysectomized rats. Cancer (Philad.) 7, $1044-1047$ (1954).

[B99,907/54

Richardson, H. L., Stier, A. R., Borsos-Nachtnebel, E.: Liver tumor inhibition and adrenal histologic responses in rats to which 3-methyl4-dimethylaminoazobenzene and 20-methyl- cholanthrene were simultaneously adminis. tered. Cancer Res. 12, 356-361 (1952).

[B 70,382/52

Richardson, K. E.: Endogenous oxalate synthesis in male and female rats. Toxicol. appl. Pharmacol. 7, 507-515 (1965).

[D 88,284/65

Richardson, K. E.: Effects of vitamin-B glycolic acid, testosterone, and castration on the synthesis, deposition and excretion of oxalic acid in rats. Toxicol. appl. Pharmacol. 10, 40-53 (1967).

[G45,620/67

Richens, A., Rowe, D. J. F.: Disturbance of calcium metabolism by anticonvulsant drugs. Brit. med. J. 1970 II, 73-76. [H30,947/70

Richet, C.: Dictionnaire de Physiologie. Paris: Félix Alcan, Edit. 1900.

[E1,101/1900

Ridder, C.: Pentamethylentetrazol (Cardiazol). IV. Mitteilung: Wird Cardiazol in der Leber entgiftet? Naunyn-Schmiedebergs Arch. Pharmak. 120, 126-128 (1927).

[A47,894/27

Riedel, H.: Tierexperimentelle Untersuchungen über Hirnveränderungen bei akuter und chronischer Hyperthyreose und ihre Wandelbarkeit durch Sauerstoffmangel. Z. ges. inn. Med. 19, $718-726$ (1964).

$[\mathrm{F} 22,473 / 64$

Riegelman, S., Rowland, M., Epstein, W. L.: Griseofulvin-phenobarbital interaction in man. J. Amer. med.Ass. 213, 426-431 (1970).

[H 27,268/70

Rigat, L.: Il trattamento ormonico dell' organismo esposto all'azione delle radiozioni ionizzanti. Radioter. Radiobiol. Fis. med. 10, 87-136 (1955).

$[\mathrm{C} 10,747 / 55$

Rigatuso, J.L., Legg, P.G., Wood, R.L.: Microbody formation in regenerating rat liver. $J$. Histochem. Cytochem. 18, 893-900 (1970).

[G80,722/70

Rîmniceanu, C., Schneider, F., Dema, E.: Actiunea cortizonului asupra metabolismului celulei hepatice- intactă, intoxicată și protejată de vitamin $\mathrm{B}_{12}$. (Action of cortisone on the metabolism of the intact, intoxicated or protected by vitamin $\mathrm{B}_{12}$ liver cell.) Morfol. norm. si pat. 12, 301-308 (1967).

[F98,503/67

Rîmniceanu, C., Schneider, F., Dema, E.: The action of cortisone on the metabolism of the normal, intoxicated, or vitamin- $B_{12}$ protected liver cell. Rom. med. Rev. 12, 11-16 (1968).

[G66,073/68

Rinaudo, M. T., Lattes, M. G., Guardabassi, A.: Effetti degli ormoni somatotropo e lattotropo su alcune reazioni della glicolisi anaerobia nel 
fegato di girini di Bufo bufo. Arch. Sci. biol. (Bologna) 51, 79-84 (1967). [F95,471/67

Rinne, U.K., Näätänen, E.K.: The effect of norandrostenolone-phenylpropionate on the atrophy of the adrenal cortex and inhibition of growth induced by cortisone acetate. Acta endocr. (Kbh.) 27, 423-431 (1958). [C 50,335/58

Ritterson, A. L.: Innate resistance of species of hamsters to Trichinella spiralis and its reversal by cortisone. $J$. infect. Dis. 105, 253-266 (1959).

$[\mathrm{C} 78,122 / 59$

Rivlin, R. S., Knox, W. E.: Effects of age, body size and growth hormone on level of tryptophan peroxidase-oxidase in rat liver. Amer. $J$. Physiol. 197, 65-67 (1959).

$[\mathrm{C} 71,249 / 59$

Rivlin, R. S., Wolf, G.: Diminished responsiveness to thyroid hormone in riboflavin-deficient rats. Nature (Lond.) 223, 516-517 (1969).

[H13,055/69

Rixon, R. H., Baird, K. M.: The therapeutic effect of serotonin on the survival of $\mathrm{X}$-irradiated rats. Radiat. Res. 33, 395-402 (1968).

[G55,192/68

Rixon, R. H., Whitfield, J. F., Youdale, T.: Increased survival of rats irradiated with $\mathrm{X}$-rays and treated with parathyroid extract. Nature (Lond.) 182, 1374 (1958). [C61,789/58

Rizzo, A. J., Webb, T. E.: Concurrent changes in the concentration of monomeric ribosomes and the rate of ribosome synthesis in rat liver. Biochim. biophys. Acta (Amst.) 169, 163-174 (1968).

$[\mathrm{H} 21,587 / 68$

Roach, M. K., Reese, W. N., Jr., Creaven, P. J.: Ethanol oxidation in the microsomal fraction of rat liver. Biochem. biophys. Res. Commun. 36, 596-602 (1969).

$[\mathrm{G} 68,807 / 69$

Robert, A., Nezamis, J. E.: Polymyxin ulcers: effect of fluid intake and of corticoids (Abstr.). Fed. Proc. 21, 264 (1962).

[D 23,064/62

Robert, A., Nezamis, J. E.: Effect of a histamine releaser on steroid induced ulcers. Proc. Soc. exp. Biol. (N.Y.) 109, 698-700 (1962).

[D23,289/62

Robert, A., Northam, J. I., Nezamis, J. E., Phillips, J. P.: Exertion ulcers in rats. Amer. J. dig. Dis. 15, 497-507 (1970). [G74,748/70

Roberts, P., Turnbull, M. J., Winterburn, A.: Diurnal variation in sensitivity to and metabolism of barbiturate in the rat: lack of correlation between in vivo and in vitro findings. Europ. J. Pharmacol. 12, 375-377 (1970).

[H31,840/70

Roberts, R. J., Plaa, G. L.: Effect of norethandrolone, acetohexamide, and Enovid on $\alpha$ - naphthylisothiocyanate-induced hyperbilirubinemia and cholestasis. Biochem. Pharmacol. 15, 333-341 (1966). [G39,694/66 Roberts, R. J., Plaa, G. L.: Studies on bilirubin production and excretion in mice and rats treated with phenobarbital, chlorpromazine, norethandrolone, acetohexamide or Enovid. Toxicol. app. Pharmacol. 15, 483-492 (1969).

$[\mathrm{G} 69,070 / 69$

Roberts, R. J., Shriver, S. L., Plaa, G. L.: Effect of norethandrolone on the biliary excretion of bilirubin in the mouse and rat. Biochem. Pharmacol. 17, 1261-1268 (1968). [H8,328/68

Roberts, S.: The influence of the adrenal cortex on the mobilization of tissue protein. J. biol. Chem. 200, 77-88 (1953).

$[\mathrm{B} 97,023 / 53$

Roberts, S., Szego, C. M.: The early reduction in uterine response to alpha-estradiol in the partially-hepatectomized rat, and the subsequent enhancement during active liver regeneration. Endocrinology 40, 73-85 (1947).

$[\mathrm{A} 49,254 / 47$

Robertson, C. H., O'Neal, M. A., Griffin, A. C., Richardson, H. L.: Pituitary and adrenal factors involved in azo dye liver carcinogenesis. Cancer Res. 13, 776-779 (1953).

$[\mathrm{B} 88,672 / 53$

Robertson, C. H., O'Neal, M. A., Richardson, H. L., Griffin, A. C.: Further observations on the role of the pituitary and the adrenal gland in azo dye carcinogenesis. Cancer Res. 14, 549-553 (1954).

$[\mathrm{E} 61,212 / 54$

Robertson, T.: Multiple injections of potassium as a test for adrenocortical function, with modifications induced by desoxycorticosterone. Fed. Proc. 8, 366 (1949).

$[\mathrm{B} 32,963 / 49$

Robertson, T.: A sex difference in the tolerance of wistar rats for potassium. Endocrinology 50, 569-573 (1952).

[B 70,810/52

Robillard, E., Crevier, M., D'Ioro, A.: Influence of sex glands on the detoxication of pentobarbital by the liver in the rat. Proc. Canad. Physiol. Soc. 14th Ann. Meet. Ottawa, p. 38 (1950).

$[\mathrm{B} 51,110 / 50$

Robillard, E., Guénel, J., Pellerin, J., D’Iorio, A., Crevier, M.: Influence de la thyroïde sur la désintoxication du pentobarbital par le foie. Rev. canad. Biol. 10, 472-478 (1951).

$[\mathrm{B} 66,661 / 51$

Robillard, E., D'Iorio, A., Pellerin, J.: Influences endocriniennes sur la désintoxication hépatique du pentobarbital. Un. méd. Can. 83, $853-860$ (1954). 
Robillard, E., Pellerin, J.: Influence of the adrenals on pentobarbital anaesthesia. Proc. Canad. Physiol. Soc., 16th Ann. Meet., Oct. 10-11, Quebec, p. 54 (1952). [B75,692/52 Robinson, D. S., MacDonald, M. G.: The effect of phenobarbital administration on the control of coagulation achieved during warfarin therapy in man. J. Pharmacol. exp. Ther. 153, 250-253 (1966).

$[\mathrm{F} 69,377 / 66$

Robinson, H. J.: Effects of cortisone on intradermal pneumococcal infections in rabbits. Fed. Proc. 10, 332 (1951).

[B57,249/51

Robinson, H. J., Phares, H. F., Siegel, H., Graessle, 0. E.: Comparative effect of indomethacin and hydrocortisone on experimental tuberculosis in mice. Amer. Rev. resp. Dis. 97, 32-37 (1968).

[G53,271/68

Robinson, S., Kincaid, R. K., Rhamy, R. K.: Effects of desoxycorticosterone acetate on acclimatization of men to heat. J. appl. Physiol. 2, 399-406 (1950). [B56,828/50

Rocha Lagoa, F. da: O potássio plasmático em infecções bacterianas experimentais. $\mathrm{Mem}$. Inst. Osw. Cruz 45, 41-57 (1947).

$[\mathrm{B} 49,008 / 47$

Roche, G. La, Leblond, C. P.: Destruction of thyroid gland of atlantic salmon (Salmo salar L.) by means of radio-iodine. Proc. Soc. exp. Biol. (N.Y.) 87, 273-276 (1954). [C434/54

Rodin, A. E., Kowalewski, K.: Histological and histochemical effects of cortisone and an anabolic androgen on long bones of young cockerels and rats. Canad. J. Surg. 6, 229-236 (1963).

[D 60,272/63

Rodriguez-0lleros, A., Galindo, L.: Acción de la cortisona y ACTH sobre la gastritis y úlceras experimentales. Bol. Asoc. méd. P. Rico 48, $65-79$ (1956).

$[\mathrm{C} 17,868 / 56$

Rodriguez-0lleros, A., Galindo, L.: The action of cortisone and anterior corticotropic hormone on experimental gastritis and gastric ulcers. Gastroenterology 32, 675-688 (1957).

$[\mathrm{C} 38,499 / 57$

Roe, J. H., Coover, M. 0.: Role of the thyroid gland in urinary pentose excretion in the rat. Proc. Soc. exp. Biol. (N.Y.) 75, 818-819 (1951).

[B54,246/51

Roger, A. E., Shaka, J. A., Pechet, G., MacDonald, R. A.: Regeneration of the liver. Absence of a 'humoral factor' affecting hepatic regeneration in parabiotic rats. Amer. J. Path. 39, $561-578$ (1961).

[E93,548/61

Rogers, L. A., Alcantara, G. A., Fouts, J. R.: p-Aminosalicylic acid-induced prolongation of hexobarbital sleeping time. J. Pharmacol. exp. Ther. 142, 242-247 (1963). [E31,897/63

Rogers, L. A., Dixon, R. L., Fouts, J. R.: The effects of SKF 525-A on hepatic glycogen and rate of hepatic drug metabolism. Biochem. Pharmacol. 12, 341-348 (1963). [D64,023/63

Rogers, L. A., Fouts, J. R.: Some of the interactions of SKF 525-A with hepatic microsomes. J. Pharmacol. exp. Ther. 146, 286-293 (1964).

[F27,894/64

Rogoff, J. M., DeNecker, J.: The influence of the adrenals on the toxicity of morphine. J. Pharmacol. exp. Ther. 26, 243-258 (1925).

$[63,527 / 25$

Rohr, H. P., Strebel, J., Bianchi, L.: Ultrastrukturell-morphometrische Untersuchungen an der Rattenleberparenchymzelle in der Frühphase der Regeneration nach partieller Hepatektomie. Beitr. path. Anat. 141, 52-74 (1970).

$[\mathrm{H} 30,433 / 70$

Rolf, L. L. Jr., Campbell, L. A.: Thiobarbiturate anesthesia: a comparative study and statistical analysis in the dog. Arch. int. Pharmacodyn. 180, 350-359 (1969).

[H 18,467/69

Romeo, F., Squadrito, G., Ceruso, D.: Effetti proepatici di alcuni anabolizzanti: risultati clinici e sperimentali. Fegato 13, 313-314 (1967).

$[$ F $91,552 / 67$

Romeo, F., Squadrito, G., Ceruso, D.: Effetti proepatici degli steroidi anabolizzanti. Risultati clinici e sperimentali. Fegato 14, 153-172 (1968).

$[\mathrm{H} 7,930 / 68$

Rona, G.: Experimental studies on the mechanism of equine estrogens on pathological epiphyseal ossification. Proc. canad. Fed. biol. Soc. 5, 67 (1962).

[D26,276/62

Rona, G., Chappel, C. I.: Protection of scorbutic bone lesions of the guinea pig by equine estrogen. Endocrinology 72, 1-10 (1963).

$[\mathrm{D} 48,101 / 63$

Róna, G., Kerényi, N., Oblatt, E., Bretán, M.: Einfluß des Methylandrostenediol (Neosteron) auf die bei experimentellem Steroid-Diabetes auftretenden vasculären Veränderungen. $Z$. ges. exp. Med. 128, 87-102 (1956).

$[\mathrm{C} 39,946 / 56$

Rondell, P.: Follicular processes in ovulation. Fed. Proc. 29, 1875-1879 (1970). [H32,853/70

Ronzoni, G., Alquati, P., Pola, P., Alcini, E.: Studio sulla carcinogenesi prostatica con 20-metil-colantrene, nel ratto albino. Chir. Pat. sper. 16, 435-444 (1968). [ [H18,409/68

Ronzoni, G., Pirozzi, V., Zucchetti, E., Alcini, E., Wiel Marin, A.: Sulle epatosclerosi: L'OH- 
prolina nelle epatectomie subtotali di ratti con cirrosi sperimentale (Nota I). Chir. Pat. sper. 16, Sup., 62-70 (1968). $\quad[\mathrm{H} 18,986 / 68$ Rooks, W. H.: Irradiation protection. In: Dorfman; Methods in Hormone Research, p. 127-137. New York, London: Academic Press 1964.

$[\mathrm{E} 4,589 / 64$

Rooks, W. H., Dorfman, R. I.: Steroid-induced increase in survival of tumor-bearing rats. Cancer Res. 26, 338-339 (1966). [F62,099/66

Root, G. T., Mann, F. C.: An experimental study of shock with special reference to its effect on the capillary bed. Surgery 12, 861 to 877 (1942).

$[\mathrm{A} 57,542 / 42$

Rosadini, G., Bernardini, G.: Ricerche sperimentali sui rapporti tra steroidi sessuali femminili ed epilessie - I. Azione del progesterone e dell-estrone solfato nel test metrazolico. Boll. Soc. ital. Biol. sper. 38, 1294-1297 (1962). [D58,047/62

Rose, D. F., Cramp, D. G.: Reduction of plasma tyrosine by oral contraceptives and oestrogens: a possible consequence of tyrosine aminotransferase induction. Clin. chim. Acta 29, 49-53 (1970).

$[\mathrm{G} 75,215 / 70$

Rose, D. P., Braidman, I. P.: Oral contraceptives, depression, and aminoacid metabolism. Lancet 1970I, 1117-1118.

$[\mathrm{H} 25,726 / 70$

Rose, M. E.: Immunity to coccidiosis: effect of betamethasone treatment of fowls on Eimeria mivati infection. Parasitology 60, 137-146 (1970).

[G73,104/70

Rose, M. E., Long, P. L.: Resistance to Eimeria infections in the chicken: the effects of thymectomy, bursectomy, whole body irradiation and cortisone treatment. Parasitology 60, 291-299 (1970).

[G74,020/70

Rose, W. C., Bradley, S. G.: Retardation by methylprednisolone of the synergistic toxicity of endotoxin with sparsomycin or pactamycin. Proc. Soc. exp. Biol. (N.Y.) 132, 729-731 (1969).

[H 19,375/69

Rose, W.C., Bradley, S.G.: Enhanced toxicity for mice of bacterial endotoxin with daunomycin or sparsomycin (in press).

[G79,576

Rosen, A., Moran, N. C.: Comparison of the action of ouabain on the heart in hypothyroid, euthyroid and hyperthyroid dogs. Circulat. Res. 12, 479-486 (1963).

[D $65,414 / 63$

Rosen, F., Harding, H. R., Milholland, R. J., Nichol, C. A.: Glucocorticoids and transaminase activity. VI. Comparison of the adaptive increases of alanine- and tyrosine- $\alpha$-ketogluta- rate transaminases. $J$. biol. Chem. 238, 3725 to 3729 (1963).

[E32,653/63

Rosen, F., Milholland, R. J.: Induction of tryptophan pyrrolase (TPO) and tyrosine- $\alpha$ ketoglutarate transaminase (TKT) by tryptophan and its analogues in intact and adrenalectomized rats. Fed. Proc. 21, 237 (1962).

$[\mathrm{D} 23,053 / 62$

Rosen, F., Milholland, R. J.: Glucocorticoids and transaminase activity. VII. Studies on the nature and specificity of substrate induction of tyrosine- $\alpha$-ketoglutarate transaminase and tryptophan pyrrolase. J. biol. Chem. 238,3730 to 3735 (1963).

$[\mathrm{E} 32,652 / 63$

Rosen, F., Roberts, N. R., Budnick, L. E., Nichol, C. A.: An enzymatic basis for the gluconeogenic action of hydrocortisone. Science 127, 287-288 (1958).

$[\mathrm{C} 47,568 / 58$

Rosen, F., Roberts, N. R., Budnick, L. E., Nichol, C. A.: Specificity of the stimulatory effect of hydrocortisone on glutamic-pyruvic transaminase. Proc. Amer. Ass. Cancer Res. 2, 339-340 (1958).

$[\mathrm{C} 50,741 / 58$

Rosen, F., Roberts, N. R., Budnick, L. E., Nichol, C. A.: Corticosteroids and transaminase activity: the specificity of the glutamic-pyruvic transaminase response. Endocrinology 65, 256-264 (1959).

$[\mathrm{C} 71,414 / 59$

Rosen, F., Roberts, N. R., Nichol, C. A.: Glucocorticosteroids and transaminase activity. I. Increased activity of glutamic-pyruvic transaminase in four conditions associated with gluconeogenesis. J. biol. Chem. 234, 476-480 (1959).

$[\mathrm{G} 66,496 / 59$

Rosen, R., Nichol, C. A.: Corticosteroids and enzyme activity. In: Harris and Wool; Vitamins and Hormones. Advances in Research and Applications 21, p. 135-214. New York, London: Academic Press 1963. [E 3,837/63

Rosenbaum, P., Obrinsky, W.: Effect of cortisone on diphtheria intoxication and the Schick test in guinea pigs. Proc. Soc. exp. Biol. (N.Y.) 83, 502-506 (1953).

$[\mathrm{B} 85,352 / 53$

Rosenblum, I.: Interaction of vasopressin with adrenocorticotrophic hormone, cortisone and somatotrophic hormone; possible relation to eclamptic convulsions. Proc. Soc. exp. Biol. (N.Y.) 89, 84-85 (1955).

$[\mathrm{C} 5,974 / 55$

Rosene, G. L., Jr.,: Alteration of tumor cell and hepatic parenchymal cell mitotic rates in tumor-injected partially hepatectomized mice. Cancer Res. 28, 1469-1477 (1968).

$[\mathrm{G} 71,661 / 68$ 
Rosenfeld, G.: Potentiation of the narcotic action and acute toxicity of alcohol by primary aromatic monoamines. Quart. J. Stud. Alcohol. 21, 584-596 (1960).

[G72,151/60

Rosenfeld, R., Krapilová, I., Steiglová, J., Rosenfeldová, A.: Sensitization of challenger effect of iron following partial hepatectomy. Physiol. bohemoslov. 16, 577-580 (1967). [G55,854/67

Rosenfeld, R., Kvapilová, I., Steiglová, J., Rosenfeldová, A.: Neobvyklý pohled na výnzam jater pro challengerový účinek želesa při kalcifylaxi. (Abstr.) Čs. Fysiol. 16, 273 (1967).

[G67,785/67

Rosenfeldová, A., Steiglová, J., Kvapilová, I., Rosenfeld, R.: Enhanced toxic effect of pharmacological doses of calciferol in rats after partial hepatectomy. Physiol. bohemoslov. 16, 581 (1967).

[G55,855/67

Rosenthal, S. M.: Experimental chemotherapy of burns and shock. III. Effects of systemic therapy on early mortality. Publ. Hlth. Rep. (Wash.) 58, 513-522 (1943). [B26,228/43

Ross, L. E., van Wagtendonk, W. J., Wulzen, R.: Evidence for a steroid compound in cane juice possessing antistiffness activity. Proc. Soc. exp. Biol. (N.Y.) 71, 281-283 (1949).

$[\mathrm{B} 37,268 / 49$

Rossi, G. B., Oriente, P., Porrazzi, L. C., Vecchione, A., Cerqua, R.: Deoxycorticosterone acetate and experimental atherosclerosis in cholesterol-fed rabbits. Nature (Lond.) 203, 252-254 (1964).

[F 18,184/64

Rosta, J., Makói, Z., Fehér, T., Korányi, G.: Steroid inhibition of glucuronization. Acta paediat. Acad. Sci. hung. 11, 67-69 (1970).

$[\mathrm{G} 77,094 / 70$

Roth, F. J., Jr., Friedman, J., Syverton, J. T.: Effects of roentgen radiation and cortisone on susceptibility of mice to Candida albicans. J. Immunol. 78, 122-127 (1956). [C32,916/56

Rothlin, E.: Sur la thérapeutique de l'intoxication par le phosgène. $C$. R. gén. XIme Congr. int. Méd. Pharm. milit., p. 1-10 (1947).

[B30,696/47

Rothlin, E., Schalch, W. R.: Zur Pharmakologie und Toxikologie des Scillirosids und des Scillirosidins. Helv. physiol. pharmacol. Acta 10, 427-437 (1952).

$[\mathrm{G} 75,565 / 52$

Rotter, W.: Untersuchungen über den Einfluß gesteigerter Schilddrüsentätigkeit auf die Höhenfestigkeit im Tierexperiment. Arch. Kreisl.-Forsch. 9, 226-257 (1942).

$[\mathrm{A} 63,564 / 42$
Röttger, P., Nolte, F., Kühn, H. A., Creutzfeldt' W.: Untersuchungen über die therapeutische Beeinflußbarkeit experimenteller Lebercirrhosen bei der Ratte. II. Die Thioacetamid-Cirrhose der Ratte und ihre Beeinflussung durch Glucocorticoide, Androgene und Tolbutamid. Z. ges. exp. Med. 136, 486-499 (1963).

[D $64,427 / 63$

Rous, P., Larimore, L. D.: Relation of the portal blood to liver maintenance. A demonstration of liver atrophy conditional on compensation. J. exp. Med. 31, 609-632 (1920).

$[\mathrm{D} 88,911 / 20$

Rowe, W.P., Black, P.H., Levey, R.H.: Protective effect of neonatal thymectomy on mouse LCM infection. Proc. Soc. exp. Biol. (N.Y.) 114, 248-251 (1963).

[E $29,673 / 63$

Rowinski, P., De Muro, P., Manunta, G.: Ipertensione sperimentale da desossicorticosterone (D.C.A.) e sesso. Boll. Soc. ital. Biol. sper. 27, 1 - 2 (1951).

[B64,142/51

Rowinski, P., Manunta, G.: Influenza dell'ovaio sulla sopravivenza di ratti paratiroidectomizzati. R. C. Accad. naz. Lincei, Cl. Sci. fis. mat. nat., Ser. VIII, 10, 495-499 (1951).

[B 64, 144/51

Roy, A.B.: The enzymic synthesis of aryl sulphamates. 2. The effect of $3 \beta$-methoxyandrost5-en-17-one on arylamine sulphokinase. Biochem. J. 79, 253-261 (1961). [D5,284/61

Rubin, A., Stohler, c. M., Novick, W. J.: Inhibition of testosterone stimulation of microsomal hexobarbital metabolism by $17 \alpha$ methyl-B-nortestosterone (SK\&F 7690). Biochem. Pharmacol. 14, 1898-1899 (1965).

$[\mathrm{F} 73,811 / 65$

Rubin, A., Tephly, T. R., Mannering, G. J.: Kinetics of drug metabolism by hepatic microsomes. Biochem. Pharmacol. 13, 1007 to 1016 (1964).

$[\mathrm{G} 58,057 / 64$

Rubin, A., Tephly, T. R., Mannering, G. J.: Inhibition of hexobarbital metabolism by ethylmorphine and codeine in the intact rat. Biochem. Pharmacol. 13, 1053-1057 (1964).

[G58,747/64

Rubin, B. L.: Sex differences in orientation of reduction products of 30 keto- $\mathrm{C}_{19}$ steroids by rat liver homogenates. J. biol. Chem. 227, 917-927 (1957).

$[\mathrm{G} 76,315 / 57$

Rubin, B. L., Strecker, H. J.: Further studies on the sex difference in $3 \beta$-hydroxysteroid dehydrogenase activity of rat livers. Endocrinology 69, 257-267 (1961).

$[\mathrm{D} 9,290 / 61$ 
Rubin, E., Hutterer, F.: Quantitation of cortisone effect on hepatic fibrosis. Fed. Proc. 20, 289 (1961).

$[\mathrm{D} 4,173 / 61$

Rubino, F., Giacalone, 0.: Sul decorso della ipoalimentazione calorica dei ratti trattati con 17 $\alpha$-metil-17 $\beta$-idrossiandrosta-1-4-dien-3-one. Boll. Soc. ital. Biol. sper. 39, 154-155 (1963).

[E 36,677/63

Rubio, M.: Influencia del acetato de cortisona sobre la virulencia y localizacion tisular de una nueva cepa de Trypanosoma cruzi. Estudio de la persistencia de los cambios observados. Biologica 21, 75-89 (1955).

$[\mathrm{C} 34,556 / 55$

Rubio, M.: Mitosis en celulas parasitadas por Trypanosoma cruzi. Estudio en animales de laboratorio. Biologica (Chile) 22, 51-62 (1956).

[C41,052/56

Rudas, B., Weissel, W.: Frühketonämie bei Alloxandiabetes, zugleich ein Beitrag zur Durabolinwirkung. Wien. klin. Wschr. 75, 846-848 (1963).

[E34,762/63

Rudofsky, S., Crawford, J. S.: Some alterations in the pattern of drug metabolism associated with pregnancy, oral contraceptives and the newly-born. Pharmacologist 8, 181 (1966).

$[\mathrm{E} 58,989 / 66$

Ruebner, B. H., Hirano, T., Slusser, R. J.: Electron microscopy of the hepatocellular and Kupffercell lesions of mouse hepatitis, with particular reference to the effect of cortisone. Amer. J. Path. 51, 163-189 (1967).

$[\mathrm{G} 48,873 / 67$

Rugh, R., Clugston, H.: Radiosensitivity with respect to the estrous cycle in the mouse. Radiat. Res. 2, 227-236 (1955). [C11,209/55

Rugh, R., Skaredoff, L., Makay, C.: Postirradiation castration of the male and enhanced survival. Proc. Soc. exp. Biol. (N.Y.) 116, 1110-1114 (1964).

[F 21,653,64

Rugh, R., Wolff, J.: Relation of gonad hormones to $X$-irradiation sensitivity in mice. Proc. Soc. exp. Biol. (N.Y.) 92, 408-410 (1956).

$[\mathrm{C} 19,209 / 56$

Rümke, C. L.: Enhancing and decreasing effects of drugs on the convulsant action of bemegride. Acta physiol. pharmacol. neerl. 10, 288-289 (1962).

[G76,692/62

Rümke, C. L.: Die Verlängerung der Hexobarbitalnarkose durch kurz vorher intraperitoneal oder subcutan verabreichtes Serotonin. Naunyn-Schmiedebergs Arch. Pharmak. 243, 298 (1962).

$[\mathrm{G} 76,693 / 62$

Rümke, C. L.: The influence of drugs on the duration of hexobarbital and hydroxydione narcosis in mice. Naunyn-Schmiedebergs Arch. Pharmak. 244, 519-530 (1963). [G69,768/63 Rümke, C. L.: Unterschiedliche Dauer der Hexobarbitalnarkose bei männlichen und weiblichen Mäusen. Naunyn-Schmiedebergs Arch. Pharmak. 255, 64-65 (1966).

$$
\text { [G68,532/66 }
$$

Rümke, C. L.: A difference between the duration of hexobarbital narcosis in male and female mice? Arzneimittel-Forsch. 18, 60-62 (1968).

[G 71,098/68

Rümke, C. L., Bout, J.: Die Beeinflussung der Hexobarbitalnarkose durch vorher verabfolgte Pharmaka. Naunyn-Schmiedebergs Arch. Pharmak. 240, 218-223 (1960).

[G74,669/60

Rümke, C. L., Noordhoek, J.: The influence of pretreatment with lynestrenol on the anticonvulsant effect of phenobarbitone and phenytoin in mice. Acta physiol. pharmacol. neerl. 15, 66 (1969).

$[\mathrm{G} 76,850 / 69$

Rümke, C. L., Noordhoek, J.: The influence of lynestrenol on the rate of metabolism of phenobarbital, phenytoin and hexobarbital in mice. Europ. J. Pharmacol. 6, 163-168 (1969).

$[\mathrm{H} 14,039 / 69$

Rümke, C. L., Noordhoek, J.: Sex differences in the duration of hexobarbital narcosis and in serum MUP content in mice. Arch. int. Pharmacodyn. 182, 399-400 (1969).

[H21,659/69

Rummel, W.: Zur Abhängigkeit der Narkoseschwelle von metabolischen, hormonellen und pharmakologischen Einflüssen. Anaesthesist 8, 328-332 (1959).

$[\mathrm{C} 79,429 / 59$

Rummel, W., Jacobi, H., Kreutzer, F. J., von der Brelie, E.: Abhängigkeit der $\mathrm{N}_{2} \mathrm{O}$-Narkoseschwelle von Erregungszustand und Stoffwechsel. Naunyn-Schmiedebergs Arch. Pharmak. 231, 141-148 (1957).

[D89,013/57

Rummel, W., Wellensiek, H. J.: Der Einfluß von Thyroxin und 2,4-Dinitrophenol auf die $\mathrm{N}_{2} \mathrm{O}$-Narkoseschwelle schilddrüsenloser Ratten. Naturwissenschaften 45, 266-267 (1958).

[D96,909/58

Rummel, W., Wellensiek, H. J., Puder, D.: Über die Wirkung von Steroidhormonen auf die $\mathrm{N}_{2} \mathrm{O}$-Narkoseschwelle der Ratte. Arch. int. Pharmacodyn. 122, 329-338 (1959).

$[\mathrm{C} 80,035 / 59$

Rumsfeld, H. W., Jr., Miller, W. L., Jr., Baumann, C. A.: A sex difference in the development of liver tumors in rats fed 3'-methyl4-dimethylaminoazobenzene or 4'-fluoro-4-dimethylaminoazobenzene. Cancer Res. 11, 814-819 (1951). 
Rupe, B. D., Bousquet, W. F., Miya, T. S.: Stress modification of drug response. Science 141, 1186-1187 (1963).

[E26,910/63

Rupp, E., Knackstedt, R.: Zur Frage der experimentellen Gonokokkeninfektion der weiBen Maus unter dem Einfluß von Cortison. Dermat. Wschr. 136, 932-936 (1957).

[C42,998/57

Rusakov, V. I., Chernov, V. N.: Another way of preventing the adhesion disease. (Russian text.) Eksp. Khir. 14/1, 28-32 (1969). [H9,072/69

Russell, F. E., Emery, J. A.: Effects of corticosteroids on lethality of Ancistrodon contortrix venom. Amer. J. med. Sci. 241, 507-511 (1961).

[D $2,497 / 61$

Rutsch, W.: Der Einfluß der Schilddrüse auf die Erregbarkeit des Zentralnervensystems, geprüft mit einer Methode quantitativer Narkose. Z. Biol. 93, 283-292 (1933).

$[7,744 / 33$

Rybová, R., Janáček, K.: A sex-dependent effect of aldosterone on frog bladder. Naturwissenschaften 57, 459-460 (1970).

$[\mathrm{G} 78,569 / 70$

Rydin, H.: Action de la chlorophylle et de la thyroxine sur la sensibilité de l'organisme à l'égard d'une rarefaction de l'oxygène. $C . R$. Soc. Biol. (Paris) 99, 1685-1686 (1928).

$[22,940 / 28$

Saarnivaara, L.: A possible role of 5-hydroxytryptamine in morphine analgesia in rabbits. Scand. J. clin. Lab. Invest. 21, Sup. 101, 85-86 (1968).

$[\mathrm{H} 2,855 / 68$

Saarnivaara, L.: Effect of 5-hydroxytryptamine on morphine analgesia in rabbits. Ann. Med. exp. Fenn. 47, 113-123 (1969).

$[\mathrm{G} 71,565 / 69$

Sackler, M. D., Sackler, A. M., Martin, C. R., Sackler, R. R.: Gonadectomy and histamine tolerance. Fed. Proc. 12, 363 (1953).

[B 78,749/53

Sacra, P., McColl, J. D.: Modification of acute toxicity of hypoglycemics by hormones. Proc. Canad. Fed. Biol. 2nd Ann. Meet. 9-11 June, Toronto, p. 58 (1959).

$[\mathrm{C} 73,654 / 59$

Sacra, P. J., Adamkiewicz, V. W.: Glycemia and the activity of compound 48-80 in the rat. Arch. int. Pharmacodyn. 156, 255-260 (1965).

[F 49,352/65

Saggers, V. H., Hariratnajothi, N., McLean, A. E. M.: The effect of diet and phenobarbitone on quinine metabolism in the rat and in man. Biochem. Pharmacol. 19, 499-503 (1970).

$[\mathrm{G} 73,683 / 70$
Saidi, P., Hoag, M.S., Aggeler, P.M.: Transplacental transfer of bishydroxycoumarin in the human. J. Amer. med. Ass. 191, 761-763 (1965).

[F 32,236/65

Saini, V. C., Patrick, S. J.: Effect of estrone on conversion of cholesterol to bile acids. Biochim. biophys. Acta (Amst.) 202, 556-559 (1970).

$[\mathrm{G} 74,405 / 70$

Saint Omer, F. B., Mincione, G.: La rigenerazione epatica dopo ampia epatectomia nel corso della steatosi da dieta ipocolinica. Arch. De Vecchi Anat. pat. 33, 597-618 (1960).

$[\mathrm{D} 53,460 / 60$

Saint-0mer, F. B., Tosi, P., Colairanceschi, M., Bruscagli, G.: Le modificazioni della rigenerazione epatica dopo epatectomia parziale in topi inoculati con carcinoma-ascite di Ehrlich e con mastocitoma-ascite. Arch. De Vecchi Anat. pat. 53, 165-190 (1968).

$[\mathrm{G} 71,148 / 68$

Saito, S. et al.: Antipicrotoxin-convulsion effects of catecholamines caused by the intracerebral in mice and the role of brain catecholamines, $5 \mathrm{HT}$ and GABA. (Japanese text.) Keio $J$. Med. 8, 879-899 (1963).

$[\mathrm{E} 27,616 / 63$

Sakamoto, A., Prasad, K. N.: Radioprotective action of $\beta$-melanocyte-stimulating hormone (MSH) in rodents exposed to whole-body X-irradiation. Int. J. Radiat. Biol. 12, 97-99 (1967).

$[\mathrm{F} 95,441 / 67$

Saksena, S. K., Chaudhury, R. R.: Androgenic, anti-androgenic and anabolic activity of azasteroids on immature castrated rats. Indian J. med. Res. 58, 513-518 (1970).

[G 78,486/70

Sakurai, K.: Utber die Rückbildung des MetHämoglobins. III. Mitteilg.: Versuche am lebenden Tier. Naunyn-Schmiedebergs Arch. Pharmak. 109, 214_232 (1925). [E67,662/25

Sala, E., Perris, C.: Ricerche sull'attivita della 5-idrossitriptamina a livello della giunzione neuromuscolare (Abstr.). Musc. Dystrophy. Abstr. 3, Nr. 1179, p. 331 (1959). [C78,420/59 Salgado, E. D., Mulroy, M. I.: The role of the pituitary and thyroid in DCA-induced cardiovascular disease in the rat. Ann. N.Y.Acad. Sci. 72, 854-862 (1959).

[C84,321/59

Salmoiraghi, G. C., Page, I. H.: Effects of LSD 25, BOL 148, bufotenine, mescaline and ibogaine on the potentiation of hexobarbital hypnosis produced by serotonin and reserpine. J. Pharmacol. exp. Ther. 120, 20-25 (1957).

[C38,518/57

Salmoiraghi, G. C., Sollero, L., Page, I. H.: Blockade by brom-lysergic-acid-diethylamide (BOL) of the potentiating action of serotonin 
and reserpine on hexobarbital hypnosis. $J$. Pharmacol. exp. Ther. 117, 166-168 (1956).

$[\mathrm{C} 21,596 / 56$

Salva, S. de: Effects of centrally acting drugs in intact and hypophysectomized rats on EST. Arch. int. Pharmacodyn. 137, 267-271 (1962).

[D27,783/62

Salva, S. de: Effect of drugs on EST in various endocrine deficient states. Arch. int. Pharmacodyn. 142, 361-365 (1963). [ [D66,176/63

Salva, S. de: EST effects of diphenylhydantoin in hypophysectomized rats. Arch. int. Pharmacodyn. 142, 366-370 (1963).

$[\mathrm{D} 66,177 / 63$

Salva, S. de, Evans, R., Johson, C., Schauer, W.: EST and drug effects in endocrine deficiencies. Fed. Proc. 17, 363 (1958). [C51,842/58

Salvador, R. A., Atkins, C., Haber, S., Conney, A. H.: Changes in the serum concentration of cholesterol, triglycerides and phospholipids in the mouse and rat after administration of either chlorcyclizine or phenobarbital. Biochem. Pharmacol. 19, 1463-1469 (1970).

[G75,529/70

Salvador, R. A., Atkins, C., Haber, S., Kozma, C., Conney, A. H.: Effect of phenobarbital and chlorcyclizine on the development of atheromatosis in the cholesterol-fed rabbit. Biochem. Pharmacol. 19, 1975-1981 (1970).

$[\mathrm{G} 74,397 / 70$

Salvador, R. A., Conney, A. H., Kozman, C.: Inhibitory effect of phenobarbital on cholesterol-induced atherosclerosis in the rabbit (Abstr.). Pharmacologist 9, 254 (1967). [ [G68,113/67

Salvin, S. B., Peterson, R. D. A., Good, R. A.: The thymus gland and resistance to infectious agents. Fed. Proc. 24, 160 (1965). [F 35,876/65 Salvin, S. B., Peterson, R. D. A., Good, R. A.: The role of the thymus in resistance to infection and endotoxin toxicity. J. Lab. clin. Med.65, 1004-1022 (1965).

[G 30,533/65

Salzberg, D. A., Griffin, A. C.: Inhibition of azo dye carciogenesis in the alloxan-diabetic rat (Abstr.). Cancer Res. 12, 294 (1952).

$[\mathrm{B} 68,802 / 52$

Samaras, S. C., Dietz, N., Jr.: Precipitation of prolonged convulsions in stressed rats and mice. Physiologist 1, 68 (1958). [C56,733/58

Sambhi, M. P., Weil, M. H., Udhoji, V. N., Shubin, H.: Adrenocorticoids in the management of shock. In: Hershey; Shock 2, p. 421 to 433. Boston, Mass.: Little, Brown \& Co. 1964.

$[\mathrm{G} 68,985 / 64$

Samiy, A. E.: Effect of thyroxin pretreatment on decarboxylation of dihydroxyphenylalanine (dopa) and production of sustained hypertension. Fed. Proc. 11, 136 (1952).

$[\mathrm{B} 68,269 / 52$

Sammalisto, L.: Blood sugar and alcohol intoxication in the rat. Acta physiol. scand. 55, 313-318 (1962).

$[\mathrm{G} 76,362 / 62$

Samuels, L. T., Eik-Nes, K. B.: Metabolism of steroid hormones. In: Greenberg, D. M.; Metabolic Pathways. II. Lipids, Steroids, and Carotenoids, p. 169-220. New York, London: Academic Press Inc. 1968. [G73,454/68

Sananès, N., Psychoyos, A.: Effet de l'actinomycine-D sur le développement du déciduome chez la ratte. C. R. Acad. Sci. (Paris) 271, $430-433$ (1970).

$[\mathrm{G} 78,230 / 70$

Sandberg, F.: The effect of hepatectomy and nephrectomy on the anaesthetic activity of some N-substituted barbiturates. Acta physiol. scand. 28, 1-5 (1953).

$[\mathrm{G} 71,886 / 53$

Sandhu, D. K., Sandhu, R. S., Damodaran, V. N., Randhawa, H. S.: Effect of cortisone on bronchopulmonary aspergillosis in mice exposed to spores of various Aspergillus species. Sabouraudia 8, 32-38 (1970). [G75,603/70

Sandri, 0., Gallarate, L., Ballarin, G.: Azione dell'ipofisi sulla ipertrofia renale compensatoria nei ratti. Atti Soc. lombarda Sci. med. biol. 10, 480-484 (1955).

$[\mathrm{C} 13, \mathbf{1 5 0 / 5 5}$

Sanfilippo, E.: Ipotermia passiva e ormone paratiroideo. Rass. terap. Patol. clin. 7, 465-480 (1935).

$[56,085 / 35$

Sanfilippo, E., Ricea, S.: Influenza dell'ormone tiroideo nell'assideramento. Resistenza dell'organismo, temperatura e peso degli organi. Riv. Pat. sper. 4, 303-317 (1935). [31,704/35

Santo, E.: Die histologischen Grundlagen der Reid Hunt-Reaktion an der Schilddrüse der weißen Maus. Z. ges. exp. Med. 93, 793-802 (1934).

$[27,439 / 34$

Sanyal, R. K.: Chemical mediators of adrenaline-induced pulmonary oedema. Int.Arch. Allergy 33, 59-64 (1968). [ [G55,044/68

Sanyal, R. K., Spencer, P. S. J., West, G. B.: Insulin and hypersensitivity. Nature (Lond.) 184, 2020 (1959).

$[\mathrm{C} 79,555 / 59$

Sarre, H.: Zur Pathogenese und Therapie des nephrotischen Syndroms. Dtsch. med. Wschr. 79, 1652-1654, 1713-1717 (1954).

[B99,950/54

Sas, M., Herezeg, J.: Das Verhalten der Steroidausscheidung und des Serum-Bilirubinspiegels bei Neugeborenen nach $\mathrm{C}_{19}$-Steroid-Belastung. Arch. Gynäk. 209, 50-57 (1970). [H27,522/70 
Sas, M., Herczeg, J.: Serum-Bilirubinwerte und Steroidausscheidung bei mit $3 \alpha, 20 \alpha$ - und $3 \alpha$, 20 $\beta$-Pregnandiol belasteten Neugeborenen. Arch. Gynäk. 209, 58-70 (1970). [H 27,523/70 Sas, M., Herczeg, J.: Serum bilirubin level and steroid excretion following progesterone loads in new-born infants. Acta paediat. Acad. Sci. hung. 11, 35-40 (1970).

[G77,093/70

Sasame, H. A., Castro, J. A., Gillette, J. R.: Studies on the destruction of liver microsomal cytochrome $\mathrm{P}-450$ by carbon tetrachloride administration. Biochem. Pharmacol. 17, 1759 to 1768 (1968).

[G72,114/68

Sátori, 0., Szabó, G.: Utber die Wirkung von Dexamethason beim Tourniquet-Schock. $Z$. ges. exp. Med. 137, 47-51 (1963). [E21,902/63

Satoskar, R. S., Trivedi, J. C.: Effect of hydrocortisone on acute pentobarbital toxicity in mice. Proc. Soc. exp. Biol. (N.Y.) 89, 695 to 696 (1955).

$[\mathrm{C} 8,678 / 55$

Saviano, M.: Azione della follicolina nel rachitismo sperimentale. Arch. Sci. biol. (Bologna) 21, 579-607 (1935). [60,155/35

Savini, E., Savini, T.: Thyroïde et anaphylaxis. C. R. Soc. Biol. (Paris) 78, 198-199 (1915).

[A24,559/15

Savoie, L., Krajny, M., Kleiman, B.: Digitoxin induced cardiac necrosis and its inhibition. Cardiologia (Basel) 54, 287-294 (1969).

[G60,080/69

Savoie, L., Krajny, M., Selye, H.: Prophylactic action of spironolactone in digitoxin poisoning (Abstr.). Proc. Canad. Fed. biol. Soc., Edmonton, Alta 12, 58 (1969).

[G60,028/69

Savoldi, F., Maggi, G. C., Noli, S.: Azione dell'adrenalina e della noradrenalina sull'attività elettrica corticale del coniglio in narcosi barbiturica. Boll. Soc. ital. biol. sper. 36, 545 a 547 (1960).

$[\mathrm{C} 92,984 / 60$

Scaffidi, L., Arrigo, F.: Studio comparativo sugli effetti di HCG e di HMG sulla cardiopatia sperimentale da emetina. Boll. Soc. ital. Biol. sper. 44, 991-993 (1968).

[G62,941/68

Scafifidi, L., Fidecaro, A.: Azione protettiva della cocarbossilasi e della gonadotropina corionica sulla miocardiopatia difterica sperimentale. Arch. Atti Soc. med.-chir. Messina 9, $3-23$ (1965).

[G51,129/65

Scaffidi, L., Fidecaro, A.: Azione protettiva della cocarbossilasi e della gonadotropina corionica sulla miocardiopatia difterica sperimentale. Boll. Soc. ital. Biol. sper. 42, 1284-1286 (1966).

[G43,543/66
Searborough, E. M.: The influence of thyroid feeding on nembutal poisoning. J. Physiol. (Lond.) 86, 183-189 (1936).

$[34,971 / 36$

Scarinci, V.: Ricerche farmacologiche sulla idrossitriptamina. I. Azione sull'epilessia riflessa. Arch. ital. Sci. farmacol. 5, 265-270 (1955).

[G66,316/55

Schachter, H., Sidloisky, S., Baker, D. G., Hamilton, J. R., Haist, R. E.: The effect of previous exposure to cold on shock secondary to limb ischaemia. Canad. J. Biochem. 37, 211-223 (1959).

[C63,544/59

Schachter, R. J., Huntington, J.: Use of orally administered desiccated thyroid in production of traumatic shock. Proc. Soc. exp. Biol. (N.Y.) 44, 66-68 (1940). [A32,970/40 Schäfer, E. L.: Tuberkulose und innere Sekretion. Ergebn. ges. Tuberk.-Forsch. 12, 209-327 (1954).

[B99,955/54

Schäfer, E. L.: Tierexperimentelle Untersuchungen zur Frage der Bedeutung des Mineralstoffwechsels für die Tuberkulose. Beitr. Klin. Tuberk. 110, 409-425 (1954). [G58,597/54 Schäfer, E. L., Greuel, H.: Orale Antidiabetika und experimentelle Meerschweinchen-Tuberkulose. Tuberk.-Arzt 16, 589-595 (1962).

[D 54,900/62

Schapiro, S.: Adrenal cortical hormones and resistance to histamine stress in the infant rat. Acta endocr. (Kbh.) 48, 249-252 (1965).

[F31,856/65

Schapiro, S.: Interaction between growth hormone and cortisol on the regulation of liver tyrosine transaminase activity. Endocrinology 83, 475-478 (1968).

[H 2,360/68

Schapiro, S., Geller, E., Yuwiler, A.: Differential effects of a stress on liver enzymes in adult and infant rats. Neuroendocrinology (Basel) 1, 138-143 (1965/66). [F 65,746/65/66

Schapiro, S., Geller, E., Yuwiler, A.: Interaction of STH and corticoids in enzyme regulation during stress and development. Program 51st Meet. Endocr. Soc., New York, N. Y., p. 186 (1969).

$[\mathrm{H} 12,411 / 69$

Schapiro, S., Yuwiler, A., Geller, E.: Stressactivated inhibition of the cortisol effect on hepatic transaminase. Life Sci. 3, 1221-1226 (1964).

[G21,848/64

Schapiro, S., Yuwiler, A., Geller, E.: Maturation of a stress-activated mechanism inhibiting induction of tyrosine transaminase. Science 152, 1642 (1966).

[F67,227/66

Scharf, J.-H., Ehrenbrand, F., Goliah, S.: Veränderungen des Zellbildes des Hypophysen- 
vorderlappens der Ratte unter getrennter und kombinierter Verabreichung von Methylthiouracil, p-Oxypropiophenon und 2,3-Dithiopropanol. Z. mikr.-anat. Forsch. 66, 251-265 (1960).

[C91,620/60

Scharf, J.-H., Wichmann, T., Marzotko, D., Schmidt, R.: Vergleiche zwischen den Lebern antithyreoidal, antadenohypophysär und contrainsular behandelter weißer Ratten. $Z$. mikr.-anat. Forsch. 74, 482-522 (1966).

[F 69,957/66

Schatzmann, H. J.: Kompetitiver Antagonismus zwischen g-Strophanthin und Corticosteron an isolierten Streifen von Rattenaorten. Experientia 15/2, 73-74 (1959).

$[\mathrm{C73,682/59}$

Schauer, A., Kunze, E., Burkhard, B., Rosnitschek, J.: Beeinflussung der Cancerisierung der Rattenleber durch Steroidhormone. Naturwissenschaften 57, 676-677 (1970). [G81,318/70

Schechet, I. A.: The effect of desiccated thyroid, iodinated casein on a rachitogenic diet. Science 113, 60-61 (1951).

$[\mathrm{B} 61,419 / 51$

Scheer, B. T., Mumbach, M. W., Cox, B. L.: Hormonal regulation of salt balance in frogs. Fed. Proc. 20, 177 (1961).

[D3,935/61

Scheffler, J., Westphal, W.: Die Beeinflussung der Leberregeneration bei Ratten durch ein Gemisch von Purinen und Orotsäure. ArzneimittelForsch. 13, 75-76 (1963).

$[\mathrm{D} 56,080 / 63$

Scheifley, C. H.: Pentothal sodium: its use in the presence of hepatic disease. Anesthesiology 7, 263-267 (1946).

[A48,124/46

Scheifley, C. H., Higgins, G. M.: The effect of partial hepatectomy on the action of certain barbiturates and a phenylurea derivative. Amer. J. med. Sci. 200, 264-268 (1940).

$[48,633 / 40$

Schenkman, J. B., Frey, I., Remmer, H., Estabrook, R. W.: Sex differences in drug metabolism in rat liver microsomes. Molec. Pharmacol. 3, 516-525 (1967).

$[\mathrm{G} 67,777 / 67$

Scherb, J., Kirschner, M., Arias, I.: Studies of hepatic excretory function. The effect of $17 \alpha$ ethyl-19-nortestosterone on sulfobromophthalein sodium (BSP) metabolism in man. J. clin. Invest. 42, 404-408 (1963).

[D 58,943/63

Scherr, G. H.: The influence of hormones on experimental moniliasis. Monogr. Therap. 2, $80-82$ (1957).

$[\mathrm{C} 39,263 / 57$

Schimke, R. T.: Studies on factors affecting the levels of urea cycle enzymes in rat liver. J. biol. Chem. 238, 1012-1018 (1963). [D39,880/63
Schimke, R. T., Doyle, D.: Control of enzyme levels in animal tissues. Ann. Rev. Biochem. 39, 929-958 (1970).

$[\mathrm{G} 75,997 / 70$

Schimke, R. T., Sweeney, E. W., Berlin, C. M.: An analysis of the kinetics of rat liver tryptophan pyrrolase induction: the significance of both enzyme synthesis and degradation. Biochem. biophys. Res. Commun. 15, 214-219 (1964).

[G11,062/64

Schimke, R. T., Sweeney, E. W., Berlin, C. M.: The roles of synthesis and degradation in the control of rat liver tryptophan pyrrolase. $J$. biol. Chem. 240, 322-331 (1965). [G 24,293/65

Schimmelpfennig, W., Hagemann, I., Korte, G.: Über den Einfluß von 4-Chlortestosteronazetat (Turinabol) auf das akute Nierenversagen der Ratte. Acta biol. med.germ. 17, 298-306 (1966).

[F 74,978/66

Schlesinger, K., Boggan, W. O., Griek, B. J.: Pharmacogenetic correlates of pentylenetetrazol and electroconvulsive seizure thresholds in mice. Psychopharmacologia (Berlin) 13, 181 to 188 (1968).

$[\mathrm{G} 61,802 / 68$

Schlesinger, K., Stavnes, K. L., Boggan, W. 0.: Modification of audiogenic and pentylenetetrazol seizures with gamma-aminobutyric acid, norepinephrine and serotonin. Psychopharmacologia (Berlin) 15, 226-231 (1969).

$[\mathrm{G} 69,565 / 69$

Schmid, K., Cornu, F., Imhof, P., Keberle, H.: Die biochemische Deutung der Gewöhnung an Schlafmittel. Schweiz. med. Wschr. 94, 235-240 (1964).

$[\mathrm{G} 34,008 / 64$

Schmid, R., Buckingham, S., Mendilla, G. A., Hammaker, L.: Bilirubin metabolism in the foetus. Nature (Lond.) 183, 1823-1824 (1959).

$[\mathrm{G} 76,338 / 59$

Schmid, R., Marver, H. S., Hammaker, L.: Enhanced formation of rapidly labeled bilirubin by phenobarbital: hepatic cytochromes as a possible source. Biochem. biophys. Res. Commun. 24, 319-328 (1966).

[G68,199/66

Schmidinger, H., Kröger, H.: Zur Hunger-Induktion der Serin-Dehydratase in der Rattenleber. Hoppe-Seylers Z. physiol. Chem. 348, 1367-1371 (1967).

$[\mathrm{F} 92,031 / 67$

Schmidt, E., Schmidt, F. W.: Enzyme activities in human liver. Enzymol. biol. clin. (Basel) 11, 67-129 (1970).

$[\mathrm{G} 73,170 / 70$

Schmidt, H.: Versuche zur therapeutischen Beeinflussung der Diphtheriegiftwirkung beim Meerschweinchen durch C-Vitamin und Nebennierenrindenhormon-Präparate. Dtsch. med. Wschr. 63, 1003-1006 (1937). $\quad[94,670 / 37$ 
Schmidt, J.: Úber die gegenseitige pharmakologische Beeinflussung von Serotonin und Noradrenalin. Biochem. Pharmacol. 12, Sup. 163 (1963).

[E32,188/63

Schmidt, J., Matthies, H.: Die Beeinflussung der Pentetrazol-Krampfschwelle durch intracerebrale Injektion von Reserpin und biogenen Aminen. Acta biol. med. germ. 8, 426-436 (1962).

[D34,219/62

Schmidt, L., Bernauer, W.: Die chronische Lithiumvergiftung an Ratten unter besonderer Berücksichtigung der Veränderungen im Steroidgehalt der Nebennierenrinde. NaunynSchmiedebergs Arch. Pharmak. 245, 112 (1963).

[D 65,293/63

Schmidt, L. H.: The effect of thyroxine ingestion on the toxicity of certain bile salts. Amer. $J$. Physiol. 108, 613-620 (1934).

$[27,511 / 34$

Schmuñis, G., Weissenbacher, M., Parodi, A. S.: Tolerance to Junin virus in thymectomized mice. Arch. ges. Virusforsch. 21, 200-204 (1967).

[G55,003/67

Schneiberg, K., Gorski, T.: X-ray irradiation and thymectomy as the factors enhancing the chemical cancerogenesis in mouse skin. Pol. med. J. 8, 647-653 (1969).

[G68,745/69

Schneiberg, K., Jonecko, A., Bartnikowa, W.: Thymus-organe hématopoiétique? I. L'âge et la saison comme facteurs déterminants. L'influence du thymus sur la radiorésistance naturelle chez la souris. Folia haemat. (Lpz.) 88, 253-259 (1967).

[G56,009/67

Schneiberg, K., Jonecko, A, Bartnikowa, W.: Der Thymus - ein hämatopoetisches Organ? III. Der Einfluß von Thymusgewebe in Diffusionskammern auf das Ưberleben und das blutbildende System von Mäusen nach subletaler Ganzkörperbestrahlung. Folia haemat. (Lpz.) 89, 265-282 (1968).

[G69,791/68

Schneiberg, K., Koziol-Bartnikowa, W., Jonecko, A.: Serum protein changes in acute radiation disease in thymectomized mice. Arch. Immunol. Ther. exp. 16, 85-91 (1968).

[G58,579/68

Schneiberg, K., Stiller-Winkler, R., Jonecko, A.: Regeneration of peripheral blood in thymectomized mice after sublethal whole-body irradiation. Pol. med. J. 6, 1163-1179 (1967).

[G58,580/67

Schneider, E., Widman, E.: Die hepatohormonale Steuerung des Vitamin-A-Umsatzes und die Ätiologie der Ostitis deformans Paget. Klin. Wschr. 14, 1786-1790 (1935).

$[33,725 / 35$
Schnitzer, A.: Klinische und experimentelle Untersuchungen zur Pathogenese der Karzinome. Oncologia (Basel) 9, 301-309 (1956).

[C32,871/56

Schoen, H. R., Voss, R.: Der Einfluß einer Vorbehandlung mit Thyroxin, anorganischem Jod und essentiellen Phospholipiden auf die Tetanustoxin-Empfindlichkeit des Meerschweinchens. Klin. Wschr. 39, 972-973 (1961).

[D 11,906/61

Schoenfield, L. J., Foulk, W.T.: Studies of sulfobromophthalein sodium (BSP) metabolism in man. II. The effect of artificially induced fever, norethandrolone (Nilevar), and iopanoid acid (Telapaque). J. clin. Invest. 43, 1419-1423 (1964).

[F 16,168/64

Schoental, R.: Hepatotoxic activity of retrorsine, senkirkine and hydroxysenkirkine in newborn rats, and the role of epoxides in carcinogenesis by pyrrolizidine alkaloids and aflatoxins. Nature (Lond.) 227, 401-402 (1970).

[H $27,417 / 70$

Scholler, K. L.: Augmentation ou suppression de l'hépatotoxicité du chloroforme. Cah. Anesth. 18, 223-230 (1970).

[G75,794/70

Scholtz, H. G.: Beeinflussung von experimentellem Hyperparathyroidismus durch Thymuspräparate. Z. ges. exp. Med. 85, 547-558 (1932).

$[4,272 / 32$

Schönbaum, E., Sellers, E. A., Johnson, G. E.: Heat production and noradrenaline. Fed. Proc. 22, 917-919 (1963).

[E21,028/63

Schoor, W. P.: Effect of anticonvulsant drugs on insecticide residues. Lancet $1970 \mathrm{II}, 520$ to 521.

[H $28,965 / 70$

Schopp, R. T., Kreutter, W. F., Guzak, S. V.: Neuromyal blocking action of mescaline. Amer. J. Physiol. 200, 1226-1228 (1961). [E92,442/61

Schopp, R. T., Rife, E. M.: Neuromuscular actions of serotonin following partial curarization. Physiologist 6, 269 (1963). [E24,636/63

Schor, J. M., Frieden, E.: Induction of tryptophan peroxidase of rat liver by insulin and alloxan. J. Biol. Chem. 233, 612-618 (1958).

$[\mathrm{C} 57,994 / 58$

Schottek, W., Bekemeier, H.: Beeinflussung experimentell erzeugter Kalkablagerungen in der Niere durch Hormone. Acta biol. med. germ. 10, Sup. 2, 237-239 (1963).

[E39,551/63

Schöttler, W. H. A.: Antihistamine, ACTH, cortisone, hydrocortisone and anesthetics in snake bite. Amer. J. trop. Med. Hyg. 3, 1083 to 1091 (1954).

$[\mathrm{C} 10,890 / 54$ 
Schöttler, W. H. A.: On the therapeutic value of ACTH and cortisone in experimental burns. Endocrinology 57, 445-449 (1955). [C8,455/55 Schou, J.: Absorption of drugs from subcutaneous connective tissue. Pharmacol. Rev. 13, 441-464 (1961).

[E92,436/61

Schreiber, E. C.: The metabolic alteration of drugs. Ann. Rev. Pharmacol. 10, 77-98 (1970).

[G 73,539/70

Schreiber, H.: Utber die Bedeutung von Schwefel in Form von SH- bzw. SS-Gruppen enthaltenden Stoffen für den Organismus. Ergebn. Hyg. Bakt. 14, 271-296 (1933). [A48,020/33 Schreiber, V.: Experimentalni přispěvek $\mathrm{k}$ poznání vlivu strumigenů na vegetativní nervový systém. Fysiologie 3, 400-401 (1954).

$[\mathrm{C} 3,482 / 54$

Schriefers, H., Ghraf, R., Brodesser, M.: Geschlechtsspezifika der Biosynthese von Steroidglucuroniden in der mit Testosteron perfundierten Rattenleber. Acta endocr. (Kbh.) 63, $59-68$ (1970).

$[\mathrm{H} 21,007 / 70$

Schriefers, H., Wassmuth, E.: Das Ausmaß der Cortison-Hydrierung durch Rattenleberschnitte in seiner geschlechtsspezifischen Abhängigkeit von der mikrosomalen $\Delta^{4}-5 \alpha$-Hydrogenase-Aktivität. Hoppe-Seylers Z. physiol. Chem. 338, 100-104 (1964). [G23,742/64

Schrogie, J. J., Solomon, H. M.: The anticoagulant response to bishydroxycoumarin. II. The effect of D-thyroxine, clofibrate, and norethandrolone. Clin. Pharmacol. Ther. 8, 70-77 (1966).

[G43,019/66

Schulte, F. J., Bruggencate, H. G. ten.: Die Wirkung von Nebennierenrindenhormon auf einzelne Nervenzellen im Rückenmark der Katze. Ein experimenteller Beitrag zum Wirkungsmechanismus des Prednisolon in der Therapie zentralnervöser Erkrankungen. Klin. Wschr. 40, 865-872 (1962).

[D 32,457/62

Schultz, J.: Influence of the presence of a sterile abscess on the detoxication of brombenzene as mercapturic acid. Fed. Proc. 7, 185 (1946).

[B 18,183/46

Schultz, M. P.: The induction of carditis by the combined effects of infection and hyperthyroidism. Trans. 3rd Int. Goiter Conf. Amer. Ass. Study Goiter, Washington, p. 355-358 (1938).

$[99,001 / 38$

Schultz, M. P., Rose, E. J.: Induction of carditis by the treatment of infected guinea pigs with insulin. U.S. publ. Health Repts. 54, 527-532 (1939).

$[\mathrm{B} 31,347 / 39$

Schulz, K.-D., Stutzer, H., Bettendorf, G.: Die Wirkung von Clomid auf die Aktivität der mikrosomalen NAD-spezifischen 17- $\beta$-Hydroxy steroiddehydrogenase in der Leber weiblicher infantiler Meerschweinchen. Endokrinologie 55, 22-27 (1969).

$[\mathrm{H} 19,404 / 69$

Schumer, W.: Dexamethasome in oligenic shock. Physiochemical effects in monkeys. Arch. Surg. 98, 259-261 (1969). 「G64,570/69

Schuurmans, R.: De invloed van de zwangerschap op ontstaan en verloop van het aneurysma dissecans. Geneesk. Gids 40, 138-141 (1962).

[D23,829/62

Schwartz, H. L., Kozyreff, V., Surks, M. I., Oppenheimer, J. H.: Increased deiodination of L-thyroxine and L-triiodothyronine by liver microsomes from rats treated with phenobarbital. Nature (Lond.) 221, 1262-1263 (1969).

$[\mathrm{H} 9,326 / 69$

Schwartz, H. L., Shapiro, H. C., Surks, M. I., Oppenheimer, J. H.: Dissociation between metabolism and action of L-thyroxine T4. (Abstr.) Program 52nd Meet. Endocr. Soc., St. Louis Miss., p. 92 (1970). $\quad$ [H26,012/70 Schwartz, K.: Inhibitory effect of cortisone on dietary necrotic liver degeneration in the rat. Science 113, 485-486 (1951). [B [ [ $57,985 / 51$

Schweizer, W.: Studies on the effect of 1-tyrosine on the white rat. J. Physiol. 106, 167-176 (1947).

$[\mathrm{B3}, 047 / 47$

Schweppe, J. S., Jungmann, R. A.: The effect of hormones on hepatic cholesterol ester synthesis in vitro. Proc. Soc. exp. Biol. (N.Y.) 131, 868-870 (1969).

[H 15,266/69

Schweppe, J. S., Jungmann, R. A.: Hormones and cholesterol ester metabolism. J. Amer. Geriat. Soc. 17, 740-754 (1969). [H 15,978/69 Schwetz, B. A., Plaa, G. L.: Catecholamine potentiation of carbon tetrachloride-induced hepatotoxicity in mice. Toxicol. appl. Pharmacol. 14, 495-509 (1969).

$[\mathrm{G} 67,000 / 69$

Scilabra, G. A., Pugliese, F.: L'influsso della noradrenalina sulla reversione controllata della xantomatosi viscerale. Arch. De Vecchi Anat. pat. 51, 883-902 (1968).

$[\mathrm{G} 68,796 / 68$

Scott, E. B., Dynes, T. F.: The effects of growth hormone on phenylalanine-tyrosine deficient and pairfed rats. Growth 21, 115-128 (1957).

$[\mathrm{C} 53,564 / 57$

Scott, W. J. M.: The influence of the adrenal glands on resistance. I. The susceptibility of adrenalectomized rats to morphine. $J$. exp. Med. 38, 543-560 (1923).

$[16,870 / 23$

Scott, W. J. M.: The influence of the adrenal glands on resistance. II. The toxic effect of killed bacteria in adrenalectomized rats. $J$. exp. Med. 39, 457-471 (1924). $\quad[17,400 / 24$ 
Scott, W. J. M., Bradford, W. L., Hartman, F. A., McCoy, O. R.: The influence of adrenal cortex extract on the resistance to certain infections and intoxications. Endocrinology 17, 529-536 (1933).

$[15,446 / 33$

Sealy, W. C.: Role of infection in the pathogenesis of liver necrosis in hyperthyroidism. Ann. Surg. 116, 851-859 (1942). [A56,716/42 Sealy, W. C., Lyons, C. K.: Necrosis of the liver produced by the combination of experimental hyperthyroidism and inflammation. Arch. Surg. 59, 1319-1326 (1949).

[B46,719/49

Segal, H. L., Beattie, D. S., Hopper, S.: Purification and properties of liver glutamic-alanine transaminase from normal and corticoidtreated rats. J. biol. Chem. 237, 1914-1920 (1962).

[G67,774/62

Segal, H. L., Kim, Y. S.: Glucocorticoid stimulation of the biosynthesis of glutamic-alanine transaminase. Proc. nat. Acad. Sci. (Wash.) 50, 912-918 (1963).

[G67,769/63

Segal, H. L., Rosso, R. G., Hopper, S., Weber, M. M.: Direct evidence for an increase in enzyme level as the basis for the glucocorticoid-induced increase in glutamic-alanine transaminase activity in rat liver. J. biol. Chem. 237, 3303-3305 (1962).

[D45,899/62

Segaloff, A., Maxfield, W. S.: The synergism between radiation and estrogen in the production of mammary cancer in the rat. Cancer Res. 31, 166-168 (1971).

[H36,188/71

Seguy, Dayot, Napie: Cancer provoqué au benzopyrène chez la rate. Etude de l'action des stimulines hypophysaires et des oestrogènes. Etude particulière de l'oestrus pendant la cancérisation. Bull. Acad. nat. Méd. (Paris) 145, 181-186 (1961).

[D 5,238/61

Seidman, I., Teebor, G. W., Becker, F. F.: Hormonal and substrate induction of tryptophan pyrrolase in regenerating rat liver. Cancer Res. 27, 1620-1625 (1967).

[F 88,452/67

Seifter, J., Rauzzino, F., Kramer, S. Z.: The effect of some indoles in chicks (Abstr.). Pharmacologist 5, 246 (1963). [G71,087/63

Seller, M. J., Spector, R. G.: Effect of aldosterone and cortisol on leptazol-induced seizures in rats. Brit. J. Pharmacol. 19, 271-273 (1962).

[D36,979/62

Sellers, ${ }^{\text {}}$ E. A., Reichman, S., Thomas, N.: Acclimatization to cold: natural and artificial. Amer. J. Physiol. 167, 644-650 (1951). [B 65,310/51

Sellers, E. A., You, R. W.: Propylthiouracil, thyroid, and dietary liver injury. J. Nutr. 44, $513-535$ (1951).

[B 68,641/51
Sellers, E. A., You, R. W., Ridout, J. H., Best, C. H.: Partial protection by cortisone against renal lesions produced by hypolipotropic diets. Nature (Lond.) 166, 514 (1950). [B52,716/50

Sellers, M. I.: Studies in the entry of viruses into the central nervous system of mice via the circulation. Differential effects of vasoactive amines and $\mathrm{CO}_{2}$ on virus infectivity. $J$. exp. Med. 129, 719-746 (1969).

[H 10,893/69

Selye, H.: A syndrome produced by diverse nocuous agents. Nature (Lond.) 138, 32 (1936).

$[36,031 / 36$

Selye, H.: Studies on adaptation. Endocrinology 21, 169-188 (1937).

$[38,798 / 37$

Selye, H.: The effect of the alarm reaction on the absorption of toxic substances from the gastro-intestinal tract. J. Pharmacol. exp. Ther. 64, 138-145 (1938).

[A 8,052/38

Selye, H.: On the toxicity of oestrogens with special reference to diethylstilboestrol. Canad. med. Ass. J. 41, 48-49 (1939). [A 18,206/39

Selye, H.: Morphological changes in female mice receiving large doses of testosterone. J. Endocr. 1, 208-215 (1939).

[A 18,308/39

Selye, H.: The effect of testosterone on the kidney and on the general condition of uremic animals. Canad. med. Ass. J. 42, 189 (1940).

[A30,863/40

Selye, H.: On the protective action of testosterone against the kidney damaging effect of sublimate. J. Pharmacol. exp. Ther. 68, 454 to 457 (1940).

$[\mathrm{A31}, 126 / 40$

Selye, H.: On the protective action of testosterone against the kidney-damaging effect of sublimate. Canad. med. Ass. J. 42, 173-174 (1940).

$[\mathrm{A} 31,128 / 40$

Selye, H.: The beneficial action of desoxycorticosterone acetate in uraemia. Canad. med. Ass. J. 43, 333-335 (1940). [A 34,190/40

Selye, H.: Anesthetic effect of steroid hormones. Proc. Soc. exp. Biol. (N.Y.) 46, 116-121 (1941).

[A35,003/41

Selye, H.: On the role of the liver in the detoxification of steroid hormones and artificial estrogens. J. Pharmacol. exp. Ther. 71, 236 to 238 (1941).

[A 35,150/41

Selye, H.: Acquired adaptation to the anesthetic effect of steroid hormones. J. Immunol. 41, 259-268 (1941).

[A35,410/41

Selye, H.: The anesthetic effect of steroid hormones. Amer. J. Physiol. 133, 442 (1941).

[A $35,659 / 41$ 
Selye, H.: Studies concerning the anesthetic action of steroid hormones. J. Pharmacol. exp. Ther. 73, 127-141 (1941). [A36,210/41

Selye, H.: The antagonism between anesthetic steroid hormones and pentamethylenetetrazol (Metrazol). J. Lab. clin. Med. 27, 1051-1053 (1942).

[A 36,443/42

Selye, H.: Studies concerning the correlation between anesthetic potency, hormonal activity and chemical structure among steroid compounds. Anesth. Analg. Curr. Res. 21, 42 (1942).

$[\mathrm{A} 36,447 / 42$

Selye, H.: Mechanism of parathyroid hormone action. Arch. Path. 34, 625-632 (1942).

[A $36,715 / 42$

Selye, H.: Correlations between the chemical structure and the pharmacological actions of the steroids. Endocrinology 30, 437 (1942).

[A $36,744 / 42$

Selye, H.: The pharmacology of steroid hormones and their derivatives. Rev. canad. Biol. 1, 577-632 (1942).

$[\mathrm{A} 37,822 / 42$

Selye, H.: Morphological changes in the fowl following chronic overdosage with various steroids. J. Morph. 78, 401-421 (1943).

$[\mathrm{A} 56,607 / 43$

Selye, H.: Encyclopedia of Endocrinology. Section I. The steroids. Montréal: A.W.T. Franks Publ. Co. 1943.

$[\mathrm{A} 57,606 / 43$

Selye, H.: Experimental investigations concerning the role of the pituitary in tumorigenesis. Surgery 16, 33-46 (1944).

$[\mathrm{A} 60,638 / 44$

Selye, H.: Role of the hypophysis in the pathogenesis of the diseases of adaptation. Canad. med. Ass. J. 50, 426-433 (1944). [A 75,044/44

Selye, H.: Textbook of Endocrinology, 2nd ed., p. 914. Montreal, Canada: Acta Endocrinologica Inc. 1947, 1949.

$[94,572 / 49$

Selye, H.: Further studies concerning the participation of the adrenal cortex in the pathogenesis of arthritis. Brit. med. J. 1949 II, 1129 to 1135 .

[B39,702/49

Selye, H.: Stress, p. 822. Montreal: Acta Inc., Med. Publ. 1950.

$[\mathrm{B} 40,000 / 50$

Selye, H.: Interactions between the adrenocorticotrophic hormone (ACTH) and the somatotrophic hormone (STH) in respect to their effects upon the kidney and the cardiovascular apparatus. In: Mote, J. R.; Proceedings of the second clinical ACTH conference, p. 95-107. New York, Philadelphia, Toronto: The Blakiston Co. 1951.

[B53,934/51
Selye, H.: Production par la somatotrophine hypophysaire (STH) d'hyalinose expérimentale. Inhibition par la cortisone, aggravation par la désoxycorticostérone. Rev. canad. Biol. 9, 473-474 (1951).

[B53,940/51

Selye, H.: Inhibition par une substance folliculoide de la néphrosclérose normalement produite par la désoxycorticostérone. Rev. canad. Biol. 9, 474 (1951).

[B53,941/51

Selye, H.: The influence of STH, ACTH and cortisone upon resistance to infection. Canad. med. Ass. J. 64, 489-494 (1951). [B57,451/51

Selye, H.: First Annual Report on Stress, p. 644 . Montreal, Canada: Acta Inc. Med. Publ. 1951.

$[\mathrm{B} 58,650 / 51$

Selye, H.: Role of somatotrophic hormone (STH) in body defense against infection. Fed. Proc. 11, 144 (1952).

$[\mathrm{B} 65,065 / 52$

Selye, H.: The Story of the Adaptation Syndrome, p. 225. Montreal, Canada: Acta Inc. Med. Publ. 1952.

[B 71,000/52

Selye, H.: Prevention of cortisone overdosage effects with the somatotrophic hormone (STH). Amer. J. Physiol. 171, 381-384 (1952).

$[\mathrm{B} 75,329 / 52$

Selye, H.: Effets d'un traitement simultané à la STH et à une substance folliculoïde. Ann. Endocr. (Paris) 14, 378-384 (1953).

$[\mathrm{B} 70,245 / 53$

Selye, H.: Use of "granuloma pouch" technic in the study of antiphlogistic corticoids. Proc. Soc. exp. Biol. (N.Y.) 82, 328-333 (1953).

[B 76,060/53

Selye, H.: On the mechanism through which obstructive jaundice influences inflammatory processes. Ann.rheum. Dis. 13, 102-108 (1954).

[B $90,556 / 54$

Selye, H.: Anticortisol action of aldosterone. Science 121, 368-369 (1955). [ [B98,268/55 Selye, H.: The Stress of Life, p. 324. New York, Toronto, London: McGraw-Hill Book Co. 1956.

$[\mathrm{C} 19,000 / 56$

Selye, H.: Protection by pregnancy against the development of experimental arteriosclerosis and metastatic calcification. Amer. J. Obstet. Gynec. 74, 289-294 (1957). [ [C25,011/57 Selye, H.: Utber die humorale Beeinflussung des experimentellen Lathyrismus. Arch. exp. Pathol. Pharmacol. 230, 155-160 (1957).

$[\mathrm{C} 25,013 / 57$

Selye, H.: Skeletal lesions produced by chronic treatment with somatotrophic hormone (STH) and aminoacetonitrile (AAN). J. Geront. 12, 270-278 (1957).

$[\mathrm{C} 25,910 / 57$ 
Selye, H.: Effect of castration upon arteriosclerosis produced by dihydrotachysterol (AT10 ) in male rats. Lab. Invest. 6, 301-304(1957).

[C27,682/57

Selye, H.: Effect of various hormones upon the syndrome of dihydrotachysterol (AT-10) intoxication. Acta endocr. (Kbh.) 25, 83-90 (1957).

$[\mathrm{C} 27,735 / 57$

Selye, H.: Utber den Einfluß lokaler Faktoren bei der Entstehung von Nierensteinen und Gewebsverkalkungen. Z. Urol. 50, 440-444 (1957).

$[\mathrm{C} 27,736 / 57$

Selye, H.: Lathyrism. Rev. canad. Biol. 16, 1-82 (1957).

[C31,369/57

Selye, H.: Participation of the adrenals in the effect of various hormones upon experimental osteolathyrism. Arch. int. Physiol. 65, 391-395 (1957).

[C31,790/57

Selye, H.: Prevention by thyroxine of the ocular changes normally produced by $\beta \beta$ '-iminodipropionitrile (IDPN). Amer. J. Ophthal. 44, 763-765 (1957).

[C36,049/57

Selye, H.: Prevention of vitamin A overdosage by somatotrophic hormone. J. Endocr. 16, 231-235 (1957).

[C36,050/57

Selye, H.: Effect of sex hormones upon hypervitaminosis-A. Rev. suisse Zool. 64, 757-761 (1957).

[C37,276/57

Selye, H.: Sensitization by oestradiol to the production of experimental nephrocalcinosis. Nature (Lond.) 180, 1420-1421 (1957).

$[\mathrm{C38,401/57}$

Selye, H.: Effect of corticoids upon skeletal and renal changes produced by stylomycin aminonucleoside. Proc. Soc. exp. Biol. (N.Y.) 96, 544-547 (1957).

$[\mathrm{C38}, 594 / 57$

Selye, H.: Influence of various hormones and vitamin-D preparations upon established bone lathyrism. Acta anat. (Basel) 33, 146-156 (1958).

[C28,810/58

Selye, H.: Prevention of the ECC syndrome by thyroxin. J. clin. exp. Psychopath. 19, 97-101 (1958).

[C36,069/58

Selye, H.: Sensitization of the skeleton to vitamin-A overdosage by cortisol. Arthr. and Rheum. 1, 87-90 (1958).

[C36,386/58

Selye, H.: Prevention of experimental nephrocalcinosis with thyroxine (Abstr.). Endocrinology 62, 227-229 (1958).

[C38,627/58

Selye, H.: Participation of ovarian hormones in the development of nephrocalcinosis. Gynaecologia (Basel) 145, 161-167 (1958).

$[\mathrm{C} 38,768 / 58$
Selye, H.: Schutzwirkung der Hypophysektomie gegenüber einer experimentellen Nephrocalcinose. Endokrinologie 35, 193-196 (1958).

$[\mathrm{C} 39,319 / 58$

Selye, H.: Protection by pregnancy against the development of "infarctoid cardiopathy" and nephrocalcinosis. J. Obstet. Gynaec. Brit. Emp. 65, 588-589 (1958).

[C44,470/58

Selye, H.: The Chemical Prevention of Cardiac Necroses, p. 235. New York: The Ronald Press Co. 1958.

[C50,810/58

Selye, H.: Wechselwirkungen zwischen Stress, Elektrolyten und Steroiden beim Entstehen verschiedener Kardiopathien und Myopathien. Endokrinologie 38, 195-217 (1959).

$[\mathrm{C} 61,814 / 59$

Selye, H.: Protection by a steroid-spirolactone against certain types of cardiac necroses. Proc. Soc. exp. Biol. (N.Y.) 104, 212-213 (1960).

$[\mathrm{C} 82,516 / 60$

Selye, H.: The Pluricausal Cardiopathies, p. 438. Springfield, Ill.: Charles C Thomas Publ. 1961.

[C92,918/61

Selye, H.: Nonspecific Resistance. Ergebn. allg. Pathol. pathol. Anat. 41, 208 (1961).

[C95,972/61

Selye, H.: Calciphylaxis, p. 552. Chicago, Ill.: The University of Chicago Press 1962.

[D 15,540/62

Selye, H.: The Mast Cells, p. 498. London: Butterworths 1965.

[G 19,425/65

Selye, H.: Thrombohemorrhagic Phenomena, p. 337. Springfield, Ill.: Charles C Thomas Publ. 1966.

[E 5,986/66

Selye, H.: Anaphylactoid Edema, p. 318. St. Louis, Miss.: Warren H. Green Inc. 1968.

[G46,715/68

Selye, H.: Spironolactone actions, independent of mineralocorticoid blockade. Steroids 13, 803 to 808 (1969).

[G60,003/69

Selye, H.: Catatoxic Steroids. Canad. med. Ass. J. 101, 51 (1969).

[G60,039/69

Selye, H.: Prevention of indomethacin-induced intestinal ulcers by spironolactone and norbolethone. Canad. J. Physiol. Pharmacol. 47, $981-983$ (1969).

[G60,046/69

Selye, H.: Role of the liver in the prevention of indomethacin-induced intestinal ulcers by spironolactone. Acta hepato-splenol. (Stuttg.) 59-74 (1969).

[G60,058/69

Selye, H.: Inhibition of anesthesia by steroids. J. Pharmacol. exp. Ther. 174, 478-486 (1970).

$[\mathrm{G} 60,044 / 70$ 
Selye, H.: Prevention of various forms of metabolic myocardial necrosis by catatoxic steroids. J. molec. Cell. Cardiol. 1, 91-99 (1970).

$[\mathrm{G} 60,064 / 70$

Selye, H.: Adaptive steroids: retrospect and prospect. (Russian text). Pat. Fiziol. éksp. Ter., (in press).

$[\mathrm{G} 70,410 / 71$

Selye, H.: Adaptive steroids: retrospect and prospect. Perspect. Biol. Med. 13, 343-363 (1970).

$[\mathrm{G} 60,070 / 70$

Selye, H.: Experimental Cardiovascular Diseases, p. 1120. Berlin, Heidelberg, New York: Springer 1970.

$[\mathrm{G} 60,083 / 70$

Selye, H.: Prevention of mephenesin intoxication by catatoxic steroids. Acta pharmacol. (Kbh.) 28, 145-148 (1970). [G60,086/70

Selye, H.: Resistance to picrotoxin poisoning induced by catatoxic steroids. Agents and Actions 1, 133-135 (1970). [G60,087/70 Selye, H.: Protection by catatoxic steroids against phenindione overdosage. Thrombos. Diathes. haemorrh. (Stuttg.) xxiv, No. 1, p. 77 (1970).

$[\mathrm{G} 60,094 / 70$

Selye, H.: Protection against methyprylon overdosage by catatoxic steroids. Canad. Anaesth. Soc. J. 17, 107 (1970).

$[\mathrm{G} 60,097 / 70$

Selye, H.: Prevention of colchicine intoxication by catatoxic steroids. Endocr. exp. 4, 71-76 (1970).

$[\mathrm{G} 60,098 / 70$

Selye, H.: Les stéroïdes catatoxiques: rétrospective et perspective. Rev. Méd. fonct. p. 163-199 (1970).

$[\mathrm{G} 60,100 / 70$

Selye, H.: Protection by catatoxic steroids against cycloheximide intoxication. Toxicol. appl. Pharmacol. 17, 721-725 (1970).

$[\mathrm{G} 70,403 / 70$

Selye, H.: Pharmaco-chemical interrelations among catatoxic steroids. Rev. canad. Biol. 29, 49-102 (1970).

$[\mathrm{G} 70,421 / 70$

Selye, H.: Mercury poisoning: prevention by spironolactone. Science 169, 775-776 (1970).

[G70,426/70

Selye, H.: Steroids and nonspecific resistance. Image 12, No. 5, p. 3 (1970).

[G70,427/70

Selye, H.: Conditioning of catatoxic steroid actions by the thyroid. J. Med. exp. clin. 1, $43-55$ (1970).

$[\mathrm{G} 70,428 / 70$

Selye, H.: Resistance to various pesticides induced by catatoxic steroids. Arch. environm. Hlth. 21, 706-710 (1970).

$[\mathrm{G} 70,435 / 70$

Selye, H.: Hormone und Widerstandsfähigkeit. Münch. med. Wschr. 31, 1401-1407 (1970).

[G70,447/70
Selye, H.: Protection by glucocorticoids against ganglioplegics. Res. Commun. chem. Path. Pharmacol. 1, No. 4, 572-579 (1970).

$[\mathrm{G} 70,448 / 70$

Selye, H.: Stress, hormones and cardiovascular disease. Proc. 3rd Ann. Meet. Int. Study Group in Cardiac Metab. Stowe, Vt. (1970).

$[\mathrm{G} 70,465 / 70$

Selye, H.: Protection by catatoxic steroids against cyclophosphamide-induced organ lesions, Virchows Arch. Pathol. Anat. 351, 248 to 259 (1970).

$[\mathrm{G} 70,466 / 70$

Selye, H.: Catatoxic steroids. G. Clin. med. 51, 619-625 (1970).

$[\mathrm{G} 70,491 / 70$

Selye, H.: Neue Ergebnisse der Streßforschung: Katatoxische Steroide. In: Jubilee Volume of German Society for the Advancement of Medical Science, p. 69-77 (1971). [G79,017/71 Selye, H.: Steroids influencing the toxicity of l-tyrosine. J. Nutr. 101, 515-524 (1971).

$[\mathrm{G} 70,468 / 71$

Selye, H.: Hormones and resistance. $J$. pharm. Sci. 60, 1-28 (1971).

[G 70,480/71

Selye, H.: Prevention of indomethacin-induced intestinal ulcers by various catatoxic steroids. Exp. Med. Surg. (in press). $\quad[$ G60,066

Selye, H.: Protection by catatoxic steroids against cocaine poisoning. Int. J. Psychobiol. (in press).

[G70,471

Selye, H.: Influence of various catatoxic steroids upon chronic dihydrotachysterol intoxication. Hormones (in press).

[G70,467

Selye, H.: Steroids and resistance. Jubilee volume of Prof. A. I. Strukov, Medicina (Kaunas), (in press).

$[\mathrm{G} 79,021$

Selye, H., Bajusz, E.: Effect of various stressors on muscular contraction induced by $\mathrm{NaH}_{2} \mathrm{PO}_{4}$ and $\mathrm{NaClO}_{4}$. Amer. J. Physiol. 196, 681-684 (1959).

$[\mathrm{C} 55,656 / 59$

Selye, H., Beland, E., Stone, H.: Effet des hormones hypophysaires, thyroïdienne et corticosurrénale sur la structure rénale. Rev. canad. Biol. 4, 120 (1945).

[B 229/45

Selye, H., Bois, P.: Experimental studies on the influence of corticoids and STH upon the course of obstructive jaundice. Gastroenterologia (Basel) 82, 193-209 (1954). [B [ [

Selye, H., Bois, P.: Morphologische Studien über den Synergismus zwischen dem somatotrophen Hormon und den Mineralocorticoiden. Virchows Arch. pathol. Anat. 327, 235-252 (1955).

$[\mathrm{C} 1,718 / 55$ 
Selye, H., Bois, P.: On the role of the adrenal cortex in the production of renal calcification. Proc. Roy. Soc. Can. 50, app. C., 54 (1956).

$[\mathrm{C} 12,616 / 56$

Selye, H., Bois, P.: Effect of corticoids on the resistance of the kidney to an excess of phosphates. Amer. J. Physiol. 187, 41-44 (1956).

$[\mathrm{C} 13,141 / 56$

Selye, H., Bois, P.: On the participation of the adrenal cortex in the production of experimental nephrocalcinosis. Acta endocr. (Kbh.) 22, 330-334 (1956).

$[\mathrm{C} 13,168 / 56$

Selye, H., Bois P.: Anticortisol action of 2methyl-9( $\alpha$ )-fluorocortisol. Proc. Soc. exp. Biol. (N.Y.) 92, 362-364 (1956). [C 14,534/56

Selye, H., Bois, P.: On the influence of various hormones upon the development of experimental lathyrism. Rev. canad. Biol. 15, 281 (1956).

$[\mathrm{C} 18,280 / 56$

Selye, H., Bois, P.: Effect of corticoids upon the resistance of the kidney to sublimate intoxication. J. Lab. clin. Med. 49, 263-266 (1957).

[C14,441/57

Selye, H., Bois, P.: On the role of corticoids in conditioning the gastric mucosa to certain toxic actions of ergocalciferol. Brit. J. Nutr. 11, 18 to 22 (1957).

$[\mathrm{C} 16,506 / 57$

Selye, H., Bois, P.: Effet des hormones adaptives sur le lathyrisme expérimental du rat. $A n n$. $A C F A S$ 23, 80 (1957).

$[\mathrm{C} 22,712 / 57$

Selye, H., Bois, P.: Effect of STH on experimental lathyrism. Proc. Soc. exp. Biol. (N.Y.) 94, 133-137 (1957).

$[\mathrm{C} 23,297 / 57$

Selye, H., Bois, P.: Effect of corticoids upon experimental lathyrism. Endocrinology 60, 507 to 513 (1957).

$[\mathrm{C} 23,298 / 57$

Selye, H., Bois, P.: Anaphylaktoide Entzündung und Magengeschwüre bei mit Serotonin behandelten Ratten. Allergie u. Asthma 3, 11-15 (1957).

$[\mathrm{C} 23,958 / 57$

Selye, H., Bois, P., Ventura, J.: Inhibition of experimental nephrocalcinosis by hypophysectomy. Proc. Soc. exp. Biol. (N.Y.) 92, 488 to 493 (1956).

$[\mathrm{C} 16,047 / 56$

Selye, H., Cantin, M.: Hormonal bedingte Dissoziation der Wirkung eines Lathyrogens auf Knochen und Herz. Beitr. pathol Anat. 124, 175-182 (1961).

$[\mathrm{C} 88,878 / 61$

Selye, H., Clarke, E.: Potentiation of a pituitary extract with $\Delta^{5}$-pregnenolone and additional observations concerning the influence of various organs on steroid metabolism. Rev. canad. Biol. 2,319 to 328 (1943).

$[55,978 / 43$

Selye, H., Collip, J. B., Thomson, D. L.: Some interrelations between water and fat meta- bolism in relation to disturbed liver function. Lancet 1935 II, 297.

$[32,783 / 35$

Selye, H., Dosne, C.: Inhibition by cortin of the blood sugar changes caused by adrenalin and insulin. Proc. Soc. exp. Biol. (N.Y.) 42, 580 to 583 (1939).

[A 30,701/39

Selye, H., Dosne, C.: Effect of cortin after partial and after complete hepatectomy. Amer. $J$. Physiol. 128, 729-735 (1940). [A 30,702/40

Selye, H., Dosne, C.: Treatment of wound shock with corticosterone. Lancet 1940I, 70-71.

$[\mathrm{A} 33,299 / 40$

Selye, H., Dosne, C.: Physiological significance of compensatory adrenal atrophy. Endocrinology 30, 581-584 (1942).

$[\mathrm{A} 37,249 / 42$

Selye, H., Dosne, G., Bassett, L., Whittaker, J.: On the therapeutic value of adrenal cortical hormones in traumatic shock and allied conditions. Canad. med. Ass. J. 43, 1-8 (1940).

[A32,768/40

Selye, H., Friedman, S. M.: The beneficial action of testosterone in experimental renal atrophy caused by ligature of the ureter. Endocrinology 29, 80-81 (1941). [A35,722/41 Selye, H., Gabbiani, G., Jean, P.: Inhibition by hypophysectomy of organ lesions normally produced by parathyroid hormone or dihydrotachysterol. Lab. Invest. 11, 1332-1339 (1962).

$[\mathrm{D} 25,666 / 62$

Selye, H., Gabbiani, G., Tuchweber, B.: Beteiligung der Hypophyse bei dem durch Dihydrotachysterin und Chromchlorid erzeugten calciphylaktischen Syndrom. Endokrinologie 43, 241-252 (1962).

[D20,710/62

Selye, H., Gabbiani, G., Tuchweber, B.: Factors influencing topical calcinosis induced by trauma following intravenous injection of lead acetate. Arch. int. Pharmacodyn. 145, 254-264 (1963).

[D25,657/63

Selye, H., Gabbiani, G., Tuchweber, B.: Organ lesions produced by hexadimethrine and their modification by various agents. Med. exp. (Basel) 8, 74-82 (1963).

[D25,745/63

Selye, H., Gabbiani, G., Tuchweber, B.: Effect of parathyroidectomy and ferric dextrin upon calciphylactic sensitization by uremia. J. Urol. (Baltimore) 90, 120-124 (1963). [D32,610/63 Selye, H., Gentile, G.: Erzeugung calciphylaktischer Speicheldrüsenveränderungen durch Serotonin. Naturwissenschaften 48, 671 (1961).

$[\mathrm{D} 6,950 / 61$

Selye, H., Goldie, I., Strebel, R.: Effect of anabolic hormones and ferric dextran upon the progeria-like syndrome produced by dihydro- 
tachysterol. Gerontologia (Basel) 7, 94-104 (1963).

[D30,544/63

Selye, H., Grasso, S., Padmanabhan, N.: Protection by anti-mineralocorticoid against an otherwise fatal dihydrotachysterol intoxication. Lancet 1960II, 1350-1351. [C93,892/60

Selye, H., Heuser, G.: Fourth annual report on stress, p. 749. Montreal, Canada: Acta Inc. Med. Publ. 1954.

$[\mathrm{C} 1,001 / 54$

Selye, H., Heuser, G.: Fifth annual report on stress, p. 815. Montreal, Canada: Acta Inc., Med. Publ. 1956.

$[\mathrm{C} 9,000 / 56$

Selye, H., Horava, A.: Second annual report on stress, p. 526. Montreal, Canada: Acta Inc., Med. Publ. 1952.

$[\mathrm{B} 87,000 / 52$

Selye, H., Horava, A.: Third annual report on stress, p. 637. Montreal, Canada: Acta Inc., Med. Publ. 1953.

[B 90,100/53

Selye, H., Jean, P., Bajusz, E.: Résistance croisée et prévention des cardiopathies expérimentales produites par un dérivé de la vitamine D. Path. et Biol. 9, 331-335 (1961).

$[\mathrm{C} 91,680 / 61$

Selye, H., Jean, P., Cantin, M.: Prevention by stress and cortisol of gastric ulcers normally produced by 48/80. Proc. Soc. exp. Biol. (N.Y.) 103, 444-446 (1960).

$[\mathrm{C} 78,128 / 60$

Selye, H., Jelinek, J., Krajny, M.: Prevention of digitoxin poisoning by various steroids. $J$. pharm. Sci. 58, 1055 (1969). [G60,023/69

Selye, H., Kovaes, K., Horvath, E., Yeghiayan, E., Blascheck, J. A., Gardell, C.: Lipoid hyperplasia of the adrenal cortex induced in rats by aniline. (Abstr.) Program 52nd Meet. Endocr. Soc., St.Louis, Miss., p. 203 (1970). [G70,424/70

Selye, H., Krajny, M., Savoie, L.: Digitoxin poisoning: prevention by spironolactone. Science 164, 842-843 (1969). [G46,800/69

Selye, H., Lefebvre, F.: Détoxification du $\mathrm{W}-1372$ (N-y-phénylpropyl-N-benzyloxy acétamide) par les stéroïdes catatoxiques. Arch. Anat. Path. (in press).

$[\mathrm{G} 79,005$

Selye, H., Lemire, Y., Cantin, M.: Topical blockade of carbon angiotaxis by cortisol. Med. exp. (Basel) 1, 11-16 (1959).

$[\mathrm{C} 70,942 / 59$

Selye, H., Mandeville, R., Yeghiayan, E.: On the catatoxic effect of antimineralocorticoids. Naunyn-Schmiedebergs Arch. Pharmak. 266, 34-42 (1970).

[G60,050/70

Selye, H., Masson, G.: Effect of pituitary anterior lobe preparations on the action of anesthetics. Canad. med. Ass. J. 51, 579 (1944).

$[\mathrm{A} 97,571 / 44$
Selye, H., Mées, I. : Blockade of catatoxic steroid actions by metyrapone. Acta physiol. Acad. Sci. hung. 37, 141-144 (1970). [G60,095/70 Selye, H., Mées, I., Savoie, L.: Inhibition of anesthetics and sedative actions by spironolactone. Anesthesiology 31, 261 (1969).

[G60,016/69

Selye, H., Mécs, I., Szabó, S.: Prevention of mercurial poisoning by steroids (Abstr.). Proc. Canad. Fed. Biol. Soc. 13, 10 (1970).

[G70,432/70

Selye, H., Mées, I., Szabó, S.: Protection by steroids against acute $\mathrm{HgCl}_{2}$ poisoning. Urol. and Nephrol. 2, 287-301 (1970). [G70,440/70

Selye, H., Mécs, I., Szabó, S.: Sensitization by estrogens to the toxic effect of octamethyl pyrophosphamide (OMPA). ArzneimittelForsch. 10, 1488-1490 (1970). [G70,457/70 Selye, H., Mées, I., Tamura, T.: Effect of spironolactone and norbolethone on the toxicity of digitalis compounds in the rat. Brit. J. Pharmacol. 37, 485-488 (1969).

[G60,042/69

Selye, H., Mishra, R. K.: On the ability of methyltestosterone to counteract catabolism in diverse conditions of stress. Arch. int. Pharmacodyn. 117, 444-451 (1958). [C38,201/58 Selye, H., Mishra, R. K.: Protection by thyroxine against intoxication with elementary yellow phosphorus. Acta pharmacol. (Kbh.) 14, 359-362 (1958). [C $40,183 / 58$

Selye, H., Mortimer, H., Thomson, D. L., Collip, J. B.: Effect of parathyroid extract on the bones of the hypophysectomized rat. A histologic study. Arch. Path. 18, 878-880 (1934).

$[30,634 / 34$

Selye, H., Nielsen, K.: Action of desoxycorticosterone on non-protein nitrogen content of blood during experimental uremia. Proc. Soc. exp. Biol. (N.Y.) 46, 541-542 (1941).

[A35,723/41

Selye, H., Nielsen, K.: On the renotropic action of an anterior pituitary extract. Endocrinology 35, 207 (1944).

$[84,644 / 44$

Selye, H., Padmanabhan, N., Walsh, J. T.: Schutzwirkung der Hypophysektomie gegenüber der sogenannten 'dystrophischen Gewebsverkalkung'. Virchows Arch. pathol. Anat. 335, $12-20$ (1962).

$[\mathrm{D} 8,010 / 62$

Selye, H., Pentz, E. I.: Pathogenetical correlations between periarteritis nodosa, renal hypertension and rheumatic lesions. Canad. med. Ass. J. 49, 264-272 (1943).

[A59,789/43

Selye, H., Prioreschi, P., Cantin, M.: Factors that determine the production of cardiovascu- 
lar and renal lesions by polymyxin. Antibiot. and Chemother. 11, 12-25 (1961). [C83,616/61 Selye, H., Renaud, S.: On the anticatabolic and anticalcinotic effects of 17-ethyl-19-nortestosterone. Amer. J. med. Sci. 235, 1-6 (1958).

[C40,518/58

Selye, H., Rowley, E. M.: Prevention of experimental nephrosclerosis with methyl-testosterone. Fed. Proc. 3, 41 (1944). [A 72,287/44 Selye, H., Rowley, E. M.: Prevention of experimental nephrosclerosis with methyl-testosterone. J. Urol. 51, 439-442 (1944).

[A 72,302/44

Selye, H., Savoie, L., Sayegh, R.: Inhibition of anesthetic and sedative actions by norbolethone. Pharmacology (Basel) 2, 265 (1969).

[G60,020/69

Selye, H., Solymoss, B.: Protection by catatoxic steroids against meprobamate. Int. J. Neuropharmacol. 9, No. 4, 327-332 (1970).

[G70,402/70

Selye, H., Stehle, R. L., Collip, J. B.: Recent advances in the experimental production of gastric ulcers. Canad. med. Ass. J. 34, 339 (1936).

$[58,020 / 36$

Selye, H., Stevenson, J.: The toxic effect of oestrogens as influenced by progesterone. Canad. med. Ass. J. 42, 190 (1940). [77,177/40 Selye, H., Strebel, R., Mikulaj, L.: A progerialike syndrome produced by dihydrotachysterol and its prevention by methyltestosterone and ferric dextran. J. Amer. Geriat. Soc. 11, 1-16 (1963).

[D 28,648/63

Selye, H., Sylvester, O., Hall, C. E., Leblond, C. P.: Hormonal production of arthritis. J. Amer. med. Ass. 124, $201-207$ (1944). [A 72,284/44 Selye, H., Szabo, S., Tache, Y., Kouroumakis, P., Szablowska, M.: Tentative rules for the SSS nomenclature of steroids. (in press). (1971).

[G79,034

Selye, H., Tuchweber, B.: El concepto de los esteroides catatoxicos: sus implicaciones clinicas. Rev. argent. Med. Interna (in press).

[G70,494

Selye, H., Tuchweber, B., Caruso, P. L.: Protection against neurotropic mastocalcergy. Exp. Neurol. 10, 451-461 (1964). [G11,123/64 Selye, H., Tuchweber, B., Gabbiani, G.: Beeinflussung der Indiumvergiftung durch Nebenschilddrüsenhormon und Dihydrotachysterin. Naunyn-Schmiedebergs Arch. Pharmak. 244, 109-116 (1962).

[D 25,667/62

Selye, H., Tuchweber, B., Gabbiani, G.: Further studies on anacalciphylaxis. J. Amer. Geriat. Soc. 12, 207-214 (1964).

[E24,117/64
Selye, H., Tuchweber, B., Jacqmin, M.: Protection by various anabolic steroids against dihydrotachysterol-induced calcinosis and catabolism. Acta endocr. (Kbh.) 49, 589-602 (1965).

[G 19,426/65

Selye, H., Tuchweber, B., Jahnke, V.: Schutzwirkung der Fesselung gegen Serotoninintoxikation in Abwesenheit der Nebennieren. Acta biol. med. germ. 13, 198-203 (1964).

[E 24,146/64

Selye, H., Tuchweber, B., Ortega, M. R.: Prevention by methyltestosterone of parathyroid cyst formation. Endocrinology 75, 619-621 (1964).

[G11,109/64

Selye, H., Ventura, J.: Effect of hypophysectomy and substitution therapy with STH upon experimental bone lathyrism. Amer. $J$. Path. 33, 919-929 (1957).

$[\mathrm{C} 27,684 / 57$

Selye, H., Yeghiayan, E., Mandeville, R.: Protection by catatoxic steroids against dihydrotachysterol intoxication. J. Atheroscler. Res. 11, 321-331 (1970).

[G60,055/70

Selye, H., Yeghiayan, E., Mées, I.: Prevention of nicotine intoxication by catatoxic steroids. Arch. int. Pharmacodyn. 183, No. 2, p. 235 (1970).

[G60,069/70

Semenov, L. F.: The testing of indoleamine compounds in the prevention of radiation sickness. (Russian text.) Med. Radiol. (Mosk.) 5/5, 47-52 (1960).

[D 7,087/60

Sen, H. G., Joshi, U. N., Seth, D.: Effect of cortisone upon Ancylostoma caninum infection in albino mice. Trans. Roy. Soc. trop. Med. Hyg. 59, 684-689 (1965).

[F 76,261/65

Sereni, F., Kenney, F. T., Kretchmer, N.: Factors influencing the development of tyrosine- $\alpha$ ketoglutarate transaminase activity in rat liver. J. biol. Chem. 234, 609-612 (1959).

[C 80,562/59

Serkes, K. D., Berman, W., Lang, S.: Hydrocortisone and lysosomal enzymes in tourniquet shock. Proc. Soc. exp. Biol. (N.Y.) 126, 362 to 365 (1967).

[F 92,105/67

Serrone, D. M., Fujimoto, J. M.: Inhibition of the metabolism of hexobarbital in vitro. Biochem. Pharmacol. 5, 263-264 (1960).

[D 83,863/60

Serrone, D. M., Fujimoto, J. M.: The diphasic effect of N-methyl-3-piperidyl-( $\left.\mathrm{N}^{\prime}, \mathrm{N}^{\prime}\right)$-diphenyl carbamate HCI (MPDC) on the metabolism of hexobarbital. J. Pharmacol. exp. Ther. 133/1, 12-17 (1961).

[D48,610/61

Serrone, D. M., Fujimoto, J. M.: The effect of certain inhibitors in producing shortening of 
hexobarbital action. Biochem. Pharmacol. 11, 609-615 (1962). [D80,098/62

Sethy, V. H., Naik, S. R., Sheth, U. K.: Effect of stress on pentobarbital sleeping time in rats. Indian J. med. Res. 58, 352-357 (1970).

[G77,511/70

Severi, F., Rondini, G., Zaverio, S., Vegni, M.: Prolonged neonatal hyperbilirubinemia and pregnane-3 $(\alpha), 20(\beta)$-diol in maternal milk. Helv. paediat. Acta 25, 517-521 (1970).

[G 82,341/70

Severin, V. N., Bashkurov, E. P.: The clinical picture and treatment of acute poisoning with methyl alcohol. (Russian text.) Klin. Med. (Mosk.) 45, 125-129 (1967). [G49,801/67 Shafer, R. B., Adicoff, A.: Digitalis antagonism by a specific lactone. Curr. ther. Res. 12, 755 to 758 (1970).

[G 80,179/70

Sharpless, S. K.: Hypnotics and sedatives. I. The barbiturates. In: Goodman, L. S. and Gilman, A.; The Pharmacological Basis of Therapeutics, p. 98-120. New York: McMillan Co. 1970.

$[\mathrm{E} 8,852 / 70$

Shaw, F. H., Shankley, K. H.: Factors affecting the duration of Nembutal anaesthesis in rats. Austral. J. exp. Biol. med. Sci. 26, 481-491 (1948).

$[\mathrm{A} 52,203 / 48$

Shay, H., Aegerter, E. A., Gruenstein, M., Komarov, S. A.: Development of adenocarcinoma of the breast in the Wistar rat following the gastric instillation of methyl-cholanthrene. J. nat. Cancer Inst. 10, 255-266 (1949).

[H 26,763/49

Shay, H., Gruenstein, M., Kessler, W.B.: Estrogenic inhibition of methylcholanthrene-induced breast cancer in the rat. (Abstr.) Proc. Amer. Ass. Cancer Res. 3, 268 (1961). [D2,760/61

Shay, H., Harris, C., Gruenstein, M.: Influence of sex hormones on the incidence and form of tumors produced in male or female rats by gastric instillation of methylcholanthrene. $J$. nat. Cancer Inst. 13, 307-331 (1952).

[H31,719/52

Sheehan, H. L., Summers, V. K., Nichols, J.: D.D.D. therapy in Cushing's syndrome. Lancet 1953I, 312-314.

[B 77,668/53

Sheldon, W. H., Bauer, H.: The role of predisposing factors in experimental fungus infections. Lab. Invest. 11, 1184-1191 (1962).

[D46,962/62

Shellabarger, C.J., Aponte, G.E., Cronkite, E.P., Bond, V.P.: Studies on radiation-induced mammary gland neoplasia in the rat. VI. The effect of changes in thyroid function, ovarian function, and pregnancy. Radiat. Res. 17, 492-507 (1962).

[D39,218/62

Shelton, E.: Production of liver tumors in mice with 2-amino-5-azotoluene (Abstr.). Proc. Amer. Ass. Cancer Res. 1, 44 (1954).

[G76,339/54

Sherlock, S.: Primary biliary cirrhosis (chronic intrahepatic obstructive jaundice). Gastroenterology 37, 574-586 (1959). [G79,591/59

Sherman, I. W., Ruble, J. A.: Virulent Trypanosoma lewisi infections in cortisone-treated rats. J. Parasit. 53, 258-262 (1967). [G49,628/67

Sherwin-Weidenreich, R., Herrmann, F.: Hair cycle and chemically induced epidermal carcinogenesis in mice receiving tri-iodothyronine. I. Findings after single application of 9,10dimethyl-1,2-benzanthracene. $J$. invest. Derm. 40, 225-232 (1963).

[D 67,842/63

Shiba, S., Matsuyoshi, H., Miyatake, M.: Tryptophan pyrrolase in the isolated perfused liver of a tumor-bearing animal. Gann 56, 121-126 (1965).

[G31,114/65

Shibata, H., Mizuta, M., Combes, B.: Hepatic glucuronyl transferase activity and bilirubin $\mathrm{T}_{m}$ in pregnancy in the rat. Amer. J. Physiol. 211, 967-970 (1966).

$[\mathrm{G} 80,058 / 66$

Shibata, K., Komiya, A.: Effect of adrenocortical steroids on duration of pentothal anesthesia in adrenalectomized mice. Proc. Soc. exp. Biol. (N.Y.) 84, 308-310 (1953).

[B88,660/53

Shibata, K., Komiya, A., Machida, J., Fukushima, K.: Effect of cortisone acetate on barbital anesthesia in normal rabbits. Endocr. jap. 4, 28-34 (1957).

$[\mathrm{C} 49,533 / 57$

Shideman, F. E., Kelly, A. R., Adams, B. J.: The role of the liver in the detoxication of thiopental (Pentothal) and two other thiobarbiturates. J. Pharmacol. exp. Ther. 91, 331-339 (1947).

$[\mathrm{E} 60,046 / 47$

Shigei, M.: Effects of adrenalectomy and hydrocortisone administration on the fine structure of parenchymal cells of normal and regenerating rat liver. J. Fac. Sci. Tokyo, Sect. 4, 11, $511-536$ (1969).

[H27,112/69

Shih-Chi, L., Hsiu-Yuan, C., Chen-Yu, S.: Effects of thyroxine and propylthiouracil on the toxicity of trivalent ammonium antimonyl gluconate and the distribution and excretion of antimony after administration of the compound. (Chinese text with English summary.) Acta physiol. sinica 22, 289-293 (1958).

$[\mathrm{C} 72,194 / 58$ 
Shimamoto, T.: Experimental study on atherosclerosis. An attempt at its prevention and treatment. Acta path. jap. 19, 15-43 (1969).

[G70,917/69

Shimazu, T.: Biological mechanism of the effect of 20-methylcholanthrene on the induction of dimethylaminoazobenzene-demethylase activity of rat liver. Gann 56, 143-149 (1965).

[G31,110/65

Shimazu, T.: Response to 20-methylcholanthrene of hepatic aniline- and acetanilide 4hydroxylase of rats with hypothalamic lesions Biochim. biophys. Acta (Amst.) 105, 377-380 (1965).

[G34,311/65

Shimazu, T., Suda, M.: Mechanism of 20-methylcholanthrene on the induction of DABdemethylase in rat liver. Gann 50, Sup. 65-66 (1959).

[G76,684/59

Shipley, R. A., Chudzik, E. B., György, P., Rose, C. S.: Mechanism of the lipotropic action of estrogen. Arch. Biochem. 25, 309-315 (1950).

[B50,163/50

Shipley, R. A., György, P.: Effect of dietary hepatic injury on inactivation of estrone. Proc. Soc. exp. Biol. (N.Y.) 57, 52-55 (1944).

$[20,418 / 44$

Shirasu, Y., Grantham, P. H., Weisburger, E. K., Weisburger, J. H.: Effects of adrenocorticotropic hormone and growth hormone on the metabolism of $\mathrm{N}$-hydroxy-N-2-fluorenylacetamide and on physiologic parameters. Cancer Res. 27, 81-87 (1967).

[F 76,819/67

Shirasu, Y., Grantham, P. H., Yamamoto, R. S., Weisburger, J. H.: Effects of pituitary hormones and prefeeding $\mathrm{N}$-hydroxy-N-2-fluorenylacetamide on the metabolism of this carcinogen and on physiologic parameters. Cancer Res. 26, 600-606 (1966).

[F65,704/66

Shisa, H.: Studies on the mechanism of 7, 12dimethylbenz $[\alpha]$ anthracene leukemogenesis in mice. III. Acceleration of DMBA leukemogenesis in mice by pretreatment of cortisone acetate. Mie med. J. 19, 111-121 (1969).

[G72,582/69

Shklar, G.: Cortisone and hamster buccal pouch carcinogenesis. Cancer Res. 26, 2461 to 2463 (1966).

[F 74,973/66

Shleser, I. H., Asher, R.: Efficacy of adrenal cortical extract and of paredrine in the prevention of experimental shock following venous occlusion of a limb. Amer. J. Physiol. 138, 1-6 (1942).

[A56,711/42

Shmelev, N. A., Uvarova, 0. A.: The effect of ACTH on the course of experimental TB.
(Russian text.) Probl. Endokr. Gormonoter. 2/6, $38-43$ (1956).

$[\mathrm{C53}, 553 / 56$

Sholiton, L.J., Werk, E.E., Jr., MacGee, J.: The in vitro effect of 5,5'-diphenylhydantoin on the catabolism of cortisol by rat liver. Metabolism 13, 1382-1392 (1964).

[F 23,871/64

Shore, P. A., Silver, S. L., Brodie, B. B.: Interaction of serotonin and lysergic acid diethylamide (LSD) in the central nervous system. Experientia (Basel) 11, 272 (1955).

$[\mathrm{C} 18,383 / 55$

Shou, L., Pan, F., Chin, S. F.: Pancreatic hormones and hepatic methionine adenosyltransferase in the rat. Proc. Soc. exp. Biol. (N.Y.) 131, 1012-1018 (1969).

[H 15,277/69

Shrotri, D. S., Bhadkamkar, U. A., Balwani, J. H.: Modification of hexobarbitone action by insulin. Indian J. med. Res. 50, 446-448 (1962).

$[\mathrm{D} 27,239 / 62$

Shubik, P., Ritehie, A. C.: Sensitivity of male dba mice to the toxicity of chloroform as a laboratory hazard. Science 117, 285 (1953).

[D 67,964/53

Shuster, L.: Metabolism of drugs and toxic substances. Ann. Rev. Biochem. 33, 571-596 (1964).

[F 38,575/64

Shwartzman, G.: Enhancing effect of cortisone upon poliomyelitis infection (Strain MEFI) in hamsters and mice. Proc. Soc. exp. Biol. (N.Y.) 75, 835-838 (1950).

[B54,248/50

Shwartzman, G.: Enhancement of susceptibility to experimental poliomyelitis by means of cortisone (Abstr.). Amer. J. Path. 27, 714 (1951).

[B66,955/51

Shwartzman, G.: Poliomyelitis infection in cortisone-treated hamsters induced by the intraperitoneal route. Proc. Soc. exp. Biol. (N.Y.) 79, 573-576 (1952). [B69,778/52

Shwartzman, G., Aronson, S. M.: Poliomyelitis infection by parenteral routes made possible by cortisone. Ann. N.Y. Acad. Sci. 56, 793-797 (1953).

[B $84,833 / 53$

Shwartzman, G., Fisher, A.: Alteration of experimental poliomyelitis infection in the Syrian hamster with the aid of cortisone. J. exp. Med. 95, 347-362 (1952).

[B69,580/52

Sidransky, H.: Sex difference in induction of fatty liver in the rat by dietary orotic acid. Endocrinology 72, 709-714 (1963).

$[\mathrm{D} 64,556 / 63$

Sidransky, H., Farber, E.: Sex difference in induction of periportal fatty liver by methionine deficiency in the rat. Proc. Soc. exp. Biol. (N.Y.) 98, 293-297 (1958). [C55,020/58 
Sidransky, H., Verney, E., Egan, R. F.: The influence of testosterone on the induction of fatty liver by methionine deficiency. $L a b$. Invest. 16, 858-863 (1967). $\quad[\mathrm{G} 48,110 / 67$ Sidransky, H., Verney, E., Lombardi, B.: Factors influencing orotic acid-induced fatty liver. Fed. Proc. 22, 371 (1963).

$[\mathrm{G} 4,364 / 63$

Sidransky, H., Wagle, D. S., Verney, E.: Hepatic protein synthesis in rats force-fed a threoninedevoid diet and treated with cortisone acetate or threonine. Lab. Invest. 20, 364-370 (1969).

$[\mathrm{G} 65,724 / 69$

Sidransky, H., Wagner, B. P., Morris, H. P.: Sex difference in liver tumorigenesis in rats ingesting N-2 fluorenylacetamide. J. nat. Cancer Inst. 26, 151-187 (1961).

$[\mathrm{C} 99,347 / 61$

Siegel, B. V., Aird, R. B., Anderson, W. W.: Effect of trypan red on Columbia-SK virus pathogenicity. Neurology (Minneap.) 11, 982 to 988 (1961).

[D $13,002 / 61$

Siegel, S.: Nonparametric Statistics for the Behavioral Sciences, p. 270. New York, Toronto, London: McGraw-Hill Book Co. Inc. 1956.

$[\mathrm{G} 67,296 / 56$

Siegel, W.V., Shklar, G.: The effect of dimethyl sulfoxide and topical triamcinolone on chemical carcinogenesis of hamster buccal pouch. Oral Surg. 27, $772-779$ (1969).

$[\mathrm{H} 35,238 / 69$

Siegert, M., Alsleben, B., Liebenschütz, W., Remmer, H.: Unterschiede in der mikrosomalen Oxydation und Acetylierung von Arzneimitteln bei verschiedenen Arten und Rassen. Naunyn-Schmiedebergs Arch. Pharmak. 247, 509-521 (1964).

[G 71,866/64

Siegler, R., Duran-Reynals, M.L.: Observations on the pathogenesis of experimental skin tumors. A study of the mechanism by which papillomas develop. J. nat. Cancer Inst. 29, 653-673 (1962).

$[\mathrm{D} 54,814 / 62$

Silberberg, R., Silbergber, M.: Strain differences in skeletal growth and ageing of mice fed a high fat diet. Fed. Proc. 9, 344 (1950).

$[\mathrm{B} 48,364 / 50$

Silk, M. R.: The effect of progesterone on cats administered endotoxin. J. surg. Res. 7, 35-40 (1967).

[F 95,477/67

Silvestri, F.: Eliminazione urinaria dei 17chetosteroidi nella steatosi sperimentale da colesterine e nella steatosi da colesterina trattata con sostanze metilanti, testosterone e vit. E. (Ricerche sperimentali). Chir. Pat. sper. 12, 695-711 (1964).

$[\mathrm{F} 62,336 / 64$

Šimek, J., Erbenová, Z., Deml, F., Dvořáčková, I.: Liver regeneration after partial hepat- ectomy in rats exposed before the operation to the stress stimulus. Experientia (Basel) 24, 1166-1167 (1968).

[H 13,837/68

Šimek, J., Husáková, A., Erbenová, Z., Dvořáčková, I.: The relationship of glucocorticoids to the early changes of liver triglycerides content after partial hepatectomy in rats. Sborn. ved. Praci lék. Fak. Hradci Králové 11, 5-7 (1968).

[G71,089/68

Šimek, J., Husáková, A., Erbenová, Z., Kanta, J.: The role of the adrenals in changes of liver triglycerides content after partial hepatectomy in rats of different ages. Physiol. bohemoslov. $563-567$ (1968).

[H 22,183/68

Simionovici, M., Winter, D., Sterescu, N.: Sur le rôle des amines biogènes dans l'antagonisme de certains phénomènes réserpiniques centraux chez la souris. Rev. roum. Physiol. 2, 43-48 (1965).

$[\mathrm{F} 43,099 / 65$

Simmons, D. J., Pankovieh, A. M., Budy, A. M.: Osteolathyrism in mice and inhibition of the endosteal bone reaction in estrogen-treated mice by aminoacetonitrile. Amer. J. Anat. 116, 387-399 (1965).

[G 28,592/65

Simmons, F., Boyle, J. D.: Effect of heterologous serum albumin on liver regeneration after partial hepatectomy. Arch. Surg. 98, 369-371 (1969).

[H 22,141/69

Simon, A.: Utber die Wertbestimmung des Parathyreoideahormons mit Magnesiumsulfat. Naunyn-Schmiedebergs Arch. Pharmak. 178, 57-63 (1935).

$[31,369 / 35$

Simon, E. R., Pesch, L. A., Topper, Y. J.: Localization of the steroid hormone effect on galactose metabolism. Biochem. biophys. Res. Commun. 1, 6-8 (1959).

$[\mathrm{C} 84,793 / 59$ Simpson, L. L.: The interaction between 5hydroxytryptamine and botulinum toxin type A. Toxicol. appl. Pharmacol. 12, 249-259 (1968).

$[\mathrm{G} 60,451 / 68$

Simpson, L. L.: Evidence for the non-specificity of the interaction between 5-hydroxytryptamine and botulinum toxin. Toxicon 5, 239-246 (1968).

$[\mathrm{H} 5,300 / 68$

Simpson, W.L., Bond, B., Leithauser, G., Yamaguchi, I., Horeglad, S.: Effects of thymectomy on the response of Sprague-Dawley rats to a single feeding of 7-12 dimethylbenzanthracene (Abstr.) Proc. Amer. Ass. Cancer Res. 5, 58 (1964).

[F 2,965/64

Simpson-Herren, L., Griswold, D. P., Jr.: Studies of the kinetics of growth and regression of 7,12-dimethylbenz ( $\alpha$ )anthracene-induced mammary adenocarcinoma in Sprague-Dawley rats. Cancer Res. 30, 813-818 (1970).

$[\mathrm{H} 26,708 / 70$ 
Sinclair, K. B.: The effect of corticosteroid on the pathogenicity and development of Fasciola Hepatica in lambs. Brit. vet. J. 124, 133-139 (1968).

$[\mathrm{G} 65,622 / 68$

Sindram, I.: Der Einfluß von Cortin auf die Empfindlichkeit für Narkotika. Acta brev. neerl. Physiol. 5, 29-30 (1935). $\quad[52,504 / 35$

Singer, E.: Experimental studies on the combined sulphanilamide and serum treatment of gas gangrene infections. Med. J. Austral. 2, $275-279$ (1940).

[B316/40

Singer, S., Mason, M.: Tyrosine- $\alpha$-ketoglutarate transaminase effect of the administration of sodium benzoate and related compounds on the hepatic enzyme level. Biochim. biophys. Acta (Amst.) 110, 370-379 (1965). [G66,500/65

Singh, I., Sehra, K. B., Bhargaya, S. P.: Tolbutamide in cirrhosis of the liver. Lancet 1961 I, 1144.

[D6,799/61

Singhal, R. L., Valadares, J. R. E., Ling, G. M.: Influence of chronic phenobarbitone treatment on uterine phosphorfructokinase induction. $J$. Pharm. Pharmacol. 19, 545-547 (1967).

[G67,770/67

Singhal, R.L., Valadares, J.R.E., Schwark, W.S.: Inhibition by phenobarbitone of oestrogen-stimulated increases in uterine enzymes. J. Pharm. Pharmacol. 21, 194-195 (1969).

$[\mathrm{G} 78,387 / 69$

Sirsat, S.M., Ketkar, M.B.: Influence of DOC on induced epidermal cancers in mice. $J$. invest. Derm. 46, 331-340 (1966). [F 65,926/66 Skalka, M.: Nebennierenfunktion und Veränderungen der Leber nach Röntgenbestrahlung. Experientia (Basel) 15/4, 153-155 (1959).

$[\mathrm{C} 71,368 / 59$

Skanse, B.: The effect of altered sexual functions on the storage of arsenic in mice. Upsala Läk.-Fören. Förh. 47, 55-79 (1941).

[A 72,698/41

Skanse, B., Nyman, G. E., Törnegren, L.: Electroencephalographic abnormalities in vitamin $\mathrm{D}$ intoxication and the effect of cortisone. Acta endocr. (Kbh.) 31, 282-290 (1959).

$[\mathrm{C} 69,514 / 59$

Skinhøj, P., Quaade, F.: Intracutaneous serotonin test in dysthyroid and normal persons. Acta allerg. (Kbh.) 24, 280-283 (1969).

$[\mathrm{G} 72,600 / 69$

Sklower, A.: Ưber Beziehungen zwischen Schilddrüse und Thymus. Z. vergl. Physiol. 6, 150-166 (1927).

$[25,299 / 27$

Skobba, T., Miya, T. S.: Hyperthermic responses and toxicity of chlorpromazine in L-thyroxine sodium-treated rats. Toxicol. appl. Pharmacol. 14, 176-181 (1969).

$[\mathrm{G} 64,738 / 69$

Skuratova, N. A.: A comparative study of the ACTH and the growth hormone effect on the resistance of albino mice to diphtheria toxin. (Russian text.) Probl. Endokr. Gormonoter. 8/2, 38-43 (1962).

[D20,887/62

Sladek, N.E., Mannering, G.J.: Induction of drug metabolism. I. Differences in the mechanisms by which polycyclic hydrocarbons and phenobarbital produce their inductive effects on microsomal $\mathrm{N}$-demethylating systems. Molec. Pharmacol. 5, 174-185 (1969).

[G66,219/69

Sladek, N. E., Mannering, G. J.: Induction of drug metabolism. II. Qualitative differences in the microsomal $\mathrm{N}$-demethylating systems stimulated by polycyclic hydrocarbons and by phenobarbital. Molec. Pharmacol. 5, 186-199 (1969).

$[\mathrm{G} 66,220 / 69$

Slebodzinski, A., Srebro, Z.: The course of radiation disease in hyper and hypothyreotic rats. Folia Biol. (Krakow) 17, 145-158 (1969).

[H $29,972 / 69$

Slocombe, A. G.: Effects of lysergic acid diethylamide and related amines on the electrical activity of the rat brain. Fed. Proc. 15, 172 (1956).

[C14,144/56

Sloper, J. C., Pegrum, G. D.: Regeneration of crushed mammalian skeletal muscle and effects of steroids. J. Path. Bact. 93, 47-63 (1967).

$[\mathrm{G} 49,073 / 67$

Smart, K. M., Kilbourne, E. D.: The influence of cortisone on experimental viral infection. VII. Kinetics of interferon formation and its inhibition with hydrocortisone in relation to viral strain and virulence. J. exp. Med. 123, 309 to 325 (1966).

$[\mathrm{G} 33,810 / 66$

Smiecinski, W., Gorski, T.: The induction of uterine cervical carcinoma in thymectomised mice. Folia biol. (Krakow) 16, 211-212 (1968).

[H $20,765 / 68$

Smith, A. U.: Further observations on the closed vessel technique for testing thyroid activity. J. Endocr. 5, lxiv (1947). [B4,939/47 Smith, A. U., Emmens, C. W., Parkes, A. S.: Assay of thyroidal activity by a closed vessel technique. J. Endocr. 5, 186-206 (1947).

$[\mathrm{B} 4,928 / 47$

Smith, C. W., Bean, J. W., Bauer, R.: Thyroid influence in reactions to $\mathrm{O}_{2}$ at atmospheric pressure. Amer. J. Physiol. 199, 883-888 (1960).

$[\mathrm{C} 95,244 / 60$

Smith, D. C. W.: The role of the endocrine organs in the salinity tolerance of trout. In: 
Jones, I. C., and Eckstein, P.: The Comparative Endocrinology of Vertebrates, Part II, p. 83 to 101. Toronto: MacMillan Co. Canada Ltd. 1956.

$[\mathrm{C} 46,496 / 56$

Smith, D. E., Tyree, E. B.: Influence of X-irradiation upon water consumption by the rat. Amer. J. Physiol. 184, 127-133 (1956).

$$
[\mathrm{C} 12,045 / 56
$$

Smith, E., MeMillan, E., Mack, L.: Factors influencing the lethal action of illuminating gas. $J$. industr. Hyg. 17, 18-20 (1935). [45,163/35 Smith, I. M., Lindell, S. S., Hazard, E. C.: Inhibitory action of the testosterone and liver extract on staphylococcal infections in mice. Nature (Lond.) 211, 722-723 (1966).

$[\mathrm{F} 68,892 / 66$

Smith, J. M., Dubos, R. J.: The effect of dinitrophenol and thyroxin on the susceptibility of mice to staphylococcal infections. J. exp. Med. 103, 119-126 (1956).

$[\mathrm{C} 12,130 / 56$

Smith, J. M., Murphy, J. S., Mirick, G. S.: Effect of adrenal hormones on infection of mice with pneumonia virus of mice (PVM). Proc. Soc. exp. Biol. (N.Y.) 78, 505-510 (1951).

$[\mathrm{B} 64,635 / 51$

Smith, L. C., Dugal, L. P.: Effect of food and water consumption, liver function, and thyroid function on the spontaneous running activity of white rats. Canad. J. Physiol. Pharmacol. 44, 455-464 (1966).

[F 65,692/66

Smith, L. L., Muller, W., Hinshaw, D. B.: The management of experimental endotoxin shock. The circulatory effects of levarterenol, hydrocortisone, phenoxybenzamine hydrochloride, and blood volume expansion. Arch. Surg. 89, 630-636 (1964).

[D 18,862/64

Smith, M. W.: The effect of hyaluronidase and cortisol on the inactivation of vasopressins by rat kidney slices. J. Endocr. 24, 415-424 (1962).

[D27,805/62

Smith, 0. W., Smith, G. van S.: Menstrual discharge of women. I. It's toxicity in rats. Proc. Soc. exp. Biol. (N.Y.) 44, 100-104 (1940).

[A 32,972/40

Smith, R. T., Thomas, L. : Lethal action of gramnegative bacterial endotoxins on the chick embryo. Fed. Proc. 14, 478 (1955). [C5,334/55

Smith, R. T., Thomas, L.: The letal effect of endotoxins on the chick embryo. J. exp. Med. 104, 217-231 (1956).

$[\mathrm{C} 97,047 / 56$

Smith, W. W.: The effect of thyroid hormone and radiation on the mitotic index of mouse epidermis. J. cell. comp. Physiol. 38, 41-49 (1951).

$[\mathrm{B} 66,170 / 51$
Smith, W. W., Alderman, I. M., Schneider, c., Cornfield, J.: Sensitivity of irradiated mice to bacterial endotoxin. Proc. Soc. exp. Biol. (N.Y.) 113, 778-781 (1963). [E 21,486/63 Smith, W. W., Dooley, R., Thompson, E. C.: Simulated high altitude following whole-body radiation of mice. J. Aviat. Med. 19, 227-237 (1948).

$[\mathrm{B} 48,252 / 48$

Smith, W. W., Smith, F.: Effect of thyroid hormone on radiation lethality. Amer. J. Physiol. 165, 639-650 (1951).

$[\mathrm{B} 60,347 / 51$

Smith, W. W., Smith, F.: Effects of thyroid and radiation on sensitivity to hypoxia, basal rate of $\mathrm{O}_{2}$ consumption and tolerance to exercise. Amer. J. Physiol. 165, 651-661 (1951).

$[\mathrm{B} 60,348 / 51$

Smith, W. W., Smith, F., Thompson, E. C.: Failure of cortisone or ACTH to reduce mortality in irradiated mice. Proc. Soc. exp. Biol. (N.Y.) 73, 529-531 (1950). [B $\quad[77,642 / 50$

Smoake, J. A., Mulvey, P. F., Jr.: Factors influencing tolerance time in rats exposed to severe hypoxia (33,000 ft.) (Abstr.). Fed. Proc. 29, 581 (1970).

[H 23,262/70

Smookler, H.H., Buckley, J.P.: Effect of drugs on animals exposed to chronic environmental stress. Fed. Proc. 29, 1980-1984 (1970).

$[\mathrm{H} 32,862 / 70$

Smuckler, E.A.: Structural and functional alteration of the endoplasmic reticulum during $\mathrm{CCl}_{4}$ intoxication. FEBS Symp. Oslo (1967) 14, 13-55 (1968).

[G80,996/68

Snyder, F., Cress, E. A., Kyker, G. C.: Liver lipid response to intravenous rare earths in rats. $J$. Lipid. Res. 1, 125-131 (1959). [C99,417/59 Soave, 0. A.: Reactivation of rabbits virus in a guinea pig with adrenocorticotropic hormone. J. infect. Dis. 110, 129-131 (1962).

$[\mathrm{D} 22,275 / 62$

Sobel, H., Sideman, M., Arce, R.: Effect of cortisone on survival of morphine treated guinea pigs under decompression hypoxia. Proc. Soc. exp. Biol. (N.Y.) 104, 31-32 (1960).

$[\mathrm{C} 90,836 / 60$

Sobis, H.: Pathomorphological changes in the lungs of mice in experimental influenza. Pol. med. J. 3/2, 287-307 (1964). [G29,127/64

Soffer, L.J.: Bilirubin excretion as a test for liver function during normal pregnancy. Bull. Johns Hopk. Hosp. 52, 365-375 (1933).

$[7,166 / 33$

Soiva, K., Grönroos, M., Aho, A. J., Rinne, U.: Ưber die Einwirkung von "Stress" auf die Geschlechtsorgane und -funktionen der schwange- 
ren und nichtschwangeren Ratten. Geburtsh. Frauenheilk. 20, 505-508 (1960). [C97,218/60

Solanki, B. R., Junnarkar, R. V.: Influence of thyroid gland on tuberculosis; studies on mode of action. Indian J. med. Res. 49, 1063-1074 (1961).

[D21,370/61

Solomon, H. M., Schrogie, J. J.: Change in receptor site affinity: a proposed explanation for the potentiating effect of D-thyroxine on the anticoagulant response to warfarin. Clin. Pharmacol. Ther. 8, 797-799 (1968).

$[\mathrm{H} 1,868 / 68$

Solotorovsky, M., Gregory, F. J., Stoerk, H. C.: Loss of protection by vaccination following cortisone treatment in mice with experimentally induced tuberculosis. Proc. Soc. exp. Biol. (N.Y.) 76, 286-288 (1951). [B [B6,305/51

Solymoss, B.: The effect of various steroids, partial hepatectomy, SKF 525-A and cycloheximide on the plasma digitoxin level. Proc. on Drug metabolism in man. New York 1970.

[G70,484/70

Solymoss, B.: A máj-microsomális enzymek szerepe a szervezet védedezöreactiöiban. Budapest: Medicina (in press).

[G79,009

Solymoss, B., Classen, H. G., Varga, S.: Increased hepatic microsomal activity induced by spironolactone and other steriods. Proc. Soc. exp. Biol. (N.Y.) 132, 940-942 (1969).

$[\mathrm{G} 60,054 / 69$

Solymoss, B., Classen, H. G., Varga, S.: The role of electrolyte disturbances and extracellular alkalosis in metabolic cardiac necrosis and the preventive effect of amiloride. Amer. J. Cardiol. 26, 46-51 (1970).

$[\mathrm{G} 60,053 / 70$

Solymoss, B., Krajny, M., Varga, S.: Independence of antimineralocorticoid and catatoxic effects of various steroids. J. pharm. Sci. 59, 712-714 (1970).

$[\mathrm{G} 60,084 / 70$

Solymoss, B., Krajny, M., Varga, S., Werringloer, J.: Suppression by nucleic acid- and protein-synthesis inhibitors of drug detoxication induced by spironolactone or ethylestrenol. J. Pharmacol. exp. Ther. 174, 473 to 477 (1970).

[G 70,412/70

Solymoss, B., Selye, H.: Protection by catatoxic steroids against chronic digitoxin and indomethacin intoxication (Abstr.). Fed. Proc. 29, 833 (1970).

[G70,409/70

Solymoss, B., Somogyi, A., Kováes, K.: Effect of spironolactone and SKF 525-A on 7,12-dimethylbenz $(\alpha)$ anthracene-induced hematologic changes. Haematologia (in press). [G70,445
Solymoss, B., Tóth, S., Varga, S., Krajny, M.: Enhancement of digitoxin biotransformation by spironolactone and other steroids (Abstr.). Proc. 3rd Ann. Meet. int. Study group for Res. in cardiac metabolism, Stowe, Vt., p. 66 (1970).

$[\mathrm{G} 70,461 / 70$

Solymoss, B., Tóth, S., Varga, S., Krajny, M.: The influence of spironolactone and other steroids on the plasma level of digitoxin. Proc. 3rd Ann. Meet. int. Study group for Res. in cardiac metabolism, Stowe, Vt., p. 71 (1970).

$[\mathrm{G} 70,463 / 70$

Solymoss, B., Tóth, S., Varga, S., Krajny, M.: The influence of spironolactone on its own biotransformation. Steroids 16:3, 263-275 (1970).

$[\mathrm{G} 70,464 / 70$

Solymoss, B., Tóth, S., Varga, S., Selye, H.: Protection by spironolactone and oxandrolone against chronic digitoxin or indomethacin intoxication. Toxicol. appl. Pharmacol. 18, 586 to 592 (1971).

[G70,441/71

Solymoss, B., Tóth, S., Varga, S., Werringloer, J.: Effect of spironolactone and ethylestrenol on benzo $(\alpha)$ pyrene-hydroxylase and other chemical constituents of hepatic microsomes. Canad. J. Physiol. Pharmacol. (in press). $\quad[$ G70,488 Solymoss, B., Varga, S.: Spironolacton és egyéb steroidok hatása bishydroxycumarin enxymaticus lebontására és alvadásgátlo hatására. Orvosképzée (in press).

$[\mathrm{G} 70,500$

Solymoss, B., Varga, S., Classen, [H. G.: Effect of various steroids on microsomal aliphatic hydroxylation and N-pealkylation. Europ. $J$. Pharmacol. 10, 127-130 (1970). [G60,075/70

Solymoss, B., Varga, S., Krajny, M.: Increased drug metabolism induced by various steroids and its suppression by SKF 525-A. Acta physiol. Acad. Sci. hung. 37, 145-149 (1970).

$[\mathrm{G} 60,099 / 70$

Solymoss, B., Varga, S., Krajny, M.: Effect of spironolactone, norbolethone, progesterone, hydroxydione and SKF 525-A on the disappearance rate of indomethacin from blood. Arzneimittel-Forsch. 21, 384 (1971).

$[\mathrm{G} 60,093 / 71$

Solymoss, B., Varga, S., Krajny, M., Werringloer, J.: Influence of spironolactone and other steroids on the enzymatic decay and anticoagulant activity of bishydroxycoumarin. Thrombos. Diathes. haemorrh. (Stuttg.) XXIII, No. 3, p. 562-568 (1970). [ [G 70,423/70

Solymoss, B., Werringloer, J., Toth, S.: The influence of pregnenolone-16 $\alpha$-carbonitrile on hepatic mixed-function oxygenases. Steroids 17/4, 427-433 (1971).

$[\mathrm{G} 79,015 / 71$ 
Solymoss, B., Zsigmond, G., Werringloer, J.: Stimulation of sulfobromophthalein sodium (BSP) metabolism and bile flow by spironolactone, pregnenolone-16 $\alpha$-carbonitrile and other steroids. (Abstr.) Proc. canad. Fed. biol. Soc. 14, 110 (1971).

$[\mathrm{G} 79,007 / 71$

Solymoss, B., Zsigmond, G., Werringloer, J.: Increased sulfobromophthalein sodium (BSP) metabolism and bile flow induced by spironolactone and other steroids. J. Lab. clin. Med. (in press).

[G79,023

Somlyo, A. P.: The Toxicology of Digitalis. Amer. J. Cardiol. 5, 523-533 (1960).

$[\mathrm{G} 62,791 / 60$

Sommer, S.: Experimenteller Beitrag zur Reid Hunt-Reaktion mit besonderer Berücksichtigung der Sera von Schwangeren, Eklamptischen und Karzinomkranken und Extrakte aus Schwangerenharn. Zbl. Gynäk. 58, 385-388 (1934).

$[44,648 / 34$

Sommer, S.: Zum Einfluß von somatotropem Hormon und Cortison auf den Verlauf einer experimentellen Trypanosomeninfektion (Trypanosoma cruzi). Arch. exp. Pathol. Pharm. 626, 527-531 (1955).

[C9937/55

Somogyi, A.: Inhibition of DMBA-induced adrenal necrosis by spironolactone. Workshop on DMBA Activity, Laval Univ. Quebec City, p. 55-56 (1969).

[G 70,406/69

Somogyi, A.: The effect of various steroids on certain biologic actions 7,12-dimethylbenz $(\alpha)$ anthracene. Thesis, University of Montreal (1970).

$[\mathrm{G} 70,416 / 70$

Somogyi, A., Kovács, K.: Inhibition by spironolactone of 7-hydroxymethyl-12-methylbenz $(\alpha)$ anthracene-induced adrenal necrosis in rats. Endokrinologie 56, 245-247 (1970).

[G60,061/70

Somogyi, A., Kováes, K.: Effect of various steroids on the adrenal necrosis induced by 7,12-dimethylbenz $(\alpha)$ anthracene in rats. Rev. canad. Biol. 29, 169-180 (1970). [G60,074/70 Somogyi, A., Kovács, K.: Effect of stress on the adrenocorticolytic and carcinogenic action of 7,12-dimethylbenz $(\alpha)$ anthracene. $Z$. Krebsforsch. 75, 288-295 (1971). [G70,482/71

Song, C. S., Kappas, A.: The influence of estrogens, progestins and pregnancy on the liver. Vitam. and Horm. 26, 147-195 (1968).

[G68,413/68

Song, C. S., Kappas, A.: The influence of hormones on hepatic function. In: Popper, $\mathrm{H}$. and Schaffner, F., Progress in liver diseases., pp. 89-109. New York, London: Grune and Stratton, 3, 1970.

[G80,521/70
Song, C. S., Rifkind, A. B., Gillette, P. N., Kappas, A.: Hormones and the liver. The effect of estrogens, pogrestins, and pregnancy on hepatic function. Amer. J. Obstet. Gynec. 105, 813-847 (1969).

$[\mathrm{G} 70,575 / 69$

Soriano, L.: Etude sur la différenciation in vitro de l'épithélium oesophagien embryonnaire de souris. Action de la vitamine A et de l'hydrocortisone. J. Embryol. exp. Morph. 17, 247-261 (1967).

[G44,574/67

Soroff, H. S., Rozin, R. R., Mooty, J., Lister, J., Raben, M. S.: Role of human growth hormone in the response to trauma. I. Metabolic effects following burns. Ann. Surg. 166, 739-752 (1967).

[G52,127/67

Sotaniemi, E., Arvela, P., Hakkarainen, H., Huhti, E.: The clinical significance of microsomal enzyme induction in the therapy of epileptic patients. Ann. clin. Res. 2, 223-227 (1970).

$[\mathrm{G} 78,917 / 70$

Souda, S.: Correlation between mitotic activity and DPN content of regenerating liver in normal and cortisone-treated rats. J. Fac. Sci. Univ. (Tokyo) 9, 379 (1962). [ [D62,846/62

Southam, C. M., Babcock, V. I.: Effect of cortisone, related hormones, and adrenalectomy, on susceptibility of mice to virus infections. Proc. Soc. exp. Biol. (N.Y.) 78, 105-109 (1951).

$[\mathrm{B} 63,662 / 51$

Southren, A. L., Gordon, G. G.: Studies in androgen metabolism. Mt. Sinai J. Med. 37, 516-527 (1970).

$[\mathrm{G} 77,117 / 70$

Southren, A. L., Gordon, G. G., Altman, K.: Inhibition of cortisol induction of rat liver tryptophan pyrrolase by $6 \beta$-hydroxycortisol. Program 48th Meet. Endocr. Soc., June, Chicago, Ill., p. 101, 1966 . [F66,647/66 Southren, A. L., Gordon, G. G., Tochimoto, S., Krikun, E., Krieger, D., Jacobson, M., Kuntzman, R.: Effect of N-phenylbarbital (phetharbital) on the metabolism of testosterone and cortisol in man. J. clin. Endocr. 29, 251-256 (1969).

$[\mathrm{H} 8,265 / 69$

Southren, A. L., Tochimoto, S., Isurugi, D., Gordon, G. G., Drikun, E., Stypulkowski, W.: The effect of 2,2 -bis ( 2 chlorophenyl-4 chlorophenyl)-1, 1-dichloroethane (o, $\left.p^{\prime}-D D D\right)$ on the metabolism of infused cortisol 7-3 H. Steroids 7, 11-29 (1966).

$[\mathrm{F} 73,262 / 66$

Southren, A. L., Tochimoto, S., Strom, L., Ratuschni, A., Ross, H., Gordon, G.: Remission in Cushing's syndrome with o, $\mathrm{p}^{\prime}$-DDD. J. clin. Endocr. 26, 268-278 (1966). [F63,163/66 Soyka, L. F.: Determinants of in vitro binding of barbiturates by rat hepatic subcellular 
fractions. Proc. Soc. exp. Biol. (N.Y.) 128, 322-325 (1968).

[H30,981/68

Soyka, L. F.: Determinants of hepatic aminopyrine demethylase activity. Biochem. Pharmacol. 18, 1029-1038 (1969). [G66,626/69

Soyka, L.F., Campbell, P., Gyermek, L.: Metabolism and distribution of pregnanolone, a pharmacologically active metabolite of progesterone. (Abstr.) Clin. Res. 18, 125 (1970).

$[\mathrm{H} 33,315 / 70$

Soyka, L.F., Gyermek, L., Campbell, P.: A study of the mechanism responsible for the sensitivity of newborn rats to pregnanolone. $J$. Pharmacol. exp. Ther. 175, 276-282 (1970).

[H31,803/70

Spain, D. M.: Symposium on cortisone and ACTH studies on the effect of cortisone on the guinea pig's resistance to tuberculosis. Trans. nat. Ass. Tuberc. (Lond.) 47th Ann. Meet. May 14-18, p. 41-46 (1951). [B69,019/51

Spain, D. M., Molomut, N.: Effects of cortisone on the development of tuberculous lesions in guinea pigs and on their modification by streptomycin therapy. Amer. Rev. Tuberc. 62, 337-344 (1950).

[B $60,878 / 50$

Spain, D. M., Molomut, N.: The effect of cortisone-streptomycin on experimental tuberculosis in guinea pigs. Proc. N.Y. St. Ass. Publ. Hlth Lab. 30, 7-8 (1950).

$[\mathrm{B} 80,256 / 50$

Sparano, B. M.: Sex difference in chlortetracycline-induced fatty livers in rats. Lab. Invest. 14, 1931-1938 (1965).

[F 71,594/65

Specchia, G.: Azione del Luminal sull'ittero anemolitico a bilirubinemia indiretta dell' adulto: descrizione di un caso. Minerva Med. 61, 2068-2071 (1970).

$[\mathrm{H} 27,907 / 70$

Specht, 0.: Weitere Untersuchungen an Meerschweinchen über den Einfluß endokriner Drüsen auf die Krampffähigkeit und die elektrische Erregbarkeit. Bruns' Beitr. klin. Chir. 128, 25-53 (1923).

$[13,475 / 23$

Speck, L. B.: Toxicity and effects of increasing doses of mescaline. J. Pharmacol. exp. Ther. 119, 78-84 (1957).

$[\mathrm{C} 31,193 / 57$

Speirs, R. S.: Effect of oxytetracycline upon cortisone-induced pseudotuberculosis in mice. Antibiot. and Chemother. 6, 395-399 (1956).

$[\mathrm{C} 34,744 / 56$

Spencer, P. S. J., Waite, R.: Barbiturate-induced sleep in hyperthyroid mice. Europ. J. Pharmacol. 11, 392-394 (1970).

[H30,100/70

Spencer, P. S. J., West, G. B.: Further observations on the relationship between the thyroid gland and the anaphylactoid reaction in rats. Int. Arch. Allergy 20, 321-343 (1962).

$[\mathrm{D} 32,617 / 62$

Spiegel, E.: Anticonvulsant effects of desoxycorticosterone, testosterone and progesterone. Fed. Proc. 2, 47 (1943).

$[83,892 / 43$

Spiegel, E., Wycis, H.: Anticonvulsant effects of steroids. J. Lab. clin. Med. 30, 947-953 (1945).

$[93,925 / 45$

Spiess-Bertschinger, A.: Die Bedeutung der Schilddrüse für die Reaktionsweise der Leber bei experimenteller Schädigung. Virchows Arch. pathol Anat. 312, 601-615 (1944).

[B40,585/44

Spigolon, G.: Ascite sperimentale da legatura lenta della vena porta associata a 'tiroidectomia chimica da tioureici'. Ormonologia 11, 201-208 (1949).

[B52,689/49

Spinelli, A.: Influenza della tiroide sull' avvelenamento acuto da istamina. Boll. Soc. ital. Biol.sper. 4, 937-941 (1929).

$[14,294 / 29$

Spinelli, A.: Ricerche sulle variazioni di sensibilità verso alcune sostanze tossiche, conseguenti alla ablazione della tiroide nella cavia (Abstr.). Riv. Pat. sper. 7, 294-323 (1931).

$[10,086 / 31$

Spinelli, A.: Osservazioni intorno ai rapporti tra funzione tiroidea e anafilassi. I. Influenza della tiroidectomia sullo shock anafilattico nella cavia. Riv. Pat. sper. 9, 212-221 (1932).

$[7,369 / 32$

Spinelli, A.: Azione protettiva della tiroide contro l'intossicazione guanidinica nella cavia. Arch. Fisiol. 31, 598-608 (1932). $\quad$ [7,409/32

Spink, W. W.: The pathogenesis and management of shock due to infection. Arch. intern. Med. 106, 433-442 (1960). [C91,027/60

Spink, W. W.: Endotoxin shock. Ann. intern. Med. 57, 538-552 (1962). [D39,028/62

Spink, W. W., Anderson, D.: Experimental studies on the significance of endotoxin in the pathogenesis of brucellosis. J. clin. Invest. 33, $540-548$ (1954).

[B 95,168/54

Spink, W. W., Vick, J.: Evaluation of plasma, metaraminol and hydrocortisone in experimental endotoxin shock. Circulat. Res. 9, 184-188 (1961).

$[\mathrm{C} 98,717 / 61$

Spink, W. W., Vick, J. A.: Reversal of experimental endotoxin shock with a combination of aldosterone and metaraminol. Proc. Soc. exp. Biol. (N.Y.) 107, 777-779 (1961).

$[\mathrm{D} 12,885 / 61$

Spink, W. W., Vick, J. A., Melby, J. C., Finstad, J.: Influence of aldosterone and angiotensin II 
on endotoxin shock in the primate. Proc. Soc. exp. Biol. (N.Y.) 112, 795-799 (1963).

$[\mathrm{D} 61,007 / 63$

Spinks, A., Burn, J. H.: Thyroid activity and amine oxidase in the liver. Brit. J. Pharmacol. 7, 93-98 (1952).

$[\mathrm{B} 72,891 / 52$

Spode, E.: Utber den Stoffwechsel von RadioQuecksilber ${ }^{230} \mathrm{Hg}$ ) im Organismus der weißen Maus unter Berücksichtigung von Dekorporationsmaßnahmen. Z. ges. inn. Med. 15, 603 bis 609 (1960).

[G72,979/60

Spremolla, G., Grassi, B.: Nefropatia da deplezione potassica. Rilievi istologici ed umorali in corso di trattamento con steroidi anabolizzanti. Minerva nefrol. 10, 5-11 (1963).

[G68,941/63

Sprunt, D. H., McDearman, S.: Studies on the relationship of sex hormones to infection. III. A quantitative study of the increased resistance to vaccinial infection produced by the estrogenic hormone and pseudopregnancy. $J$. Immunol. 38, 81-95 (1940).

$[\mathrm{A33}, 321 / 40$

Srebro, Z., Slebodzinski, A., Szirmai, E.: Radiation disease in hypo- and hyperthyreotic rats. Agressologie 11, 343-356 (1970). [H32,848/70

Srinivasan, S., Balwani, J. H.: Effect of thyroxine on thioacetamide hepatotoxicity. Acta pharmacol. (Kbh.) 26, 475-481 (1968).

[G64,503/68

Srinivasan, S., Srinivasan, U., Balwani, J.H.: Effect of thyroxine, reserpine and serotonin on allyl alcohol induced hepatotoxicity in rats. Acta pharmacol. (Kbh.) 28, 338-345 (1970)

[G 78,977/70

Srivastava, P. N., Etoh, H., Hyodo, Y., Egami,N.: Thyroid activity and radiosensitivity relationship in goldfish, Carassius auratus L. Strahlentherapie 125, 305-308 (1964).

[G 23,764/64

Stahnke, H. L.: Stress and the toxicity of venoms. Science 150, 1456-1457 (1965).

[F 57,253/65

Stalhandske, T.: Effects of increased liver metabolism of nicotine on its uptake, elimination and toxicity in mice. Acta physiol. scand. 80, $222-234$ (1970).

$[\mathrm{G} 80,388 / 70$

Stalhandske, T., Slanina, P.: Effect of nicotine treatment on the metabolism of nicotine in the mouse liver in vitro. Acta pharmacol. (Kbh.) 28, 75-80 (1970).

[G73,544/70

Stamler, J., Pick, R., Katz, L. N.: Prevention of coronary atherosclerosis by estrogen-androgen administration in the cholesterol-fed chick. Circulat. Res. 1, 94-98 (1953). [B91,353/53
Stamler, J., Pick, R., Katz, L. N.: Further observations on the effects of thyroid hormone preparations on cholesterolemia and atherogenesis in cholesterol-fed cockerels. Circulat. Res. 6, 825-829 (1958).

$[\mathrm{C} 81,655 / 58$

Stämplli, H.: Der Einfluß der Thymusdrüse auf die Empfindlichkeit gegen Sauerstoffmangel mit besonderer Berücksichtigung des Atmungszentrums. Biochem. Z. 185, 192-204 (1927).

$[931 / 27$

Stanbury, J. B., Morris, M. L., Corrigan, H. L., Lassiter, W. E.: Thyroxine deiodination by a microsomal preparation requiring $\mathrm{FE}$, oxygen, and cysteine or glutathione. Endocrinology 67, 353-362 (1960).

$[\mathrm{C} 90,693 / 60$

Starnes, W. R.: Metabolism of dexamethasone by rat liver. Ala. J. med. Sci. 6, 149-151 (1969)

$[\mathrm{G} 68,434 / 69$

Starr, T. J., Pollard, M.: Susceptibility of cortisone-treated mice to infection with mouse hepatitis virus. Proc. Soc. exp. Biol. (N.Y.) 99, 108-110 (1958).

$[\mathrm{C} 60,012 / 58$

Stasney, J., Paschkis, K. E., Cantarow, A., Rothenberg, M. S.: Neoplasms in rats with 2-acetaminofluorene and sex hormones. Cancer Res. 7, 356-362 (1947).

[B26,653/47

Staudinger, H., Degkwitz, E., Ullrich, V.: Oxidativer Arzneimittelabbau. Med. Welt (Stuttg.) 20, 2747-2754 (1969).

[H $20,267 / 69$

Stavinoha, W. B., Emerson, G. A., Nash, J. B.: The effects of some sulfur compounds on thallotoxicosis in mice. Toxicol. appl. Pharmacol. 1, 638-646 (1959).

$[\mathrm{C} 94,628 / 59$

Stearner, S. P., Christian, E. J. B., Brues, A. M.: Protective action of low oxygen tension and epinephrine against X-ray mortality in the chick. Amer. J. Physiol. 176, 455-460 (1954).

$[\mathrm{B} 92,163 / 54$

Stechschulte, D. J.: Plasmodium berghei infection in thymectomized rats. Proc. Soc. exp. Biol. (N.Y.) 131, 748-752 (1969).

$[\mathrm{H} 15,256 / 69$

Steelman, S. L., Brooks, J. R., Morgan, E. R., Patanelli, D. J.: Antiandrogenic activity of spironolactone. Steroids 14, 449-450 (1969).

$[\mathrm{G} 69,340 / 69$

Stein, R. J., Kent, G., Popper, H.: Effect of cortisone and growth hormone upon ductular cell proliferation in liver ethionine intoxication. Proc. Soc. exp. Biol. (N.Y.) 99, 24-28 (1958).

$[\mathrm{C} 59,992 / 58$

Steinbach, M. M.: Experimental tuberculosis in the albino rat. The comparative effects of avitaminosis, suprarenalectomy and thyroid- 
parathyroidectomy on experimental tuberculosis. Amer. Rev. Tuberc. 26, 52-76 (1932).

$[92,528 / 32$

Steinbach, M. M., Duca, C. J., Molomut, N.: Experimental tuberculosis in hypophysectomized rats. Amer. Rev. Tuberc. 49, 105-108 (1944).

[B 7,316/44

Steiner, A., Davidson, J. D., Kendall, F. E.: Further studies on the production of arteriosclerosis in dogs by cholesterol and thiouracil feeding. Amer. Heart J. 36, 13 (1948).

[B28,166/48

Steiner, P. E., Martinez, B.: Effects on the rat liver of bile duct, portal vein and hepatic artery ligations. Amer. J. Path. 39, 257-289 (1961).

[D40,903/61

Steinetz, B.G., Leathem, J.H.: Effects of methylandrostenediol on weight and cholesterol content of adrenals of cortisone or thiouraciltreated rats. Proc. Soc. exp. Biol. (N.Y.) 108 113-115 (1961).

[D 14,466/61

Stender, H. S., Hornykiewytsch, T.: Der Einfluß der $\mathrm{O}_{2}$-Spannung auf die Strahlenempfindlichkeit bei Ganzkörperbestrahlung. Strahlentherapie 96, 445-452 (1955). [C37,079/55

Stender, H. S., Hornykiewytsch, T.: Die Abhängigkeit des Dosiseffektes von der Sauerstoffspannung und Reaktionslage bei Ganzkörperbestrahlung. Z. Naturforsch. 10, 32-34 (1955).

[C37,086/55

Stenger, R.J.: Organelle pathology of the liver. The endoplasmic reticulum. Gastroenterology 58, 554-574 (1970).

[G74,578/70

Stenger, R.J., Miller, R.A., Williamson, J.N.: Effects of phenobarbital pretreatment on the hepatotoxicity of carbon tetrachloride. Exp. molec. Path. 13, 242-252 (1970). [G78,940/70

Stenram, U.: The effect of vitamin $\mathrm{B}_{12}$ and the animal protein factor on thyroid-fed rats, with special reference to liver cytology. Exp. Cell. Res. 3, 147-153 (1952).

[B69,173/52

Stenram, U.: The ultrastructure of the liver in thyroid-fed rats. Z. Zellforsch. 100, 402-410 (1969).

[G70,339/69

Stenram, U., Nordgren, H., Willén, R.: Liver ultrastructure and RNA labelling after partial hepatectomy in protein-fed and protein-deprived rats. Virchows Arch. Abt. B Zellpathol. 6, 12-23 (1970).

[H30,015/70

Sterental, A., Dominguez, J.M., Weissman, C., Pearson, 0.H.: Pituitary role in the estrogen dependency of experimental mammary cancer. Cancer Res. 23, $481-484$ (1963). [D61,608/63
Stern, E., Mickey, M.R.: Neural mechanism in induction of dioestrus and tumor in the androgen sterile rat. Nature (Lond.) 216, 185-187 (1967).

[F 89,080/67

Stern, L., Khanna, N. N., Levy, G., Yaffe, S. J.: Effect of phenobarbital on hyperbilirubinemia and glucuronide formation in newborns. Amer. J. Dis. Child. 120, 26-31 (1970). [G76,135/70

Stewart, R. B.: The effect of cortisone on the lethality of psittacosis virus for the chick embryo. J. infect. Dis. 103, 129-134 (1958).

[C59,979/58

St. George, S., Bine, R., Jr., Friedman, M.: Role of the liver in excretion and destruction of digitoxin. Circulation 6, 661-665 (1952).

[G71,843/52

Stitzel, R. E., Furner, R. L.: Stress-induced alterations in microsomal drug metabolism in the rat. Biochem. Pharmacol. 16, 1489-1494 (1967).

[G48,920/67

Stöcker, E.: Autoradiographische Untersuchungen zum zellulären Proliferationsstoffwechsel im Parenchym von Leber und Niere der Ratte. Acta histochem. (Jena), Sup. 8, 205-229 (1968).

[G76,916/68

Stoerk, H. C., Boeninghaus, J., Celozzi, E.: Interactions of parathormone and hydrocortisone on endochondral ossification. Fed. Proc. 22, 546 (1963).

[G5,410/63

Stoffel, W.: Biosynthesis of polyenoic fatty acids. Biochem. biophys. Res. Commun. 6, 270 to 273 (1961).

[G66,819/61

Stolk, A.: Effect of castration on experimental liver lesion in Iguana iguana. Nature (Lond.) 190, 93 (1961). [D2,285/61

Stoppani, A. 0. M., Brignone, C. M. C. de, Brigone, J. A.: Structural requirements for the action of steroids as inhibitors of electron transfer. Arch. Biochem. 127, 463-475 (1968).

$[\mathrm{H} 19,278 / 68$

Störtebecker, T. P.: Further results concerning the acute antinarcotic effect of estrone. Skand. Arch. Physiol. 77, 78 (1937). [69,765/37

Störtebecker, T. P.: Die Antinarkotische Wirkung von Follikulin und Testishormon. Klin. $W s c h r .16,302-303$ (1937).

[A 1,993/37

Störtebecker, T. P.: Hormones and resistance. An acute antinarcotic and antitoxic effect of the estrogenic hormones. Acta path. microbiol. scand. Sup. 41, 294 (1939).

$[76,398 / 39$

Stowe, C. M., Plaa, G. L.: Extrarenal excretion of drugs and chemicals. Ann. Rev. Pharmacol. 8, 337-356 (1968).

[G73,241/68 
Straube, R. L., Patt, H. M., Swift, M. N.: Influence of estrogens on x-ray toxicity. Amer. J. Physiol. 155, 471 (1948). [B [B3,113/48 Straube, R. L., Patt, H. M., Tyree, E. B., Smith, D. E.: Influence of level of adrenal cortical steroids on sensitivity of mice to X-irradiation. Proc. Soc. exp. Biol. (N.Y.) 71, 539-541 (1949).

[B39,082/49

Strebel, R. F., Dickinson, E. O., Payan, H., Bouverot, M.: Effect of pregnancy and lactation on an aging-like syndrome of rats (Abstr.). Fed. Proc. 24, 165 (1965).

[F 35,901/65

Strebel, R. F., Payan, H., House, E. L., Pansky, B., Barath, M.: Sex differences in a progerialike syndrome. Proc. Soc. exp. Biol. (N.Y.) 117, 583-586 (1964).

[F 25,229/64

Strebel, R. F., Payan, H., Levine, S.: Thymic calcification in the neonatal rat. Proc. Soc. exp. Biol. (N.Y.) 118, 617-620 (1965).

[F 34,734/65

Street, J. C., Chadwick, R. W., Wang, M., Phillips, R. L.: Insecticide interactions affecting residue storage in animal tissues. J. agric. Food. Chem. 14, 545-549 (1966). [G75,678/66

Streffer, C., Langendorff, H., Allert, U.: Untersuchungen über einen biologischen Strahlenschutz. 83. Mitteilg. Utber die Schutzwirksamkeit des 5-Hydroxytryptamins bei Teilkörperbestrahlung. Strahlentherapie 135, 76-82 (1968).

$[\mathrm{G} 55,078 / 68$

Strehler, E., Sollberger, H.: Der Einfluß von Cholesterin, Mais und Tetramethylthioharnstoff auf die Entstehung und Form der Masuginephritis des Kaninchens. Helv. med. Acta 17, 79-90 (1950).

[B 54,646/50

Streicher, E., Garbus, J.: The effect of age and sex on the duration of hexobarbital anesthesia in rats. $J$. Geront. 10, 441-444 (1955).

$[\mathrm{G} 76,681 / 55$

Streuli, H.: Das Verhalten von schilddrüsenlosen, milzlosen, schilddrüsen- und milzlosen Tieren bei $\mathrm{O}_{2}$-Mangel, zugleich ein Beitrag zur Theorie der Bergkrankheit. Biochem. Z. 87, 359-417 (1918).

$[32,220 / 18$

Stripp, B., Hamrick, M., Zampaglione, N.: Effect of spironolactone treatment of rats on the oxidation of drugs by liver microsomes (Abstr.). Fed. Proc. 29, 346 (1970).

$[\mathrm{H} 22,743 / 70$

Stripp, B., Hamrick, M.E., Zampaglione, N.C., Gillette, J.R.: The effect of spironolactone on drug metabolism by hepatic microsomes. $J$. Pharmacol. exp. Ther. 176, 766-771 (1971). [G79,538/71

Strittmatter, C. F., Umberger, F. T.: Oxidative enzyme components of avian liver microsomes.
Changes during embryonic development and the effects of phenobarbital administration. Biochim. biophys. Acta (Amst.) 180, 18-27 (1969).

[G66,629/69

Ströder, J., Garbe, A., Hiller, H.: Rachitisheilung unter Cortison. Klin. Wschr. 40, 1014 bis 1015 (1962).

[D36,990/62

Stromberg, K., Reuber, M. D.: Influence of age and sex on hepatic lesions induced by chemical carcinogenesis: ingestion of N-4-( $4^{\prime}$-fluorobiphenyl)acetamide by Buffalo strain rats. $J$. nat. Cancer Inst. 44, 1047-1054 (1970).

[G 75,306/70

Strong, F. M.: Deleterious compounds in foods. Amer. J. clin. Nutr. 11, 500-501 (1962).

[G73,964/62

Strong, F. M., Lalich, J. J., Lipton, S. H., Sievert, H. W., Garbutt, J. T.: Aminonitriles related to rat lathyrism (odoratism). (Abstr.). 4th Int. Congr. Biochem. Wien, p. 100 (1958).

[G61,885/58

Strubelt, 0., Sieger, C.P., Breining, H.: Der Einfluß von Noradrenaline auf die Hepatotoxicität von Tetrachlorkohlenstoff und Allylalkohol. Arch. Toxikol. 27, 53-66 (1970).

[G 80,282/70

Strubelt, 0., Steffen, J., Stutz, U.: Der Einfluß der Schilddrüsenfunktion auf die chronotropen und einige metabolische Wirkungen von Theophyllin und Coffein. Naunyn-Schmiedebergs Arch. Pharmak. 267, 135-154 (1970).

[G78,572/70

Studer, A.: Zur Frage der Angriffsorte von Compound $\mathbf{E}$ (Cortison). Eine experimentelle Studie. Z. ges. exp. Med. 121, 287-418 (1953).

[B 89,161/53

Stuhlfauth, K., Englhardt-Gölkel, A.: Ưber die Beeinflussung der Schlafzeit nach PentothalNatrium bei normalen und nebennierenlosen Ratten durch Glucose und Fructose. NaunynSchmiedebergs Arch. Pharmak. 221, 328-335 (1954).

[G 78,396/54

Stumpf, H. H., Wilens, S. L.: Inhibitory effect of cortisone hyperlipemia on arterial lipid deposition in cholesterol-fed rabbits. Proc. Soc. exp. Biol. (N.Y.) 86, 219-223 (1954).

[G95,325/54

Stupiel, M., Bouley, G., Romary, F., Magnier, M., Champsavin, M. de, Polianski, J.: Facteurs sexuels et résistance à l'hypoxie expérimentale. C. R. Acad. Sci. (Paris) 272, 1120-1122 (1971).

$[\mathrm{G} 82,171 / 71$

Sturtevant, F. M.: The vascular reactivity of normotensive and metacorticoid hypertensive 
rats. Anat. Rec. 122, 479 (1955). $\quad$ [C9,089/55 Sturtevant, F. M.: Studies on vascular reactivity in normotensive and metacorticoid hypertensive rats. Amer. Heart J. 52, 410-418 (1956).

$[\mathrm{C} 21,591 / 56$

Sturtevant, F. M.: Prolongation of hexobarbital-hypnosis in mice by iproniazid, serotonin, and reserpine. Naturwissenschaften 43, 67-68 (1956).

[D 87,568/56

Sturtevant, F. M.: Antihypertensive effects of an aldosterone antagonist. Science 127, 1393 to 1394 (1958).

$[\mathrm{C} 54,613 / 58$

Suchowsky, G. K., Junkmann, K.: Utber zwei neue anabol wirksame Steroide. Klin. Wschr. 39, 369-371 (1961).

[D 2,674/61

Sugihara, R.: The ultrastructure of regenerating parenchymal cells of the albino rat liver. (Japanese text.) Jap. J. clin. Elect. Micr. 1, 143-157 (1969).

$[\mathrm{H} 18,030 / 69$

Sugiura, K.: Chemotherapy of induced skin tumors in mice. Gann 59, 367-376 (1968).

[G64,932/68

Suhrmann, R.: Weitere Versuche über die Temperaturadaptation der Karauschen (Carassius vulgaris NILS.) Biol. Ztrbl. 74, 432 bis 448 (1955).

[D 76,901/55

Sulcová, J., Stárka, L.: Extrahepatic $7 \alpha$ hydroxylation of dehydroepiandrosterone. $E x$ perientia (Basel) 19, 632-633 (1963).

$[\mathrm{E} 37,298 / 63$

Sulman, F. G., Khazan, N., Steiner, J. E.: Biotransformation of prednisone by "trained" blocked and "untrained" liver enzymes. Arch. int. Pharmacodyn. 122, 180-189 (1959).

$[\mathrm{C} 79,823 / 59$

Sulser, F., Kunz, H. A., Gantenbein, R., Wilbrandt, W.: Zur Frage einer antagonistischen Wirkung zwischen Herzglykosiden und Corticosteroiden auf die Elektrolytausscheidung der Niere. Naunyn-Schmiedebergs Arch. Pharmak. 285, 400-411 (1959).

[D96,543/59

Sundaresan, P. R., Winters, V. G., Therriault, D. G.: Effect of low environment temperature on the metabolism of vitamin A (retinol) in the rat. J. Nutr. 92, 474-478 (1967). [G50,127/67

Sunderman, F. W., Jr.: Effect of nickel carbonyl upon incorporation of ${ }^{14} \mathrm{C}$-leucine into hepatic microsomal proteins. Res. Commun. chem. Path. Pharmacol. 1, 161-168 (1970).

[G 73,628/70

Sunderman, F. W., Jr., Leibman, K. C.: Nickel carbonyl inhibition of induction of aminopyrine demethylase activity in liver and lung. Cancer Res. 30, 1645-1650 (1970).

$[\mathrm{H} 28,301 / 70$
Sung, C. Y., Way, E. L.: The effect of altered thyroid function on the actions and fate of DL-methadone. J. Pharmacol. exp. Ther. 108, 1-10 (1953).

[B91,323/53

Sure, B., Buchanan, K. S.: Antithyrogenic action of crystalline vitamin B. J. Nutr. 13, 513-519 (1937).

$[\mathrm{A} 6,259 / 37$

Sure, B., Buchanan, K. S.: Influence of hyperthyroidism on vitamin A reserves of the albino rat. J. Nutr. 13, 521-524 (1937). [A48,611/37

Süssmann, H.: Experimentelle Studien mit Parathormone-Collip an weißen Mäusen. $Z$. ges. exp. Med. 56, 817-830 (1927). [24,462/27

Sutherland, J.M., Keller, W.H.: Novobiocin and neonatal hyperbilirubinemia. An investigation of the relationship in an epidemic of neonatal hyperbilirubinemia. A. M. A. Amer. J. Dis. Child. 101, 447-453 (1961). $\quad[G 78,607 / 61$

Suzman, M. M., Freed, C. C., Prag, J. J.: Studies on experimental peripheral vascular disease, with special reference to thromboangeitis obliterans. The effect of ovarian follicular hormone and of castration on the development of the trophic changes produced by ergotamine tartrate in albino rats. S. Afr. J. med. Sci. 3, 29-39 (1938).

$[\mathrm{A} 44,452 / 38$

Suzue, K., Sano, A., Yosida, H.: Utber die Beziehungen der Schilddrüsenfunktionsstörungen zur Bildung der sogenannten Xanthominseln durch Fettüberfütterung. Trans. Soc. Path. jap. 26, 480-483 (1936). $\quad[38,509 / 36$

Svedmyr, N.: The influence of thyroxine treatment and thyroidectomy on the calorigenic and some other metabolic effects of adrenaline and noradrenaline in experiments on fasted rabbits. Acta physiol. scand. 66, 257-268 (1966).

$[\mathrm{G} 39,171 / 66$

Svirbely, J. L.: The effect of desiccated thyroid, $\alpha$-dinitrophenol, and cortical hormone extract on the vitamin C content of some organs of the guinea pig fed graded doses of ascorbic acid. J. biol. Chem. 111, 147-154 (1935).

$[33,140 / 35$

Svoboda, D., Azarnoff, D., Reddy, J.: Microbodies in experimentally altered cells. II. The relationship of microbody proliferation to endocrine glands. J. Cell Biol. 40, 734-746 (1969).

[G64,564/69

Swann, H. E., Jr., Woodson, G. S., Ballard, T. A.: The acute toxicity of intramuscular parathion in rats and the relation of weight, sex and sex hormones to this toxicity. Amer. industr. Hyg. $J .19,190-195$ (1958).

$[\mathrm{C} 73,379 / 58$

Swann, H. G.: The relation of morphine withdrawal symptoms in the rat to the thyroid 
gland. Proc. Amer. physiol. Soc., 53rd Ann. Meet., Chicago, Ill., p. 279 (1941). [80,669/41 Swanson, H. E.: Interrelations between thyroxin and adrenalin in the regulation of oxygen consumption in the albino rat. Endocrinology 59, 217-225 (1956).

$[\mathrm{C} 22,149 / 56$

Swartz, F. J.: Polyploidization of liver after partial hepatectomy in the dwarf mouse and hypophysectomized rat; effect of extended regenerative periods. Exp. Cell. Res. 48, 557 to 568 (1967).

[G53,670/67

Swedberg, B.: Studies in experimental tuberculosis. An investigation of some problems of immunity and resistance. Acta med. scand. 139, Sup. 254, 1-120 (1951).

[B 59,988/51

Swedberg, B., Dahlström, G., Luft, R.: The effect of adrenocorticotrophic hormone (ACTH) on experimental tuberculosis in mice; preliminary report. Acta endocr. (Kbh.) 6, 215-220 (1951).

[B58,412/51

Swensson, A., Uliarson, U.: Experiments with different antidotes in acute poisoning by different mercury compounds. Effects on survival and on distribution and excretion of mercury. Int. Arch. Gewerbepathol. Gewerbehygiene 24, 12-50 (1967).

[F 89,451/67

Swingle, W. W., Overman, R. R., Remington, J. W., Kleinberg, W., Eversole, W. J.: Ineffectiveness of adrenal cortex preparations in the treatment of experimental shock in nonadrenalectomized dogs. Amer. J. Physiol. 139, $481-489$ (1943).

[A61,337/43

Swinyard, E. A., Sehiffman, D. O., Goodman, L. S.: Effect of variations in extracellular sodium concentration on the susceptibility of mice to pentylenetetrazole (metrazol)-induced seizures. J. Pharmacol. exp. Ther. 114, 160 to 166 (1955).

$[\mathrm{C} 17,213 / 55$

Swinyard, E. A., Weaver, L. C., Goodman, L. S.: Effect of liver injury and nephrectomy on the anti-convulsant activity of clinically useful hydantoins. J. Pharmacol. exp. Ther. 104, $309-316$ (1952).

[G74,657/52

Swyer, G. I. M., Little, V.: Absence of hepatic impairment in long-term oral-contraceptive users. Brit. med. J. 1965 I, 1412-1414.

[F $42,188 / 65$

Symeonidis, A.: Inibizione della formazione dei tumori epatici nei topi C3Hf surrenalectomizzati. Minerva med. 61, 1863-1868 (1970).

$[\mathrm{H} 27, \mathbf{3 3 6} / 70$

Symeonidis, A., Mulay, A. S., Burgoyne, F. H.: Effect of adrenalectomy and of desoxycorticosterone acetate on the formation of liver lesions in rats fed p-dimethylaminoazobenzene. $J$. nat. Cancer Inst. 14, 805-817 (1954). [B93,003/54 Symons, A.M., Lewis, D.A., Aneill, R.J.: The uptake of anti-inflammatory steroids by lysosomes. J. Pharm. Pharmacol. 22, 944-945 (1970).

[G 80,345/70

Szablowska, M., Selye, H.: L'Influence des hormones sur l'intoxication par l'ethylène glycol (Abstr.). Ann. ACF AS (38e Congr.) Sup. 37, 12 (1970).

$[\mathrm{G} 70,499 / 70$

Szablowska, M., Selye, H.: Hormonal influences upon ethylene glycol poisoning. Arch. environm. Hlth 23, 13-17 (1971).

$[\mathrm{G} 70,475 / 71$

Szabó, G., Sátori, 0. Grandtner, G.: Prevention and treatment of shock with corticosteroids. Effect of prednisolone in norepinephrine- and epinephrine-induced shock. Acta med. Acad. Sci. hung. 23, 49-52 (1966). [G44,867/66 Szabó, S.: Catatoxic steroids. 10th Med. Days, Subotica, Yugoslavia, June 24-28 (1970).

$[\mathrm{G} 70,456 / 70$

Szabó, S.: Katatoksični steroidi. In: Perčič, V.: Zbornik Radova Internistickih Dana (in press).

[G 70,498

Szabó, S., Kovaes, K., Garg, B.D., Khandekar, J.D., Selye, H.: Effect of pregnenolone-16 $\alpha$ carbonitrile upon drug intoxication and hepatic ultrastructure in hypophysectomized rats. (Abstr.) Proc. canad. Fed. biol. Soc. 14, 135 (1971).

[G79,024/71

Szabó, S., Selye, H.: L'effet de l'hypophysectomie et des stéroïdes catatoxiques sur la toxicité du parathion et du navadel (Abstr.). Ann. $A C F A S$ (38e Congr.) Sup., 37, 12 (1970).

$[\mathrm{G} 70,497 / 70$

Szabó, S., Selye, H.: Inhibition by hypophysectomy of nephrocalcinosis produced by mercuric chloride. Urol. int. (Basel) 26, 39-44 (1971).

$[\mathrm{G} 70,478 / 71$

Szabó, S., Selye, H.: Adrenal apoplexy and necrosis produced by acrylonitrile. Endokrinologie (in press).

[G70,493

Szabó, S., Selye, H.: Adrenal apoplexy produced by acrylonitrile and its prevention by ACTH and hypophysectomy. (Abstr.) Fed. Proc. 30, 307 (1971).

[G79,010/71

Szabó, S., Selye, H., Mees, I.: Katatoxikus steroidok hatasa az indomethacin és digitoxin mérgezésre hörcsögökben. Kisérl. Orvostud. (in press).

[G79,013

Szarvas, F., Kováes, K.: Die Untersuchung der Serotoninwirkung bei der mit Hormonen hervorgerufenen Nierenrindennekrose bei Ratten. Med. exp. (Basel) 9, 241-248 (1963).

$[\mathrm{E} 34,633 / 63$ 
Szeberényi, S., Fekete, G.: Influence of spironolactone on the action and metabolism of various drugs. (Abstr.) Excerpta med. (Amst.), Int. Congr. Ser. No. 210, p. 182-183 (1970) 3rd. Int. Congr. on Hormonal steroids, Hamburg.

[H 29,579/70

Szeberényi, S., Garattini, S.: Effect of metopirone on the rate of cortisol disappearance from plasma. Biochem. Pharmacol. 18, 927 to 928 (1969).

[G66,140/69

Szeberényi, S., Szalay, K. S., Garattini, S.: Removal of plasma metyrapone in rats submitted to previous pharmacological treatment. $J$. Pharm. Pharmacol. 21, $201-202$ (1969).

[G64,752/69

Szego, C. M., Roberts, S.: Steroid action and interaction in uterine metabolism. Recent Progr. Hormone Res. 8, 419-469 (1953). [B 73,573/53 Szeri, I., Bános, Z., Anderlik, P., Balázs, M., Földes, P.: Pathogenesis of the wasting syndrome following neonatal thymectomy. Acta microbiol. Acad. Sci. hung. 13, 255-262 (1966).

[G56,565/66

Szilágyi, T., Csernyánszky, H., Csernyánszky, I., Szabó, E., Csaba, B.: Effect of hypothermia on the adrenaline-chloroform syncope. Acta physiol. Acad. Sci. hung. 20, 149-153 (1961).

[D21,498/61

Szilágyi, T., Tóth, S., Miltényi, L., Jóna, G.: Oxygen poisoning and thyroid function. Acta physiol. Acad. Sci. hung. 35, 59-61 (1969).

[G68,248/69

Szold, A., Weisz, P., Dési, I., Kádas, T.: Wirkung des Methylandrostendiols und Norandrostenolons auf experimentelle Urämie. Z. Urol. 52, $652-658$ (1959).

[C79,889/59

Szold, E., Gimes, B., Erdös, B.: Anabolic steroids and radiation damage. Lancet 1960I, 289-290.

[C80,607/60

Szold, E., Szendröi, Z., Weisz, P., Pintér, I., Dési, I., Kádas, T.: Anabolic steroids in uraemia. Lancet 1959 I, 368.

[C64,498/59

Szontagh, F.E., Kovacs, L.: Post-coital contraception with dienoestrol. Med. Gynaec. Sociol. 4, 36-37 (1969).

[G73,899/69

Tabachnick, I. I. A., Parker, R. E., Wagner, J., Anthony, P. Z.: A re-evaluation of the calorigenic action of the $\mathrm{L}$ - and $\mathrm{D}$-isomers of thyroxine. Endocrinology 59, 153-158 (1956).

$[\mathrm{C} 22,161 / 56$

Tabachnick, I. I. A., Thorstad, J. A., Wagner, J., Parker, R. F.: A partial pharmacologic profile of the response to neuromuscular blocking agents as modified by sodium l-thyroxine. Arch. int. Pharmacodyn. 114, 210-216 (1958).

$[\mathrm{C} 50,317 / 58$

Taber, K. W.: Counteracting the acute radiation syndrome with corticotropin (ACTH). Amer. J. Roentgenol. 73, 259-264 (1955).

$[\mathrm{C} 10,417 / 55$

Tabusse, L., Curveille, J., Olsen, 0.: Modifications de la tolérance à l'anoxémie par la cortisone. C. R. Soc. Biol. (Paris) 148, 567 (1954).

$[\mathrm{C} 10,563 / 54$

Tada, H.: Studies on the relation between steroid hormones and the liver. (Japanese.) Jap. J. Gastroent. 57/3, 373-397 (1960).

[E96,131/60

Tainter, M. L.: Prevention of the edema of paraphenylenediamine by drugs acting on the adrenals. J. Pharmacol. exp. Ther. 27, 201-229 (1926).

$[25,429 / 26$

Tainter, M. L.: Comparative antiedemic efficiency of epinephrine and related amines and pituitary in experimental edemas. $J$. Pharmacol. exp. Ther. 33, 129-146 (1928). [23,737/28

Takabatake, E.: Metabolism of drugs. XI. The relationship between hypnotic activity and metabolism of ethylhexabital. (2) The effect of sex hormones. Pharm. Bull. (Tokyo) 5, 266 to 271 (1957).

[G76,713/57

Takabatake, E., Ariyoshi, T.: Biochemical studies on the drug metabolism. II. The effects of some steroids on the metabolism of cyclobarbital. Endocr. jap. 9, 193-200 (1962).

[D48,245/62

Takáes, L., Kovách, A. G. B., Moháesi, A., Káldor, V., Kalmár, Z.: Die Wirkung von Stoffwechselveränderungen auf die Schockempfindlichkeit. Acta physiol. hung. Sup. 5, 30-31 (1954).

$[\mathrm{C} 29,459 / 54$

Takagaki, Y., Naiki, M., Fujiwara, K., Tajima, Y.: Maladie de Tyzzer expérimentale de la souris traitée avec la cortisone. C. R. Soc. Biol. (Paris) 157, 438-441 (1963). [D69,101/63

Takahashi, A., Kato, R.: Effect of toxohormone on microsomal cytochromes and hydroxylating systems of rat liver. J. Biochem. (Tokyo) 65, 325-327 (1969).

[H 15,250/69

Takemori, A. E., Mannering, G. J.: Metabolic $\mathrm{N}$ - and $\mathrm{O}$-demethylation of morphine- and morphinan-type analgesics. J. Pharmacol. exp. Ther. 123, 171-179 (1958). [H24,294/58

Takens, H.: Vitamin $\mathrm{D}_{2}$ (calciferol) intoxication. An experimental investigation. Acta med. scand. 163, 417-428 (1959).

$[\mathrm{C} 69,439 / 59$ 
Tanabe, K.: Hypersensitive toxicity of 5-nbutyl-1-cyclohexyl-2,4,6-trioxoperhydropyrimidine in the pregnant rat. Jap. J. Pharmacol. 17, 381-392 (1967).

[F 92,176/67

Tanabe, S.: Experimental study of chronic cadmium poisoning especially about the accumulation in the bodies of rats. No. 3. An experiment of giving some drinking water including 300 ppm Cd. (Japanese text). J. Juzen med. Soc. 76, 34-14-34-17 (1968).

[G72,457/68

Tanabe, T., Cafruny, E. J.: Adrenal hypertrophy in rats treated chronically with morphine. $J$. Pharmacol. exp. Ther. 122, 148-153 (1958).

$[\mathrm{C} 48,625 / 58$

Tanaka, Y., Dao, T. L.: Effect of hepatic injury on induction of adrenal necrosis and mammary cancer by 7,12-dimethylbenz[ $\alpha]$ anthracene in rats. J. nat. Cancer Inst. 35, 631-640 (1965).

[G34,593/65

Tanret, P., Thomas, J., Cottenot, F.: Evolution des dépôts oxaliques et lipidiques au cours de la lithiase rénale expérimentale par l'éthylèneglycol et l'acide oxalique. C. R. Soc. Biol. (Paris) 155, 1025-1027 (1961). [G68,367/61

Tanret, P., Thomas, J., Thomas, E., Cottenot, F.: Influence du sexe sur les formations de dépôts d'oxalate de calcium dans les reins chez le rat intoxiqué par l'éthylène-glycol. C. R. Soc. Biol. (Paris) 156, 1285-1287 (1962). [D44,140/62 Tao, L., Nakamura, A., Sakurai, H.: Study on susceptibility of hamster to various strains of mycobacteria. Report IV. Influence of cortisone administration upon tuberculous lesion of hamster. Jap. J. Tuberc. 7, 62-75 (1959).

$[\mathrm{C} 82,168 / 59$

Tarantino, C., Natali, P.: Modificazioni indotte dall'ACTH sul quadro ateromatoso sperimentale da colesterina. Folia endocr. (Roma) 5, 279-288 (1952).

$[\mathrm{B} 71,460 / 52$

Tardiff, R. G., DuBois, K. P.: Inhibition of hepatic microsomal enzymes by alkylating agents. Arch. int. Pharmacodyn. 177, 445-456 (1969).

[H $11,752 / 69$

Tarján, G., Czeizel, E., Görgényi, F., Székesi, J.: Medikamentöse Prävention der Endotoxinbedingten Mortalität trächtiger Tiere. Z Zbl. Gynäk. 89, 1420-1427 (1967). [G54,411/67

Tarnowski, W., Seitz, H. J., Lierse, W.: A critical experimental contribution concerning the value of $\mathrm{CCl}_{4}$-intoxicated liver in metabolic studies. Biochem. Pharmacol. 19, 1409-1417 (1970).

$[\mathrm{G} 75,524 / 70$

Tatum, H. J., Kozelka, F. L.: Distribution, excretion and rate and site of detoxification of metrazol. J. Pharmacol. exp. Ther. 72, 284 to 290 (1941).

$[81,376 / 41$

Tauber, H., Garson, W.: Effect of cortisone, properdin and reserpine on Neisseria gonorrhoea endotoxin activity. Proc. Soc. exp. Biol. (N.Y.) 97, 886-888 (1958).

$[\mathrm{C} 51,966 / 58$

Tavassoli, M., Crosby, W. H.: The fate of fragments of liver implanted in ectopic sites. Anat. Rec. 166, 143-151 (1970).

$[\mathrm{G} 73,038 / 70$

Tawara, S.: Du mode d'action de l'adrénaline et des acides vis-à-vis des toxines bactériennes. C. R. Soc. Biol (Paris) 85, 401-402 (1921).

$[12,478 / 21$

Taylor, A., Carmichael, N.: Male mice tolerate dosages of pteroylglutamic acid lethal to females. Proc. Soc. exp. Biol. (N.Y.) 71, 544 to 545 (1949).

$[\mathrm{A} 49,002 / 49$

Taylor, D. W.: Effects of adrenalectomy on oxygen poisoning in the rat. J. Physiol. (Lond.) 140, 23-36 (1958).

$[\mathrm{C} 47,861 / 58$

Taylor, W.: Steroid metabolism in the rabbit. Biliary and urinary excretion of metabolites of $\left[4^{-14} \mathrm{C}\right]$ cortisone. Biochem. J. 117, 263-265 (1970).

$[\mathrm{G} 74,178 / 70$

Tehen, T. T., Bloch, K.: On the conversion of squalene to lanosterol in vitro. J. biol. Chem. 226, 921-930 (1957).

$[\mathrm{G} 66,130 / 57$

Tedeschi, G., Gualandi, G.: Azione del metilandrostendiolo sulla steatosi epatica di ratti digiunanti trattati con etionina. Boll. Soc. ital. Biol. sper. 32, 628-629 (1956). [C33,614/56 Teilum, G., Engbaek, H. C., Harboe, N., Simonsen, M.: Effects of cortisone on experimental glomerulonephritis. J. clin. Path. 4, 301-315 (1951).

$[\mathrm{B} 62,687 / 51$

Telivuo, L., Louhimo, I.: Experimental haemorrhagic shock in rabbits. The effect of noradrenaline and hydrocortisone on survival and acid base balance. Acta anaesth. scand. 10, 1-8 (1966).

$[\mathrm{G} 39,506 / 66$

Temple, T. E., Jr., Jones, D. J., Jr., Liddle, G. W., Dexter, R. N.: Treatment of Cushing's disease. Correction of hypercortisolism by o, $\mathrm{p}^{\prime} \mathrm{DDD}$ without induction of aldosterone deficiency. New Engl. J. Med. 281, 801-805 (1969).

$[\mathrm{H} 17,091 / 69$

Templeton, R. D., Patras, M. C.: Effects of thyroparathyroidectomy and of thyroid feeding in rats on limited intake of vitamin B. Amer. J. Physiol. 105, 95 (1933). $\quad[9,640 / 33$ Tenhunen, R., Marver, H. S., Schmid, R.: The enzymatic catabolism of hemoglobin: stimulation of microsomal heme oxygenase by hemin. J. Lab. clin. Med. 75, 410-421 (1970).

$[\mathrm{G} 73,193 / 70$ 
Tentori, L., Toschi, G., Vivalci, G.: L'effetto dell'ipertiroidismo sperimentale sulla comparsa di lesioni muscolari nel ratto mantenuto ad una dieta carente di vitamina E. R. C. Ist. sup. Sanita 17, 106-114 (1954). $\quad[C 7,904 / 54$ Teodorovic, S., Ingalls, J. W., Greenberg, L.: Effects of corticosteroids on experimental amoebiasis. Nature 197, 86-87 (1963).

$$
\text { [D 52,087/63 }
$$

Tephly, T. R., Mannering, G. J.: Inhibition of microsomal drug metabolism by steroid hormones (Abstr.). Pharmacologist 6, 186 (1964).

$[\mathrm{G} 67,764 / 64$

Tephly, T. R., Mannering, G. J.: Inhibition of drug metabolism. V. Inhibition of drug metabolism by steroids. Molec. Pharmacol 4, 10-14 (1968).

[G53,874/68

Terawaki, A., Yasui, 0., Yamanouchi, M., Fukuyama, T., Nakajima, S.: Phenylalanine hydroxylase in tumor-bearing animals. Gann. $58,177-183$ (1967).

[G50,735/67

Terayama, H., Takata, A.: Effect of adrenal hormones, methylcholanthrene and ionizing irradiation upon aminoazo dye N-demethylating activity in regenerating rat liver. $J$. Biochem. (Tokyo) 60, 1-11 (1966).

$[\mathrm{F} 69,475 / 66$

Terragna, A.: Azione di ormoni proteino-anabolici sul decorso dell'infezione sperimentale da virus influenzale APR 8. G. Mal. infett. No. 12, $1-16$ (1963).

[G36,765/63

Terragna, A., Jannuzzi, C.: Ormoni steroidei e anticorpopoiesi. Nota II: Valutazione comparativa di vari ormoni anabolizzanti. G. Mal. infett. 15, 360-362 (1963).

$[\mathrm{G} 2,778 / 63$

Terragna, A., Jannuzzi, C.: Valutazione degli effetti dell'ormone somatotropo ipofisario sull'anticorpopoiesi. Minerva med. 57, 367-369 (1966).

$[\mathrm{F} 62,290 / 66$

Terragna, A., Jannuzzi, C., Giovanelli, A.: Decorso dell'epatite virale trattata con steroidi anabolizzanti. Studio bioptico e funzionale. $G$. Mal. infett. 16, 484-489 (1964). [G25,811/64

Terragna, A., Jannuzzi, C., Quazza, G. F.: Studio istologico (con particolare riguardo all'apparato mitocondriale) in casi di epatite virale trattati con steroidi proteinoanabolici. Minerva pediat. 17, 772-776 (1965). $\quad[36,590 / 65$

Terragna, A., Roscioli, B., Chiossi, F. M.: Azione degli steroidi proteino-anabolici sul decorso dell'intossicazione difterica sperimentale della cavia. Boll. Ist. sieroter. ital. 45, 407 to 416 (1966).

$[\mathrm{E} 66,111 / 66$
Terragna, A., Roscioli, B., Chiossi, F. M.: Azione degli steroidi proteino-anabolici nella intossicazione da lipopolisaccaride di E. coli 0127 : B 8. Studio sperimentale. Pathologica 58, 567 a 571 (1966).

[F 86,979/66

Tessmann, D.: Zur Frage des Prednisoneffekts bei akuter Leberschädigung (Tetrachlorkohlenstofftest an der Rattenleber). Z. ges. inn. Med. 19, 204-209 (1964).

$[\mathrm{F} 8,084 / 64$

Tessmann, D.: Elektronenmikroskopische und enzymhistochemische Untersuchungen über den Einfluß des Testosterons auf die ischämisierte Mäuse- und Rattenniere. Exp. Pathol. 1, 363-378 (1967).

$[\mathrm{H} 5,695 / 67$

Tessmann, D.: Ưber den Einfluß des Testosterons auf die tubuläre Regeneration der Mäuse- und Rattenniere nach Sublimatintoxikation. Histologische und enzymhistochemische Untersuchungen. Z. ges. inn. Med. 23, 174-178 (1968).

$[\mathrm{G} 65,320 / 68$

Tessmann, D., Niesovies, K., Holtz, M.: Histologische und enzymhistochemische Untersuchungen über den Prednisoneffekt auf die Bindegewebsentwicklung der Kaninchenleber bei chronischer Allylalkoholvergiftung unter Einbeziehung quantitativer Bindegewebsbestimmungen. Zbl.allg. Pathol. pathol. Anat. 107, 370-377 (1965).

$[\mathrm{G} 38,224 / 65$

Tessmann, D., Ziegler, P. F.: Experimentelle Vergleichsuntersuchungen zur Frage des Prednisoneffektes auf die akute Leberschädigung bei unterschiedlicher Kortikoidapplikation. $Z$. ges. inn. Med. 21, 45-48 (1966). [F64,393/66 Thaler, M. M., Dallman, P. R., Goodman, J. R.: Effect of phenobarbital on microsomal enzyme induction and biliary excretion in man (Abstr.). Program Amer. Soc. clin. Invest. Inc., 62nd Ann. Meet., Atlantic City, p. 95a-96a (1970).

$[\mathrm{H} 23,990 / 70$

Thatcher, J. S., Radike, A. W.: Tolerance to potassium intoxication in the albino rat. Amer. J. Physiol. 151, 138-146 (1947). [B4,515/47 Theile, H., Reich, J.: Die Wirkung von Phenobarbital auf den Bilirubinspiegel bei Frühgeborenen. Helv. paediat. Acta 25, 77-82 (1970).

$[\mathrm{G} 73,421 / 70$

Theologides, A., Zaki, G. F.: Mitotic index in the regenerating liver of tumor-bearing mice. Cancer Res. 29, 1913-1915 (1969).

[H 19,577/69

Thibault, 0., Lachaze, A.: Recherches sur la nature de la 'thyroxine active'. Renforcement immédiat par la thyroxamine des effets de l'adrénaline sur divers muscles lisses. $C$. R. Soc. Biol. (Paris) 145, 797-800 (1951).

$[\mathrm{B} 69,990 / 51$ 
Thiéblot, L., Berthelay, J., Lavarenne-Vannier, J.: Action de la thyroxine sur l'excitabilité réflexe sympathique. J. Physiol. (Paris) 48, 718-720 (1956).

$[\mathrm{C} 18,452 / 56$

Thier, D., Gravenstein, J. S.: Thyroxin and reserpin on rate of atrial contraction. Fed. Proc. 19, 294 (1960).

$[\mathrm{C} 83,115 / 60$

Thiersch, J. B.: Effect of 2,4,6,triamino-"S"triazine (TR), 2,4,6 "Tris" (ethyleneimino)" $\mathrm{S}$ "-triazine (TEM) and $\mathrm{N}, \mathrm{N}^{\prime}, \mathrm{N}^{\prime}$-triethylenephosphoramide (TEPA) on rat litter in utero. Proc. Soc. exp. Biol. (N.Y.) 94, 36-40 (1957).

$[\mathrm{C} 28,993 / 57$

Thiersch, J. B., Conroy, L., Stevens, A. R., Jr., Finch, C. A.: Adverse effect of cortisone on marrow regeneration following irradiation. $J$. Lab. clin. Med. 40, 174-181 (1952)

$[\mathrm{B} 76,313 / 52$

Thoenes, F., Schröter, P.: Nebennierenrindenhormone und Rachitis. Z. Kinderheilk. 81, 239 bis 260 (1958).

$[\mathrm{C} 56,987 / 58$

Thomas, C. S., Brockman, S. K.: Steroids in endotoxin shock. Clin. Res. 14, 96 (1966).

[F 82,789/66

Thomas, L.: The physiological disturbances produced by endotoxins. Ann. Rev. physiol. 16, 467-490 (1954).

[B92,009/54

Thomas, L.: Reversible collapse of rabbit ears after intravenous papain, and prevention of recovery by cortisone. J. exp. Med. 104, 245 to 252 (1956).

$[\mathrm{C} 20,800 / 56$

Thomas, L.: The effects of papain, vitamin A and cortisone on cartilage matrix in vivo. Biophys. J. 4, 207-213 (1964). [E37,875/64 Thomas, L., MeCluskey, R. T., Li, J.: Prevention of vitamin A-induced depletion of cartilage matrix in rabbits by cortisone (Abstr.). Fed. Proc. 21, 467 (1962).

[D23,234/62

Thomas, L., MeCluskey, R.T., Li, J., Weissmann, G.: Prevention by cortisone of the changes in cartilage induced by an excess of vitamin A in rabbits. Amer. J. Path. 42, 271-283 (1963).

[D 57,729/63

Thomas, L, Mogabgab, W. J., Good, R. A.: The effects of cortisone on experimental bacterial infection and on the tissue damage produced by bacterial toxins. Amer. Soc. clin. Invest. (43rd Meet.), p. 57. (1951).

[B 57,977/51

Thomas, L, Smith, R. T.: Effect of cortisone on response to endotoxin in mature rabbits. Proc. Soc. exp. Biol. (N.Y.) 86, 810-813 (1954).

$[\mathrm{E} 23,202 / 54$

Thomas, R. M.: Sex hormone therapy in experimental peripheral gangrene. Yale J. Biol. Med. 12, 415-418 (1940).

$[\mathrm{A} 33,372 / 40$
Thomas, W. C., Jr., Morgan, H. G.: The effect of cortisone in experimental hypervitaminosis D. Endocrinology 63, 57-64 (1958).

$[\mathrm{C} 55,688 / 58$

Thompson, E. B., Tomkins, G. M., Curran, J. F.: Induction of tyrosine $\alpha$-ketoglutarate transaminase by steroid hormones in a newly established tissue culture cell line. Proc. nat. Acad. Sci. (Wash.) 56, 296-303 (1966).

$[\mathrm{F} 81,633 / 66$

Thompson, G. E., Scheel, L. D.: Alteration of lung pathology from diisocyanate by glycemic or sensitizing agents. Arch. environm. Hlth 16, $363-370$ (1968).

$[\mathrm{G} 55,229 / 68$

Thompson, J. S., Crawiord, M. K., Reilly, R. W., Severson, C. D.: The effect of estrogenic hormones on immune responses in normal and irradiated mice. J. Immunol. 98, 331-335 (1967).

[G44,654/67

Thompson, J. S., Gurney, C. W., Kirsten, W. H.: The tumor-inhibitory effects of 3-methylcholanthrene on transplantable and 3-methylcholanthrene-induced tumors in $\mathrm{C} 3 \mathrm{H}$ mice. Cancer Res. 20, 1214-1219 (1960).

$[\mathrm{C} 92,646 / 60$

Thompson, J. S., Simmons, E. L., Crawford, M. K., Severson, C. D.: Studies on the mechanisms of estradiol-induced radioprotection. Radiat. Res. 40, 70-84 (1969).

$[\mathrm{G} 70,145 / 69$

Thompson, R. P. H., Eddleston, A. L. W. F., Williams, R.: Low plasma-bilirubin in epileptics on phenobarbitone. Lancet 1969I, 21 to 22.

$[\mathrm{G} 71,802 / 69$

Thompson, R. P. H., Pilcher, C. W. T., Robinson, J., Stathers, G. M., MeLean, A. E. M., Williams, R.: Treatment of unconjugated jaundice with dicophane. Lancet 1969II, 4-6. [G71,801/69 Thompson, R. P. H., Williams, R.: Treatment of chronic intrahepatic cholestasis with phenobarbitone. Lancet 1967 II, 646-648.

$[\mathrm{G} 71,813 / 67$

Thomson, D. L., Collip, J. B., Selye, H.: The effect of parathyroid hormone on the bones of hypophysectomized rats. Proc. Roy. Soc. Can. 28, 124 (1934).

[A239/34

Thomson, D. L., Collip, J. B., Selye, H.: The antihormones. J. Amer. med. Ass. 116, 132 (1941).

$[\mathrm{A} 35,782 / 41$

Thomson, J. F., Mikuta, E. T.: Effect of total body $\mathrm{X}$-irradiation on the tryptophan peroxidase activity of rat liver. Proc. Soc. exp. Biol. (N.Y.) 85, 29-32 (1954). [B90,975/54 Thomson, J. F., Mikuta, E. T.: The effect of cortisone and hydrocortisone on the trypto- 
phan peroxidase-oxidase activity of rat liver. Endocrinology 55, 232-233 (1954).

[B 96,579/54

Thorn, G. W., Clinton, M., Jr., Davis, B. M., Lewis, R. A.: Effect of adrenal cortical hormone therapy on altitude tolerance. Endocrinology 36, 381-390 (1945).

[B335/45

Tillotson, C., Kochakian, C. D.: Effect of castration and testosterone on weight of organs and individual muscles of the fasting guinea pig. Fed. Proc. 15, 187 (1956).

$[\mathrm{C} 14,153 / 56$

Timar, M., Hädrich, I., Botez, A., Vrejoiu, G.: Rôle de la fonction granulopexique du système réticulo-histiocytaire (SRH) dans le mécanisme d'installation de l'accoutumance au phénobarbital. Med. Pharmacol. exp. (Basel) 16, 193-198 (1967).

[F 82,696/67

Timiras, P. S., Koch, P.: Modifications chimiques et morphologiques induites par la cortisone et l'acétate de desoxycorticostérone au niveau du foie du lapin. Rev. canad. Biol. 9, $481-482$ (1951).

[B53,947/51

Timiras, P. S., Koch, P.: Morphological and chemical changes elicited in the liver of the rabbit by cortisone and desoxycorticosterone acetate. Anat. Rec. 113, 349-363 (1952).

[B 54,551/52

Timmler, R.: Die Bedeutung der N-Demethylierung für die Gewöhnung an Morphin und morphinähnlich wirkende Verbindungen. Thesis. University of Berlin (1960). [E48,422/60

Tinacei, F.: L'azione di alcune sostanze antitiroidee (Tiuracile, Metiltiuracile e Aminotiazolo) sul Mustelus Laevis. Publ. Staz. Zool. Napoli 21, 124-131 (1947). [B [B 28,546/47

Tindall, V.R., Beazley, J.M.: An assessment of changes in liver function during normal pregnancy using a modified bromsulphthalein test. J. Obstet. Gynaec. Brit. Cwlth. 72, 717-737 (1965).

[G34,865/65

Tinel, J., Ungar, G.: Epilepsie expérimentale par l'adrénaline chez le cobaye préparé par la yohimbine, l'ergotamine ou la peptone. $C . R$. Soc. Biol. (Paris) 112, 542-543 (1933).

$[14,897 / 33$

Tinozzi, F. P., Pannella, A.: Influenza del diabete da allossana sui tumori sperimentali da 20-metilcolantrene. Arch. De Vecchi Anat. pat. 36, 311-327 (1961).

[D54,092/61

Toberentz, H.: Utber einige Wirkungsbedingungen der Basisnarkotika. Narkosebreite, Streuung der Empfindlichkeit und Weckbarkeit. Naunyn-Schmiedebergs Arch. exp. Pathol. Pharmak. 171, 346-362 (1933).

$[\mathrm{A} 51,399 / 33$
Tobian, L., Jr., Strauss, E.: Effect of adrenal cortical extract on recovery from severe pneumococcic infection in mice. Proc. Soc. exp. Biol. (N.Y.) 69, 529-531 (1948).

[B28,613/48

Todd, A. C.: Thyroactive iodocasein and thiouracil in the diet, and growth of parasitized chicks. Poultry Sci. 27, 818-821 (1948).

[G71,890/48

Todd, A. C.: Thyroid condition of chickens and development of parasitic nematodes. J. Parasit. 35, 255-260 (1949).

[B40,185/49

Todd, R. S., Laine, J. B., Howard, J. M., Singh, L. M., Vega, R. E.: Effects of aldosterone on prolongation of renal homografts in dogs. Surg. Forum 14, 501-502 (1963). [G 10,342/63

Toivanen, P.: Effect of estrogens and progestins on the susceptibility of mice to experimental staphylococcal infection. Ann. Univer. Turk. (Ser. A/II), No. 35, p. 7-27 (1966).

[G59,609/66

Toivanen, P.: Enhancement of staphylococcal infection in mice by estrogens. I. Effect of the timing, quantity and quality of the hormone. Ann. Med. exp. Fenn. 45, 138-146 (1967).

[G49,847/67

Toivanen, P.: Enhancement of staphylococcal infection in mice by estrogens. II. Effect of the inoculum size and the strain variation of bacteria and mice. Ann. Med. exp. Fenn. 45, 147 to 151 (1967).

[G49,848/67

Tolekmitt, W.: Utber den Einfluß von Steroidpräparaten mit Hormonwirksamkeit auf den Umsatz von L-Tryptophan beim Säugling. Arch. Kinderheilk. 181, 158-168 (1970).

$[\mathrm{G} 77,793 / 70$

Tolentino, P.: Protein anabolic steroid hormones and antibody formation. Ann. paediat. (Basel) 199, 467-471 (1962). [D34,052/62

Tolentino, P., Terragna, A., Jannuzzi, C.: Ormoni steroidei e anticorpopoiesi. Nota I. Blocco enzimatico della 11-idrossilasi surrenalica. Effetto della somministrazione di androgeni. G. Mal. infett. 13, 561-563 (1961).

[D 16,593/61

Tolentino, P., Terragna, A., Jannuzzi, C.: Ormoni steroidei ed anticorpopoiesi. Mancata azione di stimolo da parte di steroidi proteinoanabolici nella somministrazione distanziata dall'antigene ' $O$ ' nella risposta anamnestica. Ann. Sclavo 6, 439-444 (1964). [G70,136/64

Tomich, E. G., Woollett, E. A., Pratt, M. A.: Some biological actions of iodo-1-thyronines. J. Endocr. 20, 65-68 (1960). [C83,307/60 
Tomkins, G. M.: The enzymatic reduction of $\Delta^{4}$-3-ketosteroids. J. Biol. Chem. 225, 13-24 (1957).

[C32,526/57

Tomkins, G. M., Garren, L. D., Howell, R. R., Peterkofsky, B.: The regulation of enzyme synthesis by steroid hormones: the role of translation. J. cell. comp. Physiol. 66, Sup. 1, 137-152 (1965).

$[\mathrm{G} 35,353 / 65$

Tomkins, G. M., Gelehrter, T. D., Granner, D., Martin, D., Jr., Samuels, H. H., Thompson, E. B.: Control of specific gene expression in higher organisms. Expression of mammalian genes may be controlled by repressors acting on the translation of messenger RNA. Science 166, 1474-1480 (1969).

$[\mathrm{H} 19,499 / 69$

Tomkins, G. M., Thompson, E. B., Hayashi, S., Gelehrter, T., Granner, D., Peterkofsky, B.: Tyrosine transaminase induction in mammalian cells in tissue culture. Symp. Quant. Biol. (Cold Spring Harbor) 31, 349-360 (1966).

[G49,588/66

Tomlinson, G. A., Yaffe, S. J.: The formation of bilirubin and p-nitrophenyl glucuronides by rabbit liver. Biochem. J. 99, 507-512 (1966).

[G76,303/66

Tonutti, E.: Toxische Gewebsschäden, Entstehungsmechanismus und Folgerungen. Langenbecks Arch. klin. Chir. 264, 61-68 (1950).

[B $48,892 / 50$

Tonutti, E.: Desoxycorticosteron und Cortison bei Diphtherietoxinvergiftung, insbesondere ihre Wirkungsunterschiede hinsichtlich des allgemeinen Resistenzvermögens. ArzneimittelForsch. 2, 97-102 (1952).

[B 69,136/52

Tonutti, E., Fetzer, S.: Einfluß von Desoxycorticosteron und Cortison auf das Resistenzvermögen gegen Giftstoffe des Tuberkelbazillus. Münch. med. Wschr. 94, 2161-2168 (1952).

[B 75, 190/52

Torda, C., Wolff, H. G.: Effect of cortisone and ACTH on the threshold of convulsions induced by pentamethylene tetrazol. Fed. Proc. 10, 137 (1951).

[B $57,149 / 51$

Torda, C., Wolff, H. G.: Effects of various concentrations of adrenocorticotrophic hormone on electrical activity of brain and on sensitivity to convulsion-inducing agents. Amer. J. Physiol. 168, 406-413 (1952).

$[\mathrm{B} 69,986 / 52$

Tormey, J., Lasagna, L.: Relation of thyroid function to acute and chronic effects of amphetamine in the rat. J. Pharmacol. exp. Ther. 128, 201-209 (1960).

$[\mathrm{C} 80,689 / 60$

Torrence, J.L., Bauer, G.E.: Protection from 7,12-dimethylbenz(a)anthracene-induced adre- nal apoplexy and necrosis by Celite. Endocrinology 88, 1069-1071 (1971). [H37,366/71 Tournade, A., Raymond-Hamet: Syncope noradrénalino-chloroformique. C. R. Soc. Biol. (Paris) 111, 897-900 (1932). $\quad[7,436 / 32$ Tourniaire, A., Blum, J., Guyot, R., Madignier, M.: L'hyperexcitabilité myocardique des cardiopathies décompensées. Effet de la spironolactone. Sem. Hôp. Paris 45, 1388-1392 (1969).

$[\mathrm{G} 66,481 / 69$

Traeger, A., Klinger, W.: Der Einfluß von Triorthokresylphosphat auf die Hexobarbitalseitenlagenzeit verschieden alter Ratten. Acta biol. med. germ. 23, 925-928 (1969).

$[\mathrm{H} 23,856 / 69$

Traina, V.: Adrenotropic hormone (ACTH), aminopterin and eosinophil count. Nature (Lond.) 168, 250 (1951).

$[\mathrm{B} 72,887 / 51$

Trainin, N.: Adrenal imbalance in mouse skin carcinogenesis. Cancer Res. 23, 415-419 (1963).

[D61,599/63

Trasino, M.: Effetti della splenectomia in varie condizioni sperimentali. Boll. Soc. ital. Biol. sper. 26, 1152-1154 (1950). [ [B56,794/50

Travis, J. W., Keyl, A. C., Dragstedt, C. A.: The effect of pancreatectomy on the toxicity of $\mathrm{k}$-strophanthin in the dog. J. Pharmacol. exp. Ther. 117, 148-150 (1956). [ [C18,863/56

Treadwell, A. de G., Gardner, W. U., Lawrence, J. H.: Effect of combining estrogen with lethal doses of roentgen-ray in Swiss mice. Endocrinology 32, 161-164 (1943). [A56,593/43

Trentini, G. P., Scilabra, G. A., Botticelli, A., Pugliese, F.: Il quadro arterioso e splancnico del coniglio trattato con 5-HT e colesterolo, e con 5-HT, colesterolo e tween 80. Arch. De Vecchi Anat. pat. 53, 455-471 (1968).

$$
\text { [G71,152/68 }
$$

Trinci, M.: Effetti della stimolazione surrenalica con ormone corticotropo, in ratti irradiati su tutto il corpo con raggi $\gamma$ del $\mathrm{Co}^{60}$. Nunt. radiol. (Roma) 32, 437-453 (1966). [G45,713/66

Triner, L., Mráz, M., Chmelařová, M.: The effect of glucose and glucose together with insulin on the resistance of fasted rats to trauma in the Noble-Collip drum. Physiol. bohemoslov. 12, 136 to 144 (1963).

$[\mathrm{D} 65,801 / 63$

Tripi, H. B., Kuzell, W. C., Gardner, G. M.: Thiouracil administration and thyroidectomy in experimental polyarthritis of rats. Ann. rheum. Dis. 8, 125-131 (1949). [B12,732/49

Trnavský, K., Trnavská, Z., Cebecauer, L.: Attempt to influence the increased solubility of 
collagen in lathyrism by hydrocortisone. $N a$ ture (Lond.) 207, 993-994 (1965). F 49,077/65

Trnavská, Z., Trnavský, K.: Effect of antirheumatic drugs on experimental lathyrism. Biochem. Pharmacol. 17, 71-74 (1968).

[G54,556/68

Trojanová, M.: The effect of thyroidectomy and parathyroidectomy during the early postnatal period upon survival of the respiratory centre in the rat in anoxia. Physiol. bohemoslov. 15, 454-458 (1966).

[G42,905/66

Trolle, D.: Phenobarbitone and neonatal icterus. Lancet 1968 I, 251-252. [G71,807/68

Trolle, D.: Decrease of total serum-bilirubin concentration in newborn infants after phenobarbitone treatment. Lancet 1968 II, 705-708.

[G71,809/68

Trolle, D.: A possible drop in first-weekmortality rate for low-birth-weight infants after phenobarbitone treatment. Lancet 1968 II, 1123 to 1124 .

$[\mathrm{G} 77,159 / 68$

Trotter, N. L.: The effect of partial hepatectomy in subcutaneously transplanted hepatomas in mice. Cancer. Res. 21, 778-782 (1961).

[E90,324/61

Trotter, N. L.: A fine structure study of lipid in mouse liver regenerating after partial hepatectomy. J. Cell Biol. 21, 233-244 (1964).

$[\mathrm{G} 71,660 / 64$

Tsuru, C.: Influence of endocrinous medicine upon the formation of Rhodan compound. (Japanese text p. 619-639.) J. orient. Med. 19, 47 (1933).

$[44,467 / 33$

Tuchmann-Duplessis, H., Mercier-Parot, L.: Essais de prévention des effets embryotoxique et tératogène de l'actinomycine $D$. I. Action de la progestérone ou d'une association progestérone folliculine. C. R. Soc. Biol. (Paris) 164, 6-10 (1970).

$[\mathrm{H} 28,871 / 70$

Tuchmann-Duplessis, H., Mercier-Parot, L.: Essais de prévention des effets embryotoxique et tératogène de l'actinomycine D. II. Influence de l'hormone lactogène. C. R. Soc. Biol. (Paris) 164, 60-63 (1970).

$[\mathrm{H} 28,876 / 70$

Tuchweber, B., Gabbiani, G., Côté, G.: Effect of thyroxine and calcitonin on experimental hyperparathyroidism. Present. Nat. Found. Conf. Hormones in Development, Nottingham University, Sept. 9-12, 1968. [G 46,759/68 Tuchweber, B., Gabbiani, G., Selye, H.: Einfluß des Hypophysen-Nebennierenrindensystems auf die durch Hexadimethrin hervorgerufenen Organveränderungen. Med. Welt (Stuttg.) No. 45, 2272-2275 (1963).

$[\mathrm{G} 27,884 / 63$
Tuchweber, B., Gabbiani, G., Selye, H.: Effect of vitamin $\mathbf{E}$ and methyltestosterone upon the progeria-like syndrome produced by dihydrotachysterol. Amer. J. clin. Nutr. 13, 238-242 (1963).

$[\mathrm{D} 65,261 / 63$

Tuchweber, B., Garg, B. D.: Protection by spironolactone and various anabolic steroids against vitamin-A overdosage (Abstr.). Proc. Canad. Fed. Biol. Soc. Montreal, Quebec, 13, 10 (1970).

[G70,434/70

Tuchweber, B., Garg, B. D., Hatakeyama, S.: Prevention of hypervitaminosis-A by spironolactone and anabolic steroids. Int. Z. Vitamin. forsch. 40, 575-584 (1970).

$[\mathrm{G} 70,477 / 70$

Tuchweber, B., Kovaes, K.: Influence of phenobarbital and various steroids on $\mathrm{CCl}_{4}$ hepatotoxicity. Arch. Toxikol. 27, 159-167 (1971). [G70,489/71

Tuchweber, B., Kovacs, K., Khandekar, J. D., Garg, B.D.: Intramitochondrial lamellar formations induced by pregnenolone-16 $\alpha$-carbonitrile in the hepatocytes of pregnant rats. $J$. Ultrastruct. Res. (in press).

$[\mathrm{G} 79,031$

Tuchweber, B., Solymoss, B., Khandekar, J.D., Garg, B. D., Kovacs, K.: Effect of pregnenolone$16 \alpha$-carbonitrile on the liver ultrastructure and microsomal enzyme activity in pregnant rats. (Abstr.) Program 52nd Meet. Endocr. Soc. St. Louis, Miss., (in press).

[G79,020

Tullio, P.: Il tasso glicemico come indice della resistenza dell'organismo al raffreddamento. Arch. Sci. biol. (Bologna) 14, 379-390 (1930).

$[22,671 / 30$

Tuohy, G.F.: Drugs : reactions and interactions. S. Dak. J. Med. 22, 19-22 (1969).

$[\mathrm{G} 66,351 / 69$

Turcotte, J. G., Haines, R. F., Brody, G. L., Meyer, T. J., Schwartz, S. A.: Immunosuppression with medroxyprogesterone acetate. Transplant. Bull. 6, 248-260 (1968). [G56,529/68

Tureman, J., Maloney, A. H., Booker, W. M., Froix, C., Jones, W.: Further studies on the depressant action of pentobarbital sodium on adrenalectomized rats (Abstr.). J. Pharmacol. exp. Ther. 106, 420 (1952).

[B 80,379/52

Turner, K. B., De Lamater, A.: Effect of thyrotropic hormone on blood cholesterol of thyroidectomized rabbits. Proc. Soc. exp. Biol. (N.Y.) 49, 150-152 (1942).

[A37,602/42

Turner, M. M., Berry, L. J.: Inhibition of gastric emptying in mice by bacterial endotoxin. Amer. J. Physiol. 205, 1113-1116 (1963).

$[\mathrm{E} 36,911 / 63$ 
Turner, T. B., Hollander, D. H.: Cortisone in experimental syphilis (a preliminary note). Bull. Johns Hop. Hosp. 87, 505-509 (1950).

[B55,488/50

Tyce, G. M., Flock, E. V., Owen, C. A., Jr., Stobie, G. H. C., David, C.: 5-Hydroxyindole metabolism in the brain after hepatectomy. Biochem. Pharmacol. 16, 979-992 (1967).

$[\mathrm{G} 47,432 / 67$

Tyce, G. M., Stobie, G. H. C., Flock, E. V., Bollman, J. L.: 5-Hydroxytryptamine content of the brain after hepatectomy. Fed. Proc. 21, 301 (1962).

[D23,092/62

Tyler, F.H., West, C.D., Jubiz, W., Meikle, A.W.: Dilantin and metyrapone: a clinically significant example of enzyme induction. Trans. Amer. clin. climat. Ass. 81, 213-219 (1969).

$[\mathrm{G} 79,95 \mathrm{~s} / 69$

Tyree, E. B., Swift, M. N., Patt, H. M.: X irradiation of the hypophysectomized rat. Amer. J. Physiol. 155, 473 (1948).

[B33,116/48

Tyslowitz, R., Astwood, E. B.: The effect of corticotrophin on the resistance of hypophysectomized rats to low environmental temperatures. Proc. Amer. physiol. Soc. 53rd Ann. Meet. Chicago, Ill. P284-P285 (1941). $\quad$ [80,678/41

Uehleke, H.: Extrahepatic microsomal drug metabolism. In: Baker and Tripod; Sensitization to Drugs. Int. Congr. Ser. No. 181, 10, p. 94-100. Amsterdam: Excerpta Medica Foundation 1969.

[G70,915/69

Uehleke, H., Greim, H.: Stimulierung der Oxydation von Fremdstoffen in Nierenmikrosomen durch Phenobarbital. Naunyn-Schmiedebergs Arch. Pharmak. 261, 152-161 (1968).

[G70,906/68

Uete, T.: Mode of action of adrenal cortical hormones. J. Biochem (Tokyo) 65, 513-521 (1969).

$[\mathrm{H} 15,157 / 69$

Ulmansky, M., Sela, J.: Changes in the epiphyseal cartilages of mice treated with parathormone, fluoride and copper. J. comp. Path. 79, 367-370 (1969).

$[\mathrm{G} 70,273 / 69$

Ungváry, G., Demeter, J., Hudák, A., Tari, J.: Changes in the vascular structure of the liver following subtotal hepatectomy in the rat. Acta morph. Acad. Sci. hung. 17, 143-155 (1969).

$[\mathrm{G} 72,366 / 69$

Urist, M. R., Deutsch, N. M., Pomerantz, G., MeLean, F. C.: Interrelations between actions of parathyroid hormone and estrogens on bone and blood in avian species. Amer. J. Physiol. 199, 851-855 (1960).

$[\mathrm{C} 95,236 / 60$
Uroić, B., Rabadjija, M., Supek, Z.: Toxicity of a nucleotoxic agent, mustine hydrochloride, and its enhancement by 5-hydroxytryptamine pretreatment. J. Pharm. Pharmacol. 16, 61-62 (1964).

$[\mathrm{E} 37,637 / 64$

Uspenskaya, G. S.: Role of the thyroid gland in thallium intoxication. (Russian text.) Vestn. Vener. Derm., No. 2-3, 78-80 (1939).

[D34,628/39

Usuelli, F., Piana, G., Mainardi, B.: Testosterone e digiuno. Folia endocr. (Roma) 2, 31-39 (1949).

[B34,756/49

Uyldert, I. E.: The effect of DOCA and of adrenal cortical extract on hepatic regeneration in adrenalectomized rats. Acta physiol. pharmacol. neerl. 1, 359-362 (1950). [G76,358/50 Vacek, L.: Studie o steroidní anestesii: 3. Desoxykortikosteron a krecove latky. Scr. med. Fac. Med. Brun. 31, 323-328 (1958).

$[\mathrm{C} 63,230 / 58$

Vacek, L.: Studie o steroidní anestesii: 6. Vliv serotoninu a jeho antagonistû na centrál ne tlumivý účinek hydroxypregnandionu.(A study of steroid anesthesia: 6 . The influence of serotonin and its antagonists on the central inhibitive effect of hydroxypregnandion). Scr. med. Fac. Med. Brun. 34, 65-72 (1961).

[D 10,919/61

Vácha, J., Pošpísil, M.: Individual differences in the stress respone of mice and their relationship to the differences in radiation tolerance. Med. exp. (Basel) 19, 58-63 (1969).

$[\mathrm{H} 17,170 / 69$

Vakilzadeh, J., Vandiviere, M. R.: Hormones in experimental tuberculoimmunity. Acta tuberc. pneumol. scand. 43, 170-180 (1963).

$[\mathrm{E} 32,626 / 63$

Valderrama, J. A. F. de, Munuera, L. M.: The effect of cortisone and anabolic agents on bone. In: Fleisch, Blackwood and Owen; Calcified Tissues (Proc. 3. europ. Symp.), p. 245-249. Berlin, Heidelberg, New York: Springer 1966. $[\mathrm{E} 6,008 / 66$

Valeriote, F. A., Auricchio, F., Tomkins, G. M., Riley, D.: Purification and properties of rat liver tyrosine aminotransferase. J. biol. Chem. 244, 3618-3624 (1969).

$[\mathrm{G} 67,621 / 69$

Vallecalle, E., Soto-Rivera, A., de Armas, T. G., Luque, A. G.: Influencia de las hormonas sexuales sobre la excitabilidad del sistema nervioso central. Acta endocr. (Kbh.) 51, 99 to 100 (1960).

$[\mathrm{C} 93,280 / 60$

Valori, P.: Influenza della tiroidectomia sopra l'ipertrofia di compenso e l'attività metabolica 
del rene superstite a nefrectomia monolaterale. Arch. Fisiol. 48, 196-203 (1948). [B46,667/48 Valtin, H., Tenney, S. M.: Respiratory and circulatory adaptation to hyperthyroidism in rats at rest and during exercise. Fed. Proc. 18, 162 (1959).

$[\mathrm{C} 66,148 / 59$

Vanamee, P., Winawer, S.J., Sherlock, P., Sonenberg, M., Lipkin, M.: Decreased incidence of restraint-stress induced gastirc erosions in rats treated with bovine growth hormone. Proc. Soc. exp. Biol. (N.Y.) 135, 259-262 (1970).

$[\mathrm{H} 32,254 / 70$

Van Cauwenberge, H., Jaques, L. B., ct. Cauwenberge, H. van, Jaques, L. B. [C58,521/58 Van Cauwenberge, H., Jaques, L. B., ct. Cauwenberge, H. van, Jaques, L. B. [C72,748/59 Van den Brenk, H. A. S., cf. Brenk, H. A. S. van den

$[\mathrm{C} 57,624 / 58$

Vanderlinde, R. E., Westerfeld, W. W.: The inactivation of estrone by rats in relation to dietary effects on the liver. Endocrinology 47, 265-273 (1950).

[B51,537/50

Vandestrate, M.: Action du chlorure de manganèse et de l'hyposulfite de soude sur l'intoxication tuberculinique et sur la sensibilité du derme à la tuberculine chez le cobaye tuberculeux. C. R. Soc. Biol. (Paris) 112, 357-359 (1933).

[A48,036/33

Vanha-Perttula, T. P. J., Näätänen, E. K.: The effect of cortisone on cardiovascular sclerosis induced in rats with cholesterol and vitamin $D$. Acta endocr. (Kbh.) 35, 20-33 (1960).

$[90,637 / 60$

Vanzo, J. P. da: Effect of 2-methyl-9 $\alpha$ fluorohydrocortisone on survival of tourniquetshocked rats. Arch. int. Pharmacodyn. 150, 442 to 446 (1964).

[F 19,865/64

Varga, F., Fischer, E.: Hexobarbital sleeping time in male rats with hepatic injury. Acta physiol. Acad. Sci. hung. 36, 431-439 (1969).

[G76,189/69

Vargas, M. V.: Antagonismo farmacologico del propionato de testosterona y bicloruro de hidrargirio. Crón. méd. (Lima) 65, 57-72 (1948).

$[\mathrm{B} 44,689 / 48$

Various authors: Application of metabolic data to the evaluation of drugs. A report prepared by the Committee on Problems of Drug Safety of the Drug Research Board, National Academy of Sciences-National Research Council. Clin. Pharmacol. Ther. 10, 607-634 (1969).

$[\mathrm{G} 68,203 / 69$

Vauthey, P., Vauthey, M.: Effet protecteur de la vitamine $\mathrm{C}$ contre les intoxications. $J$. Méd. Lyon 28, 305-308 (1947).

$[\mathrm{A} 48,670 / 47$
Velluda, C. C., Russu, I. G.: Le système réticuloendothélial et la syncope adrénalino-chloroformique. J. Physiol. Path. gén. 34, 815-823 (1936).

$[38,782 / 36$

Venkatesan, N., Argus, M.F., Areos, J.C.: Mechanism of 3-methyl-cholanthrene-induced inhibition of dimethylnitrosamine demethylase in rat liver. Cancer. Res 30, 2556-2562 (1970).

[H31,273/70

Vennet, K. V., Schneewind, J. H.: The effect of steroids on mortality in experimental traumatic shock. Proc. Soc. exp. Biol. (N.Y.) 109, 674 to 675 (1962).

[D 23,294/62

Ventura, J., Richer, C. L., Selye, H.: Effect of hypophysectomy upon the leukemoid organ infiltrations in Walker tumor-bearing rats. Cancer Res. 17, 215-217 (1957). [C23,299/57

Ventura, J., Selye, H.: Inverse 'conditioning' by hypophysectomy of mineralocorticoid and glucocorticoid activities of $9(\alpha)$-chlorocortisol. Amer. J. Physiol. 189, 412-414 (1957).

$[\mathrm{C} 24,231 / 57$

Verbin, R. S., Sullivan, R. J., Farber, E.: The effects of cycloheximide on the cell cycle of the regenerating rat liver. Lab. Invest. 21, 179-182 (1969).

$[\mathrm{G} 70,538 / 69$

Verne, J., Hébert, S., Barbarin, Y.: Action de la cortisone sur l'intoxication par le cyanure de potassium. Presse méd. 62, 1101 (1954).

$[\mathrm{B} 99,912 / 54$

Verne, J., Roth, P.C.J.: The preventive effect of norandrostenolone phenylpropionate on carcinogenesis. Bull. Cancer 50, 49-52 (1963).

$[\mathrm{E} 48,050 / 63$

Vernikos-Danellis, J., Marks, B. H.: Pituitary inhibitory effects of digitoxin and hydrocortisone. Proc. Soc. exp. Biol. (N.Y.) 109, 10-14 (1962).

[D 21,210/62

Vesell, E. S.: Induction of drug-metabolizing enzymes in liver microsomes of mice and rats by softwood bedding. Science 157, 1057-1058 (1967).

$[\mathrm{F} 88,031 / 67$

Vesselinovitch, S. D., Mihailovich, N.: The effect of gonadectomy on the development of hepatomas induced by urethan. Cancer Res. 27, 1788-1791 (1967).

[F 91,584/67

Vest, M., Signer, E., Weisser, K., Olaisson, A.: A double blind study of the effect of phenobarbitone on neonatal hyperbilirubinaemia and frequency of exchange transfusion. Acta paediat. scand. 59, 681-684 (1970). [H32,456/70

Vest, M., Wyler, F., Girard, J.: Zur Entwicklungsphysiologie der Leber. Praxis 57, 1693 bis 1695 (1968).

[H14,687/68 
Viale, L. C. San M. de, Viale, A. A., Nacht, S., Grinstein, M.: Experimental porphyria induced in rats by hexachlorobenzene. A study of the porphyrins excreted by urine. Clin. chim. Acta 28, 13-23 (1970).

[G74,147/70

Vick, J.: Interaction of ionizing radiation and E. coli endotoxin. Fed. Proc. 26, 628 (1967).

$[\mathrm{F} 79,609 / 67$

Vick, J., Spink, W. W.: Supplementary role of hydralazine in reversal of endotoxin shock with metaraminol and hydrocortisone. Proc. Soc. exp. Biol. (N.Y.) 106/2, 280-283 (1961).

[D $43,929 / 61$

Vick, J. A.: Physiological and pharmacological studies on the reversibility of endotoxin shock in dogs (Abstr.). J. clin. Invest. 39, 1037 (1960).

$[\mathrm{C} 84,708 / 60$

Vick, J. A.: Use of isoproterenol and phenoxybenzamine in treatment of endotoxin shock. Physiologist 8, 296 (1965).

[F 48,509/65

Vick, J. A., Ciuchta, H. P., Manthei, J. H.: Use of isoproterenol and phenoxybenzamine in treatment of endotoxin shock. J. Pharmacol. exp. Ther. 150, 382-388 (1965). [F 58,531/65

Vick, J. A., Lafave, J. W., MacLean, L. D.: Effect of treatment of endotoxin shock on renal hemodynamics and survival. Surgery $54,78-85$ (1963).

$[\mathrm{E} 20,146 / 63$

Vilehez, C. A., Sadnik, I. L., Bade, E. G.: Influence of starvation on liver regeneration in the mouse. Naturwissenschaften 55, 392-393 (1968).

[H 15,524/68

Vincent, V., Motin, J.: Intoxication volontaire associant insuline et barbituriques. Lyon méd. 218, 407-408 (1967).

[G51,414/67

Visconti, J. A.: Use of drug interaction information in patient medication records. Amer. $J$. Hosp. Pharm. 26, 378-387 (1969).

$$
\text { [G 77,709/69 }
$$

Vittorio, P. V., Mars, H., Johnston, M. J.: Effect of X-irradiation on normal, hypothyroid, and hyperthyroid rabbits. Canad. J. Biochem. 37, 1271-1275 (1959).

$[\mathrm{C} 76,156 / 59$

Vittorio, P. V., Watkins, E. A., Dziubalo-Blehm, S.: The effect of erythropoietin on survival in irradiated polycythemic mice. Canad. $J$. Physiol. Pharmacol. 47, 221-223 (1969).

$[\mathrm{H} 7,759 / 69$

Vittorio, P.V., Wight, E.W., Sinnott, B.E.: A study of the protective action of serotonin (5hydroxytryptamine) against whole-body $\mathrm{X}$ irradiation in mice with the aid of chromium 51. Canad. J. Biochem. 41, 347-360 (1963).

[D 56,243/63
Vivan, A., Braito, E.: Ricerche sperimentali sul ruolo del fegato nella patogenesi degli itteri emolitici. Attual. Ostet. Ginec. 8, 113-120 (1962).

[D 22,638/62

Vivanco, F., Gabay, S., Martin, J. A. S., Ramos, F.: Effect of DL-thyroxine on the PBI and BMR of rats poisoned with aminonitriles. Endocrinology 69, 654-658 (1961). [ [D 10,627/61

Vivaneo, F., Ramos, F., Jimenez-Diaz, C.: Determination of $\gamma$-aminobutyric acid and other free amino acids in whole brains of rats poisoned with $\alpha, \gamma^{\prime}$-iminodipropionitrile and $\beta, \beta$-diaminobutyric acid with, or without, administration of thyroxine. J. Neurochem. 13, 1461-1467 (1966).

$[\mathrm{G} 43,566 / 66$

Vivanco, F., Sanchez-Martin, J. A., Diaz, C. J.: Neuronal degeneration, electroencephalographic disturbances and polyserositis in rats produced by iminodipropionitrile and prevented by l-thyroxine. Endocrinology 69, 1111-1116 (1961).

[D $15,606 / 61$

Vizet, J.: De quelques relations de perméabilité de la barrière hémo-encéphalique et de pénétration des dérivés barbituriques dans les tissus nerveux centraux. Biol. méd. (Paris) 56, 1 to 107 (1967).

[F 77,760/67

Vodicka, I., Dostál, M.: Ein Beitrag zur Wirkungsanalyse der anabolen Steroide bei der akuten Strahlenkrankheit von Ratten. Strahlentherapie 135/6, 739-744 (1968).

$[\mathrm{G} 69,171 / 68$

Vogel, R. A., Michael, M., Jr., Timpe, A.: Cortisone in experimental histoplasmosis. Amer. J. Path. 31, 535-543 (1955). $\quad$ [C 10,597/55

Vogt, 0., Tissières, A., Verzár, F.: Einfluß der Thymektomie auf die Empfindlichkeit von Ratten gegenüber A und D Vitamin Mangel sowie eiweißarme Diät. Int. Z. Vitamin-forsch. 20, 44-60 (1948).

[B36,750/48

Voigt, W., Fernandez, E. P., Hsia, S. L.: P-450 level and taurochenodeoxycholate $6 \beta$-hydroxylase system of rat liver microsomes. Proc. Soc. exp. Biol. (N.Y.) 133, 1158-1161 (1970).

$[\mathrm{H} 25,247 / 70$

Vollmer, E. P., Hurlbut, H. S.: Ineffectiveness of cortisone therapy in mice infected with Japanese $B$ encephalitis and the adverse effect of high doses. J. infect. Dis. 89, 103-106 (1951).

$[\mathrm{B} 66,973 / 51$

Vollmer, H., Buchholz, C.: Untersuchungen über die Giftempfindlichkeit weißer Mäuse nach Vorbehandlung mit oxydationssteigernden Substanzen. Naunyn-Schmiedebergs Arch. Pharmak. 155, 185-218 (1930). [A48,810/30 
Volterrani, U.: ACTH, cortisone e ipossia. Ormonologia 17, 415-424 (1957). [C64,384/57 Volterrani, U.: Ipossia e cortisone. Ormonologia 17, 425-435 (1957). $[\mathrm{C} 64,385 / 57$ von der Decken, A., cf. Decken, A. von der

Von Rummel, W., cf. Rummel, W. von [G68,039/60

$[\mathrm{C} 79,429 / 59$

Von Zwehl, T., cf. Zwehl, T. von

$[25,477 / 26$

Vorhaus, E. F., Vorhaus, L. J.: Protective effects of pretreatment with cortisone, aureomycin, and folic acid in carbon tetrachlorideinduced hepatic injury in rats. Gastroenterology 26, 887-894 (1954).

[B 97,869/54

Voss, J.: Pentamethylentetrazol (Cardiazol). III. Mitteilung über die Wirkung von Cardiazol bei peroraler Applikation. Naunyn-Schmiedebergs Arch. Pharmak. 118, 259-266 (1926).

$[\mathrm{A} 47,860 / 26$

Voss, R., Walther, D.: Einfluß der Drosselung endokriner Leistungen auf die Wiederbelebungszeit des Rückenmarks. Langenbecks Arch. klin. Chir. 293, 616-622 (1960). [E 53,093/60

Vunder, P. A., Lapshina, V.F.: Strumous action of paraaminosalicylic acid. (Russian text). Probl. Endokr. Gormonoter. 2/4, 76-81 (1956).

[D34,912/56

Wada, F., Hirata, K., Nakao, K., Sakamoto, Y.: Participation of the microsomal electron transport system involving cytochrome $\mathrm{P}-450$ in $7 \alpha$ hydroxylation of cholesterol. J. Biochem. (Tokyo) 66, 699-703 (1969).

[H 19,993/69

Wada, F., Hirata, K., Sakamoto, Y.: Relation of cholesterol synthesis and NADPH oxidation by microsomal electron transport system involving P-450. Biochim. biophys. Acta (Amst.) 143, 273-275 (1967).

[G67,771/67

Wada, F., Hirata, K. Sakamoto, Y.: Possible participation of cytochrome P-450 in cholesterol synthesis. J. Biochem. (Tokyo) 65, 171 to $175(1969)$.

$[\mathrm{H} 15,247 / 69$

Wada, F., Shimakawa, H., Takasugi, M., Kotake, T., Sakamoto, Y.: Effects of steroid hormones on drug-metabolizing enzyme systems in liver microsomes. J. Biochem. (Tokyo) 64, 109-113 (1968).

$[\mathrm{H} 15,468 / 68$

Wada, J. A., Ikeda, H., MeGeer, E. G.: The susceptibility to audiogenic stimuli of rats treated with methionine sulfoximine and various psychoactive agents. Exp. Neurol. 18, 327 to 337 (1967).

[G48,380/67

Waelsch, H., Selye, H.: Beiträge zur Entgiftung im tierischen Organismus. III. Mitteilung: Bedeutung der Leber bei Avertin- und Magnesium- narkosen. Naunyn-Schmiedebergs Arch. Pharmak. 161, 115-118 (1931).

$[3,972 / 31$

Wagner, W. H., Lammers, L.: Cortison und Prednison bei der experimentellen Mäusetuberkulose. In: Various Authors; Medizin und Chemie 6, p. 225-248. Weinheim, Bergstr.: Verlag Chemie GmbH 1958.

$[\mathrm{C83,426/58}$

Wajda, I., Lehr, D., Krukowski, M.: Sex difference in aortic rupture induced by lathyrus odoratus in immature rats. Fed. Proc. 16, 343 (1957).

$[\mathrm{C} 33,241 / 57$

Wajda, I., Lehr, D., Krukowski, M.: Influence of sex hormones upon incidence of dissecting aortic aneurysm in immature rats on a sweet pea seed diet. J. Pharmacol. exp. Ther. 122, $79 \mathrm{~A}-80 \mathrm{~A}$ (1958).

$[\mathrm{C} 48,618 / 58$

Wakabayashi, I., Arimura, A., Schally, A. V.: Effect of adrenocortical hormones on plasma radioimmunoassayable growth hormone (RIAGH) in rats (Abstr.). Physiologist 13, 332 (1970).

$[\mathrm{H} 27,784 / 70$

Wakim, K. G., McKenzie, B. F., McGuckin, W. F., Brown, A. L., Jr.: The effects of heparin, nicotinic acid and ACTH on experimental nephrosis. Amer. J. med. Sci. 245, 259-276 (1963).

[D39,883/63

Walden, B., Brunson, J. G.: A study on tolerance to experimental shock in rabbits. Fed. Proc. 22, 639 (1963).

[G 5,968/63

Walker, D. G., Wirtschafter, Z. T.: Resorption of embryos in rats on Lathyrus odoratus diet. J. Nutr. 58, 147-160 (1956). [C29,985/56 Walker, J. M., Parry, C. B. W.: The effect of hepatectomy on the action of certain anaesthetics in rats. Brit. J. Pharmacol. 4, 93-97 (1949).

$[\mathrm{B} 46,639 / 49$

Walker, W., Hughes, M. I., Barton, M.: Barbiturate and hyperbilirubinaemia of prematurity. Lancet 1969 I, 548-550. [G77,714/69

Wall, M. E., Abernethy, G. S., Jr., Carroll, F. I., Taylor, D. J.: The effects of some steroidal alkylating agents on experimental animal mammary tumor and leukemia systems. $J$. med. Chem. 12, 810-818 (1969).

$[\mathrm{G} 69,969 / 69$

Wallace, E. Z., Silverstein, J. N., Villadolid, L. S., Weisenfeld, L. S.: Cushing's syndrome due to adrenocortical hyperplasia. Treatment with an inhibitor of adrenocortical secretions. New Engl. J. Med. 265, 1088-1093 (1961).

[E 89,875/61

Wallon, D., Browaeys, J.: Aplasie éosinophile de la moelle après corticothérapie massive chez le rat. Sang, No. 6, 587-595 (1959).

$[\mathrm{C} 78,322 / 59$ 
Walser, A.: Untersuchungen über die antikatabole Wirkung anaboler Steroide. Schweiz. med. Wschr. 92, 396-398 (1962). [D33,753/62 Walther, D., Voss, R.: Ưber die Verlängerung der Wiederbelebungszeit des Rückenmarks nach vorheriger Schilddrüsenbehandlung mit Endojodin. Langenbecks Arch. klin. Chir. 295, 800-804 (1960).

$[\mathrm{G} 71,664 / 60$

Waltman, R., Bonura, F., Nigrin, G., Pipat, C.: Ethanol in prevention of hyperbilirubinaemia in the newborn. A controlled trial. Lancet 1969 II, 1265-1267.

[H 19,551/69

Waltregny, A., Mesdjian, E.: Hypoglycémie et seuil pentétrazolique. C. R. Soc. Biol. (Paris) 160, 1912-1914 (1966).

$[\mathrm{F} 78,025 / 66$

Waltregny, A., Mesdjian, E.: Etude polygraphique des crises d'épilepsie induites par surcharge hydrique chez le chat. C. R. Soc. Biol. (Paris) 161, 389-394 (1967).

[F 85,818/67

Waltz, H., Bartels, M., Matthies, H.: Zur Wirkung von ACTH, DOCA, Testosteronpropionat und Thyroxin auf die Pentothal-Schlafzeit hypophysektomierter Ratten. Arch. exp. Pathol. Pharmakol. 224, 523-527 (1955). [C11,847/55 Wang, C.-I., Schaefer, L. E., Adlersberg, D.: Tissue permeability - a factor in atherogenesis. Studies with cortisone and hyaluronidase. Circulat. Res. 3, 293-296 (1955).

$[\mathrm{E} 83,672 / 55$

Ward, J.C., Crabtree, D. G.: Strychnine. X. Comparative accuracies of stomach tube and intraperitoneal injection methods of bioassay. $J$. Amer. pharm. Ass., sci. Ed. 31, 113-115 (1942).

$[\mathrm{A} 29,199 / 42$

Ward, K. A., Pollak, J. K.: The composition of rat liver microsomes. The structural proteins of rat liver microsomes. Biochem. $J$. 114, 41-48 (1969).

$[\mathrm{G} 69,320 / 69$

Wardle, E.N., Wright, N.A.: Endotoxin and acute renal failure associated with obstructive jaundice. Brit. med. J. Nov. 21, 472-474 (1970).

$[\mathrm{H} 32,903 / 70$

Wasielewski, E. von, Knick, B.: Experimenteller Beitrag zur Cortisonwirkung am Tier nach Inoculation pathogener und apathogener Mikroorganismen. Z. ges. exp. Med. 129, 548 bis 558 (1958).

$[\mathrm{G} 68,292 / 58$

Wassermann, M., Wassermann, D., Lazarovici, S.: Effects of thyroidectomy on the storage of organochlorine insecticides. Bull. environm. Contam. Toxicol. 4, 327-336 (1969).

[G74,485/69

Wasz-Höckert, 0., Backman, A.: An attempt at shortening the diagnostic guinea-pig test. Ann. Med. exp. Fenn. 34, 433-437 (1956).

$[\mathrm{C} 30,700 / 56$
Wasz-Höckert, 0., Backman, A.: Effect of somatotropic hormone on the course of experimental guinea pig tuberculosis. Ann. Paediat. Fenn. 2, 150-155 (1956). [C34,801/56

Wasz-Höckert, 0., Backman, A., Poppius, H.: Influence of hyperthyroidism and hypothyroidism on guinea-pig tuberculosis. Ann. Med. exp. Fenn. 34, 411-419 (1956). [C30,699/56

Wasz-Höckert, 0., McCune, R.M.: The influence of somatotropin on growth and chronic tuberculosis in mice. Amer. Rev. resp. Dis. 88, 680 to 688 (1963).

$[\mathrm{E} 31,145 / 63$

Wattenberg, L. W., Leong, J. L.: Effects of phenothiazines on protective systems against polycyclic hydrocarbons. Cancer Res. 25, 365 to 370 (1965).

[F 38,140/65

Wattenberg, L. W., Leong, J. L., Strand, P. J.: Benzpyrene hydroxylase activity in the gastrointestinal tract. Cancer Res. 22, 1120-1125 (1962).

$[\mathrm{D} 40,287 / 62$

Wattenberg, L. W., Page, M. A., Leong, J. L.: Induction of increased benzpyrene hydroxylase activity by 2 -phenylbenzothiazoles and related compounds. Cancer Res. 28, 2539-2544 (1968).

[G71,805/68

Waugh, D., Pearl, M. J.: Serotonin-induced acute nephrosis and renal cortical necrosis in rats. A morphologic study with pregnancy correlations. Amer. J. Path. 36, 431-455 (1960).

$[\mathrm{C} 83,389 / 60$

Weatherall, J. A. C.: Anaesthesia in new-born animals. Brit. J. Pharmacol. 15, 454-457 (1960).

$[\mathrm{G} 76,306 / 60$

Weber, G., Allard, C., Lamirande, G. de, Cantero, A.: Liver glucose-6-phosphatase activity and intracellular distribution after cortisone administration. Endocrinology 58, 40-50 (1956).

$[\mathrm{C} 11,010 / 56$

Weber, G., Marconi, G., Serrâo, D.: Ricerche sperimentali sopra la rigenerazione epatica. I. La rigenerazione epatica dopo ampia epatectomia nel corso della colostasi da legatura del coledoco. Arch. De Vecchi Anat. pat. 30, 923 to 944 (1960).

$[\mathrm{G} 71,819 / 60$

Webster, D. E., Gentile, G.: Effect of chemical thymectomy on skin homografts. A preliminary report. Canad. med. Ass. J. 89, 914-916 (1963).

[E $30,434 / 63$

Wei, E., Wilson, J.T.: Stress-mediated decrease in liver hexobarbital metabolism: the role of corticosterone and somatotropin. $J$. Pharmacol. exp. Ther. 177, 227-233 (1971).

$[\mathrm{H} 37,417 / 71$

Weidenreich-Sherwin, R., Herrmann, F.: Hair cycle and chemically induced epidermal car- 
cinogenesis in mice receiving Liothyronine. II. Findings after multiple applications of methylcholanthrene. Dermatologica (Basel) 128, 483 to 490 (1964).

[F 16,179/64

Weihe, W. H.: Influence of age, physical activity and ambient temperature on acclimatization of rats to high altitude. Fed. Proc. 25, 1342-1347 (1966).

$[\mathrm{F} 69,421 / 66$

Weil, M. H.: Experimental studies on the treatment of shock produced by endotoxin. Clin. Res. 8, 124 (1960).

$[\mathrm{C} 91,305 / 60$

Weil, M. H.: Adrenocortical steroid for therapy of acute hypotension. Amer. Practit. 12, 162 to 168 (1961).

$[\mathrm{G} 68,214 / 61$

Weil, M. H., Allen, K. S.: The effect of steroids on shock due to endotoxin. In: Mills and Moyer; Inflammation and Diseases of Connective Tissue, p. 768-778. Philadelphia, London: W. B. Saunders Co. 1961.

[D 7,883/61

Weil, M. H., Allen, K. S.: A comparison of the effectiveness of hydrocortisone and its analogues against lethal effects of endotoxin. Clin. Res. 12, 94 (1964).

[F 14,091/64

Weil, M. H., Miller, B. S.: Studies on the effects of a vasopressor agent, sympatholytic drugs, and corticosteroid in shock caused by bacterial toxin. Circulation 22, 830 (1960). [D97,273/60

Weil, M. H., Shubin, H., Allen, K. S.: Superiority of prednisolone over cortisol against lethal effects of endotoxin. Fed. Proc. 23/1, 416 (1964).

$[\mathrm{F} 4,907 / 64$

Weil, M. H., Shubin, H., Whigham, H.: Reversal of hemorrhagic shock with pharmacological doses of cortico-steroid (Abstr.). Clin. Res. 13, 233 (1965).

$[\mathrm{F} 61,024 / 65$

Weil, M. H., Spink, W. W.: A comparison of shock due to endotoxin with anaphylactic shock. J. Lab. clin. Med. 50, 501-515 (1957).

[D96,274/57

Weil, M. H., Udhoji, V. N., Sambhi, M. P., Rosoff, L.: Hemodynamic studies on the mechanism and treatment of bacteremic shock (Abstr.). Circulation 26, 801 (1962).

[G68,706/62

Weil, M. H., Whigham, H.: Experimental observations on the effects of corticosteroid hormones for the treatment of 'irreversible' hemorrhagic shock. Circulation 30, Sup. 3, 176 (1964).

[F 13,600/64

Weil, M. H., Whigham, H.: Corticosteroids for reversal of hemorrhagic shock in rats. Amer. J. Physiol. 209, 815-818 (1965).

$[\mathrm{F} 52,838 / 65$
Weil, M. H., Whigham, H., Marbach, E. P.: Mechanism of corticosteroid reversal of fatal shock after blood loss. Physiologist 8, 302 (1965).

$[\mathrm{F} 48,510 / 65$

Weil, P. G., Rose, B., Browne, J. S. L.: The reduction of mortality from experimental traumatic shock with adrenal cortical substances. Canad. med. Ass. J. 43, 8-11 (1940).

$[78,692 / 40$

Weinbren, K.: The effect of bile duct obstruction on regeneration of the rat's liver. Brit. $J$. exp. Path. 34, 280-289 (1953). [B 90,949/53

Weinbren, K.: Regeneration of the liver. Gastroenterology 37, 657-668 (1959). [D95,941/59

Weinbren, K., Billing, B.H.: Hepatic clearance of bilirubin as an index of cellular function in the regenerating rat liver. Brit. J. exp. Path. 37, 199-204 (1956).

[G 76,309/56

Weiner, I. M.: Mechanisms of drug absoption and excretion. The renal excretion of drugs and related compounds. Ann. Rev. Pharmacol. 7, $39-56$ (1967).

[G 74,032/67

Weiner, M., Blake, D. A., Buterbaugh, G. G.: The possible involvement of cyclic AMP in altered hepatic drug metabolism produced by diabetes or starvation. (Abstr.) Fed. Proc. 29, 804 (1970).

$[\mathrm{H} 24,942 / 70$

Weiner, M., Siddiqui, A. A., Bostanci, N., Dayton, P. G.: Drug interactions: the effect of combined administration of the half-life of coumarin and pyrazolone drugs in man. Fed. Proc. 24, 153 (1965).

[F 35,871/65

Weinstein, L.: Further studies on the prophylaxis of experimental infections and intoxications with various hormone preparations. Yale J. Biol. Med. 12, 549-557 (1940).

$[\mathrm{A} 33,940 / 40$

Weinstein, L.: Prophylaxis of experimental anthrax infection with various hormone preparations. LT Yale J. Biol. Med. 11, 369-392 (1939).

[B 15,029/39

Weintraub, S., Kraus, S. D., Wright, L. T.: Influence of sex hormones on tolerance to aminopterin. Proc. Soc. exp. Biol. (N.Y.) 74, 609-612 (1950).

$[\mathrm{B} 49,800 / 50$

Weisburger, E.K., Yamamoto, R., Glass, R., Grantham, P.H., Weisburger, J.H.: Hormonal status of rats and liver cancer induction by N-hydroxy-N-2-fluorenyl acetamide. Proc. Amer. Ass. Cancer Res. 8, 71 (1967).

$[\mathrm{F} 78,862 / 67$

Weisburger, E.K., Yamamoto, R.S., Glass, R.M., Grantham, P.H., Weisburger, J.H.: Effect of neonatal androgen and estrogen injection on liver tumor induction by $\mathrm{N}$-hydroxy- 
$\mathrm{N}$-2-fluorenylacetamide and on the metabolism of the carcinogen in rats. Endocrinology 82 , 685-692 (1968).

$[\mathrm{F} 97,904 / 68$

Weisburger, J.H., Grantham, P.H., Weisburger, E.K.: Metabolism of N-2-fluorenylacetamide in the hamster. Toxicol. appl. Pharmacol. 6, 427-433 (1964).

$[$ G79,387/64

Weisburger, J. H., Pai, S. R., Yamamoto, R. S.: Pituitary hormones and liver carcinogenesis with N-hydroxy-N-2-fluorenylacetamide. $J$. nat. Cancer Inst. 32, 881-904 (1964).

[D 18,583/64

Weisburger, J.H., Schmehl, E.A., Pai, S.R.: Liver damage by the carcinogen N-hydroxy$\mathrm{N}$-2-fluorenylacetamide. Pentobarbital sleeping time and liver morphology. Toxicol. appl. Pharmacol. 7, 579-587 (1965). [G78,956/65

Weisburger, J. H., Yamamoto, R. S., Korzis, J., Weisburger, E. K.: Liver cancer: neonatal estrogen enhances induction by a carcinogen. Science 154, 673-674 (1966). [F72,720/66

Weiss, A. K.: Tissue responses in the coldexposed rat. Amer. J. Physiol. 188, 430-434 (1957).

[C34,561/57

Weiss, A. K.: Effects of aging on adaptation to cold. Fed. Proc. 18, 168 (1959) $\quad$ [C66,153/59

Weiss, A. K.: Artificial acclimatization of aging rats. Excerpta med. (Amst.) Int. Congr. Ser. No. 57, p. 37 (1963).

$[\mathrm{G} 21,456 / 63$

Weiss, C.F., Glazko, A.J., Weston, J.K.: Chloramphenicol in the newborn infant. A physiologic explanation or its toxicity when given in excessive doses. New Engl. J. Med. 262, 787 to 794 (1960).

$[\mathrm{H} 33,308 / 60$

Weisskopi, A., Burn, H. F., Schoenholz, W. K.: Protective action of estrogen against streptococcal infection in mice, and its relation to connective tissues. Laryngoscope (St. Louis) 71, $788-799$ (1961).

[D35,320/61

Weissmann, G.: Changes in connective tissue and intestine caused by vitamin A in amphibia, and their acceleration by hydrocortisone. $J$. exp. Med. 114, 581-592 (1961). [D 10,768/61

Weissmann, G.: The effects of steroids and drugs on lysosomes. In: Dingle, J.T. and Fell, H.B., Lysosomes in biology and pathology, p. 276-295. Amsterdam, London: NorthHolland Publ. Co. 1969.

[G 79,855/69

Weissmann, G., Bell, E., Thomas, L.: Prevention by hydrocortisone of changes in connective tissue induced by an excess of vitamin A acid in amphibia. Amer. J. Path. 42, 571-585 (1963).

[D $64,001 / 63$
Weissmann, G., Dingle, J.: Release of lysosomal protease by ultraviolet irradiation and inhibition by hydrocortisone. Exp. Cell Res. 25, 207 to 210 (1961).

$[D 14,268 / 61$

Weissmann, G., Fell, H. B.: The effect of hydrocortisone on the response of fetal rat skin in culture to ultraviolet irradiation. $J$. exp. Med. 116, 365-380 (1962).

$[\mathrm{D} 46,242 / 62$

Weissmann, G., Thomas, L.: Studies on lysosomes. The effect of cortisone and endotoxin. Annual Meet. Amer. Soc. clin. Invest., Inc., Atlantic City, April 30, p. 75 (1962)

$[\mathrm{D} 23,630 / 62$

Weissman, G., Thomas, L.: Studies on lysosomes. I. The effects of endotoxin, endotoxin tolerance, and cortisone on the release of acid hydrolases from a granular fraction of rabbitliver. J. exp. med. 116, 443-450 (1962).

[D 35,555/62

Weissmann, G., Thomas, L.: Studies on lysosomes. II. The effect of cortisone on the release of acid hydrolases from a large granule fraction of rabbit liver induced by an excess of vitamin A. J. clin. Invest. 42, 661-669 (1963).

[D $65,709 / 63$

Weissmann, G., Thomas, L.: The effects of corticosteroids upon connective tissue and lysosomes. In: Pincus; Recent Progress in Hormone Research 20, p. 215-245. New York, London: Academic Press 1964.

$[\mathrm{E} 4,216 / 64$

Weissmann, G., Thomas, L.: On a mechanism of tissue damage by bacterial endotoxins. In: Landy and Braun; Bacterial Endotoxins, p. 602 to 609. New Brunswick, N.J.: Institute of Microbiology, Rutgers, The State University 1964.

$[\mathrm{E} 8,482 / 64$

Welch, R. M., Conney, A. H.: Organophosphate insecticide inhibition and phenobarbital stimulation of testosterone hydroxylase in rat liver microsomes. Fed. Proc. 24, 639 (1965).

$[\mathrm{F} 36,508 / 65$

Welch, R. M., Harrison, Y. E., Burns, J. J.: Implications of enzyme induction in drug toxicity studies. Toxicol. appl. Pharmacol. 10, 340-351 (1967).

$[\mathrm{G} 47,232 / 67$

Welch, R. M., Harrison, Y. E., Gommi, B. W., Poppers, P. J., Finster, M., Conney, A. H.: Stimulatory effect of cigarette smoking on the hydroxylation of 3,4-benzpyrene and the $\mathrm{N}$ demethylation of 3-methyl-4-monomethylaminoazobenzene by enzymes in human placenta. Clin. Pharmacol. Ther. 10, 100-109 (1969).

$[\mathrm{G} 65,788 / 69$

Welch, R. M., Levin, W., Conney, A. H.: Insecticide inhibition and stimulation of steroid 
hydroxylases in rat liver. J. Pharmacol. exp. Ther. 155, 167-173 (1967). [F76,642/67 Welch, R. M., Levin, W., Conney, A. H.: Stimulatory effect of phenobarbital on the metabolism in vivo of estradiol-17 B and estrone in the rat. J. Pharmacol. exp. Ther. 160, 171-178 (1968).

[F 96,172/68

Welch, R. M., Levin, W., Conney, A. H.: Estrogenic action of DDT and its analogs. Toxicol. appl. Pharmacol. 14, 358-367 (1969).

[G65,737/69

Weller, 0.: Die antikatabole Wirkung des I Methyl- $\triangle 1$ androstenolons (Methenolon). Med. Welt. (Stuttg.) Nr. 40, 2073-2078 (1961).

[D $13,995 / 61$

Weller, 0.: Klinische Untersuchungen mit dem oral anwendbaren Methenolon-acetat. Arzneimittel-Forsch. 12, 234-240 (1962).

[D 22,262/62

Wellmann, K. F., Volk, B. W., Lazarus, S. S.: Renal changes in experimental hypercholesterolosis in normal and subdiabetic rabbits (Abstr.). Fed. Proc. 28, 368 (1969). [H9,536/69 Wells, J. A., Anderson, L. H.: Mechanism of increased susceptibility to ergot gangrene in thyrotoxicosis. Proc. Soc. exp. Biol. (N.Y.) 74, 374-377 (1950).

[G74,995/50

Weltman, A.S., Sackler, A.M.: Effects of thymectomy on the resistance of rats to drowning and histamine stress. Nature (Lond.) 192, 460 to 461 (1961).

[D 14,302/61

Wendt, H.: Natriumthiosulfat in der Therapie. Äußerliche Wirkung als Schwefel in statu nascendi, innerliche Wirkung als chemisches Antidot und als Antiallergikum. Fortschr. Therap. 14, 88-96, 147-154, 202-207 (1938).

[A48,250/38

Wenzel, D. G., Keplinger, M. L.: Central depressant properties of uracil and related oxypyrimidines. J. Amer. pharm. Ass., sci. Ed. 44, 56-59 (1955).

[G76,357/55

Wenzel, M., Pollow-Hanisch, B., Pollow, K.: Änderung der Sexualspezifität bei der Androstendionreduktion durch Östradiol-17 $\beta$-Wasserstoff in Rattenleber nach Feminisierung durch Cyproteronacetat. Hoppe-Seylers Z. physiol. Chem. 350, 791 - 792 (1969). [H14,785/69 Werboff, J., Hedlund, L., Havlena, J.: Audiogenic seizures in adult female ovariectomized rats (Sprague-Dawley) treated with sex hormones. J. Endocr. 29, 39-46 (1964).

[F 10,255/64

Werder, E. A., Yaffe, S. J.: Glucuronyl transferase activity in experimental neonatal hypothyroidism. Biol. Neonat. (Basel) 6, 8-15 (1964).

[G12,065/64
Werk, E. E., MacGee, J., Sholiton, L. J.: Effect of diphenylhydantoin on cortisol metabolism in man. J. clin. Invest. 43, 1824-1835 (1964).

[F 20,780/64

Werk, E. E., Jr., Sholiton, L. J., Olinger, C. P.: Amelioration of non-tumorous Cushing's syndrome by diphenylhydantoin (Abstr.). 2nd Int. Congr. on Hormonal steroids Milan, Italy, p 301 (1966).

[G67,762/66

Werle, E. Lentzen, J.: Utber die Beeinflussung der Injektionsnarkose durch kreislaufaktive Stoffe. Naunyn-Schmiedebergs Arch. Pharmak. 190, 328-340 (1938). [A 28,007/38

Westermann, E. 0., Maickel, R. P., Brodie, B. B.: Some biochemical effects of reserpine mediated by the pituitary. Fed. Proc. 19, 268 (1960).

$[\mathrm{C} 83,072 / 60$

Westifall, B. A.: Pyruvic acid antagonism to barbiturate depression. J. Pharmacol. exp. Ther. 87, 33-37 (1946). [B31,306/46

Westiall, B. A., Boulos, B. M., Shields, J. L., Garb, S.: Sex differences in pentobarbital sensitivity in mice. Proc. Soc. exp. Biol. (N.Y.) 115, 509-510 (1964).

[F 2,504/64

Westmoreland, B., Bass, N.H.: Diphenylhydantoin intoxication during pregnancy. A chemical study of drug distribution in the albino rat. A. M. A. Arch. Neurol. (Chic.) 24, 158-164 (1971).

[G80,590/71

Westphal, F., Hagen, U.: Strahlenschutz und Strahlensensibilisierung an den Chromosomen lymphatischer Zellen. Strahlentherapie 132, 284-295 (1967).

[G45,683/67

Wheatley, D. N.: Action of drugs affecting the functioning of the adrenal cortex on adrenal necrosis induced by 7, 12-dimethylbenz $(\alpha)$ anthracene and its 7-hydroxymethyl derivative in rats. Endocrinology 82, 1217-1222 (1968). [F 98,919/68

Wheatley, D. N., Kernohan, I. R., Currie, A. R.: Liver injury and the prevention of massive adrenal necrosis from 9,10-dimethyl-1,2-benzanthracene in rats. Nature (Lond.) 211, 387 to 389 (1966).

$[\mathrm{F} 68,548 / 66$

Wheeler, R. S., Hofimann, E., Barber, C. W.: The effect of thiouracil-induced hypothyroidism on the resistance of chicks artificially infected with Eimeria tenella. J. Amer. vet. med. Ass. 112, 473-474 (1948).

[A 48,602/48

Wheeler, R. S., Perkinson, J. D., Jr.: Influence of induced hypo- and hyperthyroidism on vitamin $\mathrm{E}$ requirement of chicks. Amer. $J$. Physiol. 159, 287-290 (1949). [B43,572/49 Whigham, H.: Effect of corticosteroids on the progression of hemorrhagic shock in rats. Calif. Med. 106, 10-11 (1967).

[F 75,787/67 
White, M. R., Finkel, A. J., Schubert, J.: Effect of adrenocorticotrophic hormone on tissue distribution and acute toxicity of beryllium. Proc. Soc. exp. Biol. (N.Y.) 80, 603-604 (1952).

$[\mathrm{B} 74,079 / 52$

Whitfield, C. F., Tidball, M. E.: Estrogen effect on skeletal muscle and degenerative signs of experimental $\mathrm{Mg}$ deficiency (Abstr.). Fed. Proc. 27, 498 (1968).

[H549/68

Wiancko, K. B., Kowalewski, K.: Strength of callus in fractured humerus of rat treated with anti-anabolic and anabolic compounds. Acta endocr. (Kbh.) 36, 310-318 (1961).

[D270/61

Wiberg, G. S., Carter, J. R., Stephenson, N. R.: The bioassay of thyroactive materials by the mouse anoxia test and goitre-prevention response in the same experimental animals. Acta endocr. (Kbh.) 43, 609-617 (1963).

[E 23,265/63

Wicher, K., Jakubowski, A.: Effect of cortisone on the course of experimental syphilis in the guinea-pig. I. Effect of previously-administered cortisone on guinea-pigs infected with Treponema pallidum intradermally, intratesticularly, and intravenously. Brit. J. vener. Dis. 40, 213-216 (1964).

[G26,810/64

Wicks, W.D., Greenman, D.L., Kenney, F.T.: Stimulation of ribonucleic acid synthesis by steroid hormones. I. Transfer ribonucleic acid. J. biol. Chem. 240, 4414-4419 (1965).

[G35,046/65

Wiesbader, H.: Reid Hunt reaction and the thyrotropic hormone. Endocrinology 20, 100 to 102 (1936).

$[68,823 / 36$

Wiese, C. E., Mehl, J. W., Deuel, H. J., Jr.: Studies on carotenoid metabolism. IX. Conversion of carotene to vitamin A in the hypothyroid rat. J. biol. Chem. 175, 21-28 (1948).

[B39,257/48

Wietek, H. F., Taupitz, E. : Der Einfluß lyophilisierter Placenta auf die experimentelle Arteriosklerose von Ratten. Arzneimittel-Forsch. 7, 479-485 (1957).

$[\mathrm{C} 40,028 / 57$

Wilbrandt, W., Weiss, E. M.: Antagonismus zwischen Herzglykosid und Corticosteroiden am Froschhautpotential. Arzneimittel-Forsch. 10, 409-412 (1960).

$[\mathrm{C} 88,230 / 60$

Wilgram, G.F.: Cardiovascular changes induced in choline-deficient rats by growth hormone. Ann. N.Y. Acad. Sci. 72, 863-869 (1959).

$[\mathrm{C} 84,322 / 59$

Wilgram, G. F., Best, C. H., Blumenstein, J.: Effect of growth hormone and testosterone on induction of cardiovascular changes in cholinedeficient rats. Proc. Soc. exp. Biol (N.Y.) 91, 620-622 (1956).

$[\mathrm{C} 15,960 / 56$

Wilgram, G. F., Hartroft, W. S.: Pathogenesis of fatty and sclerotic lesions in the cardiovascular system of choline-deficient rats. Brit. $J$. exp. Path. 36, 298-305 (1955). [C14,392/55 Williams, D. J., Rabin, B. R.: The effects of aflatoxin $B_{1}$ and steroid hormones on polysome binding to microsomal membranes as measured by the activity of an enzyme catalysing disulphide interchange. FEBS Lett. 4, 103-107 (1969).

[G77,164/69

Williams, R. H.: Textbook of Endocrinology, 4th ed., pp. 1258. Philadelphia, London, Toronto: W. B. Saunders Co. 1968.

$[\mathrm{E} 8,139 / 68$

Williams, R. T.: Detoxication Mechanisms. The Metabolism and Detoxication of Drugs, Toxic Substances and Other Organic Compounds, 2nd ed., pp. 796. New York: John Wiley and Sons Inc. 1959.

[E $906 / 59$

Williams, R.T.: Detoxication mechanisms in vivo. In: Brodie, B. B., Erdös, E.G., Metabolic factors controlling duration of drug action. (Proc. 1st int. Pharmacol. Meet. 'Mode of action of drugs', Stockholm, 1961). p. 1-12. New York: MacMillan Co., 1962. [G 73,007/62 Williams, R. T.: Detoxication mechanisms in man. Clin. Pharmacol. Ther. 4, 234-254 (1963).

$[\mathrm{G} 77,567 / 63$

Willmer, H.A.: The disappearance of phosphatase from the hydronephrotic kidney. $J$. exp. Med. 78, 225-230 (1943). [A48,603/43

Willmer, J. S., Foster, T. S.: Enzymatic and metabolic adaptions. II. Changes in adrenalectomized rats subjected to dietary modifications. Canad. J. Biochem. 40, 961-972 (1962).

$[D 28,163 / 62$

Wilson, G., Care, A. D., Anderson, C. K.: The effect of cortisone on vitamin $\mathrm{D}_{2}$-induced nephrocalcinosis in the rat. Clin. Sci. 16, 181-185 (1957).

$[\mathrm{C} 33,679 / 57$

Wilson, J.L., Ashburn, A.D., Williams, W.L.: Effects of sex hormones on diet-induced atrial thrombosis. Anat. Res. 168, 331-337 (1970). $[\mathrm{G} 79,508 / 70$

Wilson, J. T.: Prevention of the normal postnatal increase in drug-metabolizing enzyme activity in rat liver by a pituitary tumor. Pediat. Res. (Basel) 2, 514-518 (1968).

$[\mathrm{G} 63,125 / 68$

Wilson, J. T.: Identification of somatotropin as the hormone in a mixture of somatotropin, 
adrenocorticotropic hormone and prolactin which decreased liver drug metabolism in the rat. Biochem. Pharmacol. 18, 2029-2031 (1969).

$[\mathrm{G} 69,098 / 69$

Wilson, J. T.: Alteration of normal development of drug metabolism by injection of growth hormone. Nature (Lond.) 225, 861 to 863 (1970).

$[\mathrm{H} 21,345 / 70$

Wilson, J.T.: Altered rat hepatic drug metabolism after implantation of a pituitary mammotropic tumor (MtT), Walker carcinosarcoma or adenocarcinoma and after removal of the MtT. Endocrinology 88, 185-194 (1971).

$[\mathrm{H} 34,926 / 71$

Wilson, J. W., Leduc, E. H.: The effect of coramine on mitotic activity and growth in the liver of the mouse. Growth 14, 31-48 (1950).

$[\mathrm{E} 43,062 / 50$

Wilson, S. G. F., Pfefer, J., Nash, G., Heymann, W.: Aminonucleoside nephrosis in rats. J. Dis. Child. 94, 572 (1957).

$[\mathrm{C} 45,755 / 57$

Wilson, W. S.: Metabolism of digitalis. Progr. cardiovasc. Dis. 11, 479-487 (1969).

$[\mathrm{G} 71,238 / 69$

Wimberly, J.E., Martin, C.E., Foster, J.H.: Temporary hepatic inflow occlusion in dogs treated with methylprednisolone and antibiotics. Amer. Surg. 35, 271-273 (1969).

$[\mathrm{G} 65,769 / 69$

Winberg, J., Zetterström, R.: Cortisone treatment in vitamin $\mathrm{D}$ intoxication. Acta paediat. (Scand.) 45, 96-101 (1956). [C12,829/56 Windorfer, A.: Utber die Phenobarbitalbehandlung des Neugeborenenikterus. Dtsch. med. Wschr. 95, 1617-1619 (1970). [H28,824/70

Winter, C. A., Flataker, L.: The effect of cortisone, desoxycorticosterone, and adrenocorticotrophic hormone upon the responses of animals to analgesic drugs. J. Pharmacol. exp. Ther. 103, 93-105 (1951).

$[\mathrm{B} 62,935 / 51$

Winter, C. A., Flataker, L.: The effect of cortisone, desoxycorticosterone, adrenocorticotrophic hormone and diphenhydramine upon the responses of albino mice to general anesthetics. J. Pharmacol. exp. Ther. 105, 358 (1952).

[B 73,509/52

Winter, C.A., Hollings, H.L., Stebbins, R.B.: The effect of androgenic hormones upon the adrenal atrophy produced by cortisone injections and upon the anti-inflammatory action of cortisone. Endocrinology 52, 123-134 (1953).

$[\mathrm{B} 79,381 / 53$

Winter, D.: Le rôle du terrain thyroïdien dans la modification de la réactivité de l'organisme aux médicaments. Recherches expérimentales de pathopharmacologie. Prod. Prob. pharm. 20, $591-595$ (1965).

$[\mathrm{G} 71,836 / 65$

Winter, D.: Toxizitätsveränderung neurotroper Pharmaka bei Versuchstieren mit experimentell hervorgerufener Hyperthyreoidie. Med. Pharmacol. exp. (Basel) 14, 391-394 (1966).

$[\mathrm{F} 64,465 / 66$

Winter, D.: The thyroid and the reactivity of the organism to drugs. Rev. roum. Physiol. 5, 89-96 (1968).

[F 98,019/68

Winter, H.: Conditions influencing the course of steroid hormone anesthesia. Endocrinology 29, 790-792 (1941).

$[\mathrm{A} 36,333 / 41$

Winter, H., Bélanger, L. F.: On the protective action of testosterone against the kidneydamaging effect of phlorhizin. Proc. Canad. physiol. Soc. (7th Ann. Meet., Montebello), p. 17 (1941).

[A36,751/41

Winter, H., Selye, H.: Conditions influencing the course of steroid hormone anesthesia. Amer. J. Physiol. 133, 495 (1941). [A35,658/41

Winternitz, M. C., Waters, L. L.: The effect of hypophysectomy on compensatory renal hypertrophy in dogs. Yale J. Biol. Med. 12, 705-709 (1940).

[A34,910/40

Winton, F. R.: The rat-poisoning substance in red squills. J. Pharmacol. exp. Ther. 31, 123 to 136 (1927).

[A42,964/27

Wirtheimer, C.: A propos de l'accélération par les hormones gonadotrophiques de l'apparition des manifestations ulcéreuses postréserpiniques. C. R. Soc. Biol. (Paris) 153, 1284-1285 (1959).

$[\mathrm{D} 10,158 / 59$

Wishart, M. B., Pritchett, I. W.: Experimental studies in diabetes. Ser. II. The internal pancreatic function in relation to body mass and metabolism. 6. Gas bacillus infections in diabetic dogs. Amer. J. Physiol. 54, 382-387 (1920).

$[12,285 / 20$

Wiśniewski, K.: Influence of insulin on the action of analgesics. Biochem. Pharmacol. 12, Sup., 5 (1963).

$[\mathrm{E} 32,005 / 63$

Wiśniewski, K., Buczko, W.: The central pharmacological effect of chlorpromazine in rats with alloxan-diabetes. Biochem. Pharmacol. 16, $2227-2230$ (1967).

[G51,489/67

Wiśniewski, K., Danysz, A.: The study on the insulin controlling and directing of chlorpromazine action and level in brain tissue. Biochem. Pharmacol. 15, 669-673 (1966).

$[\mathrm{G} 40,054 / 66$

Wiśniewski, K., Zarebski, M.: Insulin-dependent transport of drugs in vivo and in vitro. 
(Abstr. 27th. Ann. Meet. Amer. Diabetes Ass.) Diabetes 16, 515 (1967).

$[\mathrm{F} 85,977 / 67$

Wiśniewski, K., Zarebski, M.: Effect of insulin on the transport and the analgesic action of sodium salicylates. Metabolism 17, 212-217 (1968).

[F 96,973/68

Witzel, H.: Utber anaesthetisch wirksame Steroide. Z. Vitamin-, Hormon- u. Fermentforsch. 10, 46-75 (1959).

$[\mathrm{C} 68,395 / 59$

Wohl, M. G., Feldman, J. B.: Vitamin A deficiency in disease of the thyroid gland: its detection by dark adaptation. Endocrinology 24, 389-396 (1939).

$[A 30,107 / 39$

Wohl, M. G., Robertson, H. F.: Bromide intoxication: some observations on its treatment with sodium chloride and desoxycorticosterone. Penn. med.J. 47, 802-808 (1944). [93,481/44

Wolbach, S. B., Maddock, C. L.: Vitamin-A acceleration of bone growth sequences in hypophysectomized rats. Arch. Path. 53, 273-278 (1952).

[B 83,297/52

Wolbach, S. B., Maddock, C. L., Cohen, J.: The hypervitaminosis - A syndrome in adrenalectomized rats. Arch. Path. 60, 130-135 (1955).

$[\mathrm{C} 14,796 / 55$

Wolfram, J., Zwemer, R. L.: Cortin protection against anaphylactic shock in guinea pigs. $J$. exp. Med. 61, 9-15 (1935).

$[30,809 / 35$

Wollenberger, A., Karsh, M. L.: A note on the influence of sex upon the response of the rat heart to ouabain. J. Amer. pharm. Ass., sci. Ed. 40, 637-638 (1951).

[D95,331/51

Wong, D. T., Terriere, L. C.: Epoxidation of aldrin, isodrin, and heptachlor by rat liver microsomes. Biochem. Pharmacol. 14, 375-377 (1965).

$[\mathrm{G} 77,538 / 65$

Wood, J. S., Jr., Knox, W. E.: Studies on liver tryptophan peroxidase in mice bearing a transplantable sarcoma. Proc. Amer. Ass. Cancer Res. 1, 52-53 (1954).

[D 81,779/54

Wood, S., Jr., Rivlin, R. S., Knox, W. E.: Biphasic changes of tryptophan peroxidase level in tumor-bearing mice and in mice subjected to growth hormone and stress. Cancer Res. 16, 1053-1058 (1956).

$[\mathrm{C} 27,721 / 56$

Woodbury, D. M.: Effect of hormones on brain excitability and electrolytes. In: Recent Progress in Hormone Research 10, p. 65-107. New York: Academic Press Inc. 1954.

[B98,594/54

Woodbury, D. M., Cheng, C.-P., Sayers, G., Goodman, L. S. : Antagonism of adrenocorticotrophic hormone and adrenal cortical extract to desoxycorticosterone: electrolytes and electroshock threshold. Amer. J. Physiol. 160, 217-227 (1950).

[B $46,344 / 50$

Woodbury, D. M., Davenport, V. D.: Brain and plasma cations and experimental seizures in normal and desoxycorticosterone-treated rats. Amer. J. Physiol. 157, 234-240 (1949).

$[\mathrm{B} 37,243 / 49$

Woodbury, D. M., Hurley, R. E., Lewis, N. G., MeArthur, M. W., Copeland, W. W., Kirsehvink, J. F., Goodman, L. S.: Influence of thyroidectomy, propylthiouracil and thyroxin on brain excitability. Fed. Proc. 11, 404 (1952).

$[\mathrm{B} 68,423 / 52$

Woodbury, D. M., Rosenberg, C. A., Sayers, G.: Antagonism of adrenocorticotrophic hormone (ACTH) and adrenal cortical extract (ACE) to desoxycorticosterone (DCA): pathological changes. Fed. Proc. 9, 139 (1950).

$[\mathrm{B} 47,201 / 50$

Woodbury, D. M., Timiras, P. S., Vernadakis, A.: Influence of adrenocortical steroids on brain function and metabolism. In: Hoagland, H.; Hormones, Brain Function, and Behavior, p. 27-54. New York: Acad. Press Inc. Publ. 1957.

[C34,538/57

Wooles, W. R., Borzelleca, J. F.: Prolongation of barbiturate sleeping time in mice by stimulation of the reticuloendothelial system (RES). J. reticuloendoth. Soc. 3, 41-47 (1966).

$[\mathrm{F} 93,374 / 66$

Wooles, W.R., Munson, A.E.: The effect of stimulants and depressants of reticuloendothelial activity on drug metabolism. $J$. reticuloendothel. Soc. (in press).

$[\mathrm{G} 78,975$

Woollam, D. H. M., Millen, J. W.: Influence of 4-methyl-2-thiouracil on the teratogenic activity of hypervitaminosis-A. Nature (Lond.) 181, 992-993 (1958).

$[\mathrm{C} 64,432 / 58$

Woolley, D. E., Timiras, P. S., Srebnik, H. H., Silva, A.: Threshold and pattern of electroshock convulsions during estrous cycle in the rat. Fed. Proc. 20, 198 (1961). [ [D4,062/61

Wragg, L. E., Speirs, R. S.: Strain and sex differences in response of inbred mice to adrenal cortical hormones. Proc. Soc. exp. Biol. $(N, Y$.) 80, 680-684 (1952).

[B74,080/52

Wright, D. H.: The effect of neonatal thymectomy on the survival of golden hamsters infected with Plasmodium berghei. Brit. J. exp. Path. 49, 379-384 (1968).

$[\mathrm{H} 1,836 / 68$

Wulf, H. de, Hers, H. G.: The stimulation of glycogen synthesis and of glycogen synthetase in the liver by glucocorticoids. Europ. $J$. Biochem. 2, 57-60 (1967).

[G53,099/67 
Wulfsohn, N. L., Politzer, W. M.: 5-Hydroxytryptamine in anaesthesia. Anaesthesia 17, 64 to 68 (1961).

[D22,421/61

Wurtman, R. J., Axelrod, J.: Sex steroids, cardiac ${ }^{3} \mathrm{H}$-norepinephrine, and tissue monoamine oxidase levels in the rat. Biochem. Pharmacol. 12, 1417-1419 (1963).

$[\mathrm{E} 36,478 / 63$

Wurtman, R. J., Axelrod, J., Anton-Tay, F.: Inhibition of the metabolism of $\mathrm{H}^{3}$-melatonin by phenothiazines. J. Pharmacol. exp. Ther. 161, 367-372 (1968).

[F 99,396/68

Wüstenberg, P. W., Börner, H., Tessmann, D., Holtz, M.: Tierexperimentelle Untersuchungen zur Frage des Testosteroneinflusses bei akuter toxischer Nierenschädigung. Zbl. allg. Pathol. pathol. Anat. 107, 378-388 (1965).

[G38,225/65

Wuth, 0.: Utber biologische Wirkungen proteinogener Amine. Zugleich ein Beitrag zur Frage der Acetonitrilreaktion. Biochem. Z. 116, 237-245 (1921).

[A 48,026/21

Wyler, R., Kradolfer, F., Gross, F.: Entgiftende Wirkung von Dexamethason und Aldosteron gegenüber bakteriellen Lipopolysacchariden. Helv. physiol. pharmacol. Acta 18, 357-365 (1960).

$[\mathrm{D} 5,696 / 60$

Wynn, J., Gibbs, R., Royster, B.: Thyroxine degradation. I. Study of optimal reaction conditions of a rat liver thyroxine-degrading system. J. biol. Chem. 237, 1892-1897 (1962).

$[\mathrm{G} 67,767 / 62$

Yaffe, S. J., Levy, G., Matsuzawa, T., Baliah, T.: Enhancement of glucuronide-conjugating capacity in a hyperbilirubinemic infant due to apparent enzyme induction by phenobarbital. New. Engl. J. Med. 275, 1461-1466 (1966).

[G67,125/66

Yam, K. M., DuBois, K. P.: Effects of X-irradiation on the hexobarbital-metabolizing enzyme system of rat liver. Radiat. Res. 31, 315 to 326 (1967).

[G58,163/67

Yamada, A., Osada, Y., Takayama, S., Akimoto, T., Ogawa, H., Oshima, Y., Fujiwara, K.: Tyzzer's disease syndrom in laboratory rats treated with adrenocorticotropic hormone. Jap. J. exp. Med. 39, 505-518 (1969).

[H 24,079/69

Yamamoto, S., Lin, K., Bloch, K.: Some properties of the microsomal 2,3-oxidosqualene sterol cyclase. Proc. nat. Acad. Sci. (Wash.) 63, 110-117 (1967).

$[\mathrm{G} 67,939 / 67$

Yanagimoto, Y.: Liver circulation and function. Cyto- and biochemical studies of liver glycogen on a liver lobe ligation. Ann. Histochim. 14, 265 to 273 (1969).

[G71,560/69
Yanagimoto, Y., Nakahama, S., Noda, Y.: Liver circulation and function. Changes in lipids of rat liver following ligation of liver lobe. Ann. Histochim. 14, 215-223 (1969). [G71,328/69

Yang, T. L., Lissak, K.: The effect of various temperatures and ACTH on physical performance. Acta physiol. Acad. Sci. hung. 16, 47 to 49 (1959).

$[\mathrm{C} 77,913 / 59$

Yano, R., Nobunaga, M.: Experimental study on the significance of serum $\beta$-glucuronidase activity in liver diseases. Jap. J. Med. 2, 308 to 309 (1963).

[E21,714/63

Yaoi, H., Goto, N., Yamasawa, R., Nagata, A.: Studies on the rabies vaccine XIVth report: On the effects of PVL and cortisone upon immunizing power of anti-rabies vaccine. Yokohama med. Bull. 7, 371-382 (1956).

$[\mathrm{C} 34,360 / 56$

Yates, F. E., Herbst, A. L., Urquhart, J.: Sex difference in rate of ring $A$ reduction of $\Delta^{4}$-3. keto-steroids in vitro by rat liver. Endocrinology 63, 887-902 (1958).

$[\mathrm{C} 61,952 / 58$

Yates, F. E., Urquhart, J., Herbst, A. L.: Effect of thyroid hormones on ring A reduction of cortisone by liver. Fed. Proc. 17, 174 (1958).

$[\mathrm{C} 51,744 / 58$

Yates, F. E., Urquhart, J., Herbst, A. L.: Impairment of the enzymatic inactivation of adrenal cortical hormones following passive venous congestion of the liver. Amer. J. Physiol. 194, 65-71 (1958).

$[\mathrm{C} 56,413 / 58$

Yeh, S. Y., Woods, L. A.: The effect of tolerance and withdrawal on the in vivo metabolism of N-C14-methyl-dihydromorphine in the rat. J. Pharmacol. exp. Ther. 169, 168-174 (1969).

[H 17,933/69

Yesair, D. W., Remington, L., Callahan, M., Kensler, C. J.: Comparative effects of salicylic acid, phenylbutazone, probenecid and other anions on the metabolism, distribution and excretion of indomethacin by rats. Biochem. Pharmacol. 19, 1591-1600 (1970).

$[\mathrm{G} 75,388 / 70$

Yeung, C. Y., Field, C. E.: Phenobarbitone therapy in neonatal hyperbilirubinaemia. Lancet 1969 II, 135-139.

[G73,821/69

Ying, S. Y., Meyer, R. K.: Effect of steroids on neuropharmacologic blockade of ovulation in pregnant mare's serum (PMS)-primed immature rats. Endocrinology 84, 1466-1474 (1969).

[H 13,672/69

Yohn, D. S., Funk, C. A.: Sex-related resistance in hamsters to adenovirus-12 oncogenesis. IV. Gonadal hormone influences. $J$. nat. Cancer Inst. 48, 133-139 (1969).

$[\mathrm{G} 68,339 / 69$ 
Yohn, D. S., Funk, C.A., Grace, J.T., Jr.: Sexrelated resistance in hamsters to adenovirus-12 oncogenesis. III. Influence of immunologic impairment by thymectomy or cortisone. $J$. Immunol. 100, 771-780 (1968). [G57,790/68

Yokoi, Y., Kuwamura, T., Muto, Y.: A new explanation for the biphasic pattern of fever induced by bacterial pyrogen. Jap. J. Physiol. 11, 270-280 (1961).

$[\mathrm{D} 8,839 / 61$

You, S. S., Sellers, E. A.: Effect of desoxycorticosterone acetate and adrenal cortical extracts on survival of adrenalectomized and intact rats after burning. Amer. J. Physiol. 160, 83-88 (1950).

$[\mathrm{B} 46,218 / 50$

Youmans, G. P., Youmans, A. S.: The effect of hormonal preparations on the survival of mice injected intravenously with virulent, attenuated, and avirulent mycobacteria. Amer. Rev. Tuberc. 69, 790-796 (1954). [B [B5,169/54

Young, A. G., Taylor, F. H. L.: Studies of the effect of sodium thiosulphate on mercury intoxication (Abstr.). J. Pharmacol. exp. Ther. 39, 248 (1930).

[A48,227/30

Young, A. G., Taylor, F. H. L.: The effect of sodium thiosulphate on mercury poisoning. $J$. Pharmacol. exp. Ther. 42, 185-195 (1931).

[A 48,535/31

Young, S., Cowan, D. M., Davidson, C.: The production of mammary carcinomas in rats by 9,10-dimethyl-1,2-benzanthracene and its relationship to the oestrous cycle. Brit. J. Cancer 24, 328-332 (1970).

$[\mathrm{G} 77,809 / 70$

Young, S., Helfenstein, J.E., Baker, R.A.: Relationship of adrenocortical insufficiency to spontaneous regression in mammary tumours induced in rats by oral administration of dimethylbenzanthracene. Nature (Lond.) 203, 1079-1080 (1964).

[F 20,579/64

Yousef, M. K., Chaffee, R. R. J., Robertson, W. D., Johnson, H. D.: Cold survival of surgicallyand radio-thyroidectomized hamsters (Abstr.). Physiologist 10, 354 (1967).

[F 86,757/67

Yousef, M. K., Chaffee, R. R. J., Robertson, W. D., Johnson, H. D.: Significance of thyroid in cold survival of hamsters. Proc. Soc. exp. Biol. (N.Y.) 127, 829-831 (1968). [F98,470/68

Yu, C.A., Gunsalus, I.C.: Crystalline cytochrome P-450 cam. Biochem. biophys. Res. Commun. 40, 1431-1436 (1970). [G81,295/70

Yun, I. S., Lee, Y. C.: Experimental studies on the relation between nicotine and sexual hormone. Folia endocr. Jap. 11, 9-12 (1935).

$[34,178 / 35$
Yuwiler, A., Geller, E., Schapiro, S.: Response differences in some steroid-sensitive hepatic enzymes in the fasting rats. Canad. J. Physiol. Pharmacol. 47, 317-328 (1969). [H9,994/69 Zacco, M., Pratesi, G.: Lo choc papainico. Boll. Soc. ital. Biol. sper. 23, 553-555 (1947).

[B37,559/47

Zackheim, H. S.: Effect of castration on the induction of epidermal neoplasms in male mice by topical methylcholanthrene. J. invest. Derm. 54, 479-482 (1970).

[H 26,549/70

Zaltzman, S.: Efecto de la esplenectomía sobre la regeneración hepática. Thesis. University of Mexico (1956).

[D92,764/56

Zanowiak, P., Rodman, M. J.: A study of LSDserotonin central interaction. J. Amer. pharm. Ass., sci. Ed. 48, 165-168 (1959). [C85,018/59

Zapata-0rtiz, V., de la Mata, R. C.: The influence of aldosterone on hemorrhagic shock. Arzneimittel-Forsch. 12, 953-954 (1962).

[D37,373/62

Zárday, I., Weiner, P.: A thyroxin és az altatószerek között fennálló antagonismusról, különös tekintettel a constitutióra. Orv. Hetil. 78, 682-684 (1934).

[A 52,879/34

Zárday, I., Weiner, P.: Barbitursäure und Schilddrüse. Zugleich ein Beitrag zur Kenntnis der funktionellen Konstitution. Wien. Arch. inn. Med. 26, 353-362 (1935). $\quad[53,715 / 35$

Zarrow, M. X., Hiestand, W. A., Stemler, F. W., Wiebers, J. E.: Comparison of effects of experimental hyperthyroidism and hypothyroidism on resistance to anoxia in rats and mice. Amer. J. Physiol. 167, 171-175 (1951). [B63,316/51

Zarrow, M. X., Money, W. L.: Involution of the adrenal cortex of rats treated with thiouracil. Endocrinology 44, 345-358 (1949).

[B27,880/49

Zarrow, M. X., Quinn, D. L.: Super ovulation in the immature rat following treatment with PMS alone and inhibition of PMS-induced ovulation. J. Endocr. 26, 181-188 (1963).

[E 20,351/63

Zauder, H.L.: The effect of certain analgesic drugs and adrenal cortical hormones on the brain of normal and hypophysectomized rats as measured, by the thiobarbituric acid reagent. J. Pharmacol. exp. Ther. 101, 40-46 (1951).

/B57,611/51

Zauder, H.L.: The effect of prolonged morphine administration on the in vivo and in vitro conjugation of morphine by rats. J. Pharmacol. exp. Ther. 104, 11-19 (1952). [G75,347/52 
Zbinden, G.: Modification of the irritant effects of intraperitoneally administered phenylbutazone in rats after prolonged treatment with the same drug or phenobarbital. Toxicol. appl. Pharmacol. 9, 319-323 (1966). [G66,033/66

Zeckwer, I..T.: Compensatory renal hypertrophy after unilateral nephrectomy in thyroidectomized rats, considered in relation to histological changes in the pituitary. Fed. Proc. 3, $53-54$ (1944).

$[84,592 / 44$

Zeisberger, E., Brück, K.: Quantitative Beziehung zwischen Noradrenalin-Effekt und Ausmaß der zitterfreien Thermogenese beim Meerschweinchen. Pflügers Arch. ges. Physiol. 296, 263-275 (1967).

[F 89,184/67

Zeisberger, E., Brück, K., Wünnenberg, W., Wietasch, C.: Das Ausmaß der zitterfreien Thermogenese des Meerschweinchens in Abhängigkeit vom Lebensalter. Pflügers Arch. ges. Physiol. 296, 276-288 (1967).

[F 89,185/67

Zelioli-Lanzini, F.: Differenza dell'azione degli estratti epatici e di quella delle piccole dosi di raggi Röntgen sull'attività mitotica del fegato parzialmente epatectomizzato. Osped. ItalChir. 20, 523-527 (1969).

[H 19,493/69

Zeller, J., Margaretten, W., McKay, D. G.: Effect of saline infusion and norepinephrine on response of the kidney to bacterial endotoxin. Proc. Soc. exp. Biol. (N.Y.) 126, 446-449 (1967).

[F 92,117/67

Zicha, L., Heck, K.-J.: Untersuchungen über die Beeinflussung der glukokortikoidbedingten Hemmung von Histamin-, Serotonin- und Azetylcholinwirkungen durch anabole Steroide. Allergie u. Asthma 12, 303-308 (1967).

[F 78,128/67

Ziegler, D.M., Pettit, F.H.: Microsomal oxidases. I. The isolation and dialkylarylamine oxygenase activity of pork liver microsomes. Biochemistry 5, 2932-2938 (1966). [G79,382/66 Zilberstein, R. M.: Effects of reserpine, serotonin and vasopressin on the survival of coldstressed rats. Nature (Lond.) 185, 249 (1960).

[C80,282/60

Zimel, H., Macrineanu, A.: Recherches sur l'action hépatotrope de certaines substances hormonocytostatiques. Rev. roum. Endocr. 1, 335-341 (1964).

[F 35,084/64

Zondek, B.: Ưber das Schicksal des Follikelhormons (Follikulin) im Organismus. Skand. Arch. Physiol. 70, 133-167 (1934).

$[30,531 / 34$

Zondek, B., Sulman, F., Sklow, J.: Inactivation of stilbestrol by liver in vitro. Endocrinology 33, 333-336 (1943).

$[\mathrm{A} 74,477 / 43$
Zondek, H.: Die Beeinflussung des Blutdrucks der akuten experimentellen Nephritis des Kaninchens durch Pankreasextrakt. Dtsch. Arch. klin. Med. 115, 1-46 (1914). [36,326/14 Zsigmond, G., Solymoss, B.: Influence of $3 \beta$-hydroxy-20-oxo-5-pregnene-16 $\alpha$-carbonitrile (PCN) on the anesthetic effect and hepatic microsomal metabolism of progesterone. (Abstr.) Proc. canad. Fed.biol.Soc. 14, 80(1971). [G79,025/71

Zuchlewski, A. C., Gaebler, 0. H.: Changes in the activity of transaminases and L-glutamic acid dehydrogenase induced by growth hormone. Arch. Biochem. 66, 463-473 (1957).

[D 91,862/57

Zumofi, B., Fishman, J., Cassouto, J., Gallagher, T. F., Hellman, L.: Influence of age and sex on normal estradiol metabolism. J. clin. Endocr. 28, 937-941 (1968).

[H 1,151/68

Zumofi, B., Fishman, J., Levin, J., Gallagher, T. F., Hellman, L.: Reversible reproduction of the abnormal estradiol metabolism of biliary obstruction by administration of norethandrolone. J. clin. Endocr. 30, 598-601 (1970).

[H 25,277/70

Zwadyk, P., Jr., Harrison, E. F.: Comparison of the protective properties of soterenol and isoproterenol against endotoxin lethality. Proc. Soc. exp. Biol. (N.Y.) 133, 66-68 (1970).

[H 19,753/70

Zwehl, T. von: Beiträge zur Wirkung des Dijodtyrosins im Säugetierversuch. Arch. Entwickl.-Mech. Org. 107, 456-480 (1926).

$[25,477 / 26$

Zweifach, B. W., Thomas, L.: The relationship between the vascular manifestations of shock produced by endotoxin, trauma, and hemorrhage. I. Certain similarities between the reactions in normal and endotox intolerant rats. $J$. exp. Med. 106, 385-401 (1957). [D91,826/57

Zwemer, R. I., Jungeblut, C. W.: Effect of various corticoadrenal extracts on diphtheria toxin in vivo and in vitro. Proc. Soc. exp. Biol. (N.Y.) 32, 1583-1588 (1935). $\quad[53,287 / 35$

Zwemer, R. L., Truszkowski, R.: The imporance of corticoadrenal regulation of potassium metabolism. Endocrinology 21, 40-49 (1937).

$[\mathrm{A} 2,330 / 37$

Zykov, A. A.: The influence of adrenocorticotropic hormone, hormone preparations of the adrenals and adrenalectomy on the course and issue of the dicain intoxication in mice. (Russian text.) Eksp. Khir. Anest. 14/6, 70-72 (1969). 